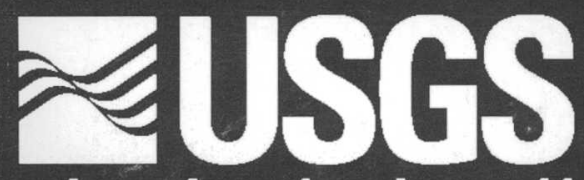

science for a changing world

Toxic Substance Hydrology Program

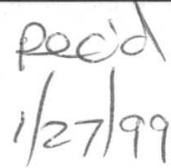

\title{
Lithology and Fracture Characterization From Drilling Investigations in the Mirror Lake Area, Grafton County, New Hampshire
}

Water-Resources Investigations Report 98-4183

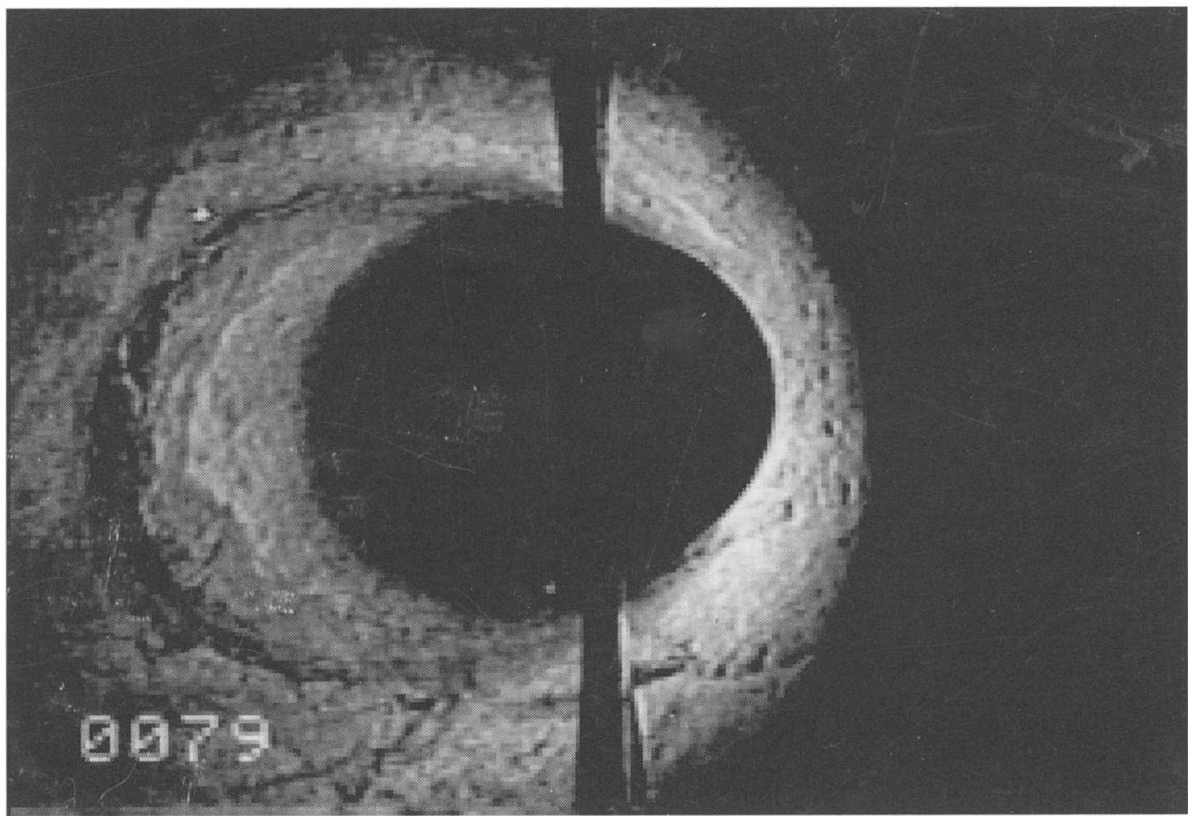


Front cover: A photograph from submersible borehole video survey showing a steeply dipping fracture at a depth of 79 feet below land surface in a borehole near Mirror Lake in Grafton County, New Hampshire. 
U.S. Department of the Interior

U.S. Geological Survey

Toxic Substance Hydrology Program

\section{Lithology and Fracture Characterization From Drilling Investigations in the Mirror Lake Area, Grafton County, New Hampshire}

By Carole D. Johnson and Alicia H. Dunstan

Water-Resources Investigations Report 98-4183

Pembroke, New Hampshire

1998 


\title{
U.S. DEPARTMENT OF THE INTERIOR BRUCE BABBITT, Secretary
}

\author{
U.S. GEOLOGICAL SURVEY \\ Charles G. Groat, Director
}

The use of firm, trade, and brand names in this report is for identification purposes only and does not constitute endorsement by the U.S. Geological Survey.

For additional information write to:

District Chief

U.S. Geological Survey

New Hampshire/Vermont District

361 Commerce Way

Pembroke, NH 03275-3718
Copies of this report can be purchased from:

U.S. Geological Survey Branch of Information Services Box 25286, Federal Center Denver, CO 80225 


\section{CONTENTS}

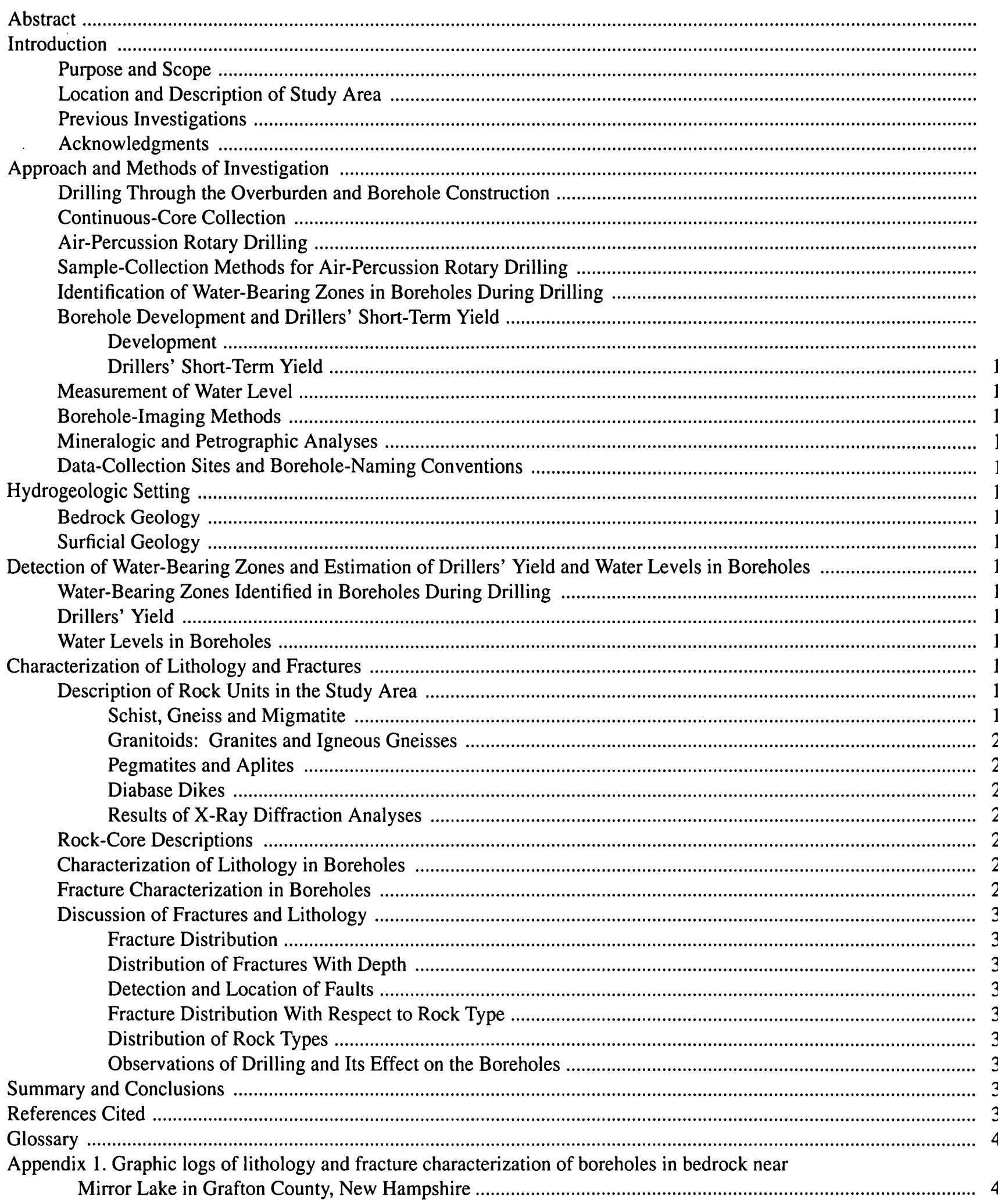




\section{FIGURES}

1. Map showing location of study area and data-collection locations near Mirror Lake in Grafton County, New Hampshire.....

2. Map showing bedrock geology of the study area near Mirror Lake .....................................................................

3. Photograph showing bedrock in highway outcrop near Mirror Lake ................................................................. 13

4. Diagram showing comparison of flowmeter logs that show upward vertical flow in boreholes R1 (4a) and IS1 (4b) under pumping conditions with water-bearing zones that were identified while drilling the boreholes near Mirror Lake

5-8. Photographs showing:

5. Bedrock core from borehole $\mathrm{CO} 7$ near Mirror Lake............................................................................ 26

6. Borehole video image from $\mathrm{CO} 7$ near Mirror Lake ............................................................................. 26

7. Selected borehole video images of rock types near Mirror Lake .................................................................... 28

8. Selected borehole video images showing frequently used fracture descriptors in boreholes near Mirror Lake

9. Graph showing fracture density as a function of depth below top of casing in selected boreholes near Mirror Lake

10. Graph showing cumulative-fracture frequency as a function of depth below top of casing in selected boreholes near Mirror Lake.

\section{TABLES}

1. Description of boreholes installed near Mirror Lake in Grafton County, New Hampshire

2. Water levels and well-drillers' estimates of yield in boreholes installed near Mirror Lake.

3. Results of petrographic point-count analysis of selected rock samples from the highway outcrop near Mirror Lake

4. Minerals and relative amounts of compositional elements identified by scanning electron microscope and x-ray fluorescence spectrometry for selected bedrock samples obtained from highway outcrops and boreholes near Mirror Lake

5. Results of $\mathrm{x}$-ray diffraction analysis of rock samples from selected boreholes near Mirror Lake.

6. Description of fractures in core samples from boreholes CO7, FSE5, and TR2 near Mirror Lake

7. Relative proportions of rock types and fracturing in selected boreholes near Mirror Lake

8. Codes used to describe fractures shown in Appendix 1

\section{CONVERSION FACTORS AND VERTICAL DATUM}

\begin{tabular}{rcl}
\hline Multiply metric unit & By & To obtain inch-pound unit \\
\hline millimeter $(\mathrm{mm})$ & Length & inch \\
centimeter $(\mathrm{cm})$ & 25.40 & inch \\
meter $(\mathrm{m})$ & 2.540 & foot \\
square kilometer $\left(\mathrm{km}^{2}\right)$ & 0.3048 & mile squared \\
liter per minute $(\mathrm{L} / \mathrm{min})$ & 0.3861 & gallon per minute \\
\hline
\end{tabular}

Sea Level: In this report "sea level" refers to the National Geodetic Vertical Datum of 1929 (NGVD of 1929) - a geodetic datum derived from a general adjustment of the first-order level nets of both the United States and Canada, formerly called Sea Level Datum of 1929. 


\section{Lithology and Fracture Characterization From Drilling Investigations in the Mirror Lake Area, Grafton County, New Hampshire}

\author{
By Carole D. Johnson and Alicia H. Dunstan
}

which range in depth from 60 to 305 meters, that were drilled for this study. Drilling logs and color video surveys were used to locate and characterize the fractures and rock types in the subsurface. Solid bedrock core was obtained from three of the boreholes. Petrographic thin-section, $\mathrm{x}$-ray diffraction and scanning electron microscope with energy dispersive $\mathrm{x}$-ray fluorescence spectrometry analyses were done on selected samples from boreholes and outcrops. Observations recorded at the time of drilling, descriptions of rock samples collected from the boreholes, interpretation of rock type and fractures based on boreholeimaging surveys, descriptions of rock core and petrographic analyses of selected rock samples are in tables and figures.

Analysis of the data provided information on the distribution of fractures and lithology in the boreholes at Mirror Lake. The relative abundances of the rock types were computed for three groups of boreholes, including (1) the Forest Service Experimental (FSE) well field, (2) the Camp Osceola (CO) well field, and (3) the index boreholes, which are 15 boreholes distributed areally throughout the study area including the deepest borehole from each of the two well fields. The index boreholes are separated by hundreds of meters and are typically 100 meters deep. The FSE well field includes 13 boreholes that are separated by 10 to 40 meters. These 13 boreholes are approximately 100 meters deep, except for one borehole that is 230 meters deep. The rocks penetrated by the FSE wells are predominantly igneous. Approximately 70 percent of the rocks encountered in the boreholes in the FSE well field 
were granite, pegmatite, and aplite. The $\mathrm{CO}$ well field includes 9 boreholes that range from 60-70 meters deep and one borehole that is 175 meters deep. The rocks encountered in these boreholes were predominantly metamorphic. The distribution of rock types in the $\mathrm{CO}$ well field is similar to the distribution of rocks in highway roadcuts, that are approximately 90 to 150 meters east of the well field. Seventy percent of the roadcut exposures are schist. Collectively, in the 15 index boreholes, the metamorphic and igneous rocks are equally distributed. Analysis of the rock types in these boreholes indicates that the rock types tend to "change" every 5 to 9 meters.

Although the metamorphic and igneous rocks each comprise approximately 50 percent of the rock types observed in the 15 index boreholes, 73 percent of the fractures were in the igneous rocks. This indicates that the granitoids tend to be more fractured than the metamorphic rocks. Pegmatite, diabase, quartzite, and gneissic rocks are relatively unfractured.

Boreholes completed in bedrock generally have one or two water-bearing zones, which were identified during the drilling process. At the completion of drilling a borehole, the driller estimated the yield of the borehole with an air-lift test. Yields estimated by drillers ranged from less than 3 to 378 liters per minute. These yields are typical of the yields measured for domestic wells in Grafton County. Water levels measured in the open boreholes after the boreholes recovered from the hydraulic stresses of drilling were usually in the steel casing and were within 10 meters of the land surface. Water levels in eight of the boreholes were above the top of casing or above land surface.

\section{INTRODUCTION}

Bedrock in the Mirror Lake area in Grafton County, N.H., is characterized by pelitic schists of Silurian to Devonian age, which were generally metamorphosed to sillimanite grade during the Acadian orogeny. The schists have been complexly folded and intruded by Devonian anatectic granites and pegmatites, and Mesozoic diabase dikes (Lyons and others, 1997), and fractured in response to tectonic stresses (Hardcastle, 1989) and local stresses (Trainer, 1988). The geometry of fracture networks and openness of individual fractures control the flow of fluids in the rocks and the advection, dispersion and storage of solutes.

Approximately 97 percent of the bedrock at Mirror Lake is covered by surficial deposits. Bedrock outcrops generally are limited to the stream beds, ridges, and exposures produced by highway excavations. Hence, detailed characterization of the rock types and fractures relies on data collected during subsurface exploratory drilling and geophysical surveys. Forty boreholes, ranging in depth from 60 to $305 \mathrm{~m}$, were drilled from $1979-95$ by use of the airpercussion rotary drilling method (table 1). From June through August 1992, in August 1994, and in August 1995, a color video camera was used to survey the boreholes and improve the interpretation of the subsurface bedrock. Cores were collected from three of the boreholes to obtain representative subsurface samples of rock units and fracture surfaces that could be compared with fracture and lithology interpretations based on borehole logging and borehole imaging methods.

The 40 boreholes were installed as part of an ongoing multidisciplinary research effort to characterize fluid movement and chemical transport in fractured crystalline bedrock in the Mirror Lake drainage basin. The research is supported by the U.S. Geological Survey (USGS) Toxic Substance Hydrology Program. An overview of the research is provided by Shapiro and Hsieh (1991). General descriptions of geologic, hydraulic, geophysical, and geochemical methods used in this investigation are provided by Hsieh and others (1993).

The objectives of the test-drilling program described here were to install a network of boreholes for hydraulic testing, water-quality sampling, geophysical testing, long term water-level monitoring, and for improving the characterization of the distribution of lithology and fractures in the subsurface. Fractures and changes in lithology could be detected and detailed descriptions of the boreholes were generated by using borehole-imaging methods and characterization of rock samples collected at the time of drilling. These characterizations of the boreholes serve as a basis for other work being conducted in the boreholes. The borehole characterizations can be used for statistical analyses of subsurface fracturing and distribution of rock type, for planning hydraulic or geophysical tests, or for comparing the results of other borehole analyses. 
Table 1. Description of boreholes installed near Mirror Lake in Grafton County, New Hampshire

[Total length of casing and depth to bedrock are measured from top of casing. Latitude and longitude are in degrees, minutes, seconds; Altitude is based on sea level; --, no data; $\sim$, indicates approximation. All length measurements are in meters. All boreholes are $15 \mathrm{~cm}$ in diameter.]

\begin{tabular}{|c|c|c|c|c|c|c|c|c|c|c|}
\hline \multirow{2}{*}{$\begin{array}{c}\text { Well } \\
\text { name } \\
\text { (fig. 1) }\end{array}$} & \multicolumn{3}{|c|}{ Altitude of } & \multirow{2}{*}{$\begin{array}{c}\text { Total } \\
\text { length of } \\
\text { casing }\end{array}$} & \multirow{2}{*}{$\begin{array}{l}\text { Depth to } \\
\text { bedrock } \\
\text { surface }\end{array}$} & \multirow{2}{*}{$\begin{array}{c}\text { Total } \\
\text { depth of } \\
\text { well }\end{array}$} & \multirow{2}{*}{$\begin{array}{l}\text { Previous } \\
\text { well name }\end{array}$} & \multirow[b]{2}{*}{ Date drilled } & \multicolumn{2}{|c|}{ Well location } \\
\hline & $\begin{array}{l}\text { Top of } \\
\text { casing }\end{array}$ & $\begin{array}{l}\text { Land } \\
\text { surface }\end{array}$ & $\begin{array}{l}\text { Bedrock } \\
\text { surface }\end{array}$ & & & & & & Latitude & Longitude \\
\hline $\mathrm{COl}$ & 217.69 & 217.14 & 211.90 & 9.14 & 5.79 & 175.86 & CO87-BR & $10 / 08 / 89$ & $43^{\circ} 56^{\prime} 28.20^{\prime \prime}$ & $71^{\circ} 41^{\prime} 23.77^{\prime \prime}$ \\
\hline $\mathrm{CO} 2$ & 216.87 & 216.23 & 211.51 & 7.62 & 5.36 & 61.87 & CO89-BR & $10 / 24 / 89$ & $43^{\circ} 56^{\prime} 27.85^{\prime \prime}$ & $71^{\circ} 41^{\prime} 24.24^{\prime \prime}$ \\
\hline $\mathrm{CO} 3$ & 215.41 & 214.91 & 210.93 & 7.92 & 4.48 & 64.46 & -- & $07 / 22 / 91$ & $43^{\circ} 56^{\prime} 27.10^{\prime \prime}$ & $71^{\circ} 41^{\prime} 24.34^{\prime \prime}$ \\
\hline $\mathrm{CO} 4$ & 216.11 & 215.30 & 210.11 & 8.84 & 6.00 & 60.65 & -- & $05 / 26 / 92$ & $43^{\circ} 56^{\prime} 27.15^{\prime \prime}$ & $71^{\circ} 41^{\prime} 23.11^{\prime \prime}$ \\
\hline $\cos$ & 217.38 & 216.71 & 213.11 & 8.14 & 4.27 & 70.00 & -- & $06 / 27 / 94$ & $43^{\circ} 56^{\prime} 27.73^{\prime \prime}$ & $71^{\circ} 41^{\prime} 23.18^{\prime \prime}$ \\
\hline $\mathrm{CO6}$ & 217.37 & 216.52 & 212.19 & 9.39 & 5.18 & 70.04 & -- & $06 / 22 / 94$ & $43^{\circ} 56^{\prime} 27.81^{\prime \prime}$ & $71^{\circ} 41^{\prime} 22.38^{\prime \prime}$ \\
\hline $\mathrm{CO} 7$ & 215.92 & 215.01 & 213.18 & 6.25 & 2.74 & 71.05 & -- & $06 / 29 / 94$ & $43^{\circ} 56^{\prime} 26.66^{\prime \prime}$ & $71^{\circ} 41^{\prime} 22.37^{\prime \prime}$ \\
\hline $\mathrm{CO} 8$ & 217.83 & 216.98 & 212.66 & 8.81 & 5.80 & 76.90 & -- & $08 / 13 / 94$ & $43^{\circ} 56^{\prime} 28.24^{\prime \prime}$ & $71^{\circ} 41^{\prime} 23.04^{\prime \prime}$ \\
\hline $\mathrm{CO} 9$ & 217.85 & 216.94 & 213.47 & 7.16 & 4.39 & 76.47 & -- & $08 / 15 / 94$ & $43^{\circ} 56^{\prime} 28.34^{\prime \prime}$ & $71^{\circ} 41^{\prime} 22.46^{\prime \prime}$ \\
\hline $\mathrm{CO} 10$ & 215.78 & 214.90 & 209.38 & 10.06 & 6.40 & 77.11 & -- & $07 / 28 / 95$ & $43^{\circ} 56^{\prime} 26.83^{\prime \prime}$ & $71^{\circ} 41^{\prime} 21.43^{\prime \prime}$ \\
\hline $\mathrm{CO} 11$ & 225.74 & 224.92 & 217.51 & 12.28 & 8.23 & 183.79 & -- & $07 / 27 / 95$ & $43^{\circ} 56^{\prime} 30.00^{\prime \prime}$ & $71^{\circ} 41^{\prime} 20.64^{\prime \prime}$ \\
\hline FS1 & 261.88 & 261.27 & 247.86 & 16.46 & 14.02 & 137.15 & FS-79-BR & 08/30/79 & $43^{\circ} 56^{\prime} 44.58^{\prime \prime}$ & $71^{\circ} 42^{\prime} \quad 5.34^{\prime \prime}$ \\
\hline FS2 & 255.71 & 255.04 & 248.34 & 9.75 & 7.38 & 152.39 & FS-87-BR & $08 / 28 / 87$ & $43^{\circ} 56^{\prime} 40.62^{\prime \prime}$ & $71^{\circ} 42^{\prime} 3.57^{\prime \prime}$ \\
\hline${ }^{1} \mathrm{FS} 3$ & 274.45 & 273.84 & 265.00 & 12.04 & 9.44 & 225.54 & FS-89-BR & $10 / 12 / 89$ & $43^{\circ} 56^{\prime} 47.81^{\prime \prime}$ & $71^{\circ} 42^{\prime} \quad 6.87^{\prime \prime}$ \\
\hline FS4 & 346.12 & 345.36 & 342.16 & 7.62 & 3.96 & 305.70 & -- & $07 / 24 / 93$ & $43^{\circ} 57^{\prime} 4.00^{\prime \prime}$ & $71^{\circ} 42^{\prime} 16.05^{\prime \prime}$ \\
\hline FSE1 & 240.20 & 239.83 & 226.46 & 16.92 & 13.75 & 107.60 & FS83E-BR & $08 / 31 / 83$ & $43^{\circ} 56^{\prime} 36.36^{\prime \prime}$ & $71^{\circ} 41^{\prime} 59.98^{\prime \prime}$ \\
\hline FSE2 & 241.06 & 240.39 & 225.91 & 17.07 & 15.15 & 108.00 & FS83E2-BR & $09 / 20 / 83$ & $43^{\circ} 56^{\prime} 36.40^{\prime \prime}$ & $71^{\circ} 42^{\prime} \quad 0.39^{\prime \prime}$ \\
\hline FSE3 & 241.01 & 240.31 & 226.42 & 18.59 & 14.60 & 108.20 & FS83E3-BR & $09 / 22 / 83$ & $43^{\circ} 56^{\prime} 36.07^{\prime \prime}$ & $71^{\circ} 42^{\prime} 0.03^{\prime \prime}$ \\
\hline FSE4 & $241.26^{\circ}$ & 240.71 & 226.38 & 18.29 & 14.87 & 229.50 & FS83E4-BR & $07 / 02 / 84$ & $43^{\circ} 56^{\prime} 36.11^{\prime \prime}$ & $71^{\circ} 42^{\prime} 0.44^{\prime \prime}$ \\
\hline FSE5 & 242.36 & 241.65 & 229.16 & 16.92 & 13.20 & 61.26 & FSE5-BR & $10 / 26 / 89$ & $43^{\circ} 56^{\prime} 35.50^{\prime \prime}$ & $71^{\circ} 42^{\prime} \quad 1.51$ \\
\hline FSE6 & 242.88 & 242.21 & 222.71 & 22.55 & 20.18 & 76.20 & -- & 08/06/90 & $43^{\circ} 56^{\prime} 34.34^{\prime \prime}$ & $71^{\circ} 42^{\prime} 3.56^{\prime \prime}$ \\
\hline FSE7 & 242.31 & 241.88 & 226.34 & 18.90 & 15.97 & 76.50 & -- & 08/06/90 & $43^{\circ} 56^{\prime} 35.88^{\prime \prime}$ & $71^{\circ} 42^{\prime} \quad 1.94^{\prime \prime}$ \\
\hline FSE8 & 242.27 & 241.82 & 227.99 & 21.03 & 14.30 & 76.20 & -- & $07 / 18 / 91$ & $43^{\circ} 56^{\prime} 35.11^{\prime \prime}$ & $71^{\circ} 42^{\prime} \quad 1.10^{\prime \prime}$ \\
\hline FSE9 & 242.82 & 242.13 & 228.40 & 20.12 & 14.42 & 76.20 & -- & $07 / 22 / 91$ & $43^{\circ} 56^{\prime} 35.06^{\prime \prime}$ & $71^{\circ} 42^{\prime} 2.28^{\prime \prime}$ \\
\hline FSE10 & 244.33 & 243.72 & 225.44 & 22.55 & 18.90 & 77.11 & -- & $07 / 24 / 91$ & $43^{\circ} 56^{\prime} 34.86^{\prime \prime}$ & $71^{\circ} 42^{\prime} 4.71^{\prime \prime}$ \\
\hline FSE11 & 242.59 & 242.09 & 221.35 & 24.99 & 21.24 & 84.58 & -- & $06 / 02 / 92$ & $43^{\circ} 56^{\prime} 34.44^{\prime \prime}$ & $71^{\circ} 42^{\prime} 1.61^{\prime \prime}$ \\
\hline FSE12 & 243.71 & 242.92 & 227.07 & 20.73 & 16.64 & 88.10 & -- & $06 / 03 / 92$ & $43^{\circ} 56^{\prime} 35.83^{\prime \prime}$ & $71^{\circ} 42^{\prime} 3.13^{\prime \prime}$ \\
\hline FSE13 & 240.61 & 239.79 & 218.15 & 24.38 & 22.46 & 75.90 & - & $06 / 04 / 92$ & $43^{\circ} 56^{\prime} 33.73^{\prime \prime}$ & $71^{\circ} 42^{\prime} \quad 1.98^{\prime \prime}$ \\
\hline $\mathrm{H} 1$ & 232.15 & 231.56 & 228.51 & 9.14 & 3.64 & 91.74 & -- & $07 / 16 / 91$ & $43^{\circ} 56^{\prime} 25.61^{\prime \prime}$ & $71^{\circ} 41^{\prime} 51.22^{\prime \prime}$ \\
\hline IS1 & 224.67 & 224.13 & 211.93 & 17.07 & 12.74 & 151.50 & -- & $05 / 29 / 92$ & $43^{\circ} 56^{\prime} 42.96^{\prime \prime}$ & $71^{\circ} 41^{\prime} 20.09^{\prime \prime}$ \\
\hline $\mathrm{K} 1$ & 215.40 & 214.15 & 203.21 & 15.54 & 12.19 & 46.33 & Kh-1-BR & $08 / 28 / 89$ & $43^{\circ} 56^{\prime} 31.42^{\prime \prime}$ & $71^{\circ} 41^{\prime} 35.77^{\prime \prime}$ \\
\hline $\mathrm{K} 2$ & 215.18 & 214.81 & 201.10 & 17.37 & 14.08 & 48.77 & K-BR & $08 / 24 / 79$ & $43^{\circ} 56^{\prime} 28.77^{\prime \prime}$ & $71^{\circ} 41^{\prime} 40.60^{\prime \prime}$ \\
\hline $\mathrm{K} 3$ & 209.28 & 207.15 & 187.80 & 23.77 & 21.49 & 53.34 & Kh-B-BR & $08 / 22 / 79$ & $43^{\circ} 56^{\prime} 25.69^{\prime \prime}$ & $71^{\circ} 41^{\prime} 39.17^{\prime \prime}$ \\
\hline${ }^{2} \mathrm{R} 1$ & 255.93 & 255.91 & 239.76 & 20.42 & 16.92 & 193.54 & - & $08 / 08 / 90$ & $43^{\circ} 56^{\prime} 51.83^{\prime \prime}$ & $71^{\circ} 41^{\prime} 53.66^{\prime \prime}$ \\
\hline $\mathrm{T} 1$ & 229.08 & 228.47 & 225.42 & 6.10 & 3.66 & 152.39 & -- & $07 / 25 / 91$ & $43^{\circ} 56^{\prime} 42.36^{\prime \prime}$ & $71^{\circ} 41^{\prime} 50.32^{\prime \prime}$ \\
\hline TR1 & 249.29 & 248.56 & 197.66 & 53.19 & 51.63 & 190.49 & TR-BR & $09 / 13 / 83$ & $43^{\circ} 56^{\prime} 49.50^{\prime \prime}$ & $71^{\circ} 41^{\prime} 40.66^{\prime \prime}$ \\
\hline TR2 & 232.94 & 232.24 & 219.74 & 16.15 & 13.20 & 231.64 & -- & $08 / 08 / 91$ & $43^{\circ} 56^{\prime} 26.50^{\prime \prime}$ & $71^{\circ} 42^{\prime} 6.82^{\prime \prime}$ \\
\hline FS5 & $\sim 499.2$ & $\sim 498.3$ & $\sim 491.6$ & 7.62 & 3.90 & $\sim 66.44$ & -- & $07 / 05 / 94$ & $43^{\circ} 56^{\prime} 54.46^{\prime \prime}$ & $71^{\circ} 43^{\prime} 48.80^{\prime \prime}$ \\
\hline${ }^{3} \mathrm{FS} 6$ & $\sim 243.8$ & $\sim 244.1$ & -232.7 & 13.47 & 11.12 & 182.57 & -- & $07 / 24 / 95$ & $43^{\circ} 56^{\prime} 23.50^{\prime \prime}$ & $71^{\circ} 42^{\prime} 10.00^{\prime \prime}$ \\
\hline RR1 & $\sim 184.4$ & $\sim 183.5$ & $\sim 153.6$ & 30.78 & 27.13 & 183.48 & -- & $08 / 01 / 95$ & $43^{\circ} 55^{\prime} 58.00^{\prime \prime}$ & $71^{\circ} 40^{\prime} 58.00^{\prime \prime}$ \\
\hline
\end{tabular}

\footnotetext{
'FS3 caved in at 196.6 meters.

${ }^{2} \mathrm{R} 1$ caved in at 165.5 meters.
}

${ }^{3} \mathrm{FS} 6$ caved in at 125.0 meters. 
Typically, each borehole has two to three waterbearing fractures that were detected during the drilling process. Detailed geophysical surveys of the boreholes indicate numerous fractures in each borehole. Flowmeter testing and hydraulic tests identify only a few hydraulically conductive fractures. All fractures identified in the boreholes by use of geophysical methods are tested for hydraulic conductivity. Straddle-packer tests, conducted over 3 to $5 \mathrm{~m}$ intervals, indicate that the hydraulic conductivity (and transmissivity) ranges over six orders of magnitude (Hsieh and others, 1993; Shapiro, 1993; and Hsieh and Shapiro, 1996).

\section{Purpose and Scope}

The purpose of this report is to describe the hydrogeology of a bedrock aquifer and to report geologic and hydraulic information resulting from the 1979-95 drilling program at Mirror Lake. The testdrilling program included field observations recorded at the time of drilling, lithologic sampling, and detailed descriptions of rock samples. In addition, borehole-imaging techniques were used to characterize the lithology and the fractures in boreholes. This report describes the lithologic units in the study area and the well-drilling methods and other techniques used to characterize the fractures and rocktypes in the boreholes. The fractures and the rock types observed in the boreholes are described, and data are presented in tables and figures.

\section{Location and Description of Study Area}

The study area is in the Pemigewasset River Valley and surrounding uplands near the towns of Woodstock and Thornton, in Grafton County in central New Hampshire (fig. 1). The entire study area is approximately $2 \mathrm{~km}^{2}$ in size. Part of the study area is in the Hubbard Brook Experimental Forest, which is operated and maintained by the Northeastern Forest Experimental Station, U.S. Department of Agriculture (USDA) Forest Service, Radnor, Penn. The Hubbard Brook Experimental Forest has been the site of numerous scientific investigations during the past three decades (Likens, 1991). The study area is in the central highlands physiographic province of New England (Denny, 1982). This area was covered at least twice by glaciers from $2,000,000$ to 10,000 years ago, and is characterized by steep bedrock uplands that are covered by glacial till and discontinuous stratified-drift deposits. The Mirror Lake drainage basin has high ridges and steep slopes, with occasional bedrock-cored knobs and sand terraces. The landsurface altitude ranges from $180 \mathrm{~m}$ near the Pemigewasset River to $720 \mathrm{~m}$ on the mountain top on the northwestern side of the study area. The underlying bedrock is predominantly high-grade metamorphic rocks that have been intruded by felsic igneous intrusions and to a lesser extent by pegmatites and diabase.

\section{Previous Investigations}

Several investigators have studied the geology and hydrogeology of the Mirror Lake area. The bedrock geology has been mapped at several scales, ranging from several square kilometers to mapping outcrop faces that are tens to hundreds of meters in length. Lyons and others (1997) mapped the geology at a scale of 1:250, 000. Their map and publication provide a thorough description of the rock units. Hatch and Moench (1984) provided geologic maps at the scale of 1:125,000 of the Wilderness Area, which includes the Mirror Lake area. The bedrock geology of the Plymouth, N.H., 15-minute quadrangle was mapped by Moke (1946) at a scale of 1:65,000. Lyons mapped the Woodstock, N.H., 7.5-minute quadrangle at a scale of 1:24,000 (John Lyons, Dartmouth College, written communication, 1993). In addition, fractures on the highway outcrops and rock exposures within the study area were mapped in detail by Barton (1996 and 1997). All fractures on the outcrops that exceed $1 \mathrm{~m}$ in length were individually characterized by six parameters: orientation, length, connectivity, aperture, surface roughness, and mineralization (Barton, 1996). Figure 2, which is modified from Barton (1997), shows the distribution of rock types in the study area at a scale of 1:12,000.

The hydrogeology of the study area also has been the subject of many recent investigations. Winter (1985) provides a detailed description of the hydrogeology and physical setting of the area. Studies of surface- and ground-water processes and interactions were done by Winter (1984) and Winter and others (1989). Other studies have provided information relating to hydraulic and physical properties of the rock. A characterization of the lithology and 


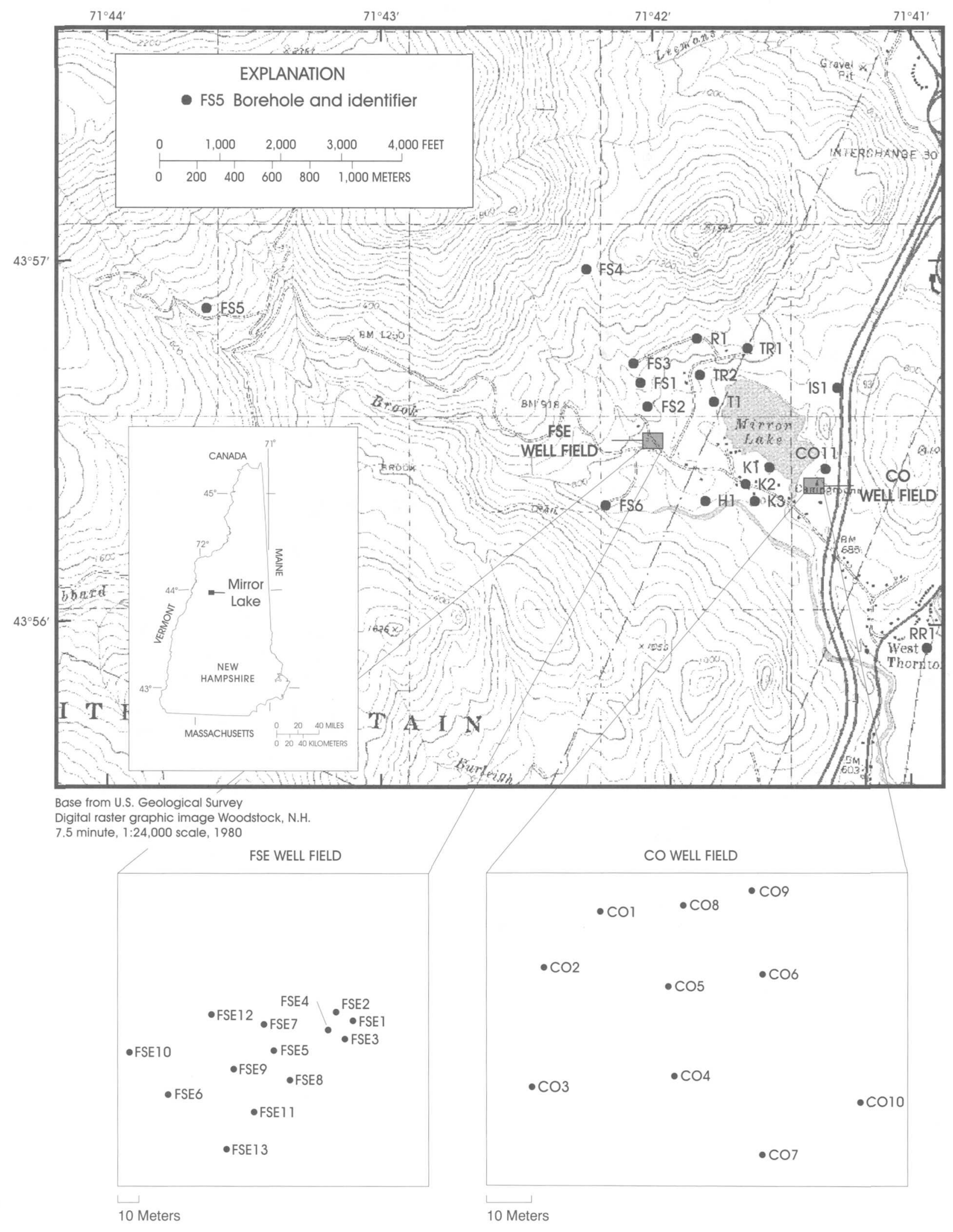

Figure 1. Location of study area and data-collection locations, near Mirror Lake in Grafton County, New Hampshire. 


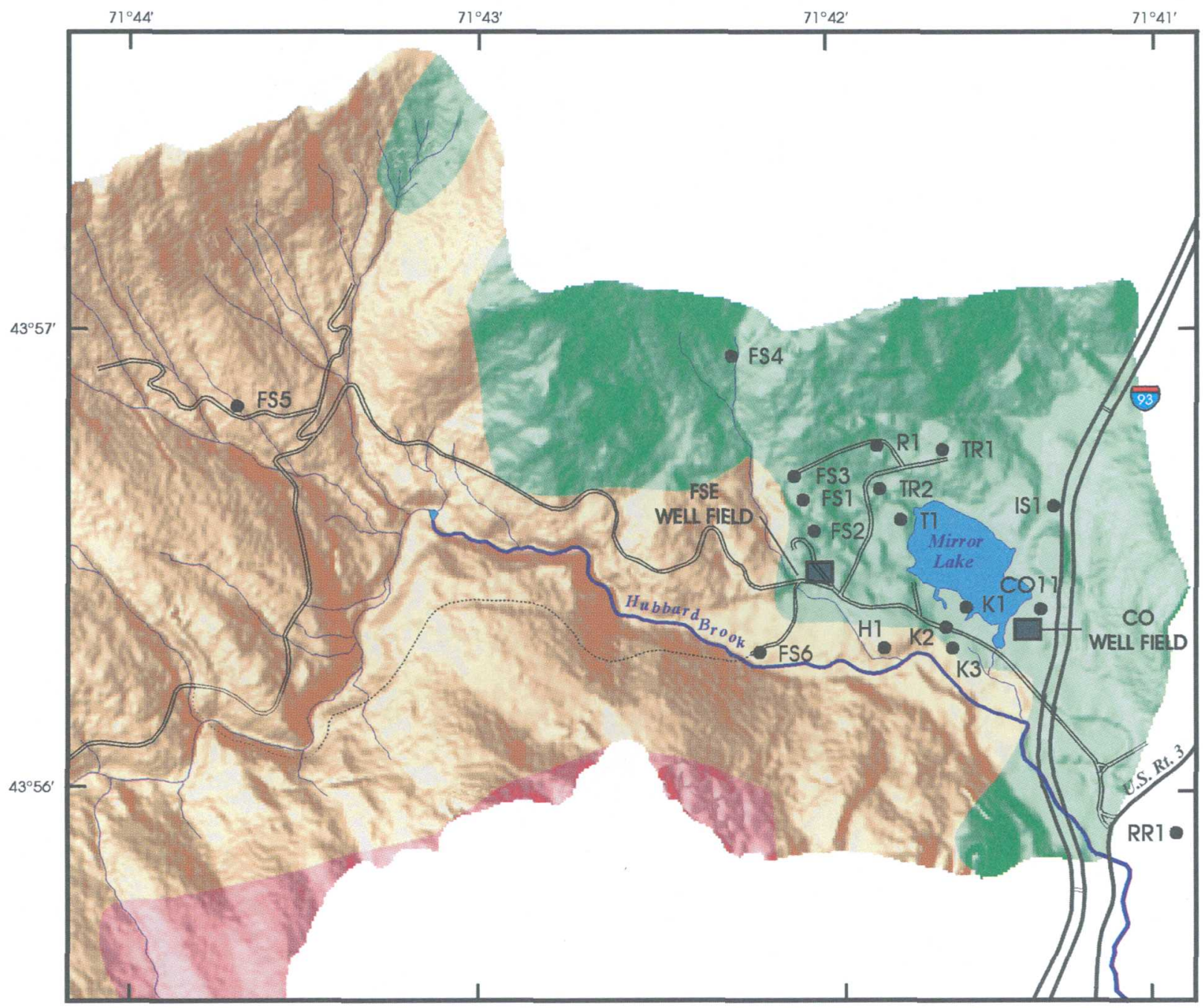

Shaded relief base created from digital elevation model interpolated from digital contour data. Hydrography and roads from U.S. Geological Survey digital line graphs

U.S. Geological Survey Woodstock, N.H.

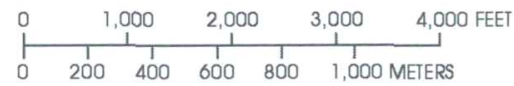

7.5 minute, $1: 24,000$ scale, 1980

EXPLANATION

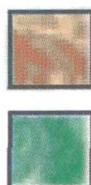

Upper Member of Rangeley Formation (Silurian)

Lower Member of Rangeley Formation (Silurian)

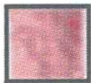

Perry Mountain Formation (Silurian)

- K1 Borehole and identifier

Figure 2. Bedrock geology of the study area, near Mirror Lake in Grafton County, New Hampshire. (Well fields FSE and CO are shown in figure 1.) 
hydraulic properties of the overburden and the upper 3 to $5 \mathrm{~m}$ of the bedrock, which was not evaluated as part of this study, is reported by Harte (1997). Results of borehole geophysical surveys for selected boreholes in the Mirror Lake Basin have been published in various reports (Paillet, 1985; Paillet and Kapucu, 1989). Borehole identifiers of some boreholes in previous reports are different than the borehole identifiers used in this report. Information provided in table 1 can be used to cross-reference the borehole names in these various reports. Previous work done in conjunction with this investigation is summarized by Hsieh and others (1993).

\section{Acknowledgments}

The authors express their appreciation to the employees of the U.S. Department of Agriculture Forest Service, the Institute of Ecosystem Studies, the State of New Hampshire Department of Transportation, and the many private land owners who permitted access to drill boreholes and collect borehole data. The authors are especially grateful to the following individuals and their families: Mr. and Mrs. Herzog, Mr. Ketanna, Mr. Kendal, Mr. Richards, and Mr. Thomas. The authors extend special thanks to Wayne Martin of the U.S. Forest Service for his cooperation and assistance in logistical aspects.

The writers gratefully acknowledge the following scientists whose help and instruction have been extremely valuable: Robert Moench at the USGS in Denver, Colo., Dr. Eugene Boudette, New Hampshire State Geologist, Dr. Jo Laird and Dr. Wallace Bothner of the University of New Hampshire (UNH), Dr. John Lyons of Dartmouth College, and Fred Murphey of the USGS in Menlo Park, California. Special thanks are extended to John Evans (USGS) for his expertise on the scanning electron microscope and to Warren Wood (USGS) for making those analyses possible. Thanks are extended to Jane Parks from UNH for completing point count analyses of petrographic thin sections, and to Christopher VanNess (UNH) for completing x-ray diffraction analyses. The authors appreciate the cooperation of Curtis Crow and Kerrie Hartshorn of the U.S. Coast and Geodetic Survey in providing Global Positioning System surveys of borehole locations, roads and base-map control points.

\section{APPROACH AND METHODS OF INVESTIGATION}

All boreholes were constructed using the same technique to reduce differences in hydraulic properties that are caused by differences in borehole installation. In addition, techniques for collecting samples were used consistently at all boreholes. The methods used in this investigation are described in detail in this section. Inclined drilling was not attempted. All of the boreholes that were installed were intended to be near vertical. In some of the boreholes, especially in metamorphic rocks, the boreholes deviated from vertical.

\section{Drilling Through the Overburden and Borehole Construction}

The equipment used for the borehole design included a combination of rotary and air-percussion drilling. Rotary drilling was used to penetrate the unconsolidated overburden material and approximately $3 \mathrm{~m}$ into competent bedrock. A biodegradable drilling fluid, which is designed to break down after approximately 48 hours, was used when drilling through the overburden in order to hold the borehole open. Steel casing, $15.2 \mathrm{~cm}$ in diameter, was set through the overburden and into the rock by use of the following methods. The steel casing, which had a drive shoe affixed to its lower end, was set into the pre-drilled borehole. Lengths of casing were threaded together or welded until the drive shoe reached the bottom of the hole. A mixture of cement and bentonite grout was pumped to the bottom of the hole and into the annular space around the casing, in order to seal the casing and isolate the water in the glacial drift from the water in the bedrock. The entire length of casing was lifted up $1.5 \mathrm{~m}$ in the hole and then dropped into place to insure that the grout filled the annular space. The casing was hammered or advanced up to 0.3 to $0.5 \mathrm{~m}$ into the rock to assure a tight fit. Once the grout set, an air-percussion tool was used to ream-out the grout in the bottom of the casing and to penetrate the bedrock to the total depth of the borehole. The finished borehole is defined as the open hole from the bottom of the casing to the extent drilled. 


\section{Continuous-Core Collection}

Cores were taken in selected boreholes in order to collect rock samples from the subsurface that were less disturbed than the samples collected by airpercussion drilling. The cored holes were near vertical as no attempt was made to drill inclined core holes. Bedrock core, which measures approximately $5 \mathrm{~cm}$ in diameter, was obtained in three boreholes (FSE5, TR2, and CO7) (fig. 1). After coring was completed, the cored holes were reamed to approximately $15 \mathrm{~cm}$ in diameter by air-percussion drilling.

A diamond-impregnated carbide bit was used with a rotary-coring tool to cut the rock. Two coring methods were used to retrieve the core samples. A conventional core-barrel system was used to obtain $46 \mathrm{~m}$ of core from borehole FSE5. A wire-line system was used to obtain $46 \mathrm{~m}$ of core from borehole TR2 and $15 \mathrm{~m}$ of core from observation borehole $\mathrm{CO} 7$. The wire-line method allows the drill rod to remain in the hole, while the core barrel is pulled up the borehole through the drill rod on a wire line. This method saves time and also reduces the possibility of the borehole collapsing that sometimes occurs when removing the entire length of drill rod and conventional core barrel at the end of each run ( 1.5 or $3 \mathrm{~m}$ advancement).

Field observations recorded at the time of coring include the rate and smoothness of coring, the loss or gain of circulating wash water, and changes in color of the wash water. The rate of penetration for each core sample was recorded, since the speed of drilling is an indication of the relative hardness of the rock. In addition, changes in the rate of drilling over short distances, the roughness of drilling, or "sinking" of the drill rods indicates incompetent zones, such as fracture zones, faults, very soft rocks, or altered zones. It is important to observe and note these zones at the time of drilling because sometimes the rock samples from these locations are not recovered in the core, and the amount of core recovered is less than the distance that was cored.

Once the core barrel was retrieved, the core was extracted from the core barrel and set in a box. The core was photographed, and the fractures and lithologic contacts were documented. The core was reconstructed by matching the pieces together. Each piece was marked with an arrow that indicated the upward direction, labeled, described, and stored for future use. Core pieces were numbered sequentially with increasing depth. Zones that were completely fragmented and reduced to angular pieces that could not be reconstructed were stored in plastic bags, labeled, and placed in sequence. All breaks in the rock were determined to be either natural fractures or drilling or handling induced (Kulander and others, 1979 and 1990; Pollard and Aydin, 1988). The locations of natural fractures and completely fragmented zones were described in terms of position in the core sample and depth from land surface.

When the amount of core retrieved was less than the distance that was cored, the depth to the fractures along the length of the core was estimated by one of two methods. The first method, which is preferred by the authors, uses the drilling logs to identify the exact location of fractures. The second method uses the depth to the bottom of the drill rod, which is the best known location of the core. The bottom of the core sample is determined as the depth of the bottom of the drill rod, and depth locations of fractures in the core are determined relative to that known depth. This second method attempts to limit possible errors in the depth of fractures over a short interval. For example, if a $1.5 \mathrm{~m}$ core were drilled, but only $1 \mathrm{~m}$ was recovered, then the pieces would be reconstructed and labeled relative to the position of the bottom of the core barrel. In this method the lost core is positioned at the top of the run. Core recovery from the three cored holes averaged 99.1 percent, and so these two methods were used infrequently.

Fracture faces were examined for weathering and degree of alteration and mineralization, such as, calcite, quartz, clay, and manganese or iron hydroxide. If partial or total coatings or fracture fillings were found, notations were made in the drilling logs. The length of all pieces and fracture angles were measured and recorded. Solid-rock sections were described in terms of rock type, mineralogy, texture, and color. The mechanical aperture of the reconstructed core was not measured.

\section{Air-Percussion Rotary Drilling}

Air-percussion rotary drilling uses a hollowstem drill rod attached to a percussion-cutting tool, which simultaneously rotates and hammers the rock. With this method the drilling fluid, compressed air, and a small amount of water are forced down the center of the drill rods and through the air hammer to 
evacuate water and rock fragments from the borehole and to cool the drill bit. The air, water, and cuttings are forced up the wellbore annulus to the land surface. If a borehole does not produce sufficient amounts of water, water is added to the drilling fluid to prevent compaction, caking, and collaring of the rock fragments downhole. If a collar of rock fragments adheres to the rods downhole, the evacuation of the borehole can be impeded or completely blocked. The addition of water generally removes the blockage, and cuttings and water are transported to the land surface. Water used for drilling purposes was obtained from Mirror Lake.

\section{Sample-Collection Methods for Air-Percussion Rotary Drilling}

In air-percussion rotary drilling, rock fragments (cuttings) and fluids are returned to the land surface under the force of the compressed air. The rock fragments generally measure from a fine dust size to a few centimeters in length. Samples were collected at the land surface over regular intervals of $1.5 \mathrm{~m}$ in depth or at any changes in rock units. A sample was collected by placing a sieve at the well head such that a continuous stream of rock fragments was deposited in it. Rock chips measuring 1 to $2 \mathrm{~mm}$ in diameter were sieved and washed in a wire-mesh strainer, and were transferred to plastic bags for storage. If the coarse portion of the sample looked significantly different than the fine portion, the fine portion was also sampled. For example, when all of the rock cuttings observed in the wash water were grayish black and the coarse portion of the sample, which was obtained by sieving, was predominantly white, both portions were sampled. In this example, all of the fine-grained dark minerals (biotite) were preferentially removed by washing the sample. Thus, by sampling the fine and the coarse portions of the rock fragments, a representative sample was obtained.

Field observations made at the time of drilling include depth, drilling rates, smoothness of drilling, size of rock fragments, changes in lithology and amount and color of the drilling fluid, and the amount of cuttings returned to the land surface. The rate of penetration indicates the relative hardness of the rocks. When the drilling rate increases rapidly, it indicates that there is a change in rock type or a discontinuity, such as a fracture or fault. A rapid decrease in the rate of penetration is likely caused by a change in rock type. Sometimes weathered zones are indicated by iron-oxide staining and crumbling or friable rocks that are at the bedrock surface or deep in the boreholes. Fracture zones in the bedrock often can be identified in the process of drilling. The drill cuttings in these zones are frequently larger than drill cuttings from more competent rock and are sometimes iron stained or friable. As the drill rod penetrates a fracture, the fracture can cause "chattering" or rough drilling. In addition, the presence of fractures can cause an increase or a decrease in the amount of drilling fluid. These signs, which indicate the presence of fractures, were recorded.

\section{Identification of Water-Bearing Zones in Boreholes During Drilling}

Identification of the locations of water-bearing zones can be determined during drilling by carefully observing the volumetric flow rate and the actions of the driller. If the driller has not changed the injection rate of the drilling fluid, then any change in the volumetric flow rate can indicate the presence of underground fractures. An increase in the flow rate indicates the drill bit has penetrated a water-bearing zone. A sudden decrease in the flow rate is caused by the presence of a fracture or fractures that are conducting water away from the borehole. Although this method of observation is not highly quantitative, it can be used for locating the major water-bearing zones in boreholes. One disadvantage is that the method is insensitive to low-yielding zones. During the drilling process, if there was a change in volumetric flow rate, the depth and the volume of the change were noted.

\section{Borehole Development and Drillers' Short-Term Yield}

The boreholes were minimally developed at the end of drilling for two purposes: (1) to clean the boreholes of particles and debris and (2) to provide a well-driller's estimate of short-term yield.

\section{Development}

Once the borehole was drilled to its completed depth, compressed air was discharged through the drill stem and drill bit and into the borehole. The air forced 
the evacuation of the water and small rock fragments and particles from the borehole. Each borehole was minimally developed this way until the water cleared of rock fragments or for at least 1 hour. The length of these tests varied but typically lasted 20 to 30 minutes. Water from the drill truck was used to clean the borehole when there was insufficient water production in the borehole. The production rate of water coming from the fractures intersecting the borehole was used as an estimate of short term yield.

\section{Drillers' Short-Term Yield}

Short-term yield was estimated by the driller after developing the borehole. This estimate is frequently referred to as the "well driller's yield", the "blow-test", or an air-lift test. The water that is removed from the borehole by compressed air is channeled into a calibrated container for measurement. The rate at which the water is removed from the borehole is monitored, as the rate is increased or decreased, until the maximum rate that can be sustained without dewatering the borehole is determined. Usually, the rate of flow is greatly reduced after several seconds to minutes. This change in flow indicates that the borehole storage has been removed from the borehole. Most often the flow rate stabilizes; in some cases, however, the boreholes are blown dry and the fractures that intersect the borehole are unable to sustain yield. Usually the driller can reduce the force of the air lift such that a sustainable well yield can be measured. Short-term yield is routinely measured by well drillers for home owners and for reporting agencies, and these measurements are considered reliable indicators of yield compared to short-term aquifer-production tests (Paillet and Duncanson, 1994; and Borchers, 1996). Borchers (1996), however, noted that the short-term yields measured in crystalline rocks are not good indicators of long-term sustained production.

\section{Measurement of Water Level}

The water level is greatly affected by the drilling process. Sometimes it takes a few days for the water level to rise to a static level after drilling, but generally the water level in the bedrock recovers overnight. All water levels were measured in open holes after the borehole recovered from drilling and before any inflatable packers were installed in the boreholes for long-term water-level monitoring (Hsieh and others, 1996). The water levels were measured using a calibrated electric tape or a steel tape to the nearest one-hundredth of a foot and converted to metric values. The water levels were measured from the top of casing and converted to altitude above sea level.

\section{Borehole-Imaging Methods}

Borehole-imaging methods were used to improve interpretations of the rock types that previously were based only on initial logs made at the time of drilling and later detailed examinations of drill cuttings. Submersible color video cameras were used to view bedrock and fractures in boreholes to verify and describe rock types in the boreholes. The video images were used to describe texture, grain-size, color, contacts of rock types, occurrence and details of fractures, foliation, folds, and faults, as well as the condition of the borehole wall. Video images provide a direct verification and precise location of contacts between rock types and fractures. In addition, video images can be used to describe fracture zones that are sometimes missing from, or completely fragmented in, the bedrock core. Comparisons of interpretations of borehole video, core, and drilling logs indicate that the interpretations are similar. The similarities indicate that video borehole imaging is an effective, practical, and low-cost alternative to coring for the purpose of characterizing rock types and fractures and for assessing the integrity of the borehole.

Two submersible color video cameras were used in this investigation. From June through August 1992, the camera system with a digital-depth indicator (in whole feet) superimposed on the analog picture was used. In order to evaluate and locate the occurrence of fractures more accurately than one-foot intervals, the distance from the upper expression of a fracture in the borehole to the bottom of the fracture was determined by directly measuring the displacement of the logging cable at land surface, and was recorded in the field. In August 1994 and August 1995, the camera used had digital depth indicators that recorded depths in increments of tenths of feet. For all borehole surveys, the depth measurements were referenced to the top of the steel casing. All depth measurements were converted to metric for reporting. 
Techniques and equipment for borehole imaging used in all borehole surveys are described by Johnson (1996). The submersible borehole color video camera systems had two lighthead attachments with two perspectives of the borehole. One lighthead attachment permitted a view of the borehole looking down the borehole, the other permitted a view of the borehole wall. All boreholes were surveyed with the two light attachments.

The dip of planar features (such as fractures or foliation) in the borehole was determined by a combination of measurement and computation. The vertical distance from the top of the feature to the bottom of the feature was measured along the axis of the borehole. A constant borehole diameter of $152 \mathrm{~mm}$ was assumed, and the angle at which the fracture intersects the borehole was calculated using right angle trigonometry. Because the borehole can be inclined, this angle is not necessarily the true dip of the feature. In addition, in zones where the borehole has an enlarged diameter, the actual dip of a feature would be less than the angle estimated by this method.

\section{Mineralogic and Petrographic Analyses}

Rock fragments collected during drilling were examined using a hand lens and binocular microscope to determine fragment color, texture, and mineralogy. Descriptive colors of the rock fragments are referenced to a standardized rock color chart (Geological Society of America, 1991).

Detailed analyses were performed on representative samples from rock outcrops and rock fragments obtained from boreholes to describe the mineralogy, petrology, and geochemistry of rocks in the study area. Thin sections were made from 11 rock samples from a nearby interstate highway outcrop (fig. 1) and 7 were made from rock fragments obtained from drilling boreholes. The thin sections of the rock fragments were made by embedding the fragments in epoxy. Thirteen thin-section samples were analyzed by use of a polarizing microscope and a scanning electron microscope-energy-dispersive $x$-ray fluorescence spectrometer (SEM-XRF). Polarizing-microscope analyses were done on the thin sections to provide detailed information about the mineral composition, texture, and structure of the rocks. Point counts, based on a minimum of 500 points, were performed on 10 thin sections to determine the relative abundance of mineral composition. SEM and XRF analyses were used to identify the size and shape of mineral grains, to determine mineralogy and elemental composition, and to characterize the pores between mineral grains. The equipment and methods of analyses are described by Marshal and others (1986). SEM magnifications of 10 to 20,000 times were used in order to obtain information on the mineral shape and morphology of the samples. The general composition of the samples was determined by the XRF tool, which measures the energy dispersion of the samples. Mineral identifications were based on the composition and physical properties of the minerals. The SEM and XRF tools can be used to indicate general or relative abundance of mineral content, but the results should not be considered accurate chemical analyses.

In addition, $\mathrm{x}$-ray diffraction techniques, which make use of the crystallographic spacing of minerals, were used to determine the mineralogy of selected samples. Six samples of rock fragments obtained by drilling were crushed, pulverized, and analyzed by powdered x-ray diffraction techniques. Samples for $\mathrm{x}$-ray diffraction were specifically collected from highly altered, fractured, or faulted zones within boreholes whose mineralogy was difficult to distinguish in hand samples. These analyses provide the relative proportion of the minerals in the sample and are quantitative.

\section{Data-Collection Sites and Borehole- Naming Conventions}

Boreholes in the study area were located in order to provide data over various scales. Twentythree boreholes are clustered in two well fields. The boreholes in the well fields are separated by 10 to $40 \mathrm{~m}$. At least one borehole in each well field was drilled to a depth greater than $175 \mathrm{~m}$. The rest of the boreholes in the well fields were drilled to a depth of approximately $75 \mathrm{~m}$ (table 1 ). Seventeen boreholes are areally distributed throughout the subbasin. The areally distributed boreholes were installed in order to define the geology and hydrology on a scale of hundreds of meters; therefore, these boreholes are spaced several hundred meters apart. Locations of boreholes are indicated on figure 1 . These boreholes were drilled to depths of 150 to $305 \mathrm{~m}$, where conditions permitted. In borehole FS5, excessive water production and borehole instability 
(at approximately $64 \mathrm{~m}$ below land surface) prevented drilling the borehole to a depth similar to the other areally distributed boreholes.

In this report, boreholes are referenced by a borehole-numbering system that is unique to this study. Each borehole is classified with a 2- or 3-letter prefix that indicates the landowner, and is followed by a sequential number. The borehole name TR2, for example, was assigned to the second borehole installed on the Town Road property. The prefix "FS" refers to the boreholes that are located on Forest Service property; whereas "FSE" refers to a specific location on the Forest Service land called the Forest Service Experimental well field (fig. 1).

The boreholes were also assigned identifiers consistent with the USGS site-identifying system, which is based on latitude and longitude. The 15-digit identification number consists of 6 digits for latitude, 7 digits for longitude, and 2 digits (assigned sequentially) for adjacent sites located in the same 1-squaresecond area. Although this borehole-naming convention is based on latitude and longitude, it should not be used for exact coordinate locations. Exact borehole locations are shown in table 1. Boreholes were located using a Global Positioning System (GPS) (Curtis Crow, U.S. Coast and Geodetic Survey, written commun., 1994) and standard surveying techniques. The northern and eastern locations of boreholes are accurate to within $10 \mathrm{~m}$. In the CO and FSE well fields, one borehole was designated as a datum, and all of the other borehole locations were surveyed relative to that datum to a $30 \mathrm{~cm}$ accuracy. The altitude of the top of casing and land surface were measured to 0.3 to $0.9 \mathrm{~mm}$ accuracy (except for the boreholes noted in table 1) using standard surveying techniques. The altitudes are referenced to local benchmarks that were established by the U.S. Coast and Geodetic Survey.

\section{HYDROGEOLOGIC SETTING}

Complex ground-water-flow patterns in the Mirror Lake study area indicate a high degree of interconnection between surface water, unconsolidated deposits, and bedrock (Winter, 1984). The flow patterns also indicate the flow system is highly heterogeneous, and the flow is predominantly controlled by (1) topography, (2) the presence of surface-water bodies, which act as sinks, and (3) the extent and permeability of overburden deposits (Harte and Winter, 1994).
The transmissive properties of the bedrock are primarily controlled by fractures. The hydraulic conductivity of the fractures is much greater than the hydraulic conductivity of the matrix. Hence, ground water is stored and transmitted primarily through the fractures. The bedrock aquifer in the Mirror Lake study area is typical of most crystalline-rock aquifers, which are characterized by a low primary porosity and low hydraulic conductivity. The primary porosity, measured in 20 samples of granite from the Mirror Lake area, ranged from 1.07 to 2.32 percent and had a mean value of 1.46 percent (Wood and others, 1996). Results of detailed hydraulic testing of boreholes indicate a high degree of areal and vertical variation in hydraulic properties. Results of hydraulic testing indicate that the hydraulic conductivity of fractures measured over discrete (3-5 m) intervals ranges over six orders of magnitude (Hsieh and Shapiro, 1996).

Because most of the flow is through the fractures, it is necessary to characterize the geometry of the fracture system in the subsurface. The parameters that are frequently used to describe the fractures-location, orientation, aperture, length, connectedness, and properties of the adjacent rock (Barton and Hsieh, 1989, and Long and others, 1992) - can be collected in boreholes. The next step, which is beyond the scope of this report, is to relate these geologic and geometric data to the hydraulic properties in boreholes.

\section{Bedrock Geology}

The Mirror Lake study area lies in the Gander terrane, one of three litho-tectonic terranes in New Hampshire (Boudette, 1990). This region is also assigned to the central Maine terrane (Eusden and Lyons, 1993) and to the Kearsarge-central Maine synclinorium (Lyons and others, 1982), which was formerly referred to as the Merrimack synclinorium by Billings (1956). These various names refer to a northeast-tending belt or region that is comprised of clay-rich sediments that were eroded from the Bronson Hill anticlinorium and deposited in a basin during the Silurian and Devonian. The sediments were subsequently metamorphosed and deformed during the Acadian orogeny and possibly the Alleghanian orogeny. The bedrock has undergone multiple deformations, leaving it complexly folded, fractured, and intruded by igneous rocks. Four phases 
of deformation and four phases of folding have been recognized to the north (Eusden and Lyons, 1993) and to the southeast (Eusden and others, 1987). Thompson and others (1993) and Eusden and Lyons (1993) provide a detailed history of structural deformation in the central Maine terrane. The general history of structural deformation includes large-scale folding and faulting, the formation of nappes, and doming of preexisting structures. Partial melting of pre-existing rocks formed migmatites and caused anatectic granites, generally in sheet-like tabular bodies, to be injected into the stratigraphic layers of the metasediments.

The local stratigraphy of the Woodstock quadrangle and the Mirror Lake area, which was mapped by Lyons and others (1997), is predominantly the Silurian Rangeley Formation. The Rangeley here is a pelitic schist of sillimanite-grade metamorphism (Lyons and others, 1997). These metasedimentary rocks, which were previously assigned to the Devonian Littleton Formation by Billings (1955), have been reinterpreted and reassigned to the lower and upper parts of the Rangeley Formation, and are considered to be 438-428 Mega-annum (Ma).

Folding, faulting, metamorphism, and igneous intrusions associated with the Acadian and possibly Alleghanian orogeny have resulted in a complex distribution of lithology and fractures. The variability and complexity of the rock types that are exposed on the highway outcrop are shown in figure 3 . The host rock was intruded by granitoids (felsic igneous intrusions), pegmatites, and diabase. The granitoids in the eastern part of the study area are predominantly anatectic, two-mica granite of the Devonian Concord Granite (370-365 Ma) (Armstrong and Boudette, 1984; Lyons and others, 1997). The granitoids also include gneissic textured Bethlehem Granodiorite (Lyons and others, 1997), which was previously referred to as Bethlehem Gneiss (Billings, 1956).

In parts of the area west of Norris Brook, (fig. 2) the granitoids are typically Kinsman Granodiorite (Barton, 1997). Partial melting of the country rocks has resulted in migmatite gneisses, which are found throughout the study area. Pegmatites and aplites (likely differentiates of the granitoids) are intruded into the metasediments and the granitoids (Olson, 1941). The diabase dikes of Middle-Jurassic through Early Cretaceous age (190-95 Ma) (McHone, 1984) are found cross-cutting all other rock units.

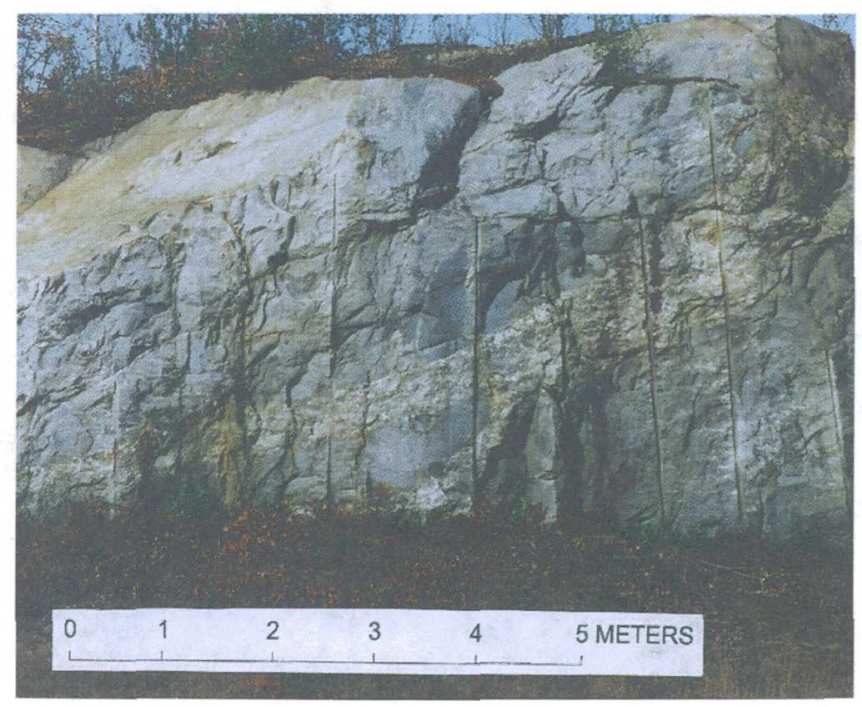

Figure 3. Bedrock in highway outcrop near Mirror Lake in Grafton County, New Hampshire.

McHone (1984) mapped Mesozoic dikes in the northeastern Appalachians, and provided age, composition relations, and the implied history of stress field rotation. Paleostress fields, which McHone (1984) determined relative to the orientation of Mesozoic dike intrusion controlled the orientation of dike and sill emplacement. These fields were similar to the results of a detailed study of brittle deformation by Hardcastle and Albaugh (1990). Hardcastle and Albaugh (1990) analyzed 3,000 mineralized fractures, veins, and dikes, which formed as a result of continental rifting and tectonism in the northeastern Appalachians. These data were used to determine the chronology and implied stress fields during the Mesozoic.

The current ambient stress field is the result of the combination of contemporary tectonic stress and local stresses, such as unloading. Work completed by Borchers and others (1993) and Zoback and Zoback (1989) indicates a correlation between the contemporary stress field and the anisotropy of fracture permeability, with the most open fractures being perpendicular to the minimal stress component. There appears to be some variability in the measurements of the orientation of the current stress field in New England (Gephart and Forsyth, 1985; Zoback and Zoback, 1989). The current state-of-stress has not been measured locally. Plumb and others (1984), however, report the orientation of near-surface maximum compressive stress in New Hampshire is $\mathrm{N} 50^{\circ} \mathrm{E} \pm 33^{\circ}$, based on a statistical analysis of existing stress data. 


\section{Surficial Geology}

Approximately 97 percent of the bedrock are overlain by Wisconsinian-age unconsolidated glacial deposits characterized by sandy, silty till with some stratified drift deposited in ice-contact, outwash, and alluvium deposits. Till typically ranges from 0 to $10 \mathrm{~m}$ thick, but in the topographic saddle or ridge northwest of Mirror Lake near borehole TR2, it is as much as $50 \mathrm{~m}$ thick. This sandy till is predominantly ablation till (Carl Koteff, U.S. Geological Survey, oral commun., 1995). The most permeable stratified drift is located in a valley south of Mirror Lake (Winter, 1984) and in the Pemigewasset River Valley (Cotton and Olimpio, 1996). The extent, location, and hydraulic conductivity of stratified-drift deposits in the study area greatly affect the recharge from the overburden to bedrock aquifers (Harte, 1992).

During Pleistocene glaciation, ice sheets scoured the bedrock surface removing weathered bedrock and soils. The bedrock was subsequently covered by glacial deposits. Isolated exposures of saprolite, formed from small pockets of soil and weathered bedrock that were not glacially removed, have been identified in isolated outcrops throughout New Hampshire (Goldthwait and Kruger, 1938). Saprolite, however, was neither identified in boreholes drilled as part of this study nor observed in the shallow boreholes that were drilled through the overburden in a related study in the Mirror Lake area (Harte, 1997).

\section{DETECTION OF WATER-BEARING ZONES AND ESTIMATION OF DRILLERS' YIELD AND WATER LEVELS IN BOREHOLES}

The methods and tests described in this section are used routinely by well drillers and hydrogeologists in New England to identify water-bearing zones and estimate yield. Measurements made at the time of drilling, are considered to be "quick and dirty" estimates of hydraulic properties of boreholes. These measurements can be compared to the detailed and precise measurements of flow and hydraulic properties determined from discrete-interval hydraulic and tracer tests, pumping tests, and borehole flowmeter surveys.

\section{Water-Bearing Zones Identified in Boreholes During Drilling}

Boreholes were identified during drilling, as boreholes usually have one or two water-bearing zones that can be identified in the drilling process. Water-bearing (and water-yielding) zones that were identified during the drilling generally were confirmed later by borehole flowmeter and hydraulic testing. These geophysical and hydraulic borehole techniques, however, are capable of identifying other zones that have much lower permeability than can be detected in the drilling process. Comparison of water-bearing zones detected during drilling and the results of flowmeter logging for selected boreholes is shown in figure 4. The flowmeter $\log$ for R1 (fig. 4a) indicates 3 inflow zones, at depth intervals 20.7 to $24.7 \mathrm{~m}, 33.5$ to $39.0 \mathrm{~m}$, and 45.7 to $50.3 \mathrm{~m}$. These inflow zones also were detected while drilling this borehole, as noted in the figure.

There are some limitations to the identification of water-bearing zones during drilling. The detailed flowmeter log for IS1 (fig. 4b) indicates inflow zones at 24, 30, 111, and $124 \mathrm{~m}$ depth. These zones coincide with the major water-bearing zones that were identified while drilling ( $24 \mathrm{~m}, 111 \mathrm{~m}$, and $124 \mathrm{~m}$ ). These three zones are noted on the right side of figure $4 \mathrm{~b}$ with arrows. Although a fracture at $29.5 \mathrm{~m}$ was identified during drilling, it did not produce additional water. The zones at 111 and $124 \mathrm{~m}$ were high yielding zones that were estimated at 75 and $375 \mathrm{~L} / \mathrm{min}$, respectively. A fracture below these flowing zones would have to add a significant amount of flow in order to be detected during drilling. This method is effective only for identifying the major water-bearing zones in a borehole if they significantly increase the flow. This method is not effective in boreholes that have extremely low yield. The flowmeter $\log$ for FSE12 indicates an inflow zone at a depth of $56 \mathrm{~m}$. Inflow zones were not observed while drilling FSE12, however, and the estimated welldriller's yield was $2.8 \mathrm{~L} / \mathrm{min}$. FSE12 is an example of the limitation of this method and indicates that specialized tools, such as a borehole flowmeter, are required for the detection and measurement of all water-bearing zones in boreholes. 
(a) R1

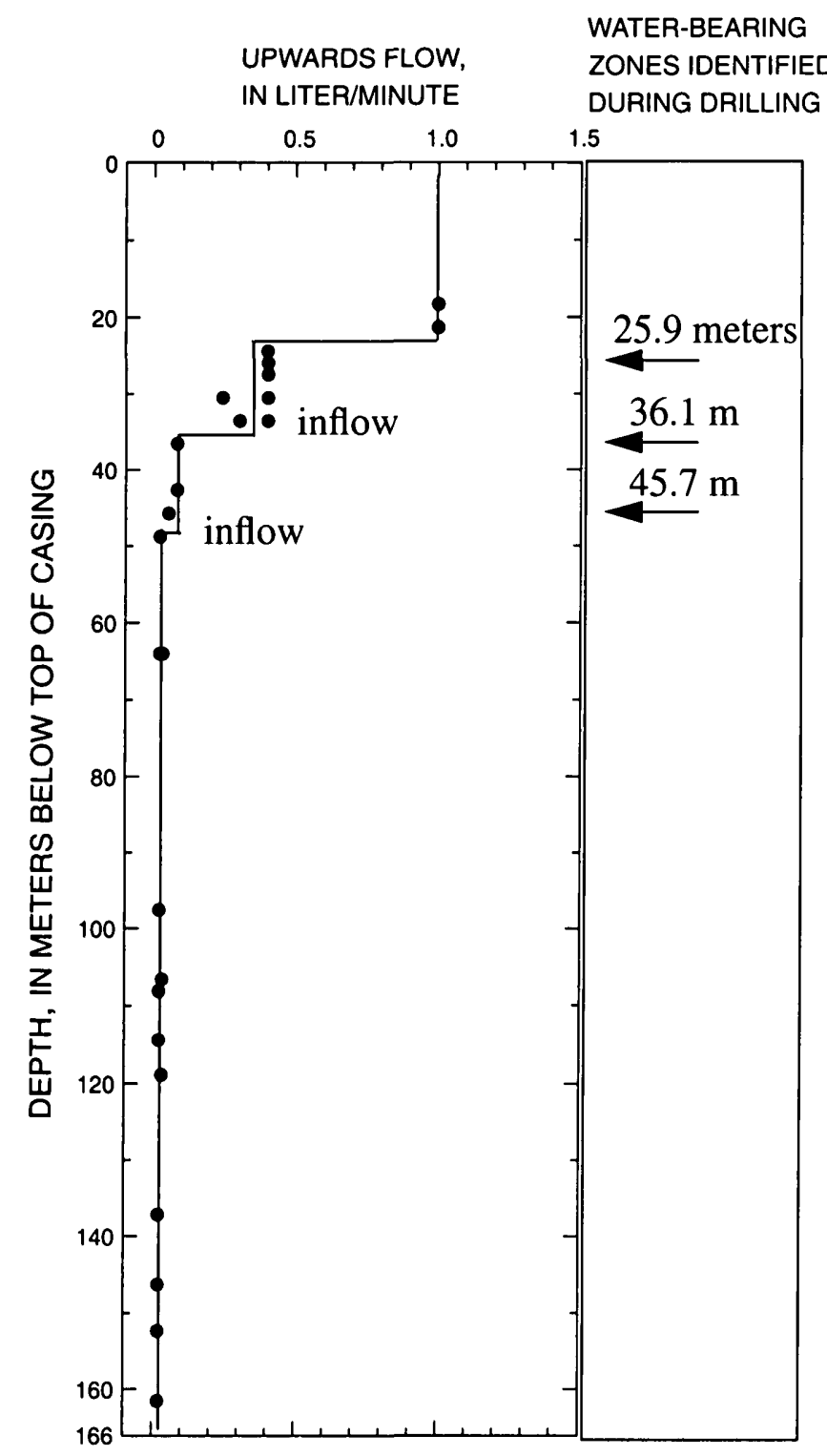

(b) IS1

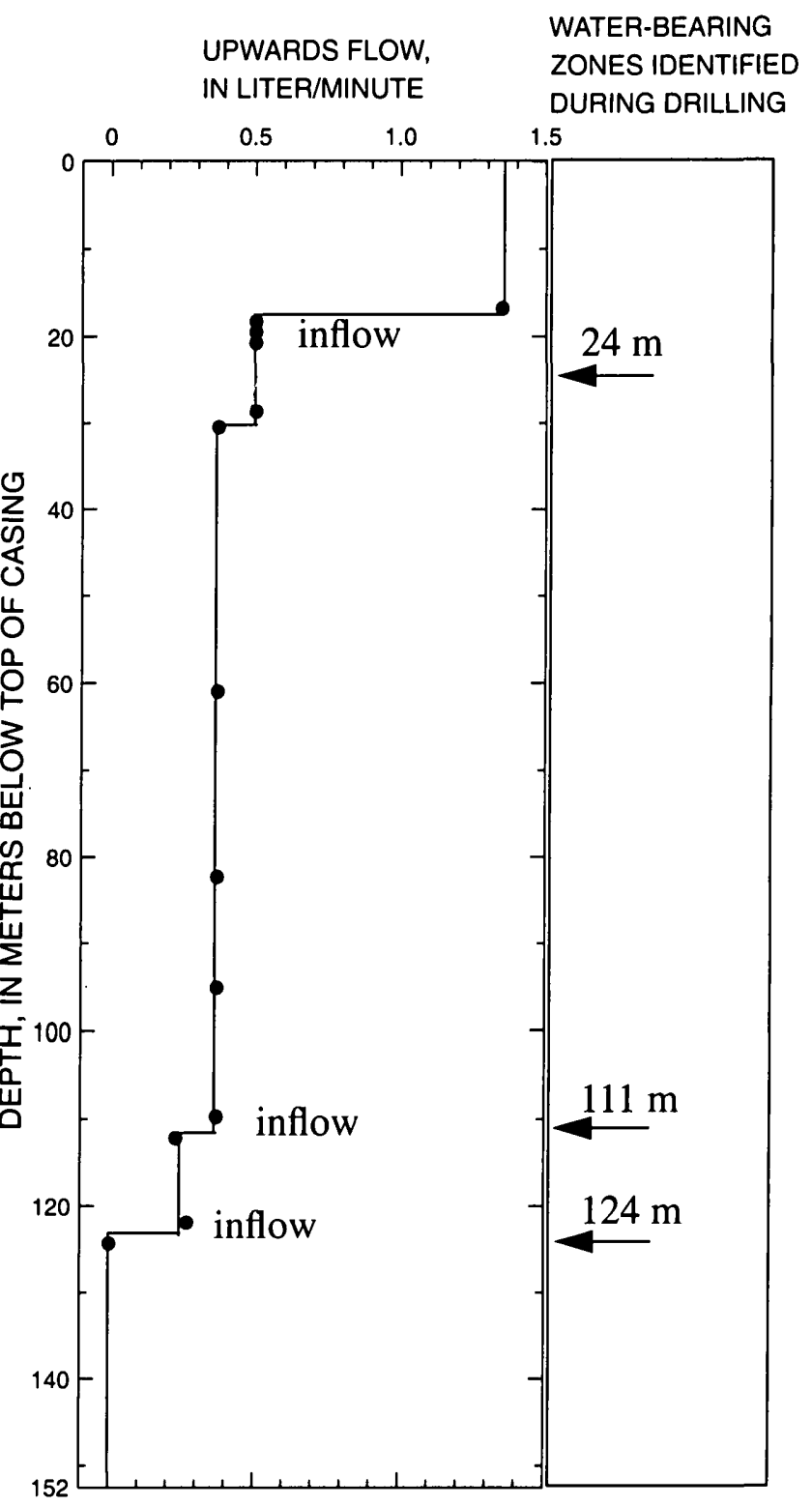

Figure 4. Comparison of flowmeter logs that show upward vertical flow in boreholes R1 (4a) and IS1 (4b) under pumping conditions with water-bearing zones that were identified while drilling the boreholes near Mirror Lake in Grafton County, New Hampshire.

\section{Drillers' Yield}

Once the borehole was drilled to the final depth, compressed air was used to remove residual rock fragments and particles from the borehole. The boreholes were only minimally developed. The duration of borehole development varied from $15 \mathrm{~min}$ to 1 hour. Estimates of the total yield of the borehole were made during and after development.

The drillers' yields ranged from less than $2.84 \mathrm{~L} / \mathrm{min}$ to greater than $378.48 \mathrm{~L} / \mathrm{min}$ for the boreholes (table 2). The depths of these boreholes ranged from 61 to $305 \mathrm{~m}$ below land surface. Drillers' yields from boreholes in the study area were compared to yields obtained throughout Grafton County and were found to be similar (Joseph Olimpio, U.S. Geological Survey, written commun., 1996). For this analysis, all boreholes with known yield, diameter, date drilled, depth to water, and total depth were used. The Wilcoxon-Mann-Whitley test was used to compare the two data sets of yield values. 
Table 2. Water levels and well-drillers' estimates of yield in boreholes installed near Mirror Lake in Grafton County, New Hampshire

[All length measurements are in meters. Altitudes are above sea level. Depths are below land surface. --, no data; + , indicates water level is above top of casing (flowing); , indicates approximation]

\begin{tabular}{|c|c|c|c|c|}
\hline \multirow{2}{*}{$\begin{array}{c}\text { Well name } \\
\text { (fig. 1) }\end{array}$} & \multicolumn{2}{|c|}{ Altitude of } & \multirow{2}{*}{$\begin{array}{l}\text { Depth to } \\
\text { water level }\end{array}$} & \multirow{2}{*}{$\begin{array}{l}\text { Yield, in } \\
\text { liters/minute }\end{array}$} \\
\hline & $\begin{array}{l}\text { Top of } \\
\text { casing }\end{array}$ & $\begin{array}{l}\text { Water } \\
\text { level }\end{array}$ & & \\
\hline $\mathrm{CO} 1$ & 217.69 & 215.83 & 1.86 & -- \\
\hline $\mathrm{CO} 2$ & 216.87 & 215.75 & 1.12 & -- \\
\hline $\mathrm{CO} 3$ & 215.41 & 214.86 & 0.55 & $56.7-75.7$ \\
\hline $\mathrm{CO} 4$ & 216.11 & 213.83 & 2.28 & 7.57 \\
\hline $\mathrm{CO} 5$ & 217.38 & 215.59 & 1.79 & 18.92 \\
\hline $\mathrm{CO} 6$ & 217.37 & 217.37 & 0.00 & 7.57 \\
\hline $\mathrm{CO} 7$ & 215.92 & 214.33 & 1.59 & 7.57 \\
\hline $\cos$ & 217.83 & 214.79 & 3.04 & 35.95 \\
\hline $\mathrm{CO} 9$ & 217.85 & 215.28 & 2.57 & 7.57 \\
\hline $\mathrm{CO} 10$ & 215.78 & +215.78 & Flow & 13.25 \\
\hline CO11 & 225.74 & 218.88 & 6.86 & 11.35 \\
\hline FS1 & 261.88 & 255.88 & 6.00 & 45.42 \\
\hline FS2 & 255.71 & 241.56 & 14.15 & -- \\
\hline FS3 & 274.45 & 267.28 & 7.17 & 56.77 \\
\hline FS4 & 350.50 & 394.04 & 1.46 & 13.25 \\
\hline FSE1 & 240.20 & 233.79 & 6.41 & 15.14 \\
\hline FSE2 & 241.06 & 233.28 & 7.78 & 3.78 \\
\hline FSE3 & 241.01 & 233.62 & 7.39 & 2.84 \\
\hline FSE4 & 241.26 & 233.73 & 7.53 & -- \\
\hline FSE5 & 242.36 & 233.74 & 8.62 & 7.57 \\
\hline FSE6 & 242.88 & 235.20 & 7.68 & 30.28 \\
\hline FSE7 & 242.31 & 233.11 & 9.20 & 6.62 \\
\hline FSE8 & 242.27 & 235.06 & 7.21 & 3.57 \\
\hline FSE9 & 242.82 & 235.12 & 7.70 & 22.71 \\
\hline FSE10 & 244.33 & 235.51 & 8.82 & 3.78 \\
\hline FSE11 & 242.59 & 235.03 & 7.56 & 22.71 \\
\hline FSE12 & 243.71 & 235.51 & 8.20 & 2.84 \\
\hline FSE13 & 240.61 & 234.97 & 5.64 & 22.71 \\
\hline $\mathrm{H} 1$ & 232.15 & 217.58 & 14.57 & 2.84 \\
\hline IS1 & 224.67 & 218.30 & 6.37 & $283.9-378.5$ \\
\hline $\mathrm{K} 1$ & 215.40 & 213.57 & 1.83 & -- \\
\hline $\mathrm{K} 2$ & 215.18 & 211.28 & 3.90 & - \\
\hline K3 & 209.28 & 207.45 & 1.83 & -- \\
\hline R1 & 256.67 & 249.69 & 6.98 & 30.28 \\
\hline $\mathrm{T} 1$ & 229.08 & 224.85 & 4.23 & 37.85 \\
\hline TR1 & 249.29 & 228.44 & 20.85 & -- \\
\hline TR2 & 232.94 & 232.94 & 0 & 30.28 \\
\hline FS5 & $\sim 499.2$ & 499.20 & 0 & 378.48 \\
\hline FS6 & $\sim 243.8$ & 237.97 & 5.83 & 45.42 \\
\hline RR1 & $\sim 184.4$ & 181.11 & 3.29 & 9.46 \\
\hline
\end{tabular}

\section{Water Levels in Boreholes}

The water levels listed in table 2 were measured after drilling the boreholes and represent a hydraulic head value for the entire open hole. Typically, the water levels are in the steel casing. In a few boreholes, the water level is above the land surface or even above the casing, which results in a flowing borehole. The static water levels in boreholes CO3, CO6, FS5, and FS4 are above the land surface, and TR2, FS6, and CO10 flow during most of the year. The water levels in table 2 were obtained as part of a long-term waterlevel monitoring program (Richard L. Perkins, U.S. Geological Survey, written commun., 1995). The water levels were measured after the boreholes recovered from the hydraulic stresses of borehole drilling and before pneumatic packers were installed for multi-level water-level monitoring.

\section{CHARACTERIZATION OF LITHOLOGY AND FRACTURES}

A detailed description of rock units observed in outcrop and in the subsurface is provided in this section. The rocks exposed in the highway roadcut are generally similar to the rocks in the boreholes. The roadcut obviously provides a better opportunity to view the rocks than does a borehole that measures about $15 \mathrm{~cm}$ in diameter. Geologic names were not assigned to the rocks in the boreholes but the schists probably correspond to the metamorphic rocks of the Silurian-age Rangeley Formation (Lyons and others, 1997). The granite is most likely anatectic, two-mica granite of the Devonian Concord Granite (Armstrong and Boudette, 1984; Lyons and others, 1982;

J.B. Lyons, Dartmouth College, written commun., 1994). Gneissic textured igneous rocks are likely the Bethlehem Granodiorite (J.B. Lyons, written commun., 1994) or the Kinsman Granodiorite (Barton, 1997). The diabase probably corresponds to the lamprophyric intrusions of Middle-Jurassic through Early Cretaceous age (McHone, 1984).

Studies of fractures in the highway rock outcrop (fig. 3 ) indicate that the fractures in granite are more numerous, more planar, and are shorter than the fractures observed in the metasedimentary rocks (Barton, 1996). Additional work, perhaps employing the method of Terzaghi (1965), would be required to determine if the fracturing observed in the boreholes is similar to the fractures investigated in the highway outcrop. The Terzaghi method accounts for the vertical bias of the fracture sampling that is inherent in vertical to near vertical boreholes. 


\section{Description of Rock Units in the Study Area}

Six major rock types, including schist, gneiss, granite, pegmatite, diabase, and migmatite, have been identified in the bedrock outcrops, drill cuttings, and borehole video images in the Mirror Lake area. Each rock unit is described in detail in this section. The rock units are distinguished by their color, texture, form, contact relations, and mineralogy. A view of the bedrock outcrop in the exposure along the highway is shown in figure 3.

\section{Schist, Gneiss and Migmatite}

The schists and gneisses of the Mirror Lake region contain a foliation comprised of biotite, muscovite, and sometimes sillimanite. Some schists exhibit fine banding or thicker felsic layers, augen, and folded foliation. Characteristic features of schist include boudins, coticule layers, and layers of quartzite and calc-silicate. Layers of fine-grained quartz and garnet, which are referred to as coticule, and impure quartzite layers, which consist of quartz, garnet, diopside, chlorite, and amphibole, are locally abundant in the schist. Petrographic analyses of schist samples from the highway outcrop and rock chips obtained by drilling indicate that the schists are comprised of biotite, muscovite, quartz, and plagioclase with lesser amounts of garnet, ilmenite, zircon, monazite and pyrite (tables 3 and 4). In table 4, minerals that were identified in the sample are denoted with an "X." The relative elemental compositions are shown for selected minerals. The elemental compositions are listed in decreasing proportions below the "X."

The schists are gray to brownish black with some zones that are green, yellow, or white. In borehole video images, the coarse-grained biotites and muscovites reflect the downhole illumination and appear shiny, whereas fine-grained schists appear dark. The schists exhibit moderately to highly schistose foliation. Compositional layering in the schists, where present, is usually less than $2.5 \mathrm{~cm}$ in thickness. The schist locally grades to gneiss, which is very coarse grained (with individual grains measuring 1 to $2 \mathrm{~cm}$ in length) and exhibits less than 50 percent foliation. The metasedimentary gneiss is overall gray, with alternating bands of white and gray to brownish black layers. The gneisses exhibit compositional banding with quartzo-felsic layering approximately
Table 3. Results of petrographic point-count analysis of selected rock samples from the highway outcrop near Mirror Lake in Grafton County, New Hampshire

[S indicates schist; $\mathrm{G}$ indicates granite; and $\mathrm{P}$ indicates pegmatite; --, no data]

\begin{tabular}{|c|c|c|c|c|c|c|}
\hline \multirow[b]{2}{*}{ Sample } & \multicolumn{6}{|c|}{$\begin{array}{c}\text { Mineral composition } \\
\text { (percent) }\end{array}$} \\
\hline & Quartz & $\begin{array}{c}\text { Plagio- } \\
\text { clase }\end{array}$ & $\begin{array}{l}\text { Musco- } \\
\text { vite } \\
\text { and } \\
\text { sericite }\end{array}$ & Biotite & Garnet & Opaques \\
\hline \multicolumn{7}{|l|}{ SCHIST } \\
\hline S1 & 10 & 5 & 20 & 60 & None & Some \\
\hline S1-2 & 10 & 10 & 20 & 60 & Some & Some \\
\hline $\mathrm{S} 1-3$ & 25 & 15 & 20 & 40 & Some & Some \\
\hline \multicolumn{7}{|c|}{ GRANITOIDS } \\
\hline $\mathrm{G} 2$ & 20 & 15 & 25 & 30 & Some & None \\
\hline G2-1 & 60 & 10 & 15 & 15 & Some & None \\
\hline G2-2 & 50 & 20 & 10 & 20 & Some & Few \\
\hline G2-3 & 30 & 25 & 20 & 20 & Few & None \\
\hline G3-1 & 25 & 20 & 15 & 40 & Some & Some \\
\hline G5 & 20 & 20 & 30 & 30 & Some & None \\
\hline \multicolumn{7}{|c|}{ PEGMATITE } \\
\hline P2 & 25 & 40 & 30 & -- & Some & Few \\
\hline
\end{tabular}

1 to $25 \mathrm{~cm}$ wide with 1 to $5 \mathrm{~cm}$ wide foliated, biotiterich layers. In general, the schists and gneisses exhibit more foliation than the granites and are darker.

Partial melting of the sedimentary rocks in the study area has produced migmatite and migmatitic gneiss (Winkler, 1979; Allen, 1992; and Dougan, 1981). Migmatites are generally grayish in color. They appear to be a swirly, layered mixture of granitic-looking and schistose-looking units. The felsic-rich granitic layers, which are referred to as leucosomes, were melted and recrystallized. The darker, biotite-rich layers, which were not completely melted, are called melanosomes. Migmatites sometimes exhibit gradational contacts with schist and pegmatite. At outcrop scale, migmatites are frequently ignored and are mapped as part of the adjacent non-migmatized unit. At the scale of a borehole, the view of the rocks surrounding the borehole is limited. Hence, when migmatites were identified in the boreholes, they could not be grouped with the adjacent rock units and were noted in the characterization of the subsurface lithology. 


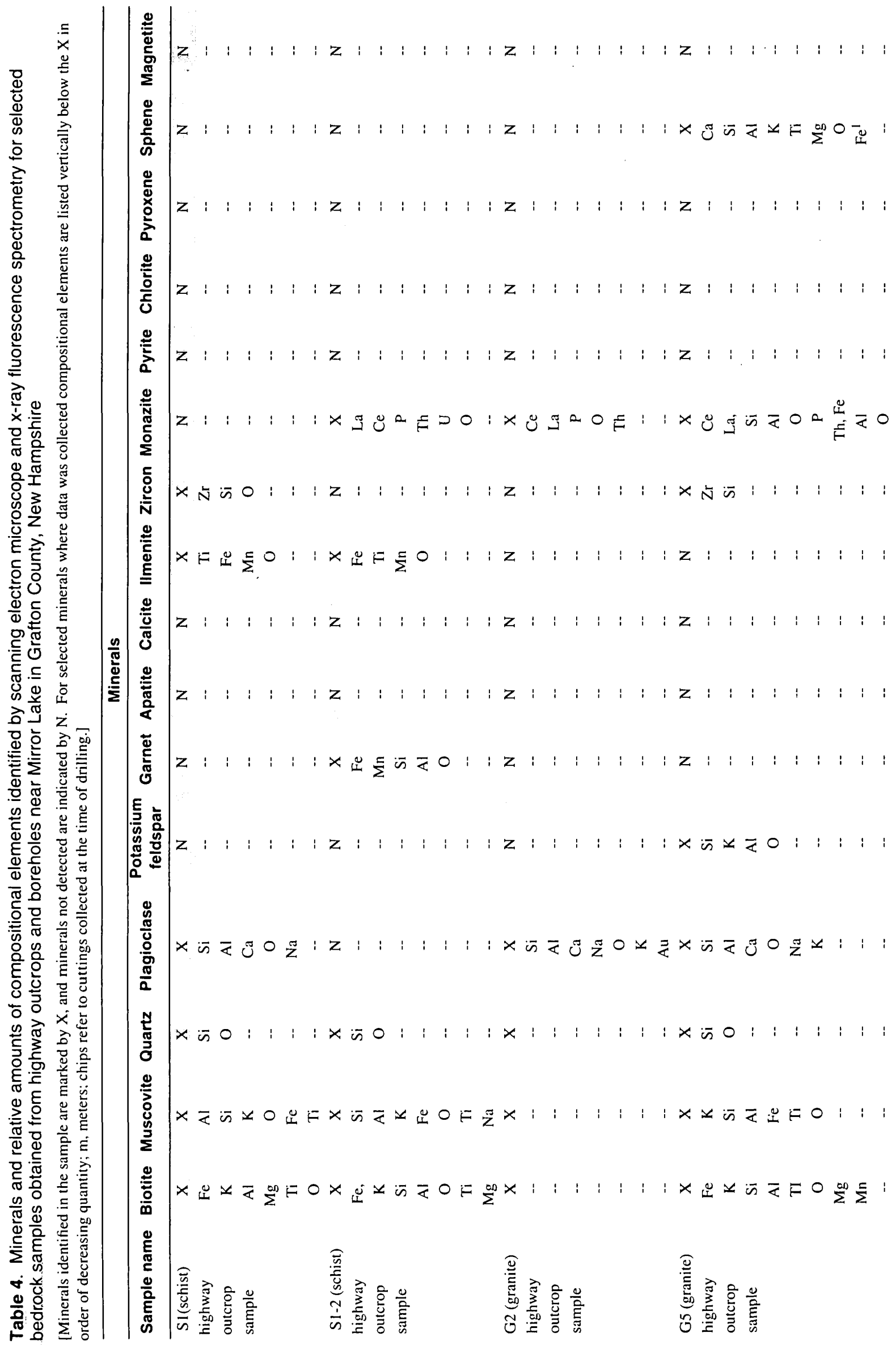

18 Lithology and Fracture Characterization From Drilling Investigations in the Mirror Lake Area, Grafton County, New Hampshire 


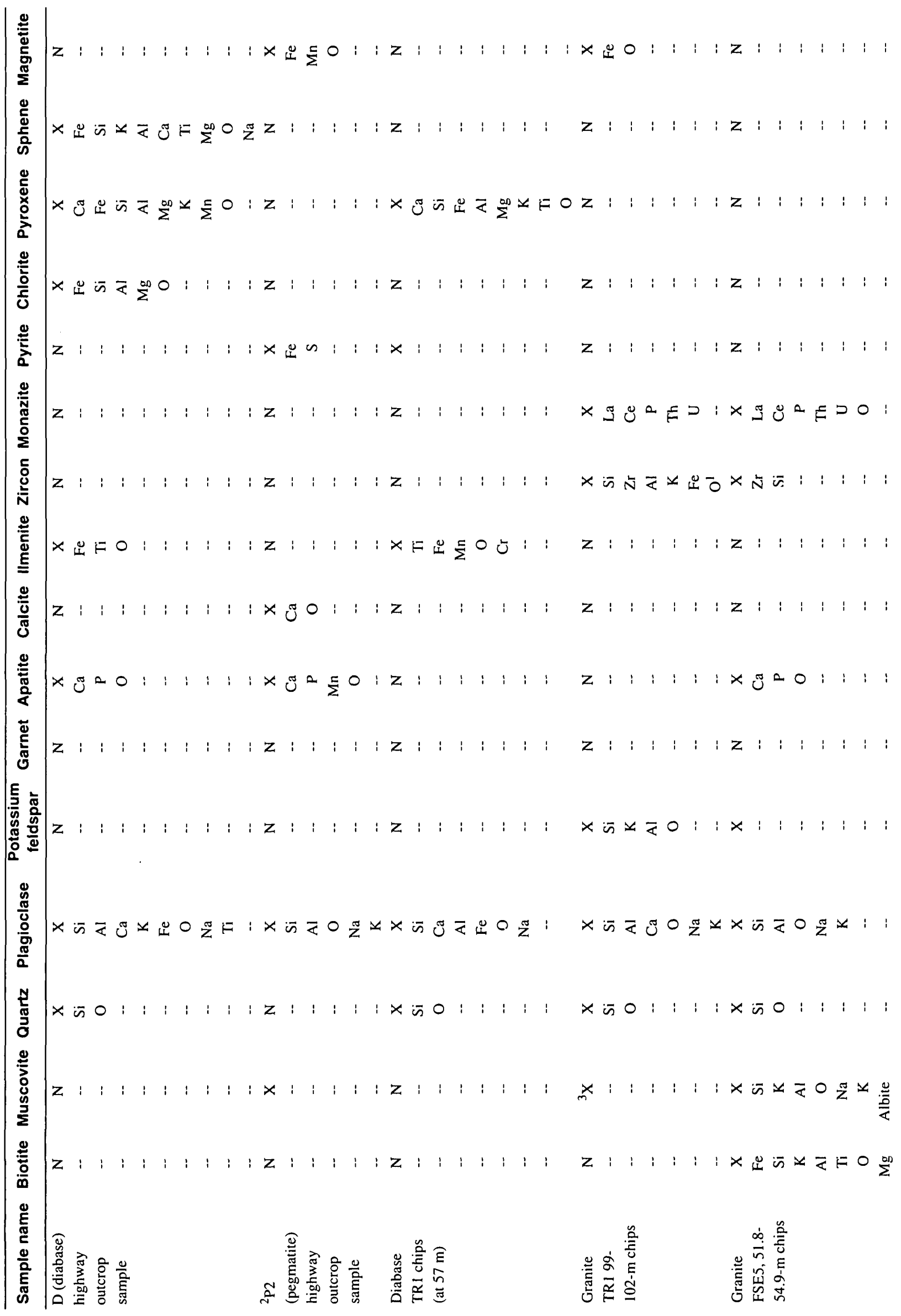




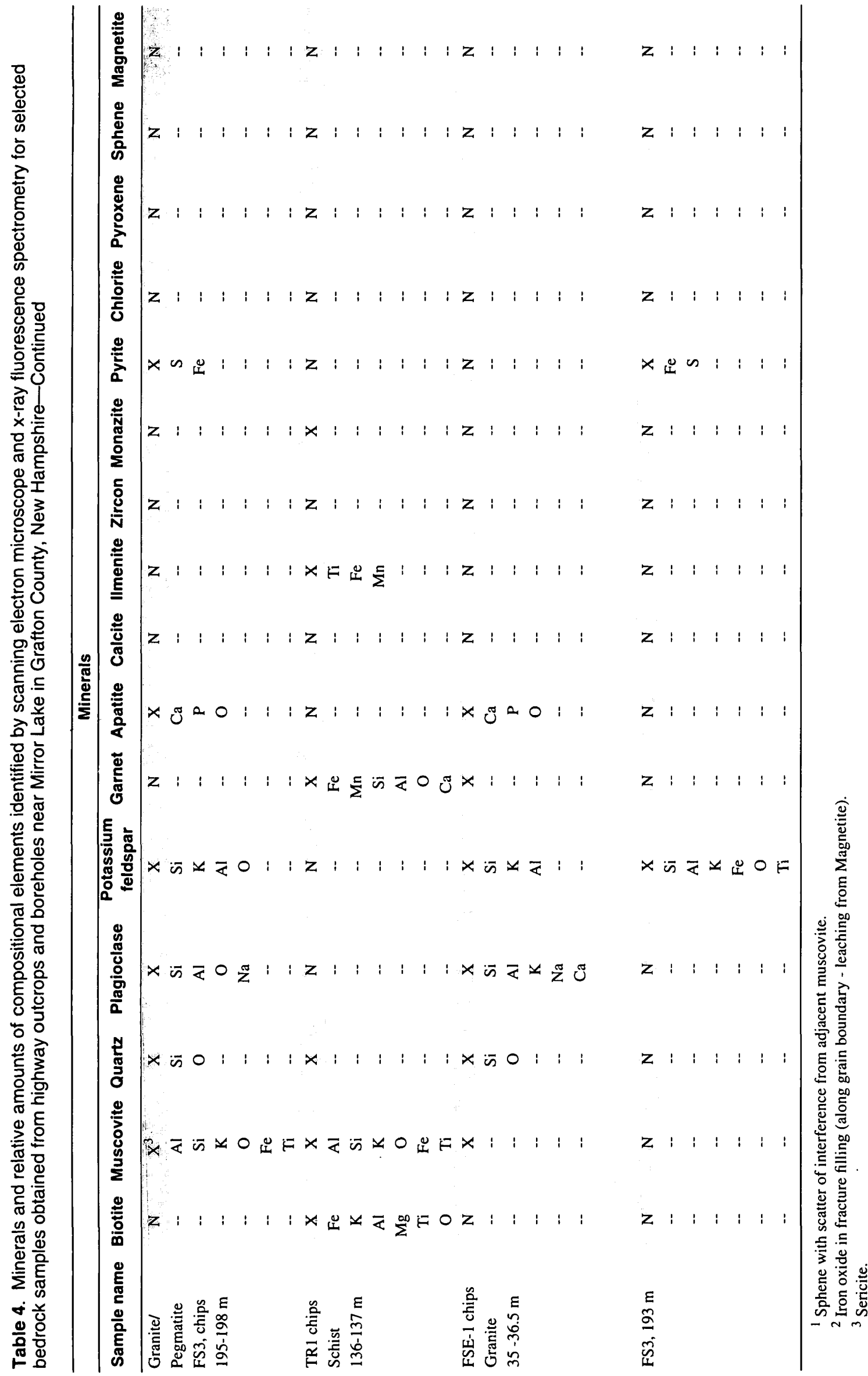

20 Lithology and Fracture Characterization From Drilling Investigations in the Mirror Lake Area, Grafton County, New Hampshire 


\section{Granitoids: Granites and Igneous Gneisses}

Granitoids in the study area include the Concord Granite, Bethlehem Granodiorite, and Kinsman Granodiorite (Lyons and others, 1997). These rocks are all igneous intrusions. They are distinguished by their composition and texture. The Concord Granite is a two-mica granite that typically exhibits an equigranular, hypidiomorphic-granular, sugary, fine-to-coarsegrained texture. The composition of the two-mica granite ranges from granite to quartz-monzonite and locally to tonalite. Two-mica granites are generally leucocratic, creamy white to gray with an occasional greenish tinge. These anatectic granites, derived from the melting of pre-existing rocks, were injected into the overlying host rocks. Commonly two-mica granites are found in sheet-like, tabular bodies that have been intruded along preferred zones of weakness that conform to the fabric of the host rock. These tabular bodies occasionally exhibit weak foliation comprised of biotite and muscovite, and sometimes contain strongly foliated biotite schlieren, which are oriented parallel to major structural features in the host rock (Armstrong and Boudette, 1984).

The two-mica granites typically contain quartz, feldspar, microcline, oligoclase, biotite, muscovite, and sometimes chlorite replacing biotite. Petrographic analysis indicates that the two-mica granites are devoid of amphiboles and magnetite. Tables 3 and 4 show that the granitoids include accessory minerals of garnet, pyrite, and apatite. They also contain trace amounts of zircon, monazite, and rarely sphene. Rock samples and borehole images reveal textural and compositional variations in the two-mica granite that produce variations in color and fabric of the rock. The two-mica granite is locally aplitic and grades into gneissic migmatite.

The Kinsman Granodiorite and Bethlehem Granodiorite are strongly foliated igneous gneisses (orthogneisses) that have been assigned to the New Hampshire Plutonic Suite (Lyons and others, 1997). The Kinsman Granodiorite is a porphyritic granodiorite that has a dark-gray matrix and felsic (usually orthoclase) phenocrysts. It ranges in composition from tonalite to granite and contains potassium feldspar and garnet phenocrysts in a matrix comprised of plagioclase, microcline, quartz, biotite, and muscovite. It often contains inclusions of the country rock as xenoliths. The composition of the Bethlehem gneiss ranges from granite to tonalite. It is a coarse-grained, gray unit that contains quartz, plagioclase, microcline, biotite, muscovite, and garnet. The gneiss is strongly foliated and conformable with the foliation of the surrounding country rocks.

Granitoids of this area, including the two-mica granites, Bethlehem Granodiorite, and Kinsman Granodiorite, exhibit moderate to high concentrations of uranium (Lyons, 1964; Gunderson and Schurmann, 1993) and are considered to be potential sources of radon. The SEM and XRF analyses (table 4) indicate that the sources of uranium and thorium are the rareearth element phosphates such as allanite and monazite. In general, the granitoids have higher radioactivity than the schists (Olson and Overstreet, 1964; Gunderson and Schurmann, 1993). This is also confirmed by a comparison of natural-gamma emissions (Paillet, 1985) and rock types in the boreholes at Mirror Lake.

Granite dikes observed in the highway outcrop vary in strike from $\mathrm{N} 32^{\circ} \mathrm{E}$ to $\mathrm{N} 78^{\circ} \mathrm{E}$ and dip from $56^{\circ} \mathrm{E}$ to $59^{\circ} \mathrm{NW}$ (Barton, 1996). In the boreholes in the $\mathrm{CO}$ well field, which is near the highway outcrop, granite dikes ranged in strike from $\mathrm{N} 25^{\circ} \mathrm{E}$ to $55^{\circ} \mathrm{E}$ and dipped 20 to $70^{\circ} \mathrm{NW}$ (Johnson, 1998).

\section{Pegmatites and Aplites}

Pegmatites are characterized by their coarsegrained texture and are generally felsic and are light in color. Large individual crystals (4 cm in diameter) of muscovite, biotite, feldspar, and quartz were observed in video images. Pegmatite frequently occurs in sheetlike, tabular bodies (dikes or sills) that are parallel to the foliation of the host rock. Pegmatites are also characterized as irregular shaped masses, lenses, and pods. Pegmatites and aplites observed in the highway outcrop vary in orientation from $\mathrm{N} 09^{\circ} \mathrm{E}, 34^{\circ} \mathrm{SE}$ to $\mathrm{N} 68^{\circ} \mathrm{E}, 48^{\circ} \mathrm{SE}$ (Barton, 1996).

Pegmatite was easily identified in the drill cuttings and in the borehole-video surveys by the characteristically large mica flakes (biotite or muscovite) and felsic minerals. Petrographic analyses indicate pegmatite is comprised mostly of albitic feldspar, microcline, muscovite, quartz, biotite, garnet and trace sphene, magnetite, sulfide minerals, monazite, and (or) allanite. Feldspar is frequently altered to sericite, which is a white, fibrous mica formed during retrograde metamorphism. 
Locally, pegmatites correspond to high-gammaactivity counts that are observed in natural-gammaradiation surveys in boreholes (Paillet, 1985; Paillet and Kapucu, 1989). These gamma-photon emissions are likely caused by the radioactive decay of potassium $\left({ }^{40} \mathrm{~K}\right)$ in biotites and by radioactive decay of uranium and thorium in the rare-earth element phosphate minerals. The biotites that were observed in the thin-section samples exhibited zone damage from radioactive decay. These observations are consistent with Gunderson and Schurmann (1993) and Lyons (1964) who noted that the pegmatites associated with two-mica granites often had the highest uranium content and radioactivity in the state. The fact that high counts of gamma-photon emissions come from granitoids and pegmatites should be considered when using natural gamma surveys to interpret lithology. The surveys should be used in conjunction with rock cuttings or video surveys in order to avoid inaccurate interpretations.

Aplites have the same mineralogic composition as pegmatites; however, they have a much finer grained texture, which is characterized as an allotriomorphic-granular, or sugary texture. Aplite is generally observed in the highway outcrop and in boreholes cutting pegmatites, granitoids, and metasediments.

Pegmatites and aplites are not abundant in the study area. They comprise less than 5 percent of all of the rocks in the 15 index boreholes. Frequently, pegmatites intruded granitoids rather than the metasediments rocks. The pegmatites and aplites seen in the boreholes varied in size and width. Aplites generally form in sheets or veins that are a few centimeters wide; whereas pegmatites range in width from a few centimeters to several meters. Pegmatites are typically less than 1 meter wide and occur over a range of depths. A massive pegmatite, which extends vertically over several meters, was identified in the FSE well field and in FS6 and RR1. Some pegmatite dikes observed in the borehole images and in the highway outcrops show arrangements of minerals by zone. The form and shape of the pegmatites in the study area are generally similar to those observed in Grafton County (Bannerman, 1943; and Olson, 1941).

\section{Diabase Dikes}

Diabase is the least frequently found rock type in the boreholes and in the bedrock outcrops. Diabase dikes were injected into fractures in schist and granitoids resulting in sheet-like tabular bodies. Chill margins along the edges of the diabase dikes and their extremely fine-grained texture indicate rapid cooling of the diabase following injection. Diabase in the boreholes and outcrops cross-cuts the granitoids and schist. Diabase dikes occur in the boreholes over a range of depths, and range from sub horizontal to sub vertical. The diabase exhibits an aphanitic (extremely fine-grained), panidiomorphic-granular matrix. Contacts are sharp and exhibit an extremely fine grained matrix along the margins. The diabase dikes exhibit thermally induced fractures that formed during the cooling process. These thermal joints are numerous but not extensive. Felsic inclusions, including feldspar phenocrysts and cavity fillings, are highly reflective and discernible in video images. A few diabase samples effervesce in hydrochloric acid solution, which indicates the samples contain carbonate minerals. SEM analysis indicates that diabase is comprised of pyroxene, calcic plagioclase, ilmenite, pyrite, chlorite, and sphene (table 4).

\section{Results of X-Ray Diffraction Analyses}

$\mathrm{X}$-ray diffraction analyses were used to determine the mineralogy and rock type of finegrained rock samples that could not be identified in hand-sample analysis. Quantitative x-ray diffraction analyses reveal that the composition of the samples from boreholes FSE5, FSE11, CO5, TR2, and R1 were highly altered and comprised of greater than 95 percent quartz (table 5). The remainder of the sample consisted of plagioclase, illite, and phylosilicates, including muscovite, biotite, phlogopite, clinochlore, and zinnwaldite. The zones represented by these samples appear to be the result of alteration. The fact that quartz remains as a residue indicates normal ground-water removal of feldspars under saturated conditions.

A sample from borehole FS3 had a unique appearance in hand sample and x-ray diffraction analysis. The light-green hand sample with a cementlike matrix with seams of sulfide minerals was collected from the zone in borehole FS3 that collapsed after drilling. This zone, which was not vertically extensive in the borehole, appears to be unique and may be the result of hydrothermal deposits similar to those observed in North Woodstock, N.H. (Cox, 1970). 
Table 5. Results of x-ray diffraction ánalysis of rock samples from selected boreholes near Mirror Lake in Grafton County, New Hampshire

$[--$, no data; $>$, greater than; $<$, less than $]$

\begin{tabular}{llllll}
\hline $\begin{array}{c}\text { Sample } \\
\text { (Well name and depth, in meters, } \\
\text { below top of casing) }\end{array}$ & $\begin{array}{c}\text { Greater than } \\
95 \text { percent }\end{array}$ & & Less than 5 percent of the sample, minerals listed in descending order \\
\cline { 4 - 6 } & Quartz & Muscovite & Phlogopite & Clinochlore & Zinnwaldite \\
(percent)
\end{tabular}

${ }^{1}$ The matrix is the cream colored, clay-like portion of the sample.

${ }^{2}$ The seam is a dark, metallic parting in the sample.

\section{Rock-Core Descriptions}

Rock-core samples were collected from FSE5, located in the FSE well field, $\mathrm{CO}$, located in the $\mathrm{CO}$ well field, and TR2, located just northwest of Mirror Lake, in order to obtain representative samples of the study area. The core samples were collected to provide a verification of the interpretations based on video and rock-cutting analyses. The solid core also provides samples for whole-rock analysis and direct observation of the fracture surfaces. These fracture surfaces can be described for mineralization, roughness, alteration, and staining. An estimate of the dip of each fracture can also be measured directly from the rock core. Each fracture in the core samples from FSE5, CO7, and TR2 is listed in table 6 with the presence of the appropriate characteristics and the measurement of the dip noted.

In total, 99.2 percent of the rock-core was recovered from FSE5. Percent recovery for each run ranged from 96 to 101.6 percent. Approximately $44 \mathrm{~m}$ of solid core was collected over a depth of 17.3 to
$61.4 \mathrm{~m}$ below the top of casing. The angles of fractures observed in the core were measured from the plane perpendicular to the axis of the core, which is assumed to be horizontal. The angles of fracture intersections ranged from 10 to $90^{\circ}$. These angles correspond to downhole measurements of fracture dip, which range from less than $20^{\circ}$ to $65^{\circ}$ (Paillet, 1991). The rock core obtained from borehole FSE5 was a weakly foliated, two-mica granite with several intrusions of pegmatite and aplite.

Interpretations of the lithology of the core samples generally agree with the interpretations based on the analysis of drill cuttings and borehole imaging. A comparison of fractures in borehole FSE5 determined by borehole-imaging methods and coring indicates that approximately 94 percent of the fractures correlated between the two methods. Identification of rock types were also in agreement over approximately 95 percent of the borehole.

A total of $15.2 \mathrm{~m}$ of core was collected from $\mathrm{CO} 7$ at a depth of 6.6 to $21.8 \mathrm{~m}$ below the top of casing. The time for coring a $1.5 \mathrm{~m}$ length of core in 
Table 6. Description of fractures in core samples from boreholes CO7, FSE5, and TR2 near Mirror Lake in Grafton County, New Hampshire

[Depth is in meters below top of casing; $\mathrm{X}$ indicates the presence of a precipitation and (or) alteration; --, no data]

\begin{tabular}{lccccc|}
\hline Well & $\begin{array}{c}\text { Frac- } \\
\text { ture } \\
\text { depth } \\
\text { (meter) }\end{array}$ & $\begin{array}{c}\text { Frac- } \\
\text { ture dip } \\
\text { (degree) }\end{array}$ & $\begin{array}{l}\text { Pre- } \\
\text { cipi- } \\
\text { tate }\end{array}$ & $\begin{array}{l}\text { Alter- } \\
\text { ation }\end{array}$ & $\begin{array}{l}\text { Rock } \\
\text { type }\end{array} \quad$ Comments \\
\hline CO7 & (Core collected from 6.61 to 21.85 $\mathrm{m}$ from the top of casing)
\end{tabular}

$\begin{array}{llllll}6.73 & 14 & -- & -- & \text { Granite } & -- \\ 6.91 & 20 & -- & -- & \text { Granite } & -- \\ 6.96 & 65 & \text { X } & \text { X } & \text { Granite } & -- \\ 7.05 & 80 & -- & \text { X } & \text { Pegmatite } & -- \\ 7.17 & 54 & -- & \text { X } & \text { Schist } & \text { Rubble zone, }\end{array}$

diple zone

on bottom
of zone

$\begin{array}{rrrrr}7.32 & 70 & -- & X & \text { Schist } \\ 7.88 & 60 & -- & -- & \text { Schist } \\ 9.08 & 9 & -- & -- & \text { Schist } \\ 9.25 & 4 & -- & -- & \text { Schist } \\ 9.30 & 79 & \text { X } & -- & \text { Schist }\end{array}$

$\begin{array}{rrrrrc}9.40 & 71 & -- & -- & \text { Schist } & -- \\ 11.79 & 41 & -- & -- & \text { Schist } & -- \\ 13.17 & 58 & -- & -- & \text { Schist } & -- \\ 20.56 & 56 & -- & -- & \text { Schist } & \text { Sealed fracture } \\ 20.93 & 39 & -- & -- & \text { Schist } & \text { Sealed fracture } \\ 21.40 & 73 & -- & -- & \text { Schist } & \text { Sealed fracture }\end{array}$

FSE5 (Core collected from 17.29 to $61.35 \mathrm{~m}$ from the top of casing)

$\begin{array}{lllllc}18.85 & 36 & \text { X } & -- & \text { Granite } & -- \\ 20.39 & 23 & -- & \text { X } & \text { Granite } & \text { Greenish clay } \\ 21.31 & 31 & -- & \text { X } & \text { Granite } & \text { Greenish clay } \\ 21.39 & 53 & \text { X } & -- & \text { Granite } & -- \\ 22.54 & 26 & \text { X } & -- & \text { Granite } & -- \\ & & & & & \\ 24.80 & 34 & \text { X } & -- & \text { Granite } & -- \\ 24.80 & 34 & \text { X } & -- & \text { Granite } & -- \\ 25.18 & 34 & -- & -- & \text { Granite } & -- \\ 25.38 & 53 & \text { X } & -- & \text { Granite } & -- \\ 25.48 & 14 & \text { X } & -- & \text { Granite } & -- \\ & & & & & \\ 25.54 & 42 & \text { X } & -- & \text { Granite } & -- \\ 27.22 & 28 & \text { X } & -- & \text { Granite } & -- \\ 27.65 & 40 & -- & -- & \text { Granite } & -- \\ 28.22 & 30 & \text { X } & - & \text { Granite } & - \\ 28.35 & 27 & \text { X } & -- & \text { Granite } & -- \\ & & & & & \\ 28.74 & 20 & -- & -- & \text { Granite } & -- \\ 28.81 & 26 & \text { X } & -- & \text { Granite } & - \\ 28.87 & 26 & -- & -- & \text { Granite } & --\end{array}$

\begin{tabular}{|c|c|c|c|c|c|c|}
\hline Well & $\begin{array}{c}\text { Frac- } \\
\text { ture } \\
\text { depth } \\
\text { (meter) }\end{array}$ & $\begin{array}{l}\text { Frac- } \\
\text { ture dip } \\
\text { (degree) }\end{array}$ & $\begin{array}{l}\text { Pre- } \\
\text { cipi- } \\
\text { tate }\end{array}$ & $\begin{array}{l}\text { Alter- } \\
\text { ation }\end{array}$ & $\begin{array}{l}\text { Rock } \\
\text { type }\end{array}$ & Comments \\
\hline
\end{tabular}

FSE5 (Core collected from 17.29 to $61.35 \mathrm{~m}$ from the top of casing) -.Continued

$\begin{array}{lllll}28.87 & 26 & -- & -- & \text { Granite } \\ 29.21 & 28 & -- & -- & \text { Granite } \\ 29.21 & 28 & -- & -- & \text { Granite } \\ 29.38 & 57 & -- & -- & \text { Granite } \\ 29.38 & 50 & -- & -- & \text { Granite }\end{array}$

$29.43 \quad 44 \quad--\quad--\quad$ Granite

$29.57 \quad 59 \quad-.-\quad-.-$ Granite

$\begin{array}{lllll}29.57 & 59 & -- & -- & \text { Granite }\end{array}$

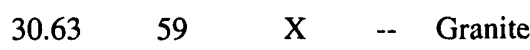

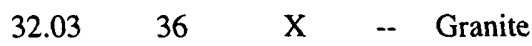

$\begin{array}{lllll}32.10 & 18 & \mathrm{X} & -- & \text { Granite }\end{array}$

$\begin{array}{lllll}32.50 & 24 & X & - & \text { Granite }\end{array}$

$\begin{array}{lllll}33.10 & 17 & X & -- & \text { Granite }\end{array}$

$\begin{array}{lllll}33.30 & 60 & X & -- & \text { Granite }\end{array}$

$\begin{array}{lllll}33.40 & 65 & X & -- & \text { Granite }\end{array}$

$\begin{array}{llllll}33.50 & 70 & - & - & \text { Granite } & \text {-- }\end{array}$

$\begin{array}{llllll}33.80 & 26 & -- & -- & \text { Granite } & -\end{array}$

$\begin{array}{llllll}34.00 & 20 & \text {-. } & -- & \text { Granite }\end{array}$

$\begin{array}{llllll}36.00 & 10 & X & -- & \text { Granite }\end{array}$

$\begin{array}{llllll}37.50 & 26 & X & -- & \text { Granite }\end{array}$

$\begin{array}{llllll}38.70 & 56 & X & -- & \text { Granite }\end{array}$

$\begin{array}{llllll}39.10 & 53 & -- & X & \text { Granite }\end{array}$

$\begin{array}{llllll}40.90 & 20 & -- & X & \text { Granite } & \text {-. }\end{array}$

$\begin{array}{llllll}41.10 & 10 & -- & X & \text { Granite } & -\end{array}$

$\begin{array}{llllll}41.50 & 60 & X & X & \text { Granite }\end{array}$

$\begin{array}{llllll}42.30 & 53 & -. & X & \text { Granite } & --\end{array}$

$\begin{array}{llllll}48.40 & 14 & - & - & \text {-- } & \text { Granite }\end{array}$

$\begin{array}{lllll}48.50 & 14 & -- & X & \text { Granite }\end{array}$

$\begin{array}{llllll}49.0 & 46 & -- & -- & \text { Granite } & --\end{array}$

$\begin{array}{llllll}49.40 & 20 & - & X & \text { Xranite } & \text {-- }\end{array}$

$\begin{array}{llllll}51.90 & 50 & X & X & \text { Granite } & --\end{array}$

$\begin{array}{llllll}52.40 & 50 & -- & -- & \text { Pegmatite } \\ 54.30 & 56 & -- & X & \text { Granite }\end{array}$

$\begin{array}{llllll}54.30 & 56 & -- & X & \text { Granite } & --\end{array}$ 
Table 6. Description of fractures in core samples from boreholes CO7, FSE5, and TR2 near Mirror Lake in Grafton County, New Hampshire--Continued

\begin{tabular}{|c|c|c|c|c|c|c|c|c|c|c|c|c|c|}
\hline Well & $\begin{array}{c}\text { Frac- } \\
\text { ture } \\
\text { depth } \\
\text { (meter) }\end{array}$ & $\begin{array}{l}\text { Frac- } \\
\text { ture dip } \\
\text { (degree) }\end{array}$ & $\begin{array}{l}\text { Pre- } \\
\text { cipi- } \\
\text { tate }\end{array}$ & $\begin{array}{l}\text { Alter- } \\
\text { ation }\end{array}$ & $\begin{array}{l}\text { Rock } \\
\text { type }\end{array}$ & Comments & Well & $\begin{array}{c}\text { Frac- } \\
\text { ture } \\
\text { depth } \\
\text { (meter) }\end{array}$ & $\begin{array}{c}\text { Frac- } \\
\text { ture dip } \\
\text { (degree) }\end{array}$ & $\begin{array}{l}\text { Pre- } \\
\text { cipi- } \\
\text { tate }\end{array}$ & $\begin{array}{l}\text { Alter- } \\
\text { ation }\end{array}$ & $\begin{array}{l}\text { Rock } \\
\text { type }\end{array}$ & Comments \\
\hline TR2 & \multicolumn{6}{|c|}{ (Core collected from 31.18 to $76.9 \mathrm{~m}$ below top of casing) } & $\overline{\text { TR2 }}$ & \multicolumn{6}{|c|}{$\begin{array}{l}\text { (Core collected from 31.18 to } 76.9 \mathrm{~m} \text { below top of casing) } \\
\text {--Continued }\end{array}$} \\
\hline & \multirow[t]{3}{*}{31.4} & \multirow[t]{3}{*}{--} & \multirow[t]{3}{*}{--} & \multirow[t]{3}{*}{$\mathrm{X}$} & \multirow[t]{3}{*}{ Schist } & \multirow{3}{*}{$\begin{array}{l}\text { Rubble zone, } \\
\text { some sam- } \\
\text { ple loss }\end{array}$} & & 36.33 & 13 & -- & -- & Quartz & -- \\
\hline & & & & & & & & 36.40 & 40 & $\mathrm{X}$ & -- & Quartz & -- \\
\hline & & & & & & & & 36.43 & 25 & - & -. & Quartz & -- \\
\hline & \multirow[t]{2}{*}{31.56} & \multirow[t]{2}{*}{7} & \multirow[t]{2}{*}{$\mathrm{X}$} & \multirow[t]{2}{*}{$\mathrm{X}$} & \multirow{2}{*}{ Schist } & \multirow{2}{*}{$\begin{array}{l}\text { Some sample } \\
\text { loss }\end{array}$} & & 36.52 & 9 & -- & -- & Quartz & -- \\
\hline & & & & & & & & 36.60 & 1 & -- & -- & Quartz & -- \\
\hline & \multirow{2}{*}{32.40} & \multirow{2}{*}{$\begin{array}{r}0 \\
12\end{array}$} & \multirow[t]{2}{*}{ - } & \multirow{2}{*}{--} & \multirow{2}{*}{$\begin{array}{l}\text { Schist } \\
\text { Schist }\end{array}$} & \multirow{2}{*}{$\begin{array}{l}\text { Some sample } \\
\text { loss }\end{array}$} & & & & & & & \\
\hline & & & & & & & & 37.02 & 2 & -- & -- & Quartz & -- \\
\hline & \multirow[t]{2}{*}{33.30} & \multirow[t]{2}{*}{8} & \multirow[t]{2}{*}{-- } & \multirow[t]{2}{*}{--} & \multirow[t]{2}{*}{ Schist } & \multirow[t]{2}{*}{-- } & & 37.25 & 5 & -- & -- & Pegmatite & -- \\
\hline & & & & & & & & 37.25 & 6 & -- & -- & Pegmatite & -- \\
\hline & 33.63 & 6 & -. & -- & Schist & Sealed fracture & & 37.61 & 5 & $\mathrm{X}$ & -- & Pegmatite & -- \\
\hline & 34.9 & 5 & .. & -- & Schist & Sealed fracture & & 38.16 & 10 & -- & -- & Pegmatite & -. \\
\hline & 34.93 & 3 & -- & -- & & -- & & & & & & & \\
\hline & 35.21 & 8 & -- & -- & Granite & -- & & 38.24 & 22 & -- & $\mathrm{X}$ & Granite & Rubble zone \\
\hline & 35.31 & 21 & -- & -- & Granite & Sealed frac- & & 38.28 & 15 & -- & -- & Granite & Rubble zone \\
\hline & & & & & & ture, calcite & & 38.33 & & -- & -- & Granite & -- \\
\hline & & & & & & filled & & 39.05 & 10 & .. & -- & Granite & -- \\
\hline & & & & & & & & 42.84 & 13 & -- & -- & Granite & Sealed frac- \\
\hline & 35.33 & 8 & -- & -- & Granite & -- & & & & & & & ture, calcite \\
\hline & 35.55 & 3 & $\mathrm{X}$ & -- & Granite & -- & & & & & & & filled \\
\hline & 35.62 & 2 & $\mathrm{X}$ & -- & Granite & -- & & 44.38 & 5 & -- & -- & Schist & -- \\
\hline & 35.71 & 9 & $\mathrm{X}$ & -- & Granite & -- & & 44.43 & & -- & -- & Schist & -- \\
\hline & 35.77 & 10 & $\mathrm{X}$ & -- & Granite & -- & & 44.82 & 16 & $\mathrm{x}$ & -- & Granite & -- \\
\hline & & & & & & & & 45.59 & 60 & -- & -- & & -- \\
\hline & 35.85 & 11 & $\mathrm{X}$ & -- & Granite & -- & & 45.63 & 24 & -- & -- & Granite & -- \\
\hline & 36.06 & 5 & .. & -- & Granite & Sealed frac- & & & & & & & \\
\hline & & & & & & $\begin{array}{l}\text { ture, calcite } \\
\text { filled }\end{array}$ & & $\begin{array}{l}48.28 \\
49.68\end{array}$ & 62 & -- & $\mathrm{X}$ & Schist & Rubble zone \\
\hline & 36.10 & 10 & -- & -- & Granite & -- & & & 00 & $\cdots$ & $\cdots$ & Schist & $\begin{array}{l}\text { ture, calcite } \\
\text { elact }\end{array}$ \\
\hline & 36.13 & 5 & -- & -- & Quartz & -- & & & & & & & filled \\
\hline & 36.18 & 3 & $\mathrm{X}$ & -- & & -- & & 51.10 & & -- & -- & Schist & Rubble zone \\
\hline & & & & & & & & 69.44 & & $\mathrm{x}$ & -- & Schist & -- \\
\hline
\end{tabular}

borehole $\mathrm{CO} 7$ ranged from 8.5 to 21.5 minutes. The rate of coring provides an indication of the relative hardness of the rocks. In $\mathrm{CO}$, the slowest drilling time was through schist, and the fastest time was through pegmatite. The natural fracture angles measured in the core ranged from 4 to $80^{\circ}$ from the axis of the core. Percent recovery ranged from 92 to 100 percent (table 6). A fracture zone was inferred during the drilling process when the drill rods advanced rapidly from $8.5 \mathrm{~m}$ below land surface. This zone corresponds to the core sample with only 92-percent core recovery.

A photograph of a core sample from $\mathrm{CO} 7$ (fig. 5) shows a fracture that is nearly perpendicular to the axis of the core. The foliation of the schist is steep and almost parallel to the axis of the core. Iron-oxide precipitates are visible as dark areas on the fracture face and in the surrounding rock matrix. 


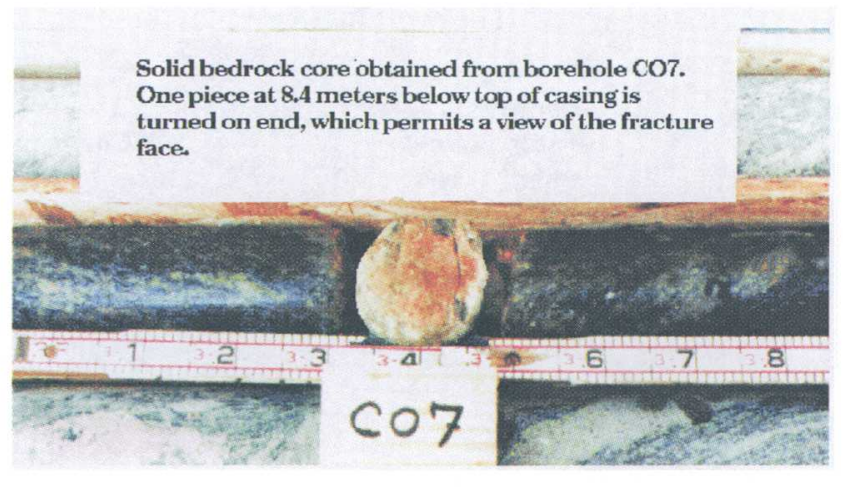

Figure 5. Bedrock core from borehole CO7 near Mirror Lake in Grafton County, New Hampshire (Ruler is in feet).

The same zone can be observed in the borehole using the color borehole-video camera. The borehole image shows a wide-open fracture that is nearly horizontal. The fracture is not parallel to the foliation of the schist, and the bedrock appears to be oxidized. Borehole-video images of the zone at approximately $8.7 \mathrm{~m}$ are shown in figure 6 . The depth (in feet below top of casing) is superimposed on the images. A fracture seen in the image at $8.6 \mathrm{~m}$ (28.4 feet) (fig. 6a) dips from the lower right side of the image towards the upper left side of the image. The borehole is enlarged and angular at 8.7 to $8.8 \mathrm{~m}$ (28.7 to 29.3 feet) (figs. $6 \mathrm{~b}$ and $6 \mathrm{~d})$.

A total of $45.7 \mathrm{~m}$ of solid core was obtained from borehole TR2. The coring started approximately $18 \mathrm{~m}$ below the bedrock surface at a depth of $31.2 \mathrm{~m}$ below top of casing. The bottom of the core sample extended to $76.9 \mathrm{~m}$ below the top of casing. In borehole TR2, the rate of penetration ranged from 6 to $86 \mathrm{~min}$ per $1.5 \mathrm{~m}$ of core. Average time to core a $1.5 \mathrm{~m}$ length was $27 \mathrm{~min}$. The hardest and most difficult rock to penetrate was a quartz vein, from 57.2 to $58.7 \mathrm{~m}$ below land surface and corresponded to the slowest drilling time. The fastest $1.5-\mathrm{m}$ core sample was obtained from 52.6 to $54.1 \mathrm{~m}$ below land surface, which penetrated granite. Fracture angles measured in the core obtained from TR 2 ranged from 0 to $62^{\circ}$ from horizontal. Several sealed microcracks were identified (a)

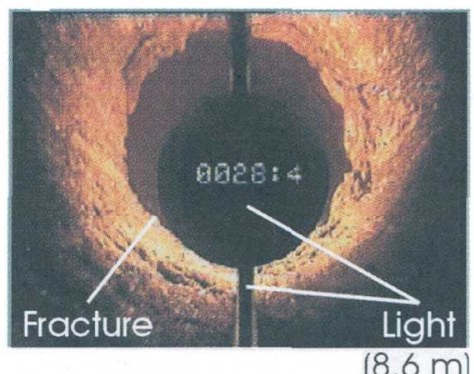

(b)

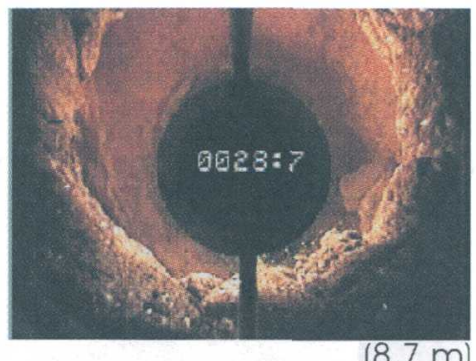

(c)

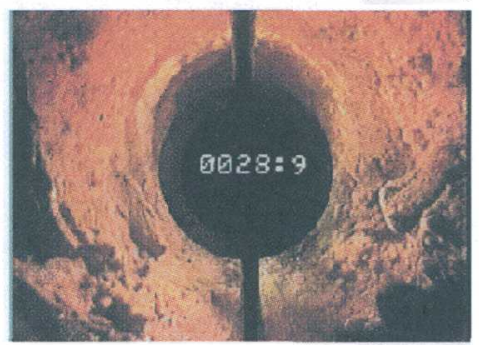

$(8.8 \mathrm{~m})$

(d)

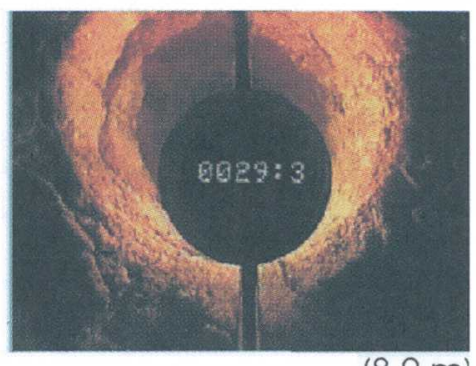

$(8.9 \mathrm{~m})$

Figure 6. Borehole-video image from $\mathrm{CO} 7$ near Mirror Lake in Grafton County, New Hampshire. (The depth, in feet below top of casing, is superimposed on the image.)

in the core at approximately 34 to $38 \mathrm{~m}$. Many of these fractures were sealed with calcite deposits that measured less than a few millimeters wide. Four intensely fractured zones, which were reduced to rubble, were identified in the core at the following depths below land surface: $38.24,38.28,48.28$, and $51.1 \mathrm{~m}$. Percent recovery for each core run ranged from 90 to 100 percent. 


\section{Characterization of Lithology in Boreholes}

Rock types in all the boreholes were described in terms of color, mineralogy, texture, size, and shape. The characterization of the lithology (appendix 1) is based on descriptions of drill cuttings and interpretations of video images. A graphic log of the rock types also is provided in appendix 1 with lithologic patterns indicating the location and extent of rock types.

Each lithologic contact shows the highest and lowest boundaries of the contact in the borehole. The altitude of the contact or the depth below the top of casing (in meters) can be read directly off the scales on the graphic log. The midpoint of the contact was used for all descriptive purposes and for the calculation of the thickness of the unit. For each borehole, the contacts were arbitrarily depicted as sloping from right to left unless they were observed to dip in a different direction relative to adjacent features, such as the foliation of schist or the contact of another rock unit. For example, the granitic dike located at a depth of $11.0 \mathrm{~m}$ below the top of casing in $\mathrm{CO} 1$ is shown to dip from right to left, which indicates that it does not cross-cut the foliation of the schist; however, the quartz vein at $29.0 \mathrm{~m}$ and the aplite vein at $94.8 \mathrm{~m}$ are shown dipping left to right (appendix 1, CO1). The actual foliation of the schist is not depicted. Rather the graphic pattern representing schist has a fixed slope dipping from right to left. All borehole logs in appendix 1 are shown with a horizontal exaggeration, in that each column representing a borehole is much wider than it would be if it were drawn to scale. Consequently, the lithologic contacts are steeper in the field than they appear in the graphic log.

In addition to the graphic log, a description of rock units is provided on the right side of appendix 1 under "DESCRIPTION." The bold text in the description is a generalized log, which identifies all units that were greater than $1 \mathrm{~m}$ in thickness. The bold text highlights a general log of the borehole lithology. The detailed description includes information on the rock type, color, grain size, texture, mineral content, foliation characteristics, and thickness of the unit observed in the borehole. Selected terms that were used in the descriptive logs are defined in the glossary.

Figure 7 shows selected borehole-video images for the rock types observed in the boreholes. The images are all taken under water with the light attachment pointed downward in the center of the borehole.
The depth, in feet below top of casing, is superimposed on the image. The well name and depth in meters is provided below the image. Typical borehole exposures of schist are shown in figures $7 \mathrm{a}, \mathrm{b}$, and $\mathrm{c}$. A fine-grained, strongly foliated schist with steeply dipping foliations is shown in figure $7 \mathrm{a}$. Figure $7 \mathrm{~b}$ shows a coarse-grained schist with augens and a pegmatite dike below the schist. Figure 7c shows a schist with a coticule (quartz and garnet) lens, which looks uniform and gray. Figure $7 \mathrm{~d}$ shows a migmatite that is characterized by a gneissic texture and swirled biotite schlieren. Granites are typically light in color, medium to coarse grained and equigranular (figs. $7 \mathrm{e}$ and $\mathrm{f}$ ). Figure $7 \mathrm{e}$ shows a granite with a schist xenolith on the left side of the image. Figure $7 \mathrm{f}$ shows granite and a diabase dike that intruded the granite. The diabase dike, on the lower half of the image, is characterized by dark color and small white minerals (phenocrysts). Pegmatite that is characterized by large quartz and feldspar crystals is shown (fig. $7 \mathrm{~g}$ ).

Figure $7 \mathrm{~h}$ shows a fine-grained aplite dike that intruded as a schist, which is shown below the aplite dike.

The distribution of the rock types in the well fields indicates the general differences in the FSE and $\mathrm{CO}$ well fields. The FSE well field is predominantly comprised of granitoids, whereas the $\mathrm{CO}$ well field is predominantly schist. The distribution of rock types was determined for 15 index boreholes, which included 13 of the deep areally-distributed boreholes plus the deepest borehole from each of the two well fields (FSE4, CO1, FS1, FS2, FS3, FS4, FS6, T1, TR1, TR2, R1, H1, IS1, CO11, RR1). The analysis indicates there are roughly equal amounts of granitoids and schist. Pegmatite and diabase comprise less than 5 percent of the rock. The relative abundances of the rock types that were encountered in the boreholes are summarized in table 7 .

\section{Fracture Characterization in Boreholes}

Fractures that were identified in the boreholes using borehole-imaging techniques are shown in appendix 1. Although microcracks were observed, they were not counted as fractures and were not recorded in appendix A. Fractures are represented in the column to the right of the graphic lithology log. Each line in the column that represents a fracture shows the highest and lowest intersection of the 


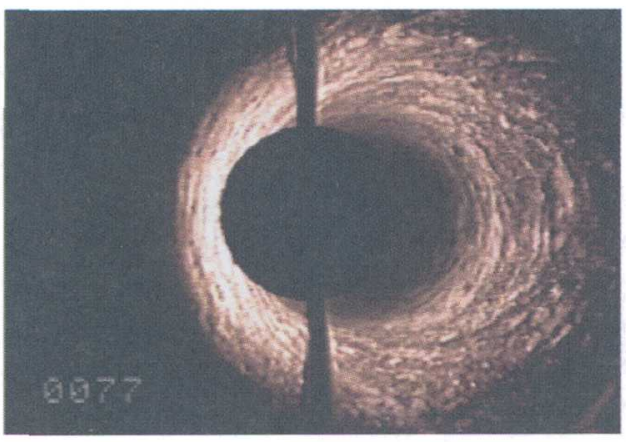

(a) Schist (H1, 23 m)

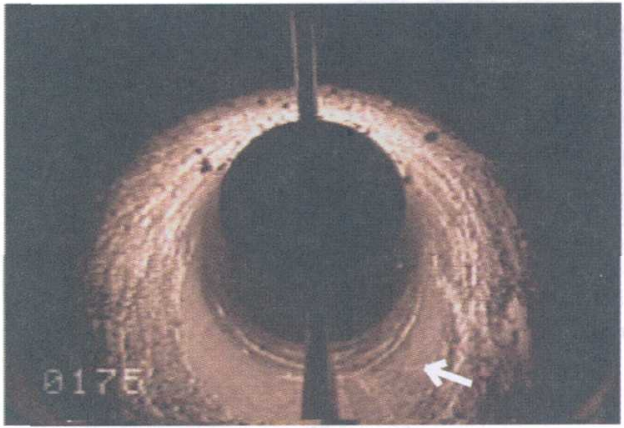

(c) Coticule layer in schist (H1, $53 \mathrm{~m})$

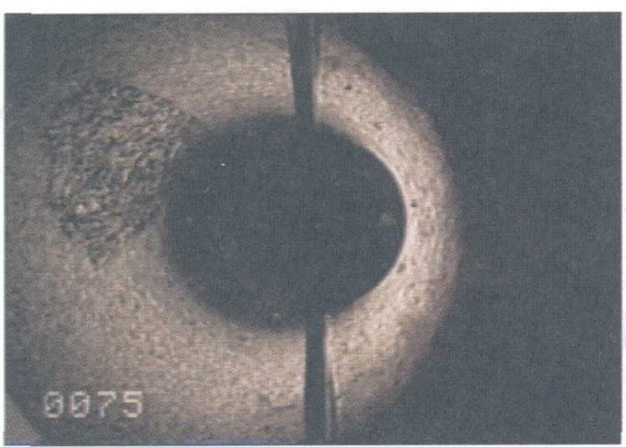

(e) Schist xenolith in granite (IS1, $23 \mathrm{~m}$ )

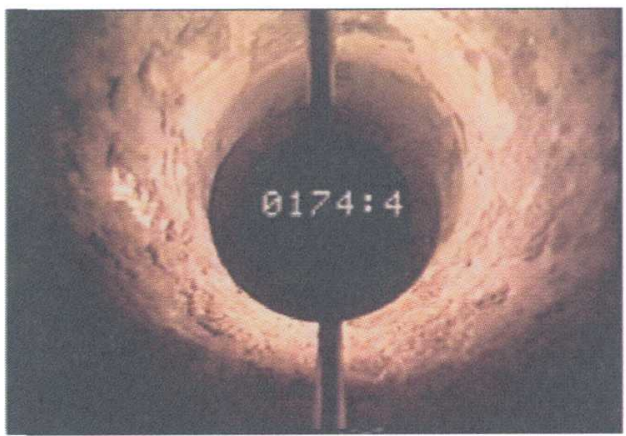

(g) Pegmatite $(\mathrm{CO}, 53 \mathrm{~m})$

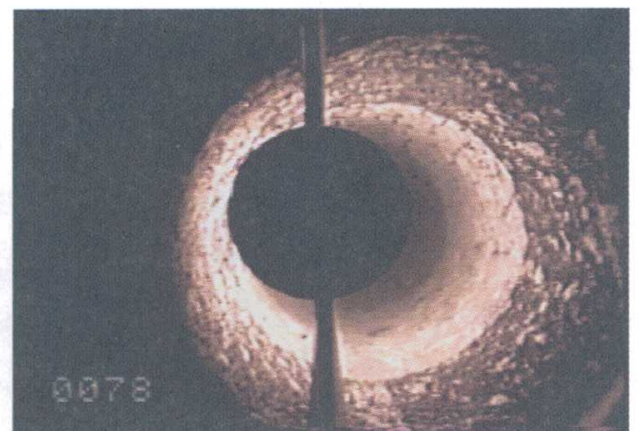

(b) Augen schist ( $\mathrm{H} 1,24 \mathrm{~m})$

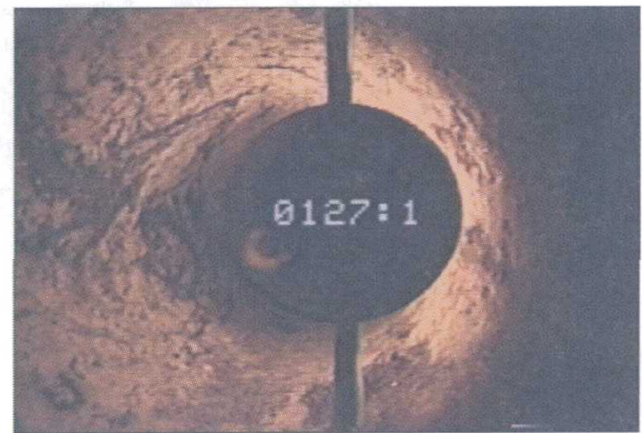

(d) Migmatite $(\mathrm{CO}, 39 \mathrm{~m})$

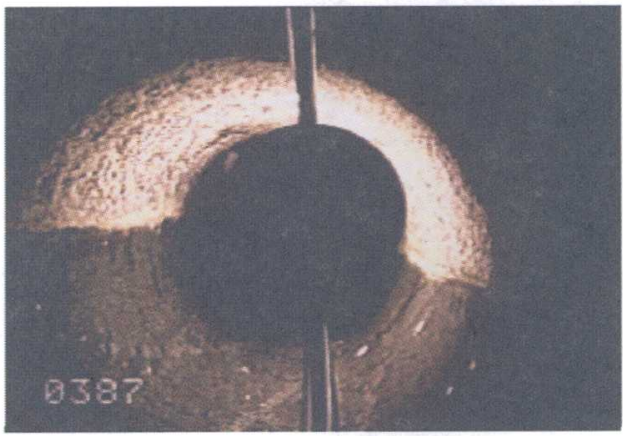

(f) Diabase dike in granite (IS1, $118 \mathrm{~m})$

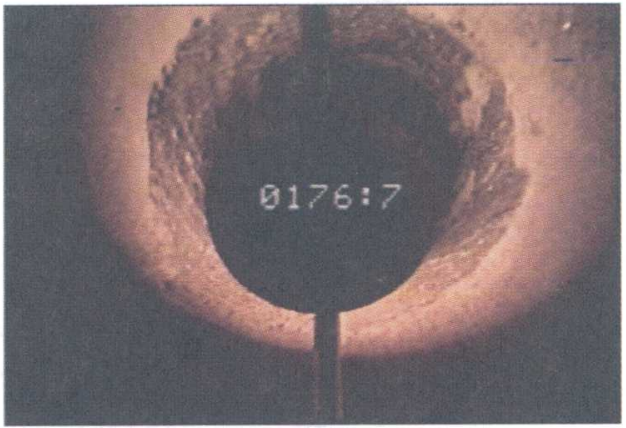

(h) Dike in schist $(\mathrm{CO}, 54 \mathrm{~m})$

Figure 7. Selected borehole-video images of rock types near Mirror Lake in Grafton County, New Hampshire. 
Table 7. Relative proportions of rock types and fracturing in selected boreholes near Mirror Lake in Grafton County, New Hampshire

\begin{tabular}{|c|c|c|c|c|c|c|}
\hline \multicolumn{7}{|c|}{$\begin{array}{l}\text { INDEX WELLS: Based on } 0.3 \text { meter intervals, from the following boreholes: } \\
\text { FSE4, CO1, FS1, FS2, FS3, FS4, FS6, T1, TR1, TR2, R1, H1, IS1, Co11, RR1 }\end{array}$} \\
\hline & Schist & Granitoid & Gneiss & Pegmatite & Diabase & Quartzite \\
\hline $\begin{array}{l}\text { Abundance of rock type shown as a percent of } \\
\text { the total number of observed intervals }\end{array}$ & 45.5 & 46.3 & 2.8 & 4.7 & 0.4 & 0.2 \\
\hline $\begin{array}{l}\text { Abundance of fractures shown as a percent of } \\
\text { the total number of observed fractures }\end{array}$ & 22.9 & 72.8 & 1.0 & 2.6 & 0.5 & 0.2 \\
\hline \multicolumn{7}{|c|}{$\begin{array}{l}\text { FSE WELL FIELD: Based on } 0.3 \text { meter intervals, from the following boreholes: } \\
\text { FSE1, FSE2, FSE3, FSE5, FSE6, FSE7, FSE8, FSE9, FSE10, FSE11, FSE12, FSE13 }\end{array}$} \\
\hline & Schist & Granitoid & Gneiss & Pegmatite & Diabase & Quartzite \\
\hline $\begin{array}{l}\text { Abundance of rock type shown as a percent of } \\
\text { the total number of observed intervals }\end{array}$ & 23.0 & 63.2 & 1.6 & 9.2 & 0.0 & 0.4 \\
\hline $\begin{array}{l}\text { Abundance of fractures shown as a percent of } \\
\text { the total number of observed fractures }\end{array}$ & 20.7 & 73.6 & 1.0 & 3.4 & 0.0 & 1.0 \\
\hline \multicolumn{7}{|c|}{$\begin{array}{l}\text { CO WELL FIELD: Based on } 0.3 \text { meter intervals, from the following boreholes: } \\
\qquad \mathrm{CO} 2, \mathrm{CO} 3, \mathrm{CO} 4, \mathrm{CO} 5, \mathrm{CO}, \mathrm{CO}, \mathrm{CO}, \mathrm{CO}, \mathrm{CO} 10\end{array}$} \\
\hline & Schist & Granitoid & Gneiss & Pegmatite & Diabase & Quartzite \\
\hline $\begin{array}{l}\text { Abundance of rock type shown as a percent of } \\
\text { the total number of observed intervals }\end{array}$ & 65.5 & 18.7 & 11.2 & 4.4 & 0.0 & 0.0 \\
\hline $\begin{array}{l}\text { Abundance of fractures shown as a percent of } \\
\text { the total number of observed fractures }\end{array}$ & 65.7 & 28.9 & 3.6 & 1.8 & 0.0 & 0.0 \\
\hline
\end{tabular}

fracture in the borehole. The actual altitude to the top or bottom of the fracture can be read in meters from the scale to the left of the column in meters. Depth below top of casing, in meters, can be read off of the column furthest to the left in appendix 1. As in the lithology column, the column representing the borehole is much wider or horizontally exaggerated than it would be if it were drawn to scale. Also, the fractures were arbitrarily depicted sloping from left to right, unless they were observed to be dipping in a different direction relative to adjacent fractures, lithologic contacts, or to the foliation of the host rock such as schist with a graphic pattern that dips from right to left. If a fracture were parallel to the foliation of the schist, it would be shown dipping from right to left in appendix 1. If a fracture were observed to cross-cut the foliation of schist it would be shown dipping from left to right.

Fracture attributes listed for each fracture are indicated to the right of the fracture column. The attributes' codes used in appendix 1 are summarized in table 8 , and example borehole images are provided for frequently used attribute codes (fig. 8a-o). The first column in appendix 1 indicates the dip score, which represents a relative measure of the dip angle. Each fracture is characterized as horizontal, moderate, or steep. Horizontal $(\mathrm{h})$ indicates a fracture that has intersected the borehole between 0 and $30^{\circ}$ from horizontal (fig. 8a). Steep (s) indicates a fracture that has intersected the borehole at an angle greater than 60 degrees from the horizontal (fig. 8c), and moderate (m) defines all fractures between horizontal and steep (fig. 8b). These scores were assigned after calculating the dip angle as the inverse tangent of the distance along the axis of the borehole from the highest point of the fracture to the lowest point of the fracture divided by the diameter of the borehole. The diameter was assumed to be a constant $152 \mathrm{~cm}$ for all measurements. The dip score is not necessarily the actual dip of the fracture because the deviation of the borehole is not taken into account. The dip score indicates the angle at which the fracture intersects the borehole.

The aperture, or openness, of a fracture can be related to the hydraulic properties of the fracture according to Snow (1968) and Borchers and others (1993). The current regional and local stress fields and fracture infilling can influence the openness of a fracture. However, determining the aperture of a fracture in the subsurface is a problem. Measuring the aperture of a fracture in a borehole is physically difficult and the apparent aperture in a borehole can be greatly changed during drilling. Although the 
mechanical fracture aperture is affected by the drilling process, a visual estimation of each fracture was made from video logs and is reported for each fracture. The aperture code, which is in the second attribute column (appendix 1), indicates a qualitative score assigned to each fracture. A "narrow" aperture (n) was assigned to all fractures that appeared to be less than $0.5 \mathrm{~cm}$ wide (fig. 8d.). Open fractures that appeared to have an aperture greater than $1 \mathrm{~cm}$ were assigned " $w$ " for wide (fig. 8f). All fractures that appeared to be wider than $0.5 \mathrm{~cm}$ but less than $1 \mathrm{~cm}$ were designated as moderate and were assigned the code " $\mathrm{m}$ " (fig. 8e). The aperture code is a subjective determination or estimation of the aperture of the fractures.

Table 8. Codes used to describe fractures shown in Appendix 1

$\left[<\right.$, less than; ${ }^{\circ}$, degree; $\geq$, greater than or equal to; $>$, greater than; $\mathrm{cm}$, centimeter]

\begin{tabular}{|c|c|c|c|}
\hline & Dip & Aperture & Attributes \\
\hline \multicolumn{4}{|l|}{ Dip } \\
\hline Near horizontal $<30^{\circ}$ & $\mathrm{h}$ & -- & -- \\
\hline Moderate $\quad 30^{\circ}$ to $60^{\circ}$ & $\mathrm{m}$ & -- & -- \\
\hline Steep $\quad>60^{\circ}$ & s & -- & -- \\
\hline \multicolumn{4}{|l|}{ Aperture } \\
\hline Narrow $<0.5 \mathrm{~cm}$ & -- & $\mathbf{n}$ & -- \\
\hline Medium 0.5 to $1 \mathrm{~cm}$ & -- & $\mathrm{m}$ & -- \\
\hline Wide $\quad \geq 1 \mathrm{~cm}$ & -- & $\mathrm{w}$ & -- \\
\hline \multicolumn{4}{|l|}{ Attributes } \\
\hline Alteration & -- & -- & a \\
\hline Abutting fractures & -- & -- & b \\
\hline $\begin{array}{l}\text { Borehole enlargement associated } \\
\text { with the fracture }\end{array}$ & -- & -- & $\mathrm{e}$ \\
\hline Fracture zone & -- & -- & $\mathrm{Fz}$ \\
\hline Jagged and angular & -- & -- & $\mathrm{j}$ \\
\hline $\begin{array}{l}\text { Multiple fractures (number indi- } \\
\text { cates the number of fractures) }\end{array}$ & -- & -- & $\operatorname{mf}(2)$ \\
\hline Oxidation on or near fracture face & -- & -- & o \\
\hline Partial fracture & -- & -- & $\mathrm{p}$ \\
\hline Crosses foliation & -- & -- & $\mathrm{xf}$ \\
\hline Parallel to foliation & -- & -- & $\mathrm{pf}$ \\
\hline Sealed & -- & -- & s \\
\hline Liesegang bands & -- & -- & $\mathrm{L}$ \\
\hline $\begin{array}{l}\text { White precipitate eminating from } \\
\text { fracture }\end{array}$ & -- & -- & w \\
\hline Water-bearing zone during drilling & -- & -- & $\mathrm{y}$ \\
\hline
\end{tabular}

Several codes are used to characterize the fractures detected in the boreholes. For instance, codes used to describe the physical or mechanical nature of the fractures include " $\mathrm{d}$ " for diffuse or porous-looking rock matrix, "e" for an enlarged borehole, "j" for a jagged or angular fracture (fig. 8g), and "p" for a fracture that partially intersects the borehole. Borehole enlargement frequently occurs where the rock has been removed between two or more parallel fractures. Enlargement sometimes occurs where multiple fractures intersect the borehole. These zones also tend to exhibit a jagged or angular appearance. Abutting fractures, which are seen in the video as one fracture that abuts another without crossing, are noted with the code "b" (fig. 8h). Multiple fractures occurring at the same location are noted with "mf." For example, two closely spaced fractures that are observed in the borehole would be annotated with "mf2". Multiple fractures are shown in figure 8i. A zone that is intensely fractured is coded "fz," which indicates a fracture zone (fig. 8j). In one borehole, TR1, some parts of the borehole are extremely fractured. The locations of these zones were noted. The fractures, however, were too numerous to count.

Microcracks that were apparent in the borehole video images were not recorded or counted as fractures in appendix 1. For example, partially sealed microcracks that were observed in the core sample of TR2 were not identified in the video logs as fractures. Microcracks are locally extensive and are too numerous to count.

Several codes were used to describe the fracture relative to characteristics of the adjacent rock mass. A fracture that appeared to be parallel to the foliation of schist or gneiss is noted by "pf" (fig. 8k); a fracture that appeared to cross-cut the foliation is coded as " $\mathrm{xf}$ " (fig. 81). Fractures were also described for the occurrence of mineralizations or coatings. If the rock mass adjacent to the fracture or the fracture face appeared to be iron stained, then the fracture is annotated with "o" (fig. 8m). If the iron-staining occurred in rhythmic bands, it was coded " $L$ " to indicate Liesegang banding. If the matrix around the fracture appeared to be altered, it was annotated with an "a" (fig. 8n). If the fracture appeared to be sealed, it was coded " $\mathrm{s}$ " (fig. 8o) and is shown as a dashed line in the graphic column. If there was white precipitate emanating from the fracture and precipitating on the adjacent rock, it was annotated with "w". 


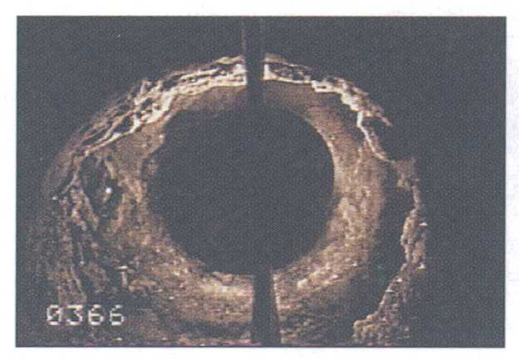

(a) Horizontal dip (IS1, $112 \mathrm{~m}$ )

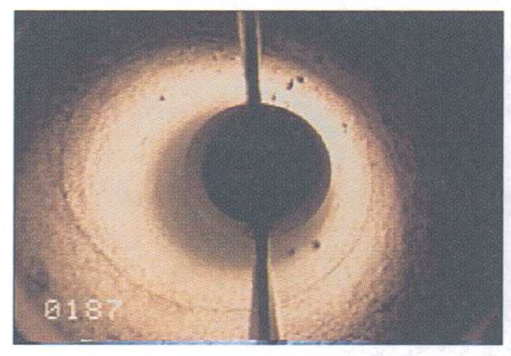

(d) Narrow aperture (H1,57 m)

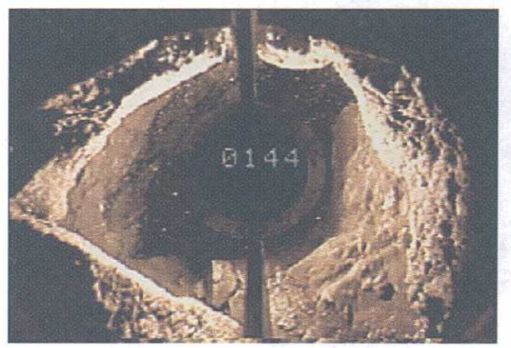

(g) Enlarged, angular, and jagged (FS2, $44 \mathrm{~m}$ )

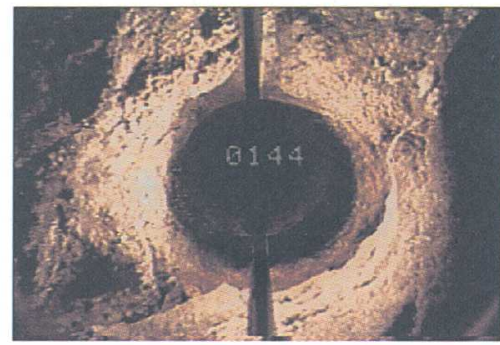

(j) Fracture zone (FS2, $44 \mathrm{~m})$

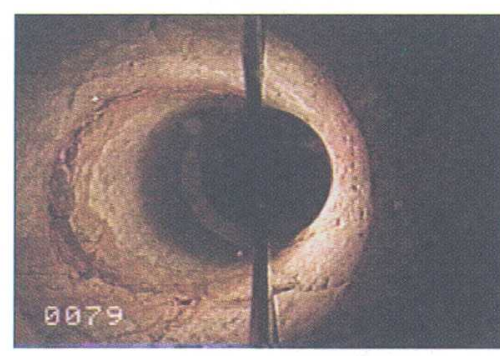

(m) Oxidized (IS1, $24 \mathrm{~m})$

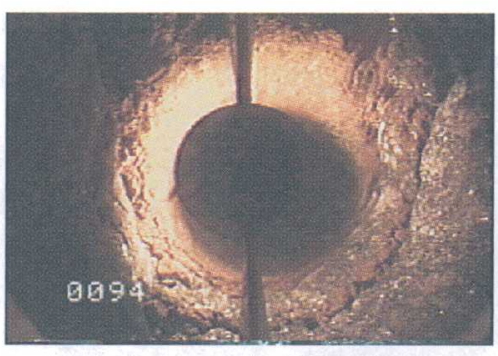

(b) Moderate dip (CO4, $29 \mathrm{~m})$

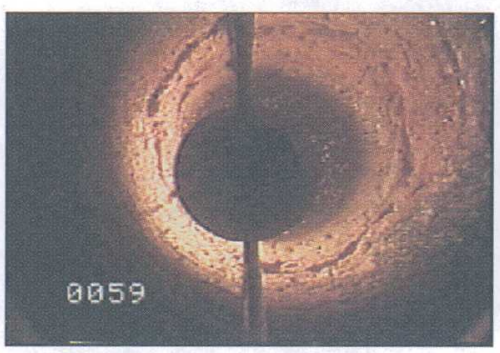

(e) Medium aperture $(\mathrm{CO} 4,18 \mathrm{~m})$

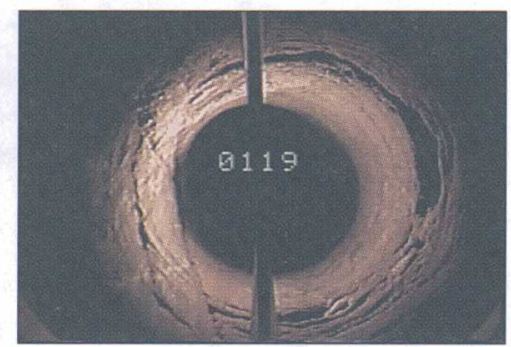

(h) Abutting and partial (FSE6, $36 \mathrm{~m}$ )

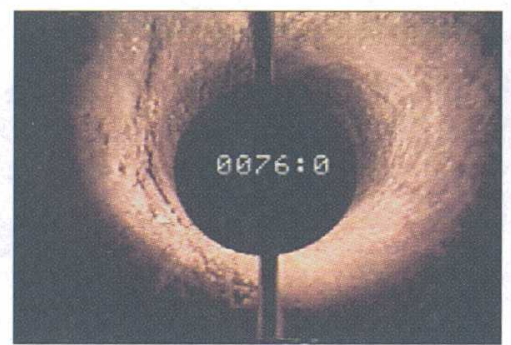

(k) Parallel to foliation $(\mathrm{CO}, 23 \mathrm{~m})$

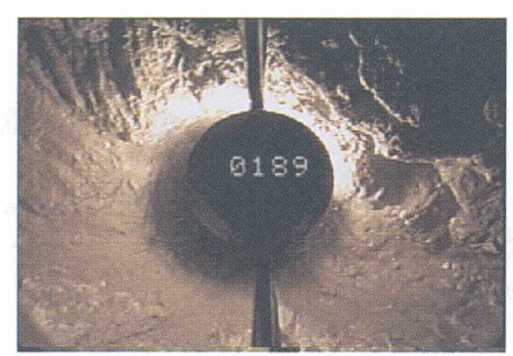

(n) Altered (FS2, $38 \mathrm{~m})$

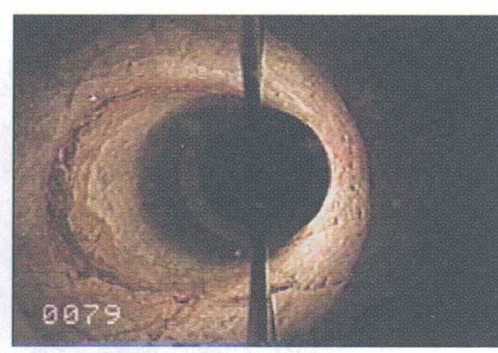

(c) Steep dip (IS1, 24 m)

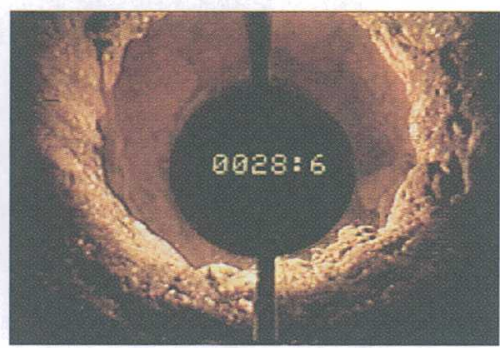

(f) Wide aperture (CO7, $9 \mathrm{~m})$

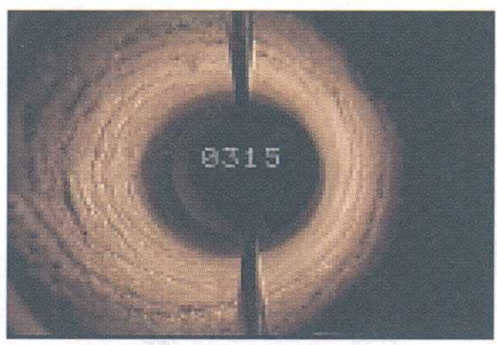

(i) Multiple fractures (TR1, $96 \mathrm{~m}$ )

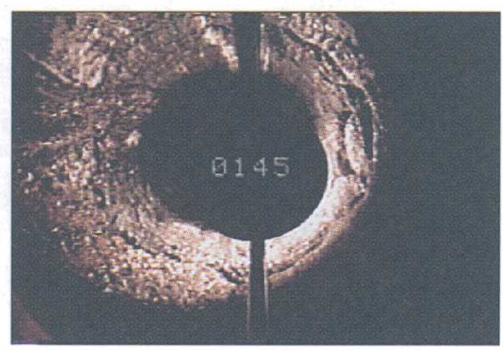

(I) Crosses foliation (FSE13, 44 m)

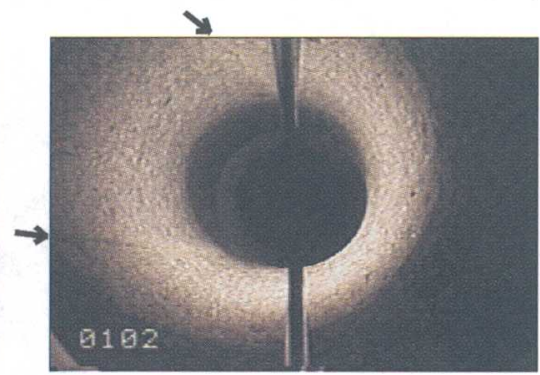

(o) Sealed (IS1, $31 \mathrm{~m})$

Figure 8. Selected borehole-video images showing frequently used fracture descriptors in boreholes near Mirror Lake in Grafton County, New Hampshire. 
This precipitate was only observed in a few boreholes in the FSE well field, where it is thought that the white calcite precipitate was caused by locally high $\mathrm{pH}$ levels (P.T. Harte, U.S. Geological Survey, written commun., 1990). Fractures that produced water during drilling were noted with a " $y$." Any additional fracture characteristics that could not be addressed by codes in the fracture-attribute column were described in parenthesis under the lithology descriptions.

\section{Discussion of Fractures and Lithology}

Some general observations that can be made from the detailed logs (appendix 1) are summarized in this section. Some generalizations can be made about the distribution of fractures with respect to spacing, depth, and rock type, as well as the distribution of rock types with respect to location, depth and topographic setting.

\section{Fracture Distribution}

The distribution of fracture orientation and frequency is highly affected by the direction of sampling. Subvertical boreholes, such as those drilled in this study, exhibit vertical bias. Subvertical boreholes undersample steeply dipping fractures relative to the total population of fractures and relative to the number of fractures identified in outcrop mapping. Mathematical corrections, which were described by Terzaghi (1965) and Barton and Zoback (1990), can be applied to oriented fracture data to correct or to reduce this bias. Because the fracture data in this report are not oriented, however, the correction cannot be applied.

A borehole represents a near-vertical scan-line along which fracture data can be compiled. Usually, a borehole intersects multiple fractures that belong to different fracture sets. The length between the fractures along the borehole can be computed, and a frequency distribution of the spacing lengths can be generated. For this analysis of fracture distributions, the distance between all fractures (regardless of the fracture orientation) in the index boreholes

(appendix 1) was measured. The arithmetic average of the interfracture spacing was $2.1 \mathrm{~m}$, which relates to an average fracture density of 0.47 .
The interfracture spacings in all 15 index boreholes were sorted and plotted in a histogram as a function of length. The frequency plot was then compared to theoretical-frequency distributions. The distribution of interfracture spacing length in the index boreholes can be described by a power law. The power-law function was fit to the observed data (the frequency of the histogram) by the method of least squares with a coefficient of determination of 0.80 . The fitting parameters for the function $y=a x^{b}$ were $a=20.6, b=-0.85$, and $x$ varied as the length of spacing. There were 1,244 observations used in this analysis. Several frequency distributions were tested, including the power, exponential, poisson, and logarithmic functions. The best fit was obtained for the power function.

The power-law distribution, as well as an exponential distribution, has a high frequency of closely spaced fractures and fewer fractures with large interfracture spacing. The results from the Mirror Lake analyses are similar to the results of other investigations in fractured crystalline rock. In other studies, the expected frequency distribution for all fractures, regardless of their orientation or fracture type, were described by exponential distributions (Snow, 1968 and 1970; Priest and Hudson, 1976; Rives and others, 1992).

The frequency distribution of interfracture spacing of all fractures in a borehole is different than the distributions for interfracture spacings of individual fracture sets. In order to analyze the frequency distribution of interfracture spacings for individual fracture sets, oriented fracture data are required. Oriented data can be separated into fracture sets that exhibit similar orientations, and interfracture spacings can be calculated. The frequency distribution of interfracture spacing for fractures that belong to a single fracture set follows a log-normal distribution (Narr and Suppe, 1991) or a gamma distribution (Huang and Angelier, 1989).

\section{Distribution of Fractures With Depth}

Several investigators have reported that the frequency of fractures decreases with increasing depth (Fuller, 1905; Clapp, 1910; Ellis 1909; Jahns, 1943; Davis and Turk, 1964; Hansen and Simcox, 1994). These analyses were based on fracture data collected in quarries and from water wells drilled in bedrock. A statement by Cushman and others (1953) is typical: 
"The deeper a well is drilled beyond a certain depth the less is the chance of striking fractures....It is probable that [horizontal sheeting joints] do not exist at depths much below $300 \mathrm{ft}$."

Many of these investigators recommended that because fracture frequency decreases with depth, water wells in New England should not be drilled deeper than 45 to $100 \mathrm{~m}$. A decrease in the frequency of fractures below $100 \mathrm{~m}$ can be expected if sheeting joints do not extend beyond $100 \mathrm{~m}$ and near vertical wells undersample steep fractures. In other investigations of bedrock in Nevada, South Carolina, and California, however, little to no decrease in fracturing was detected in wells up to $300 \mathrm{~m}$ deep (Seeburger and Zoback, 1982).

In this study, the distribution of fractures with respect to depth does not follow a linear distribution. Highly fractured intervals usually are present in the top $100 \mathrm{~m}$ of the boreholes. Some less numerous, highly fractured zones exist at depths greater than
$100 \mathrm{~m}$. A scatterplot of fracture density (the frequency of fractures divided by the interval length for each 3-m interval) plotted for all index boreholes as a function of depth below top of casing is shown in figure 9. In general, the plot shows a higher density of fractures at shallow depths than at greater depths. Unfractured zones or minimally fractured zones, which plot on or near the $\mathrm{x}$-axis, were observed at all depths. Thus, the linear-correlation coefficient between depth and fracture frequency is low, at only -0.05 .

Another way to analyze these data is to view the cumulative fracture frequency for individual boreholes as a function of depth (fig. 10). The cumulative frequency of fractures for all index boreholes that were drilled deeper than $100 \mathrm{~m}$ were plotted against depth below top of casing. Each curve in figure $10 \mathrm{a}-\mathrm{d}$ represents the cumulative-fracture frequency for an individual borehole plotted against depth. The plots show that the number of fractures per unit length of

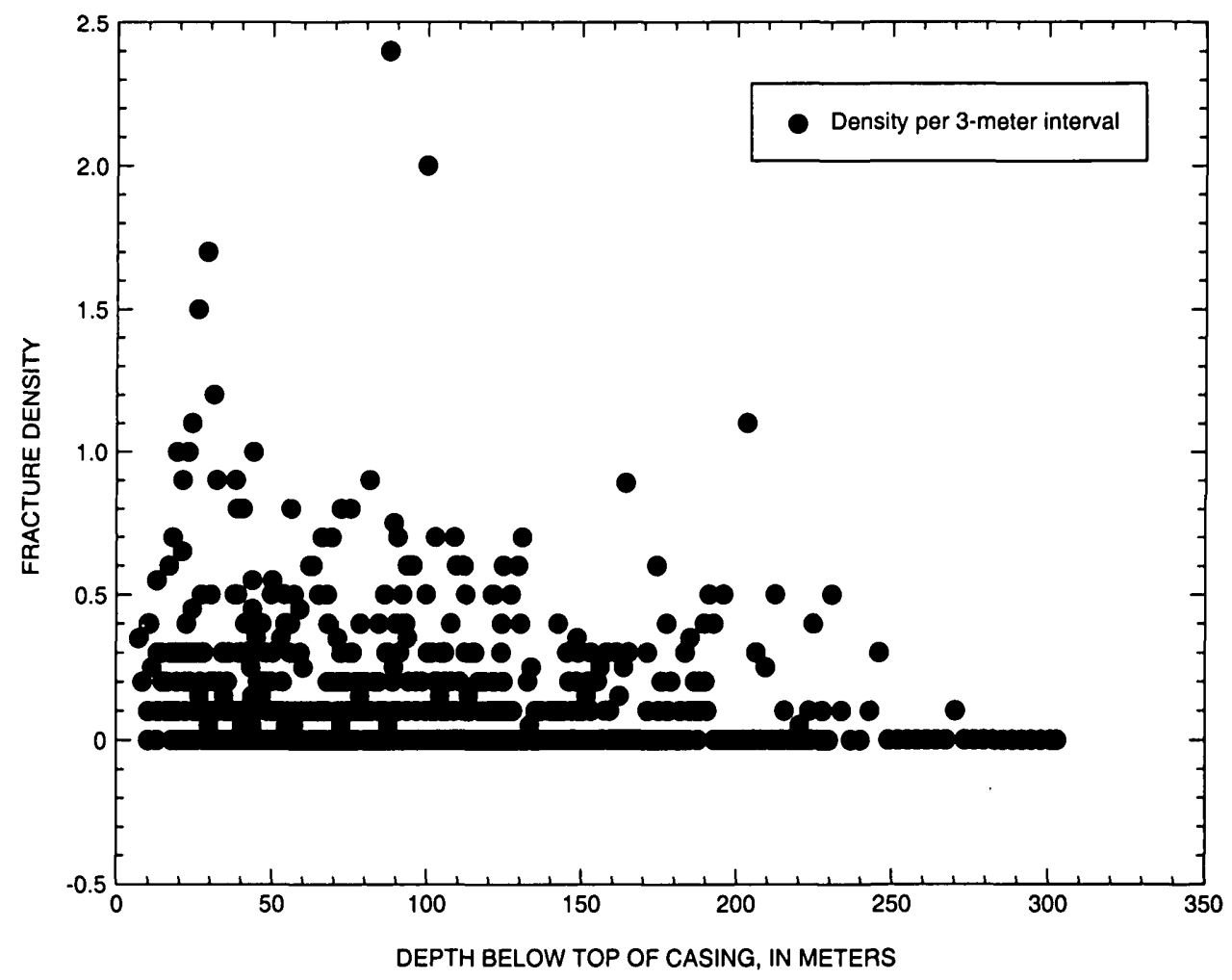

Figure 9. Fracture density as a function of depth below top of casing in selected boreholes near Mirror Lake in Grafton County, New Hampshire. Fracture density is shown for each 3-meter interval in the following wells: FSE4, CO1, CO11, FS1, FS2, FS3, FS4, FS6, IS1, TR1, TR2, R1, RR1, H1, and T1 (fig. 1). 

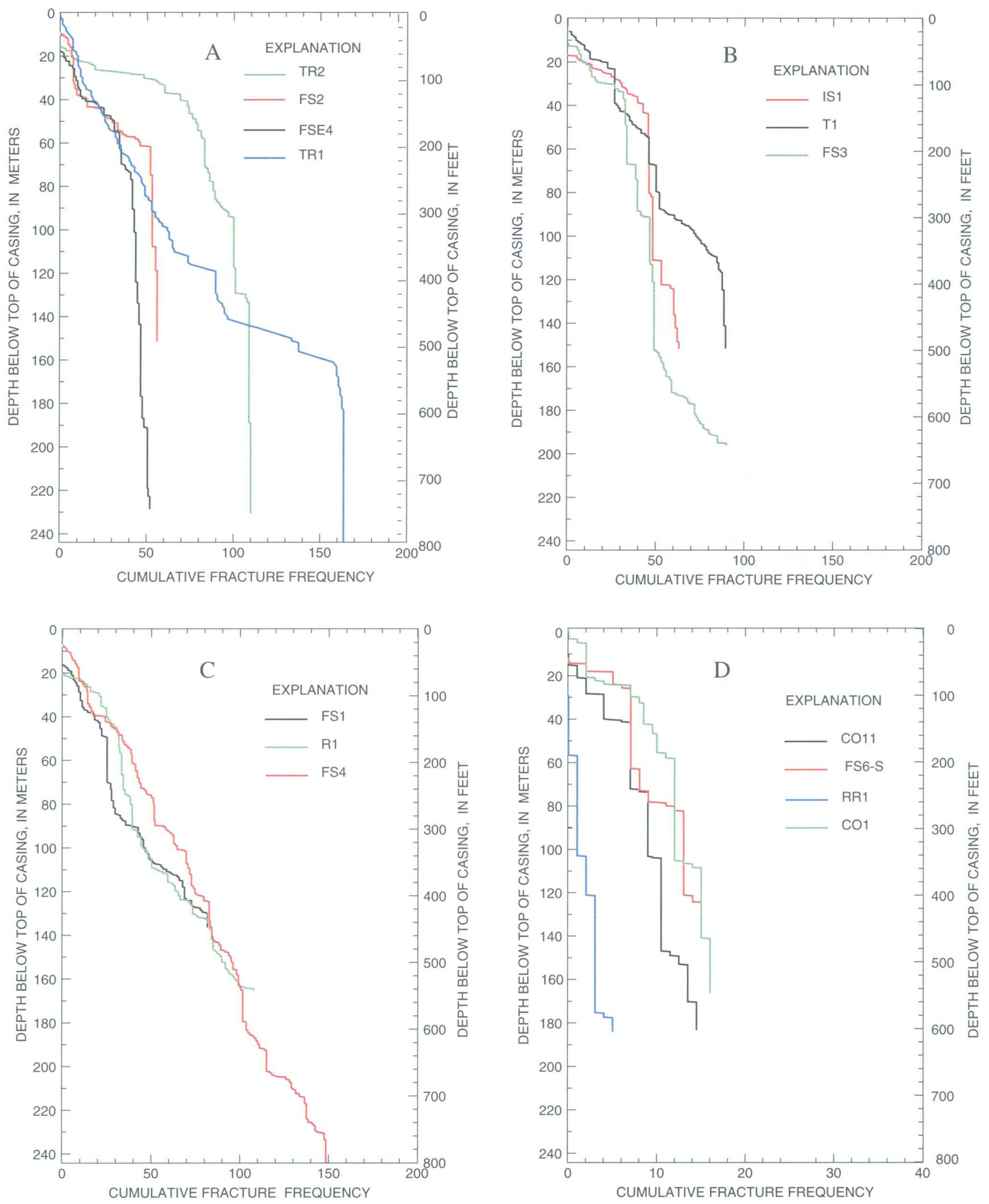

Figure 10. Cumulative-fracture frequency as a function of depth below top of casing in selected boreholes near Mirror Lake, Grafton County, New Hampshire. (The scale for the cumulative frequency in figure 10D is expanded, because there are fewer than 20 fractures in the wells.) 
borehole is not uniform. The stair-step shape of the curves indicates slight clustering of fractures. The results were plotted in groups that exhibited similar fracturing characteristics with increasing depths. Figure 10a shows a flattening or reduction in the slope of the curves at greater depths, which indicates a decrease in fracturing with depth. These cumulativefracture-frequency curves show a significant decrease in fracturing from 60 to $100 \mathrm{~m}$ to the bottom of each borehole (fig. 10a). The boreholes in figure $10 \mathrm{~b}$ exhibit a decrease in the cumulative-fracture frequency in the middle range depths, and then a small increase near the bottom of the wells. Figures $10 \mathrm{c}$ and $\mathrm{d}$ show little to no decrease in the cumulative-fracture frequencies over the length of the boreholes, from 0 to $240 \mathrm{~m}$ in depth. Although the total number of fractures in the boreholes shown in figure $10 \mathrm{~d}$ is significantly less than all of the other boreholes in the analysis, the curves do not exhibit a decrease with increasing depth. The wells in figure $10 \mathrm{~d}$ are from the same topographic setting. They are all in valley settings. Borehole IS1, which is also in the valley, does not plot in this group. Collectively, these plots suggest that there is no uniform, simple model that describes the distribution of fractures with depth (up to $240 \mathrm{~m}$ ) for all of the boreholes.

\section{Detection and Location of Faults}

Faults that exhibit displacement were difficult to identify visually in the studied boreholes, but other observations can help to identify faults in the subsurface. In FS5, the fracture zone near the bottom of the borehole at a depth of $65 \mathrm{~m}$ exhibited slickensides, quartz, and sulfide minerals. Slickensides, which indicate a fault, are detected only if the rock chips are sufficiently large. These samples from FS5 were approximately 2 to $3 \mathrm{~cm}$ in length. In borehole $\mathrm{CO} 5$ (at $12.4 \mathrm{~m}$ ) and in $\mathrm{CO} 10$ (at $42.1 \mathrm{~m}$ ) faults were identified by the presence of fault gouge. The gouge was observed in video images, as well as in the rock cuttings and drilling logs. The fault in $\mathrm{CO} 10$ is located along the strike of the prominent (1-meter wide) fault in the highway outcrop, which strikes and dips $\mathrm{N} 40^{\circ} \mathrm{E}, 8^{\circ} \mathrm{SE}$ (Barton, 1997). Borehole CO10 was drilled with the intent of intersecting this zone. The siting of the $\mathrm{CO} 10$ fault was determined by borehole radar surveys in $\mathrm{CO} 7$ (J.W. Lane, U.S. Geological Survey, written commun., 1995) and standard surveying methods.
The 50-m thick deposit of till at TR1 was likely fracture controlled (Carl Koteff, U.S. Geological Survey, written commun., 1995). The top $50 \mathrm{~m}$ of bedrock in borehole TR1 and the top $40 \mathrm{~m}$ in TR2 exhibit numerous and closely spaced fractures (appendix 1). These two boreholes exhibit zones that appear to be unusually fractured relative to other boreholes in the study area.

\section{Fracture Distribution With Respect to Rock Type}

Randall and others (1988) reported that fractures in homogeneous rocks such as granitoids are more extensive and more permeable than fractures in micaceous metasedimentary rocks. In general, fractures in the granitoids are more planar and shorter than are fractures in metasedimentary rocks (Barton, 1993). The fractures that were mapped in the granitoids in the highway outcrop exhibit more brittle fracturing and have the highest connectivity (Barton, 1996). The frequency of the fractures observed in the boreholes (appendix 1) generally supports these findings. In the 15 index boreholes, the frequency of fractures with respect to the rock type shows that approximately 73 percent of the total number of fractures were in granitoids, whereas 23 percent were in schist (table 7). Gneiss was relatively unfractured compared to schist and the granitoids, with approximately 1 percent of the total number of fractures. Less than 5 percent of the total number of fractures were in pegmatite, diabase, and quartzite. Although diabase in dikes is intensely fractured with cooling joints, these fractures do not extend into the host rock. These cooling joints were not included in appendix 1, and they were not included in the fracture frequency. The comparison of rock type with respect to fracturing indicates that fractures are lithologically controlled. In general, the granitoids are more intensely fractured than the schist and gneiss, and pegmatites, diabase, and quartzite are relatively unfractured.

Although some fractures were at or near the contacts of rock types, as in $\mathrm{CO} 7$ at approximately $28 \mathrm{~m}$ (appendix 1), fractures are not typically observed at lithologic contacts. Fractures observed in the borehole generally do not extend from one rock unit to another. These generalizations are corroborated by the observations of Barton (1996) for the fractures on the highway outcrop. 


\section{Distribution of Rock Types}

Some generalizations can be made about the distribution of rock types based on lithologic data presented in appendix 1. A comparison of the rock types with respect to location indicates that the granitoids east of Norris Brook are equigranular and are likely the two-mica granites. In borehole FS5, which is west of Norris Brook (fig. 2), the igneous rocks exhibit a blotchy-looking, porphyritic texture in a swirled and partially foliated, gneissic matrix, and are likely Kinsman Granodiorite. These rock types, although identified in only one borehole, are consistent with the map of Barton (1997). Schist, gneiss, pegmatite and diabase are found locally throughout the study area. There were, however, varying proportions of the igneous and metamorphic rocks locally throughout the Mirror Lake area.

The rock types that were mapped in the index boreholes were compared with physical parameters, such as depth, altitude, and topographic setting. The linear correlation coefficients for these analyses are less than 0.2 , indicating that no significant linear correlation exists between rock type and depth, altitude, or topographic setting.

The rock types change frequently (approximately every 5 to $9 \mathrm{~m}$ ) in the index boreholes (appendix 1). The length of each rock unit exposed in each borehole was determined and averaged for all the index boreholes. Only those rock units that spanned $30 \mathrm{~cm}$ or more of the borehole length were used in this analysis. The average length of schist exposed in the index boreholes is $5.3 \mathrm{~m}$. The average length of granitoid units is $4.6 \mathrm{~m}$. Pegmatite and diabase units in the index boreholes were less than $1 \mathrm{~m}$ long (appendix 1).

\section{Observations of Drilling and Its Effect on the Boreholes}

The locations of lithologic changes and depths of fractures that were noted in the drilling logs were generally within a meter of the locations determined from the video-camera images. This correlation indicates that there is no significant lag in the delivery of rocks to the land surface during the drilling process. Observation of drill cuttings during drilling only allows for the identification of major changes in rock types. Additional testing, such as borehole video camera logging, is needed to obtain detailed interpretations of the lithology and locations of fractures.

A common notion among drillers is that percussion drilling chokes fractures in boreholes with sediments and rock fragments. This theory is not supported by the video images. Direct inspection of the fractures in the boreholes shows that generally there are no drill cuttings on the fracture surfaces.

Boreholes that were logged with the video camera multiple times sometimes showed some precipitation of manganese and (or) iron oxides and some sedimentation. These minerals and detrital particles all coat the walls of the borehole and obscure the view of the rock type and fractures. Therefore, it is preferable to log the borehole soon after drilling to avoid these problems.

With the video camera, no particles or sediments were seen flowing from the fractures. Fractures that were identified with the borehole flowmeter as flowing did not appear to exhibit flow in the video images. If the water was pumped below an inflowing fracture, the video camera would likely "see" cascading water. If the water level was above an inflowing fracture, however, the video camera would not necessarily "see" the inflow. The method of looking for flow in fractured crystalline rock, therefore, does not appear to be a reliable method for describing the flow regime.

\section{SUMMARY AND CONCLUSIONS}

Forty boreholes, ranging in depth from 60 to $305 \mathrm{~m}$, were drilled into crystalline bedrock in the area of Mirror Lake in Grafton County, N.H. The country rock is predominantly comprised of pelitic schists that have been intruded by younger granitoids, pegmatites, aplites, and diabase.

The drillers' estimates of yield for the boreholes drilled for this study ranged from less than $3 \mathrm{~L} / \mathrm{min}$ to $378 \mathrm{~L} / \mathrm{min}$. These estimates are similar to those for wells drilled for domestic supply in Grafton County. Generally, 1 to 3 water-bearing zones were identified in each borehole at the time of drilling. These observations of yield made at the time of drilling, were frequently confirmed by flowmeter surveys, and appear to be accurate preliminary indicators of waterbearing zones. 
Open-hole water levels in the boreholes tend to be in the steel casing. These measurements were made in boreholes that were open over the entire length of the borehole. Eight of the boreholes exhibit water levels that are above the land surface. Three of the boreholes (TR2, FS6, and CO10) flow during most of the year.

All boreholes were inspected visually with a submersible color video camera in order to produce detailed profiles of the subsurface lithology and fracturing. These video images were used to describe the distribution of lithology and fractures in the subsurface. In addition, these data were used to compare fracturing, lithology, and physical parameters such as alteration and oxidation. No linear correlation was found between rock type and depth, altitude, or topographic setting. Correlation coefficients for these analyses were less than 0.2 .

The distribution of interfracture spacing lengths between all of the fractures in the index boreholes at Mirror Lake can be best described by a power function. In this distribution, there are numerous closely spaced fractures and decreasing amounts of fractures separated by large, unfractured intervals of rock. A coefficient of determination of 0.80 was obtained with a least squares regression analysis.

The distribution of fractures with respect to depth was examined. The distribution data do not show a significant relation between fractures and depth; however, there is a weak linear correlation of 0.05 . Cumulative-fracture frequency plots provide a graphic method for analyzing the distribution of subsurface fractures. Fracture-frequency plots for selected boreholes show that some of the boreholes show little to no decrease in cumulative-fracture frequency. The boreholes that were used for this analysis were between 120 and $300 \mathrm{~m}$ deep. Some boreholes exhibited a decrease in fracturing below depths of 60 to $90 \mathrm{~m}$. Half of the index boreholes that were used for this analysis exhibited a decrease in the cumulative-fracture frequency. These analyses suggest that no simple model of fracture density and depth correlation would fit all of the boreholes in the study area.

The distribution of rock types is spatially heterogeneous. Drill logs and borehole images indicate the boreholes penetrate varying amounts of schist, gneiss, granitoids, pegmatite, aplite, and diabase. The FSE well field is predominantly igneous and the $\mathrm{CO}$ well field is mostly metamorphic. Approximately 70 percent of the rocks in the boreholes in the $\mathrm{CO}$ well field were schist. In the FSE well field, approximately 70 percent of the rock units were igneous, including granite, pegmatite, and aplite. The 15 index boreholes, which include the deepest borehole in each of the two well fields and are boreholes that distributed throughout the study area, consist of 50 percent metasedimentary rocks and 50 percent granitoids. The rock types change frequently over the length of the boreholes (approximately every 5 to $9 \mathrm{~m}$ ). The average length of schist in the index boreholes was $5.3 \mathrm{~m}$, and the average length of granitoid units was $4.6 \mathrm{~m}$. The average lengths of pegmatite and diabase units in the index boreholes were each less than $1 \mathrm{~m}$.

Although metamorphic and igneous rock each comprise 50 percent of the rock types in the boreholes, the majority ( 73 percent) of fractures were in boreholes in granitoids. Approximately 23 percent of the fractures were in schist. Less than 5 percent of the fractures were in pegmatite, diabase, quartzite, and gneiss. These results indicate that the fracturing is lithologically controlled. There was no preferential fracturing along the contacts of the rock types, and few of the observed fractures in the boreholes crossed multiple rock types. The composition of the boreholes is consistent with the composition of bedrock outcrops in the study area.

The borehole drilling and borehole imaging data provided in this report can be used for more detailed analyses of fracture distributions and to determine the interrelations between characteristics of fractures (in outcrops and the subsurface), lithology, and hydraulic properties of bedrock. These additional analyses, which are beyond the scope of this report, would enable a quantitative assessment of geologic controls on ground-water flow and the transport of dissolved chemicals. 


\section{REFERENCES CITED}

Allen, Tim, 1992, Migmatite systematics and geology, Carter Dome - Wild River Region, White Mountains, New Hampshire, Ph.D. Thesis, Dartmouth College, $249 \mathrm{p}$.

Armstrong, F.C., and Boudette, E.L., 1984, Two-mica granites; Part A, their occurrence and petrography: U.S. Geological Survey Open-File Report 84-0173, $36 \mathrm{p}$.

Bannerman, H.M., 1943, Structural and economic features of some New Hampshire pegmatites: Concord, N.H., New Hampshire State Planning and Development Commission, $29 \mathrm{p}$.

Barton, C.B., 1996, Characterizing bedrock fractures in outcrop for studies of ground-water hydrology-An example from Mirror Lake, Grafton County, New Hampshire, in Morganwalp, D.W., and Aronson, D.A., eds., U.S. Geological Survey Toxic Substance Hydrology Program-Proceedings of the Technical Meeting, Colorado Springs, Colo., September 20-24, 1993: U.S. Geological Survey Water-Resources Investigations Report 94-4015, p. 81-88.

1997, Bedrock geology map of Hubbard Brook Experimental Forest and maps of fractures and geology in roadcuts along Interstate 93 , Grafton County, N.H.: U.S. Geological Survey Miscellaneous Investigations Series MAP 1-2562, 1 sheet, scale $1: 12,000$.

Barton, C.B., and Hsieh, P.A., 1989, Physical and hydrologic-flow properties of fractures: American Geophysical Union, Field Guide Book T385, 28th International Geological Congress, $36 \mathrm{p}$.

Barton, C.A., and Zoback, M.D., 1990, Self-similar distribution of macroscopic fractures at depth in crystalline rock in the Cajon Pass scientific drillhole, in Barton, N., and Stephansson, O., eds., Proceedings of the International Symposium on Rock Joints, June 4-6, 1990, Loen, Norway: A.A. Balkema, Rotterdam, p. $163-170$.

Billings, M.P., 1955, Geologic map of New Hampshire: U.S. Geological Survey State Geologic Map, 1 sheet, scale 1:250,000.

1956, The geology of New Hampshire; Part IIbedrock geology: Concord, N.H., State Planning and Economic Development, 203 p.

Borchers, J.W., 1996, Ground-water resource and watersupply alternatives in the Wawona area of Yosemite National Park, California: U.S. Geological Survey Water-Resources Investigations Report 95-4229, 77 p.

Borchers, J.W., Hickman, S., and Nimz, G.J., 1993, In-situ stress and ground-water flow in fractured granite at Wawona, Yosemite National Park, California: A model for the West-Central Sierra Nevada, American
Geophysical Union Fall Meeting, December 6-10, 1993, San Francisco, Calif., p. 581.

Boudette, E.L., 1990, The geology of New Hampshire, the Granite State: Geology, v. 65, no. 4, p. 306-312.

Clapp, F.G., 1910, Occurrence and composition of well waters in the granites of New England, in Fuller, M.L., Clapp, F.G., Matson, G.C., Sanford, Samuel, and Wolff, H.C., U.S. Geological Survey Water-Supply Paper 258, p. 40-47.

Cotton, J.E., and Olimpio, J.R., 1996, Geohydrology, yield, and water quality of stratified-drift aquifers in the Pemigewasset River Basin, central New Hampshire: U.S. Geological Survey Water-Resources Investigations Report 94-4083, 176 p., 10 pls.

Cox, D.P., 1970, Lead-zinc-silver deposits related to the White Mountain Plutonic Series in New Hampshire and Maine: U.S. Geological Survey Bulletin 1312-D, $18 \mathrm{p}$.

Cushman, R.V., Allen, W.B., and Pree, H.L., 1953, Geologic factors affecting the yield of rock wells in southern New England: Journal of New England Water Works Association, v. 67, no. 2, p. 77-95.

Davis, S.N., and Turk, L.J., 1964, Optimum depth of wells in crystalline rocks: Ground Water, v. 2, no. 2, p. 6-11.

Denny, C.S., 1982, Geomorphology of New England: U.S. Geological Survey Professional Paper 1208, 1 pl., $18 \mathrm{p}$.

Dougan, T.W., 1981, Melting reactions and trace element relationships in selected specimens of migmatitic pelites from New Hampshire and Maine: Contributions to Mineralogy and Petrology, v. 78, p. 337-344.

Ellis, E.E., 1909, Ground water in crystalline rocks of Connecticut, in Gregory, H.E., Underground water resources of Connecticut: U.S. Geological Survey Water-Supply Paper 232, p. 54-104.

Eusden, J.D., Jr., Bothner, W.A., and Hussey, A.M., 1987, The Kearsarge-Central Maine synclinorium of southeastern Maine-Stratigraphic and structural relations of an inverted section: American Journal of Science, v. 287, p. 242-264.

Eusden, J.D., Jr., and Lyons, J.B., 1993, The sequence of Acadian stratigraphy in central New Hampshire: Geological Society of America Special Paper 275, p. 51-66.

Fuller, M.L., 1905, Underground waters of Eastern United States: U.S. Geological Survey Water-Supply and Irrigation Paper No. 114, p. 28.

Gephart, J.W., and Forsyth, D.D., 1985, On the State of Stress as determined from earthquake focal mechanisms: Geology, v. 13, p. 70-72.

Goldthwait, J.W., and Kruger, F.C., 1938, Weathered rock in and under the drift in New Hampshire: Bulletin Geological Society of America, v. 49, p. 1183-1198. 
Gunderson, L.C.S., and Schurmann, R.R., 1993, Preliminary geologic radon potential assessment of New Hampshire, in Schurmann, R.R., ed., Geologic radon potential of EPA Region 1- Connecticut, Maine, Massachusetts, New Hampshire, Rhode Island, and Vermont: U.S. Geological Survey Open-File Report 93-292-A, p. 157-190.

Geological Society of America, 1991, The Geological Society of America rock-color chart: Boulder, Colo., $8 \mathrm{p}$.

Hansen, B.P., and Simpcox, A.C., 1994, Yields of bedrock wells in Massachusetts: U.S. Geological Survey Water-Resources Investigations Report 93-4115, 43 p.

Hardcastle, K.C., 1989, Analysis of faults and fracture fillings along a cross section of the New England Appalachians-Clues to the later brittle evolution of an orogenic belt: published PhD thesis; Amherst, Mass., University of Massachusetts, $242 \mathrm{p}$.

Hardcastle, K.C., and Albaugh, D.S., 1990, Stress and timing relationships of a fault-related, paleohydrothermal system in central New Hampshire-Bedrock of a Mesosoic stress change in New England: Tectonics, v. 9, no. 4, p. 623-639.

Harte, P.T., 1992, Regional ground-water in crystalline bedrock and interaction with glacial drift in the New England Uplands: published master's thesis, Durham, N.H., University of New Hampshire, 147 p.

1997, Preliminary assessment of the lithologic and hydraulic properties of the glacial drift and shallow bedrock in the Mirror Lake area, Grafton County, New Hampshire: U.S. Geological Survey Open-File Report 96-654A, $56 \mathrm{p}$.

Harte, P.T., and Winter, T.C., 1994, Simulations of flow in crystalline rock and recharge from overlying glacial deposits in a hypothetical New England setting: Ground Water, v. 33, no. 6, p. 935-964.

Hatch, N.L., and Moench, R.H., 1984, Bedrock geologic map of the wilderness and roadless areas of the White Mountain National Forest, Coos, Carroll, and Grafton Counties, New Hampshire: U.S. Geological Survey Map MF-1594-A, scale 1:250,000.

Hsieh, P.A., Perkins, R.L., and Rosenbury, D.O., 1996, Field instrumentation for multilevel monitoring of hydraulic head in fractured bedrock at the Mirror Lake site, Grafton County, New Hampshire, in Morganwalp, D.W., and Aronson, D.A., eds., U.S. Geological Survey Toxic Substance Hydrology Program-Proceedings of the Technical Meeting, Colorado Springs, Colo., September 20-24, 1993: U.S. Geological Survey Water-Resources Investigations Report 94-4015, v. 1, p. 137-140.
Hsieh, P.A., and Shapiro, A.M., 1996, Hydraulic characteristics of fractured bedrock underlying the FSE well field at the Mirror Lake site, Grafton County, New Hampshire, in Morganwalp, D.W., and Aronson, D.A., eds., U.S. Geological Survey Toxic Substance Hydrology Program-Proceedings of the Technical Meeting, Colorado Springs, Colo., September 20-24, 1993: U.S. Geological Survey Water-Resources Investigations Report 94-4015, v. 1, p. 127-130.

Hsieh, P.A., Shapiro, A.M., Barton, C.C., Haeni, F.P., Johnson, C.D., Martin, C.W., Paillet, F.L., Winter, T.C., and Wright, D.L., 1993, Methods of characterizing fluid movement and chemical transport in fractured rock, in Chaney, J.T., and Hepburn, J.C., eds., 1993, Field Trip Guidebook for Northeastern United States: Geological Society of America, Annual Meeting, October 25-28, Boston, Mass., p. R1-29.

Huang, Quin, and Angelier, J., 1989, Fracture spacing and its relation to bed thickness: Geology Magazine, v. 126 , p. 335-362.

Jahns, R.H., 1943, Sheet structure in granites: Its origin and use as a measure of glacial erosion in New England: Journal of Geology, v. 51, p. 71-98.

Johnson, C.D., 1996, Use of a borehole color video camera to identify lithologies, fractures, and borehole conditions in bedrock wells in the Mirror Lake Area, Grafton County, New Hampshire, in Morganwalp, D.W., and Aronson, D.A., eds., U.S. Geological Survey Toxic Substance Hydrology Program-Proceedings of the Technical Meeting, Colorado Springs, Colo., September 20-24, 1993: U.S. Geological Survey Water-Resources Investigations Report 94-4015, v. 1, p. 89-94.

1998, Subsurface lithology and fracture occurrence and their effects on hydraulic conductivity: Mirror Lake research site, Grafton County, New Hampshire: Durham, N.H., University of New Hampshire, unpublished Master's thesis, $159 \mathrm{p}$.

Kulander, B.R., Barton, C.C., and Dean, S.L., 1979, Applications of fractography to core and outcrop investigations: U.S. Department of Energy Report METC/SP-79/3, $179 \mathrm{p}$.

Kulander, B.R., Dean, S.L., and Ward, B.J., 1990, Fracture core analysis-Interpretation, logging, and use of natural and induced fractures in core: Tulsa, Okla., Association of Petroleum Geologists, Methods in Exploration Series, no. 8, 88 p.

Likens, P.C., 1991, Publications of the Hubbard Brook Ecosystem Study: Millbrook, N,Y., Institute of Ecosystem Studies, 109 p.

Long, J.C.S., Remer, J.S., Wilson, C.R., and Witherspoon, P.A., 1992, Porous media equivalents for networks of discontinuous fractures: Water Resources Research, v. 18 , no. 3 , p. $645-658$. 
Lyons, J.B., 1964, Distribution of thorium and uranium in three early Paleozoic plutonic series of New Hampshire: U.S. Geological Survey Bulletin 144-F, $43 \mathrm{p}$.

Lyons, J.B., Bothner, W.A., Moench, R.H., and Thompson, J.B., Jr., 1997, Bedrock geologic map of New Hampshire: U.S. Geological Survey State Geologic Map, 2 sheets, scales 1:250,000 and 1:500,000.

Lyons, J.B., Boudette, E.L., and Aleinikoff, J.N., 1982, The Avalon and Gander zones in central eastern New England, in St. Julien, P., and Beland, J. eds., Major structural zones and faults of the northern Appalacians: Geological Association of Canada Special Paper 24, p. 43-66.

Marshal, D.J., Giles, J.H., and Mariano, A., 1986, Combined instrumentation for EDS elemental analysis and cathodoluminescence studies of geologic materials, in Hagni, R.D., ed., Proceedings of symposium on process mineralogy, Annual Meeting, New Orleans, La., March 2-6, 1986: The Metallurgical Society, Process Mineralogy VI, p. 117-135.

McHone, J.G., 1984, Mesozoic igneous rocks of northern New England and adjacent Quebec-Summary, description map, and bibliography of data sources: Geological Society of America, Map and Chart Series, MC-49.

Moke, C.B., 1946, The geology of the Plymouth Quadrangle, New Hampshire: Concord, N.H., State Planning and Economic Development, $21 \mathrm{p}$.

Narr, William, and Suppe, J., 1991, Joint spacing in sedimentary rocks: Journal of Structural Geology, v. 13, p. 1037-1048.

Olson, J.C., 1941, Mica-bearing pegmatites of New Hampshire: U.S. Geological Survey Strategic Minerals Investigation, Bulletin 931-P, p. 363-403.

Olson, J.C., and Overstreet, W.C., 1964, Geologic distribution and resources of thorium: U.S. Geological Survey Bulletin 1204, $61 \mathrm{p}$.

Paillet, F.L., 1985, Geophysical well log data for study of water flow in fractures in bedrock near Mirror Lake, West Thornton, New Hampshire: U.S. Geological Survey Water-Resources Investigations Report 85-340, $27 \mathrm{p}$.

-1991, Comparing geophysical logs to core and cross-hole flow logging in the Mirror Lake drainage basin, in Mallard, G.E., and Aronson, D.A., eds., U.S. Geological Survey, Toxic Substances Hydrology Program-Proceedings of Technical Meeting, Monterey, Calif., March 11-15, 1991: U.S. Geological Survey Water-Resources Investigations Report 91-4034, v., p. 162-171.

Paillet, F.L., and Duncanson, Russell, 1994, Comparison of drilling reports and detailed geophysical analysis of ground-water production in bedrock wells: Ground Water, v. 32, no. 2, p. 200-206.

Paillet, F.L., and Kapucu, Kemal, 1989, Fracture characterization and fracture permeability estimates from geophysical logs in Mirror Lake watershed, New Hampshire: U.S. Geological Survey Water-Resources Investigations Report 89-4058, 49 p.

Plumb, R., Engelder, T., and Yale, D., 1984, Near-surface in-situ stress correlation with microcrack fabric within New Hampshire granites: Journal of Geophysical Research, v. 89. no. B11, p. 9350-9364.

Pollard, D.D., and Aydin, Atilla, 1988, Progress in understanding jointing over the past century: Geological Society of America Bulletin, v. 100, p. 1181-1204.

Priest, S.D., and Hudson, J.A., 1976, Discontinuity spacing in rock: International Journal of Rock Mechanics and Mining Science and Geomechanics Abstracts, v. 13, p. 135-148.

Randall, A.D., Francis, R.M., Frimpter, M.H., and Emery, J.M., 1988, Region 19, Northeastern Appalachians, in Back, William, Rosenshein, J.S., and Seaber, P.R., eds., Hydrogeology: Boulder, Colo., Geological Survey of America, The Geology of North America, v. O-2, p. 177-187.

Rives, T., Razack, M., Petit, J.P., and Rawnsley, K.D., 1992, Joint spacing-Analogue and numerical simulations: Journal of Structural Geology, v. 14, no. 8/9, p. 925937.

Seeburger, D.A., and Zoback, M.D., 1982, The distribution of natural fractures and joints at depth in crystalline rock: Journal of Geophysical Research, v. 87, no. B7, p. 5517-5534.

Shapiro, Allen, 1993, Influence of heterogeneity on regional hydraulic properties of crystalline rock, in Banks, Shelia, and Banks, David, eds., International Association of Hydrologists 24th Congress on the Hydrology of Hard Rocks, Oslo Norway, June 28-July 2, 1993: International Association of Hydrologists Memoirs, v. XXIV, part 1, p. 125-136.

Shapiro, A.M., and Hsieh, P.A., 1991, Research in fractured rock hydrogeology: Characterizing fluid movement and chemical transport in fractured rock at the Mirror Lake drainage basin, New Hampshire, in Mallard, G.E., and Aronson, D.A., eds., U.S. Geological Survey Toxic Substances Hydrology Program Proceedings of Technical Meeting, Monterey, Calif., March 11-15, 1991: U.S. Geological Survey WaterResources Investigations Report 91-4034, p. 155-161.

Snow, D.T., 1968, Rock-fracture spacings openings and porosities: Journal of the Soil Mechanics \& Foundations Division, American Society of Civil Engineers, v. 94, no. SMI 1-5, p.73-91. 
1970 , The frequency and aperture of fractures in rock: International Journal of Rock Mechanics and Mining Sciences, v. 7, p. 23-40.

Terzaghi, R.D., 1965, Sources of error in joint surveys: Geotechnique, v. 15, p. 287-304.

Thompson, J.B., Jr., Bothner, W.A., Robinson, Peter, Isachsen, Y.G., and Klitgord, K.D., 1993, ContinentOcean Transect E-1-Adirondacks to George's Bank: Geological Society of America DNAG Series, scale 1:500,000 and pamphlet, $55 \mathrm{p}$.

Trainer, F.W., 1988, Hydrogeology of the plutonic and metamorphic rocks, in Back, William, Rosenshein, J.S., and Seaber, P.R., eds., Hydrogeology: Boulder, Colo., Geological Survey of America, The Geology of North America, v. O-2, p. 367-380.

Winkler, H.G.F., 1979, Petrogenesis of metamorphic rocks: N.Y., Springer-Verlag, p. 348.

Winter, T.C., 1984, Geohydrologic setting of Mirror Lake, West Thornton, New Hampshire: U.S. Geological Survey Water-Resources Investigations Report 84-4266, $61 \mathrm{p}$.

1985, Mirror Lake and its watershed, A physiographic setting and geologic origin of Mirror Lake, in Likens, G.E., ed., An ecosystem approach to aquatic Ecology-Mirror Lake and its environment: N.Y., Springer-Verlag, p. 40-53.

Winter, T.C., Eaton, J.S., and Likens, G.E., 1989, Evaluation of inflow to Mirror Lake, New Hampshire: Water Resources Bulletin, v. 25, no. 5, p. 991-1008.

Wood, W.W., Shapiro, A.M., and Hsieh, P.A., 1996, Observational, experimental and inferred evidence for solute diffusion in fractured granite aquifers; examples from the Mirror Lake Watershed, Grafton County, New Hampshire, in Morganwalp, D.W., and Aronson, D.A., eds., U.S. Geological Survey Toxic Substance Hydrology Program-Proceedings of the Technical Meeting, Colorado Springs, Colo., September 20-24, 1993: U.S. Geological Survey Water-Resources Investigations Report 94-4015, v. 1, p. 167-170.

Zoback, M.D., and Zoback, MaryLou, 1989, Stress in the Earth's lithosphere, in James, D.E., ed., The encyclopedia of solid earth geophysics: N.Y.,Van Nostrand Reinhold Co., p. 1221-1232.

\section{GLOSSARY}

\section{Air-hammer rotary drilling. See percussion rotary} drilling.

Allotriomorphic granular. Crystalline texture of an igneous or metamorphic rock characterized by crystals that are mostly anhedral, or without crystalline form.
Anhedral. A descriptive term for a mineral grain that does not exhibit its own crystal outline.

Anatectic. A term that is used to describe a rock that has undergone anatexis, which is a partial to complete melting of existing rocks.

Annulus. A drilling term used to describe the space in a borehole around the casing or around the drill stem.

Aphanitic. Texture of an igneous rock in which the crystalline components are not distinguishable by the unaided eye.

Aplite. Light-colored igneous rocks characterized by a fine-grained allotriomorphic-granular texture. They consist essentially of quartz, potassium feldspar, and acid plagioclase.

Augen. A large lenticular mineral grain or cluster of grains in foliated metamorphic rocks. In cross-section the augen is eye-shaped.

Diabase. A general term for a group of igneous rocks that are rich in mafic minerals and are typically dark in color. They can be intrusive (as in a dike) or extrusive (as in volcanics).

Borehole. An open hole created in the subsurface by drilling. It is synonymous with well.

Borehole development. A procedure followed after drilling a borehole in order to remove fine particulate rock fragments and drilling fluids from the borehole.

Boudin. Sausage-shaped, elongated structures that are formed along bedding planes from the stretching, pinching, and failure of competent layers, which are surrounded by less competent material. The boudins observed in this sudy area are rich in diopside (a calcium silicate).

Brecciated. A descriptive term for a rock structure that exhibits an accumulation of angular fragments.

Chill margin. The border or marginal area of an igneous intrusion, characterized by finer grain than the interior of the rock mass, owing to more rapid cooling.

Clinochlore. A magnesium-rich mineral in the chlorite group. It is usually green. It is common in metamorphic assemblages and is frequently an alteration product of pyroxenes, biotites, and garnet in igneous rocks.

Contact. A plane or irregular surface between two different types or ages of bedrock or unconsolidated sediments.

Core. A cylindrical sample of bedrock obtained by use of a special drilling bit and retrieved by use of a core barrel.

Core barrel. Two nested tubes above the drill bit, the outer rotating with the bit, the inner receiving and preserving a continuous section or core of the material penetrated.

Coring-induced fractures. Fractures caused by the drilling process. The occurrence is related to the stresses imposed during drilling and to the location of structural flaws in the rock matrix. 
Core recovery. A measurement of the length of the core that was obtained relative to the length that was drilled. The core recovery is expressed as a percent.

Coticule laminae. A layer of fine-grained quartz and spessartite garnet that is found in metasedimentary rocks.

Coticule layers. Metamorphosed, fine grained quartz and spessartite garnet that usually are formed in layers.

Cuttings. Drill cuttings are fragments of rock that were created by drilling.

Dike. A planar or tabular intrusive that is usually discordant with the surrounding country rock.

Drilling fluid. A fluid (or gas) that is used in the drilling process to remove cuttings and naturally occurring fluids from the borehole.

Drive shoe. A steel collar that is fixed to the lower end of the casing. It serves as a protective leading edge of the casing as it is hammered into solid bedrock.

XRF. Energy dispersive $x$-ray fluorescence spectrometry (XRF) uses a electrons from $x$-ray beam to interact with the sample. Outer shell electrons on the sample are forced to drop to a lower shell, which causes a characteristic release of energy. Energy detectors sample all elements at the same time, and count the occurrence of each element. XRF is used in conjunction with scanning electron microscope.

Euhedral. A descriptive term for a mineral grain that is bounded by its own rational crystal face.

Exfoliation. A process of weathering in which sheets of rocks are removed from the rock mass.

Fault. A fracture or a zone of fractures along which there has been displacement of the sides relative to one another parallel to the fracture.

Feldspar. A group of aluminosilicate minerals containing potassium (as in orthoclase), or a mixture of sodium (albite) and calcium (anorthite).

Felsic. An igneous rock having abundant light-colored minerals in its mode.

Felsic stringers. In this report the term has been used to describe very thin $(<2 \mathrm{~cm})$ usually irregularly shaped veins comprised of felsic minerals.

Flowmeter. A downhole tool used to measure vertical flow within a borehole. The most sensitive flowmeters use a chemical or thermal tracer that moves upward or downward under the influence of vertical gradients in a borehole.

Foliation. A general term for a planar arrangement of textural or structural features in any type of rock; especially the planar structure that results from flattening of the constituent grains of a metamorphic rock.

Fracture. A generic term for a break, crack, or opening in bedrock along which water may flow.
Fracture set. A group of fractures that exhibit similar orientations as they formed in response to the same stress or stresses.

Gamma-photon emissions. Gamma photons, which are a form of electromagnetic radiation, are natural products of radioactive decay of uranium, thorium and potassium-40. The emissions occur as one radioisotope is transformed to another in the decay process.

Global Positioning System. Global Positioning Systems (GPS) make use of satellite and land-based radio signals to determine geographically referenced locations. [The accuracy of the coordinates determined using a GPS depend on the tool and the number of satellites used for the determination of the location.]

Gouge. Fault gouge is soft, pulverized, clay-rich material that is found along some faults.

Gneiss. A coarse-grained metamorphic rock that exhibits less than 50 percent foliated minerals. A banded gneiss exhibits alternating bands of granular and micaceous minerals.

Gneissic. A descriptive term for rocks that exhibit texture that is similar to gneiss.

Granite. A coarse-grained, light-colored, igneous intrusive rock comprised of quartz, feldspar, and mica.

Granitoid. A granitic rock, or a plutonic rock with 20-60 percent quartz, and frequently with gneissic texture.

Grout. A cement slurry of high water content, which can be poured or injected and used to fill or seal spaces.

Hypidiomorphic-granular. A texture of igneous rock that is comprised of a mixture of euhedral, subhedral, and anhedral crystals.

Igneous. Descriptive term for rocks or minerals solidified from molten or partially molten material, that is, formed from a magma, such as a granite, monzonite, or diabase.

Joint. A surface fracture or parting in a rock along which there has been no displacement.

Lens. A tabular layer that is thickest at the center and pinches out at the edges.

Leucocratic. Light-colored igneous rocks with few mafic minerals.

Leucosome. The light-colored, equigranular part of a migmatite, usually coarse grained and rich in quartz, feldspar (plagioclase), and muscovite. Generally it does not exhibit foliation.

Liesegang bands. Bands of iron migration within the matrix of rock.

Lineation. A term used to describe the parallel alignment of linear structures within a rock.

Mafic. A term used to describe minerals that are rich in iron and magnesium (ferromagnesian). A mafic rock is typically dark in color. 
Matrix. (igneous rock): A descriptive term that refers to the interlocking mineral grains that comprise the solid fine-grained part of a rock. In igneous rock this is also called the groundmass. (general term): The matrix also refers to the solid rock that bounds a fracture.

Melanosome. The dark-colored, foliated part of migmatite, rich in mafic minerals.

Metamorphic. Descriptive term for rocks such as gneiss and schist, that have formed, in the solid state, from other rocks due to changes in temperature and pressure.

Metamorphism. The process of rocks, such as gneiss and schist, forming in the solid state from other rocks as the result of changes in temperature and pressure.

Metasedimentary rock. A metamorphic rock whose original material was sedimentary.

Migmatite. A rock that is a product of partial melting. Usually, it exhibits a coarse-grained mixture of igneous and (or) metamorphic characteristics. The felsic igneous part is called a leucosome, and the foliated mafic section is the melanosome.

NAD of 1927. North American datum of 1927 is a horizontal, surveying datum that is used to reference cartographic locations. All locations that are referenced to NAD27 can be converted to the more recent datum (NAD of 1983). It is important for spatial relations that features be referenced to the same datum.

Nappes. A sheet like mass of rock that has been moved in a horizontal direction either by thrust faulting or recumbent folding.

Orogeny. The process of mountain formation.

Outcrop. A part of the bedrock that is exposed at the land surface.

Oxidation. A process that causes alteration of minerals and (or) water as a result of electron transfer. The species that loses electrons in the oxidation-reduction process is said to be oxidized.

Panidiomorphic granular. A rock texture comprised almost completely of euhedral crystals. It is most often exhibited in intrusive mafic rocks such as lamprophyres.

Pegmatite. Extremely coarse-grained igneous rock with interlocking crystals. The composition is usually granitic.

Pelitic. A term used to describe metamorphosed aluminium rich (argillaceous) rocks.

Percussion rotary drilling. A method of drilling in bedrock. The drill bit pulses, or hammers, and simultaneously turns its way into the rock, causing it to fragment. Compressed air or water is forced down the center of the drill rods in order to evacuate rock cuttings and fluids from the borehole.
Petrographic. A descriptive term that refers to the classification of rock types usually by means of microscopic examination of thin-section samples of rocks. Petrographic analyses can also include $x$-ray diffraction and SEM analyses.

Phenocryst. A large, conspicuous crystal in a relatively fine-grained matrix.

Phlogopite. A magnesium-rich, iron-poor phyllosilicate that is copper-colored to reddish brown.

Phyllosilicate. Mineral and crystalline structure of siliconoxygen tetrahedra arranged in sheets. "Mica", muscovite, biotite, phologopite, and chlorite are phyllosilicates.

Pneumatic packer. A device that is positioned in the borehole and inflated in order to seal or "pack-off" portions of the borehole. One or more packers can be used at the same time to isolate discrete sections of the borehole for hydraulic testing or water sampling.

Porphoritic. An igneous rock texture that exhibits several phenocrysts (relatively large crystals) in a fine-grained matrix.

Primary porosity. The porosity that developed during the final stages of sedimentation or that was present within sedimentary particles at the time of deposition.

Quartzite. A metamorphic rock consisting of quartz and other impurites such as sulfide minerals. Quartzite formed from the metamorphism of quartz-rich deposits such as sandstone.

Rare-earth element phosphate. A mineral comprised of rare-earth metals such as cerium, lanthanum, yttrium, thorium, and phosphate. Monazite is a rare-earth element phosphate that is comprised of 1 to 20 percent thorium, which is radioactive.

Rotary drilling. Method of drilling deep boreholes using a drill bit attached to the bottom of a rotating drill pipe.

Saprolite. A clay-rich, decomposed rock formed by chemical weathering of igneous, sedimentary, and metamorphic rocks. It is commonly called "rotten rock".

Schist. A metamorphic rock characterized by strong schistosity and foliation.

Schistosity. A characteristic texture or cleavage or rock comprised of platy minerals whose long axis lies in the same direction and forms a lineation in the rock. It imparts a planar fissility in the rock.

Schlieren. Restites or residuals of mafic-rich, foliated minerals, which occur in wispy-looking layers usually less than 2.5 centimeters wide.

Secondary porosity. Porosity caused by secondary features such as fractures or solution cavities. 
SEM. A scanning electron microscope (SEM) uses a focused beam of electrons, which is moved across the sample, to produce a magnified view of the rock sample. The SEM is used in conjunction with energy dispersive $x$-ray fluorescence spectrometry (XRF) in order to measure the elemental composition of a sample.

Sericite. Product of alteration or retrograde metamorphism of potassium feldspar to white fibrous mica.

Slickenside. Shiny, striated surface that is caused by the polishing action along a fault surface.

Stress. The resultant forces, expressed in force per unit area, acting on any point within a solid.

Stress field. The state of stress for a given domain or region.

Subhedral. A descriptive term used to define the degree to which a mineral exhibits its crystalline form. A subhedral mineral exhibits some of its crystal form. Subhedral is intermediate to euhedral and anhedral.

Syncline. Folded stratified rocks that dip downward from opposite directions and meet in the middle of a trough. Younger sediments are folded towards one another.

Synclinorium. A regional fold that is concave upward and whose younger stratigraphic layers are in the core of the fold.

Texture. General physical appearance or character of a rock caused by variations in grain size, crystalline shape and orientation, and fabric of the rock.

Thin section. A very thin slice of rock that enables light to pass through so that the optical properties of the rock can be analyzed for purposes of describing and identifying minerals.

Till. A predominantly nonsorted, nonstratified sediment deposited directly by a glacier and comprised of boulders, gravel, sand, silt, and clay mixed in various proportions.
Unconsolidated rock. A sediment in which the particles are not firmly cemented together, such as a sand, in contrast to sandstone.

Vein. A tabular or sheet-like igneous body that has been intruded into a pre-existing rock along a joint or crack. In this report, the term vein has been used for igneous intrusions that are less than $20 \mathrm{~cm}$ wide.

Verging, vergence. A structure in crystalline rock that exhibits an inclined or overturned fold.

Vesicular. A term used to describe a rock texture that is characterized by vesicles or cavities formed by expansion of gases during solidification of the igneous magma.

Wilcoxon-Mann-Whitney, test. A statistical test used to determine if two different sample populations come from an identical population. It is also called the ranksum test and is a non-parametric alternative to the twosample $t$ test.

Wire-line core barrel. A core barrel that can be retrieved from the borehole by use of a steel cable and a winch. The advantage of using a wire-line core barrel over conventional tools is that all of the drill rods can remain in the borehole while the core sample is retrieved.

Xenolith. The inclusion of a pre-existing rock in an igneous rock, usually a piece of the non-igneous surrounding, or "country" rock.

X-ray diffraction. A method that uses a beam of electromagnetic radiation focused at a rock sample. Minerals in the sample are identified by the characteristic interference patterns caused by the $\mathrm{x}$-rays and the crystalline structure of the minerals.

Zinnwaldite. A phyllosilicate mineral that is often associated with lithium-bearing minerals such as monazite, flourite, beryl, or tourmaline. 
APPENDIX 


\section{LITHOLOGY}

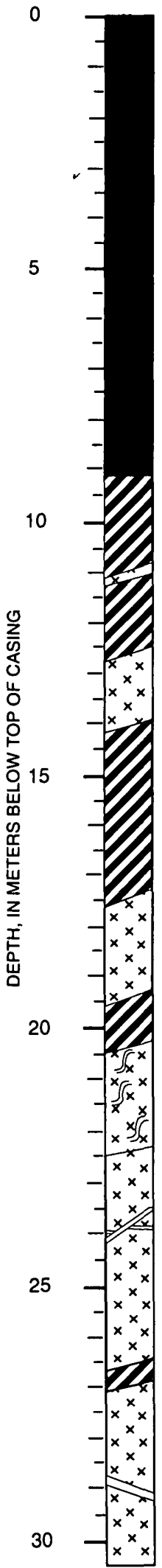

FRACTURE

ATTRIBUTES
DESCRIPTION: Generalized log in bold.

SAND from 0.55 to $1.1 \mathrm{~m}, \sim 0.55 \mathrm{~m}$ wide

TILL from 1.1 to $5.8 \mathrm{~m}$, tan, silty, $\sim 4.7 \mathrm{~m}$ wide

TILL boulders and cobbles from 5.1 to $5.8 \mathrm{~m}$

\section{BEDROCK SURFACE at $5.8 \mathrm{~m}$}

BOTTOM OF CASING at $9.1 \mathrm{~m}$

SCHIST from 9.1 to $12.8 \mathrm{~m}$, fine to medium grained, biotiterich with felsic augens, $\sim 3.7 \mathrm{~m}$ wide

GRANITE DIKE from 11.0 to $11.3 \mathrm{~m}$, biotite-muscovite, parallel to the foliation of schist, gradational contacts, $\sim 0.3 \mathrm{~m}$ wide

GRANITE DIKE from 12.8 to $14.3 \mathrm{~m}$, biotite-muscovite, parallel to the foliation of schist, $\sim 1.5 \mathrm{~m}$ wide

SCHIST from 14.4 to $17.7 \mathrm{~m}, \sim 3.3 \mathrm{~m}$ wide GNEISS/SCHIST from 14.3 to $16.5 \mathrm{~m}$, gneissic texture, banded, $\sim 2.2 \mathrm{~m}$ wide

GRANITE DIKE from 17.7 to $19.5 \mathrm{~m}$, biotite-muscovite, medium to coarse grained, upper and lower contact parallel to the foliation of schist, weakly foliated,

$\sim 1.8 \mathrm{~m}$ wide

SCHIST from 19.5 to $20.5 \mathrm{~m}$, laminated to banded, $\sim 1.0 \mathrm{~m}$ wide

GRANITE or GNEISS from $\mathbf{2 0 . 5}$ to $\mathbf{2 2 . 5} \mathrm{m}$, moderately foliated, coarse grained, $\sim 2.5 \mathrm{~m}$ wide SCHIST from 22.5 to $22.8 \mathrm{~m}, \sim 0.3 \mathrm{~m}$

24.0

GRANITE from 22.8 to $30.6 \mathrm{~m}$, biotite-muscovite granite, medium to coarse grained, $\sim 7.8 \mathrm{~m}$ wide

FELSIC BANDS at $24.0 \mathrm{~m}$ with offset $\sim 1-2 \mathrm{~cm}$ wide. Bands are $\sim 1$ to $2 \mathrm{~cm}$ wide.

FELSIC BAND at $26 \mathrm{~m}, \sim 1$ to $2 \mathrm{~cm}$ wide, not shown

SCHIST from 26.5 to $27.0 \mathrm{~m}, \sim 0.5 \mathrm{~m}$ wide

QUARTZ VEIN at $29.0 \mathrm{~m}, \sim 20 \mathrm{~cm}$ wide 


\section{FRACTURE}

FRACTURES ATTRIBUTES

30.47

$30.47-7$
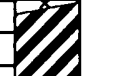

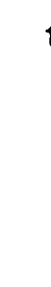$$
187
$$$$
182.7
$$

22

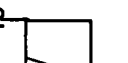

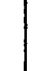<smiles>C1CCC1</smiles>

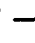
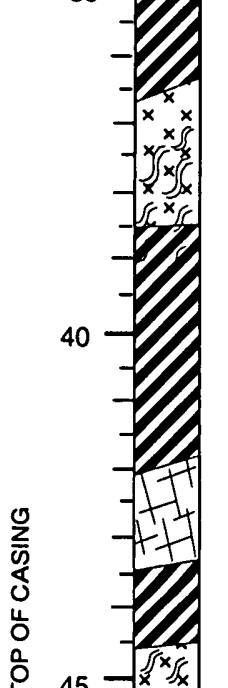

안 45

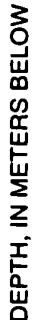

60

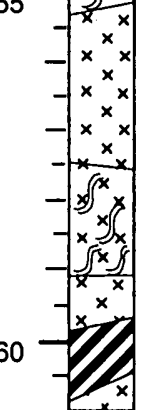

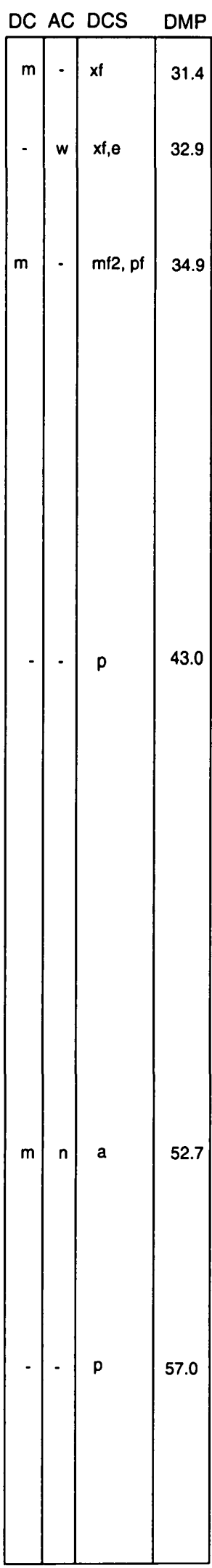

DESCRIPTION: Generalized log in bold.

GRANITE continued to $30.6 \mathrm{~m}$

SCHIST from 30.6 to $36.5 \mathrm{~m}$, gneissic, coarse grained

FELSIC VEIN at $32.8 \mathrm{~m}$, steeply dipping, $\sim 15 \mathrm{~cm}$ to $20 \mathrm{~cm}$ wide

GNEISS from 34.0 to $35.0 \mathrm{~m}$, gradual contacts, $\sim 1.0 \mathrm{~m}$ wide

GRANITE from 36.5 to $38.5 \mathrm{~m}$, fine grained, dusky, equigranular, lower 1 meter grading to foliated schist below, $\sim 2.0 \mathrm{~m}$ wide

SCHIST from 38.5 to $42.0 \mathrm{~m}$, coarse grained, $\sim 3.5 \mathrm{~m}$ wide

PEGMATITE from 42.0 to $43.4 \mathrm{~m}, \sim 1.4 \mathrm{~m}$ wide

SCHIST or GNEISS from 43.4 to $53.0 \mathrm{~m}$, equigranular matrix with some foliation, $\sim 9.6 \mathrm{~m}$ wide

SCHIST from 43.4 to $46.9 \mathrm{~m}$, gneissic texture, $\sim 3.5 \mathrm{~m}$ wide

PEGMATITE from 46.9 to $47.2 \mathrm{~m}, \sim 0.3 \mathrm{~m}$ wide GRANITE from 47.2 to $48.0 \mathrm{~m}$, gray, biotite-muscovite, $\sim 0.8 \mathrm{~m}$ wide

GRANITE from 49.7 to $50.0 \mathrm{~m}$, chlorite-muscovite, $\sim 0.3 \mathrm{~m}$ wide

SCHIST and GNEISS from $\mathbf{5 3 . 0}$ to $\mathbf{5 5 . 2} \mathrm{m}$, alternating bands of equigranular gneiss or granite and weakly foliated schist, chlorite-muscovite, gradual contacts, $\sim 2.2 \mathrm{~m}$ wide

GRANITE from 55.2 to $57.5 \mathrm{~m}$, whitish gray, $\sim 2.3 \mathrm{~m}$ wide FELSIC VEINS at 55.5 and $57.0 \mathrm{~m}, \sim 2$ to $3 \mathrm{~cm}$ wide (not shown)

GNEISS from 57.5 to $59.9 \mathrm{~m}$, coarse grained

GRANITE from 59.0 to $59.8 \mathrm{~m}$, altered, $\sim 0.8 \mathrm{~m}$ wide

SCHIST from 59.8 to $60.7 \mathrm{~m}, \sim 0.9 \mathrm{~m}$ wide

GRANITE from 60.7 to $62.5 \mathrm{~m}, \sim 1.8 \mathrm{~m}$ wide 


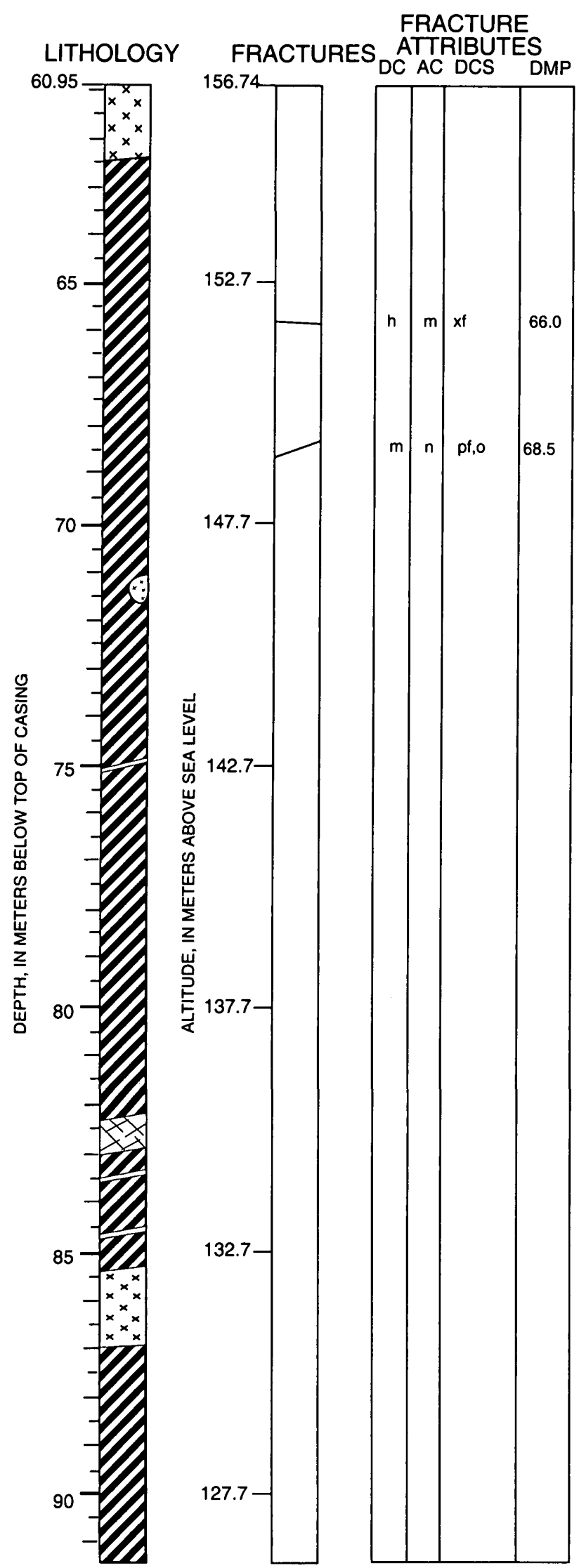

DESCRIPTION: Generalized log in bold.

GRANITE continued to $62.5 \mathrm{~m}$

GRANITE from 61.0 to $62.5 \mathrm{~m}$, altered muscovite-rich and chlorite, coarse grained, $\sim 1.5 \mathrm{~m}$ wide

SCHIST from 62.5 to $113.7 \mathrm{~m}$, steeply dipping foliation, green, chlorite-muscovite, fine grained, $\sim 22.8 \mathrm{~m}$ wide

SCHIST from 70.0 to $78.5 \mathrm{~m}$, augen schist, gradual contacts, $\sim 8.5 \mathrm{~m}$ wide

SCHIST from 71.0 to $71.4 \mathrm{~m}$, felsic zone in schist, $\sim 0.4 \mathrm{~m}$ wide

FELSIC VEIN at $75.0 \mathrm{~m}, \sim 15 \mathrm{~cm}$ wide

PEGMATITE DIKE from 82.3 to $83 \mathrm{~m}, \sim 0.7 \mathrm{~m}$ wide

FELSIC VEIN at $83.5 \mathrm{~m} \sim 5 \mathrm{~cm}$ wide

FELSIC VEIN at $84.7 \mathrm{~m} \sim 3 \mathrm{~cm}$ wide

GRANITE from 85.3 to $87.0 \mathrm{~m}$, coarse grained, some foliation, altered, $\sim 1.7 \mathrm{~m}$ wide

SCHIST from $\sim 87.0$ to $\sim 91.0 \mathrm{~m}$, chlorite-muscovite schist with some biotite, gradual contacts, $\sim 4.0 \mathrm{~m}$ wide 
C01 Continued

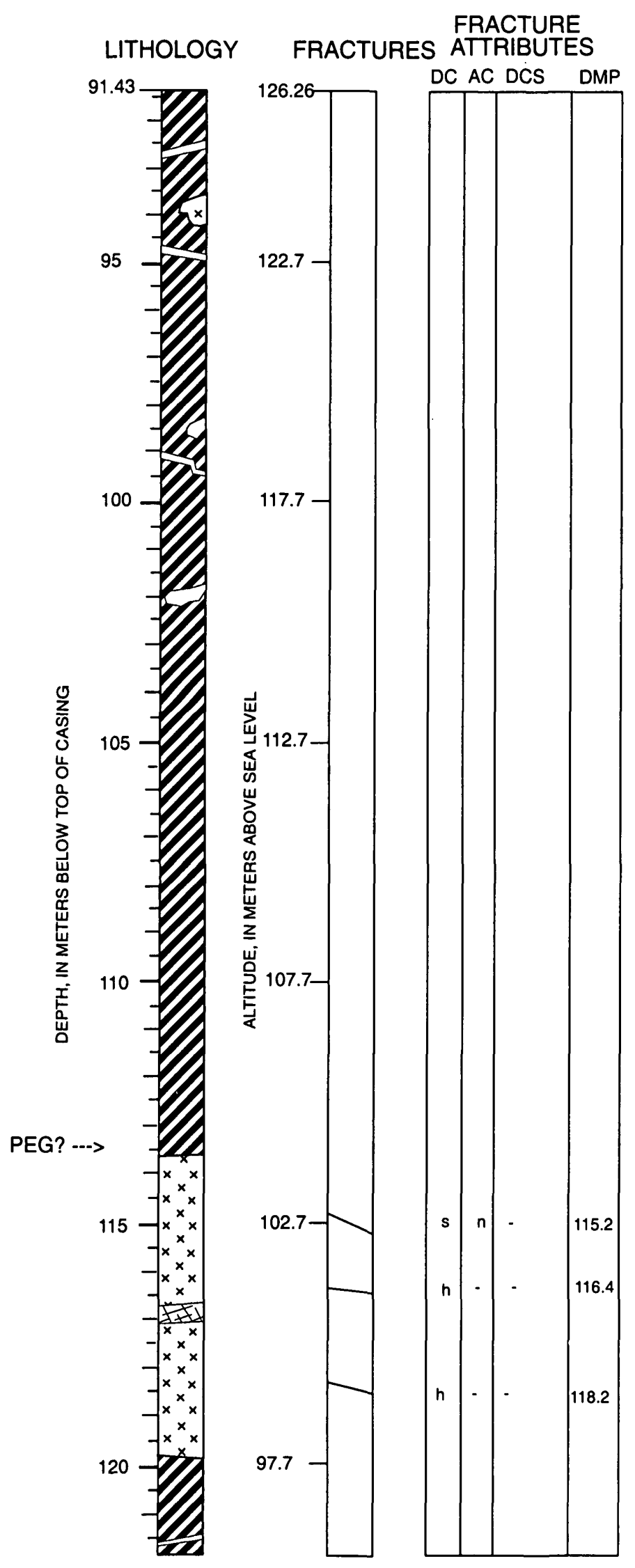

DESCRIPTION: Generalized log in bold.

SCHIST continued to $113.7 \mathrm{~m}$

PEGMATITE VEIN at $92.7 \mathrm{~m}, \sim 5 \mathrm{~cm}$ wide

APLITE VEIN at $94.8 \mathrm{~m}$, cross-cutting foliation of schist, $<5 \mathrm{~cm}$ wide

SCHIST from 95.0 to $98.7 \mathrm{~m}$, fine grained, biotite-chlorite with sulfides, $\sim 3.7 \mathrm{~m}$ wide

SCHIST from 98.4 to $98.7 \mathrm{~m}$, felsic-rich zone, $\sim 0.3 \mathrm{~m}$ wide

GRANITE or APLITE VEIN at $99.1 \mathrm{~m}$, irregularly shaped, $\sim 5 \mathrm{~cm}$ wide

SCHIST from 101.8 to $102.1 \mathrm{~m}$, felsic-rich zone, $\sim 0.3 \mathrm{~m}$ wide

SCHIST from 110.0 to $113.7 \mathrm{~m}$, augened schist with some banding, gradational upper contact, $\sim 3.7 \mathrm{~m}$ wide

GRANITE from 113.7 to $119.8 \mathrm{~m}$, light grayish white with green microcline, coarse grained, $\sim 6.1 \mathrm{~m}$ wide

PEGMATITE DIKE from 116.7 to $117.1 \mathrm{~m}, \sim 0.4 \mathrm{~m}$ wide

SCHIST from 119.8 to $144.5 \mathrm{~m}$, banded, coarse grained, $\sim 24.7 \mathrm{~m}$ wide

FELSIC VEIN at $121.6 \mathrm{~m}, \sim 5 \mathrm{~cm}$ 


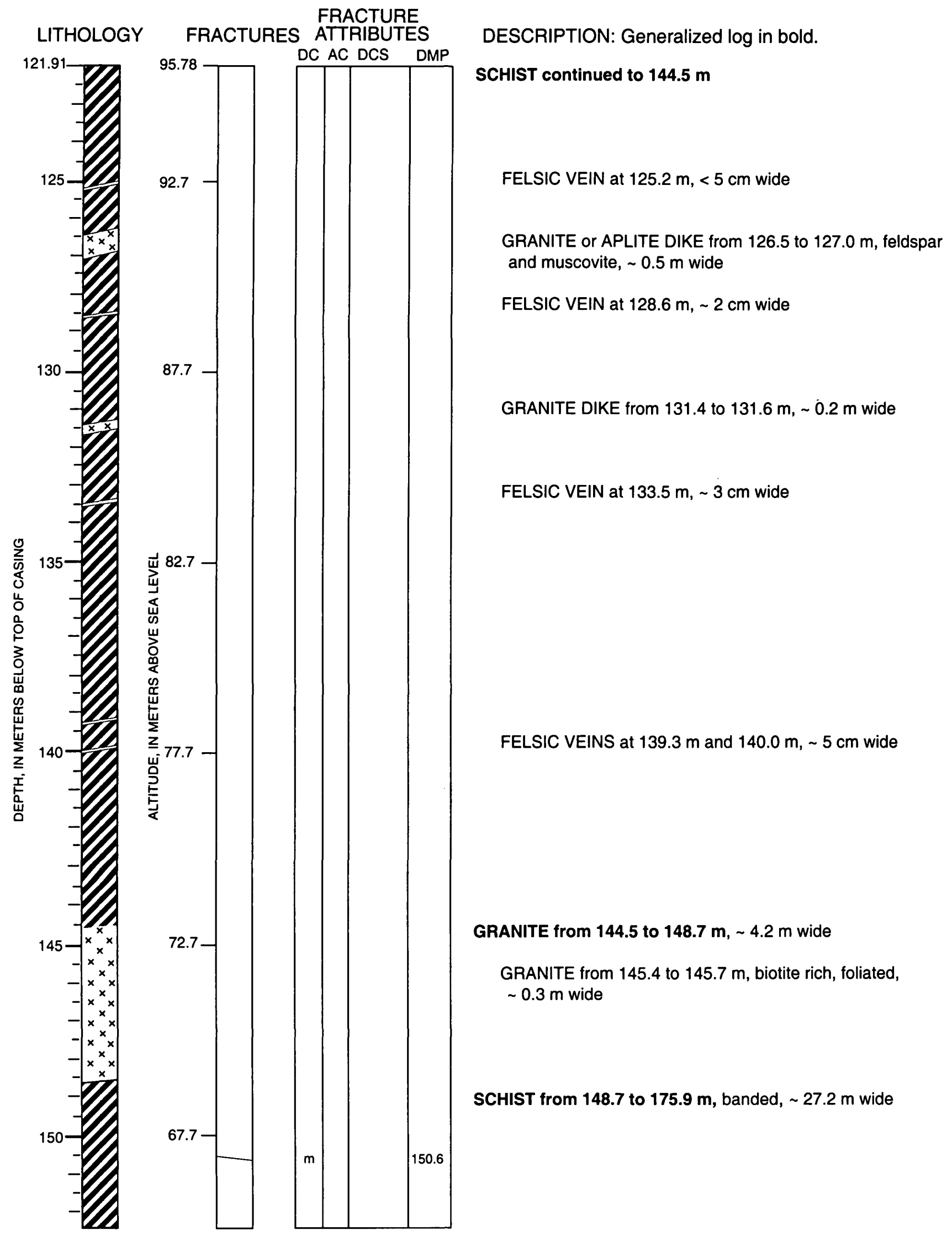


CO1 Continued

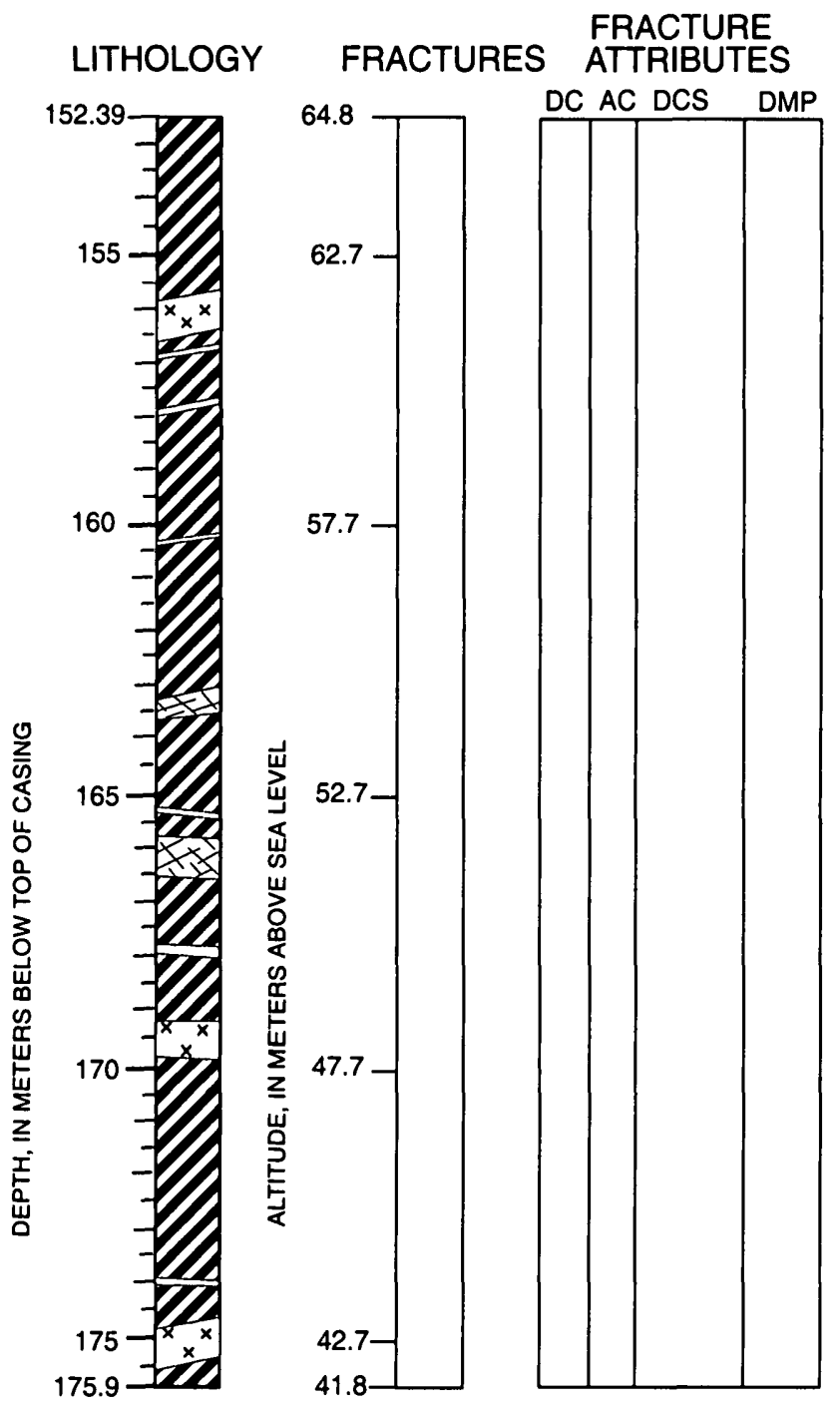

DESCRIPTION: Generalized log in bold.

SCHIST continued to $175.9 \mathrm{~m}$

GRANITE DIKE from 155.9 to $156.5 \mathrm{~m}$, parallel to foliation of schist, $\sim 0.6 \mathrm{~m}$

FELSIC VEIN at $156.7 \mathrm{~m}, \sim 2 \mathrm{~cm}$ wide

FELSIC VEIN at $157.9 \mathrm{~m}, \sim 6 \mathrm{~cm}$ wide

FELSIC VEIN at $160.3 \mathrm{~m}, \sim 2 \mathrm{~cm}$ wide

PEGMATITE DIKE from 163.3 to $163.7 \mathrm{~m}$, cross-cutting foliation of schist, $\sim 0.4 \mathrm{~m}$ wide

GRANITE or APLITE VEIN at $165.2 \mathrm{~m}$, cross-cutting

foliation of schist, $\sim 5 \mathrm{~cm}$ wide

PEGMATITE from 165.8 to $166.7 \mathrm{~m}, \sim 0.9 \mathrm{~m}$

FELSIC VEIN at $167.9 \mathrm{~m}, \sim 8 \mathrm{~cm}$ wide

GRANITE or APLITE DIKE from169.3 to $169.7 \mathrm{~m}, \sim 0.3 \mathrm{~m}$ wide

FELSIC VEIN at $174.0 \mathrm{~m}, \sim 5 \mathrm{~cm}$ wide

GRANITE from 174.9 to $175.9 \mathrm{~m}, \sim 1.3 \mathrm{~m}$ wide

BOTTOM OF WELL AT $175.9 \mathrm{~m}$ 
WELL NAME: CO2

LITHOLOGY

\section{FRACTURES}

FRACTURE
0

5

10

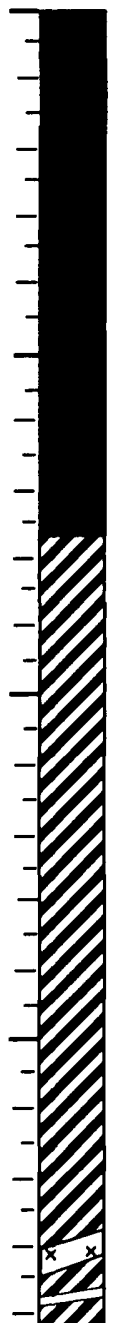

20

25

30

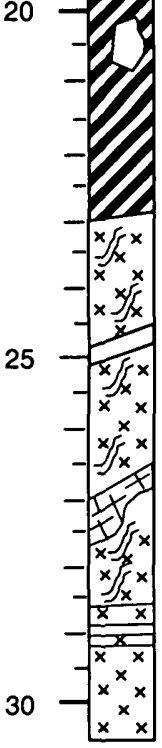

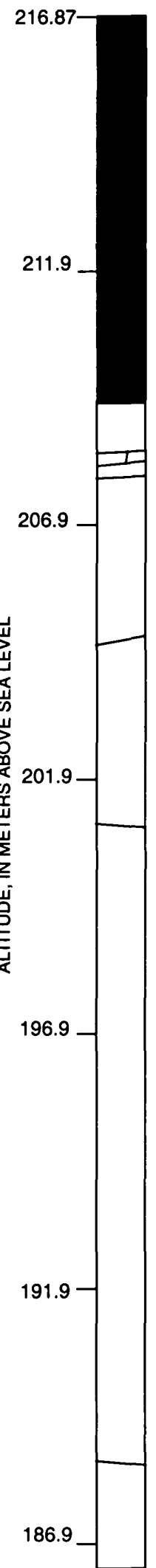

DESCRIPTION: Generalized log in bold.

SAND and SILT from 0.6 to $3.7 \mathrm{~m}$, brown, medium to coarse sand with some fine sand and silt, $\sim 3.1 \mathrm{~m}$ wide

TILL from $~ 3.7$ to $5.4 \mathrm{~m}, \sim 1.5 \mathrm{~m}$ wide

BEDROCK SURFACE at $5.4 \mathrm{~m}$. Cuttings of SCHIST: biotite, muscovite, feldspar, some garnets and trace sillimanite

\section{BOTTOM of CASING at $7.6 \mathrm{~m}$}

SCHIST from 7.6 to $22.9 \mathrm{~m}$, biotite, muscovite, feldspar, some garnets and trace sillimanite, steeply dipping foliation, $\sim 15.3 \mathrm{~m}$ wide
GRANITE DIKE from 17.9 to $18.4 \mathrm{~m}$, coarse grained, oriented parallel to foliation of schist, gradational contact on top and bottom, $\sim 0.5 \mathrm{~m}$ wide FELSIC BAND at $18.8 \mathrm{~m}, \sim 2 \mathrm{~cm}$ wide

FELSIC ZONE in the schist from 20.0 to $20.8 \mathrm{~m}$, on one side of the well, $\sim 0.8 \mathrm{~m}$ wide

GRANITE from 22.9 to $33.5 \mathrm{~m}$, coarse grained, biotitemuscovite, steeply dipping, gradational upper contact, $10.6 \mathrm{~m}$ wide

GRANITE from 22.9 to $29.1 \mathrm{~m}$, gneissic texture, weakly foliated, $\sim 6.2 \mathrm{~m}$ wide

GRANITE DIKE from 24.7 to $25.0 \mathrm{~m}$, leucocratic, equigranular, sharp contacts, near horizontal, $\sim 0.3 \mathrm{~m}$ wide

PEGMATITE from 27.1 to $27.4 \mathrm{~m}$, irregular shape as shown, $\sim 0.3 \mathrm{~m}$ wide

GRANITE DIKE from 28.6 to $28.8 \mathrm{~m}$, leucocratic, medium grained texture, near horizontal, cross-cuts foliation, $\sim 0.2 \mathrm{~m}$ wide

GRANITE OR APLITE DIKE from 29.0 to $\sim 29.2 \mathrm{~m}$, leucocratic, sugar-texture, near horizontal, $\sim 0.2 \mathrm{~m}$ wide

GRANITE from 29.2 to $31.1 \mathrm{~m}$, equigranular, coarse grained, biotite-muscovite, $\sim 2.0 \mathrm{~m}$ wide 


\section{LITHOLOGY}

FRACTURE

ATTRIBUTES
DESCRIPTION: Generalized log in bold.
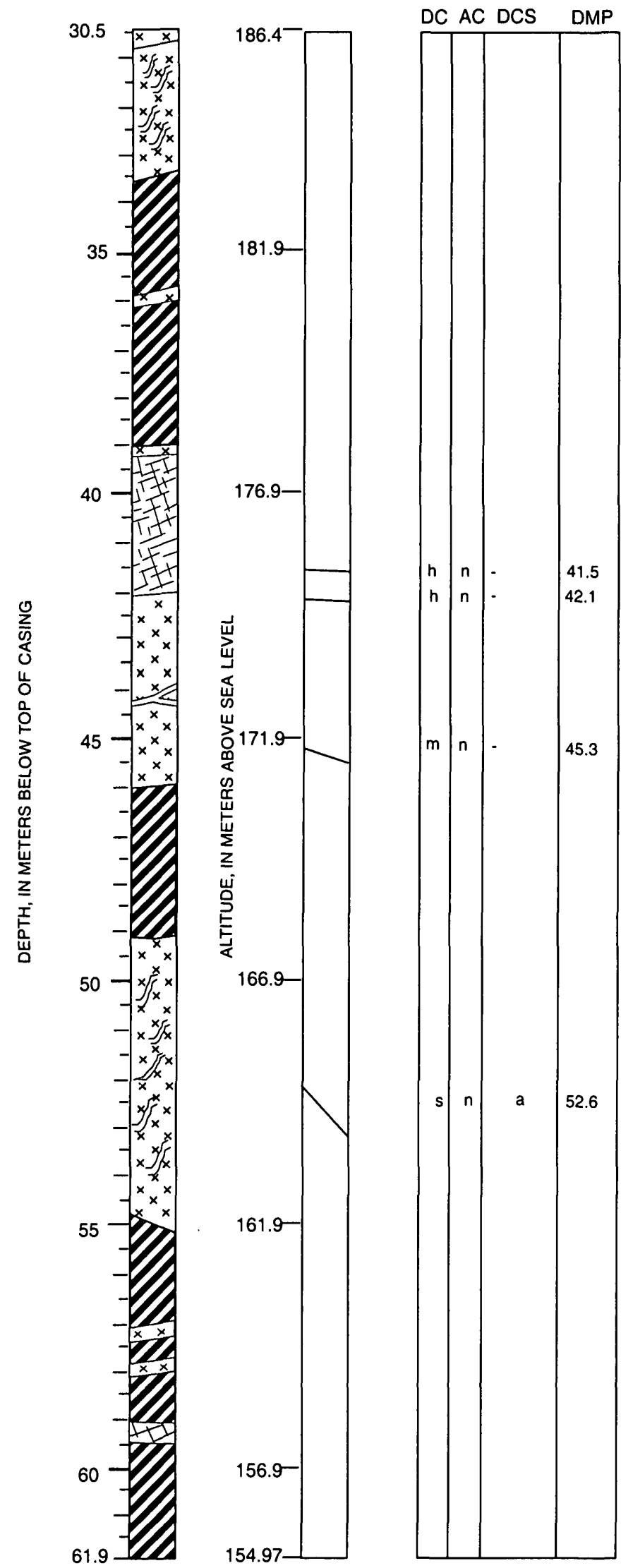

GRANITE continued to $31.1 \mathrm{~m}$

GRANITE from 31.1 to $33.5 \mathrm{~m}$, gneissic texture, vertical foliations, biotite rich, $\sim 2.4 \mathrm{~m}$ wide

FELSIC STRINGERS at $31.6 \mathrm{~m}$ and $32.0 \mathrm{~m}$, each $<5 \mathrm{~cm}$ wide (not shown)

SCHIST from 33.5 to $39.0 \mathrm{~m}$, coarse texture, with steeply dipping foliation, some banding, gradational upper contact, $\sim 5.5 \mathrm{~m}$ wide

GRANITE DIKE from 35.8 to $36.1 \mathrm{~m}$, parallel to foliation of the schist, $\sim 0.3 \mathrm{~m}$ wide

GRANITE 39.0 to $39.2 \mathrm{~m}$, coarse grained, biotitemuscovite, $\sim 0.2 \mathrm{~m}$ wide

PEGMATITE from 39.2 to $42.0 \mathrm{~m}, \sim 2.8 \mathrm{~m}$ wide

GRANITE from 42.0 to $\mathbf{4 6 . 0} \mathrm{m}$, coarse grained, biotitemuscovite, $\sim 4.0 \mathrm{~m}$ wide

FELSIC STRINGERS at $44.3 \mathrm{~m}, \sim 2 \mathrm{~cm}$ wide

SCHIST from 46.0 to $49.1 \mathrm{~m}$, steeply dipping foliation, biotite-chlorite, coarse grained, $\sim 3.1 \mathrm{~m}$ wide

GRANITE from $\mathbf{4 9 . 1}$ to $54.6 \mathrm{~m}$, fine grained, chloritemuscovite, altered, weakly foliated to gneissic, $\sim 5.5 \mathrm{~m}$ wide

FELSIC VEINS at $54.6 \mathrm{~m}$, several intersecting the well at multiple orientations, $\sim 1$ to $2 \mathrm{~cm}$ wide (not shown)

SCHIST from $\mathbf{5 4 . 6}$ to $61.9 \mathrm{~m}$, coarse grained to gneissic texture, steeply dipping foliation, $\sim 7.0 \mathrm{~m}$ wide

GRANITE DIKE from 57.0 to $57.3 \mathrm{~m}$, equigranular, coarse grained, biotite-muscovite, $\sim 0.3 \mathrm{~m}$ wide GRANITE DIKE from 57.7 to $58.0 \mathrm{~m}$, equigranular, coarse grained, biotite-muscovite, $\sim 0.3 \mathrm{~m}$ wide PEGMATITE 59.1 to $59.5 \mathrm{~m}, \sim 0.4 \mathrm{~m}$ wide 
WELL NAME: CO3

LITHOLOGY

FRACTURES

ATTRIBUTES

บ

$\longrightarrow$

10

-
-
-
-

15

(5)

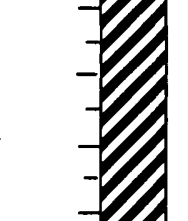

20

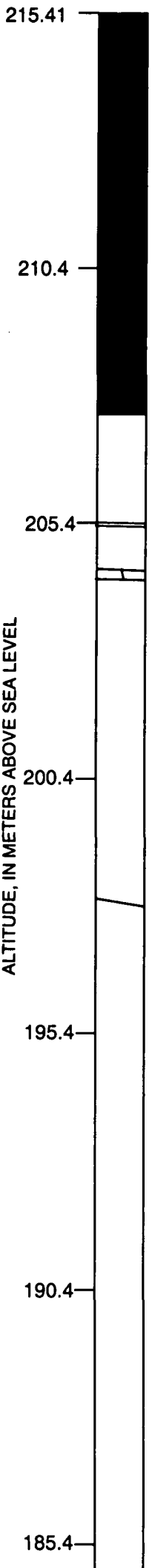

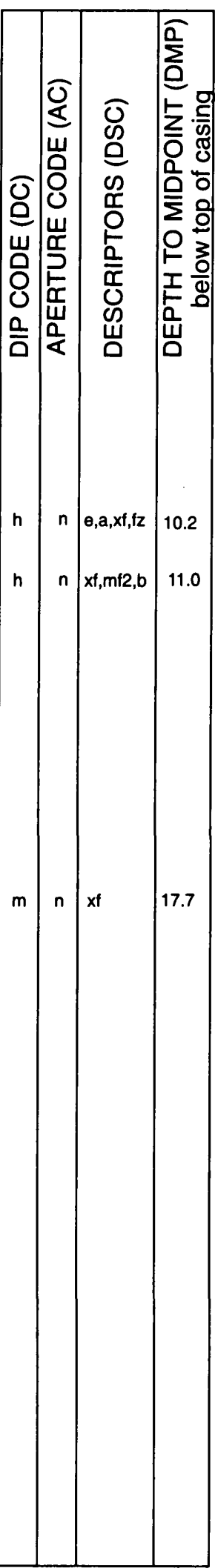

DESCRIPTION: Generalized log in bold.

SAND \& GRAVEL from 0.5 to $2.3 \mathrm{~m}$, brown, with cobbles, $\sim 1.8 \mathrm{~m}$ wide

SAND from 2.3 to $2.8 \mathrm{~m}$, medium to coarse sand, $\sim 0.5 \mathrm{~m}$ wide SAND from 2.8 to $4.2 \mathrm{~m}$, medium to coarse sand, with some fine sand, $\sim 1.4 \mathrm{~m}$ wide BEDROCK SURFACE at $4.5 \mathrm{~m}$

\section{BOTTOM OF CASING at $7.92 \mathrm{~m}$}

SCHIST from 7.92 to $26.6 \mathrm{~m}$, oxidized, coarse grained, gneissic, biotite-muscovite-quartz-feldspar, $\sim 18.7 \mathrm{~m}$ wide

FELSIC BAND at $14.6 \mathrm{~m}$, cross cuts foliation of schist, $\sim 1.0 \mathrm{~cm}$ wide

SCHIST from 16.0 to $25.0 \mathrm{~m}$, with banding, gradational contacts, $\sim 9.0 \mathrm{~m}$ wide

FELSIC ZONE from 16.1 to $16.4 \mathrm{~m}$ in schist, $\sim 0.3 \mathrm{~m}$ wide

GRANITE VEIN at $20.0 \mathrm{~m}$, parallel to foliation, $\sim 15 \mathrm{~cm}$ wide

GRANITE VEIN at $22.5 \mathrm{~m}$, parallel to foliation, $\sim 15 \mathrm{~cm}$ wide

SCHIST from 24.4 to $25.2 \mathrm{~m}$, altered, biotite-chlorite, with trace sulfide minerals, some iron-staining, gradational contacts, $\sim 0.8 \mathrm{~m}$ wide

APLITE DIKE at $25.4 \mathrm{~m}, \sim 20 \mathrm{~cm}$ wide

GRANITE from 26.6 to $33.0 \mathrm{~m}$, biotite granite, $\sim 6.5 \mathrm{~m}$ wide

SCHIST or GNEISS from 28.2 to $29.0 \mathrm{~m}$, coarse grained, biotite-muscovite, some to trace oxidation, $\sim 0.8 \mathrm{~m}$ wide 
CO3 Continued

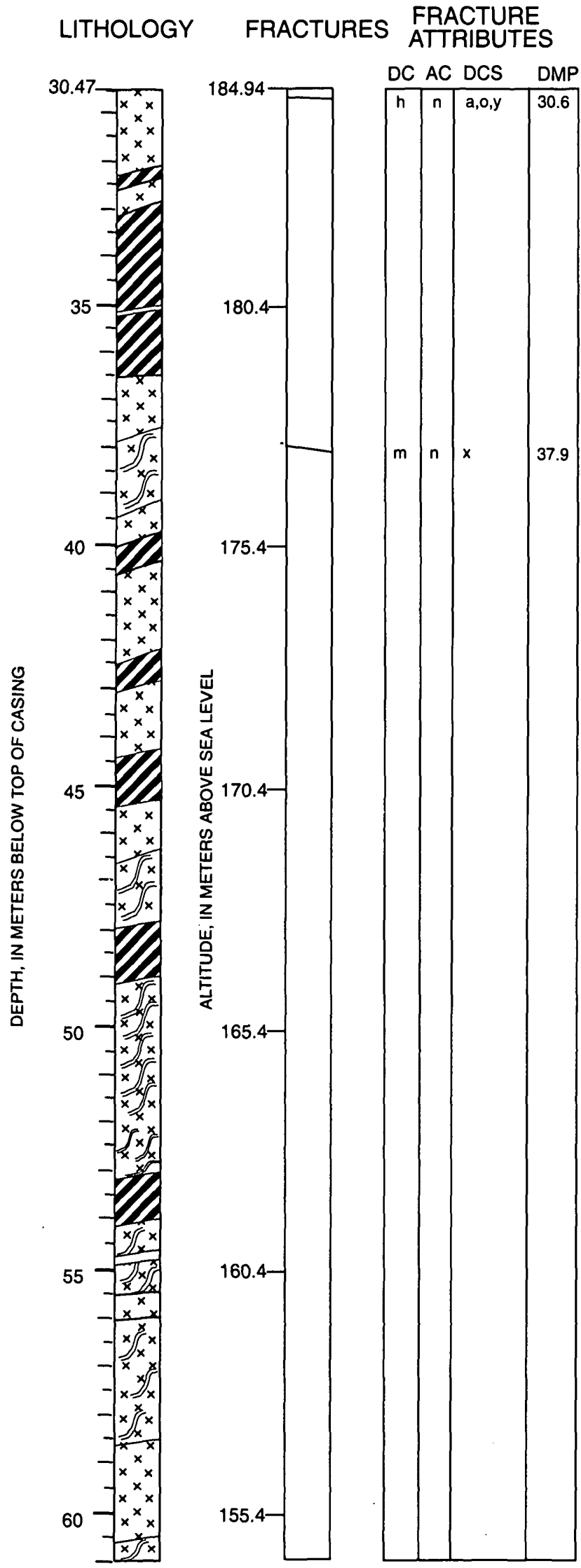

DESCRIPTION: Generalized log in bold.

GRANITE continued to $33.0 \mathrm{~m}$

SCHIST from 32.3 to $32.6 \mathrm{~m}, \sim 0.3 \mathrm{~m}$ wide

SCHIST from 33.0 to $36.5 \mathrm{~m}$, medium to coarse grained, biotite-muscovite-quartz-feldspar and trace sulfide minerals, $\sim 3.5 \mathrm{~m}$ wide

FELSIC BAND at $35.1 \mathrm{~m}, \sim 2 \mathrm{~cm}$ wide

GRANITE from 36.5 to $38.0 \mathrm{~m}$, coarse grained, biotite-rich, $\sim 1.5 \mathrm{~m}$ wide GNEISS from 38.0 to $39.4 \mathrm{~m}$, foliated, $\sim 1.4 \mathrm{~m}$ wide

SCHIST from 39.9 to $40.5 \mathrm{~m}, \sim 0.6 \mathrm{~m}$ wide GRANITE from $\mathbf{4 0 . 5}$ to $\mathbf{4 2 . 4} \mathrm{m}$, biotite-muscovite, $\sim 1.9 \mathrm{~m}$ wide

SCHIST from 42.4 to $43.0 \mathrm{~m}$, felsic augens, $\sim 0.9 \mathrm{~m}$ wide GRANITE from 43.0 to $44.4 \mathrm{~m}, \sim 1.4 \mathrm{~m}$ wide

SCHIST from 44.4 to $45.4 \mathrm{~m}, \sim 1.0 \mathrm{~m}$ wide

GRANITE from 45.4 to $46.6 \mathrm{~m}, \sim 1.2 \mathrm{~m}$ wide

GRANITE / GNEISS from 46.6. to $47.9 \mathrm{~m}, \sim 1.3 \mathrm{~m}$ wide

SCHIST from 47.9 to $49.1 \mathrm{~m}$, with some sulfide minerals, $\sim 1.2 \mathrm{~m}$ wide

GNEISS / GRANITE from 49.1 to $53.2 \mathrm{~m}$, coarse grained, weakly foliated, quartz rich, $\sim 4.1 \mathrm{~m}$ wide

SCHIST from 53.2 to $54.1 \mathrm{~m}, \sim 0.9 \mathrm{~m}$ wide GRANITE / GNEISS from 54.1 to $62.3 \mathrm{~m}$, biotite-quartzmuscovite-with trace garnets, coarse grained, $\sim 8.4 \mathrm{~m}$ wide APLITE DIKE at $54.9 \mathrm{~m}, \sim 4 \mathrm{~cm}$ wide GRANITE from 55.5 to $56.1 \mathrm{~m}$, pale green, altered, $\sim 0.6 \mathrm{~m}$ wide

GRANITE from 58.7 to $60.7 \mathrm{~m}$, altered, $~ 2.0 \mathrm{~m}$ wide 
CO3 Continued

\section{LITHOLOGY}

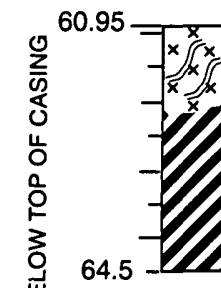

FRACTURES

FRACTURE

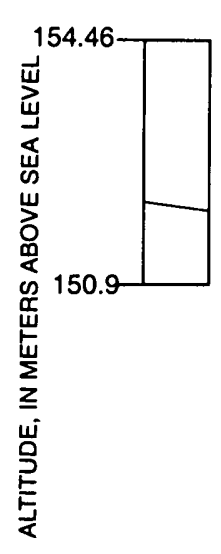
ATTRIBUTES

DESCRIPTION: Generalized log in bold. DC AC DCS DMP

\begin{tabular}{|l|l|l|l|}
\hline & & & \\
& & & \\
\hline & - & - & 63.2 \\
\hline
\end{tabular}

GRANITE continued to $62.3 \mathrm{~m}$

SCHIST from 62.3 to $64.5 \mathrm{~m}$, top contact is gradual, $\sim 2.2 \mathrm{~m}$ wide

BOTTOM OF WELL AT $64.5 \mathrm{~m}$ 


\section{LITHOLOGY}

FRACTURES

FRACTURE

ATTRIBUTES

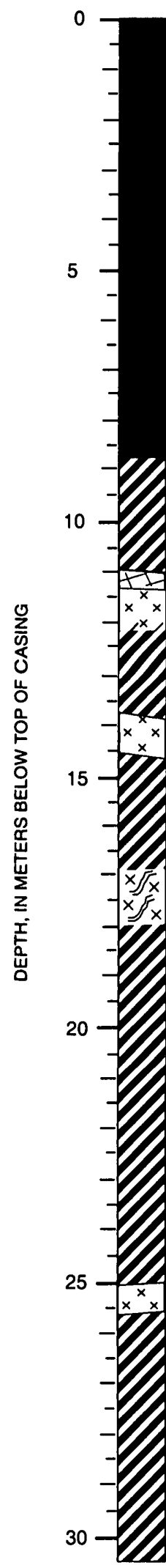

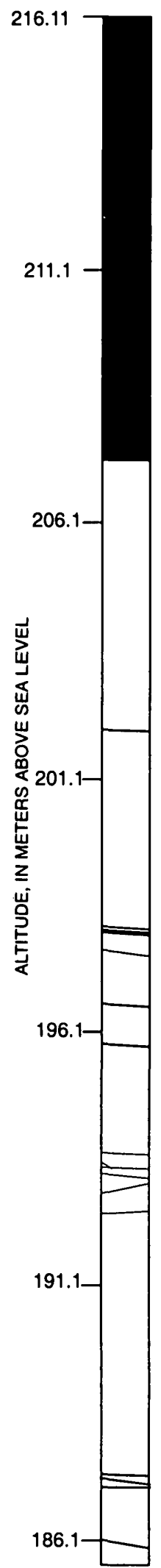

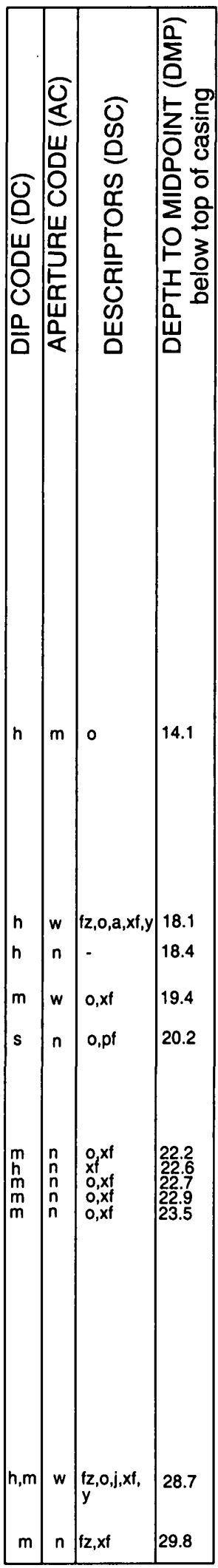

DESCRIPTION: Generalized log in bold.

SAND from 0.8 to $2.9 \mathrm{~m}$, brown, fine to very coarse, $\sim 2.1 \mathrm{~m}$ wide

SAND, SILT and COBBLES from 2.9 to $4.5 \mathrm{~m}$, tan, very fine sand, silt and rounded to sub-angular cobbles, $\sim 1.6 \mathrm{~m}$ wide

SAND, SILT and COBBLES from 4.5 to $7.0 \mathrm{~m}$, tan, medium to coarse sand, and few sub angular cobbles, possibly till, $\sim 2.5 \mathrm{~m}$ wide

\section{BEDROCK SURFACE at $6.0 \mathrm{~m}$}

SCHIST cuttings, fine grained, biotite-rich

\section{BOTTOM OF CASING at $8.84 \mathrm{~m}$}

SCHIST from 8.9 to $16.9 \mathrm{~m}$, dusky brown, coarse grained with some felsic bands and some augens, near vertical foliation, $\sim 8.0 \mathrm{~m}$ wide

PEGMATITE from 11.0 to $11.3 \mathrm{~m}, \sim 0.3 \mathrm{~m}$ wide GRANITE or GNEISS 11.3 to $12.2 \mathrm{~m}$, felsic rich, very coarse grained to gneissic, becomes more foliated with increasing depth, lower contact gradational, $\sim 0.9 \mathrm{~m}$ wide

GRANITE DIKE from13.9 to $14.5 \mathrm{~m}$, yellowish gray, oxidized, muscovite and biotite, fine grained, cross-cuts foliation of schist, $\sim 0.6 \mathrm{~m}$ wide

GNEISS from 16.9 to $17.9 \mathrm{~m}$, coarse grained, weakly foliated $\sim 1.0 \mathrm{~m}$ wide

SCHIST from 17.9 to $47.2 \mathrm{~m}$, coarse grained, with some augens, foliation is generally steeply dipping, biotite, $\sim 29.3 \mathrm{~m}$ wide

GRANITE DIKE from 25.0 to $25.5 \mathrm{~m}$, medium to coarse grained equigranular, biotite-muscovite granite, parallel to foliation, $\sim 0.5 \mathrm{~m}$ wide 


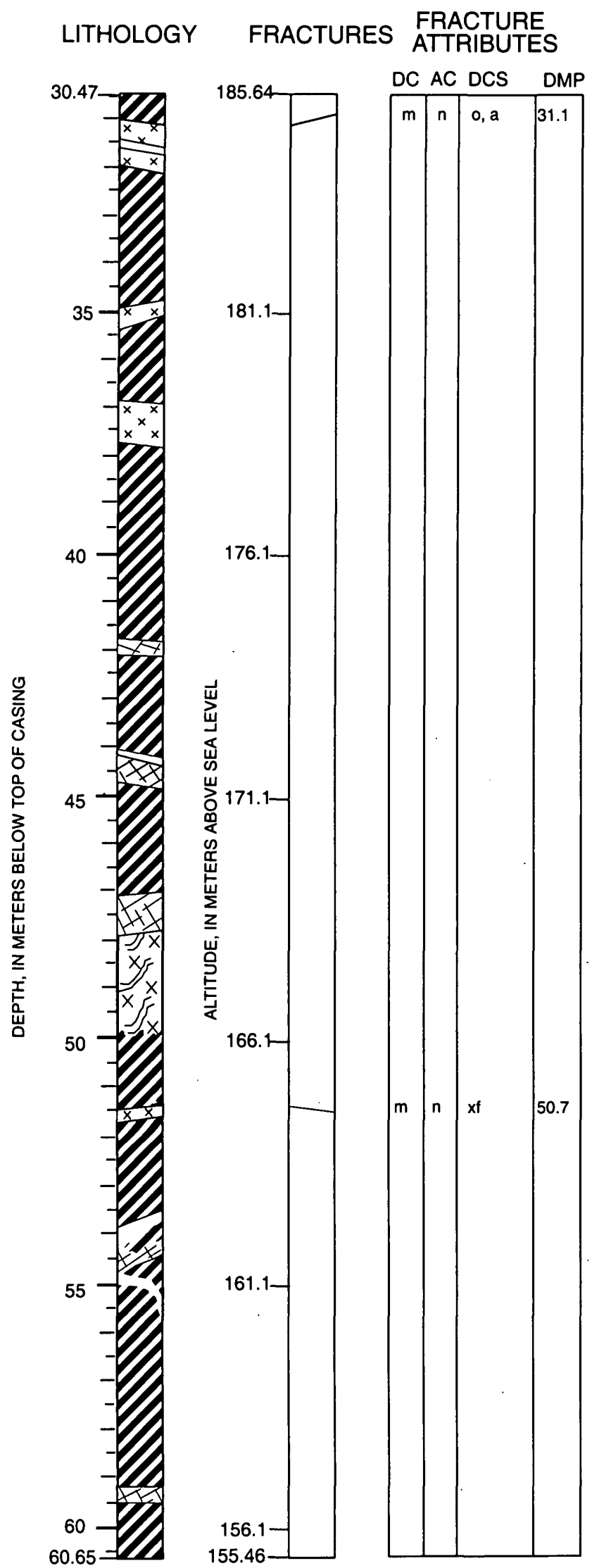

DESCRIPTION: Generalized log in bold.

\section{SCHIST continued to $47.2 \mathrm{~m}$}

GRANITE from 31.1 to $32.0 \mathrm{~m}$, fine grained, muscovitebiotite, cross cuts foliation of schist, $\sim 0.9 \mathrm{~m}$ wide APLITE from 31.4 to $31.7 \mathrm{~m}, \sim 20 \mathrm{~cm}$ wide

SCHIST from 31.7 to $32.5 \mathrm{~m}$, felsic rich, coarse grained, $\sim 0.8 \mathrm{~m}$ wide

SCHIST from 32.5 to $36.7 \mathrm{~m}$, coarse grained with narrow $(\sim 3$ to $15 \mathrm{~cm}$ wide), gray quartzitic layers at $32.4,32.9$, and $35.2 \mathrm{~m}, \sim 4.2 \mathrm{~m}$ wide

GRANITE DIKE from 34.8 to $35.1 \mathrm{~m}$, grayish white, muscovite-biotite, fine grained, foliated, parallel to the foliation of schist, $\sim 0.3 \mathrm{~m}$ wide

GRANITE DIKE from 36.7 to $37.5 \mathrm{~m}$, muscovite granite, fine grained, cross-cuts foliation of schist, $\sim 0.9 \mathrm{~m}$ wide

SCHIST from 38.0 to $41.2 \mathrm{~m}$, gneissic texture, poorly foliated, coarse grained, $\sim 3.2 \mathrm{~m}$ wide

PEGMATITE DIKE from 41.8 to $42.1 \mathrm{~m}, \sim 0.3 \mathrm{~m}$ wide

APLITE from 44.2 to $44.3 \mathrm{~m}, \sim 15 \mathrm{~cm}$ wide PEGMATITE from 44.3 to $44.8 \mathrm{~m}, \sim 0.5 \mathrm{~m}$ wide

SCHIST from 45.7 to $47.2 \mathrm{~m}$, fine grained, with coarse grained layers, $\sim 1.5 \mathrm{~m}$ wide

PEGMATITE DIKE from 47.2 to $47.8 \mathrm{~m}, \sim 0.6 \mathrm{~m}$ wide

GNEISS or SCHIST from $\mathbf{4 7 . 2}$ to $\mathbf{5 0 . 0} \mathrm{m}$, weakly foliated, coarse grained, bottom contact gradational, $\sim 2.5 \mathrm{~m}$ wide

SCHIST from 50.0 to $60.7 \mathrm{~m}$, medium to coarse grained, with some augens and some weak banding, $\sim 10.7 \mathrm{~m}$ wide

GRANITE DIKE at $51.5 \mathrm{~m}$, parallel to foliation of schist $\sim 15 \mathrm{~cm}$ wide

APLITE DIKE from 53.7 to $55.2 \mathrm{~m}$, bright white, irregularly shaped, $\sim 1.5 \mathrm{~m}$ wide

PEGMATITE from 59.1 to $59.4 \mathrm{~m}, \sim 0.3 \mathrm{~m}$ wide

BOTTOM OF WELL AT $60.65 \mathrm{~m}$ 


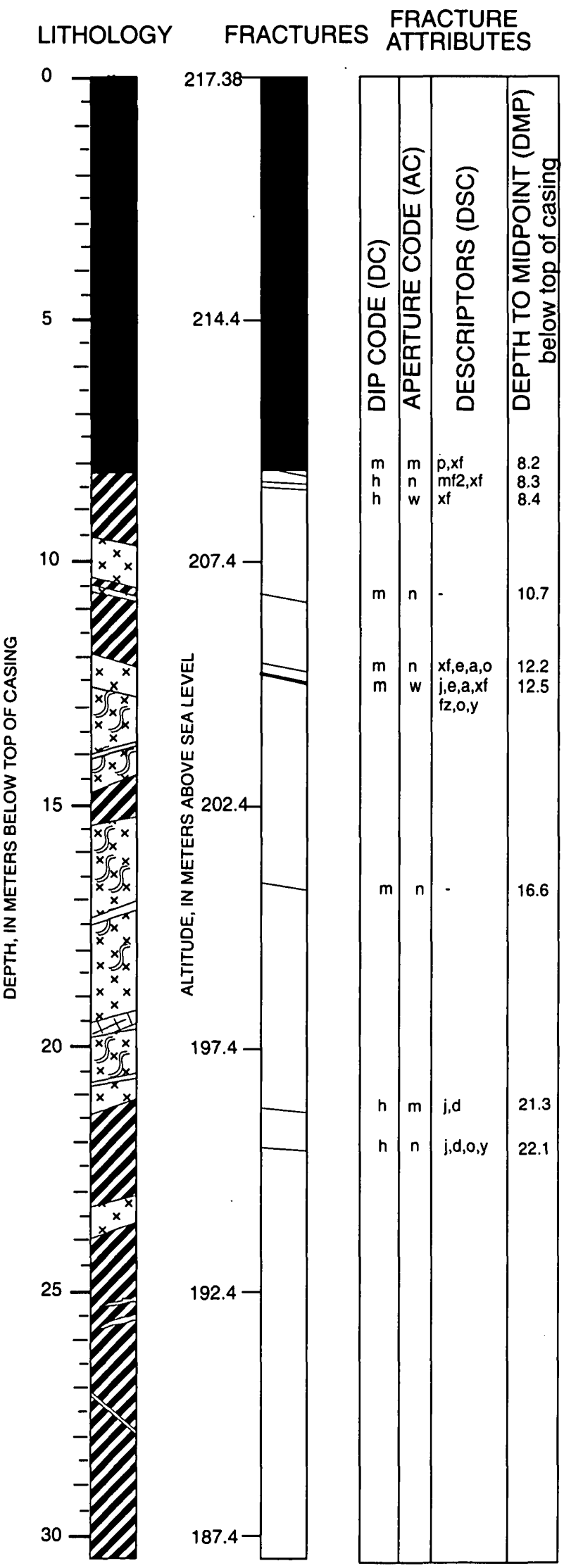

DESCRIPTION: Generalized log in bold.

OVERBURDEN from 0.67 to $5.3 \mathrm{~m}$, brown, fine to very fine sand with few coarse sand, $\sim 4.6 \mathrm{~m}$ wide GRAVEL LAYER at 1.8 to $2.0 \mathrm{~m}, \sim 0.2 \mathrm{~m}$ wide BOULDER at $2.0 \mathrm{~m}$, Granite

SAND from 1.5 to $3.1 \mathrm{~m}$, dark brown, moist, damp, fine, and fresh rock chips of granite and schist, $\sim 1.6 \mathrm{~m}$ wide BOULDER at $\sim 4.0 \mathrm{~m}, 0.2 \mathrm{~m}$ wide

SAND and BOULDERS from 3.8 to $5.3 \mathrm{~m}$, brown/tan, fine grained and flakes of muscovite, $\sim 1.5 \mathrm{~m}$ wide

BEDROCK SURFACE at $4.3 \mathrm{~m}$

Fracture noted during drilling at $5.8 \mathrm{~m}$, drill rods dropped $\sim 6 \mathrm{~cm}$

\section{BOTTOM of CASING at $8.14 \mathrm{~m}$}

SCHIST from 8.1 to $\mathbf{1 2 . 1} \mathrm{m}$, coarse grained, gneissic texture, some banding, steeply dipping foliation, $\sim 4.0 \mathrm{~m}$ wide GRANITE or APLITE DIKE from 9.6 to $10.4 \mathrm{~m}$, fine grained, cross cuts foliation of schist, $\sim 0.8 \mathrm{~m}$ wide

FELSIC BAND at $10.6 \mathrm{~m}, \sim 5 \mathrm{~cm}$ wide

FAULT GOUGE from 12.1 to $12.7 \mathrm{~m}$, altered, rubbelized, $\sim 0.6 \mathrm{~m}$ wide

GNEISS 12.7 to $21.4 \mathrm{~m}$, gneissic texture, biotite-muscovite feldspar, equigranular with some weak foliations, $\sim 6.3 \mathrm{~m}$ wide

FELSIC BAND at $14.0 \mathrm{~m}, \sim 3 \mathrm{~cm}$ wide

APLITE VEIN at $17.1 \mathrm{~m}, \sim 10 \mathrm{~cm}$ wide

PEGMATITE DIKE from 19.4 to $19.7 \mathrm{~m}, \sim 0.3 \mathrm{~m}$ wide

SCHIST from 21.4 to $36.2 \mathrm{~m}, \sim 14.8 \mathrm{~m}$ wide

SCHIST from 21.4 to $24.0 \mathrm{~m}$, fine grained with some augens, and some oxidized zones, $\sim 2.6 \mathrm{~m}$ wide

GRANITE DIKE from 23.2 to $23.8 \mathrm{~m}, \sim 0.6 \mathrm{~m}$ wide SCHIST from $\sim 24$ to $28 \mathrm{~m}$, medium grained, few augens, with weak banding, $\sim 4 \mathrm{~m}$ wide

FELSIC ZONES in the schist at 25.3 and $25.5 \mathrm{~m}$

FELSIC VEIN at $27.4 \mathrm{~m}$, steeply dipping, cross cuts foliation of the schist, $\sim 10 \mathrm{~cm}$ wide

SCHIST from $~ 28$ to $33 \mathrm{~m}$, coarse grained, possibly with a quartz and garnet coticule layer at $29.2 \mathrm{~m}$ (not shown), $\sim 5 \mathrm{~m}$ wide 


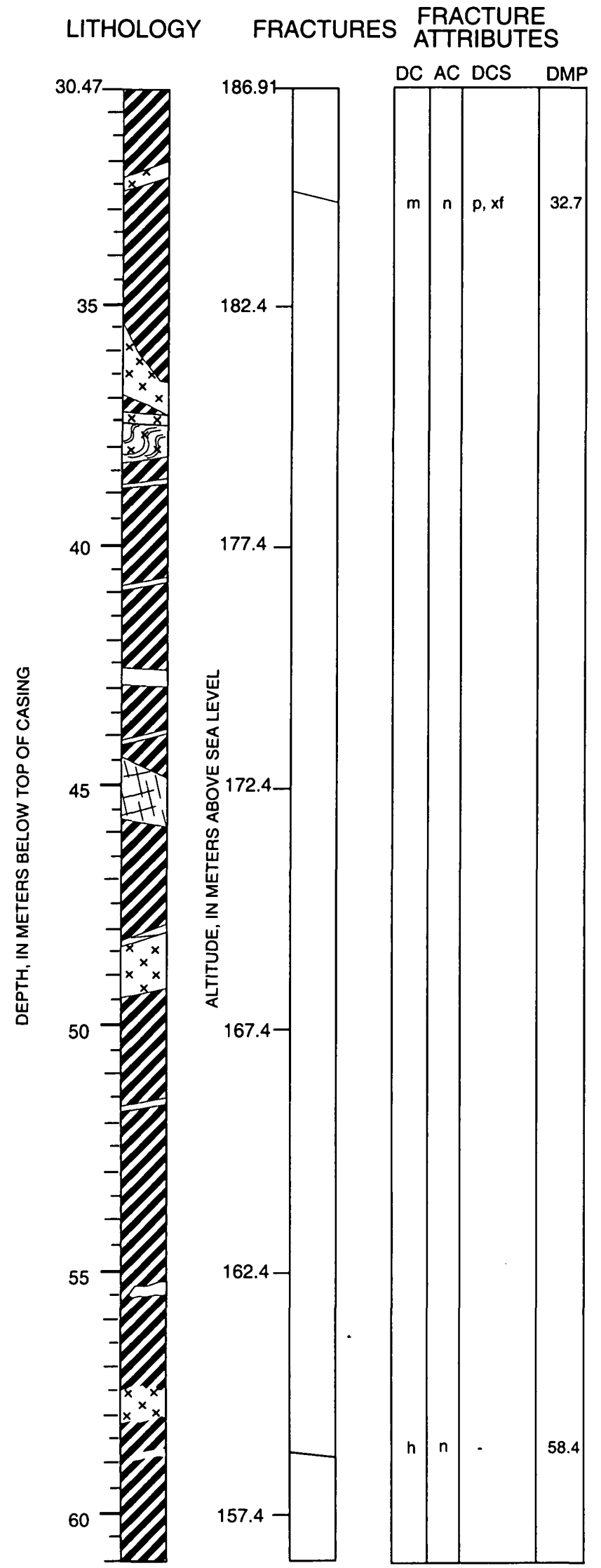

DESCRIPTION: Generalized log in bold.

SCHIST continued to $36.2 \mathrm{~m}$

GRANITE DIKE or FELSIC DIKE from 32.3 to $32.6 \mathrm{~m}$, $\sim 0.3 \mathrm{~m}$ wide

SCHIST from 33.0 to $36.2 \mathrm{~m}$, fine grained, gradual upper contact, $~ 3.2 \mathrm{~m}$

GRANITE DIKE from 36.2 to $37.2 \mathrm{~m}$, fine grained, cross cuts foliation, irregularly shaped, $\sim 1.0 \mathrm{~m}$ wide

SCHIST from 37.2 to $44.7 \mathrm{~m}, \sim 7.5 \mathrm{~m}$ wide GRANITE DIKE from 37.2 to $37.5 \mathrm{~m}, \sim 0.3 \mathrm{~m}$ wide GNEISS from 37.5 to $38.3 \mathrm{~m}, \sim 0.8 \mathrm{~m}$ wide

FELSIC VEIN at $38.8 \mathrm{~m}$, parallel to foliation, $\sim 4 \mathrm{~cm}$ wide

FELSIC VEIN at $40.8 \mathrm{~m}$, parallel to foliation, $\sim 4 \mathrm{~cm}$ wide

APLITE DIKE from 42.6 to $42.8 \mathrm{~m}$, fine grained, cross-cuts foliation, $\sim 0.2 \mathrm{~m}$ wide

FELSIC VEIN at $43.9 \mathrm{~m}$, parallel to foliation, $\sim 3 \mathrm{~cm}$ wide

PEGMATITE from 44.7 to $45.9 \mathrm{~m}, \sim 1.2 \mathrm{~m}$ wide

SCHIST from 45.9 to $48.1 \mathrm{~m}$, fine-grained, laminated, $\sim 2.3 \mathrm{~m}$ wide

PEGMATITE VEIN at $48.2 \mathrm{~m}, \sim 15 \mathrm{~cm}$ wide

GRANITE from 48.3 to $49.4 \mathrm{~m}, \sim 1.1 \mathrm{~m}$ wide

SCHIST from 50.5 to $69.7 \mathrm{~m}$, augened to banded, $19.2 \mathrm{~m}$ wide FELSIC VEIN at $51.6 \mathrm{~m}$, parallel to foliation, $\sim 3 \mathrm{~cm}$ wide SCHIST from 52.5 to $55.5 \mathrm{~m}$, gradually coarse grained, $\sim 3.0 \mathrm{~m}$

FELSIC ZONE in schist at $55.5 \mathrm{~m}$

GRANITE DIKE from 57.5 to $58.0 \mathrm{~m}$, gradual contact, $\sim 0.5 \mathrm{~m}$ wide

FELSIC BAND in schist at $58.9 \mathrm{~m}$ 
CO5 Continued

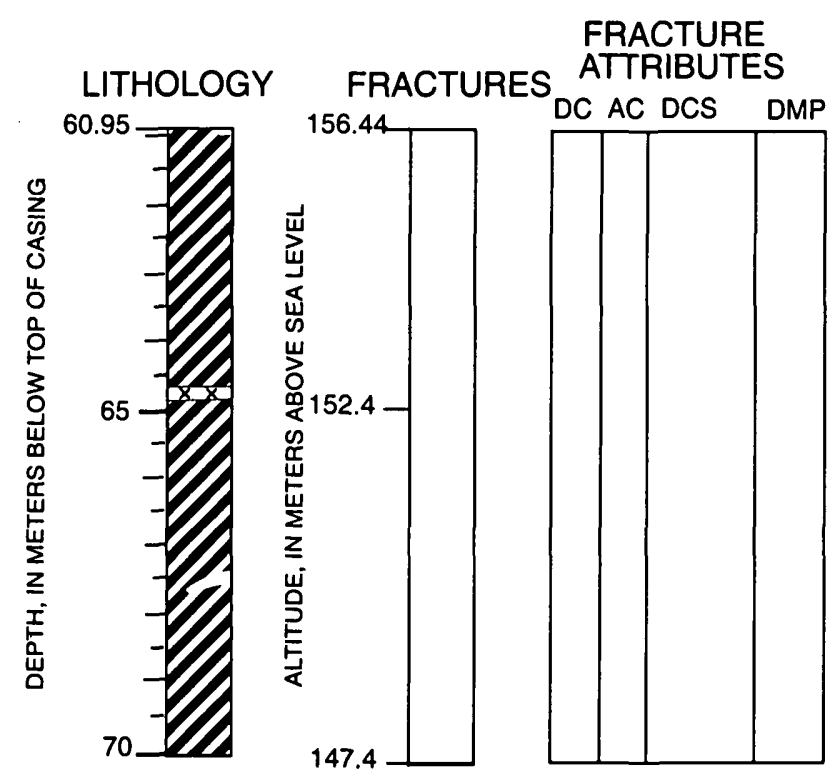

DESCRIPTION: Generalized log in bold.

SCHIST continued to $69.7 \mathrm{~m}$, banded with some augens

APLITE OR GRANITE DIKE from 64.6 to $64.8 \mathrm{~m}$, cross-cuts foliation of schist, $\sim 0.2 \mathrm{~m}$ wide

SCHIST from 65.5 to $70.1 \mathrm{~m}$, coarse grained, with augens,

$\sim 4.6 \mathrm{~m}$ wide

FELSIC ZONE in schist at $67.6 \mathrm{~m}$

BOTTOM of WELL $69.7 \mathrm{~m}$, debris in bottom of well BOTTOM of HOLE drilled to $70.1 \mathrm{~m}$ 


\section{LITHOLOGY}

\section{FRACTURES}

FRACTURE ATTRIBUTES

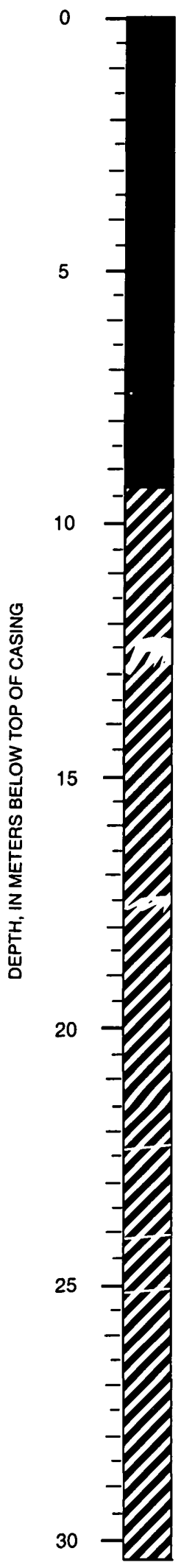

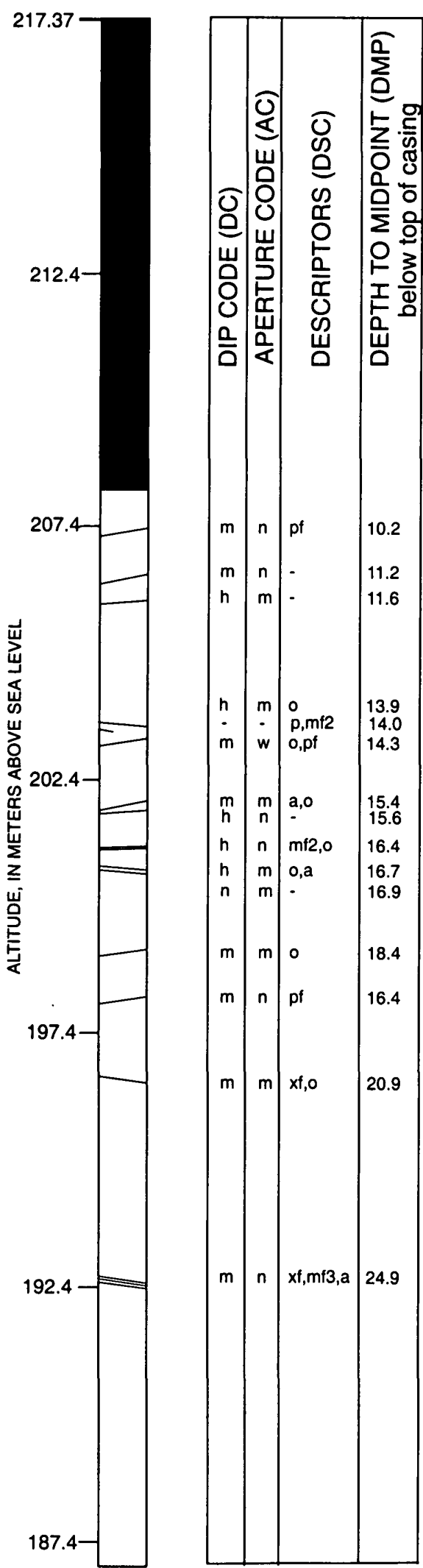

DESCRIPTION: Generalized log in bold.

BOULDER from $0.3 \mathrm{~m}$ to $1.1 \mathrm{~m}, \sim 0.8 \mathrm{~m}$ wide

SAND from 1.1 to $2.0 \mathrm{~m}$, brown medium-coarse, $\sim 0.9 \mathrm{~m}$ wide BOULDER from $2.0 \mathrm{~m}$ to $2.1 \mathrm{~m}, \sim 0.1 \mathrm{~m}$ wide

SAND from 2.1 to $2.3 \mathrm{~m}$, brown medium-coarse, $\sim 0.2 \mathrm{~m}$ wide BOULDER from 2.3 to $2.4 \mathrm{~m}, \sim 0.1 \mathrm{~m}$ wide

SAND from 2.4 to $4.6 \mathrm{~m}$, very fine to coarse with some gravel, $\sim 2.2 \mathrm{~m}$ wide

TILL from 4.6 to $5.2 \mathrm{~m}$, moist, brown, fine to medium sand with some very fine sand, silt, and boulders

BEDROCK SURFACE at $5.2 \mathrm{~m}$

Cuttings at $5.8 \mathrm{~m}$, brown, tan with felsic muscovite chips, pegmatitic muscovite flakes

Cuttings from 6.1 to $8.8 \mathrm{~m}$, extremely fine grained. Possibly biotite schist with trace of felsic chips, with some oxidation, $\sim 2.7 \mathrm{~m}$ wide

\section{BOTTOM OF CASING at $9.39 \mathrm{~m}$}

SCHIST from 9.4 to $38.1 \mathrm{~m}$, biotite-quartz-feldspar, some sillimanite, and trace garnet and graphite, $\sim 28.7 \mathrm{~m}$ wide SCHIST from 9.4 to $12.4 \mathrm{~m}$, fine to coarse grained, steeply dipping foliation, $\sim 3.0 \mathrm{~m}$ wide

FELSIC ZONE in SCHIST from 12.4 to $13.0 \mathrm{~m}$, coarse grained and migmatite, $\sim 0.6 \mathrm{~m}$ wide

SCHIST from 14.0 to $18.3 \mathrm{~m}$, brownish gray, rich in muscovite flakes, coarse grained to gneissic texture, some augens and some weak banding, $\sim 4.3 \mathrm{~m}$ wide FELSIC ZONE in SCHIST from 17.4 to $17.7 \mathrm{~m}, \sim 0.3 \mathrm{~m}$ wide

FELSIC BAND at $22.2 \mathrm{~m}$ in SCHIST, $\sim 1 \mathrm{~cm}$ wide

SCHIST from 24.4 to $25.9 \mathrm{~m}$, felsic-rich with some chlorite, quartz and oxidation, banded, $\sim 1.5 \mathrm{~m}$ wide FELSIC BAND at $25.2 \mathrm{~m}$ in schist, $\sim 2 \mathrm{~cm}$ wide SCHIST from 25.9 to $\sim 30.0 \mathrm{~m}$, extremely fine grained foliated bands and medium to coarse grained felsic bands, $\sim 4.1 \mathrm{~m}$ wide

SCHIST from 30.0 to $38.1 \mathrm{~m}$, coarse to gneissic texture, more coarse than above, $\sim 8.1 \mathrm{~m}$ wide 


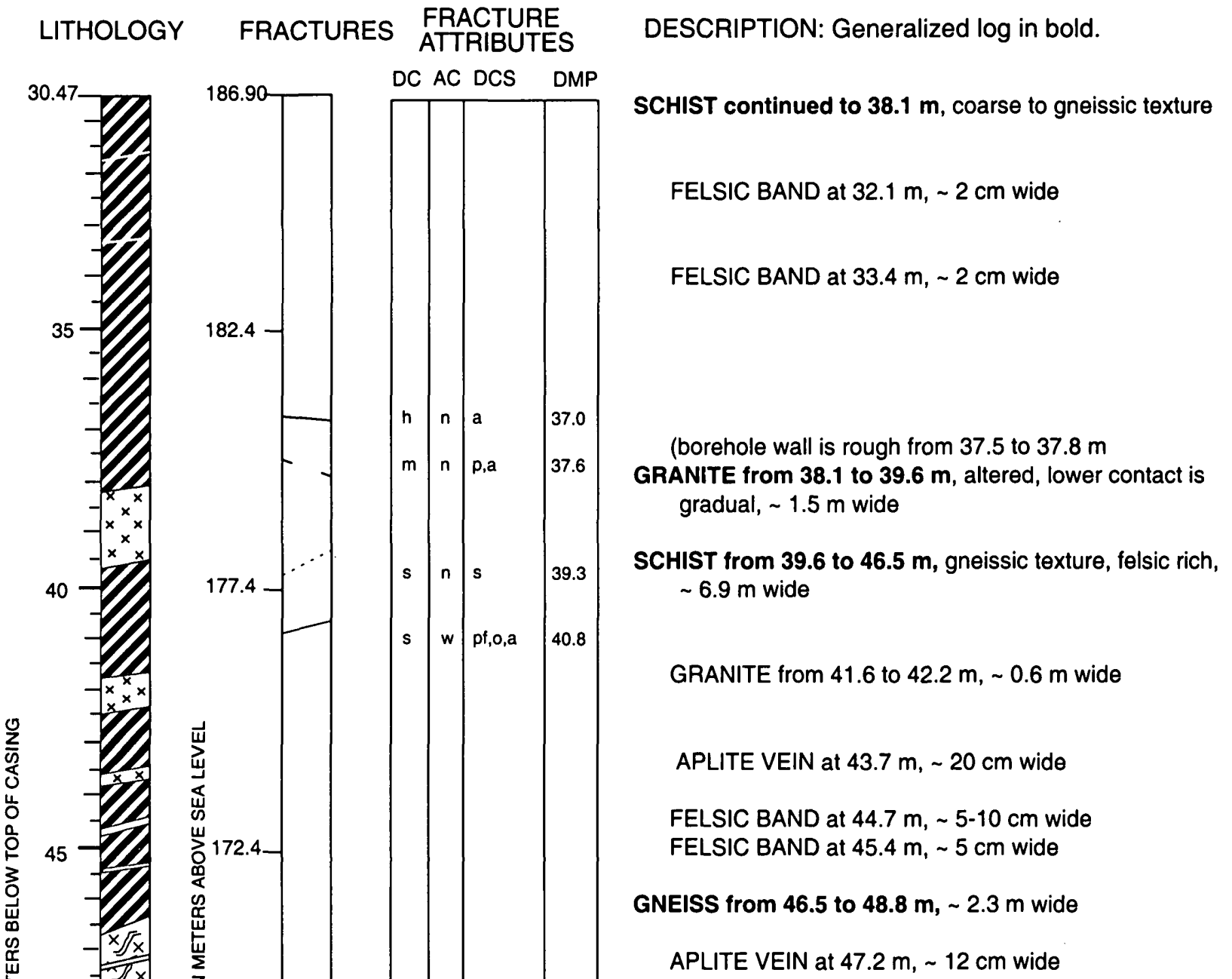

PEGMATITE DIKE from 48.8 to $49.8 \mathrm{~m}, \sim 1.0 \mathrm{~m}$ wide

GRANITE from 49.8 to $50.5 \mathrm{~m}, \sim 0.7 \mathrm{~m}$ wide

GNEISS from 50.5 to $51.9 \mathrm{~m}, \sim 1.4 \mathrm{~m}$ wide

PEGMATITE DIKE from 51.9 to $53.3 \mathrm{~m}, \sim 1.4 \mathrm{~m}$ wide

SCHIST from 53.3 to $62.8 \mathrm{~m}$, coarse to gneissic texture, quartzo-feldspathic rich $\sim 9.5 \mathrm{~m}$ wide

FELSIC BAND at $54.7 \mathrm{~m}, \sim 5 \mathrm{~cm}$ wide

FELSIC BAND at $55.0 \mathrm{~m}, \sim 5 \mathrm{~cm}$ wide

FELSIC BAND at $56.3 \mathrm{~m}, \sim 20 \mathrm{~cm}$ wide

FELSIC BAND at $59.1 \mathrm{~m}, \sim 5-10 \mathrm{~cm}$ wide

Possible APLITE from 50.0 to $50.40 \mathrm{~m}, \sim 0.4 \mathrm{~m}$ wide ? 
CO6 Continued

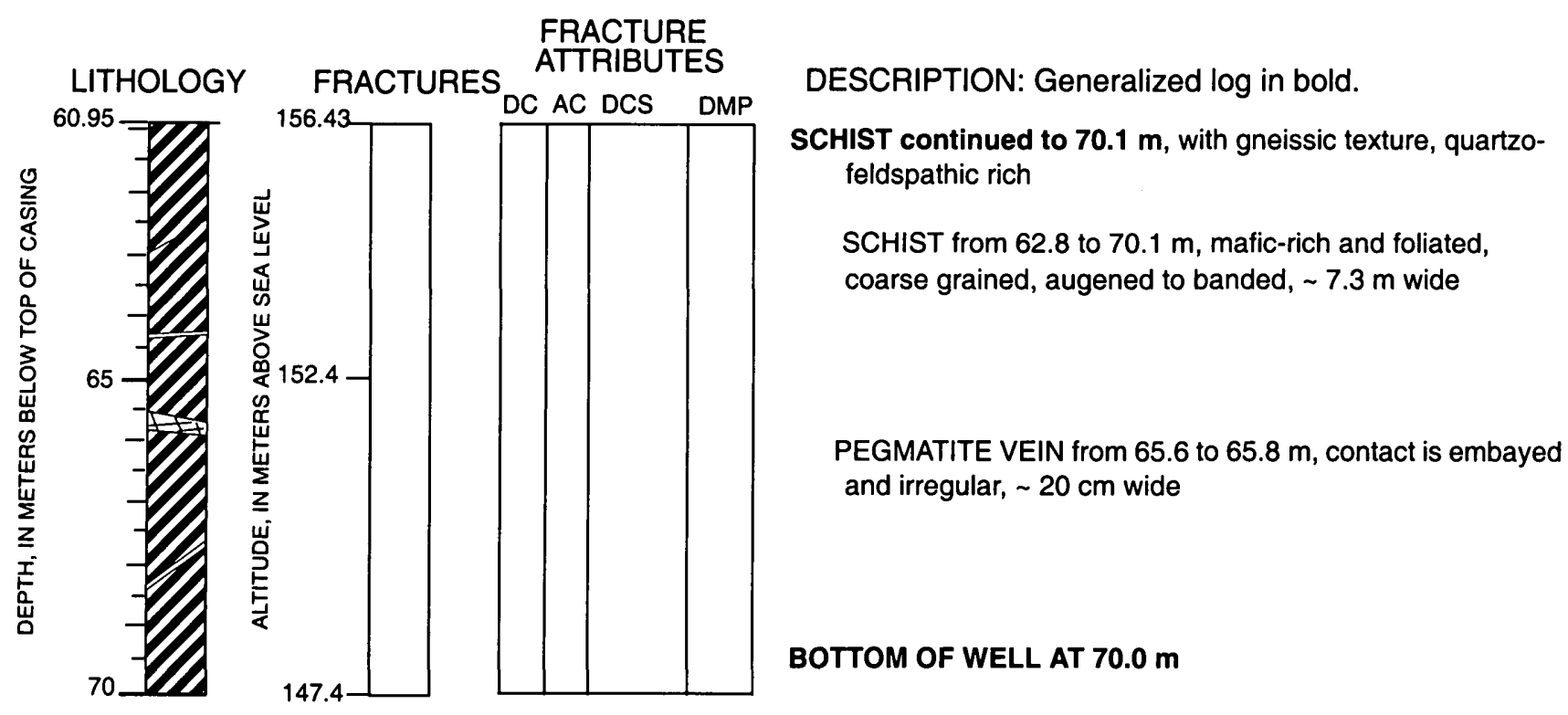




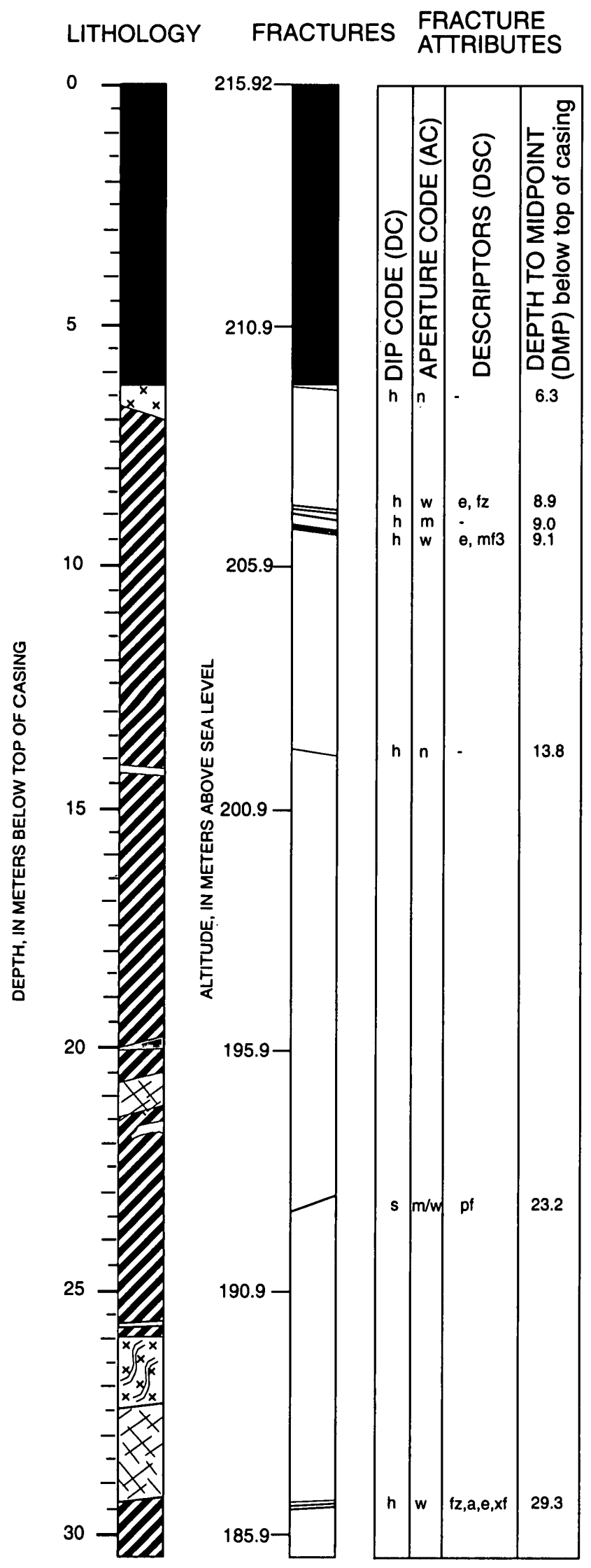

DESCRIPTION: Generalized log in bold.

\section{BEDROCK SURFACE at $2.7 \mathrm{~m}$}

\section{BOTTOM OF CASING AT $6.25 \mathrm{~m}$}

GRANITE from 6.3 to $6.7 \mathrm{~m}$, fine grained, biotite-muscovitefeldspar and quartz, grayish brown, oxidized, $\sim 0.4 \mathrm{~m}$ wide SCHIST from 6.7 to $25.9 \mathrm{~m}$, biotite-garnet, few pieces of oxidized chips, coarse grained to gneissic texture, some felsic banding, near vertical foliation, $\sim 19.2 \mathrm{~m}$ wide

SCHIST from 7.6 to $9.1 \mathrm{~m}$, large oxidized chips, graphitic schene on water observed during drilling, $\sim 1.5 \mathrm{~m}$ wide

FELSIC ZONE in the schist from 12.5 to $14.0 \mathrm{~m}, \sim 1.5 \mathrm{~m}$ wide

PEGMATITE VEIN at 14.1, near horizontal, cross-cuts foliation of schist, $\sim 6 \mathrm{~cm}$ wide

SCHIST from 14.1 to $15.5 \mathrm{~m}$, medium to coarse grained, biotite-rich schist, with some augens, $\sim 1.5 \mathrm{~m}$ wide

QUARTZ layer in SCHIST at $19.9 \mathrm{~m}$, wedged-shaped, parallel to foliation, $\sim 20 \mathrm{~cm}$ wide

SCHIST from 21.5 to $\sim 26.0 \mathrm{~m}$, gneissic texture, coarse grained, with some felsic-rich zones, $\sim 4.5 \mathrm{~m}$ wide

PEGMATITE DIKE from 20.6 to $21.3 \mathrm{~m}$, parallel to foliation of schist, $\sim 0.7 \mathrm{~m}$ wide

PEGMATITE VEIN at $25.75 \mathrm{~m}$, muscovite and feldspar, $\sim 9 \mathrm{~cm}$ wide

SCHIST is coarse to gneissic, steeply dipping foliation, some augens

FELSIC BAND at $25.8 \mathrm{~m}$, granite or aplite, $\sim 5$ to $10 \mathrm{~cm}$ wide

GNEISS from 25.9 to $27.4 \mathrm{~m}$, quartz, feldspar, muscovite, gradual contact, $\sim 1.5 \mathrm{~m}$ wide

PEGMATITE from 27.4 to $29.4 \mathrm{~m}$, quartz, feldspar, muscovite, trace garnet and apatite, $\sim 2.0 \mathrm{~m}$ wide (soft zone in drilling) (fracture zone appears to be along contact of pegmatite and gneiss)

SCHIST from 29.4 to $33.5 \mathrm{~m}$, coarse grained, gneissic texture, biotite rich foliated zones with some felsic rich non-foliated zones, $\sim 4.1 \mathrm{~m}$ wide 


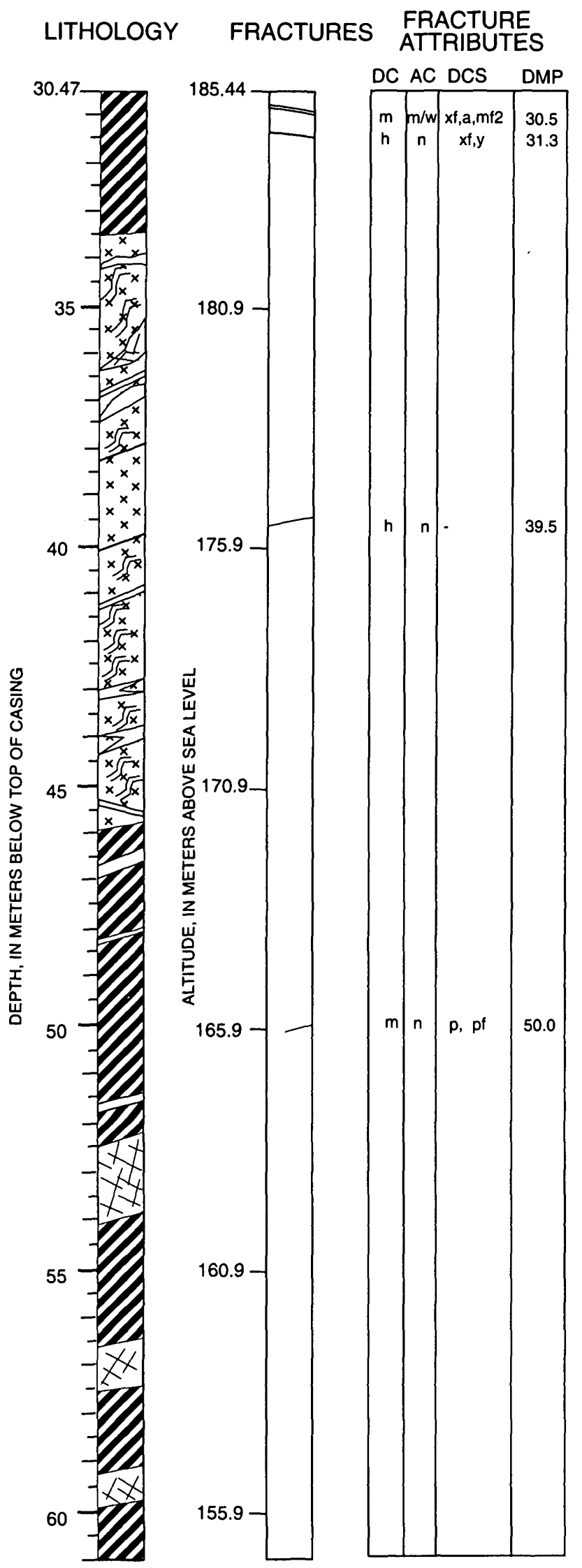

DESCRIPTION: Generalized log in bold.

SCHIST continued to $33.5 \mathrm{~m}$

GNEISS from 33.5 to $\mathbf{4 5 . 8} \mathrm{m}$, coarse grained, felsic rich, steeply dipping foliation, possibly migmatite, gradual upper and lower contacts, $\sim 12.3 \mathrm{~m}$ wide

FELSIC BAND at $34.0 \mathrm{~m}, \sim 5 \mathrm{~cm}$ wide

PEGMATITE from 35.9 to $36.3 \mathrm{~m}, \sim 0.4 \mathrm{~m}$ wide

FELSIC BAND at $36.5 \mathrm{~m},<10 \mathrm{~cm}$ wide

FELSIC ZONE from 36.8 to $37.2 \mathrm{~m}, \sim 0.4 \mathrm{~m}$ wide

GRANITE from 38.1 to $39.8 \mathrm{~m}, \sim 1.7 \mathrm{~m}$ wide

FELSIC BAND at $41.0 \mathrm{~m}, \sim 5 \mathrm{~cm}$ wide

FELSIC ZONE from 42.5 to $44.2 \mathrm{~m}, \sim 1.7 \mathrm{~m}$

FELSIC BAND at $45.5 \mathrm{~m}$, cross-cuts the foliation in the gneiss, $\sim 5$ to $10 \mathrm{~cm}$ wide

SCHIST from 45.8 to $\mathbf{5 2 . 5} \mathrm{m}$, gneissic texture, some weak banding, some augens, steeply dipping foliation, $\sim 6.7 \mathrm{~m}$ wide

FELSIC BAND at $46.5 \mathrm{~m}$, parallel to foliation, $\sim 15 \mathrm{~cm}$ wide FELSIC BAND at $48.0 \mathrm{~m}$, parallel to foliation of the schist $\sim 2 \mathrm{~cm}$ wide

FELSIC BAND at $51.7 \mathrm{~m}, \sim 7 \mathrm{~cm}$ wide

PEGMATITE DIKE from 52.5 to $54.0 \mathrm{~m}$, abundant in quartz, $\sim 1.5 \mathrm{~m}$ wide

SCHIST from 54.0 to $71.1 \mathrm{~m}$, some fine grained biotite-rich zones, felsic zones, and gneissic textured zones $\sim 17.1 \mathrm{~m}$ wide

SCHIST from 54.4 to $59.3 \mathrm{~m}$, coarse-grained, gneissic texture, $\sim 4.9 \mathrm{~m}$ wide

PEGMATITE DIKE from 56.7 to $57.5 \mathrm{~m}$, gradual upper contact, abundant in quartz, $\sim 0.8 \mathrm{~m}$ wide

PEGMATITE DIKE from 59.3 to $60.0 \mathrm{~m}$, gradual upper contact, $\sim 0.7 \mathrm{~m}$ wide 
CO7 Continued

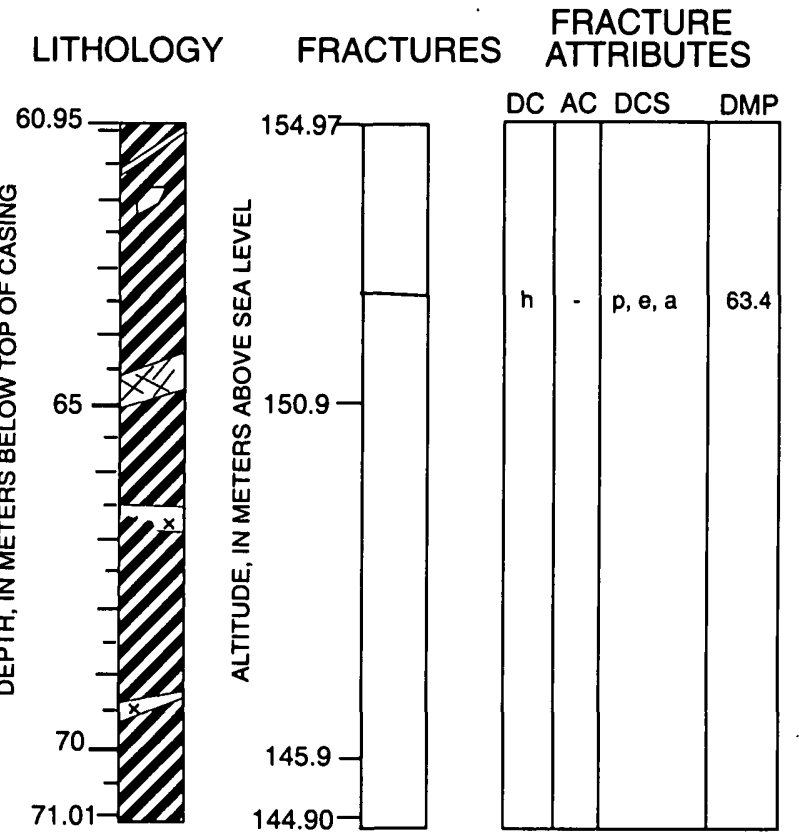

DESCRIPTION: Generalized log in bold.

\section{SCHIST continued to $71.1 \mathrm{~m}$}

FELSIC BAND at $61.3 \mathrm{~m}$, parallel to foliation, $\sim 10 \mathrm{~cm}$ wide SCHIST from $\sim 61.0$ to $64.4 \mathrm{~m}$, layers of coarse-grained to gneissic textured biotite-rich zones, felsic zones and quartzite layers, gradual upper contact, $\sim 3.9 \mathrm{~m}$ wide

PEGMATITE DIKE from 64.4 to $64.9 \mathrm{~m}$, parallel to the foliation of the schist, $\sim 0.5 \mathrm{~m}$ wide

GRANITE DIKE from 66.5 to $66.8 \mathrm{~m}$, cross-cuts foliation of schist, irregular shape, $\sim 0.2 \mathrm{~m}$ wide

GRANITE VEIN at $69.5 \mathrm{~m}$, near parallel to foliation of schist, $\sim 10$ to $15 \mathrm{~cm}$ wide

BOTTOM OF WELL AT 71.05 m 


\section{LITHOLOGY}

FRACTURE ATTRIBUTES

DESCRIPTION: Generalized log in bold.
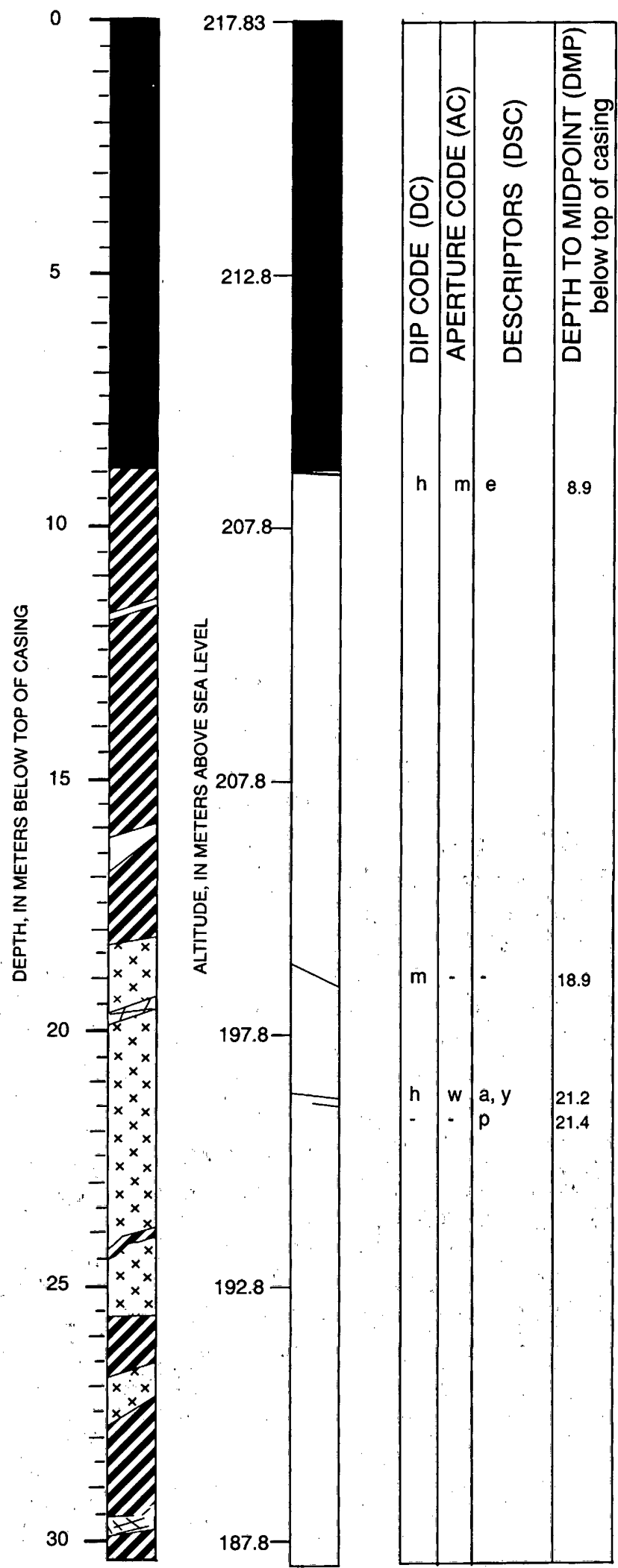

SAND from 0.9 to $2.7 \mathrm{~m}$, fine to coarse brown sand Boulder at $1 \mathrm{~m}, \sim 0.3 \mathrm{~m}$ wide

SAND from 2.7 to $5.8 \mathrm{~m}$, very fine to medium sand, with trace coarse sand, brown with some gray sand, $\sim 3.1 \mathrm{~m}$ wide

\section{BEDROCK SURFACE at $5.8 \mathrm{~m}$}

Possible fracture or very soft rock encountered in drilling at $6.7 \mathrm{~m}$

\section{BOTTOM of CASING at $8.81 \mathrm{~m}$}

SCHIST from 8.8 to $18.3 \mathrm{~m}$, biotite-quartz-feldspar, trace amounts of garnet and chlorite, with some oxidized pieces, gneissic texture, alternating bands of coarse-grained, biotite-rich and foliated layers and equigranular, felsic-rich layers, contacts are gradual, $\sim 9.5 \mathrm{~m}$ wide

FELSIC ZONE from 16.1 to $16.5 \mathrm{~m}$, in gneissic textured schist, $\sim 0.4 \mathrm{~m}$ wide

GRANITE from 18.3 to $25.6 \mathrm{~m}$, coarse grained to gneissic texture, mostly equigranular with some foliated biotite, and with some oxidized pieces of feldspar, $\sim 7.3 \mathrm{~m}$ wide PEGMATITE from 19.5 to $19.7 \mathrm{~m}$, muscovite and feldspar, $\sim 0.2 \mathrm{~m}$ wide

SCHIST from 21.3 to $21.9 \mathrm{~m}$, gradual contacts, biotite-rich, fine grained, $\sim 0.6 \mathrm{~m}$ wide

SCHIST from 25.6 to $26.7 \mathrm{~m}$, grayish, banded, $\sim 1.1 \mathrm{~m}$ wide FELSIC ZONE in schist from 26.7 to $27.5 \mathrm{~m}, \sim 0.8 \mathrm{~m}$ wide

SCHIST from 27.5 to $30.8 \mathrm{~m}$, laminated, $-3.3 \mathrm{~m}$ wide

PEGMATITE from 29.5 to $29.9 \cdot \mathrm{m}, \sim 0.4 \mathrm{~m}$ wide 


\section{LITHOLOGY}

FRACTURES

ATACTURE

30.47



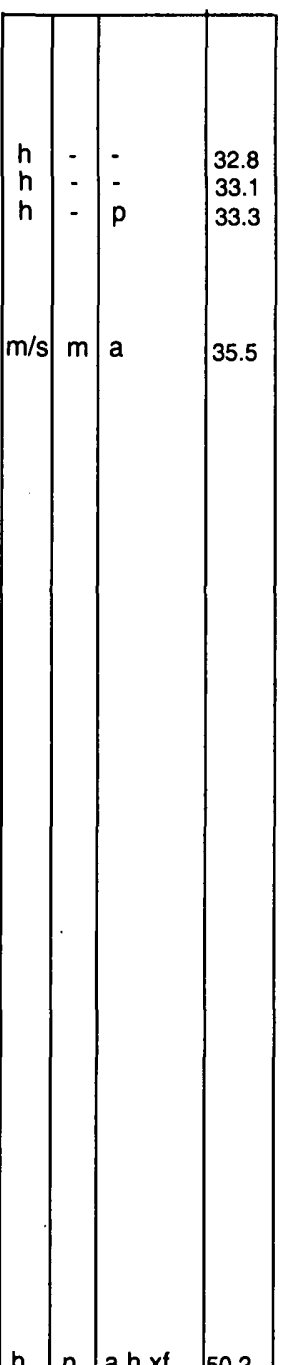

50

60
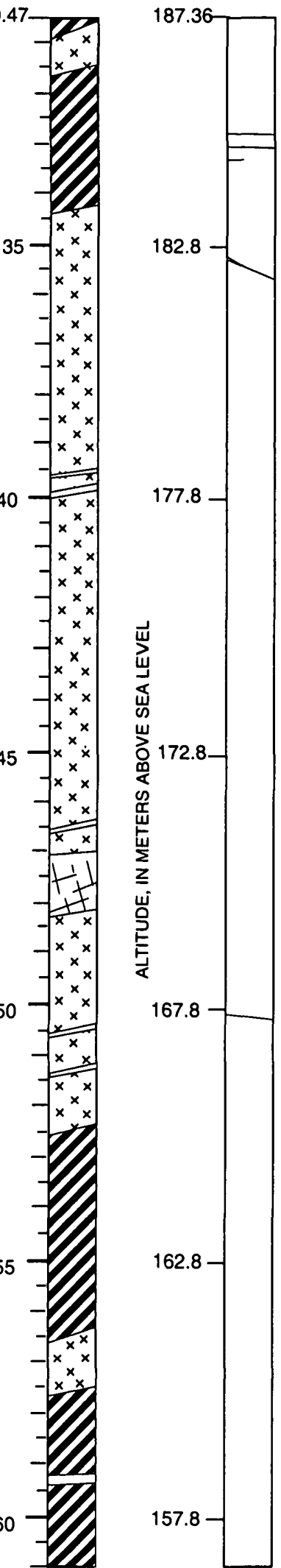
33. 33.3

GRANITE from 34.4 to $52.4 \mathrm{~m}$, biotite-rich, coarse grained, $\sim 18.0 \mathrm{~m}$ wide

Alternating bands of felsic-rich and biotite-rich zones from 36.5 to $37.5 \mathrm{~m}$ (not shown)

FELSIC BAND in GRANITE at $39.8 \mathrm{~m}$, with some pegmatitic muscovite, $\sim 10 \mathrm{~cm}$ wide
FELSIC BAND at $46.5 \mathrm{~m}, \sim 10 \mathrm{~cm}$ wide PEGMATITE from 47.0 to $48.1 \mathrm{~m}$, alternating layers of pegmatite and aplite, with many pegmatitic muscovite, $\sim 1.1 \mathrm{~m}$ wide

PEGMATITE VEIN at $50.6 \mathrm{~m}, \sim 3 \mathrm{~cm}$ wide

PEGMATITE VEIN at $51.4 \mathrm{~m}, \sim 3$ to $5 \mathrm{~cm}$ wide

SCHIST from 52.4 to $\sim 76.9 \mathrm{~m}, \sim 24.5 \mathrm{~m}$ wide SCHIST from 52.4 to $62.0 \mathrm{~m}$, ery fine grained schist with garnet, some portions exhibit augens and some exhibit banding, $\sim 9.6 \mathrm{~m}$ wide

GRANITE from 56.5 to $57.6 \mathrm{~m}$, fine to medium grained, biotite granite, contacts are parallel to foliation of the schist, $\sim 1.1 \mathrm{~m}$ wide

PEGMATITE from 59.1 to $59.3 \mathrm{~m}$, appears to be altered $\sim 20 \mathrm{~cm}$ wide 


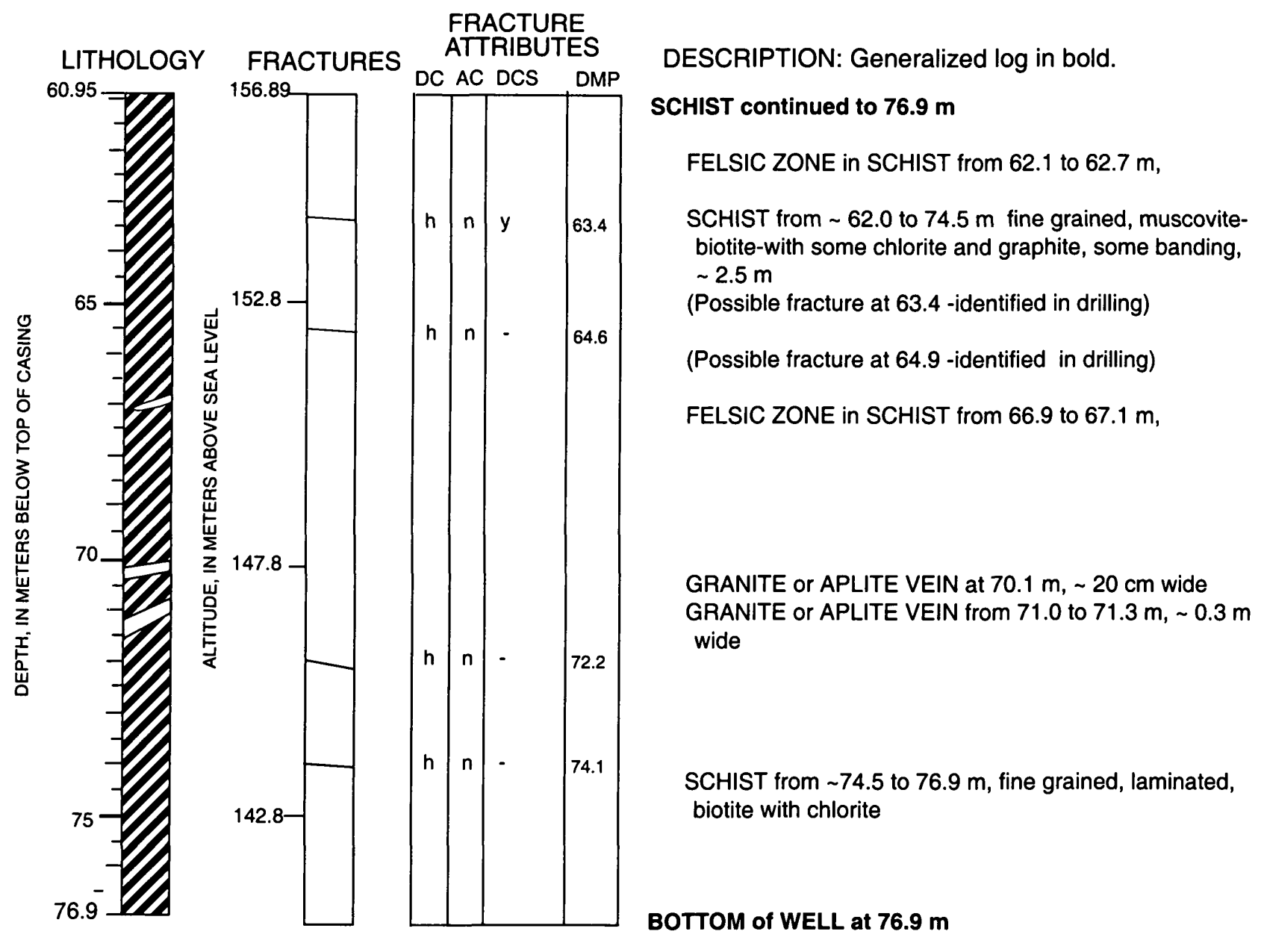


LITHOLOGY

FRACTURES

FRACTURE ATTRIBUTES
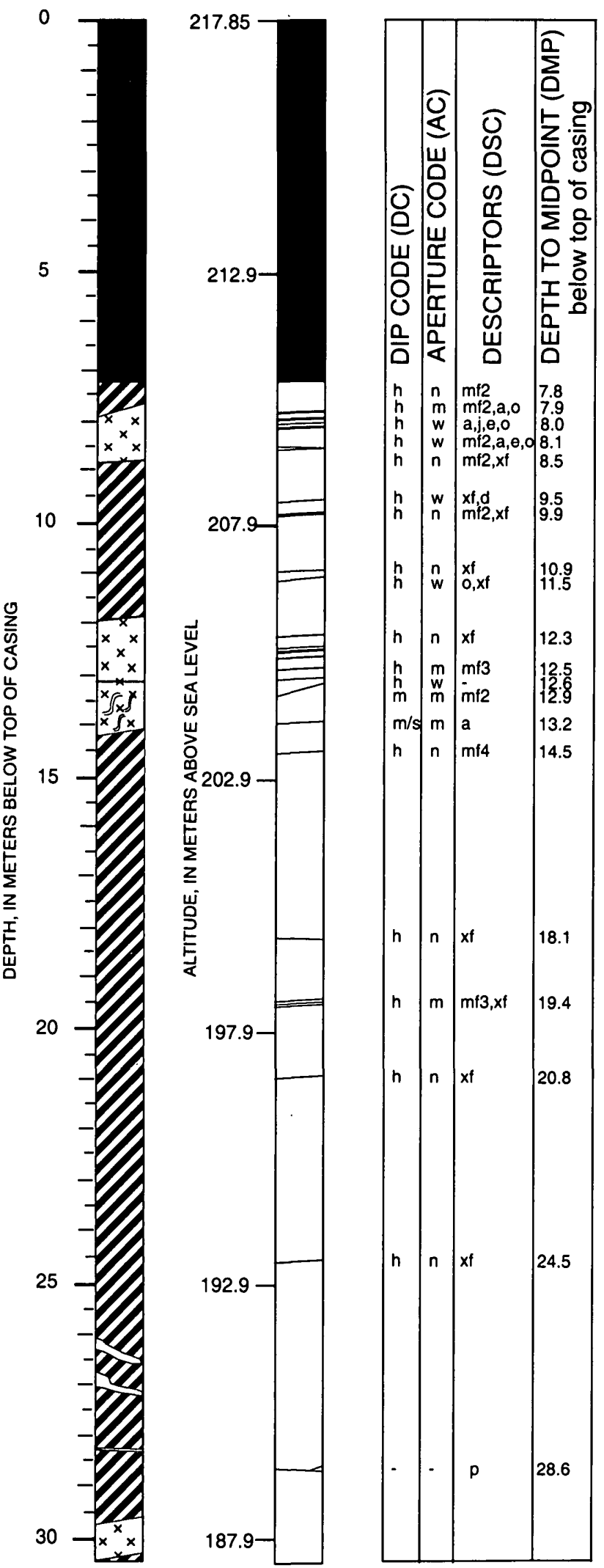

DESCRIPTION: Generalized log in bold.

SOIL from 1.1 to $1.7 \mathrm{~m}, \sim 0.6 \mathrm{~m}$ wide

BOULDER from 1.7 to $1.8 \mathrm{~m}, \sim 0.4 \mathrm{~m}$ wide

SAND from $1.8 \mathrm{~m}$ to $4.4 \mathrm{~m}$, brown, fine to medium grain, $\sim 2.6 \mathrm{~m}$ wide

BEDROCK at $4.4 \mathrm{~m}$ to $7.16 \mathrm{~m}$, cuttings of gray schist

\section{BOTTOM of CASING at $7.16 \mathrm{~m}$}

SCHIST from 7.2 to $7.8 \mathrm{~m}$, biotite, quartz, feldspar, and trace garnet, some oxidation, laminated schist, with moderately to steeply dipping foliation, $\sim 0.6 \mathrm{~m}$ wide

GRANITE DIKE from 7.8 to $8.8 \mathrm{~m}$, biotite muscovite granite, oxidized, dike is parallel to foliation of schist, $\sim 1.0 \mathrm{~m}$ wide

SCHIST from $8.8 \mathrm{~m}$ to $\sim \mathbf{1 0 . 1} \mathrm{m}$, dark reddish brown, fine grained, laminated, gradual lower contact, $\sim 1.5 \mathrm{~m}$ wide SCHIST from 10.1 to $11.9 \mathrm{~m}$, coarse grained to gneissic, steeply dipping foliation, some weak banding, gradual upper contact, $\sim 1.8 \mathrm{~m}$ wide

GRANITE from 11.9 to $13.1 \mathrm{~m}$, biotite muscovite granite, grayish, parallel to foliation, bottom contact grades to gneiss below, $\sim 1.2 \mathrm{~m}$ wide

GNEISS or GRANITE from 13.1 to $14.3 \mathrm{~m}$, altered, gneissic, grades to schist below, $\sim 1.2 \mathrm{~m}$ wide APLITE or highly altered zone at $13.4 \mathrm{~m}$, fine-grained texture, felsic, altered, $\sim 10 \mathrm{~cm}$ wide

SCHIST from 14.3 to $29.7 \mathrm{~m}$, fine to coarse grained texture, some felsic zones, some biotite-rich zones, some weak banding, steeply dipping foliation, $\sim 15.4 \mathrm{~m}$ wide FELSIC ZONE in schist from 16.6 to $17.7 \mathrm{~m}$, (not shown), $\sim 1.1 \mathrm{~m}$ wide

SCHIST from 17.7 to $19.8 \mathrm{~m}$, brownish red, fine grained, laminated, $\sim 2.1 \mathrm{~m}$ wide

SCHIST from 19.8 to $20.4 \mathrm{~m}$, grades from fine grained to gneissic texture, $\sim 0.6 \mathrm{~m}$ wide

SCHIST from 20.4 to $25.3 \mathrm{~m}$, gneissic schist with some banding, biotite rich, $\sim 4.9 \mathrm{~m}$ wide

FELSIC ZONE in schist from 21.6 to $22.2 \mathrm{~m}$ (not shown), $\sim 0.6 \mathrm{~m}$ wide

SCHIST from 27.1 to $29.7 \mathrm{~m}$, coarse grained schist, weakly foliated, equigranular texture, $\sim 2.6 \mathrm{~m}$ wide

GRANITE from $29.7 \mathrm{~m}$ to $30.4 \mathrm{~m}$, biotite-muscovite, coarse grained texture $\sim 0.7 \mathrm{~m}$ wide

SCHIST from 30.4 to $30.9 \mathrm{~m}, \sim 0.5 \mathrm{~m}$ wide 
LITHOLOGY


FRACTURES FRACTURE

DC AC DCS DMP

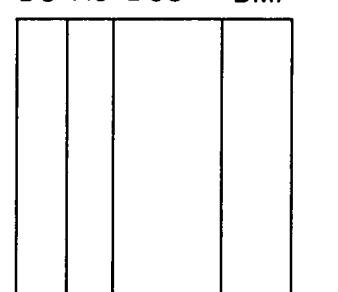

DESCRIPTION: Generalized log in bold.

\section{SCHIST continued to $30.9 \mathrm{~m}$}

MIGMATITE from 30.9 to $34.2 \mathrm{~m}, \sim 4.3 \mathrm{~m}$ wide

FELSIC ZONE in migmatite from 30.9 to $32.8 \mathrm{~m}$, felsic rich migmatite, $\sim 1.9 \mathrm{~m}$ wide

MIGMATITE from 32.8 to $34.2 \mathrm{~m}$, biotite-rich, swirls of foliated biotite in felsic matrix, foliation is vertical, gradual contacts, $\sim 1.4 \mathrm{~m}$ wide

SCHIST from $\mathbf{3 4 . 2}$ to $\mathbf{4 3 . 6} \mathrm{m}$, dusky brown, fine to medium grained texture, $\sim 9.4 \mathrm{~m}$ wide

SCHIST from 37.7 to $39.0 \mathrm{~m}$, felsic-rich schist, $\sim 1.3 \mathrm{~m}$ wide

SCHIST from 39.0 to $41.8 \mathrm{~m}$, dusky brown, biotite-rich schist, fine grained texture, $\sim 2.8 \mathrm{~m}$ wide

SCHIST from 41.8 to $42.8 \mathrm{~m}$, fine to medium grained schist, laminated, with some banding, $\sim 1.0 \mathrm{~m}$ wide (fracture at $40.3 \mathrm{~m}$ yielding during drilling) SCHIST from $42.8 \mathrm{~m}$ to $43.0 \mathrm{~m}$ altered, equigranular, felsic zone in schist, $\sim 0.2 \mathrm{~m}$ wide

GRANITE from 43.6 to $47.0 \mathrm{~m}$, biotite granite, with biotite schlieren, $-3.4 \mathrm{~m}$ wide

PEGMATITE from 47.0 to $48.9 \mathrm{~m}$, muscovite, quartz, feldspar microcline and apatite gradual lower contact with schist, $\sim 1.9 \mathrm{~m}$ wide

APLITE VEIN at $48.3 \mathrm{~m}, \sim 10 \mathrm{~cm}$ wide

SCHIST from 48.9 to $70.4 \mathrm{~m}$, dark reddish brown, with some graphitic minerals, gneissic texture, steeply dipping foliation, some augens, $\sim 21.5 \mathrm{~m}$ wide

APLITE or GRANITE DIKE from 53.3 to $53.7 \mathrm{~m}$, cross cuts foliation of schist, $\sim 0.4 \mathrm{~m}$ wide

FELSIC VEIN at $56.7 \mathrm{~m}$, cross-cuts foliation of schist, $\sim 10 \mathrm{~cm}$ wide

PEGMATITE at $60.0 \mathrm{~m}$, muscovite and feldspar, crosses foliation of schist, $\sim 20 \mathrm{~cm}$ wide

FELSIC VEIN at $60.7 \mathrm{~m}$, cross-cuts foliation of schist, $\sim 2 \mathrm{~cm}$ wide 
CO9 Continued

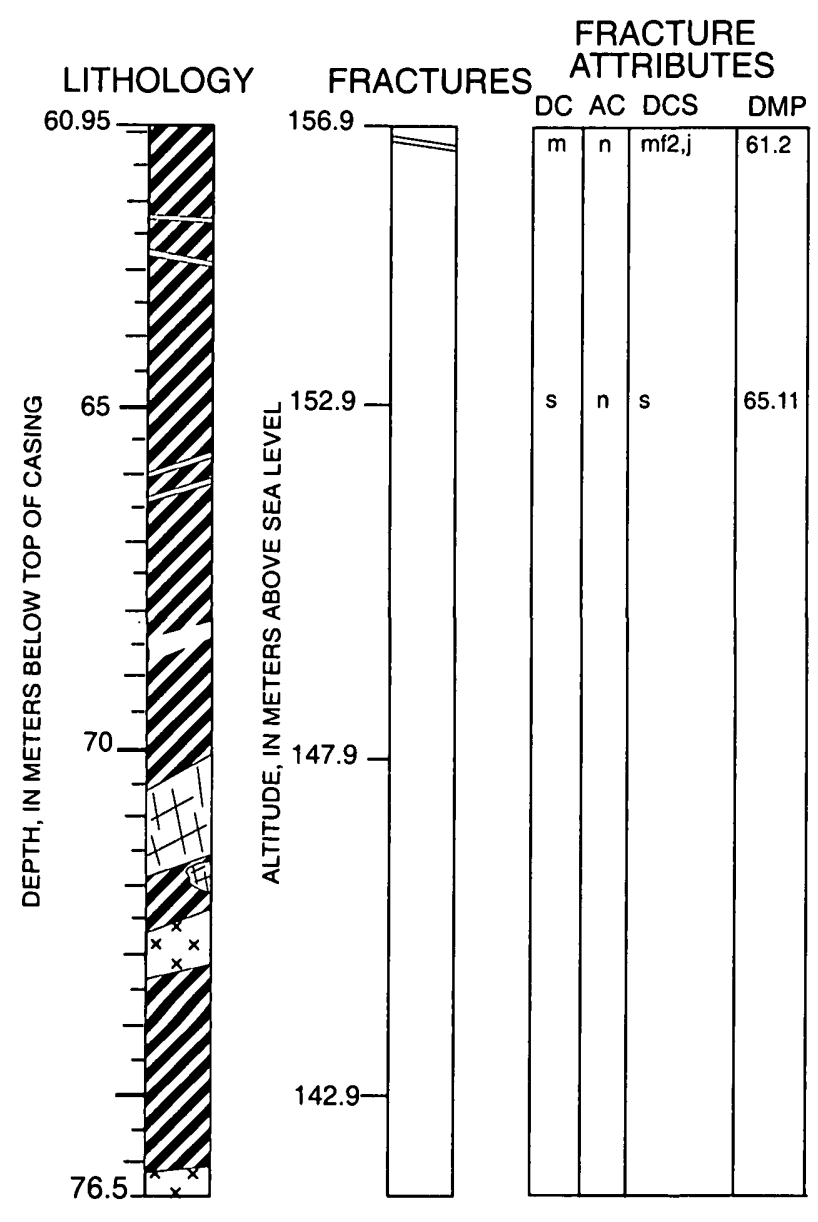

DESCRIPTION: Generalized log in bold.

\section{SCHIST continued to $70.4 \mathrm{~m}$}

FELSIC VEIN at $62.4 \mathrm{~m}$, cross-cuts foliation of schist, $\sim 2 \mathrm{~cm}$ wide

FELSIC VEIN at $63.2 \mathrm{~m}$, cross-cuts foliation of schist, $\sim 25 \mathrm{~cm}$ wide

FELSIC VEIN at $65.9 \mathrm{~m}$, parallel to foliation of schist, $\sim 5 \mathrm{~cm}$ wide FELSIC VEIN at $66.3 \mathrm{~m}$, parallel to foliation of schist, $\sim 5 \mathrm{~cm}$ wide

FELSIC ZONE from 68.3 to $68.5 \mathrm{~m}$, altered, $\sim 20 \mathrm{~cm}$ wide

PEGMATITE from 70.4 to $71.7 \mathrm{~m}, \sim 1.3 \mathrm{~m}$ wide SCHIST from 71.7 to $76.5 \mathrm{~m}, \sim 4.2 \mathrm{~m}$ wide

PEGMATITE on one side of the well from 71.8 to $72.1 \mathrm{~m}$, $\sim 0.3 \mathrm{~m}$ wide

GRANITE from 72.5 to $73.2 \mathrm{~m}, \sim 0.7 \mathrm{~m}$ wide

SCHIST from 73.2 to $76.4 \mathrm{~m}$, gneissic texture, $\sim 3.2 \mathrm{~m}$ wide

APLITE or FELSIC ZONE in schist from $76.4 \mathrm{~m}$ to bottom of hole

BOTTOM of HOLE at $76.5 \mathrm{~m}$ 
LITHOLOGY FRACTURES

FRACTURE ATTRIBUTES

DESCRIPTION: Generalized log in bold.
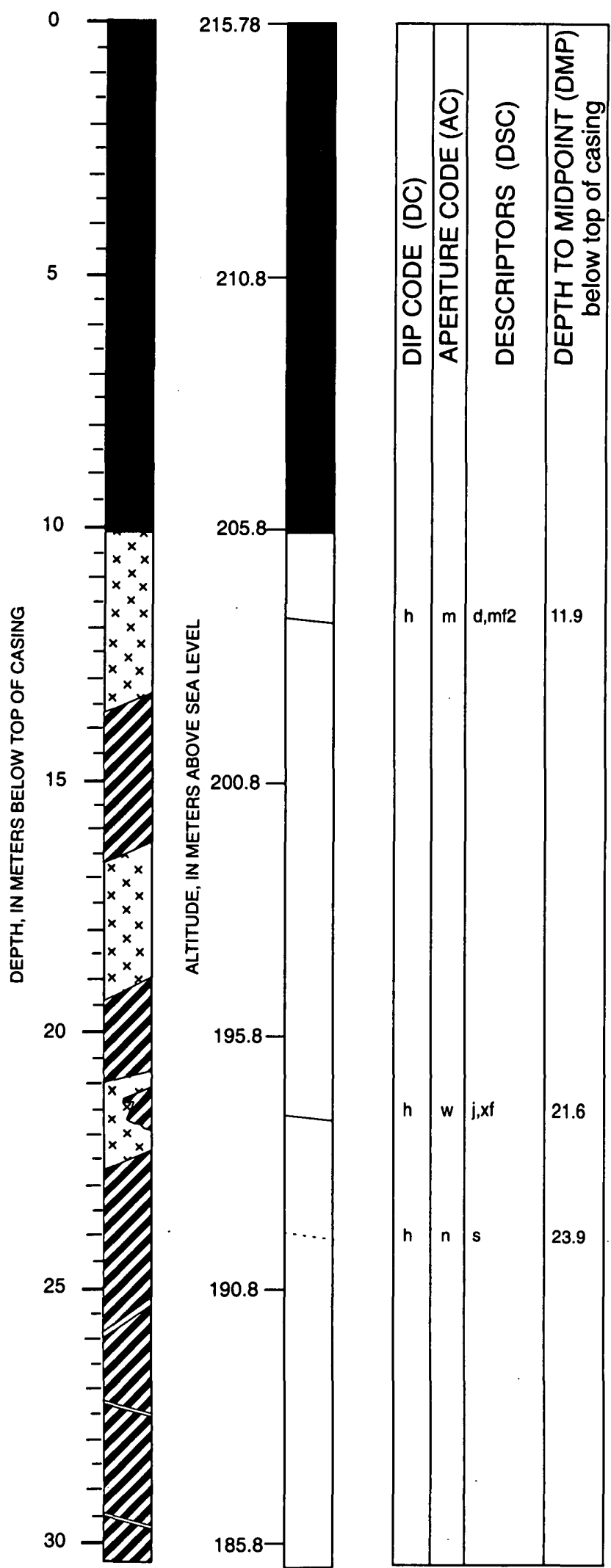

\section{BEDROCK SURFACE at $6.4 \mathrm{~m}$}

BOTTOM of CASING at $10.1 \mathrm{~m}$

GRANITE from 10.1 to $13.4 \mathrm{~m}$, coarse grained, biotite-

muscovite granite with some biotite schlieren, $\sim 3.3 \mathrm{~m}$ wide

SCHIST from 13.4 to $16.4 \mathrm{~m}$, coarse-grained, coppery-brown, biotite layers and quartzo-felspathic layers, steeply dipping, $~ 3.0 \mathrm{~m}$ wide

GRANITE from 16.4 to $19.3 \mathrm{~m}, \sim 2.9 \mathrm{~m}$ wide

SCHIST from 19.3 to $31.7 \mathrm{~m}$, quartz-rich schist, fine grained to gneissic, steeply dipping $\sim 12.4 \mathrm{~m}$ wide

FELSIC ZONE IN SCHIST, $21.0 \mathrm{~m}$ to $22.5 \mathrm{~m}, \sim 1.5 \mathrm{~m}$ wide

PEGMATITE VEIN at $25.5 \mathrm{~m}$, biotite-muscovite, parallel to foliaiton of schist, $1-3 \mathrm{~cm}$ wide

FELSIC BAND at $27.4 \mathrm{~m}$, cross-cuts foliation of schist, $\sim 1-2 \mathrm{~cm}$ wide

FELSIC BAND at $29.6 \mathrm{~m}$, cross-cuts foliation of schist, $\sim 1-2 \mathrm{~cm}$ wide 
LITHOLOGY

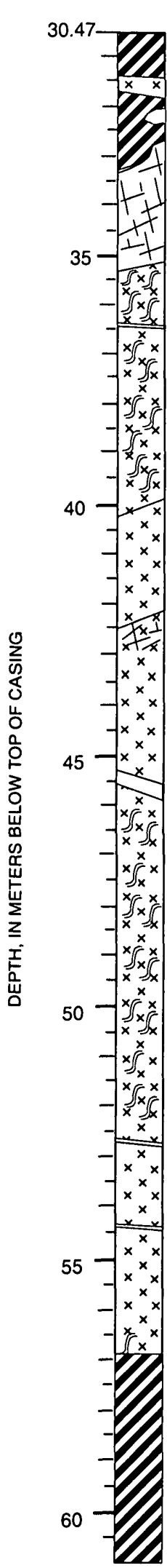

\section{FRACTURES}

ATTRIBUTES

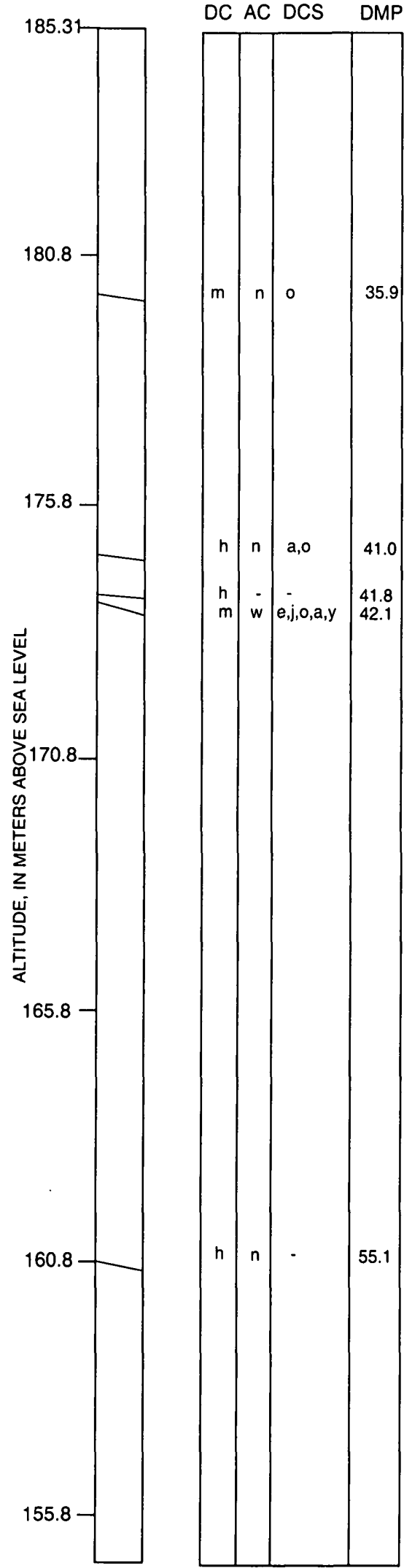

DESCRIPTION: Generalized log in bold.

SCHIST continued to $31.4 \mathrm{~m}$

GRANITE from 31.4 to $31.7 \mathrm{~m}$, medium to coarse grained, cross cuts foliation of schist, $\sim 0.3 \mathrm{~m}$ wide

SCHIST from 31.7 to $33.4 \mathrm{~m}$, coarse-grained, $\sim 1.7 \mathrm{~m}$ wide

PEGMATITE from 33.4 to $35.2 \mathrm{~m}$, $1.8 \mathrm{~m}$ wide

MIGMATITE from 34.8 to $\mathbf{4 0 . 1} \mathrm{m}$, coarse grained with some gneissic and migmatitic zones, $\sim 5.3 \mathrm{~m}$ wide

FELSIC BAND at $36.4 \mathrm{~m}, \sim 1 \mathrm{~cm}$ wide

GRANITE from $\mathbf{4 0 . 1}$ to $\mathbf{4 3 . 5} \mathrm{m}$, medium to coarse-grained granite and migmatitic zones, $\sim 3.4 \mathrm{~m}$ wide

PEGMATITE from 42.4 to $42.9 \mathrm{~m}, \sim 0.5 \mathrm{~m}$ wide

MIGMATITE from $\mathbf{4 3 . 5}$ to $\mathbf{5 2 . 2} \mathrm{m}$, near vertical foliation, gneissic textured, biotite-rich with some fine grained foliated layers with swirled fabric, $\sim 8.7 \mathrm{~m}$ wide

GRANITE DIKE from 45.4 to $45.6 \mathrm{~m}$, fine grained, crosscuts foliation of schist, $\sim 20 \mathrm{~cm}$ wide

GRANITE from $\mathbf{5 2 . 2}$ to $\mathbf{5 4 . 2} \mathrm{m}$, coarse grained from $\mathbf{5 2 . 2}$ to $53.0 \mathrm{~m}$ and fine-grained from 53.0 to $54.2 \mathrm{~m}$, cross-cuts foliation of migmatite, $\sim 2.0 \mathrm{~m}$ wide

FELSIC BAND at $52.6 \mathrm{~m}, \sim 2 \mathrm{~cm}$ wide

MIGMATITE from $\mathbf{5 4 . 2}$ to $\sim \mathbf{5 7 . 5} \mathrm{m}$, coarse-grained quartz, felspathic layers and fine-grained biotite layers, gradational contact with schist below, $-3.3 \mathrm{~m}$ wide APLITE VEIN at $54.3 \mathrm{~m}, \sim 5 \mathrm{~cm}$ wide

SCHIST from $\mathbf{5 7 . 5}$ to $\mathbf{7 7 . 1} \mathrm{m}$, steeply dipping foliation, finegrained biotite-rich layers and coarse-grained quartzwith felspathic layers, grades to a fine-grained, laminated schist, $\sim 1.3 \mathrm{~m}$ wide 
CO10 Continued

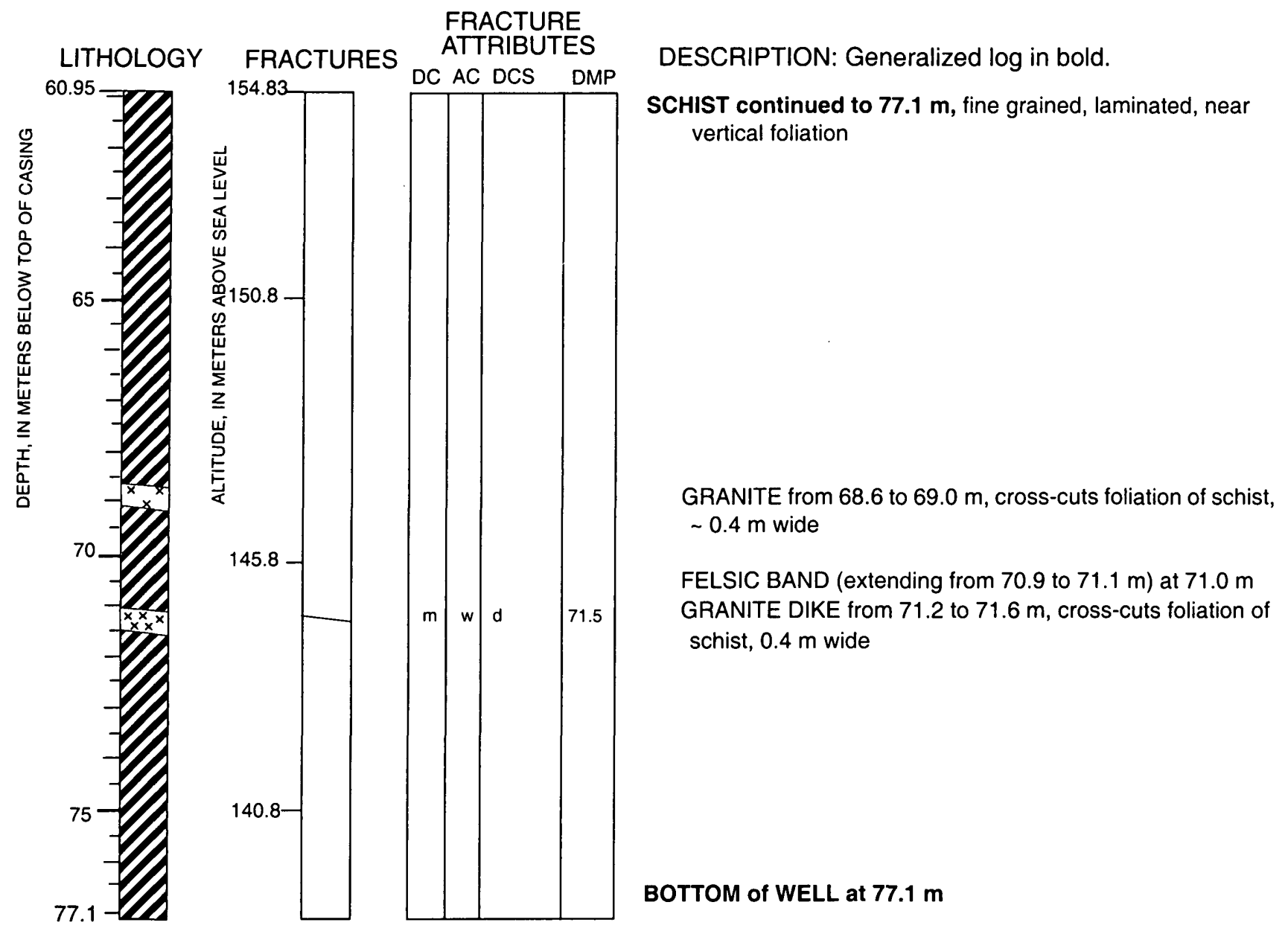


WELL NAME: CO11

LITHOLOGY

FRACTURES

FRACTURE

ATTRIBUTES

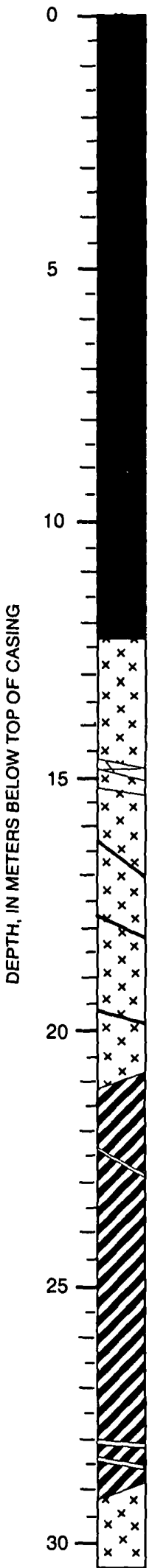

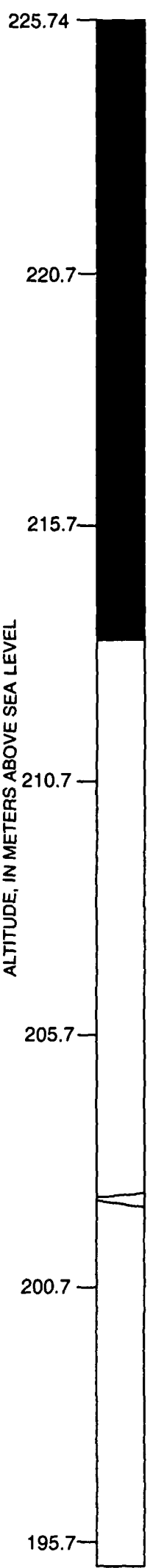

DESCRIPTION: Generalized log in bold.

Gravel and Sand from 1.5 to $3.4 \mathrm{~m}$, brown, coarse to medium sand, $\sim 1.9 \mathrm{~m}$ wide

Gravel and Sand from 3.4 to $4.6 \mathrm{~m}$, gray, coarse to medium sand, $\sim 1.2 \mathrm{~m}$ wide

Boulders from 4.6 to $4.9 \mathrm{~m}, \sim 0.3 \mathrm{~m}$ wide

Gravel from 4.9 to $5.3, \sim 0.4 \mathrm{~m}$ wide

Till from 5.3 to $8.2 \mathrm{~m}, \sim 2.9 \mathrm{~m}$ wide

BEDROCK SURFACE at $8.23 \mathrm{~m}$

BOTTOM OF CASING at $12.3 \mathrm{~m}$

GRANITE from 12.3 to $20.8 \mathrm{~m}, \sim 3.1 \mathrm{~m}$ wide

GRANITE from 12.2 to 13.8 , biotite rich, gneissic texture,

$\sim 1.6 \mathrm{~m}$ wide

GRANITE from 13.8 to 14.1 , biotite and muscovite, coarse grained texture, $\sim 0.3 \mathrm{~m}$ wide

PEGMATITE from 14.7 to $14.9, \sim 20 \mathrm{~cm}$ wide

GRANITE from 14.1 to 15.4 , biotite rich, weakly foliated with augens, $\sim 1.3 \mathrm{~m}$ wide

BIOTITE SCHLIEREN or sealed fracture?? from 16.7 to

$16.9 \mathrm{~m}, \sim 0.2 \mathrm{~m}$ wide

PEGMATITE at $18.0 \mathrm{~m}, \sim 0.3 \mathrm{~cm}$ wide

GRANITE from 15.4 to $20.8 \mathrm{~m}$, gray, medium grained,

$\sim 5.6 \mathrm{~m}$ wide

PEGMATITE at $19.8 \mathrm{~m},-2 \mathrm{~cm}$ wide

SCHIST from 20.8 to $29.0 \mathrm{~m}$, coarse grained to gneissic texture, with felsic zones, biotite-rich schist, $\sim 8.2 \mathrm{~m}$ wide

APLITE from 22.4 to $22.8 \mathrm{~m}$, felsic, irregular shape, $\sim 0.4 \mathrm{~m}$ wide

APLITE VEIN at $28.0 \mathrm{~m}$, cross-cuts foliation of schist, $\sim 5$ to $10 \mathrm{~cm}$ wide

APLITE VEIN at $28.5 \mathrm{~m}_{1}-3 \mathrm{~cm}$ wide

GRANITE from 29.0 to $33.5 \mathrm{~m}$, coarse grained to gneissic texture, $\sim 4.5 \mathrm{~m}$ wide 
LITHOLOGY

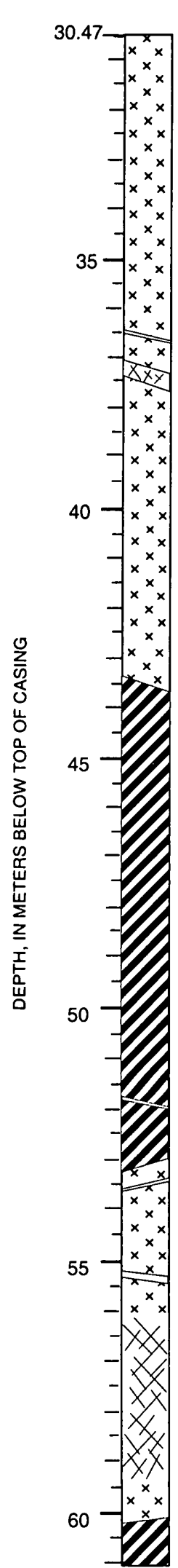

FRACTURES FRACTURE

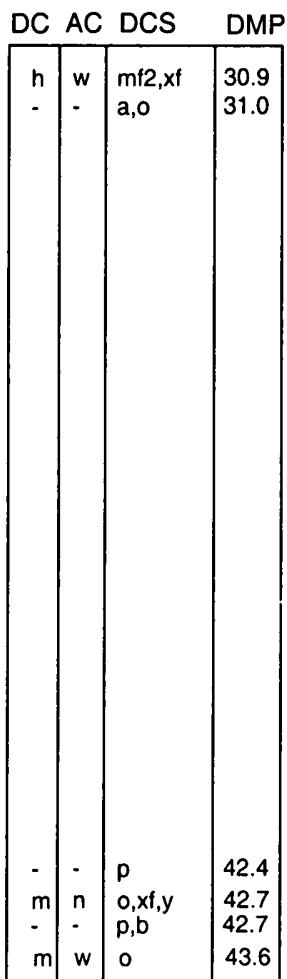

DESCRIPTION: Generalized log in bold.

GRANITE continued to $43.5 \mathrm{~m}$

PEGMATITE VEIN at $36.6 \mathrm{~m}, \sim 4 \mathrm{~cm}$ wide

PEGMATITE VEIN at $37.2 \mathrm{~m}, \sim 20 \mathrm{~cm}$ wide

Quartz, biotite, muscovite, feldspar, quartz and beryl granite, from 42.7 to $45.6 \mathrm{~m}$, coarse grained, $\sim 2.9 \mathrm{~m}$ wide

SCHIST from 43.5 to $53.3 \mathrm{~m}$, felsic rich, with biotite, muscovite and graphite and trace chlorite, gneissic, weakly foliated, steeply dipping, coarse grained, some augens, $\sim 9.8 \mathrm{~m}$ wide

FELSIC BAND at $51.8 \mathrm{~m}, \sim 5 \mathrm{~cm}$ wide

GRANITE from 53.3 to $56.0 \mathrm{~m}, \sim 2.7 \mathrm{~m}$ wide

GRANITE VEIN at $53.5 \mathrm{~m}$, parallel to foliation, $\sim 6 \mathrm{~cm}$ wide

APLITE VEIN at $55.3 \mathrm{~m}, \sim 25 \mathrm{~cm}$ wide

PEGMATITE from 56.0 to $59.4 \mathrm{~m}$, massive, cross cuts the foliation of schist, $\sim 3.4 \mathrm{~m}$ wide

GRANITE from 59.5 to $60.2 \mathrm{~m}, \sim 0.7 \mathrm{~m}$ wide SCHIST from 60.2 to $70.3 \mathrm{~m}, \sim 10.1 \mathrm{~m}$ wide 
C011 Continued

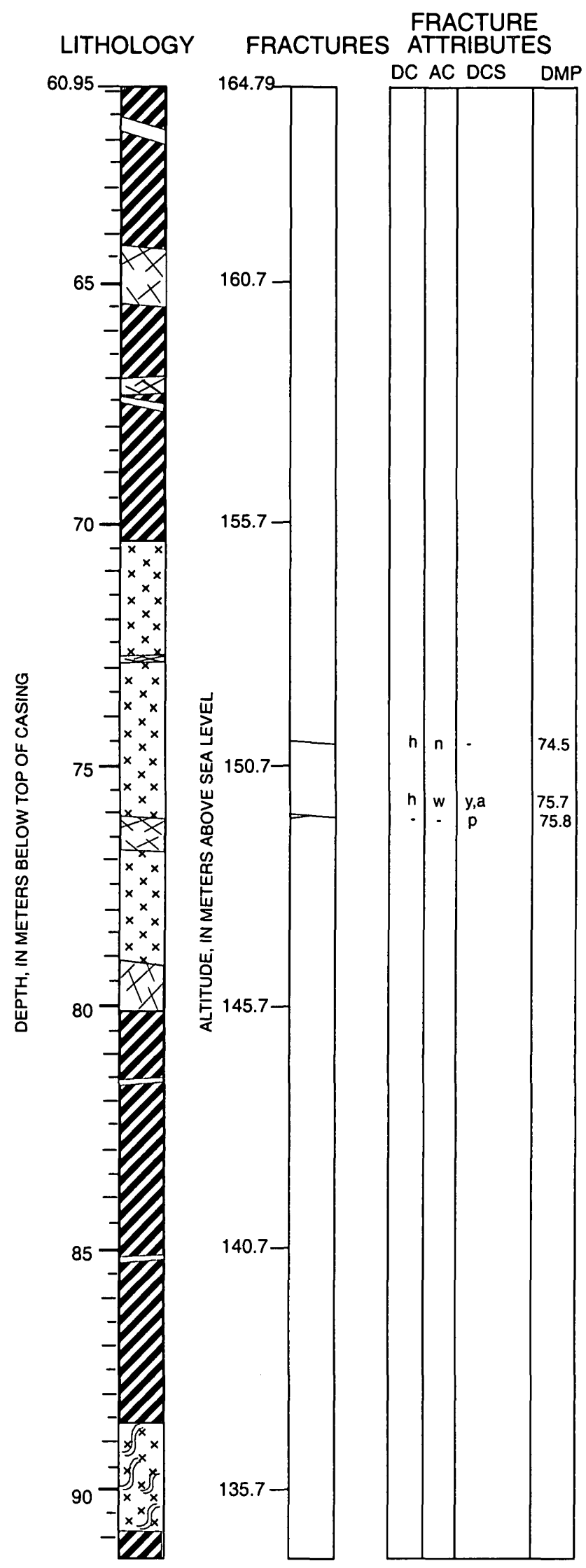

DESCRIPTION: Generalized log in bold.

SCHIST continued to $70.3 \mathrm{~m}$

GRANITE DIKE from 61.7 to $62.1 \mathrm{~m}, 0.4 \mathrm{~m}$ wide

PEGMATITE VEIN from $64.3 \mathrm{~m}$ to $65.5 \mathrm{~m}, \sim 1.2 \mathrm{~m}$ wide

PEGMATITE VEIN at $67.2 \mathrm{~m}, \sim 20 \mathrm{~cm}$ wide

APLITE at $67.6 \mathrm{~m}$, crosses foliation, $\sim 3 \mathrm{~cm}$ wide

GRANITE from 70.3 to $79.2 \mathrm{~m}$, fine to medium grained, with biotite schlieren, $\sim 8.9 \mathrm{~m}$ wide

PEGMATITE VEIN at $72.8 \mathrm{~m}, \sim 5 \mathrm{~cm}$ wide

PEGMATITE from $76.2 \mathrm{~m}$ to $76.8 \mathrm{~m}, \sim 0.6 \mathrm{~m}$ wide

PEGMATITE from 79.2 to $80.9 \mathrm{~m}, \sim 1.7 \mathrm{~m}$ wide

SCHIST from 80.9 to $88.6 \mathrm{~m}$, coarse grained, some augens, $\sim 7.7 \mathrm{~m}$ wide

APLITE at $81.6 \mathrm{~m}, \sim 9 \mathrm{~cm}$ wide

FELSIC VEIN at $85.2 \mathrm{~m}, \sim 5 \mathrm{~cm}$ wide

MIGMATITE from 88.6 to $90.8 \mathrm{~m}$, more granitic looking than schistose, $\sim 2.2 \mathrm{~m}$ wide

SCHIST from 90.8 to $116.0 \mathrm{~m}$, felsic-rich schist, banded, locally exhibiting augens, $\sim 25.2 \mathrm{~m}$ wide 


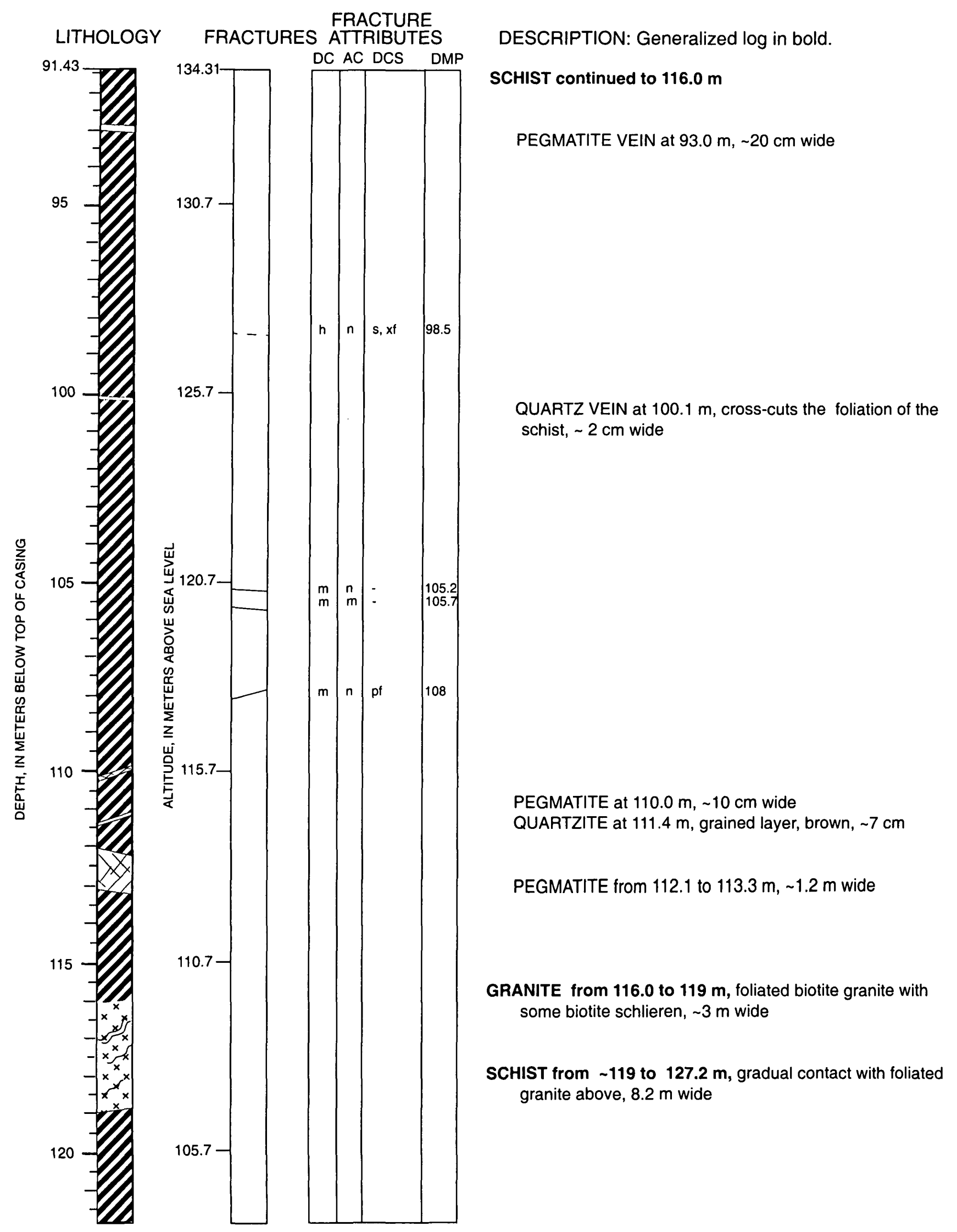


C011 Continued

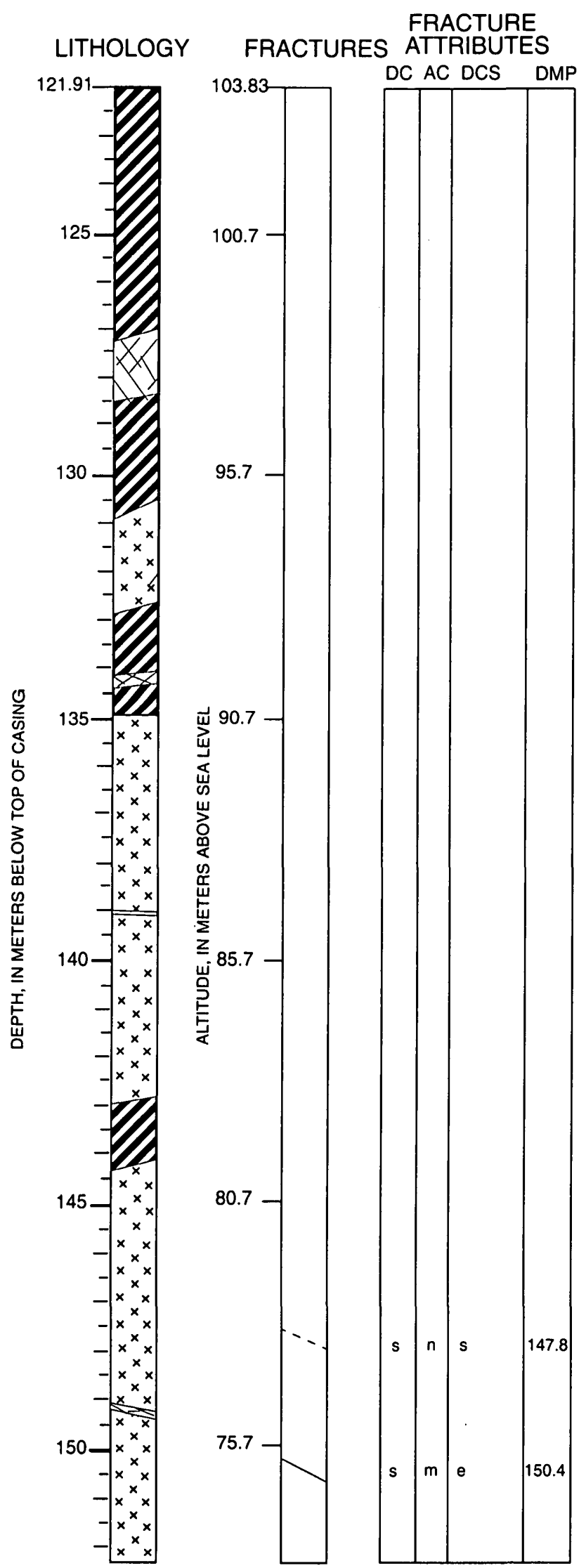

DESCRIPTION: Generalized log in bold.

\section{SCHIST continued to $127.0 \mathrm{~m}$}

SCHIST exhibits steeply dipping banding, foliated biotiterich layers and quartzo- feldspathic layers that are

$\sim 10 \mathrm{~cm}$ wide

PEGMATITE from 127.0 to $128.3 \mathrm{~m}, \sim 1.3 \mathrm{~m}$ wide

BIOTITE layer from 127.5 to $127.7 \mathrm{~m}, \sim 0.2 \mathrm{~m}$ wide SCHIST from 128.3 to $130.7 \mathrm{~m}, \sim 2.4 \mathrm{~m}$ wide

GRANITE from 130.7 to $132.9 \mathrm{~m}$, narrow, irregular shape,

$\sim 1.2 \mathrm{~m}$ wide

SCHIST from 132.9 to $134.9 \mathrm{~m}$, steeply dipping foliation, $\sim 2.0 \mathrm{~m}$ wide

PEGAMATITE VEIN at $134.2 \mathrm{~m}, \sim 0.3 \mathrm{~m}$ wide

GRANITE from 134.9 to $142.9 \mathrm{~m}$, with biotite schist xenoliths or possibly highly foliated migmatitic zones (not shown), $\sim 8.0 \mathrm{~m}$ wide

FELSIC BAND at 139.0, fine grained, near horizontal, $<1 \mathrm{~cm}$ wide

SCHIST from 142.9 to $144.4 \mathrm{~m}, \sim 1.5 \mathrm{~m}$ wide

GRANITE from 144.4 to $152.9 \mathrm{~m}, \sim 8.5 \mathrm{~m}$ wide

PEGAMTITE DIKE at $149.2 \mathrm{~m}, \sim 0.2$ to $0.3 \mathrm{~m}$ wide 
C011 Continued

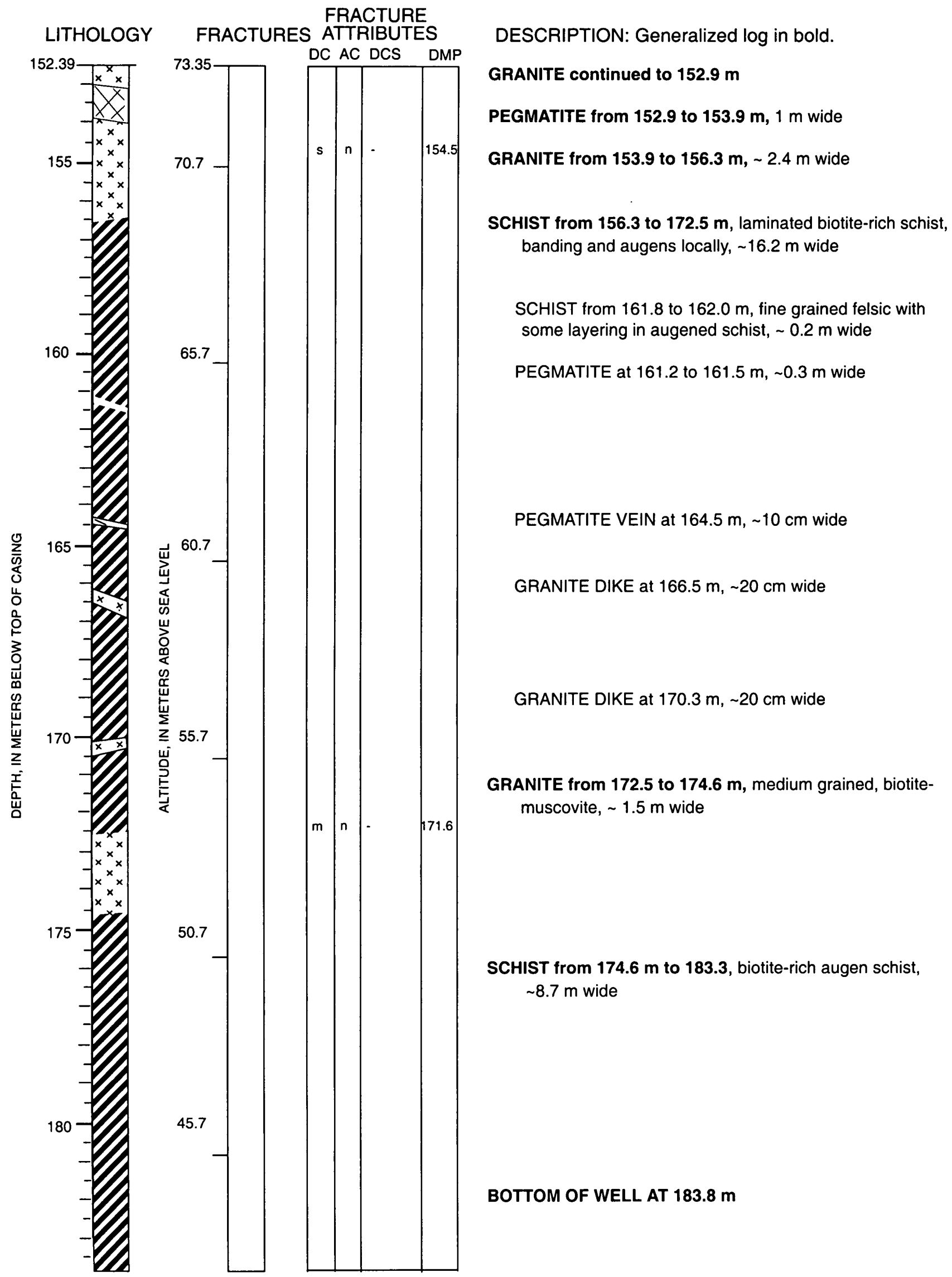




\section{LITHOLOGY}

0

$$
5
$$

5

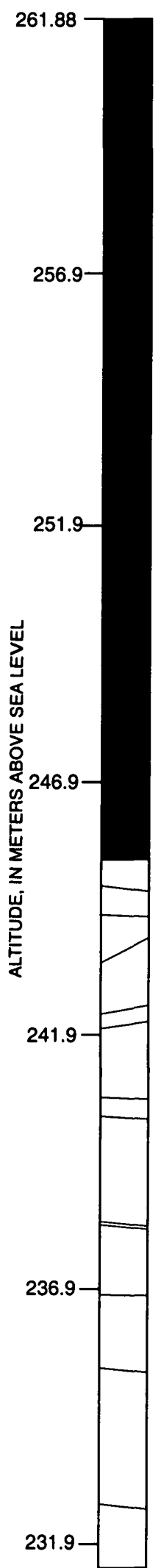

FRACTURES

FRACTURE ATTRIBUTES

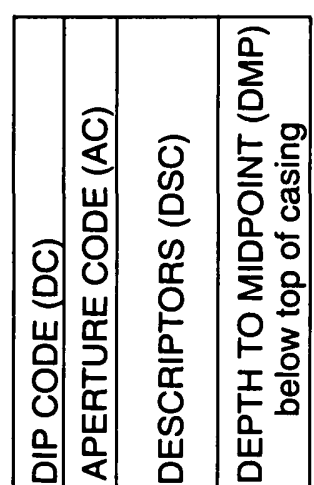

D

20

10

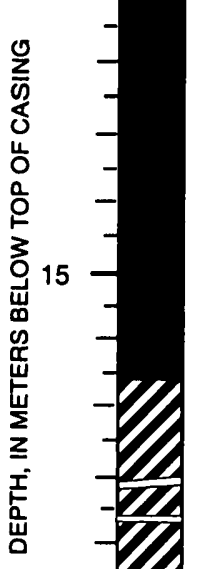

25

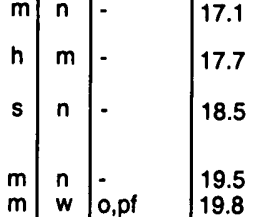

m $w$

$\begin{array}{lll}h & n \\ h & n & -\end{array}$

-

216

h $n$ mf2

23.8

h $\mathrm{m}$.

25.0

h $m$.

26.5

30

n j,d

29.2

DESCRIPTION: Generalized log in bold.

\section{SAND from 0.61 to $2.1 \mathrm{~m}$}

TILL from 2.1 to $14.0 \mathrm{~m}, \sim 11.9 \mathrm{~m}$ wide

TILL from 2.1 to $8.2 \mathrm{~m}$, gray-tan, silty, $\sim 6.1 \mathrm{~m}$ wide

TILL from 8.2 to $14.0 \mathrm{~m}$, gray, silty, $\sim 10.3 \mathrm{~m}$ wide

BEDROCK SURFACE at $14.0 \mathrm{~m}$

BOTTOM OF CASING at $16.46 \mathrm{~m}$

SCHIST from 16.5 to $34.0 \mathrm{~m}$, biotite-garnet schist with small amounts of feldspar and quartz and trace pyrite, schist with some calc-silicate lenses, medium grained, moderately to steeply dipping, $\sim 17.5 \mathrm{~m}$ wide

FELSIC VEIN at $18.1 \mathrm{~m}$

FELSIC VEIN at $18.7 \mathrm{~m}$

GRANITE DIKE or felsic zone in schist from 20.2 to $20.4 \mathrm{~m}$, $\sim 0.2 \mathrm{~m}$ wide

GRANITE DIKE from 21.2 to $21.5 \mathrm{~m}, \sim 0.3 \mathrm{~m}$ wide

SCHIST from 29.0 to $34.0 \mathrm{~m}$, sulfitic-biotite schist, finegrained foliated biotites and some medium to coarse grained felsic portions, $\sim 5.0 \mathrm{~m}$ wide 


\section{FRACTURES FRACTURE \\ ATTRIBUTES}
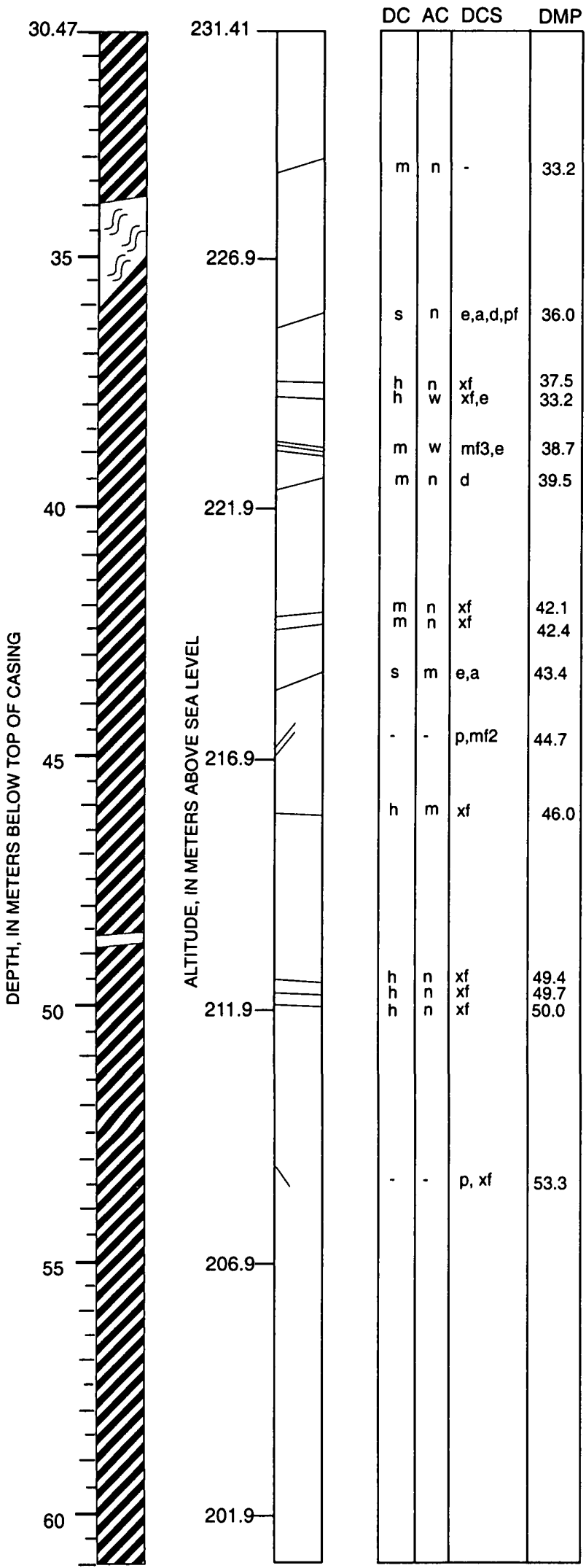

DESCRIPTION: Generalized log in bold.

SCHIST continued to $34.0 \mathrm{~m}$

FELSIC ZONE in SCHIST or Migmatite from 34.0 to $35.5 \mathrm{~m}$, coarse grained, $\sim 1.5 \mathrm{~m}$ wide

SCHIST from 35.5 to $80.2 \mathrm{~m}, \sim 44.7 \mathrm{~m}$ wide

SCHIST from 35.5 to $49.4 \mathrm{~m}$, biotite-sillimanite schist, fine grained, $13.9 \mathrm{~m}$ wide

SCHIST from 41.1 to $45.7 \mathrm{~m}$, greenish schist, with chlorite, fine grained, mottled appearance, $\sim 4.6 \mathrm{~m}$ wide

FELSIC ZONE in SCHIST from 45.4 to $45.7 \mathrm{~m}, \sim 0.3 \mathrm{~m}$ wide

FELSIC VEIN at $48.5 \mathrm{~m}, \sim 15$ to $20 \mathrm{~m}$ wide SCHIST from 49.4 to $50.6 \mathrm{~m}$, extremely fine grained, possibly altered, $\sim 1.2 \mathrm{~m}$ wide

SCHIST from 50.6 to $80.2 \mathrm{~m}$, fine to medium grained schist, biotite schist with some phlogopite and trace garnet, and weakly felsic layers, $\sim 29.6 \mathrm{~m}$ wide 
FS1 Continued

\section{LITHOLOGY}

60.95

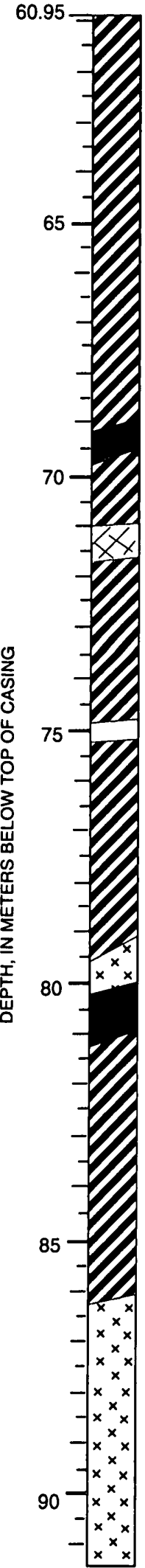

FRACTURE

FRACTURES ATTRIBUTES

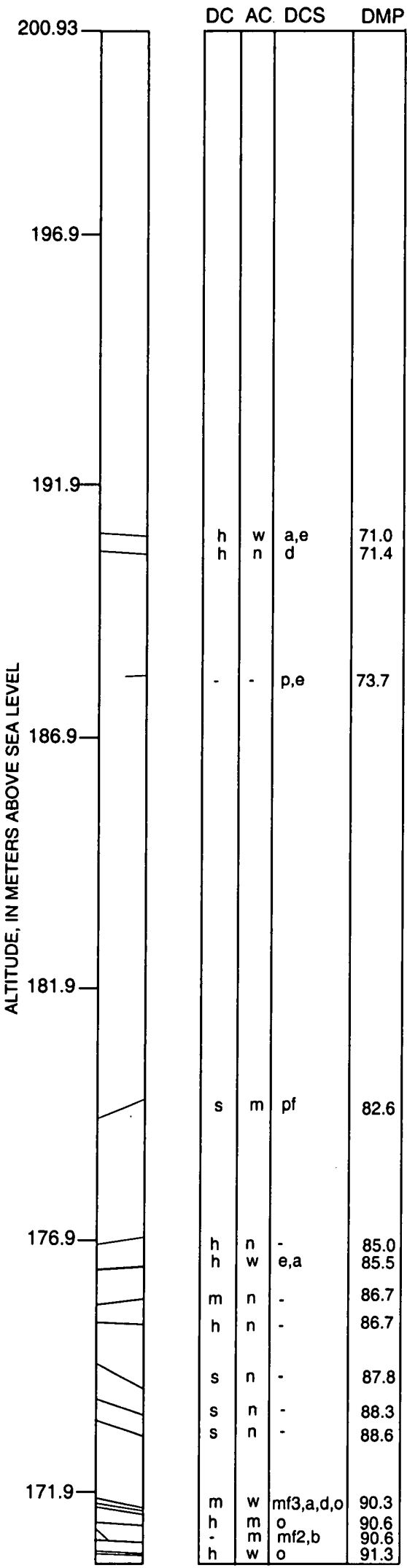

DESCRIPTION: Generalized log in bold.

SCHIST continued to $80.2 \mathrm{~m}$

SCHIST felsic-rich from 61.0 to $65.5 \mathrm{~m}, \sim 4.5 \mathrm{~m}$

SCHIST from 66.2 to $69.0 \mathrm{~m}$, coarse grained, biotite, muscovite, and phlogopite, with trace garnet, weakly banded, $\sim 2.8 \mathrm{~m}$ wide

BASALT DIKE from 69.0 to $69.7 \mathrm{~m}$, grayish-brownish black, aphanitic, parallel to foliation, $\sim 0.7 \mathrm{~m}$ wide

PEGMATITE DIKE from 70.9 to $71.7 \mathrm{~m}$, quartz, potassium feldspar, gradational lower contact, $0.8 \mathrm{~m}$ wide

FELSIC ZONE or PEGMATITE in schist at 74.7 to $75.2 \mathrm{~m}$, $\sim 0.5 \mathrm{~m}$ wide

GRANITE from 79.4 to $80.2 \mathrm{~m}, \sim 0.8 \mathrm{~m}$ wide

BASALT DIKE from 80.2 to $81.2 \mathrm{~m}$, grayish black, aphanitic, parallel to foliation in schist below, $\sim 1.0 \mathrm{~m}$ wide

SCHIST from 81.2 to $85.2 \mathrm{~m}, \sim 4.0 \mathrm{~m}$ wide

SCHIST from 84.2 to $86.2 \mathrm{~m}$, coarse grained texture to gneissic, biotite-rich and felsic sections, partially melted, altered, $\sim 2.0 \mathrm{~m}$ wide

(fracture at $86.7 \mathrm{~m}$ is located along contact)

GRANITE from 86.2 to $105.1 \mathrm{~m}$, muscovite-biotite granite, brownish-grayish white, medium to coarse grained leucocratic granite, $\sim 18.9 \mathrm{~m}$ wide 
FS1 Continued

LITHOLOGY

FRACTURE

91.43

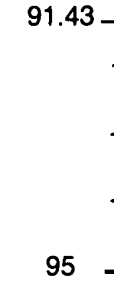

FRACTURES

ATTRIBUTES

DESCRIPTION: Generalized log in bold.

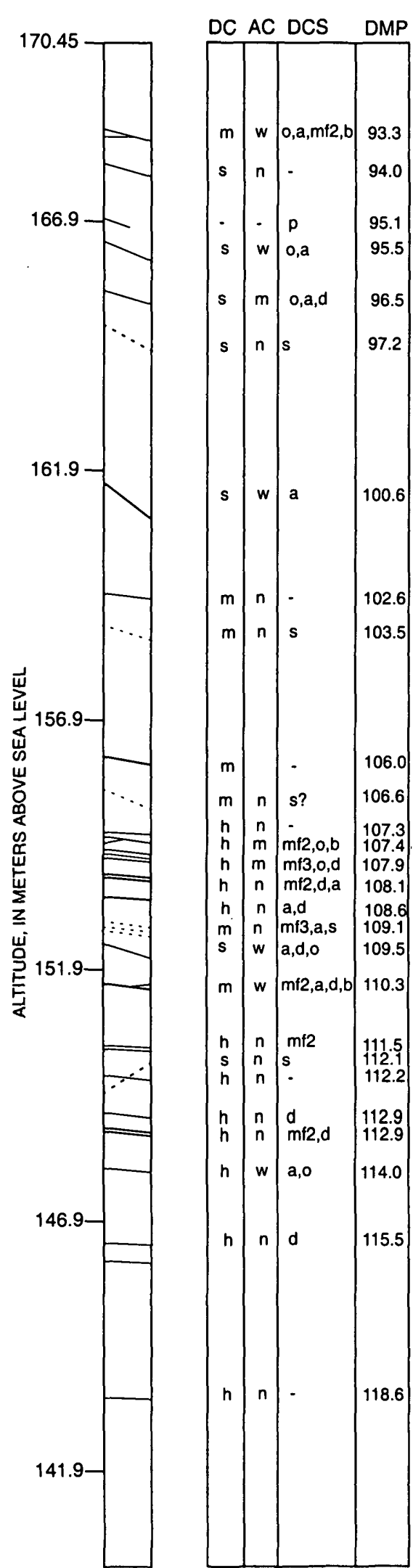

GRANITE continued to $105.1 \mathrm{~m}$

PEGMATITE from 96.9 to $97.2 \mathrm{~m}, \sim 0.3 \mathrm{~m}$ wide

GRANITE from 99.0 to $102.0 \mathrm{~m}$, light greenish gray, muscovite-chlorite, some foliation, altered, $\sim 3.0 \mathrm{~m}$ wide

PEGMATITE from 105.1 to $106.1 \mathrm{~m}$, feldspar, quartz and trace sulfide minerals, $\sim 1.0 \mathrm{~m}$ wide

GRANITE from 106.1 to $137.2 \mathrm{~m}$, light greenish gray,

muscovite-chlorite, some foliation, altered, $\sim 31.1 \mathrm{~m}$ wide

PEGMATITE from 112.0 to $112.2 \mathrm{~m}$, feldspar, quartz and trace sulfide minerals, $\sim 20 \mathrm{~cm}$ wide

GRANITE from 115.0 to $137.2 \mathrm{~m}$, gray, biotite-muscovite granite, fine grained, gradual contact with granite above, $\sim 22.2 \mathrm{~m}$ wide

APLITE at $119.2 \mathrm{~m}, \sim 5 \mathrm{~cm}$ wide 
FS1 Continued

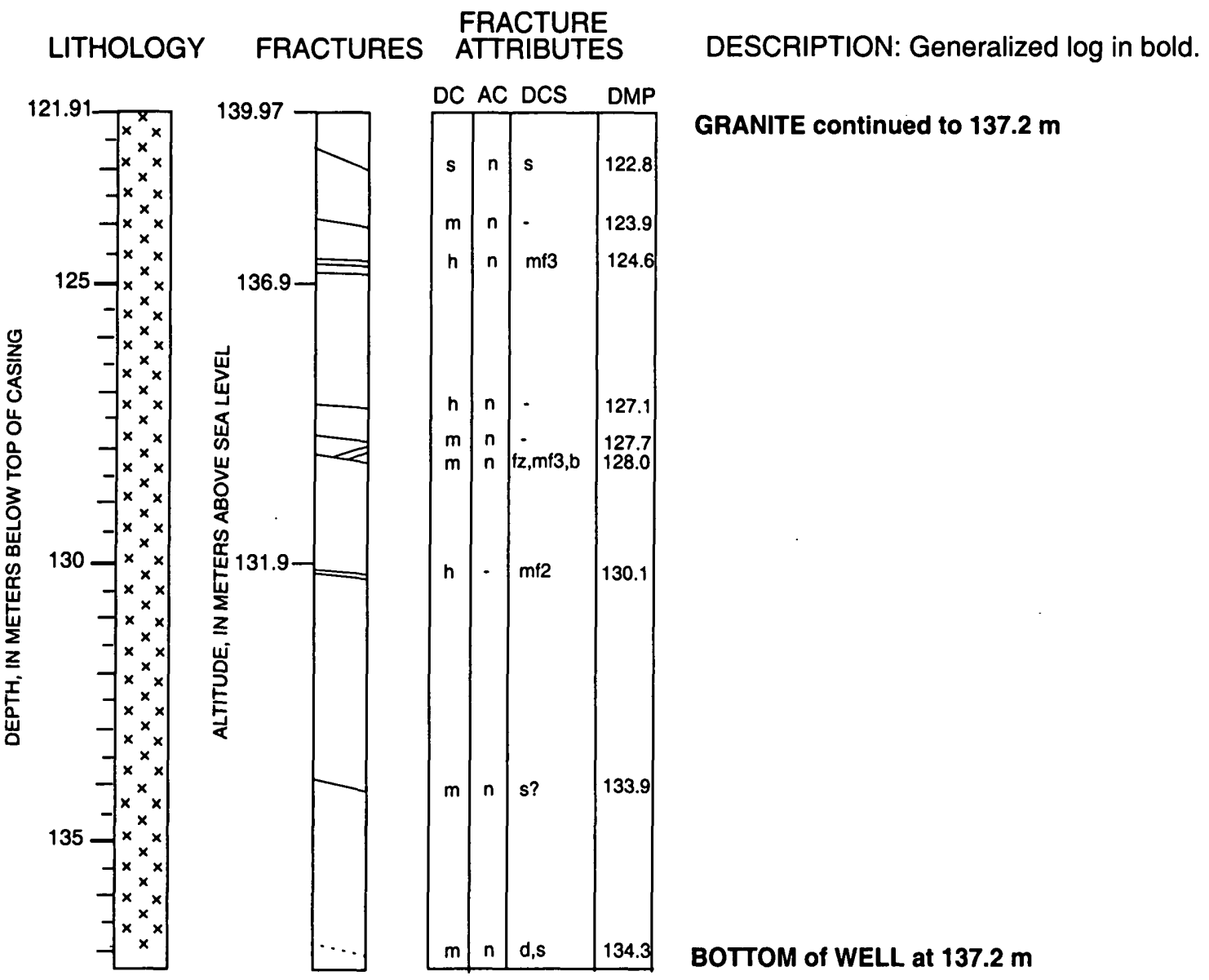




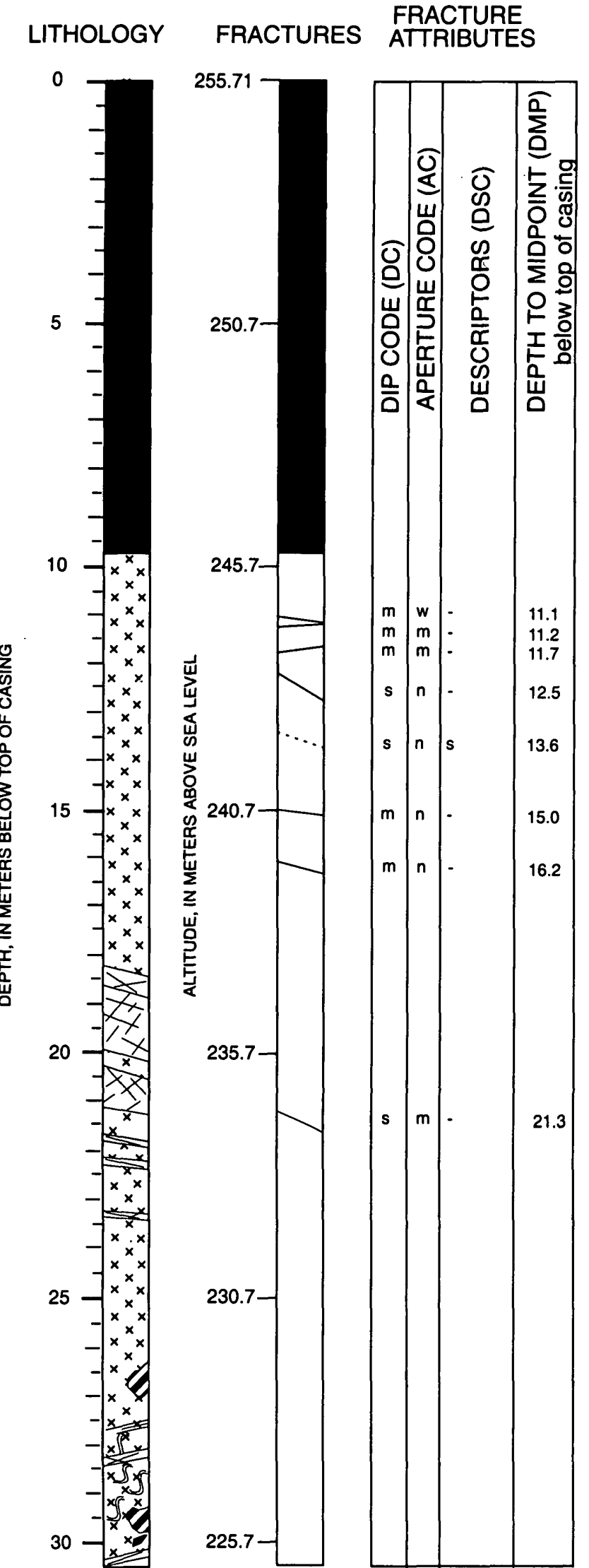

DESCRIPTION: Generalized log in bold.

SAND from 0.67 to $7.3 \mathrm{~m}, \sim 6.6 \mathrm{~m}$ wide

BEDROCK SURFACE at $7.4 \mathrm{~m}$

BOTTOM OF CASING at $9.75 \mathrm{~m}$

GRANITE from 9.8 to $18.4 \mathrm{~m}$, muscovite-biotite granite, with some chlorite, and trace amounts of garnet, some oxidation, $\sim 8.6 \mathrm{~m}$ wide

PEGMATITE and APLITE from 18.4 to $22.8 \mathrm{~m}$, alternating bands of pegmatite and fine grained felsic aplite or granite, with gradual contacts, $\sim 4.4 \mathrm{~m}$ wide

PEGMATITE DIKE from 18.4 to $20.1 \mathrm{~m}$, light greenish gray, feldspar, quartz, muscovite, and trace garnet, $\sim 1.7 \mathrm{~m}$ wide

APLITE or GRANITE from 20.1 to $22.8 \mathrm{~m}$, muscovite-rich, fine grained texture, $\sim 2.7 \mathrm{~m}$ wide PEGMATITE from 20.4 to $21.3 \mathrm{~m}, \sim 0.9 \mathrm{~m}$ wide PEGMATITE at $21.7 \mathrm{~m}, \sim 5 \mathrm{~cm}$ wide PEGMATITE at $22.2 \mathrm{~m}, \sim 10 \mathrm{~cm}$ wide PEGMATITE at $22.7 \mathrm{~m}, \sim 15$ to $20 \mathrm{~cm}$ wide

GRANITE from 22.8 to $27.4 \mathrm{~m}$, yellowish gray, biotitemuscovite granite, $\sim 4.6 \mathrm{~m}$ wide

SCHIST XENOLITH from 26.5 to $27.0 \mathrm{~m}, \sim 0.5 \mathrm{~m}$ wide BIOTITE SCHLIEREN at $27.6 \mathrm{~m}$

MIGMATITE or GNEISS from 27.4 to $29.5 \mathrm{~m}$, felsic-rich gneissic texture with some foliation, $\sim 2.1 \mathrm{~m}$ wide PEGMATITE at $28.2 \mathrm{~m}, \sim 15 \mathrm{~cm}$ wide SCHIST XENOLITH from 28.6 to $29.2 \mathrm{~m}, \sim 0.6 \mathrm{~m}$ wide GRANITE from 29.2 to $45.0 \mathrm{~m}$, yellowish gray, muscovitebiotite granite $\sim 15.8 \mathrm{~m}$ wide PEGMATITE VEIN from 30.2 to $30.5 \mathrm{~m}, \sim 5 \mathrm{~cm}$ wide 


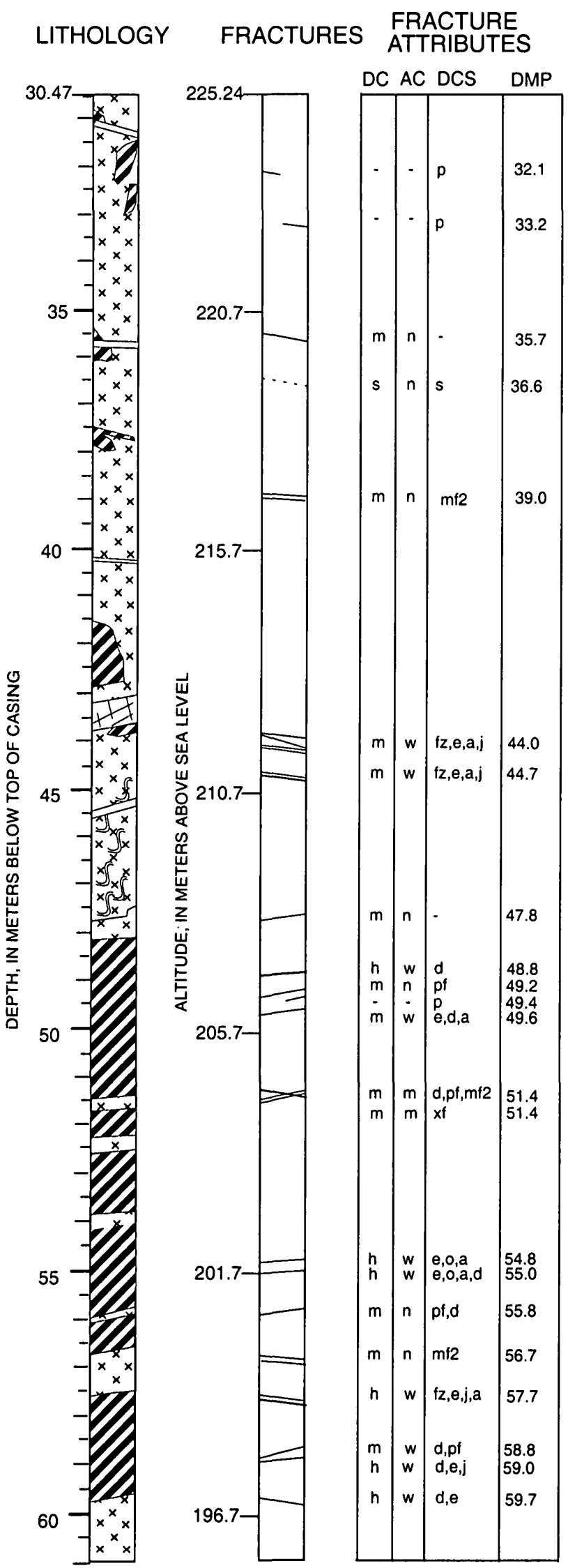

DESCRIPTION: Generalized log in bold.

GRANITE continued to $45.0 \mathrm{~m}$

APLITE VEIN at $31.2 \mathrm{~m}, \sim 10 \mathrm{~cm}$ wide

SCHIST XENOLITH from 31.6 to $32.3 \mathrm{~m}, \sim 0.7 \mathrm{~m}$ wide

SCHIST XENOLITH from 35.4 to $36.2 \mathrm{~m}, \sim 0.8 \mathrm{~m}$ wide PEGMATITE VEIN at $35.6 \mathrm{~m}, \sim 10 \mathrm{~cm}$ wide

SCHIST XENOLITH from 36.7 to $37.4 \mathrm{~m}, \sim 0.7 \mathrm{~m}$ wide

PEGMATITE VEIN at $40.2, \sim 2 \mathrm{~cm}$ wide

SCHIST from 41.6 to $42.1 \mathrm{~m}$ on one side of well, biotite schist, moderately foliated, steeply dipping, $\sim 0.5 \mathrm{~m}$ wide PEGMATITE DIKE from 42.4 to $42.9 \mathrm{~m}, \sim 0.5 \mathrm{~m}$ wide GRANITE from 42.9 to $45.0 \mathrm{~m}, \sim 2.1 \mathrm{~m}$ wide

GNEISS from $\mathbf{4 5 . 0}$ to $\mathbf{4 7 . 8} \mathrm{m}$, gray, biotite-rich, coarse grained, weakly to moderately foliated, $\sim 2.8 \mathrm{~m}$ wide

APLITE at $45.2 \mathrm{~m}, \sim 20 \mathrm{~cm}$ wide

GRANITE from 47.5 to $48.1 \mathrm{~m}, \sim 0.6 \mathrm{~m}$ wide

SCHIST from $\mathbf{4 8 . 1}$ to $59.5 \mathrm{~m}$, fine to gneissic texture, weak banding, $\sim 11.3 \mathrm{~m}$ wide

GRANITE VEIN from 51.5 to $51.7 \mathrm{~m}, \sim 20 \mathrm{~cm}$ wide GRANITE DIKE from 52.3 to $52.6 \mathrm{~m}, \sim 0.3 \mathrm{~m}$ wide SCHIST from 52.6 to $54.9 \mathrm{~m}$, mixed, equigranular felsic and mafic foliated zones, possibly migmatite, gneissic texture, $\sim 2.3 \mathrm{~m}$ wide

APLITE VEIN from 54.9 to $54.1 \mathrm{~m}, \sim 20 \mathrm{~cm}$ wide

GRANITE VEIN at $55.8 \mathrm{~m}, \sim 15$ to $20 \mathrm{~cm}$ wide

GRANITE DIKE from 56.7 to $57.4 \mathrm{~m}, \sim 0.7 \mathrm{~m}$ wide

SCHIST from 57.4 to $59.5 \mathrm{~m}$, banded, $\sim 2.1 \mathrm{~m}$ wide

GRANITE from $\mathbf{5 9 . 5}$ to $79.5 \mathrm{~m}$, muscovite-biotite granite, weak foliation, $\sim 20.0 \mathrm{~m}$ wide 


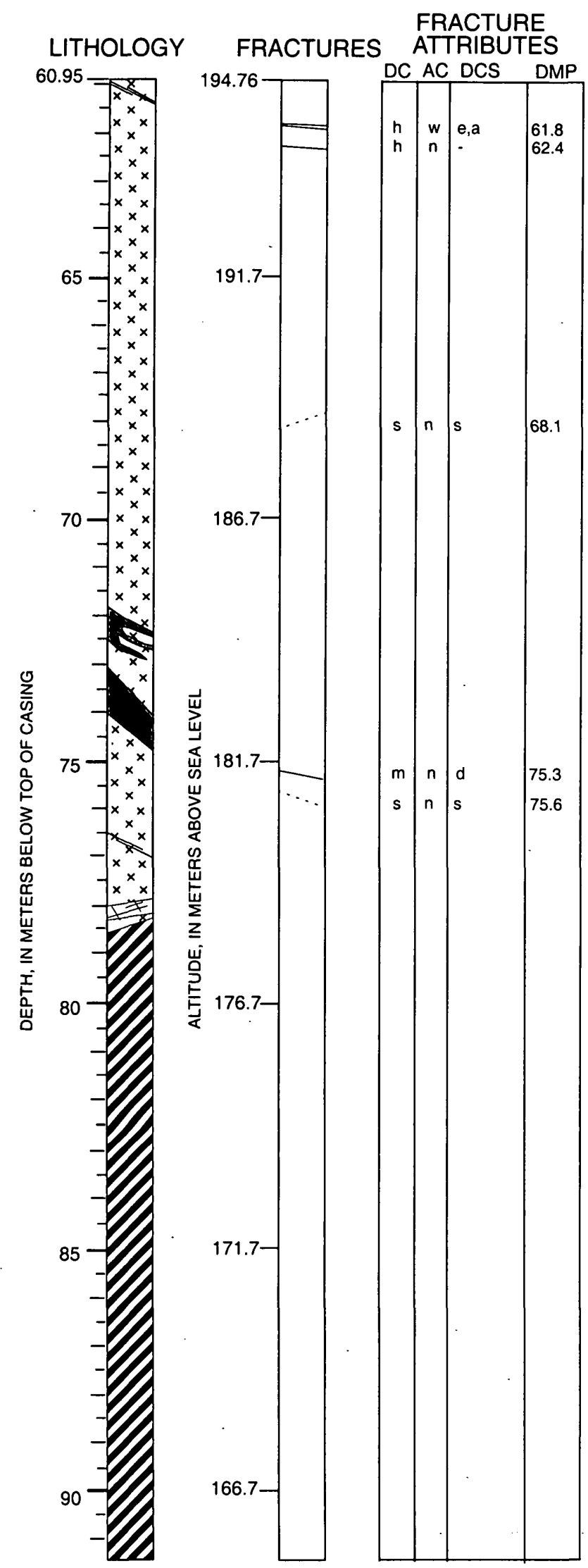

DESCRIPTION: Generalized log in bold.

GRANITE continued to $73.5 \mathrm{~m}$

Biotite schlieren at $61.3 \mathrm{~m}$

BASALT from 72.1 to $72.6 \mathrm{~m}$, on one side of well, irregular shape, $\sim 0.5 \mathrm{~m}$ wide

BASALT from 73.5 to $74.6 \mathrm{~m}$, altered, possibly oxidized, (some microcracks in basalt, which are possibly thermal jointing, were not counted as fractures), $\sim 1.1 \mathrm{~m}$ wide GRANITE from 74.6 to $79.5 \mathrm{~m}, \sim 4.9 \mathrm{~m}$ wide GRANITE from 74.6 to $75.5 \mathrm{~m}$, altered, decomposed looking, and foliated, gradational contact with granite below, $\sim 0.9 \mathrm{~m}$ wide

BIOTITE SCHLIEREN at $76.8 \mathrm{~m}$

PEGMATITE DIKE from 78.0 to $78.3 \mathrm{~m}, \sim 0.3 \mathrm{~m}$ wide SCHIST from 79.5 to $94.8 \mathrm{~m}$, biotite-rich, some weak banding, $\sim 15.3 \mathrm{~m}$ wide

FELSIC ZONE in schist from 87.8 to $91.1 \mathrm{~m}$, felsic, coarse grained, (not shown), $\sim 3.3 \mathrm{~m}$ wide

SCHIST from 91.1 to $95.0 \mathrm{~m}$, biotite schist with augens, $\sim 3.9 \mathrm{~m}$ wide 
FS2 Continued

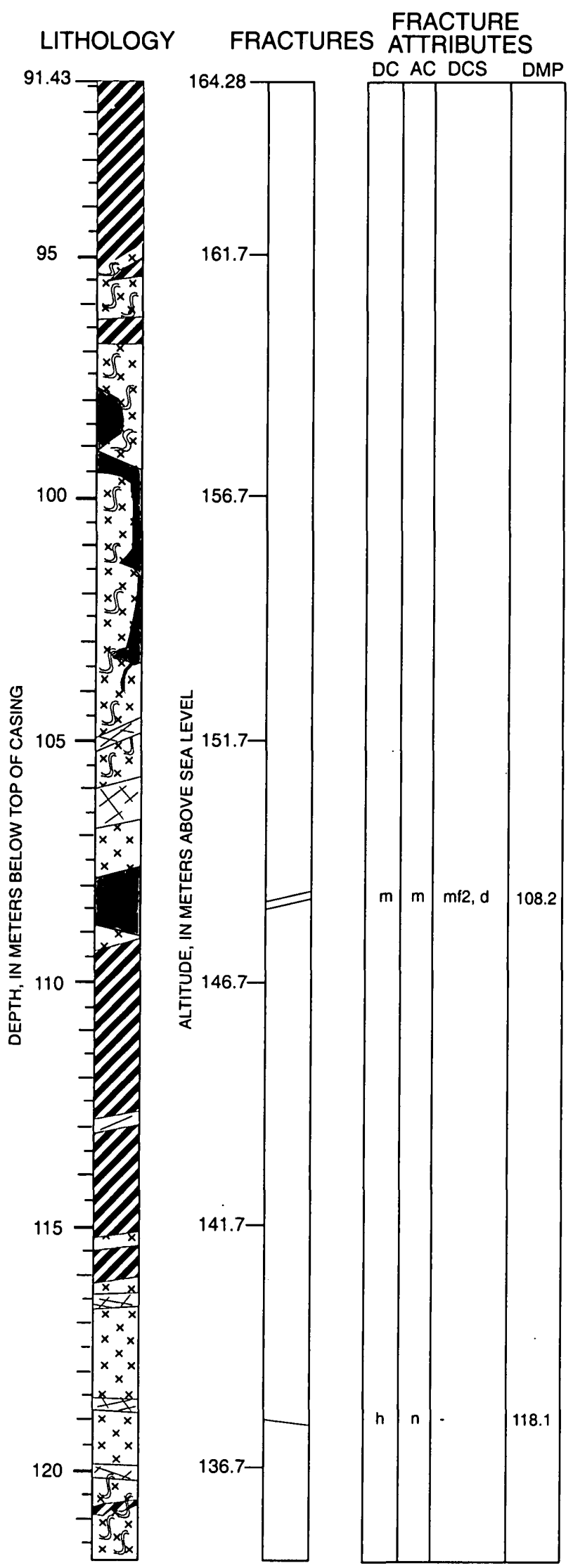

DESCRIPTION: Generalized log in bold.

SCHIST continued to $94.8 \mathrm{~m}$

MIGMATITE from 95.0 to $106.7 \mathrm{~m}$, coarse-grained to pegmatitic texture, with some swirling foliation, gradual contacts, $\sim 11.7 \mathrm{~m}$ wide

BASALT on one side of well from 97.8 to $99.1 \mathrm{~m}, \sim 1.3 \mathrm{~m}$ wide

BASALT from 99.3 to $99.6 \mathrm{~m}, \sim 0.3 \mathrm{~m}$ wide

BASALT on one side of well from 99.6 to $103.4 \mathrm{~m}, \sim 3.8 \mathrm{~m}$ wide

PEGMATITE from 104.8 to $105.1 \mathrm{~m}, \sim 0.3 \mathrm{~m}$ wide

PEGMATITE from 105.8 to $106.7 \mathrm{~m}, \sim 0.9 \mathrm{~m}$ wide

GRANITE from 106.7 to $107.7 \mathrm{~m}, \sim 1.0 \mathrm{~m}$ wide

BASALT from 107.7 to $109.0 \mathrm{~m}$, dark gray, with highly reflective calcite(?), $\sim 1.4 \mathrm{~m}$ wide

GRANITE or APLITE from 109.0 to $109.2 \mathrm{~m}, \sim 20 \mathrm{~cm}$ wide SCHIST from 109.2 to $116.2 \mathrm{~m}$, with quartzite layers, with some irregular shaped, swirling felsic bands, $\sim 7.0 \mathrm{~m}$

FELSIC ZONE IN SCHIST from 112.2 to $113.4 \mathrm{~m}$, (not shown) $\sim 1.2 \mathrm{~m}$ wide

PEGMATITE at $112.8, \sim 20 \mathrm{~cm}$ wide

APLITE DIKE from 115.2 to $115.4 \mathrm{~m}, \sim 20 \mathrm{~cm}$ wide

GRANITE from 116.2 to $120.0 \mathrm{~m}$, leucocratic granite, $\sim 3.8 \mathrm{~m}$ wide

PEGMATITE from 116.4 to $116.7 \mathrm{~m}, \sim 0.3 \mathrm{~m}$ wide

PEGMATITE from 118.6 to $118.9 \mathrm{~m}$, gradual contacts,

$\sim 0.3 \mathrm{~m}$ wide

PEGMATITE at $119.9 \mathrm{~m}, \sim 20 \mathrm{~cm}$ wide, MIGMATITE from 120.0 to $122.4 \mathrm{~m}, \sim 2.4 \mathrm{~m}$ wide 


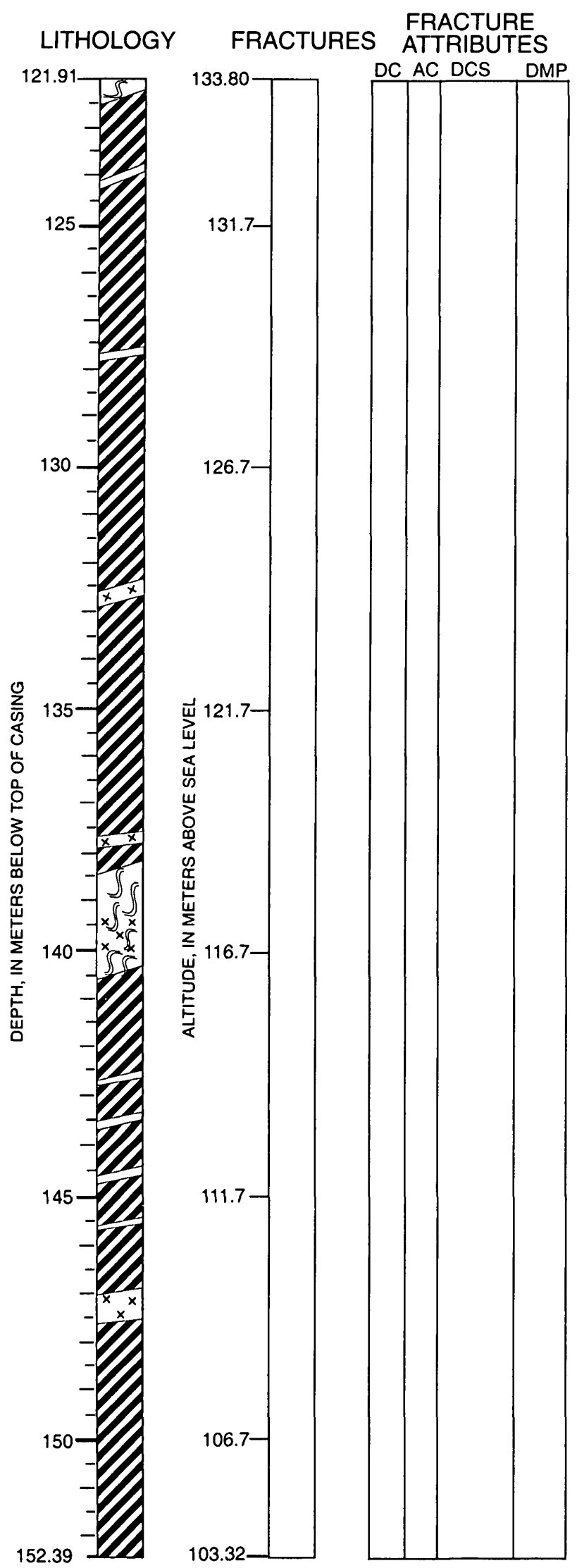

DESCRIPTION: Generalized log in bold.

MIGMATITE continued to $122.4 \mathrm{~m}$

SCHIST from 122.4 to $138.5 \mathrm{~m}, \sim 16.1 \mathrm{~m}$ wide

APLITE VEIN at $123.9 \mathrm{~m}, \sim 15 \mathrm{~cm}$ wide

SCHIST from 125.5 to $127.0 \mathrm{~m}$, gneissic, felsic-rich schist, $\sim 1.5 \mathrm{~m}$ wide

SCHIST from 127.0 to $132.5 \mathrm{~m}$, fine to coarse grained texture, with some banding, $\sim 5.5 \mathrm{~m}$ wide

APLITE VEIN at $127.7 \mathrm{~m}$, crosses the foliation of the schist, $\sim 10 \mathrm{~cm}$ wide

GRANITE DIKE from 132.6 to $132.8 \mathrm{~m}$, biotite-muscovite granite, $\sim 20$ to $25 \mathrm{~cm}$ wide

SCHIST from 132.5 to $134.5 \mathrm{~m}$, felsic-rich zone, coarse grained texture, $\sim 2.0 \mathrm{~m}$ wide

GRANITE VEIN at $137.8 \mathrm{~m}, \sim 15$ to $20 \mathrm{~cm}$ wide

MIGMATITE from 138.5 to $140.5 \mathrm{~m}$, mixed fine grained foliated zones and coarse grained felsic zones, gradual contacts with schist above and below, $\sim 2.0 \mathrm{~m}$ wide

SCHIST from 140.5 to $152.4 \mathrm{~m}$, fine to coarse grained texture, with some quartzo-feldspathic banding that are 15 to $20 \mathrm{~cm}$ wide, $\sim 11.9 \mathrm{~m}$ wide

FELSIC ZONE in schist at $142.7 \mathrm{~m}, \sim 20 \mathrm{~cm}$ wide

FELSIC ZONE in schist at $143.6 \mathrm{~m}, \sim 15$ to $20 \mathrm{~cm}$ wide

FELSIC ZONE in schist at $144.6 \mathrm{~m}, \sim 15$ to $20 \mathrm{~cm}$ wide

FELSIC ZONE in schist at $145.6 \mathrm{~m}, \sim 10 \mathrm{~cm}$ wide GRANITE or FELSIC ZONE in schist from 147.0 to $147.5 \mathrm{~m}, \sim 0.5 \mathrm{~m}$ wide 
LITHOLOGY

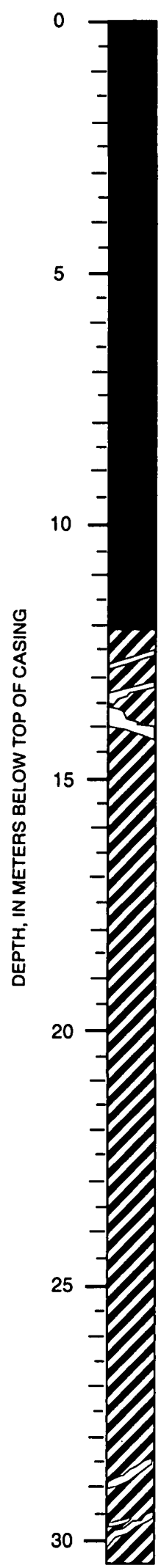

FRACTURE

FRACTURES ATTRIBUTES

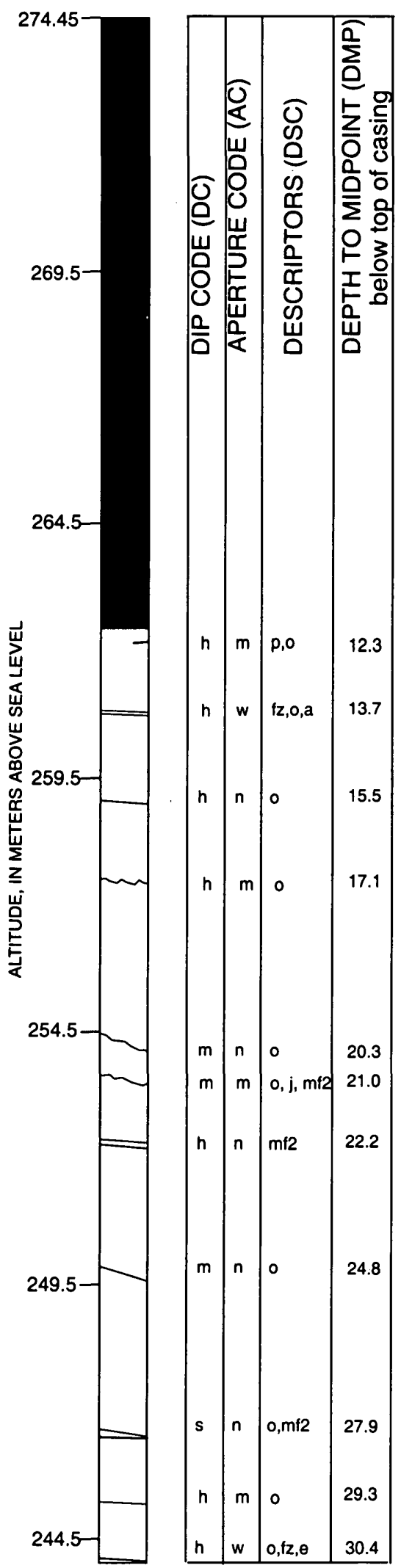

DESCRIPTION: Generalized log in bold.

SAND from 0.6 to $9.4 \mathrm{~m}$, brown to tan, medium to coarse sand, gravel and some boulders and some silt, $\sim 8.8 \mathrm{~m}$ wide

TILL from $9.1 \mathrm{~m}$ to $9.4 \mathrm{~m}$, gray, $\sim 0.3 \mathrm{~m}$ wide BEDROCK SURFACE at $9.4 \mathrm{~m}$

\section{BOTTOM OF CASING at $12.0 \mathrm{~m}$}

SCHIST from 12.0 to $68.0 \mathrm{~m}, \sim 56.0 \mathrm{~m}$ wide

SCHIST from 12.0 to $30.8 \mathrm{~m}$, reddish brown, biotite-rich with some garnets, medium to coarse grained, oxidized, with some felsic zones, $\sim 18.8 \mathrm{~m}$ wide

GRANITE or APLITE DIKE at $12.7 \mathrm{~m}, \sim 5 \mathrm{~cm}$ wide APLITE DIKE at $13.3 \mathrm{~m}, \sim 5 \mathrm{~cm}$ wide

APLITE DIKE at $14.0 \mathrm{~m}, \sim 10$ to $15 \mathrm{~cm}$ wide

SCHIST from 17.4 to $18.3 \mathrm{~m}$, felsic rich zone in schist, gradual upper and lower contacts, $\sim 0.9 \mathrm{~m}$ wide, (not shown)

SCHIST from 18.3 to $19.4 \mathrm{~m}$, biotite-rich, coarse-grained felsic zones and fine-grained foliated biotites, $\sim 1.1 \mathrm{~m}$ wide

SCHIST from 21.0 to $22.8 \mathrm{~m}$, felsic zone, gradual contact above and below, $\sim 1.8 \mathrm{~m}$ wide

SCHIST from 22.8 to $27.5 \mathrm{~m}$, coarse grained, biotite-rich, steeply dipping, strong foliation, some weak banding, $\sim 4.7 \mathrm{~m}$ wide

Coticule layers in schist at $26.5 \mathrm{~m}$ and at $27.1 \mathrm{~m}$, fine grained quartz and garnet (not shown)

FELSIC BAND at $28.8 \mathrm{~m}$, medium to coarse grain, $\sim 10 \mathrm{~cm}$ wide

SCHIST from 27.5 to $30.8 \mathrm{~m}$, greenish, oxidized brown, extremely fine grained, $\sim 3.3 \mathrm{~m}$ wide

FELSIC BAND at $28.8 \mathrm{~m}$, coarse grain, $\sim 15 \mathrm{~cm}$ wide 
FS3 Continued

LITHOLOGY

FRACTURES FRACTURE

DC AC DCS DMP

30.47

45

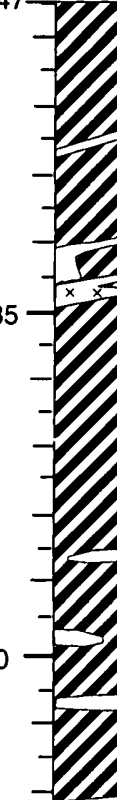

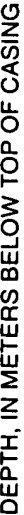

50

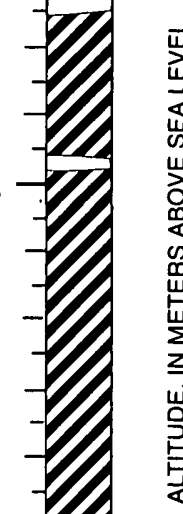

60

55

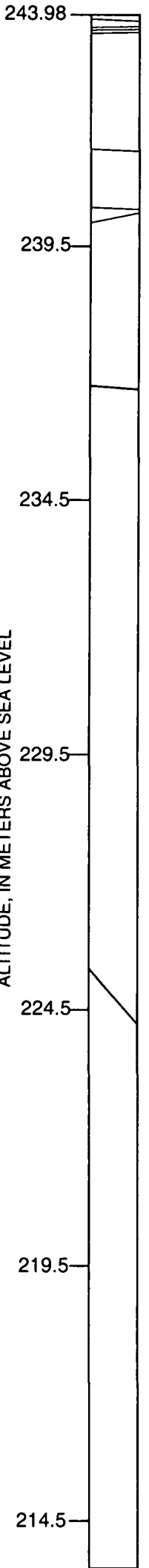

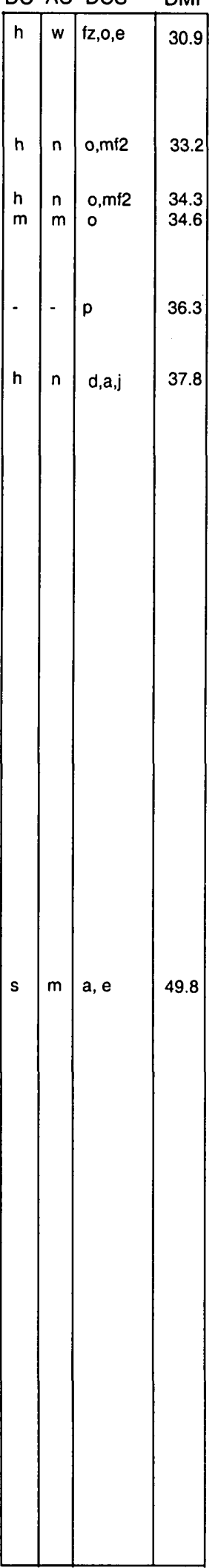

DESCRIPTION: Generalized log in bold.

\section{SCHIST continued to $68.0 \mathrm{~m}$}

SCHIST from 30.8 to $31.5 \mathrm{~m}$, banded, alternating bands of extremely fine grained foliated biotites and coarse-grained felsic minerals, $\sim 0.7 \mathrm{~m}$ wide

SCHIST from 31.5 to $32.3 \mathrm{~m}$, extremely fine grained, $\sim 0.8 \mathrm{~m}$ wide

FELSIC VEIN at $32.5 \mathrm{~m}$, white, coarse grained, $\sim 15 \mathrm{~cm}$ wide

GRANITE or APLITE DIKE from 34.5 to $34.9 \mathrm{~m}$, grayish white, fine grained texture, $\sim 0.4 \mathrm{~m}$ wide

SCHIST from 37.5 to $45.7 \mathrm{~m}$, gneissic to coarse grained texture, muscovite-biotite and feldspar, weakly foliated, with some felsic-rich zones, $\sim 8.2 \mathrm{~m}$ wide

FELSIC ZONES in SCHIST at $38.6 \mathrm{~m}, 40.0 \mathrm{~m}$ and $40.5 \mathrm{~m}$, each zone $\sim 20 \mathrm{~cm}$ wide

FELSIC ZONE in SCHIST from 42.1 to $42.5 \mathrm{~m}, \sim 0.4 \mathrm{~m}$ wide

SCHIST from 42.5 to $44.2 \mathrm{~m}$, fine grained, $~ 1.5 \mathrm{~m}$

SCHIST from 44.2 to $45.7 \mathrm{~m}$, felsic-rich, $\sim 1.5 \mathrm{~m}$ wide

SCHIST from 45.7 to $47.0 \mathrm{~m}$, fine grained, biotite-chlorite, altered, $\sim 1.3 \mathrm{~m}$ wide

SCHIST from 47.0 to $52.0 \mathrm{~m}$, gneissic texture, felsic-rich, with some strong foliations at $51.2 \mathrm{~m}, \sim 5.0 \mathrm{~m}$ wide

PEGMATITE from 50.6 to $50.9 \mathrm{~m}, \sim 0.3 \mathrm{~m}$ wide

SCHIST from 52.0 to $59.4 \mathrm{~m}$, gray, fine grained biotite-rich, with feldspars and few garnets, some augens and some banding, $\sim 7.4 \mathrm{~m}$

SCHIST from 59.4 to $61.0 \mathrm{~m}$, brownish black, coarse grained to gneissic texture, $\sim 1.6 \mathrm{~m}$

FELSIC ZONE or APLITE VEIN at $60.5, \sim 15 \mathrm{~cm}$ wide 


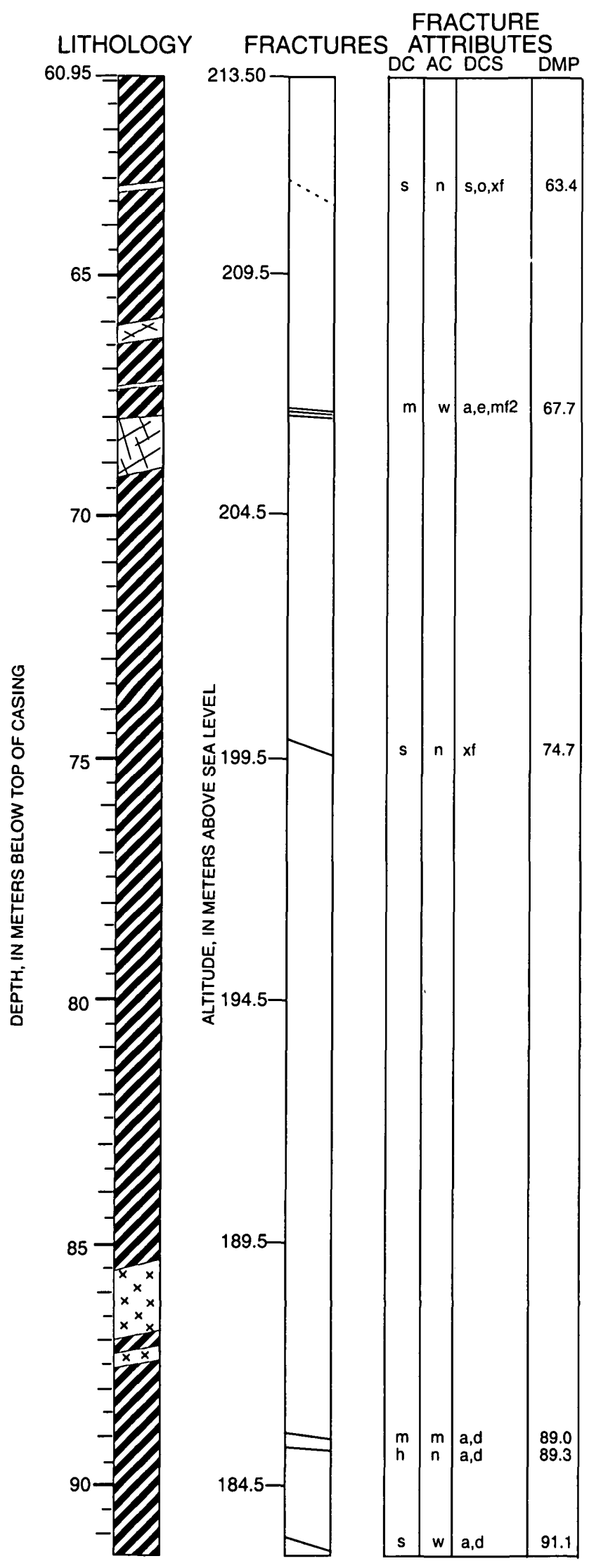

DESCRIPTION: Generalized log in bold.

SCHIST continued to $68.0 \mathrm{~m}$

SCHIST from 61.0 to $68.0 \mathrm{~m}$, biotite-rich, medium to coarse grained, with some gneissic zones, foliation near horizontal, $\sim 7.0 \mathrm{~m}$ wide

PEGMATITE VEIN at $63.1 \mathrm{~m}$, parallel to foliation, $\sim 15 \mathrm{~cm}$ wide

SCHIST from 64.0 to $66.1 \mathrm{~m}$, gneissic texture, $2.1 \mathrm{~m}$ wide

PEGMATITE DIKE from 66.1 to $66.4 \mathrm{~m}$, muscovite, feldspar and quartz, $\sim 0.4 \mathrm{~m}$ wide

PEGMATITE VEIN at $67.4 \mathrm{~m}$, parallel to foliation, $\sim 5 \mathrm{~cm}$ wide

PEGMATITE DIKE from 68.0 to $69.3 \mathrm{~m}$, muscovite, feldspar, and quartz, $\sim 1.3 \mathrm{~m}$ wide

SCHIST from 69.3 to $85.5 \mathrm{~m}, \sim 16.2 \mathrm{~m}$ wide

SCHIST from 69.3 to $71.6 \mathrm{~m}$, dark reddish black, fine grained, biotite-rich, foliation is moderately to steeply dipping, $-2.3 \mathrm{~m}$ wide

SCHIST from 71.6 to $72.2 \mathrm{~m}$ with felsic inclusions (felsic inclusions not shown), $0.6 \mathrm{~m}$ wide

SCHIST from 72.2 to $75.5 \mathrm{~m}$, biotite schist, fine grained, $3.3 \mathrm{~m}$ wide

SCHIST from 75.5 to $85.5 \mathrm{~m}$, gneissic texture, weakly foliated, $\sim 10.0 \mathrm{~m}$ wide

GRANITE from 85.5 to $86.9 \mathrm{~m}$, medium to coarse grained, dike is parallel to foliation of schist, $\sim 1.5 \mathrm{~m}$ wide BIOTITE SCHLIEREN at $85.6 \mathrm{~m}, 85.9 \mathrm{~m}, 86.6 \mathrm{~m}$, and $86.9 \mathrm{~m}$ (not shown)

SCHIST from 86.9 to $93.0 \mathrm{~m}$, chlorite schist, fine grained, appears to be altered, $\sim 6.1 \mathrm{~m}$ wide GRANITE from 87.1 to $87.4 \mathrm{~m}, \sim 0.3 \mathrm{~m}$ wide 


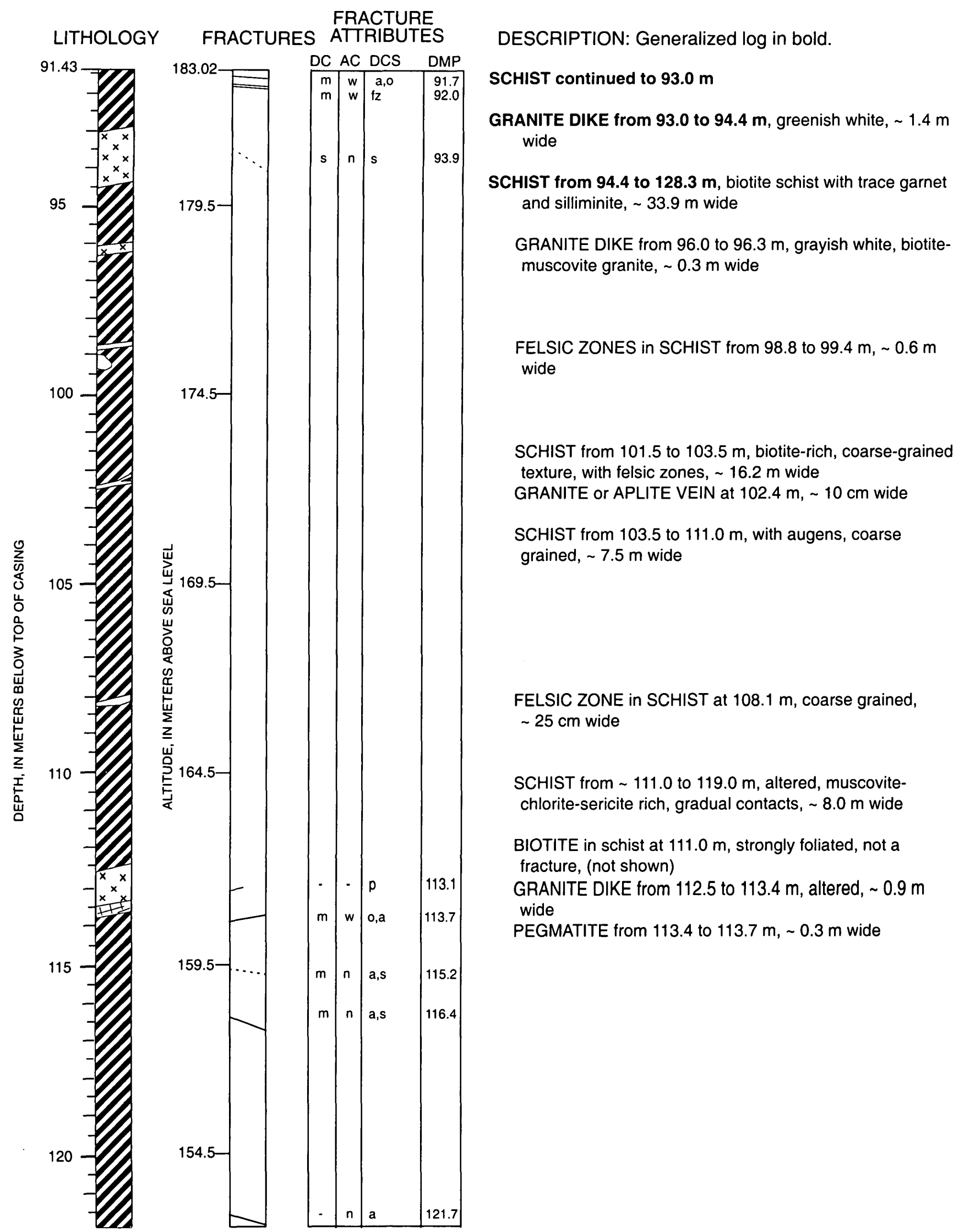


FS3 Continued

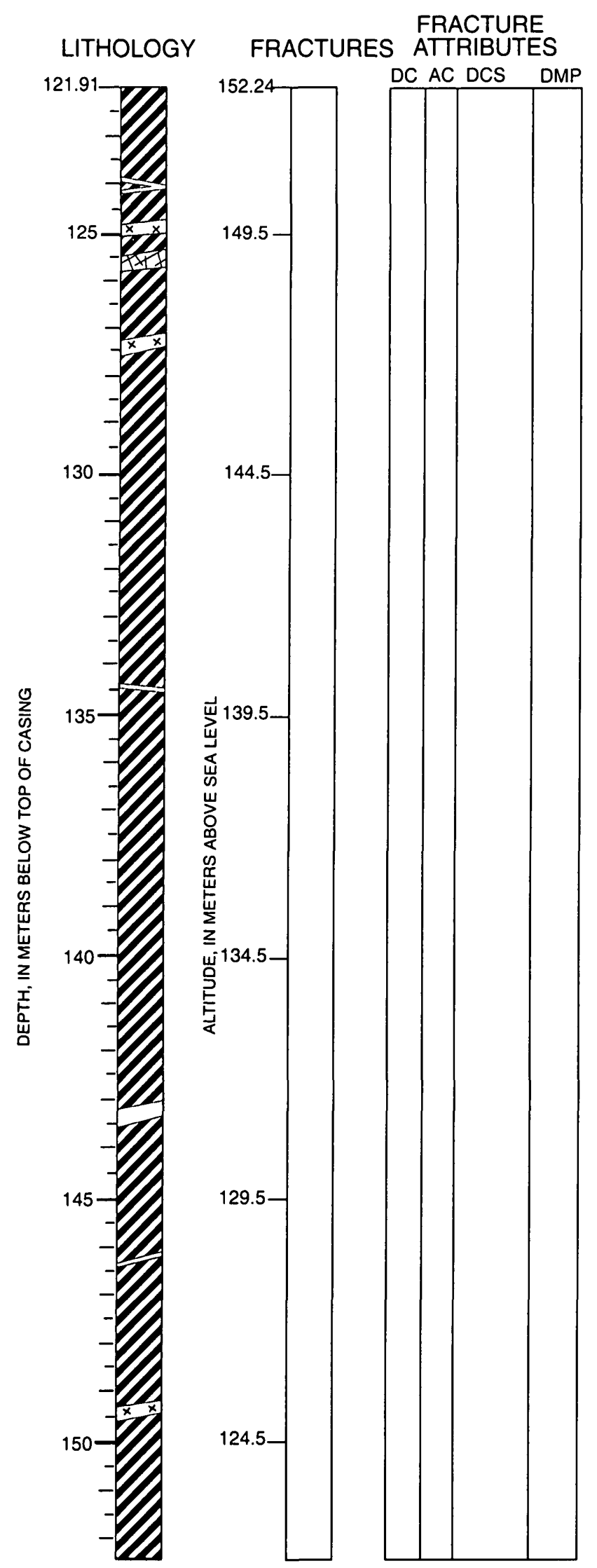

DESCRIPTION: Generalized log in bold.

\section{SCHIST continued to $153.0 \mathrm{~m}$}

SCHIST from 121.8 to $128.3 \mathrm{~m}$, felsic rich and altered,

foliation is near horizontal, $\sim 6.5 \mathrm{~m}$ wide

APLITE DIKE at $124.0 \mathrm{~m}, \sim 10 \mathrm{~cm}$ wide

APLITE DIKE at $124.7 \mathrm{~m}, \sim 15 \mathrm{~cm}$ wide

PEGAMTITE DIKE from 125.3 to $125.6 \mathrm{~m}, \sim 0.3 \mathrm{~m}$ wide

SCHIST or GNEISS from 128.3 to $143.2 \mathrm{~m}$, biotite-rich gneissic texture, weakly foliated, gradual contacts, $\sim 14.9 \mathrm{~m}$ wide

FELSIC BAND at $134.4 \mathrm{~m}, \sim 2 \mathrm{~cm}$ wide

FELSIC ZONE in schist or gneiss from 135.7 to $137.0 \mathrm{~m}$, with strongly foliated biotite at $135.6 \mathrm{~m}$ that is $\sim 1$ to $2 \mathrm{~cm}$ wide (not shown). Felsic zone is $1.3 \mathrm{~m}$ wide

SCHIST from 143.2 to $149.3 \mathrm{~m}$, gradual contacts, $\sim 6.1 \mathrm{~m}$ wide

FELSIC ZONE in schist at $143.4 \sim 20 \mathrm{~cm}$ wide

FELSIC BAND at $146.1 \mathrm{~m}, \sim 5 \mathrm{~cm}$ wide

SCHIST from 149.3 to $153.0 \mathrm{~m}$, dark brownish black, biotite- rich with trace garnet, coarse grained to gneissic texture, vertical foliation, $\sim 3.7 \mathrm{~m}$ wide 


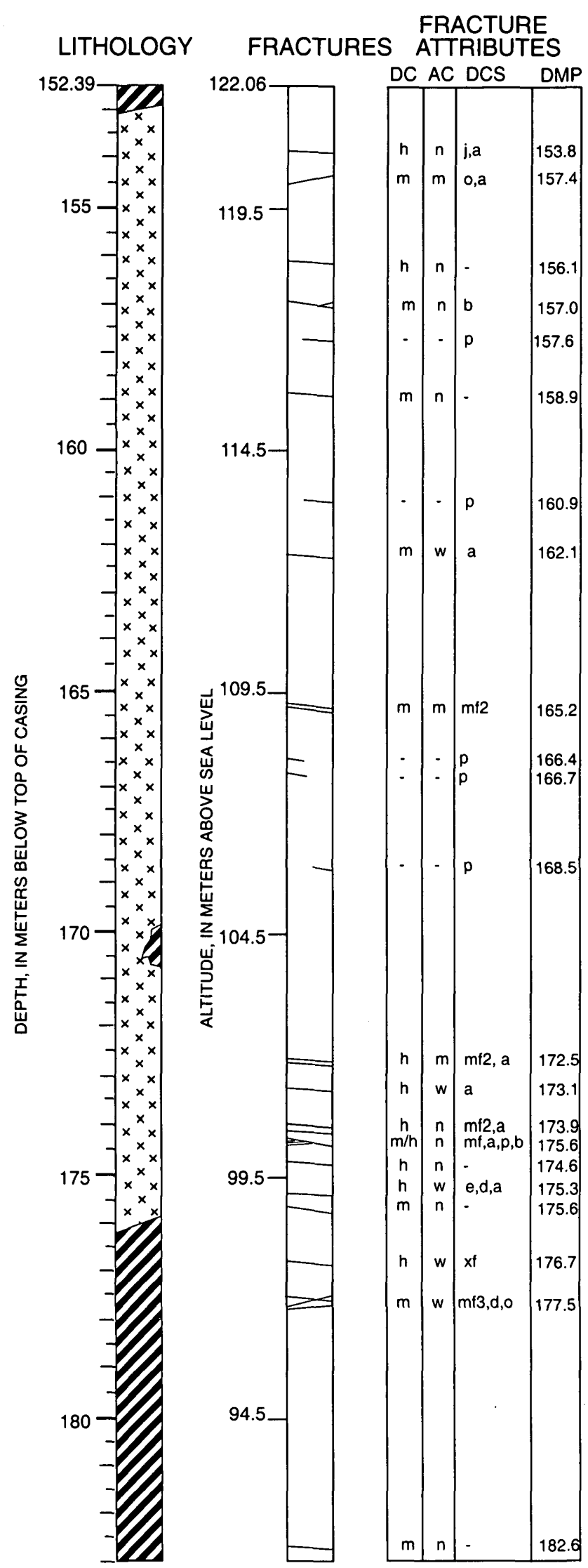

DESCRIPTION: Generalized log in bold.

SCHIST continued to $153.0 \mathrm{~m}$

GRANITE from 153.0 to $176.5 \mathrm{~m}, \sim 23.5 \mathrm{~m}$ wide

GRANITE from 153.0 to $158.5 \mathrm{~m}$, grayish white, leucocratic, muscovite-quartz granite with trace pyrite and some iron staining, gradual contacts, $5.5 \mathrm{~m}$ wide

GRANITE from 158.5 to $162.0 \mathrm{~m}$, muscovite-biotite granite, gradual contacts, $\sim 3.5 \mathrm{~m}$ wide

GRANITE from 162.0 to $165.0 \mathrm{~m}$, muscovite granite, gradual contacts, $\sim 3.0 \mathrm{~m}$ wide

GRANITE from 165.0 to $172.0 \mathrm{~m}$, muscovite-biotite granite, gradual contacts, $\sim 7.0 \mathrm{~m}$ wide

SCHIST XENOLITH in GRANITE from 170.0 to $170.7 \mathrm{~m}$, schist exposed on one side of well, $\sim 0.7 \mathrm{~m}$ wide

GRANITE from 172.0 to $176 \mathrm{~m}$, greenish gray, muscovitechlorite-sericite, altered, $4.5 \mathrm{~m}$ wide

SCHIST from 176.5 to $\mathbf{1 8 3 . 0} \mathrm{m}$ biotite-rich schist with trace garnet, coarse grained to gneissic texture, near-vertical foliation, without banding, $\sim 6.5 \mathrm{~m}$ wide 
FS3 Continued

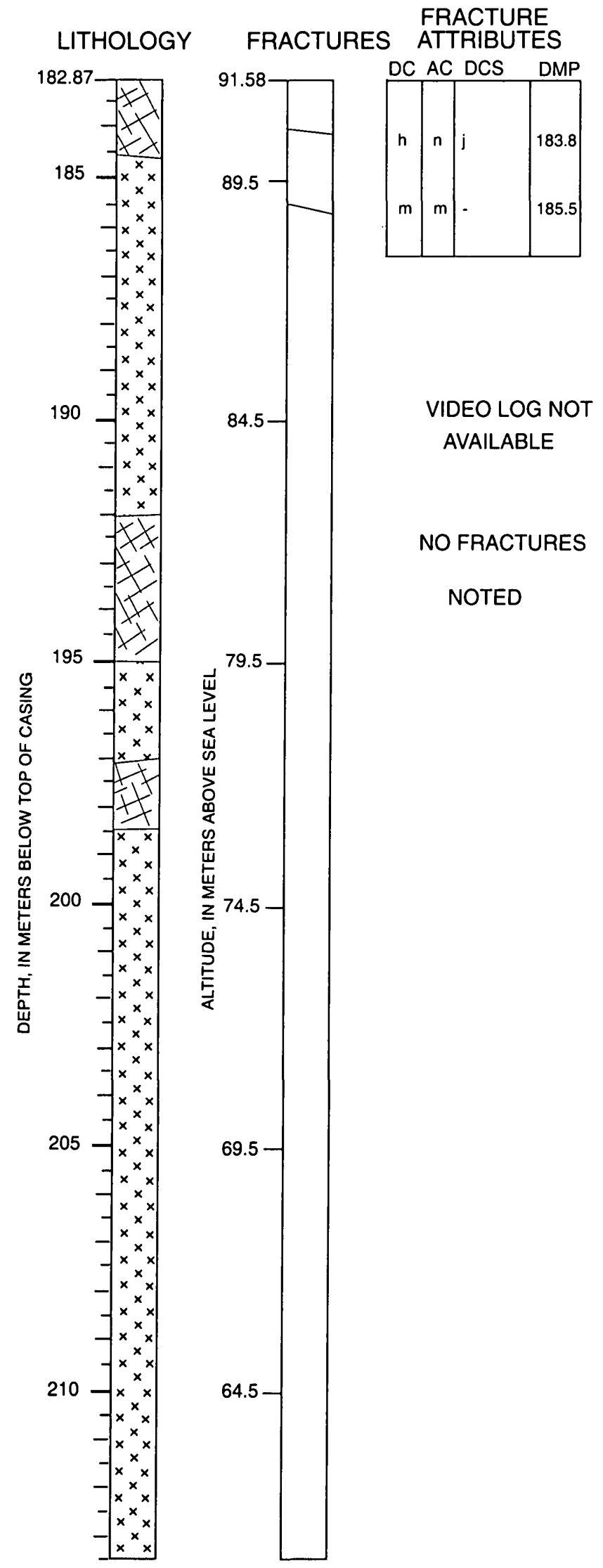

DESCRIPTION: Generalized log in bold.

PEGMATITE from 183.0 to 184.5 , iron-stained feldspars and quartz with trace sulfide minerals, $\sim 1.5 \mathrm{~m}$ wide

Description below here is based only on rock chip analysis. GRANITE from 184.5 to $192.0 \mathrm{~m}$, chlorite-muscovite granite, pale greenish yellow to light greenish gray, $\sim 7.5 \mathrm{~m}$ wide

Several fractures from 187 to $195 \mathrm{~m}$ (F.L. Paillet, U.S. Geological Survey, written commun., 1989)

VIDEO LOG NO

muscovite, $\sim 3.0 \mathrm{~m}$ wide

The well has an enlarged diameter at $195.0 \mathrm{~m}$, and it has caved-in or bridged at $\sim 196.0$ m. (F.L. Paillet, U.S. Geological Survey, written commun., 1989)

All descriptions of the well are based only on rock cutting descriptions. Hence there are no fractures noted below this point.

APLITE and PEGMATITE from 195.0 to $198.5 \mathrm{~m}$, pale greenish yellow, aphanitic, fine grained matrix with seams of pyrite. Possible gange or hydrothermally altered zone. (see table 5 . for results of $\mathrm{x}$-ray diffraction sample), $\sim 3.5 \mathrm{~m}$ wide

GRANITE from 198.5 to $216.0 \mathrm{~m}, \sim 17.5 \mathrm{~m}$ wide

GRANITE from 198.5 to $204.0 \mathrm{~m}$, muscovite granite, with quartz- feldspar aggregates with trace amounts of sulfide minerals, and trace muscovite flakes, $\sim 5.5 \mathrm{~m}$ wide

GRANITE from 204.0 to $207.5 \mathrm{~m}$, muscovite-chlorite granite, pale greenish yellow, with seams of sulfide (pyrite) minerals, appears to be altered, $\sim 3.5 \mathrm{~m}$ wide

GRANITE from 207.5 to $213.5 \mathrm{~m}$, muscovite-chlorite granite, greenish yellow feldspar, muscovite flakes and some very well-formed pyrite crystals, $\sim 6.0 \mathrm{~m}$ wide 


\section{FS3 Continued}

LITHOLOGY FRACTURES

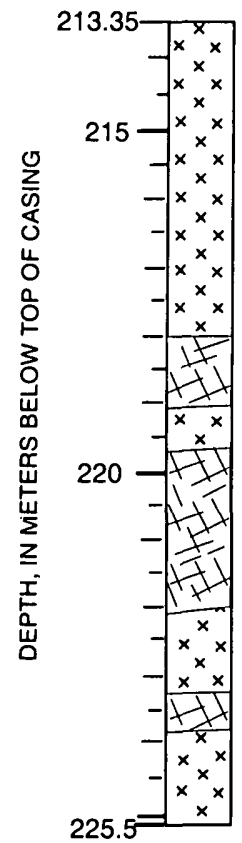

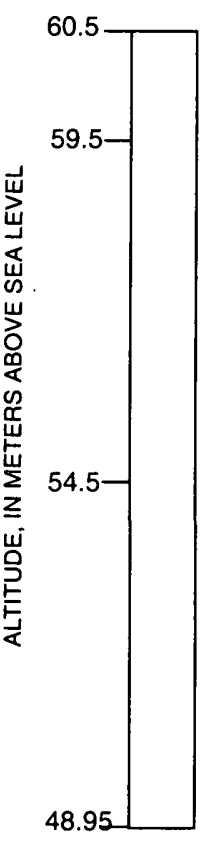

DESCRIPTION: Generalized log in bold.

\section{GRANITE continued to $216.0 \mathrm{~m}$}

GRANITE from 213.5 to $216 \mathrm{~m}$, biotite-muscovite-feldspar and quartz, with some pyrite, $\sim 2.5 \mathrm{~m}$ wide

\section{AVAILABLE}

NO FRACTURES

NOTED muscovite and feldspar. Granite is leucocratic with muscovite, pale green chlorite and sericite altered, with
PEGMATITE and GRANITE from 216.0 to $225.5 \mathrm{~m}$, pegmatitic monomineralic chips of pyrite, $\sim 9.5 \mathrm{~m}$ wide PEGMATITE from 218.0 to $219.0 \mathrm{~m}, \sim 1.0 \mathrm{~m}$ wide

PEGMATITE from 219.5 to $222.0 \mathrm{~m}$, muscovite and feldspar, $\sim 2.5 \mathrm{~m}$ wide

PEGMATITE from 223.2 to $223.8 \mathrm{~m}$, muscovite and feldspar, $0.6 \mathrm{~m}$ wide

BOTTOM OF WELL AT $225.5 \mathrm{~m}$ 


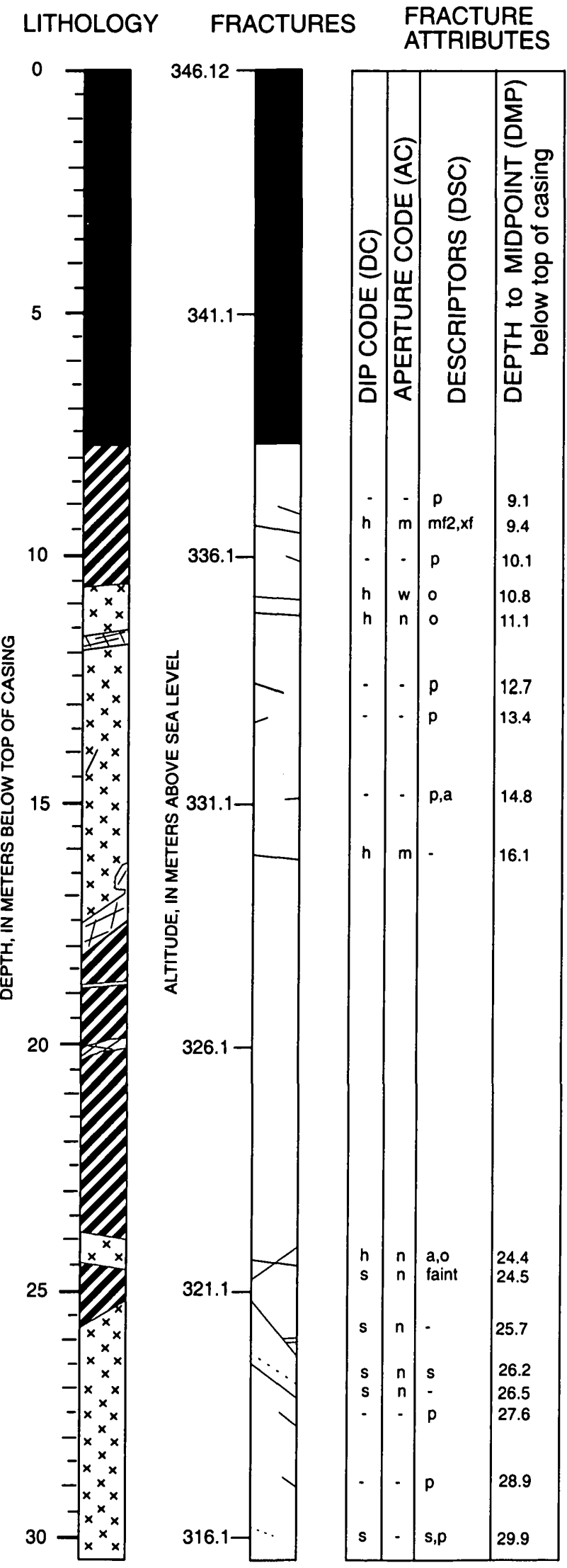

DESCRIPTION: Generalized log in bold.

SAND from 0.8 to $4.0 \mathrm{~m}$, brown, coarse, $\sim 3.2 \mathrm{~m}$ wide

\section{BEDROCK SURFACE at $4.0 \mathrm{~m}$ \\ Cuttings: BIOTITE SCHIST from 4.0 to $7.7, \sim 3.7 \mathrm{~m}$ wide}

(There appears to be iron bacteria floating in the water at the top of the well)

\section{BOTTOM OF CASING at $7.6 \mathrm{~m}$}

SCHIST from 7.6 to10.6 m, fine grained biotite and pyrite / (sulfide minerals) and medium to coarse quartzofeldspathic layers, some oxidized near vertical foliation, $\sim 3.0 \mathrm{~m}$ wide

\section{GRANITE from 10.6 to $17.5 \mathrm{~m}, \sim 6.9 \mathrm{~m}$ wide}

PEGMATITE from 17.5 to $18.1 \mathrm{~m}$, monomineralic feldspar and quartz, slight greenish tinge, $\sim 0.6 \mathrm{~m}$ wide

foliated minerals are extremely fine grained SCHIST from 18.1 to $25.5 \mathrm{~m}$, fine to coarse grained, banded, vertical foliation, $\sim 7.4 \mathrm{~m}$ wide

FELSIC BAND in schist at $23.5 \mathrm{~m}, \sim 3 \mathrm{~cm}$ wide

GRANITE from 23.8 to $24.6 \mathrm{~m}$, coarse grained and oxidized, cross-cuts foliation of schist, $\sim 0.8 \mathrm{~m}$ wide (fracture is in the granite and is parallel to the lower contact with schist.)

GRANITE from 25.5 to $49.8 \mathrm{~m}$, grayish white, biotitemuscovite granite, $\sim 24.3 \mathrm{~m}$ wide 


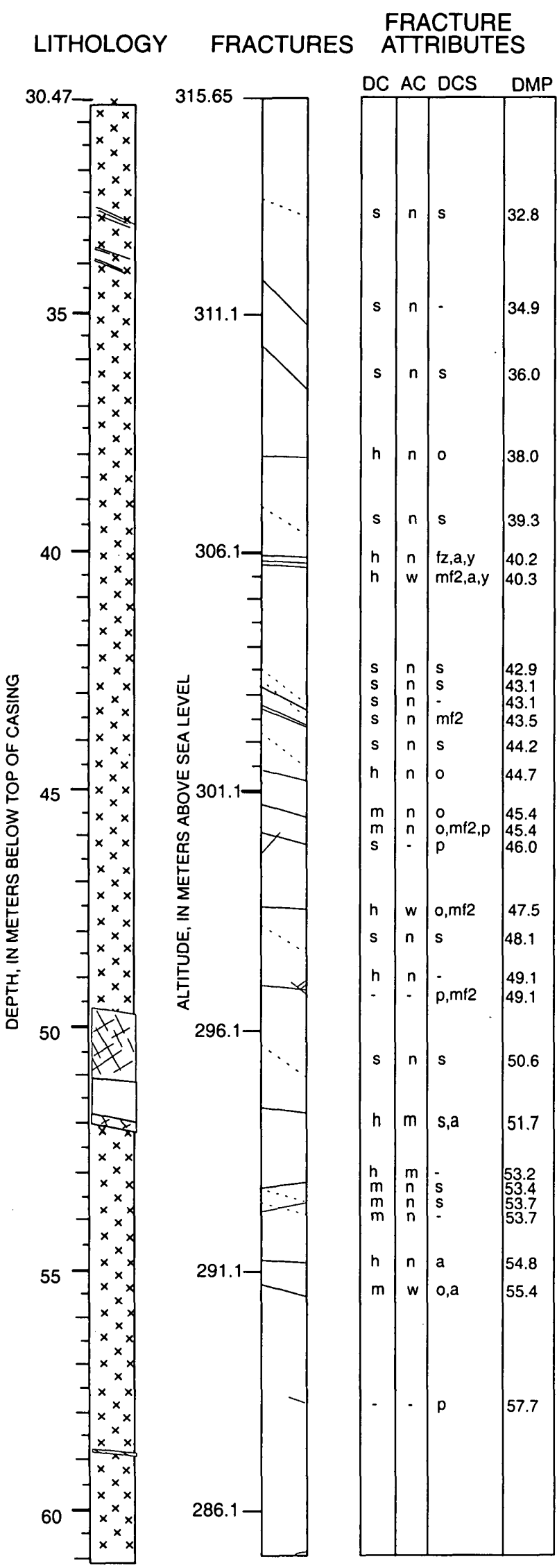

DESCRIPTION: Generalized log in bold.

GRANITE continued to $\mathbf{4 9 . 8} \mathrm{m}$, with biotite schlieren at $\sim 33.0 \mathrm{~m}, 33.8 \mathrm{~m}$, and $34.0 \mathrm{~m}$

GRANITE from $\sim 38.1$ to $47.0 \mathrm{~m}$, greenish microclinequartz-muscovite and biotite, $\sim 8.9 \mathrm{~m}$ wide

(Drill logs indicate that this fracture is water bearing.)

Borehole wall is rough at $44.7 \mathrm{~m}, \sim 10 \mathrm{~cm}$ wide

GRANITE from 47.0 to $49.8 \mathrm{~m}$, fine grain, gray, biotite granite with some muscovite, $2.8 \mathrm{~m}$ wide

PEGMATITE and APLITE from $\mathbf{4 9 . 8}$ to $\mathbf{5 2 . 1} \mathrm{m}$, alternating bands, gradational contacts, $\sim 2.3 \mathrm{~m}$ wide PEGMATITE DIKE from 49.8 to $51.2 \mathrm{~m}, \sim 0.4 \mathrm{~m}$ wide

APLITE VEIN from 51.2 to $51.9 \mathrm{~m}, \sim 0.7 \mathrm{~m}$ wide PEGMATITE DIKE from 51.9 to $52.1 \mathrm{~m}, \sim 0.2 \mathrm{~m}$ wide

GRANITE from $\mathbf{5 2 . 1}$ to $\mathbf{6 1 . 9} \mathrm{m}$, grayish white, biotite granite, gradational contact with aplite above, with some greenish zones, $\sim 9.8 \mathrm{~m}$ wide

PEGMATITE VEIN at $58.7 \mathrm{~m}$, muscovite, quartz, feldspar, $\sim 8 \mathrm{~cm}$ wide 


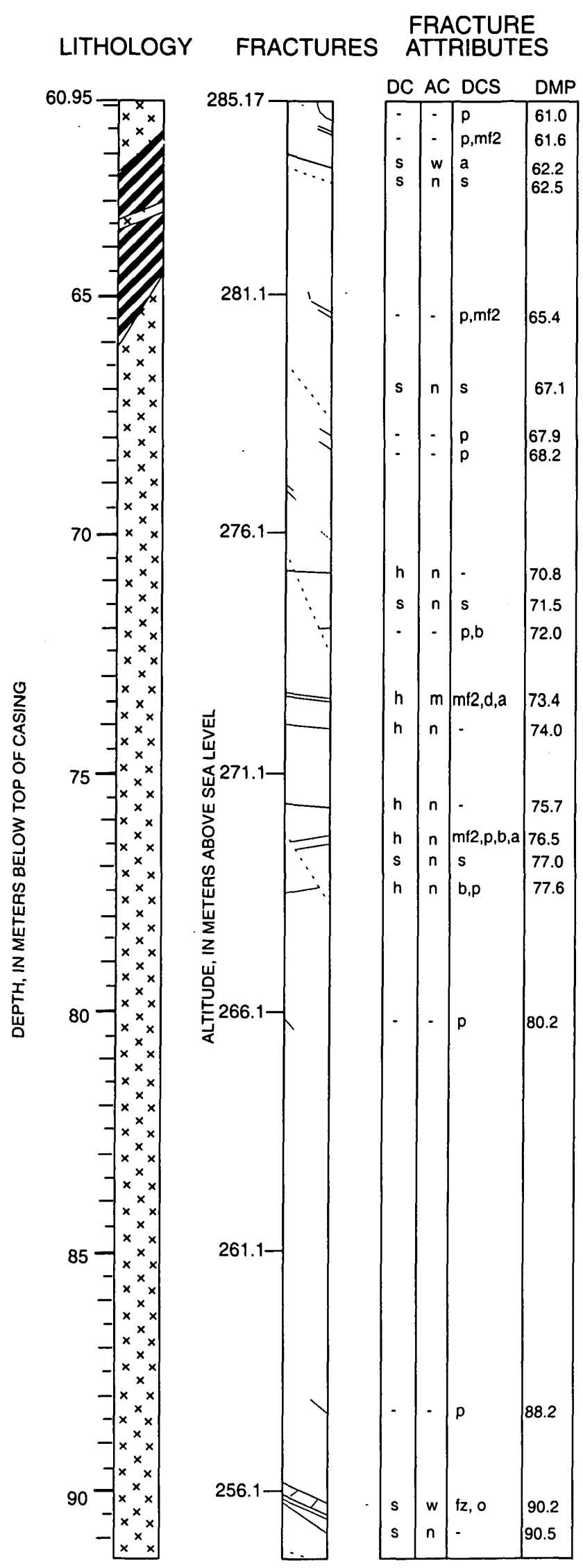

DESCRIPTION: Generalized log in bold.

\section{GRANITE continued to $61.9 \mathrm{~m}$}

Quartzite from 61.9 to $65.3 \mathrm{~m}$, quartz with some biotite and with sulfide minerals, oxidized, foliation is near vertical, (shown with foliated schist pattern), $\sim 3.4 \mathrm{~m}$ wide Quartzite from 63.4 to $65.3 \mathrm{~m}$, steeply dipping banding, yellowish tinge, $\sim 1.9 \mathrm{~m}$ wide

GRANITE from 65.3 to $116.7 \mathrm{~m}$, biotite-muscovite granite, $\sim 51.5 \mathrm{~m}$ wide

GRANITE from 74.0 to $82.0 \mathrm{~m}$, grayish white, biotitemuscovite granite with trace garnet, fine grained, $\sim 8.0 \mathrm{~m}$ wide

GRANITE from 82.0 to $88.0 \mathrm{~m}$, muscovites and biotites, near vertical foliation, altered, $\sim 6.0 \mathrm{~m}$ wide

GRANITE from 86.9 to $88.4 \mathrm{~m}$, slightly greenish, altered, biotite-muscovite-microcline-quartz granite with some chlorite, with weak to strong foliation, foliation is steeply dipping, $1.5 \mathrm{~m}$ wide 
FS4 Continued

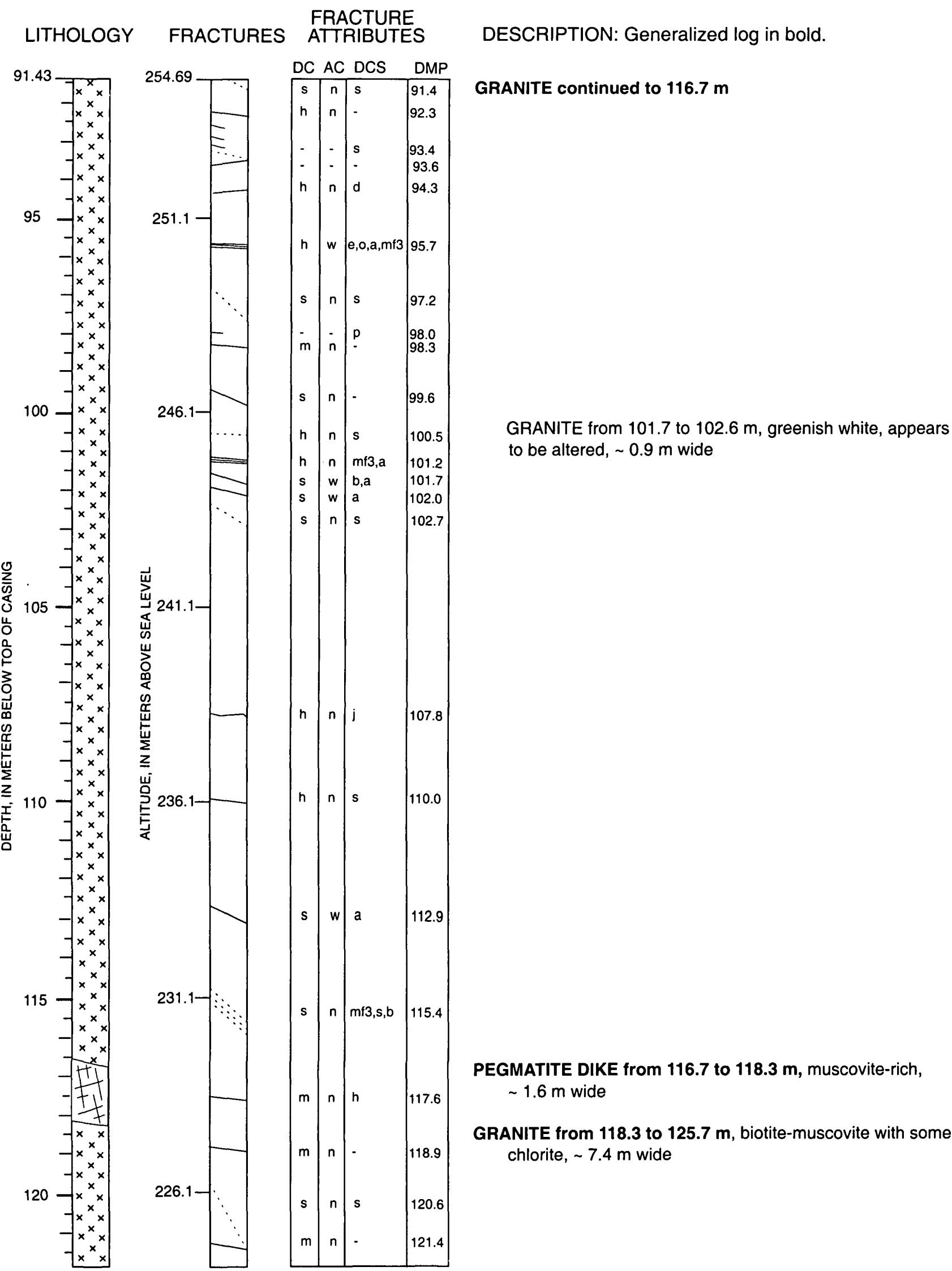


FS4 Continued

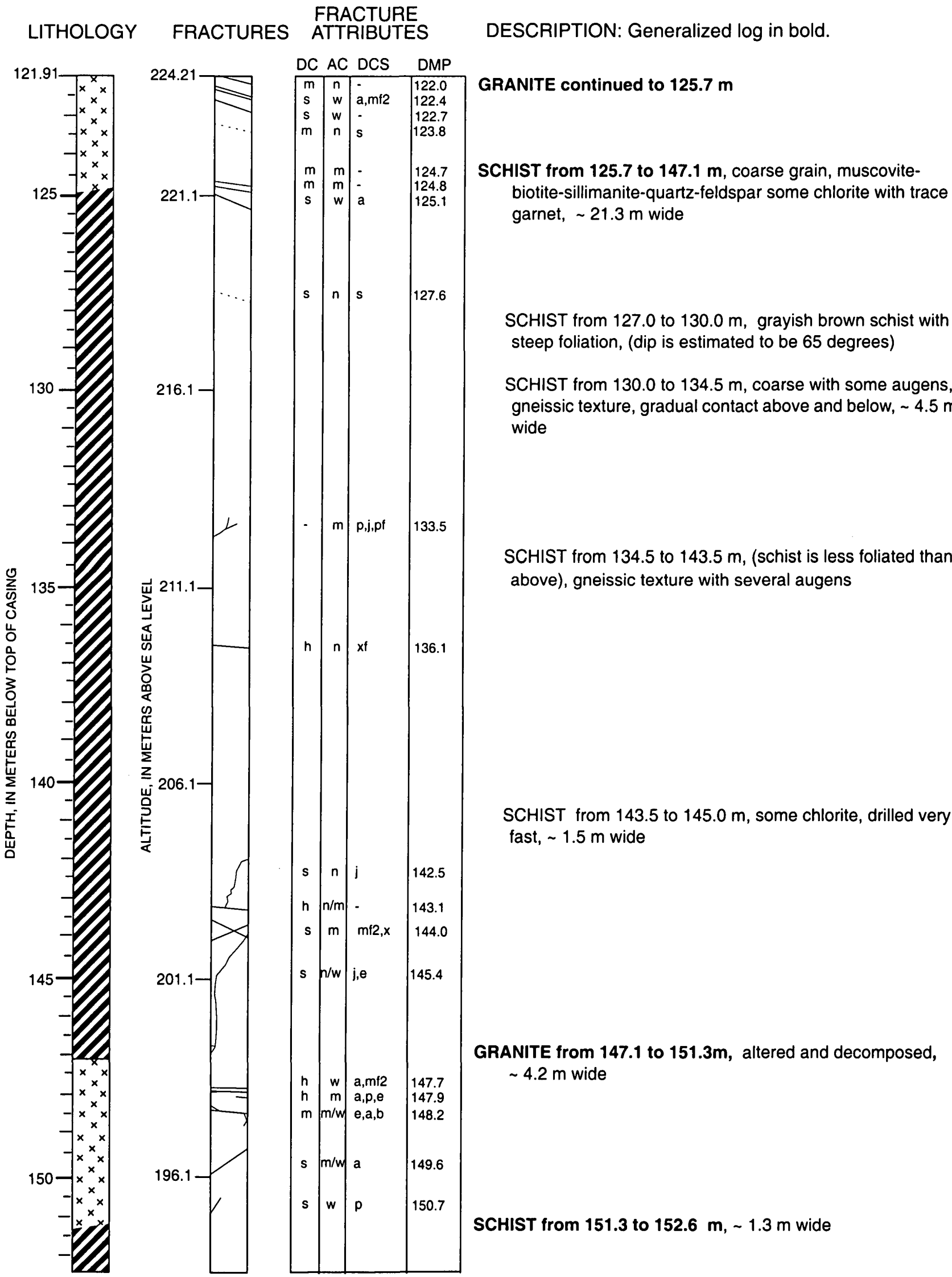


FS4 Continued

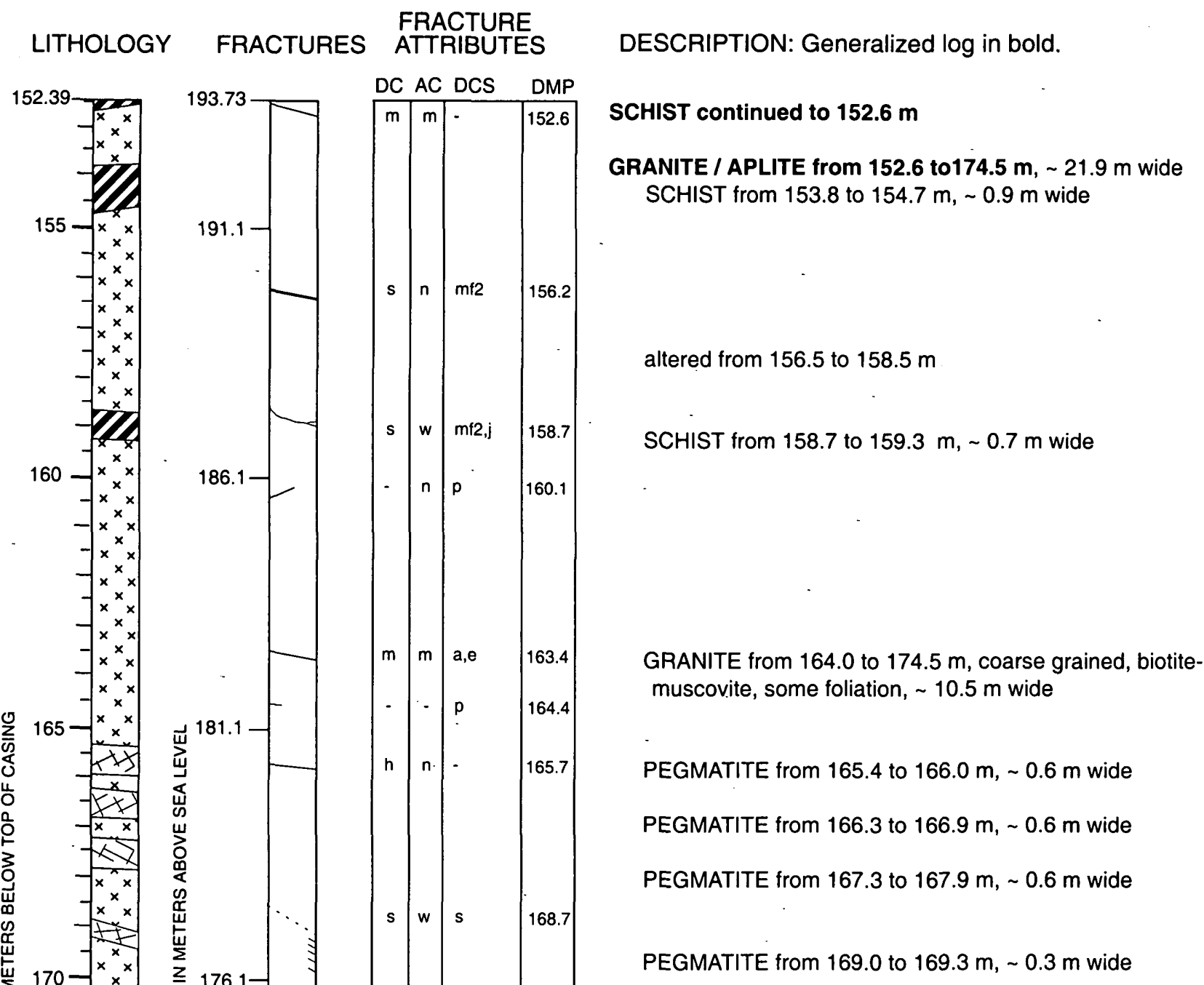

PEGMATITE from 174.5 to $175.8 \mathrm{~m}$, minerals are pegmatitic sized, the contacts are gradational, $\sim 1.3 \mathrm{~m}$ wide GRANITE from 175.8 to $195.8 \mathrm{~m}, \sim 20.0 \mathrm{~m}$ wide

FELSIC VEIN at $178.9 \mathrm{~m}, \sim 2 \mathrm{~cm}$ wide $180-x_{x}^{x} x$ 166.1

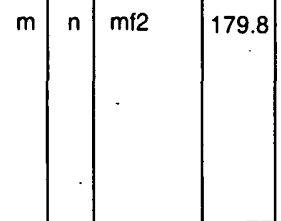

PEGMATITE from 180.9 to $181.5 \mathrm{~m}, \sim 0.6 \mathrm{~m}$ wide 
FS4Continued

LITHOLOGY

182.87

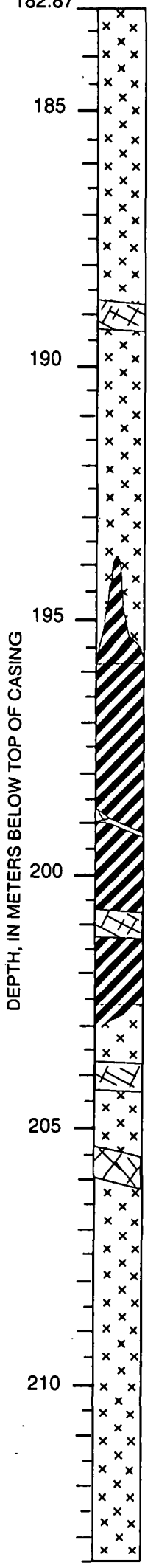

FRACTURE FRACTURES ATTRIBUTES

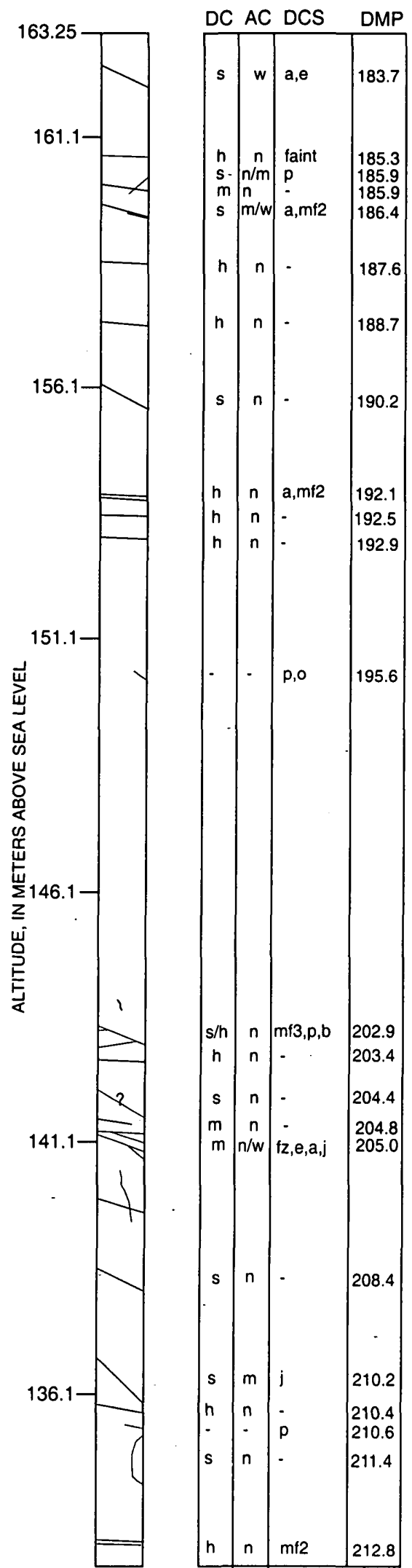

DESCRIPTION: Generalized log in bold.

GRANITE continued to $195.8 \mathrm{~m}$, weakly foliated with near vertical foliation

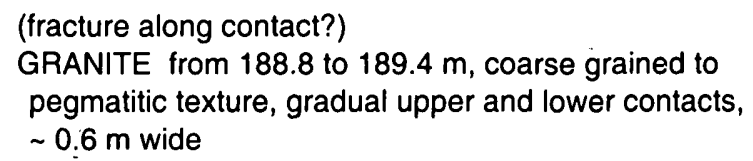

SCHIST from 195.8 to $202.7 \mathrm{~m}$,

very fine to medium grained texture, biotite-muscovite, darkreddish brown, foliations are steeply dipping, $\sim 6.9 \mathrm{~m}$ wide

PEGMATITE at $199.1 \mathrm{~m}, \sim 3 \mathrm{~cm}$ wide

PEGMATITE from 200.7 to $201.3 \mathrm{~m}, \sim 0.6 \mathrm{~m}$ wide (near horizontal, 657.2 to 658.5 , cross-cuts foliation, upper contact is irregular, embayed and gradual)

(some narrow and some wide fractures at $205.0 \mathrm{~m}$ )

GRANITE from 202.7 to $215.0 \mathrm{~m}, \sim 12.3 \mathrm{~m}$ wide

APLITE from 203.8 to $204.2 \mathrm{~m}, \sim 0.5 \mathrm{~m}$ wide

PĖGMATITE from 205.4 to $206.0 \mathrm{~m}, \sim 0.6 \mathrm{~m}$ wide

GRANITE from 206.5 to $215.0 \mathrm{~m}, \sim 8.5 \mathrm{~m}$ wide altered and fine grained 
FS4 Continued

LITHOLOGY

FRACTURE

DC AC DCS DMP
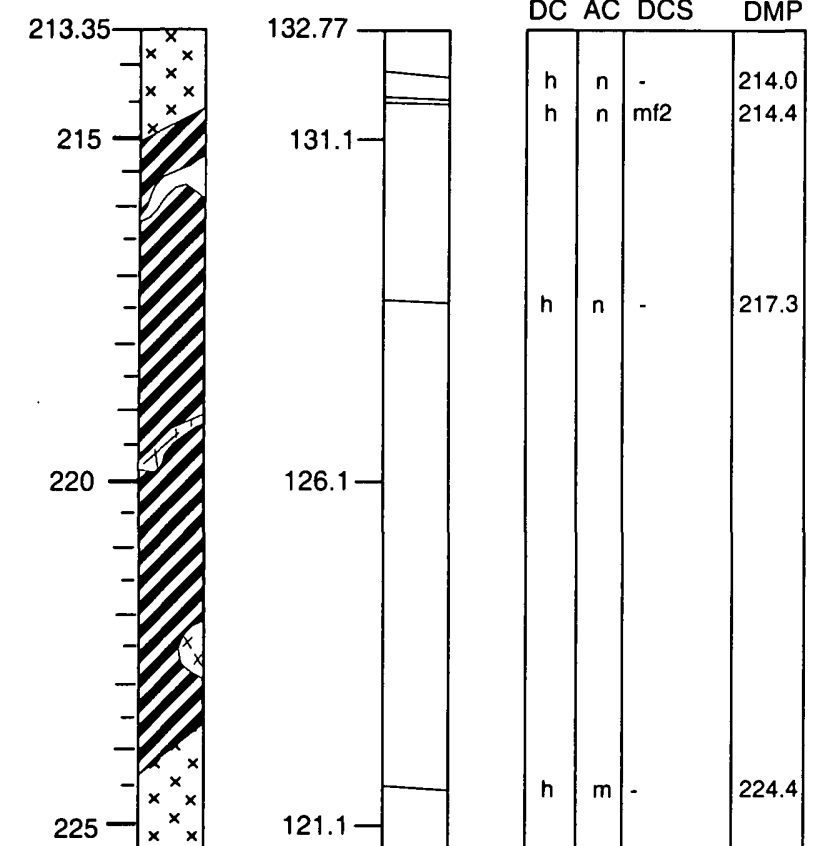

DESCRIPTION: Generalized log in bold.

\section{GRANITE continued to $215.0 \mathrm{~m}$}

SCHIST from 215.0 to $224.8 \mathrm{~m}$, coarse grained, biotitemuscovite schist, top contact looks gradual, $\sim 9.8 \mathrm{~m}$ wide

PEGMATITE from 219.2 to $219.8 \mathrm{~m}, \sim 0.6 \mathrm{~m}$ wide

GRANITE from 224.8 to $251.0 \mathrm{~m}, \sim 26.2 \mathrm{~m}$ wide
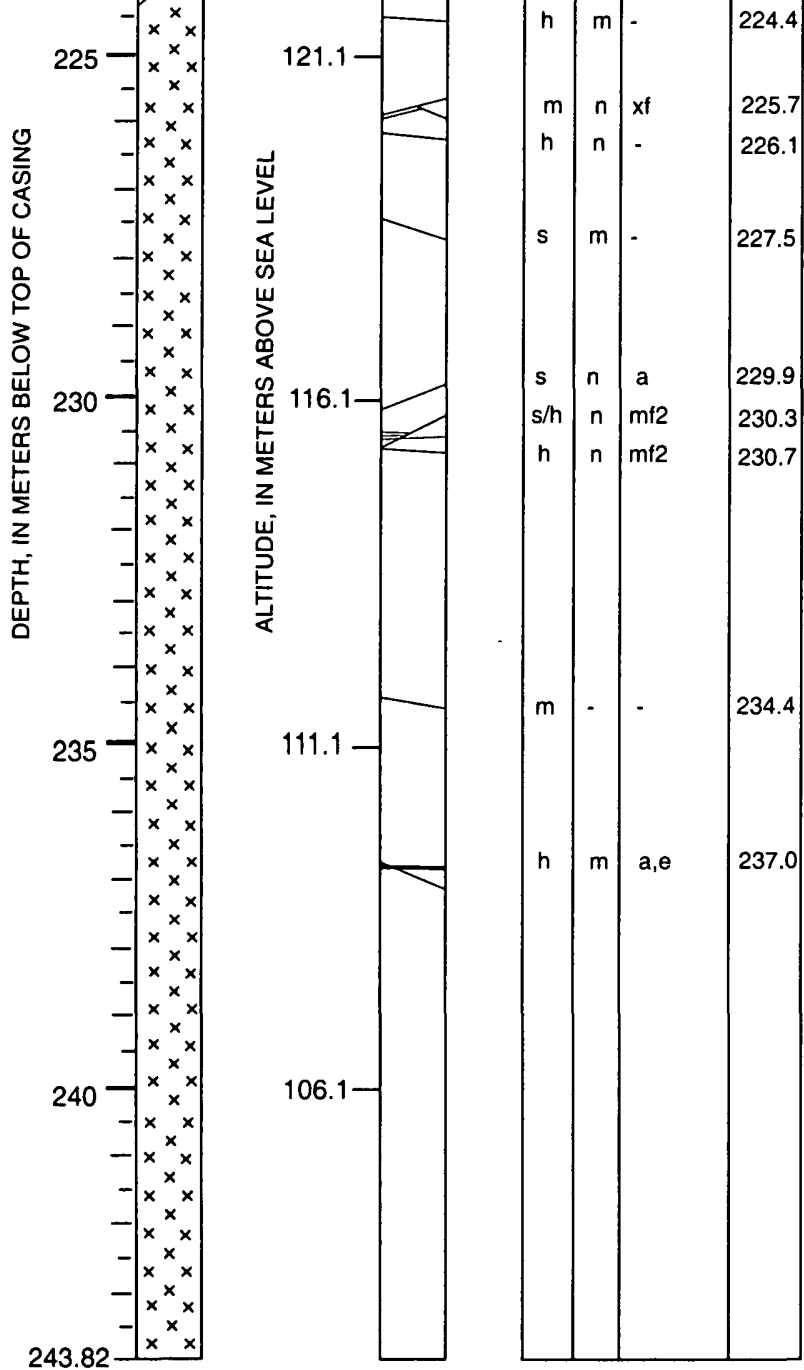
FS4 Continued

LITHOLOGY 243.82

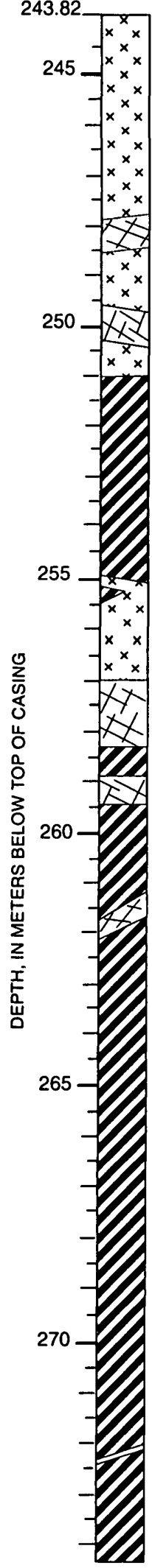

FRACTURE

FRACTURES ATTRIBUTES

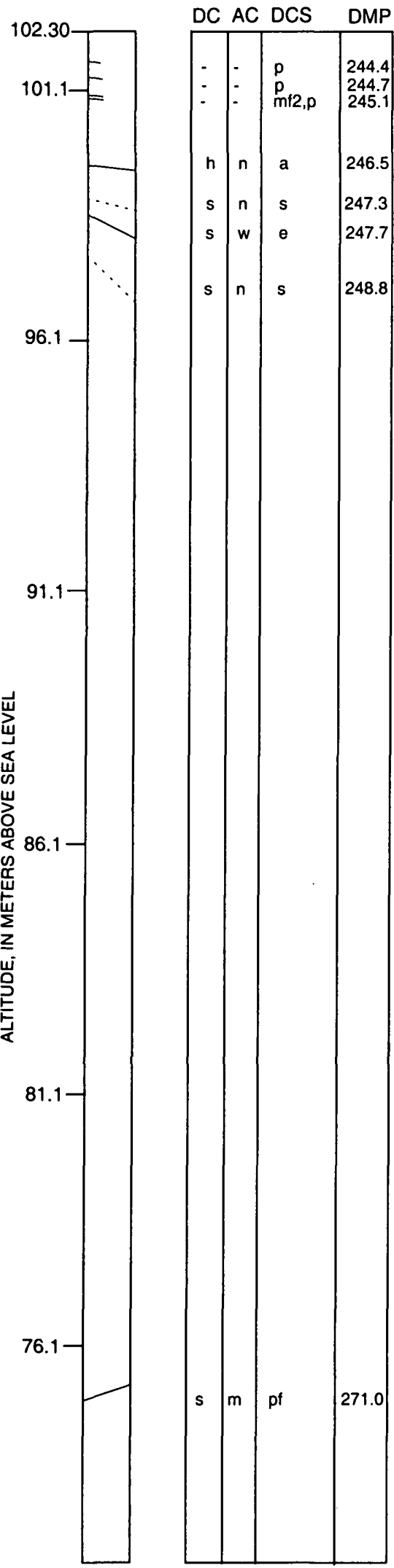

DESCRIPTION: Generalized log in bold.

\author{
GRANITE continued to $251.0 \mathrm{~m}$
}

PEGMATITE from 246.7 to $247.3 \mathrm{~m}, \sim 0.6 \mathrm{~m}$ wide

PEGMATITE from 248.1 to $249.0 \mathrm{~m}, \sim 0.9 \mathrm{~m}$ wide

PEGMATITE from 249.8 to $250.4 \mathrm{~m}, \sim 0.6 \mathrm{~m}$ wide

SCHIST from 251.0 to $255.3 \mathrm{~m}$, biotite-quartz schist, some coarse-grained minerals, $\sim 4.3 \mathrm{~m}$ wide

GRANITE from 255.3 to $256.8 \mathrm{~m}, \sim 1.5 \mathrm{~m}$ wide

PEGMATITE from 256.8 to $258.3 \mathrm{~m}, \sim 1.5 \mathrm{~m}$ wide

SCHIST from 258.3 to $306.5 \mathrm{~m}$, gray biotite-chlorite, quartzrich schist and some quartzite layers, $\sim 48.2 \mathrm{~m}$ wide PEGMATITE from 258.8 to $259.4 \mathrm{~m}, \sim 0.6 \mathrm{~m}$ wide

PEGMATITE from 261.4 to $262.0 \mathrm{~m}, \sim 0.6 \mathrm{~m}$ wide

Felsic band at $272.0 \mathrm{~m}, \sim 2 \mathrm{~cm}$ wide 
FS4 Continued

LITHOLOGY

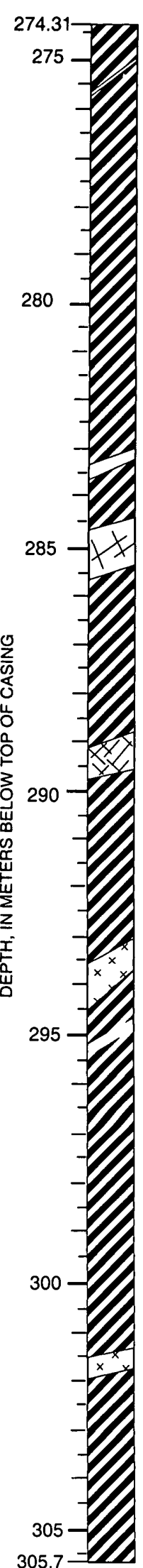

FRACTURE

FRACTURES ATTRIBUTES

DC AC DCS DMP

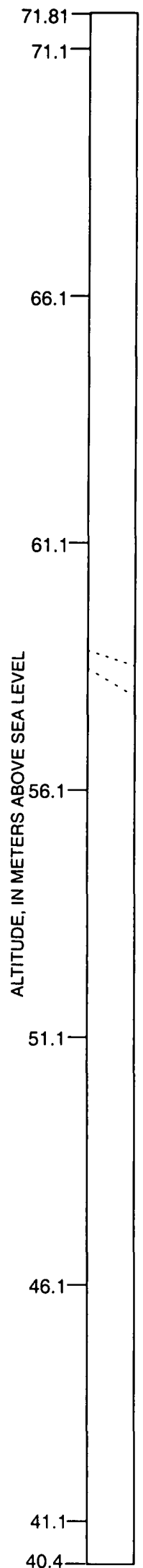

DESCRIPTION: Generalized log in bold.

SCHIST continued to $\mathbf{2 8 4 . 6} \mathrm{m}$, very fine to coarse texture, steeply dipping foliation

PEGMATITE or felsic rich zone in schist at $283.1 \mathrm{~m}, \sim 20$ to $25 \mathrm{~cm}$ wide

PEGMATITE from 284.6 to $285.6 \mathrm{~m}, \sim 1.0 \mathrm{~m}$ wide

SCHIST from 285.6 to $293.3 \mathrm{~m}$, same as above, $\sim 7.7 \mathrm{~m}$ wide

PEGMATITE from 289.1 to $289.7 \mathrm{~m}$, gradual contacts, $\sim 0.6 \mathrm{~m}$ wide

GRANITE from 293.3 to $294.3 \mathrm{~m}, \sim 1.0 \mathrm{~m}$ wide

SCHIST from 294.3 to $306.2 \mathrm{~m}$, same as above, $\sim 11.9 \mathrm{~m}$ wide FELSIC ZONE in schist at $295.2 \mathrm{~m}$, gradual contacts, $\sim 0.3 \mathrm{~m}$ wide

APLITE DIKE from 301.5 to $301.8 \mathrm{~m}, \sim 0.3 \mathrm{~m}$ wide

SCHIST from 302.7 to $304.5 \mathrm{~m}$, coarse grained texture, felsic rich, $\sim 1.8 \mathrm{~m}$ wide

SCHIST from 304.5 to $306.2 \mathrm{~m}$, coarse grained texture felsic rich, $\sim 1.7 \mathrm{~m}$ wide BOTTOM OF WELL AT $305.7 \mathrm{~m}$ 
LITHOLOGY

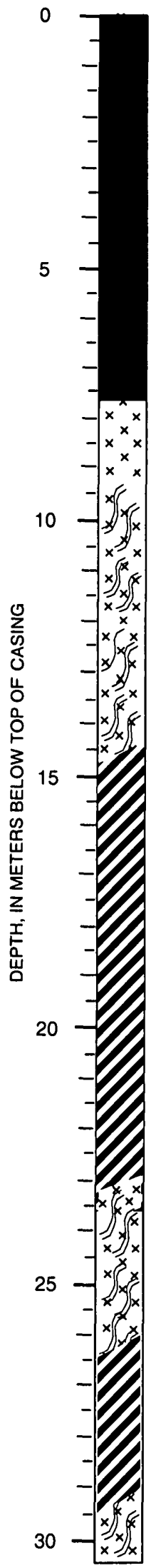

FRACTURE

ATTRIBUTES

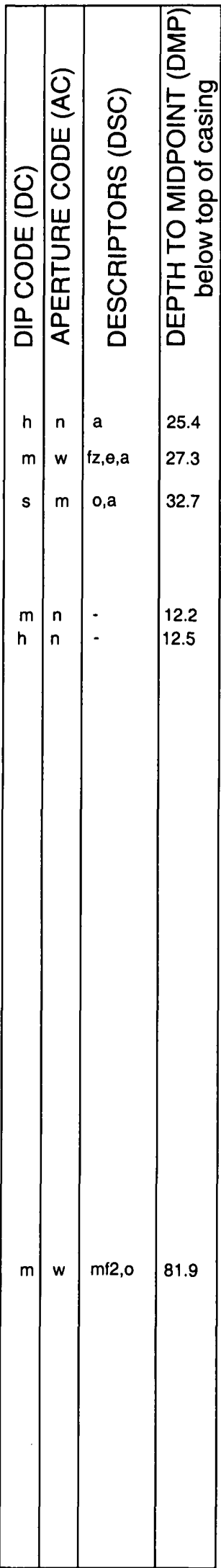

DESCRIPTION: Generalized log in bold.

BEDROCK SURFACE at $3.9 \mathrm{~m}$

\section{BOTTOM OF CASING AT $7.6 \mathrm{~m}$}

GRANITE from 7.6 to $9.4 \mathrm{~m}$, foliated, greenish-gray, quartz rich, gradual contact with gneiss below, $\sim 1.8 \mathrm{~m}$ wide

GNEISS from 9.4 to $\sim 15 \mathrm{~m}$, coarse-grained, equigranular texture to gneissic texture, with some felsic-rich zones, some biotite schlieren, gradual contact with schist or mafic portion of a migmatite, $-5.6 \mathrm{~m}$ wide

at $14 \mathrm{~m}$ the rock is banded and is more foliated than above.

SCHIST from 15 to $23.2 \mathrm{~m}$, gradual contacts with gneiss above and below, more schistose and foliated than above, some zones with gneissic texture in felsic-rich zones, some coticule or calc-silicate layers,

Felsic-rich portion of schist from 18.3 to $19.8 \mathrm{~m}$, coarse grained, $1.5 \mathrm{~m}$ wide

GNEISS 23.2 to $\sim 26 \mathrm{~m}$, gradual contacts above and below, texture is mottled and foliated, $\sim 2.8 \mathrm{~m}$ wide

SCHIST from $\sim 26$ to $29.5 \mathrm{~m}$, gradual contacts, biotite-rich, strongly foliated, steeply dipping foliation, $\sim 3.5 \mathrm{~m}$ wide

GNEISS from 29.5 to $66.4 \mathrm{~m}$, greenish gray, biotite quartz, and feldspar, 
LITHOLOGY

30.47

$$
30.47
$$

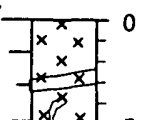

$$
\text { - }
$$$$
35-1
$$

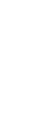
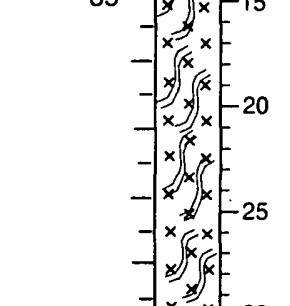

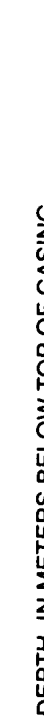

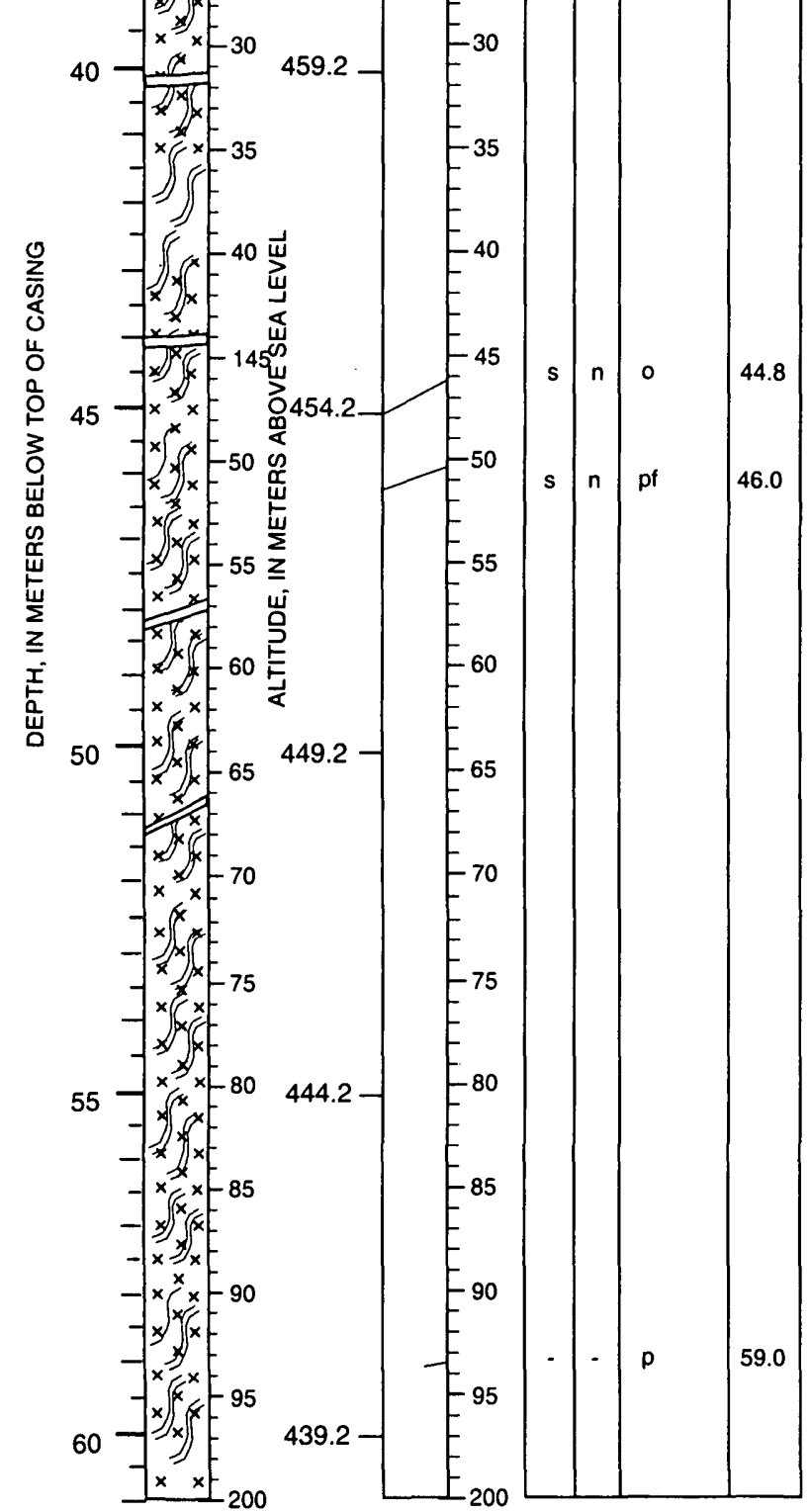

DESCRIPTION: Generalized log in bold.

\section{GNEISS continued to $66.4 \mathrm{~m}$}

GNEISS at 31.6 to $38.5 \mathrm{~m}$, coarse-grained to gneissic texture, felsic-rich equigranular zones, weak foliation, some banding, $\sim 6.9 \mathrm{~m}$ wide

GNEISS from 38.5 to $50.3 \mathrm{~m}$, banded, migmatitic texture, $\sim 3.1 \mathrm{~m}$ wide

FELSIC BAND at $40.2 \mathrm{~m},-5 \mathrm{~cm}$ wide

FELSIC BAND at $44 \mathrm{~m}, \sim 5 \mathrm{~cm}$ wide

FELSIC BAND at $48 \mathrm{~m}, \sim 8 \mathrm{~cm}$ wide

GNEISS from 50.3 to $51.8 \mathrm{~m}$, felsic rich, coarse equigranular with no foliation to weak foliation, $1.5 \mathrm{~m}$ wide

FELSIC BAND at $51 \mathrm{~m}, \sim 10 \mathrm{~cm}$ wide

GNEISS from 51.8 to $61.0 \mathrm{~m}$, some banding, gneissic to migmatitic texture, some pink and green calc-silicate layers or coticule layers, $9.2 \mathrm{~m}$ wide 
FS5 Continued

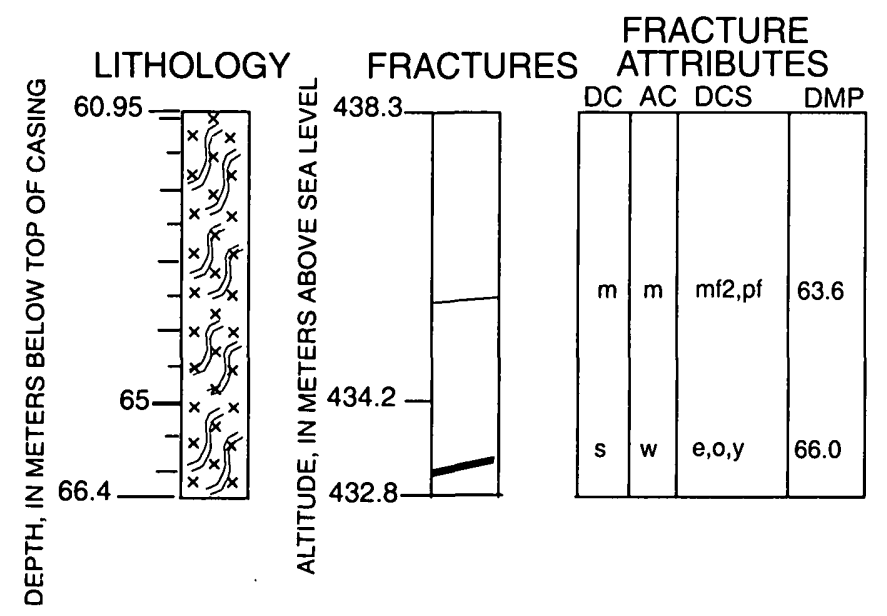

DESCRIPTION: Generalized log in bold.

\section{GNEISS continued to $66.4 \mathrm{~m}$}

GNEISS from $\sim 61.0 \mathrm{~m} 66.4 \mathrm{~m}$, banded, with some felsic, mottled-looking zones, gradual contacts, $\sim 5.4 \mathrm{~m}$ wide

Cuttings at 66.0 exhibited sulfide minerals, oxidation, and slickensides, which indicate faulting.

BOTTOM OF WELL AT $66.4 \mathrm{~m}$ 


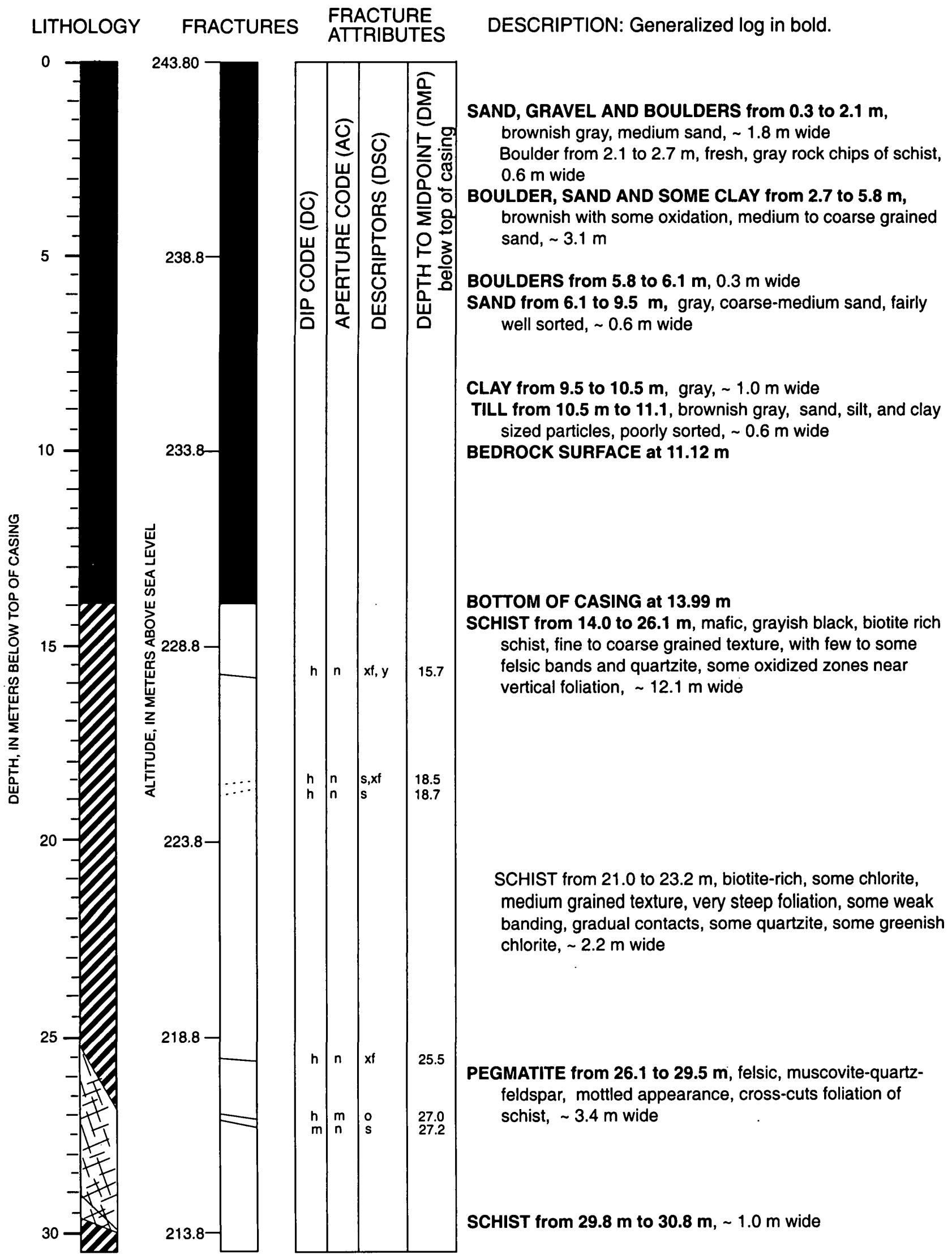




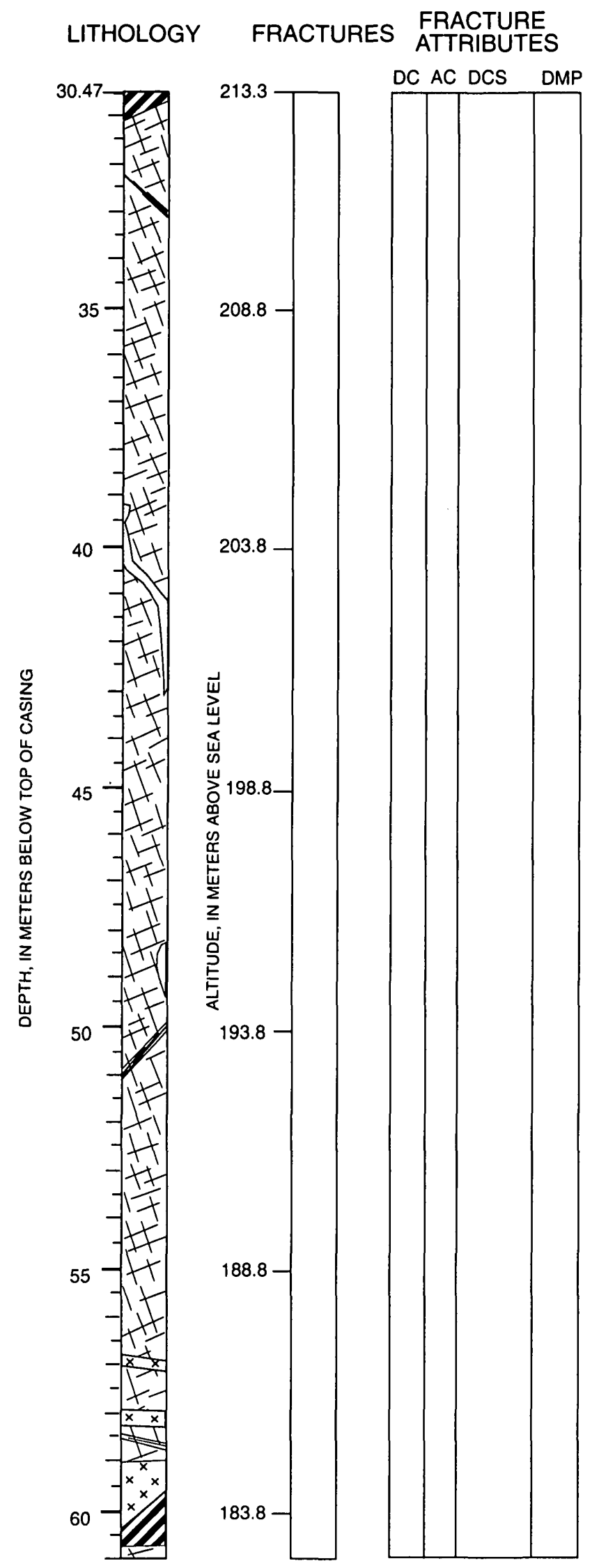

DESCRIPTION: Generalized log in bold.

\section{SCHIST continued to $30.8 \mathrm{~m}$ \\ PEGMATITE from 30.8 to $59.9 \mathrm{~m}$}

PEGMATITE from 30.8 to $35.0 \mathrm{~m}$, gray and white mottled texture, muscovite-quartz-feldspar and some phlogopite and some biotite, $\sim 4.2 \mathrm{~m}$ wide

BIOTITE SCHLIEREN at $32.6 \mathrm{~m} 2$ to $5 \mathrm{~cm}$ wide

PEGMATITE from 35.0 to $50.0 \mathrm{~m}$, muscovite rich, quartz, feldspar, biotite, trace garnet, $\sim 15.0 \mathrm{~m}$ wide

BIOTITE (and quartz?) from 39.5 to $43.0 \mathrm{~m}$, on one side of well, extremely fine grained (aphanitic), foliated biotites

BIOTITE from 48.4 to $49.5 \mathrm{~m}$ on one side of well, grayish black, fine grained biotites, foliated, $\sim 1.1 \mathrm{~m}$ wide

BIOTITE SCHLIEREN at $50.1 \mathrm{~m}$ fine grained (aphanitic) foliated biotite, $\sim 10 \mathrm{~cm}$ wide

PEGMATITE from 50.0 to $59.9 \mathrm{~m}$, felsic, muscovite-quartzfeldspar and some phlogopite and some biotite, $\sim 9.9 \mathrm{~m}$ wide

GRANITE VEIN from 56.8 to $57.0 \mathrm{~m}, \sim 0.2 \mathrm{~m}$ wide BIOTITE at $57.3 \mathrm{~m}, \sim 5 \mathrm{~cm}$ wide

GRANITE VEIN at 57.9 to $58.3 \mathrm{~m}$, gray, fine grained, $\sim 0.4 \mathrm{~m}$ wide

PEGMATITE from 58.3 to $59.0 \mathrm{~m}$, feldspar and muscovite, $\sim 0.7 \mathrm{~m}$ wide GRANITE from 59.0 to $59.9 \mathrm{~m}$,

SCHIST from 59.9 to $60.6 \mathrm{~m}$, biotite-muscovite, medium to coarse grained, not foliated, near vertical foliation, coarse felsic minerals and fine grained mafic minerals, $\sim 0.7 \mathrm{~m}$ wide

PEGMATITE from 60.6 to $70.7 \mathrm{~m}$, felsic, coarse-grained with some foliated layers or schlieren, $\sim 10.1 \mathrm{~m}$ wide 
FS6 Continued

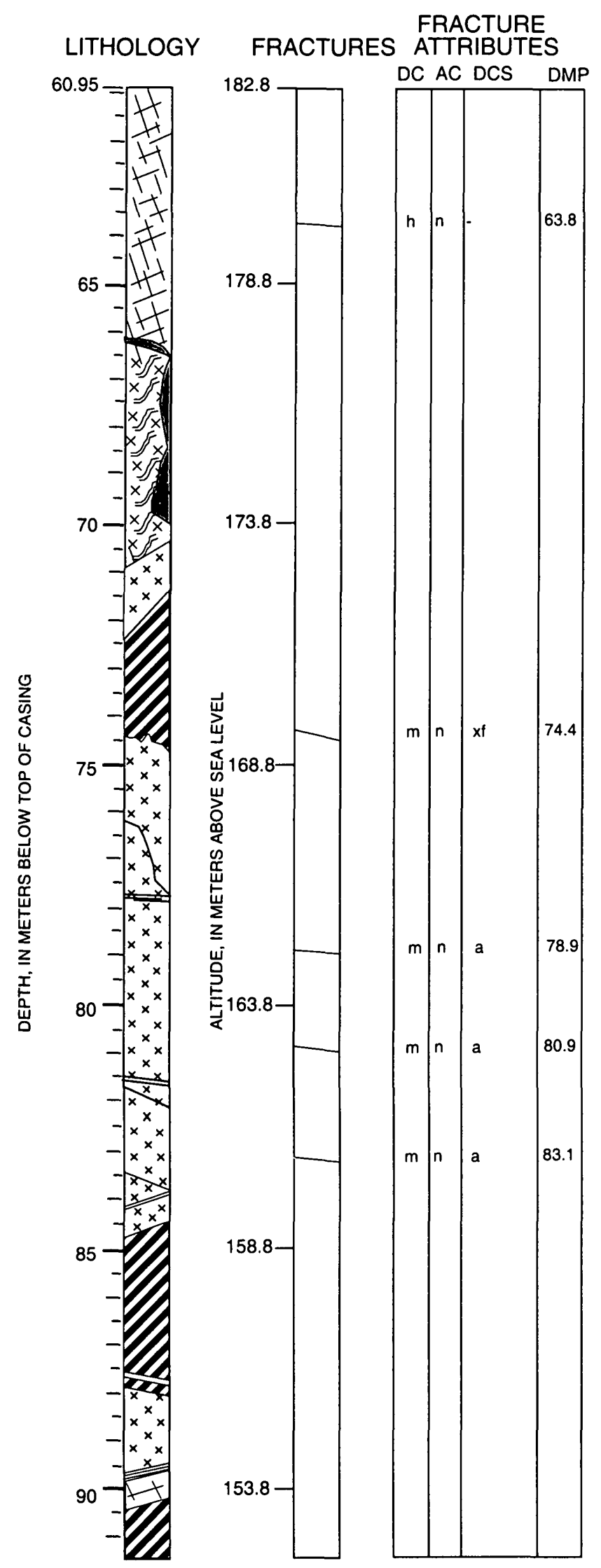

DESCRIPTION: Generalized log in bold.

PEGMATITE continued to $70.7 \mathrm{~m}$

PEGMATITE or possibly MIGMATITE from 66.4 to $70.7 \mathrm{~m}$, with small biotites, coarse grained, felsic rich, $\sim 4.3 \mathrm{~m}$ wide

GRANITE from 70.7 to $71.9 \mathrm{~m}$, biotite-muscovite quartz feldspar with trace garnet, $1.2 \mathrm{~m}$ wide

SCHIST from 71.9 to $74.5 \mathrm{~m}$, with felsic zones, more than $50 \%$ foliated and very fine grained, $\sim 2.6 \mathrm{~m}$ wide

FELSIC BAND (or fracture?) at $74.3 \mathrm{~m}$

APLITE/GRANITE from 74.7 to $75.4 \mathrm{~m}$, irregular contact, $\sim 0.7 \mathrm{~m}$ wide

BIOTITE SCHLIEREN at $77.0 \mathrm{~m}$, steeply dipping BIOTITE SCHLIEREN at $77.7 \mathrm{~m}$, horizontal

PEGMATITE at $81.6 \mathrm{~m}, \sim 3 \mathrm{~cm}$ wide

SCHIST from 83.8 to $88.0 \mathrm{~m}$, extremely fine grained schist and quartzite, $\sim 4.2 \mathrm{~m}$ wide

SCHIST from 85.3 to $88.0 \mathrm{~m}$, banded schist, near vertical foliation, some quartzite, $\sim 2.7 \mathrm{~m}$ wide

FELSIC BAND at $87.6 \mathrm{~m}$, cross-cuts the foliation of schist, $\sim 2 \mathrm{~cm}$ wide

GRANITE from 88.0 to $89.6 \mathrm{~m}, \sim 1.6 \mathrm{~m}$ wide PEGMATITE from 89.6 to $90.3 \mathrm{~m}, \sim 0.7 \mathrm{~m}$ wide

SCHIST from 90.3 to $119.8 \mathrm{~m}$, laminated, some banding, felsic layers 1 to $5 \mathrm{~cm}$ wide, and quartzite layers, steeply dipping foliation, $\sim 29.5 \mathrm{~m}$ wide 
FS6 Continued

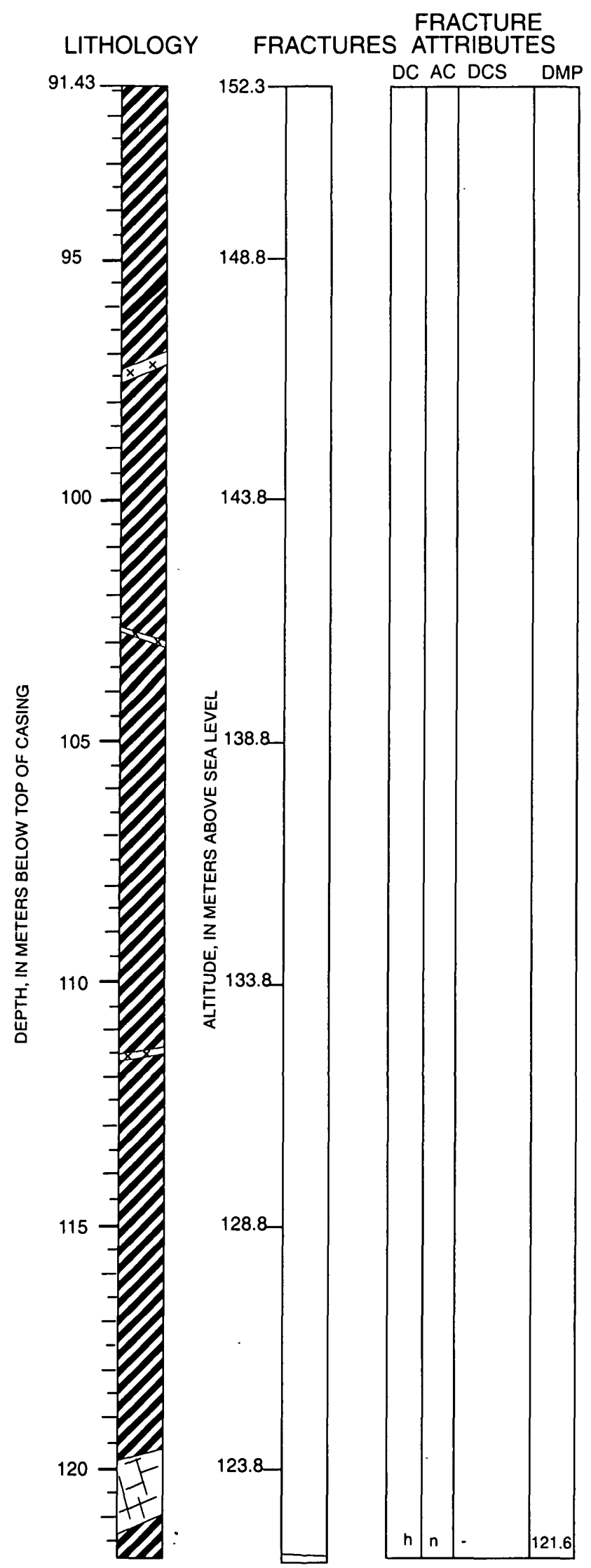

DESCRIPTION: Generalized log in bold.

SCHIST continued to $119.8 \mathrm{~m}$,

FELSIC BANDS (or GRANITE??) at $95.9 \mathrm{~m}$, laminated,

$\sim 5 \mathrm{~cm}$ wide

GRANITE or APLITE VEIN at $97.2 \mathrm{~m}, \sim 20 \mathrm{~cm}$ wide

GRANITE VEIN at $103.0 \mathrm{~m}$, cross-cuts foliation, $\sim 10 \mathrm{~cm}$ wide

FELSIC BAND at $108.0 \mathrm{~m}$, cross-cuts foliation, $\sim 1 \mathrm{~cm}$ wide

GRANITE CONTACT at $111.4 \mathrm{~m}$, cross cuts foliation,

$\sim 10 \mathrm{~cm}$ wide

PEGMATITE from 119.8 to $121.2 \mathrm{~m}$, felsic, some pegmatite muscovite, $\sim 1.4 \mathrm{~m}$ wide

SCHIST from 121.2 to $125.3 \mathrm{~m}$, with quartzite layers, $\sim 4.1 \mathrm{~m}$ wide 
FS6 Continued

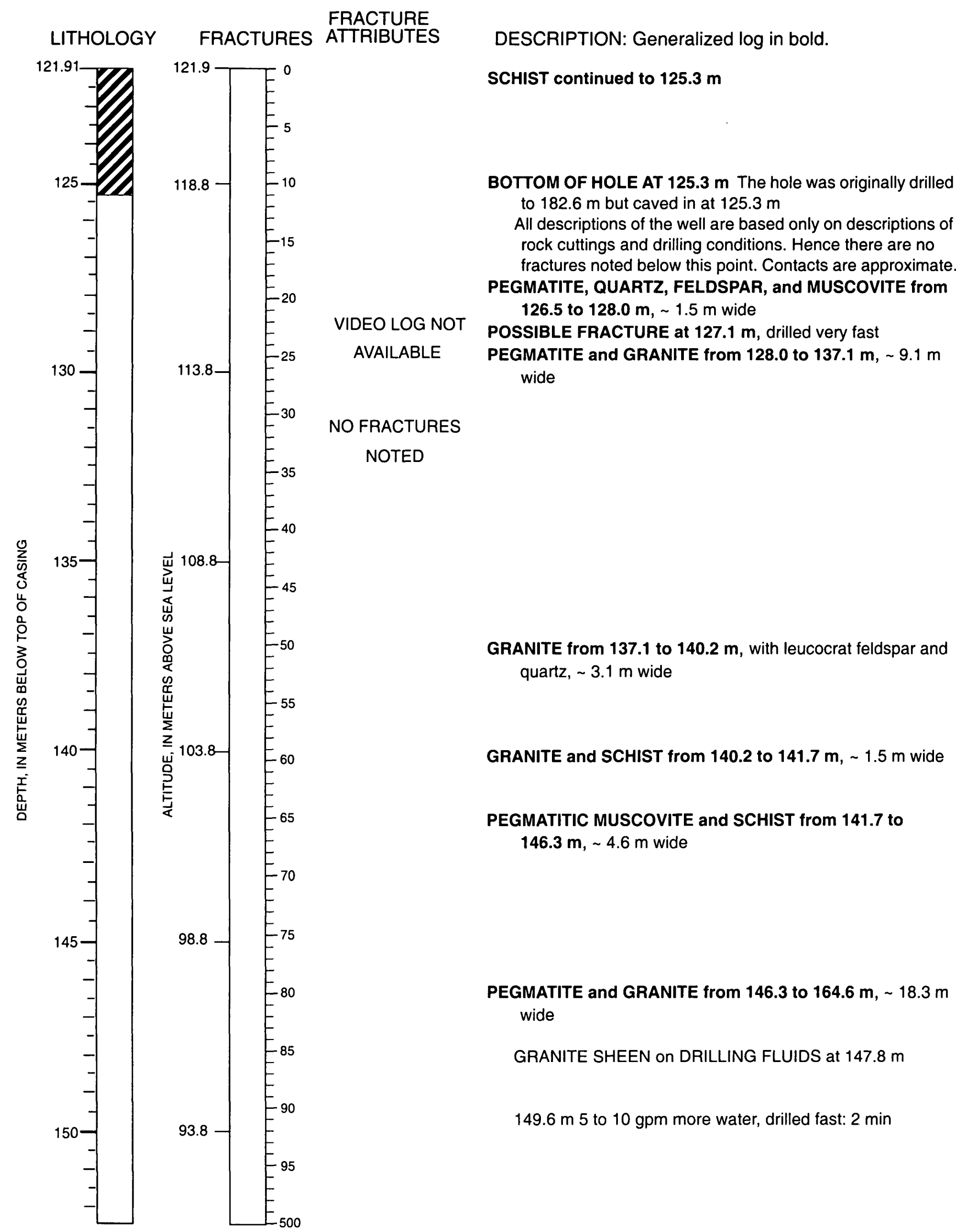

118 Lithology and Fracture Characterization From Drilling Investigations in the Mirror Lake Area, Grafton County, New Hampshire 
FS6 Continued

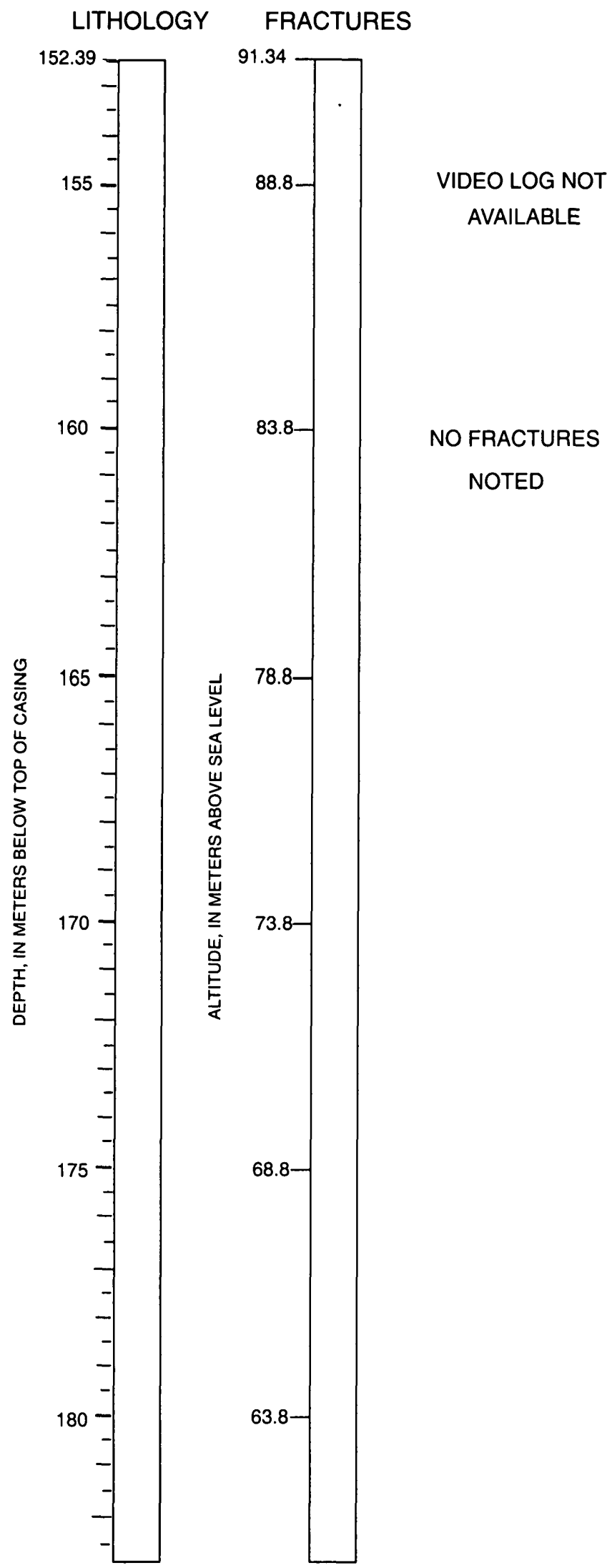

DESCRIPTION: Generalized log in bold.

PEGMATITE and GRANITE continued to $164.6 \mathrm{~m}$

GRANITE from 164.6 to $166.1 \mathrm{~m}, \sim 1.5 \mathrm{~m}$ wide

PEGMATITE and GRANITE from 166.1 to $167.6 \mathrm{~m}$, muscovite, biotite flakes, $\sim 1.5 \mathrm{~m}$ wide,

GRANITE and PEGMATITE from 167.6 to $170.7 \mathrm{~m}$, muscovite, $\sim 3.1 \mathrm{~m}$ wide

GRANITE and SCHIST from 170.7 to $172.2 \mathrm{~m}, \sim 1.5 \mathrm{~m}$ wide

GRANITE and PEGMATITE from 172.2 to $173.7 \mathrm{~m}, \sim 1.5 \mathrm{~m}$ wide

FRACTURED ZONE or VERY SOFT at $173.7 \mathrm{~m}, 12 \mathrm{gpm}$

SCHIST and GRANITE from 173.7 to $175.3 \mathrm{~m}$, epidote/bluegreen mineral in a granite matrix, $\sim 1.6 \mathrm{~m}$ wide

SCHIST from 175.3 to $176.8 \mathrm{~m}$, mafic rich, fine grains, looks more like granite, $\sim 1.5 \mathrm{~m}$ wide

GRANITE and SCHIST from 176.8 to $179.8 \mathrm{~m}$, pegmatite, muscovite and biotite, $\sim 3.0 \mathrm{~m}$ wide

GRANITE and PEGMATITE from 179.8 to $182.9 \mathrm{~m}, \sim 3.1 \mathrm{~m}$

BOTTOM of DRILLED HOLE at $182.6 \mathrm{~m}$ 


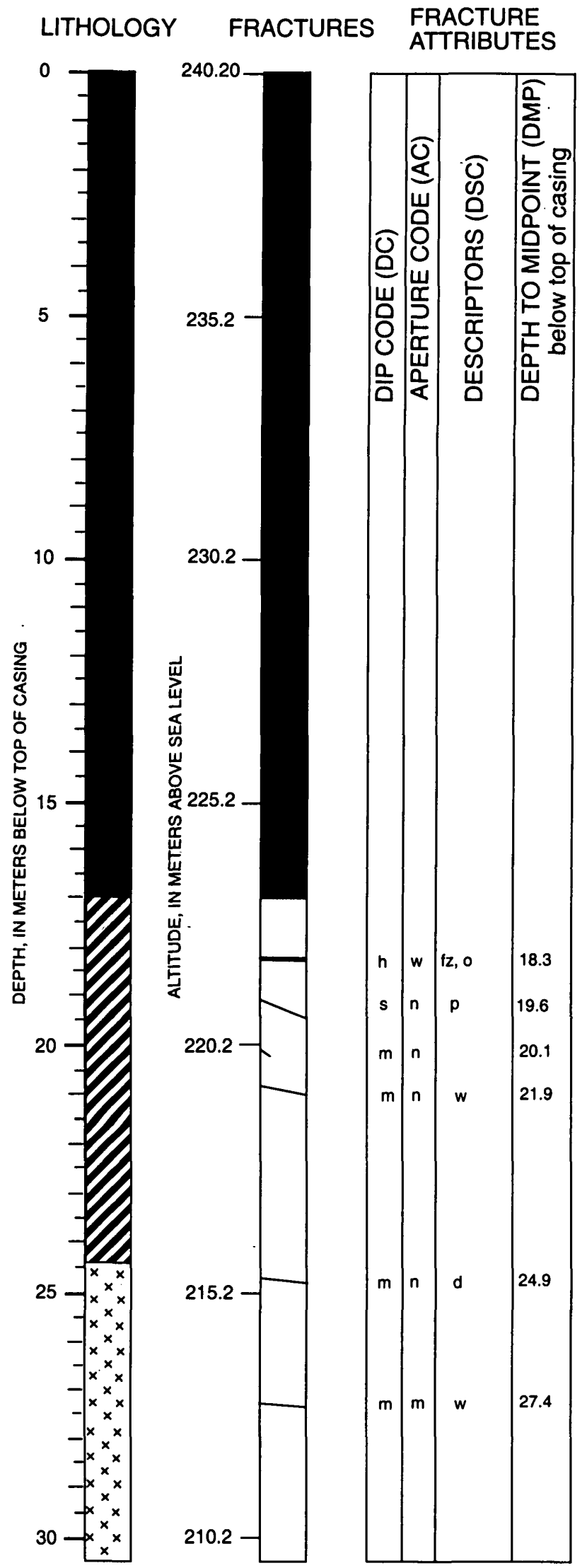

DESCRIPTION: Generalized log in bold.

SAND from 0.6 to $5.2 \mathrm{~m}$, fine to medium sand, gravel, no clay or silt, $\sim 4.6 \mathrm{~m}$ wide

TILL from 5.2 to $13.8 \mathrm{~m} \sim 8.6 \mathrm{~m}$ wide

Very cobbly or rocky drilling from 8.8 to $9.4 \mathrm{~m}, \sim 0.6 \mathrm{~m}$ wide

BEDROCK SURFACE at $13.8 \mathrm{~m}$

BOTTOM OF CASING at $16.9 \mathrm{~m}$

SCHIST from 16.9 to $\mathbf{2 4 . 5} \mathrm{m}$, dark reddish brown, very fine grained, near vertical foliation, quartz-rich, sulfitic, sillimanite-muscovite-biotite schist, $\sim 7.6 \mathrm{~m}$ wide

( 2 parallel fractures have white precipitate that emanated from the fractures and was deposited in several vertical lines above the fractures)

GRANITE from 24.5 to $61.6 \mathrm{~m}$, muscovite-quartz-rich granite, medium to coarse grained, some muscovite minerals measure up to 1 to $2 \mathrm{~cm}$ in length, $\sim 37.1 \mathrm{~m}$ wide

(white precipitate emanated from the fracture and was deposited in two vertical lines above the fracture) 


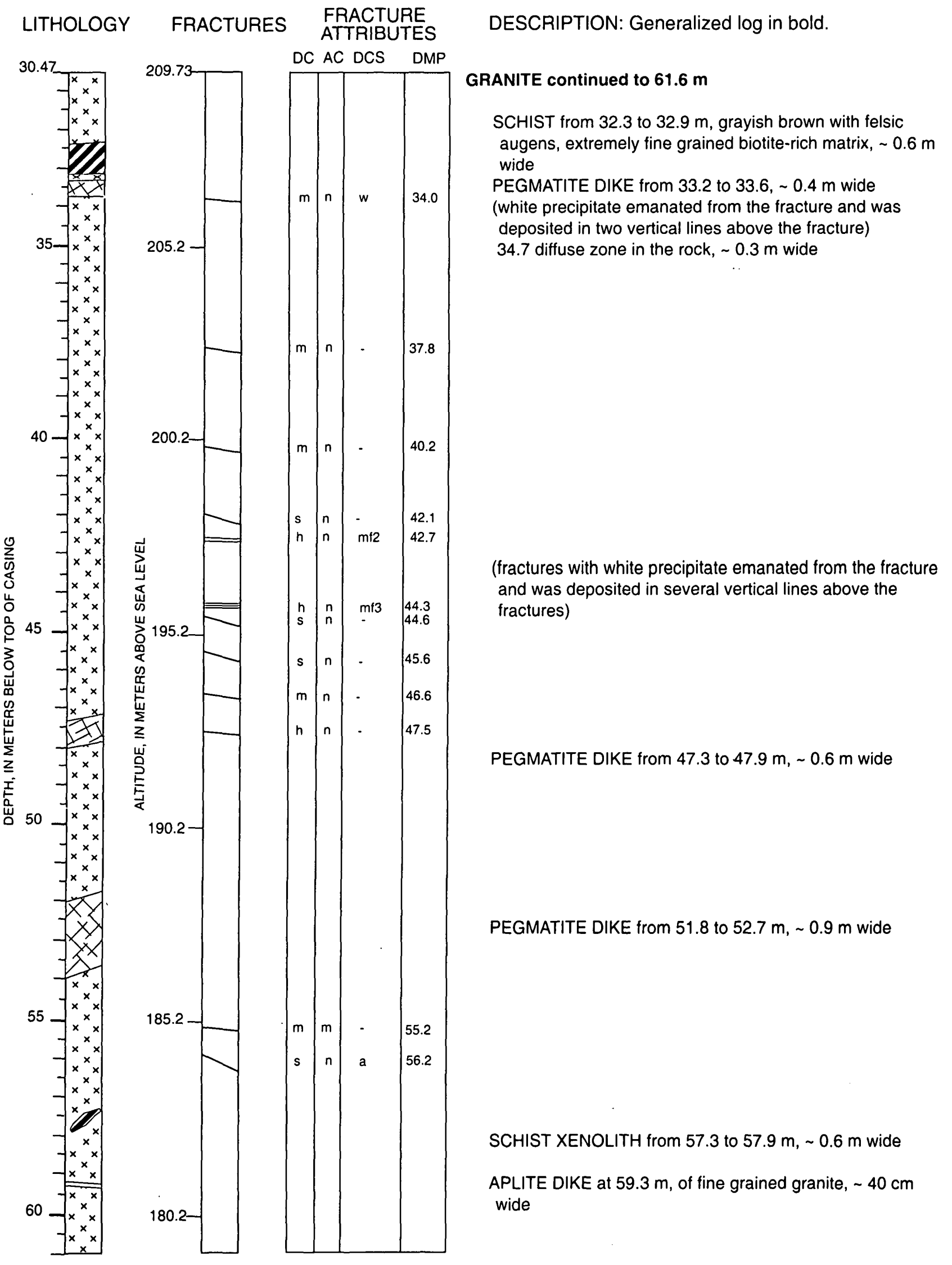


FSE1 Continued

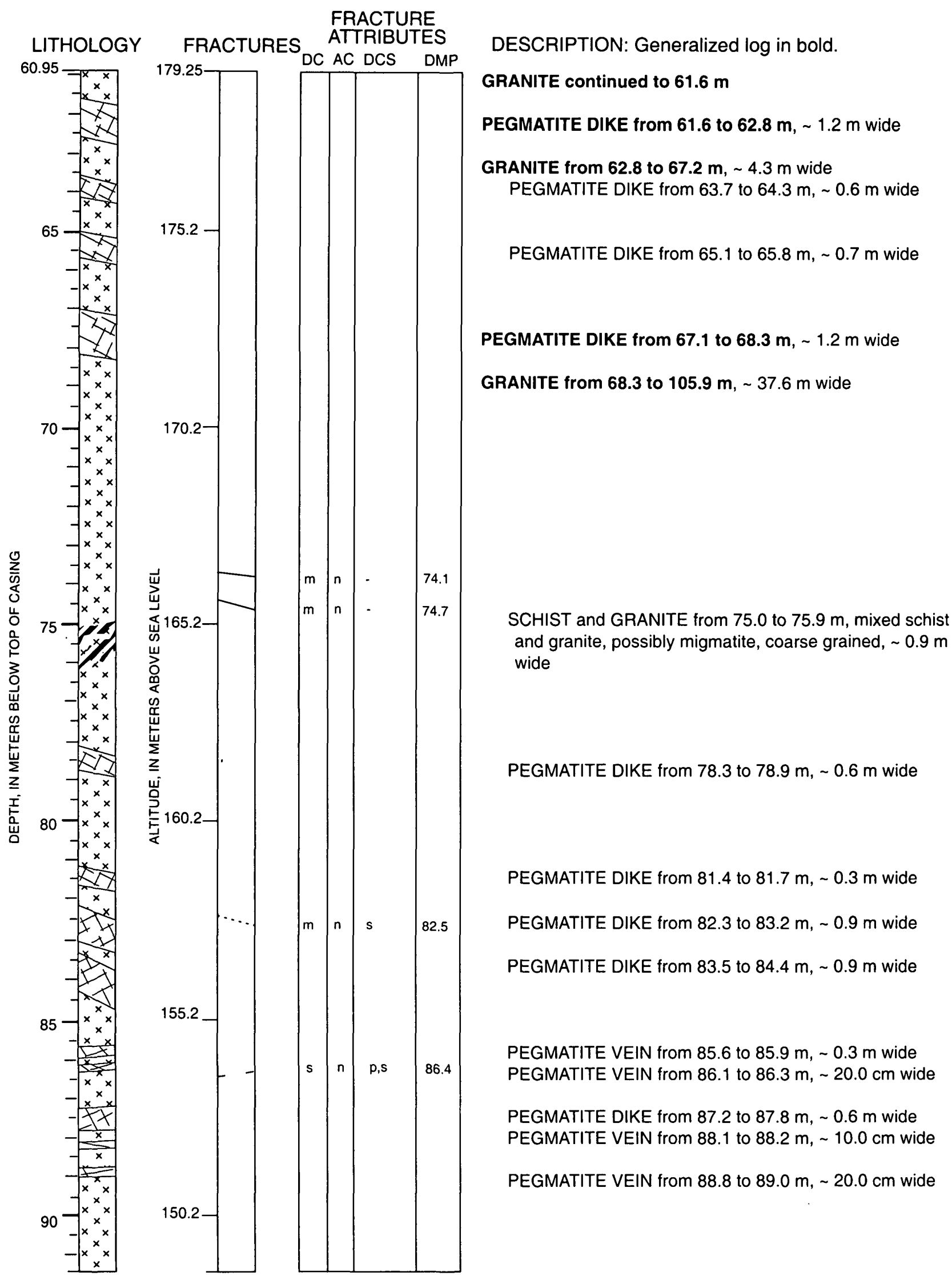


FSE1 Continued

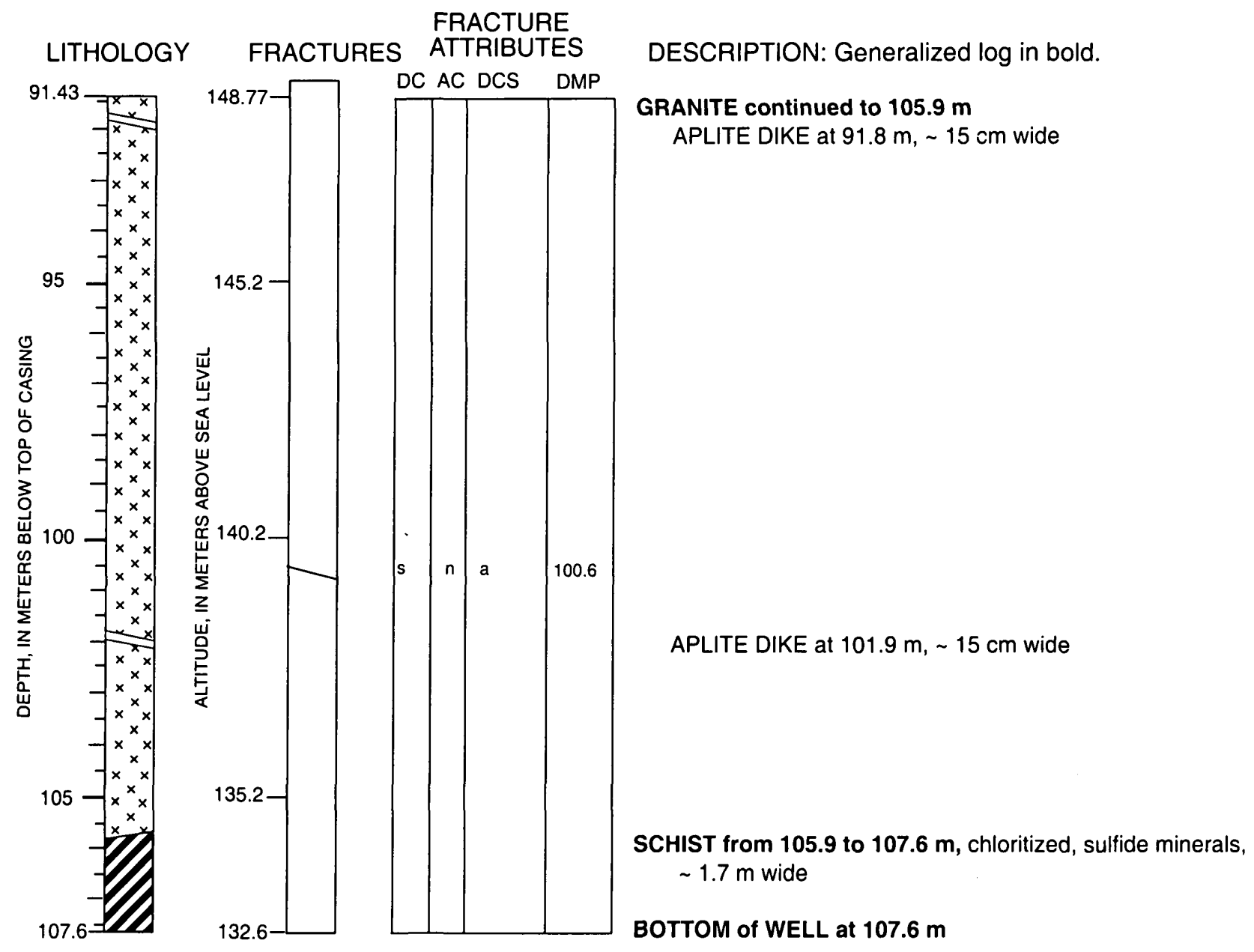


WELL NAME: FSE2

\section{LITHOLOGY}

$$
0
$$

0

7$$
5
$$

5

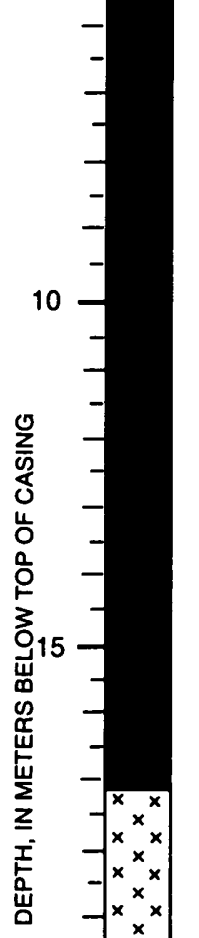

20

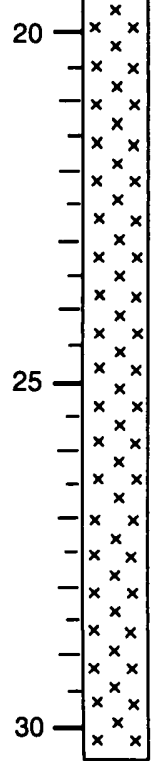

241.06

231.1

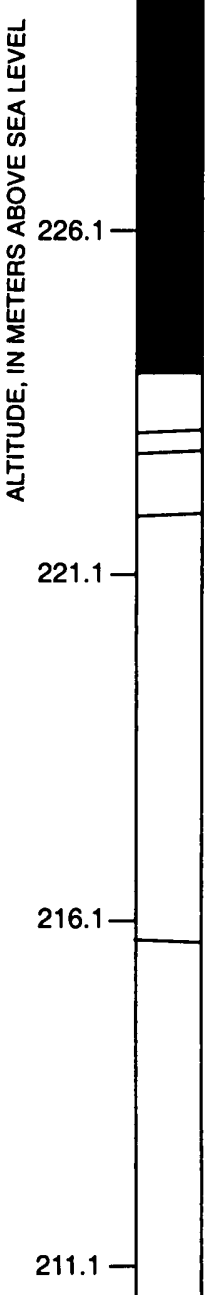

FRACTURE

ATTRIBUTES

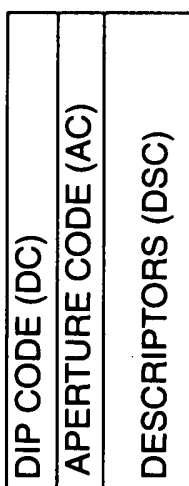

高

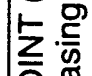

然

능

$\sum$

은

든

㟧
SAND and GRAVEL from 4.3 to 6.7 , coarse gravel, $\sim 2.4 \mathrm{~m}$ wide

TILL from 6.7 to $7.3 \mathrm{~m}$, clayey silty till with small gravels, $0.6 \mathrm{~m}$ wide
BEDROCK SURFACE at $15.1 \mathrm{~m}$

BOTTOM OF CASING at $17.07 \mathrm{~m}$

GRANITE from 17.1 to 62.0 , medium to fine grained, $44.9 \mathrm{~m}$ wide

( $\sim 20 \mathrm{~cm}$ long, ( $\sim 1 \mathrm{~cm}$ wide) vertical white precipitate lines eminating from fractures at 18.0, 18.3, and 25.4)

GRANITE from 17.1 to $20.1 \mathrm{~m}$, yellowish brown, $\sim 3.03 \mathrm{~m}$ wide

GRANITE from 20.1 to $35.0 \mathrm{~m}$, yellowish white granite, gradual contacts, $\sim 14.9 \mathrm{~m}$ wide granite, $\sim 1.5 \mathrm{~m}$ wide
GRANITE from 29.0 to $30.5 \mathrm{~m}$, fine grained, muscovite, 
FSE2 Continued

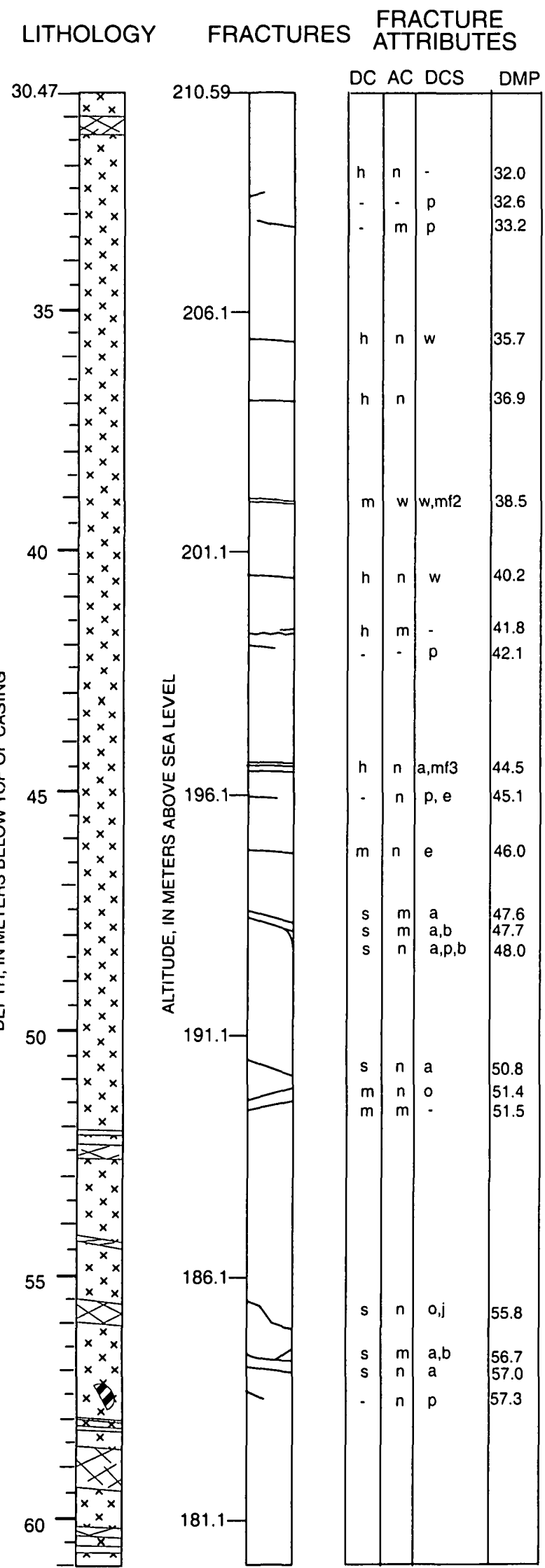

DESCRIPTION: Generalized log in bold.

\section{GRANITE continued to $62.0 \mathrm{~m}$}

PEGMATITE from 31.0 to $31.4 \mathrm{~m}, \sim 0.4 \mathrm{~m}$ wide

GRANITE from 35.0 to $42.0 \mathrm{~m}$, extremely fine grained, pale green, $\sim 7.0 \mathrm{~m}$ wide

GRANITE from 42.0 to $47.2 \mathrm{~m}$, grayish, altered-looking, fine grained, $\sim 5.2 \mathrm{~m}$ wide

GRANITE from 47.2 to $48.0 \mathrm{~m}$, yellowish white biotitemuscovite, altered, $\sim 0.8 \mathrm{~m}$ wide

BIOTITE SCHLIEREN at $49.1 \mathrm{~m}$ in granite (not shown)

PEGMATITE DIKE from 52.4 to $52.7 \mathrm{~m}, \sim 0.3 \mathrm{~m}$ wide PEGMATITE VEIN at $52.1 \mathrm{~m}, \sim 15 \mathrm{~cm}$

PEGMATITE VEIN at $54.3 \mathrm{~m}, \sim 5 \mathrm{~cm}$ wide

PEGMATITE DIKE from 55.5 to $56.1 \mathrm{~m}, \sim 0.6 \mathrm{~m}$ wide

SCHIST XENOLITH at $57.3 \mathrm{~m}$, fine grained, $\sim 0.3 \mathrm{~m}$ long PEGMATITE VEIN at $58.0 \mathrm{~m}$, narrow, diffuse, $\sim 4.0 \mathrm{~cm}$ wide PEGMATITE VEIN at $58.2 \mathrm{~m}, \sim 20 \mathrm{~cm}$ wide

PEGMATITE DIKE from 58.6 to $59.5 \mathrm{~m}, \sim 0.9 \mathrm{~m}$ wide PEGMATITE DIKE from 60.2 to $60.4 \mathrm{~m}, \sim 0.2 \mathrm{~m}$ wide APLITE VEIN at $60.7 \mathrm{~m}, \sim 15 \mathrm{~cm}$ wide 
FSE2 Continued

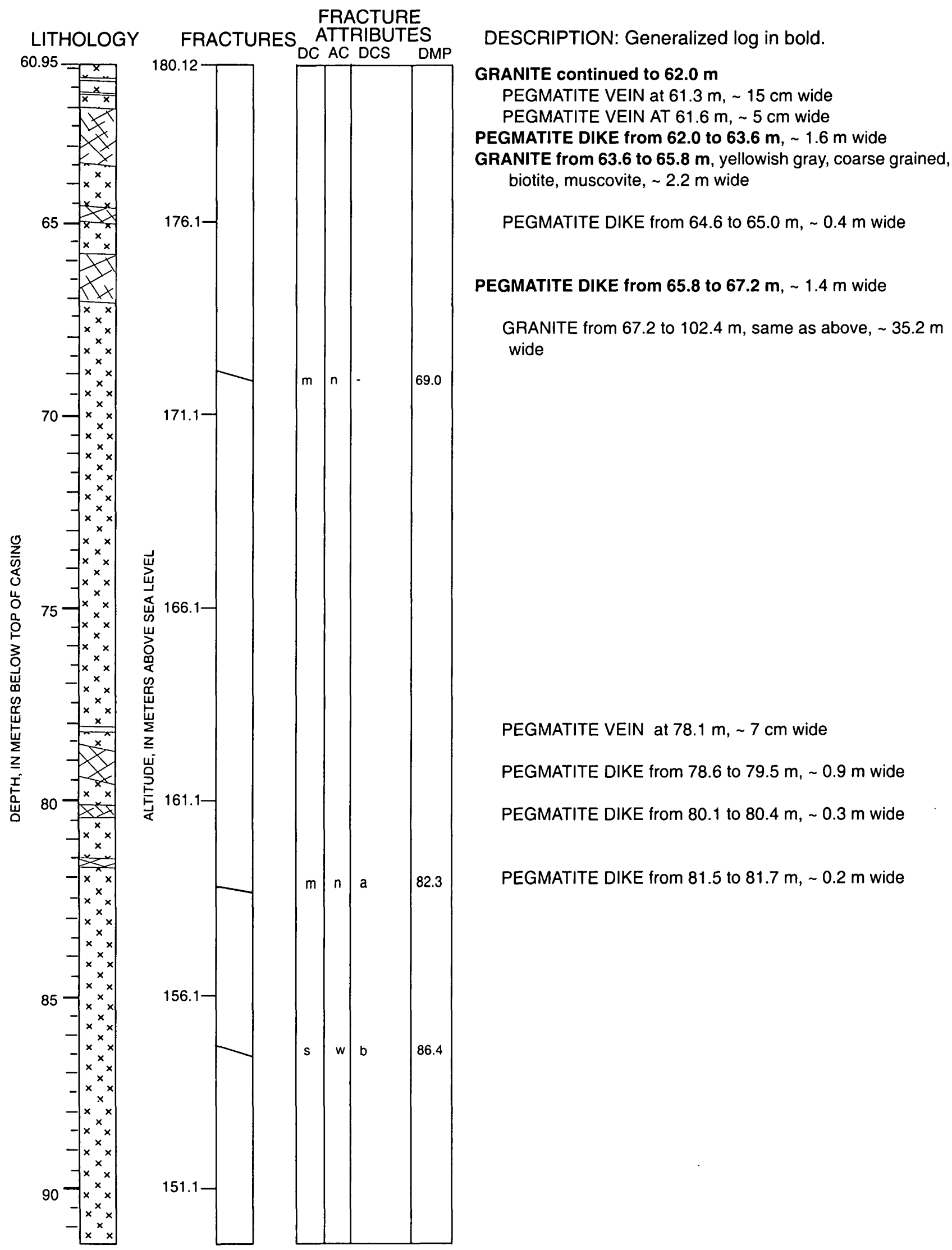


FSE2 Continued

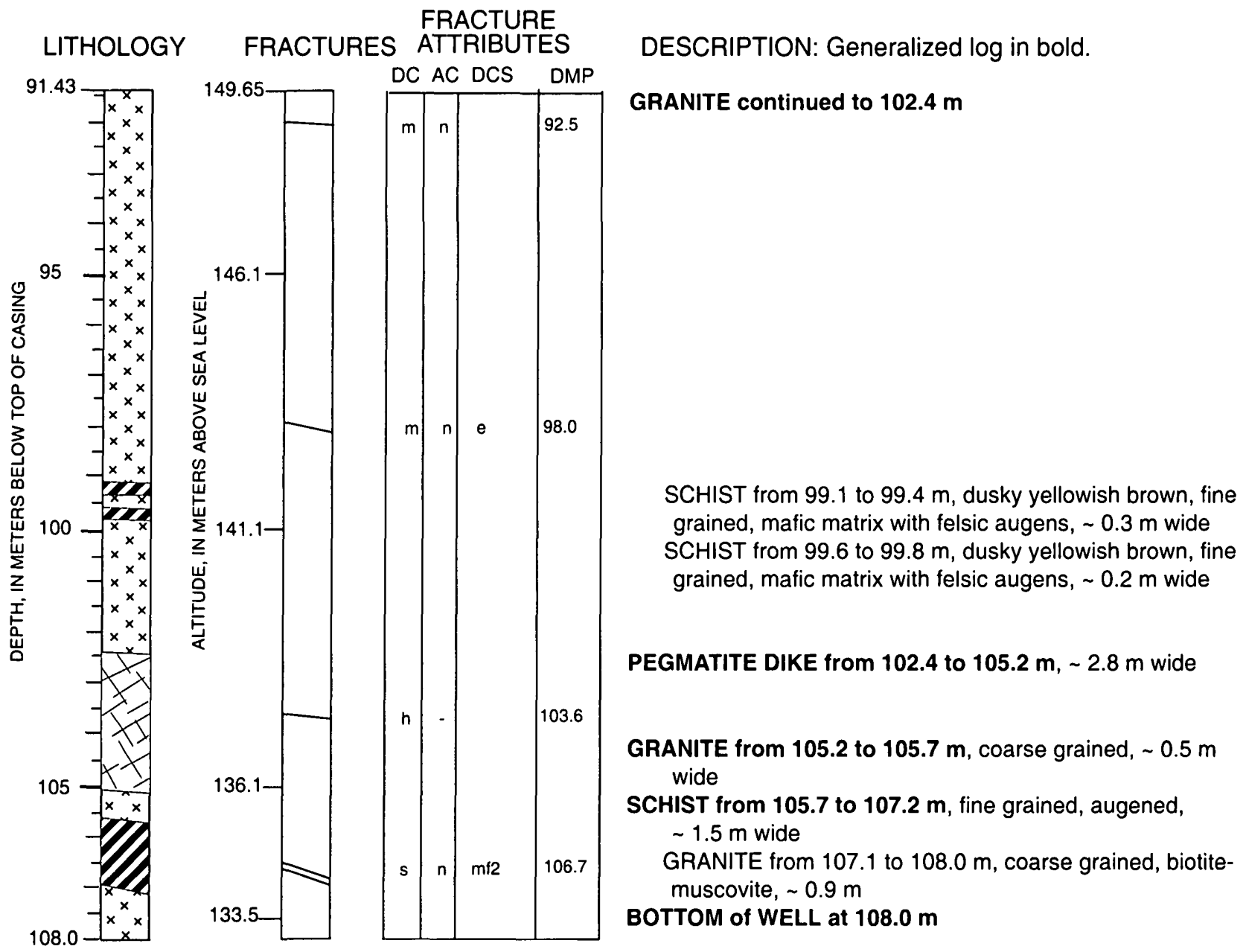


WELL NAME: FSE3

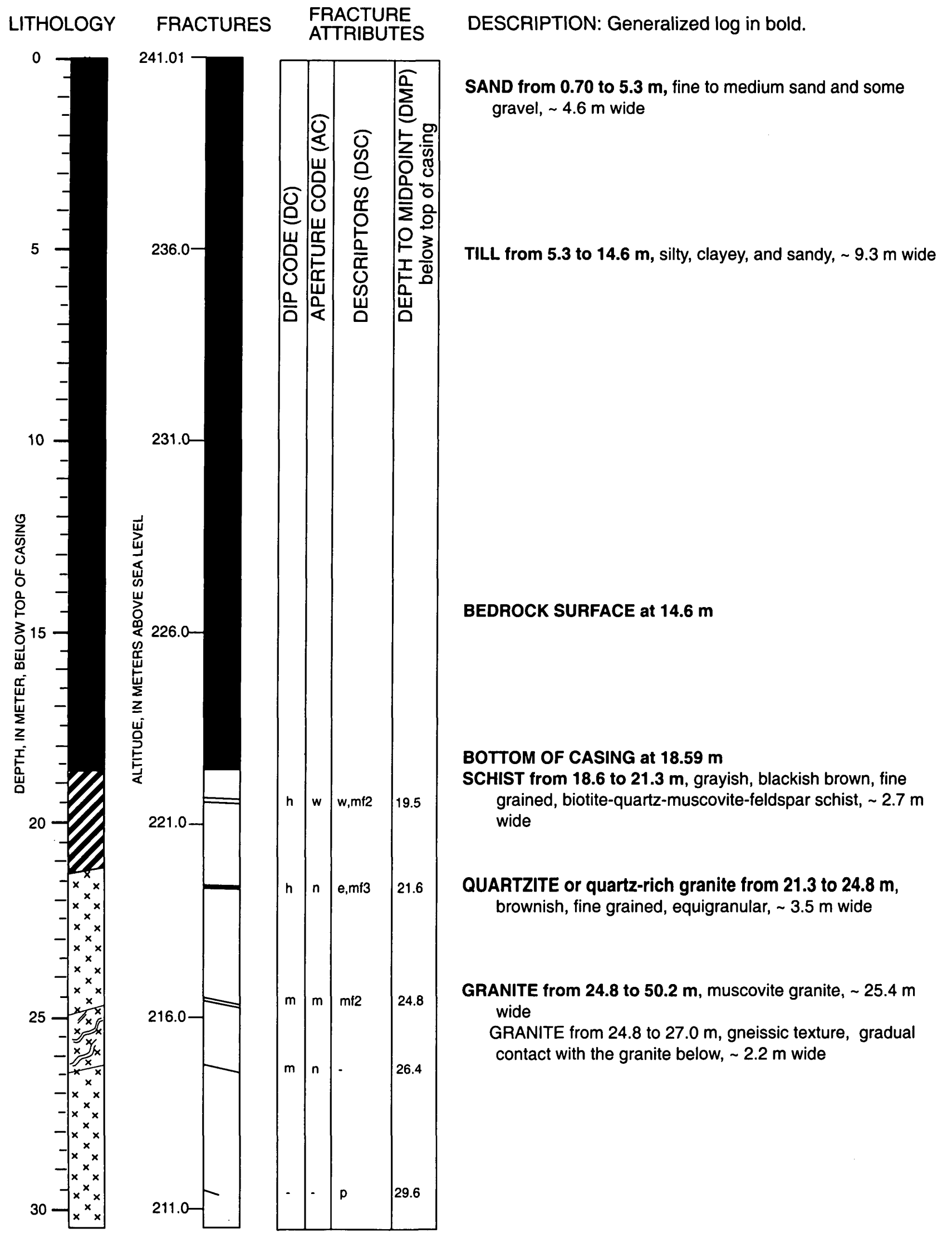


FSE3 Continued

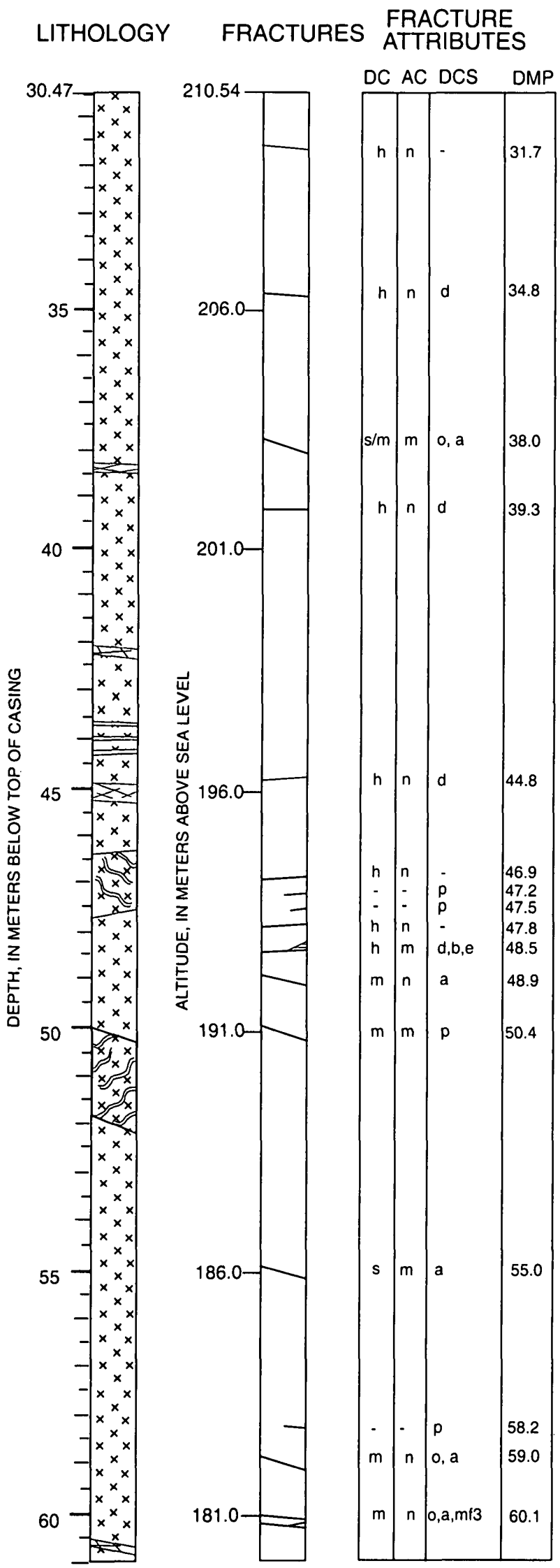

DESCRIPTION: Generalized log in bold.

GRANITE continued to $50.2 \mathrm{~m}$

PEGMATITE VEIN from 38.3 to $38.5 \mathrm{~m}, \sim 0.2 \mathrm{~m}$ wide

PEGMATITE VEIN at $42.1 \mathrm{~m}, \sim 5 \mathrm{~cm}$ wide

PEGMATITE VEIN at $43.6 \mathrm{~m}, \sim 2 \mathrm{~cm}$ wide

PEGMATITE VEIN at $43.9 \mathrm{~m}, \sim 5 \mathrm{~cm}$ wide

PEGMATITE VEIN at $44.2 \mathrm{~m}, \sim 4 \mathrm{~cm}$ wide

PEGMATITE DIKE from $44.8 \mathrm{~m}$, to $45.3 \mathrm{~m}, \sim 0.5 \mathrm{~m}$ wide

SCHIST/GNEISS from 46.3 to $47.2 \mathrm{~m}$, dusky greenish brown, coarse grained, $\sim 0.9 \mathrm{~m}$ wide

SCHIST from $\mathbf{5 0 . 2}$ to $\mathbf{5 2 . 0} \mathrm{m}$, gneissic texture, $\sim 1.8 \mathrm{~m}$ wide

GRANITE from 52.0 to $106.2 \mathrm{~m}$, greenish grayish white biotitemuscovite granite, $\sim 54.2 \mathrm{~m}$ wide 
FSE3 Continued

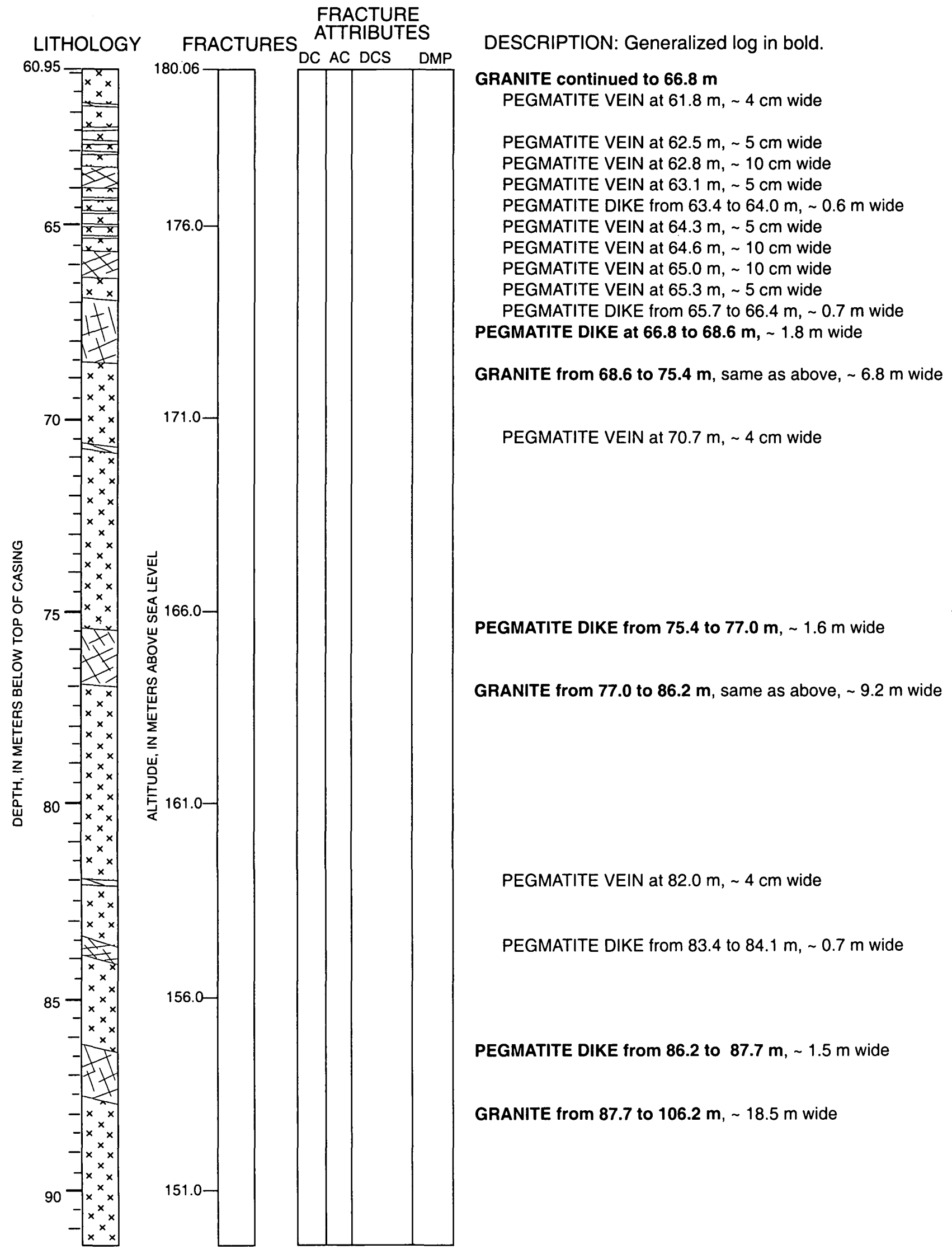


FSE3 Continued

\section{FRACTURE}

LITHOLOGY FRACTURES ATTRIBUTES

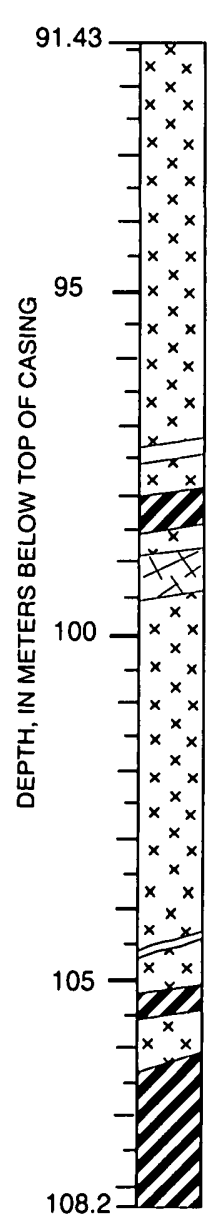

DC AC DCS

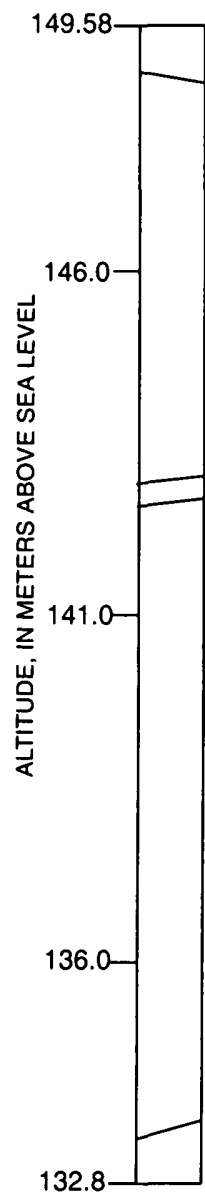

DMP

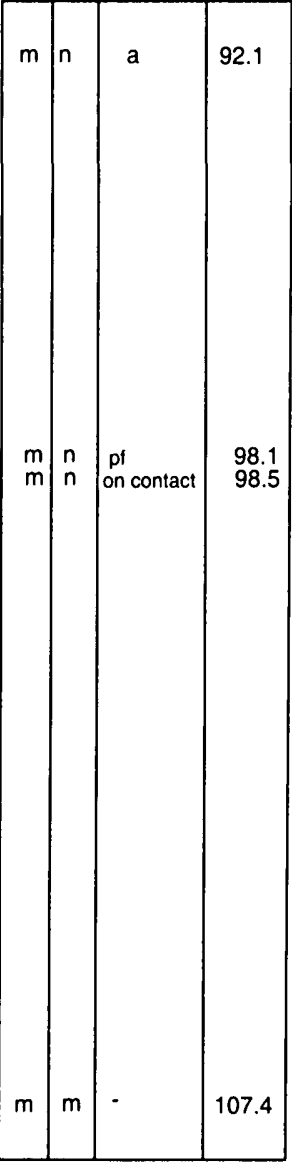

DESCRIPTION: Generalized log in bold.

\section{GRANITE continued to $106.2 \mathrm{~m}$}

APLITE DIKE from 97.3 to $97.6 \mathrm{~m}, \sim 0.3 \mathrm{~m}$ wide

SCHIST from 98.0 to $98.5 \mathrm{~m}$, dusky greenish brown, extremely fine grained $\sim 0.5 \mathrm{~m}$ wide

PEGMATITE DIKE from 98.8 to $99.4 \mathrm{~m}, \sim 0.4 \mathrm{~m}$ wide
PEGMATITE VEIN at $104.5 \mathrm{~m}, \sim 5 \mathrm{~cm}$ wide

SCHIST from 105.2 to $105.5 \mathrm{~m}$, biotite- and quartz- rich with some sulfide minerals and trace garnet, extremely fine grained, $\sim 0.3 \mathrm{~m}$ wide

SCHIST from 106.2 to $108.2 \mathrm{~m}$, dusky greenish brown biotitequartz, some sulfide minerals, trace garnet, $\sim 2.0 \mathrm{~m}$ wide 
FRACTURE ATTRIBUTES

$$
0
$$

07

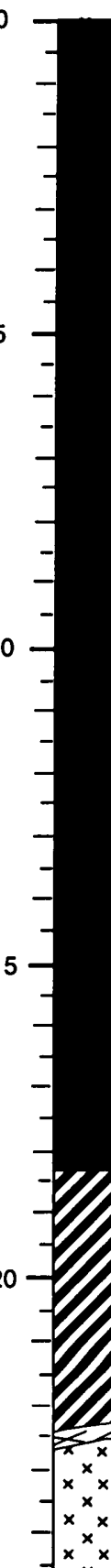

25

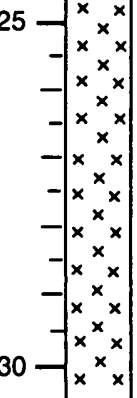

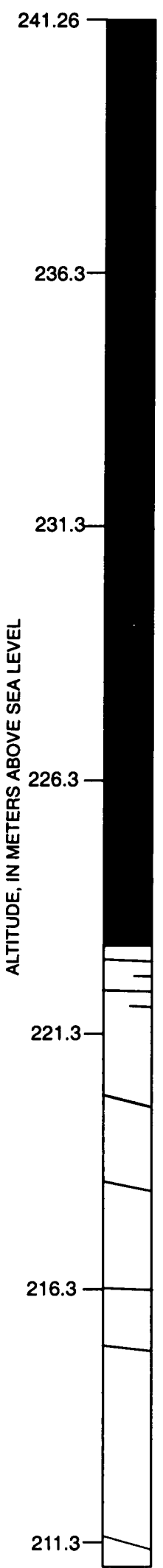

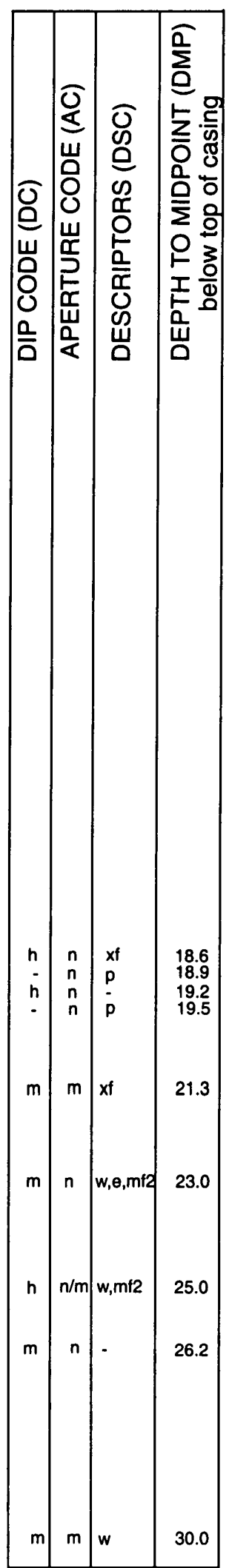

DESCRIPTION: Generalized log in bold.

OVERBURDEN, UNDIFFERENTIATED, from 0.55 to

$14.8 \mathrm{~m}, \sim 14.5 \mathrm{~m}$ wide

BEDROCK SURFACE at $14.9 \mathrm{~m}$

BOTTOM OF CASING at $18.3 \mathrm{~m}$

SCHIST from 18.3 to $22.2 \mathrm{~m}$, dusky yellowish reddish brown, extremely fine grained $\sim 3.9 \mathrm{~m}$ wide

PEGMATITE DIKE from 22.2 to $22.6 \mathrm{~m}$, creamy white, $\sim 0.4 \mathrm{~m}$ wide

GRANITE from 22.6 to $60.1 \mathrm{~m}$, yellowish light gray, biotitemuscovite medium to coarse grained, $\sim 37.5 \mathrm{~m}$ wide 
FSE4 Continued

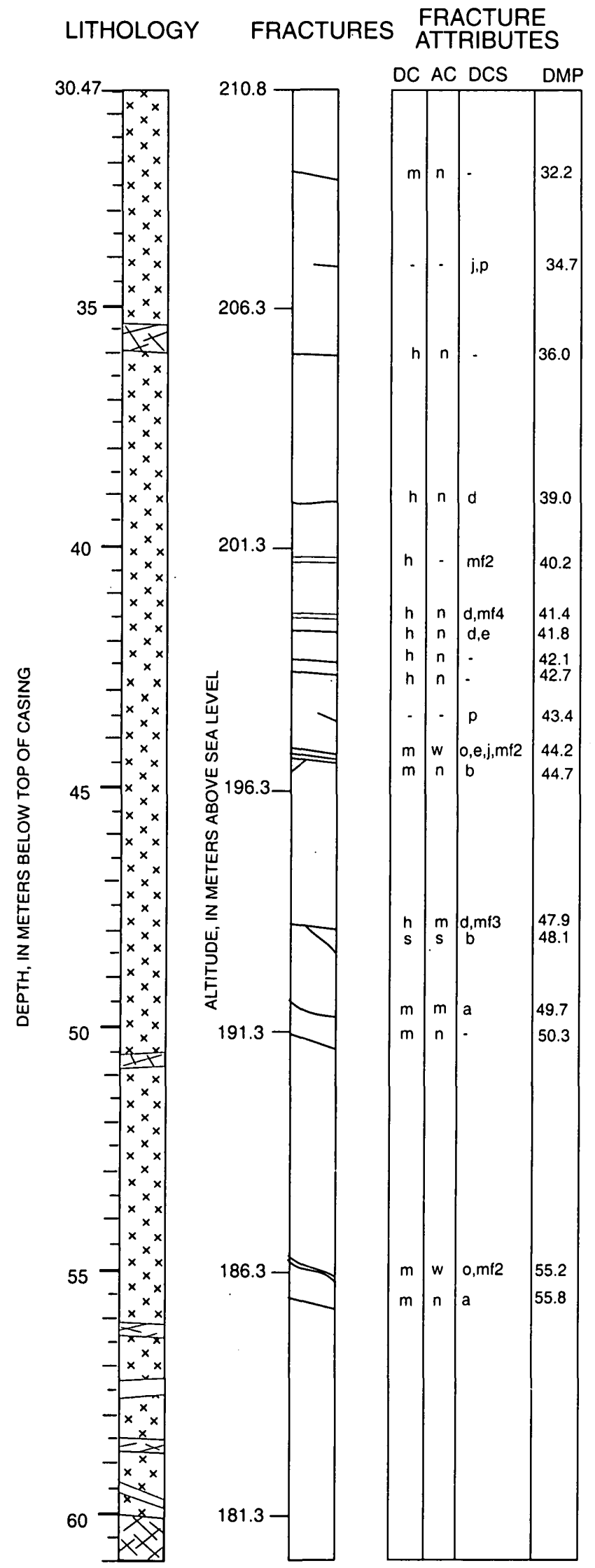

DESCRIPTION: Generalized log in bold.

GRANITE continued to $60.1 \mathrm{~m}$, coarse grained

PEGMATITE DIKE from 35.3 to $36.0 \mathrm{~m}, \sim 0.7 \mathrm{~m}$ wide

GRANITE from 39.6 to $42.7 \mathrm{~m}$, altered, $\sim 3.1 \mathrm{~m}$ wide

PEGMATITE VEIN at $50.6 \mathrm{~m}, \sim 7 \mathrm{~cm}$ wide

PEGMATITE from 56.6 to $56.9 \mathrm{~m}, \sim 0.3 \mathrm{~m}$ wide

APLITE DIKE from 57.3 to $57.6 \mathrm{~m}, \sim 0.3 \mathrm{~m}$ wide

PEGMATITE DIKE from 58.5 to $58.7 \mathrm{~m}, \sim 0.2 \mathrm{~m}$ wide

APLITE DIKE from 59.4 to $59.7 \mathrm{~m}, \sim 0.3 \mathrm{~m}$ wide

PEGMATITE AND APLITE from 60.1 to $64.9 \mathrm{~m}, \sim 4.8 \mathrm{~m}$ wide

PEGMATITE from 60.1 to $61.6 \mathrm{~m}, \sim 1.6 \mathrm{~m}$ wide 
FSE4 Continued

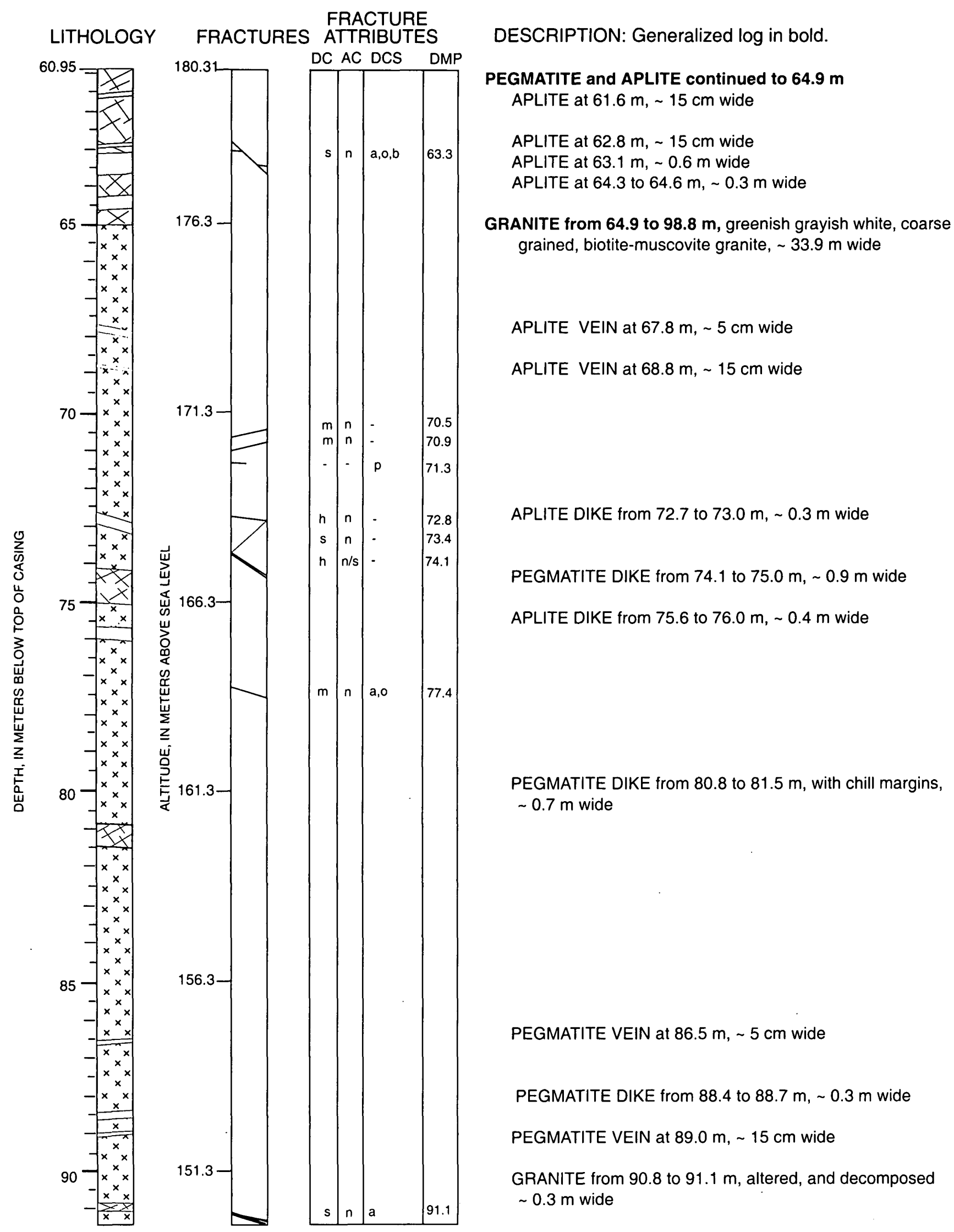


FSE4 Continued

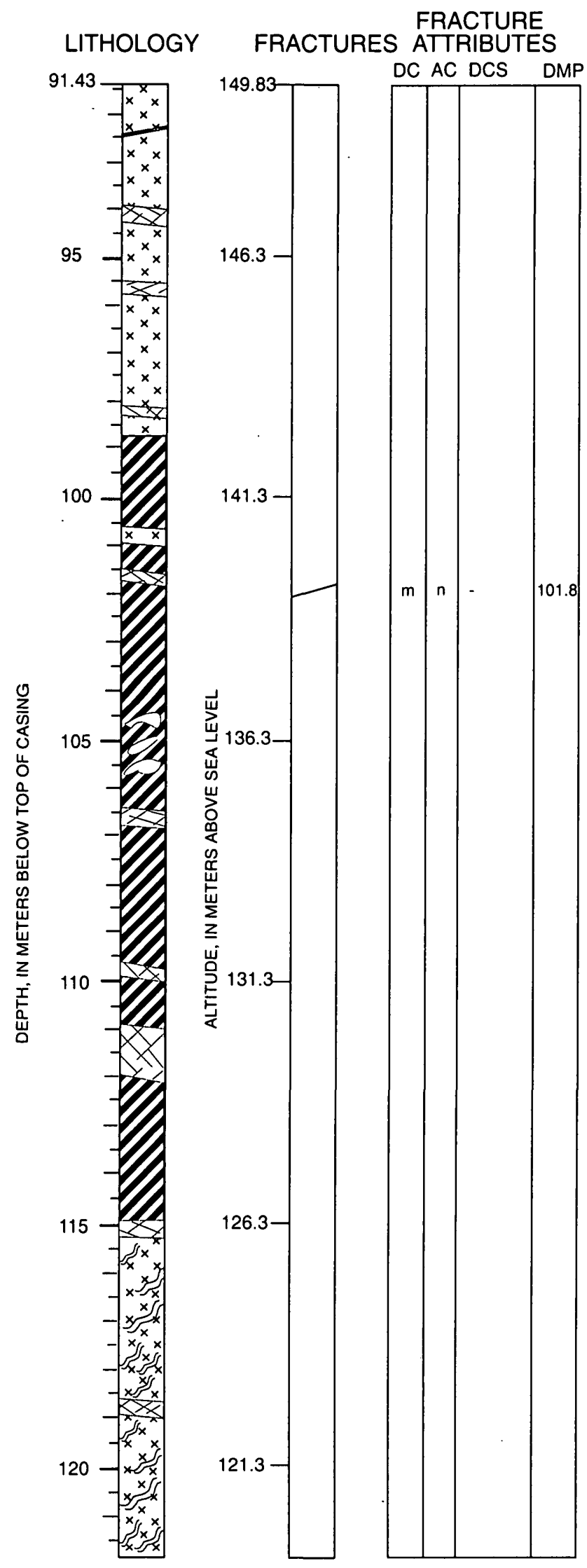

DESCRIPTION: Generalized log in bold.

GRANITE continued to $98.8 \mathrm{~m}$

GRANITE from $\sim 92.0$ to $98.8 \mathrm{~m}$, fine grained, gradual

upper contact, $\sim 6.8 \mathrm{~m}$ wide

BIOTITE SCHLIEREN at $92.5 \mathrm{~m}$

PEGMATITE DIKE from 93.9 to $94.3 \mathrm{~m}, \sim 0.4 \mathrm{~m}$ wide

PEGMATITE DIKE from 95.5 to $95.7 \mathrm{~m}, \sim 0.2 \mathrm{~m}$ wide

PEGMATITE DIKE from 98.1 to $98.3 \mathrm{~m}, \sim 0.2 \mathrm{~m}$ wide SCHIST from 98.8 to $110.9 \mathrm{~m}$, greenish brown, coarse grained to gneissic, with augens and felsic-rich zones $\sim 12.1 \mathrm{~m}$ wide

GRANITE DIKE from 100.6 to $100.9 \mathrm{~m}, \sim 0.3 \mathrm{~m}$ wide

PEGMATITE DIKE from 101.5 to $101.8 \mathrm{~m}, \sim 0.3 \mathrm{~m}$

FELSIC RICH ZONE from 104.6 to $106.0 \mathrm{~m}, \sim 1.4 \mathrm{~m}$ wide

PEGMATITE DIKE from 106.4 to $106.7 \mathrm{~m}, \sim 0.3 \mathrm{~m}$ wide

PEGMATITE DIKE from 109.7 to $110.0 \mathrm{~m}, \sim 0.3 \mathrm{~m}$ wide

PEGMATITE DIKE from 110.9 to $112.2 \mathrm{~m}, \sim 1.3 \mathrm{~m}$

SCHIST from 112.2 to $115.2 \mathrm{~m}, \sim 3.0 \mathrm{~m}$ wide

PEGMATITE from 114.9 to $115.2 \mathrm{~m}, \sim 0.3 \mathrm{~m}$ wide GNEISS from 115.2 to $127.0 \mathrm{~m}$, gradual contacts, coarse grained muscovites and biotites, weak foliation, felsic-rich, $\sim 11.8 \mathrm{~m}$ wide

PEGMATITE DIKE from 118.6 to $119.0 \mathrm{~m}, \sim 0.4 \mathrm{~m}$ wide 
FSE4 Continued

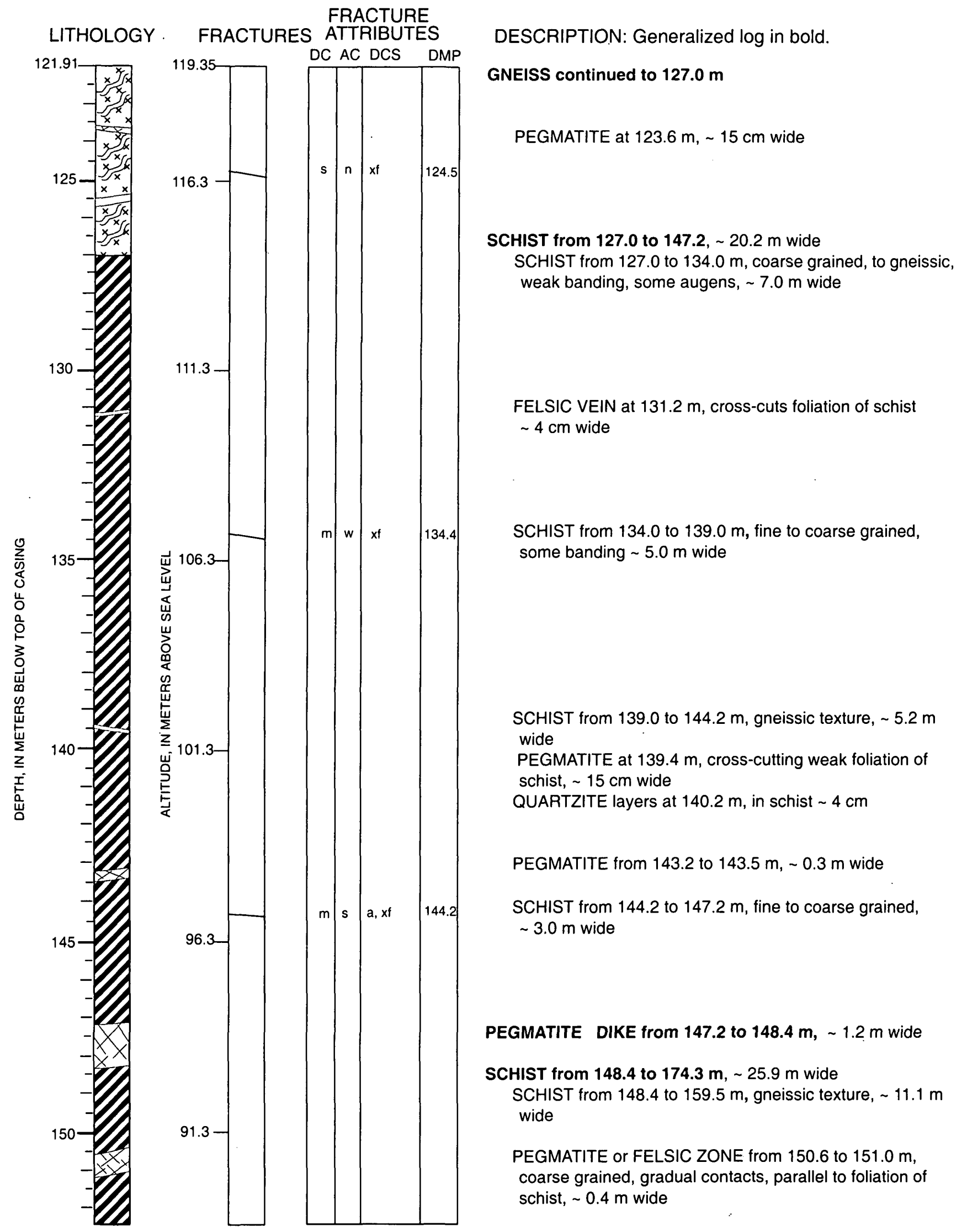


FSE4 Continued

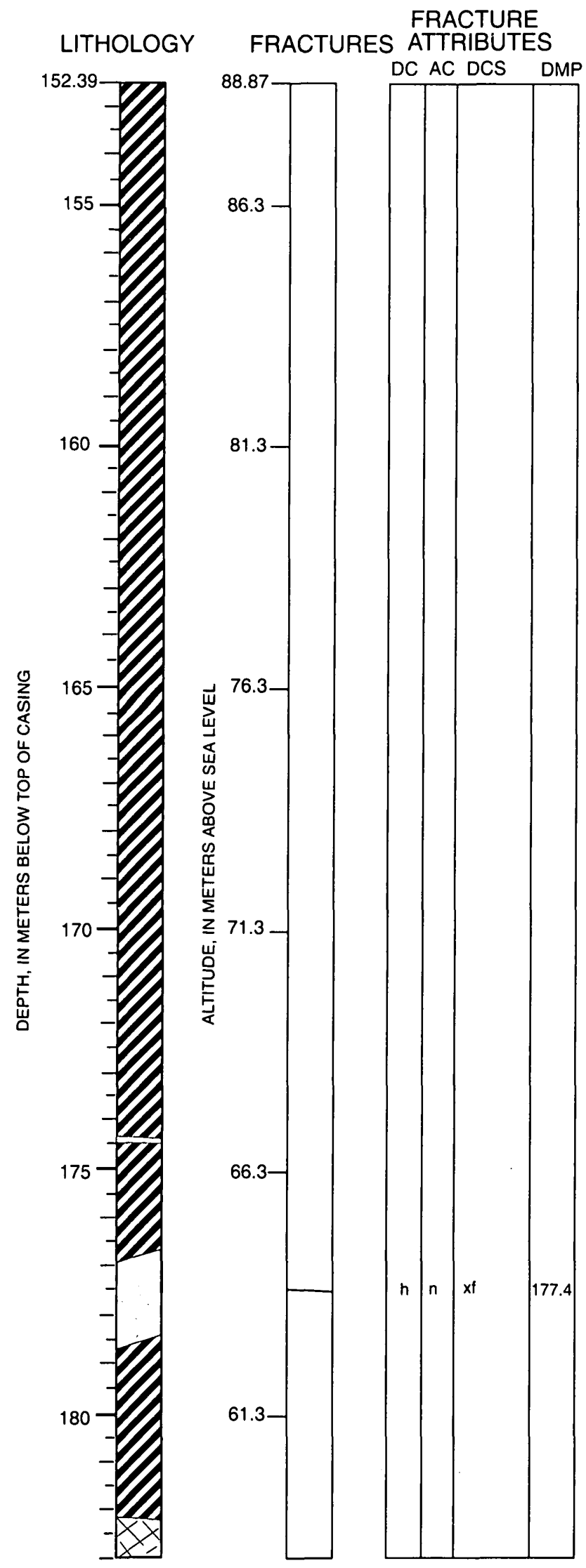

DESCRIPTION: Generalized log in bold.

SCHIST continued to $176.8 \mathrm{~m}$

SCHIST from 159.5 to $167.6 \mathrm{~m}$, fine grained, with felsic-rich zones, $\sim 8.1 \mathrm{~m}$ wide

SCHIST from 161.0 to $162.3 \mathrm{~m}$, extremely fine grained

schist with felsic stringers up to $2 \mathrm{~cm}$ in width, $\sim 1.3 \mathrm{~m}$ wide

SCHIST from 167.6 to $170.7 \mathrm{~m}$, biotite-rich matrix with felsic augens, $\sim 3.1 \mathrm{~m}$ wide

SCHIST from 170.7 to $174.3 \mathrm{~m}$, felsic rich, $\sim 3.6 \mathrm{~m}$ wide

SCHIST from 174.3 to $187.1 \mathrm{~m}$, gneissic to coarse grained, some zones very weakly foliated, $\sim 12.8 \mathrm{~m}$ wide FELSIC VEIN from 174.3 to $174.5 \mathrm{~m}, 0.2 \mathrm{~m}$ wide

QUARTZITE from 176.8 to $178.6 \mathrm{~m}$, orange, green, brown layers steeply dipping foliation fine grained, $\sim 1.8 \mathrm{~m}$ wide

SCHIST from 178.6 to $182.2 \mathrm{~m}, \sim 3.6 \mathrm{~m}$ wide

PEGMATITE or FELSIC ZONE from 182.2 to $183.2 \mathrm{~m}$, gradual contacts $\sim 1.0 \mathrm{~m}$ wide 


\section{FSE4 Continued}

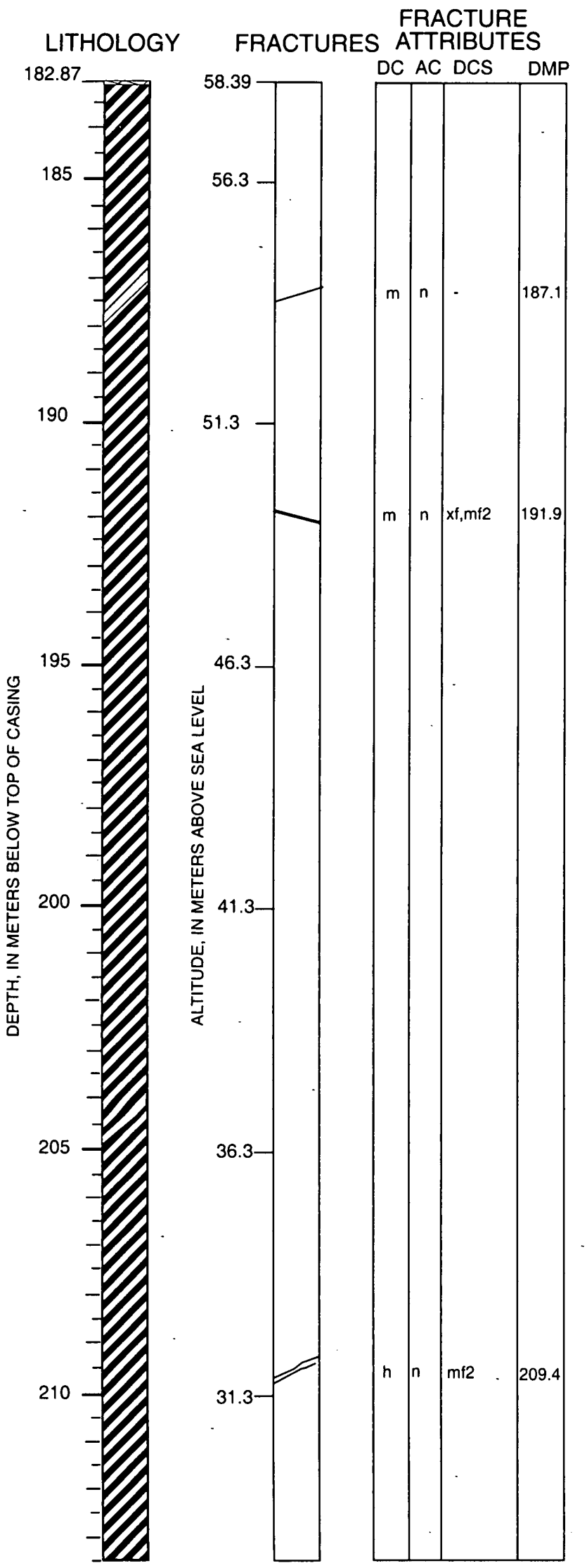

DESCRIPTION: Generalized log in bold.

PEGMATITE continued to $183.2 \mathrm{~m}$

SCHIST from to 183.2 to $187.1 \mathrm{~m}, \sim 3.9 \mathrm{~m}$ wide

QUARTZITE LAYERS from $\mathbf{1 8 7 . 1}$ to $\mathbf{1 8 8 . 7} \mathrm{m}$, green, yellow and brown layers, extremely fine grained, $\sim 1.6 \mathrm{~m}$ long

SCHIST from 188.7 to $229.2 \mathrm{~m}, \sim 40.5 \mathrm{~m}$ wide

SCHIST from 191.7 to $197.5 \mathrm{~m}$, felsic rich, fine to coarse grained, $\sim 5.8 \mathrm{~m}$ wide

SCHIST from 197.5 to $199.6 \mathrm{~m}$, fine grained biotite-rich matrix with felsic augens and weak banding, gradual contacts above and below, $\sim 2.1 \mathrm{~m}$ wide

SCHIST from 199.6 to $204.0 \mathrm{~m}$, felsic-rich, fine to coarse grained, $\sim 4.4 \mathrm{~m}$ wide

QUARTZITE from 204.0 to $204.8 \mathrm{~m}$, green, yellow and brown layers, $\sim 0.8 \mathrm{~m}$ long

SCHIST from 204.8 to $205.7 \mathrm{~m}$, gneissic texture, $\sim 0.9 \mathrm{~m}$ wide

SCHIST from 205.7 to $206.3 \mathrm{~m}$, fine grained, biotite-rich matrix with felsic augens, (gradual contacts above and below), $\sim 0.6 \mathrm{~m}$ wide

SCHIST from 206.3 to $208.5 \mathrm{~m}$, felsic-rich, some banding, mostly coarse grained

SCHIST from 208.5 to $214.0 \mathrm{~m}$, fine grained, biotite-rich matrix with felsic augens and some banding, fine to coarse grained, $\sim 5.5 \mathrm{~m}$ wide 
FSE4 Continued

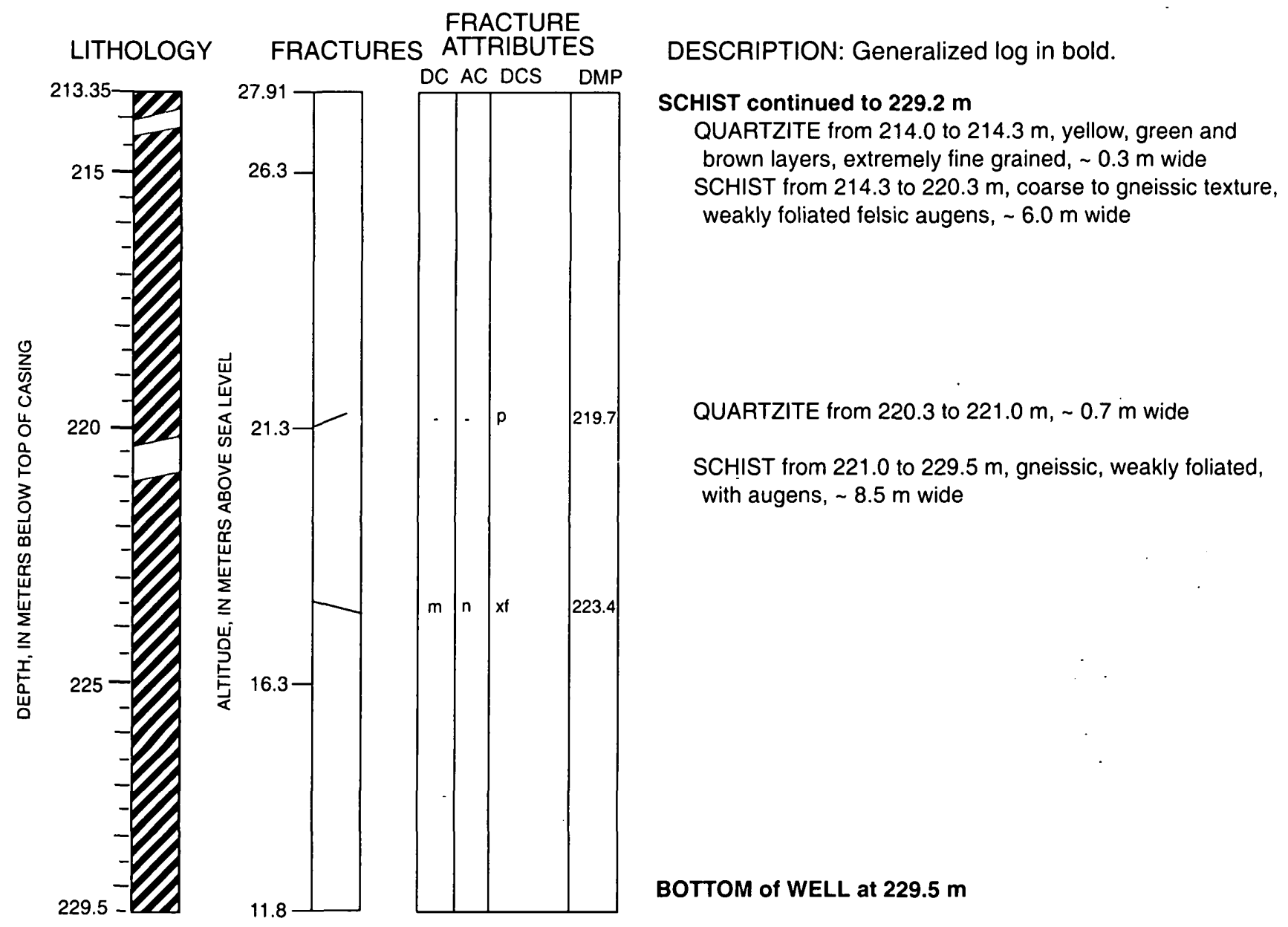


WELL NAME: FSE5

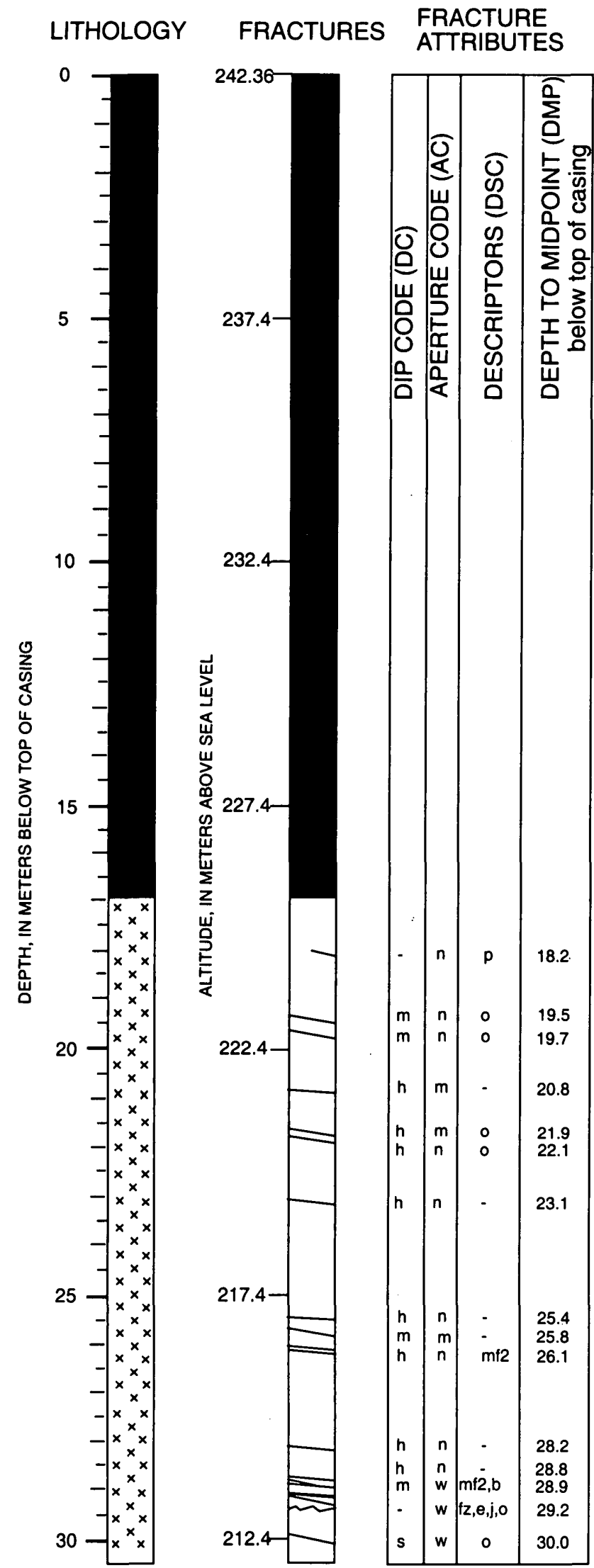

DESCRIPTION: Generalized log in bold.

SAND and COBBLES from 0.7 to $5.9 \mathrm{~m}$, brown, medium and coarse sand, $\sim 5.2 \mathrm{~m}$ wide

UNCONSOLIDATED DEPOSITS, from 5.9 to $7.4 \mathrm{~m}$, undifferentiated, $1.5 \mathrm{~m}$ wide

SAND from 7.4 to $9.8 \mathrm{~m}$, fine to coarse sand, $\sim 2.4 \mathrm{~m}$ wide

TILL from 9.8 to $13.2 \mathrm{~m}, \sim 3.4 \mathrm{~m}$ wide

BEDROCK SURFACE at $13.2 \mathrm{~m}$

BOTTOM OF CASING at $16.92 \mathrm{~m}$

GRANITE from 16.9 to $\mathbf{5 0 . 4} \mathrm{m}$, grayish white, fine to coarse grained, weakly foliated, biotite-muscovite granite with few to trace garnets, $\sim 33.5 \mathrm{~m}$ wide.

(Fracture zone extends from 29.08 to $29.4 \mathrm{~m}$ ) 
FSE5 Continued

LITHOLOGY

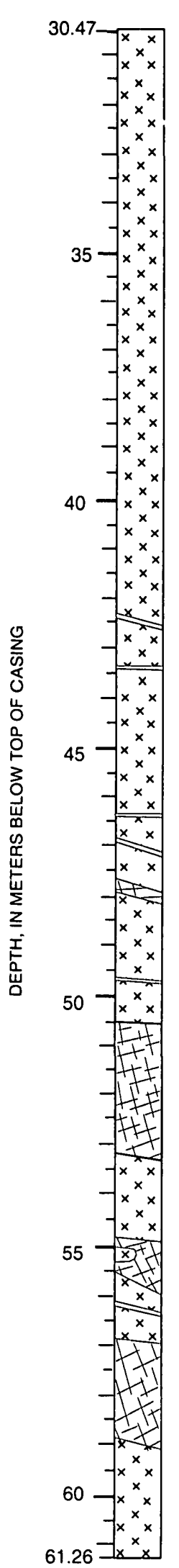

FRACTURE FRACTURES ATTRIBUTES

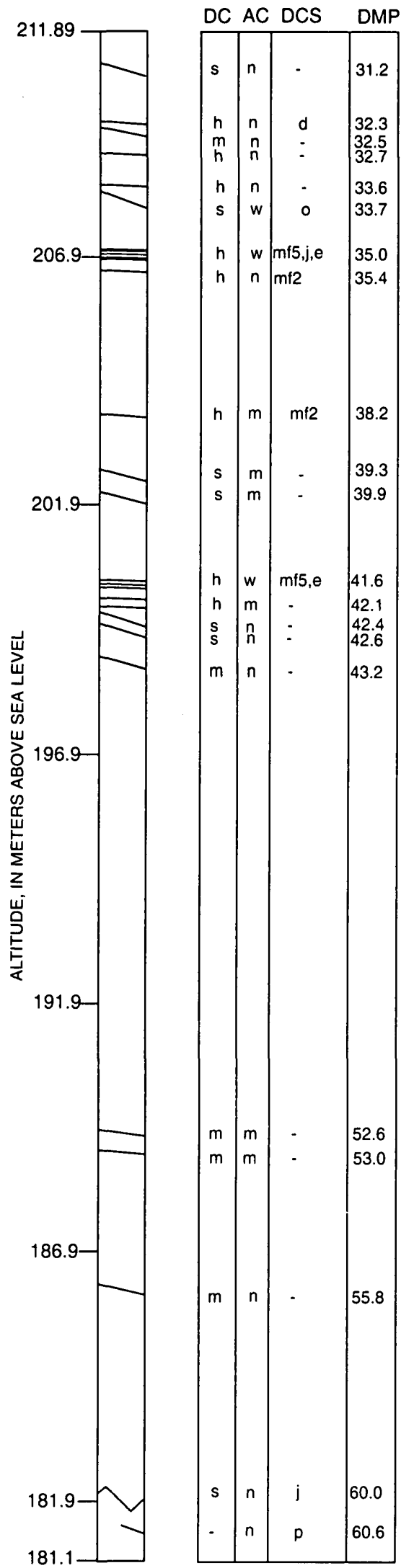

DESCRIPTION: Generalized log in bold.

\section{GRANITE continued to $50.4 \mathrm{~m}$}

PEGMATITE VEIN at $42.5 \mathrm{~m}, \sim 3 \mathrm{~cm}$ wide

PEGMATITE VEIN at $43.4 \mathrm{~m}, \sim 5 \mathrm{~cm}$ wide

PEGMATITE VEIN from 46.4 to $47.2 \mathrm{~m}$ ???, $~ 5 \mathrm{~cm}$ wide

PEGMATITE VEIN at $47.0 \mathrm{~m}, \sim 9 \mathrm{~cm}$ wide

PEGMATITE DIKE from 47.8 to $48.1 \mathrm{~m}, \sim 0.3 \mathrm{~m}$ wide

PEGMATITE VEIN at $49.6 \mathrm{~m}, \sim 3 \mathrm{~cm}$ wide

PEGMATITE DIKE from $\mathbf{5 0 . 4}$ to $\mathbf{5 3 . 3} \mathrm{m}$, muscovite, feldspar, quartz and some garnets, $\sim 2.9 \mathrm{~m}$ wide

GRANITE from $\mathbf{5 3 . 3}$ to $\mathbf{5 6 . 8} \mathrm{m}$, grayish white, fine to coarse grained, weakly foliated, biotite-muscovite granite, with some garnets, $\sim 3.5 \mathrm{~m}$ wide.

PEGMATITE DIKE from 54.8 to $55.7 \mathrm{~m}$, muscovite, feldspar and quartz, $\sim 0.9 \mathrm{~m}$ wide

PEGMATITE VEIN at $56.2 \mathrm{~m}, \sim 6 \mathrm{~cm}$ wide

PEGMATITE DIKE from 56.8 to $59.0 \mathrm{~m}, \sim 2.2 \mathrm{~m}$ wide

GRANITE from 59.0 to $61.3 \mathrm{~m}$, grayish white, fine to coarse grained, weakly foliated, biotite-muscovite granite, $\sim 2.3 \mathrm{~m}$ wide.

BOTTOM OF WELL AT $61.26 \mathrm{~m}$ 


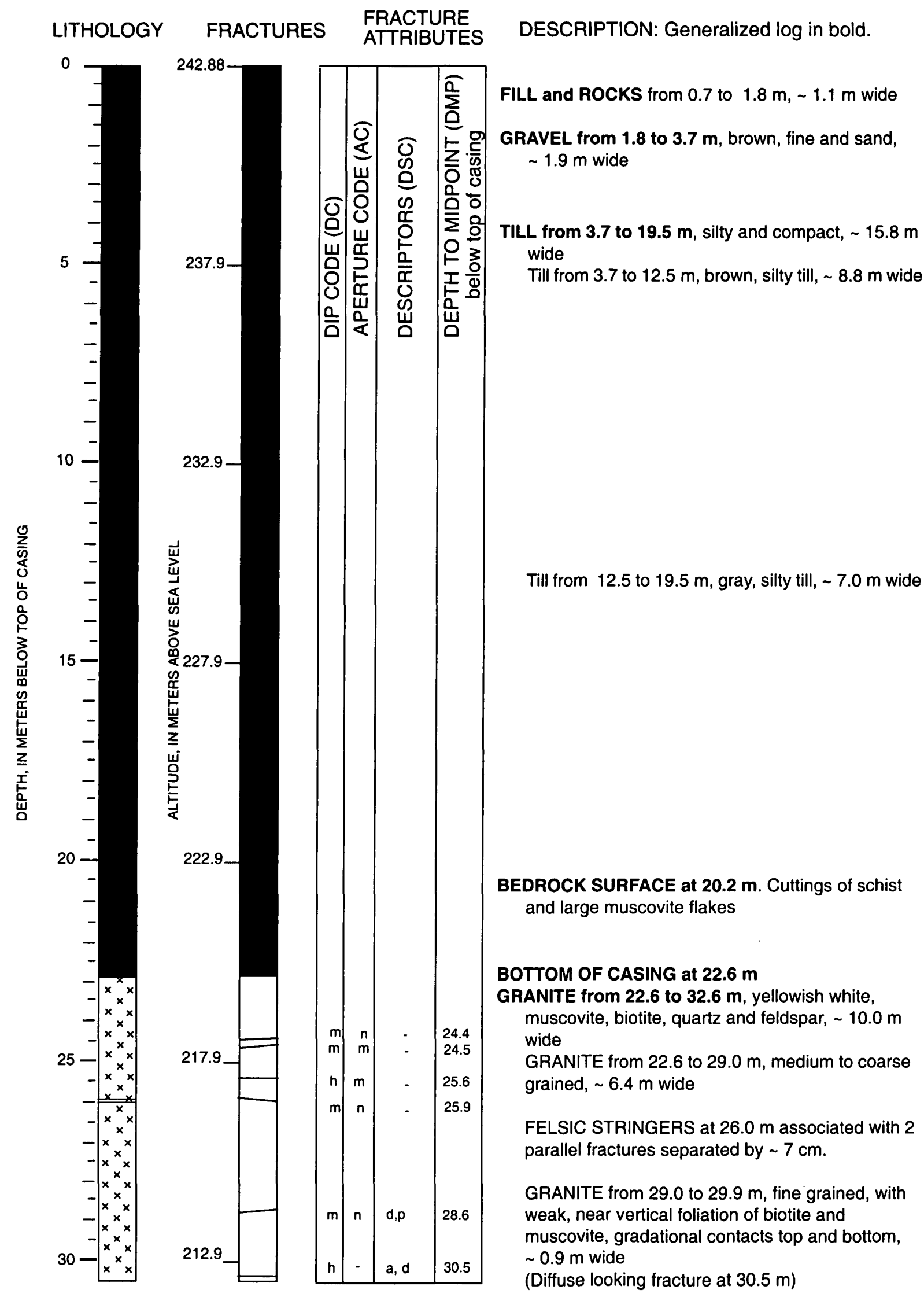


LITHOLOGY

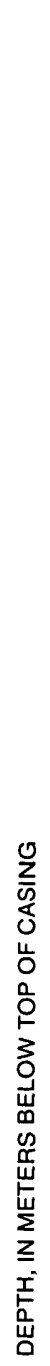

30.5

40

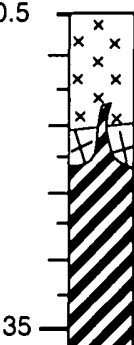

45
FRACTURES FRACTURE

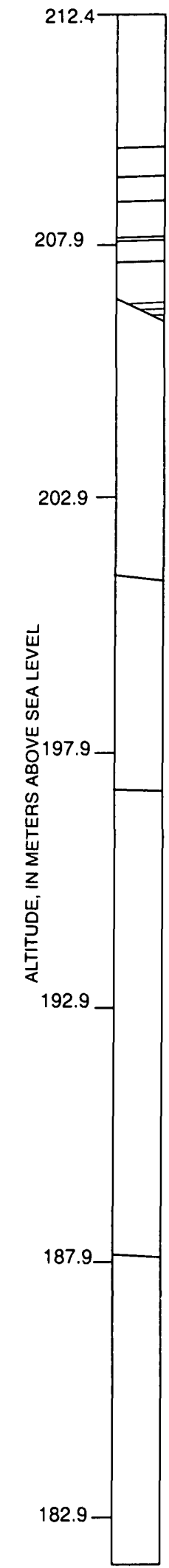

DC AC DCS DMP

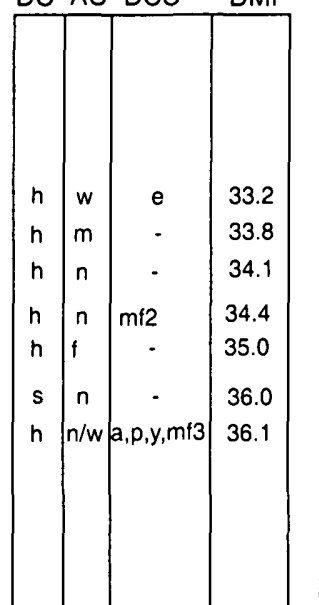

m

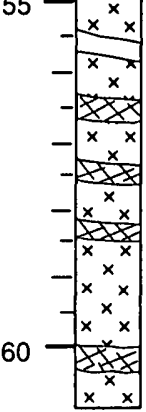

DESCRIPTION: Generalized log in bold.

GRANITE continued to $32.6 \mathrm{~m}$

GRANITE from 30.5 to $31.7 \mathrm{~m}$, mottled-looking texture,

altered, $\sim 1.2 \mathrm{~m}$ wide

SCHIST AND GRANITE at $31.7 \mathrm{~m}$

PEGMATITE from 32.0 to $32.6 \mathrm{~m}$, biotites and muscovites in felsic matrix, $0.5 \mathrm{~m}$ wide

SCHIST from 32.6 to $37.8 \mathrm{~m}$, gray, fine grained, steeply dipping foliation, $\sim 5.2 \mathrm{~m}$ wide

(steeply dipping fracture from 36.0 to $36.3 \mathrm{~m}$ with 3 parallel, near horizontal, fractures abutting)

SCHIST from $36.0 \mathrm{~m}$ to $37.3 \mathrm{~m}$, extremely fine grained, biotite-rich, trace pyrite, grading to more felsic fine grained schist, $\sim 1.3 \mathrm{~m}$ wide

MIGMATITE from 37.8 to $\mathbf{4 4 . 2} \mathrm{m}, \sim 6.4 \mathrm{~m}$ wide PEGMATITE from 40.0 to $40.1 \mathrm{~m}$, with trace pyrite $\sim 0.2 \mathrm{~m}$ wide

MELANOSOME from 40.1 to $41.2 \mathrm{~m}$, swirled foliated biotites in felsic matrix, predominantly mafic, $\sim 1.1 \mathrm{~m}$ wide LEOCOSOME from 41.2 to $41.8 \mathrm{~m}$, predominantly felsic,

$\sim 0.6 \mathrm{~m}$ wide

SCHIST and GRANITE from 41.8 to $42.1 \mathrm{~m}, \sim 0.3 \mathrm{~m}$ wide SCHIST from 42.1 to $42.4 \mathrm{~m}$, trace pyrite, $\sim 0.3 \mathrm{~m}$ wide LEOCOSOME from 42.4 to $42.8 \mathrm{~m}, \sim 0.6 \mathrm{~m}$ wide, predominantly felsic swirled foliated biotites in felsic matrix from 42.8 to $43.3 \mathrm{~m}, \sim 0.5 \mathrm{~m}$ wide

LEOCOSOME from 43.3 to $44.2 \mathrm{~m}$, predominantly felsic, $\sim 0.9 \mathrm{~m}$ wide

SCHIST from $\mathbf{4 4 . 2}$ to $\mathbf{4 5 . 4} \mathrm{m}$, gray to black, mostly fine grained, near vertical foliation, top: gradational contact, bottom: sharp, embayed and wavy contact with igneous rocks, $\sim 1.2 \mathrm{~m}$ wide

PEGMATITE 45.4 to $45.6 \mathrm{~m}$ grading into granite below, $\sim 0.2 \mathrm{~m}$ wide

GRANITE from 45.6 to $49.7 \mathrm{~m}$, coarse grained, $\sim 4.1 \mathrm{~m}$ wide (Fracture at $45.7 \mathrm{~m}$ is $0.15 \mathrm{~m}$ below contact with pegmatite) SCHIST XENOLITH from 46.3 to $46.6 \mathrm{~m}$ on one side of the well, $\sim 0.3 \mathrm{~m}$ wide

PEGMATITE from 49.7 to $53.4 \mathrm{~m}, \quad 3.4 \mathrm{~m}$ wide

GRANITE from 53.4 to $63.9 \mathrm{~m}$, with some swirling foliated biotite, $\sim 10.8 \mathrm{~m}$ wide

FELSIC DIKE from 55.5 to $55.8 \mathrm{~m}, \sim 0.3 \mathrm{~m}$ wide

PEGMATITE OR APLITE from 56.4 to $56.7 \mathrm{~m}, 0.3 \mathrm{~m}$ wide

PEGMATITE from 57.3 to $57.6 \mathrm{~m}, 0.3 \mathrm{~m}$ wide

PEGMATITE from 58.2 to $58.5 \mathrm{~m}, 0.3 \mathrm{~m}$ wide

PEGMATITE from 60.0 to $60.3 \mathrm{~m}, 0.3 \mathrm{~m}$ wide 


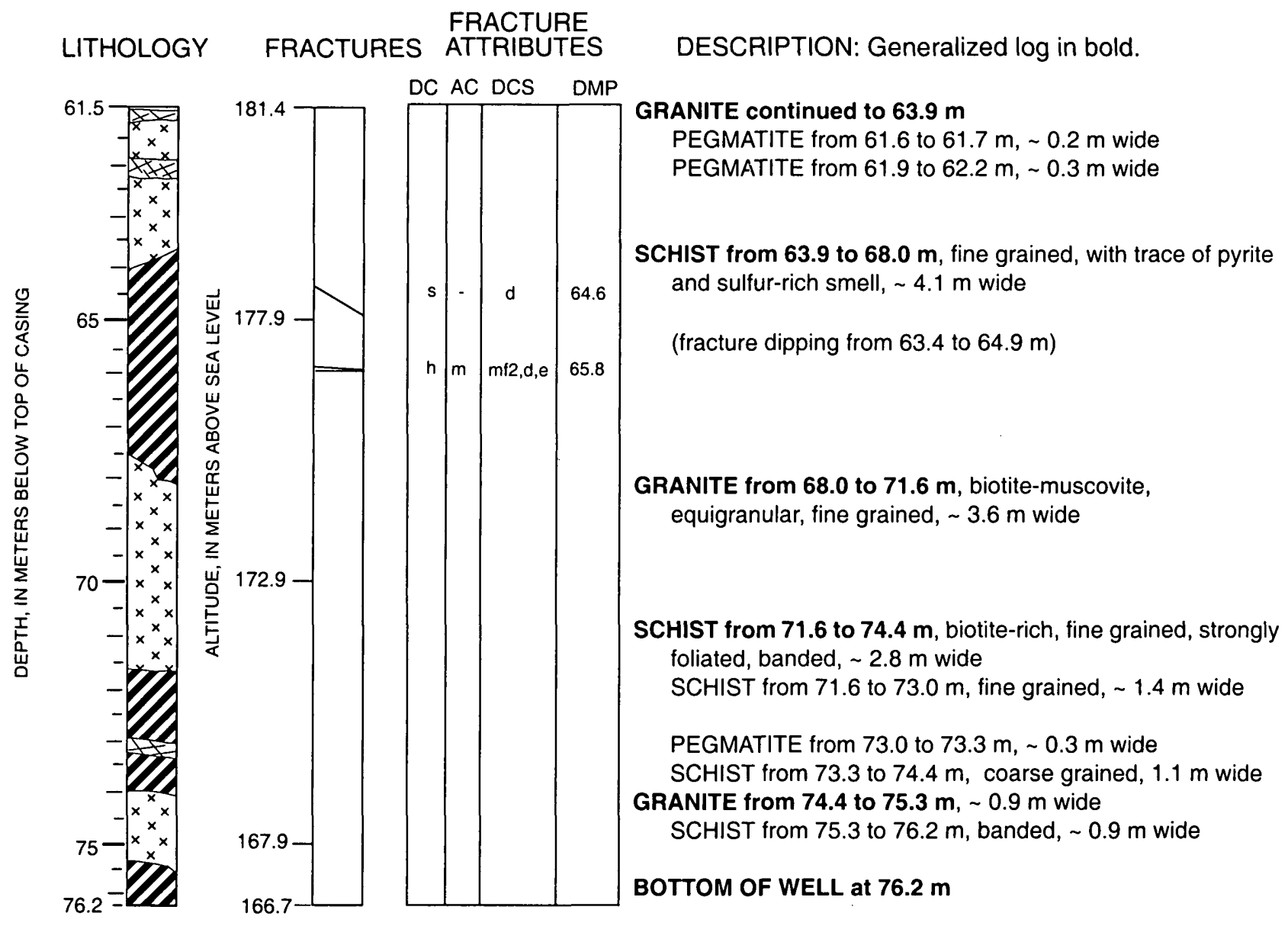


WELL NAME:FSE7

\section{LITHOLOGY FRACTURES ATTRIBUTES DESCRIPTION: Generalized log in bold.}
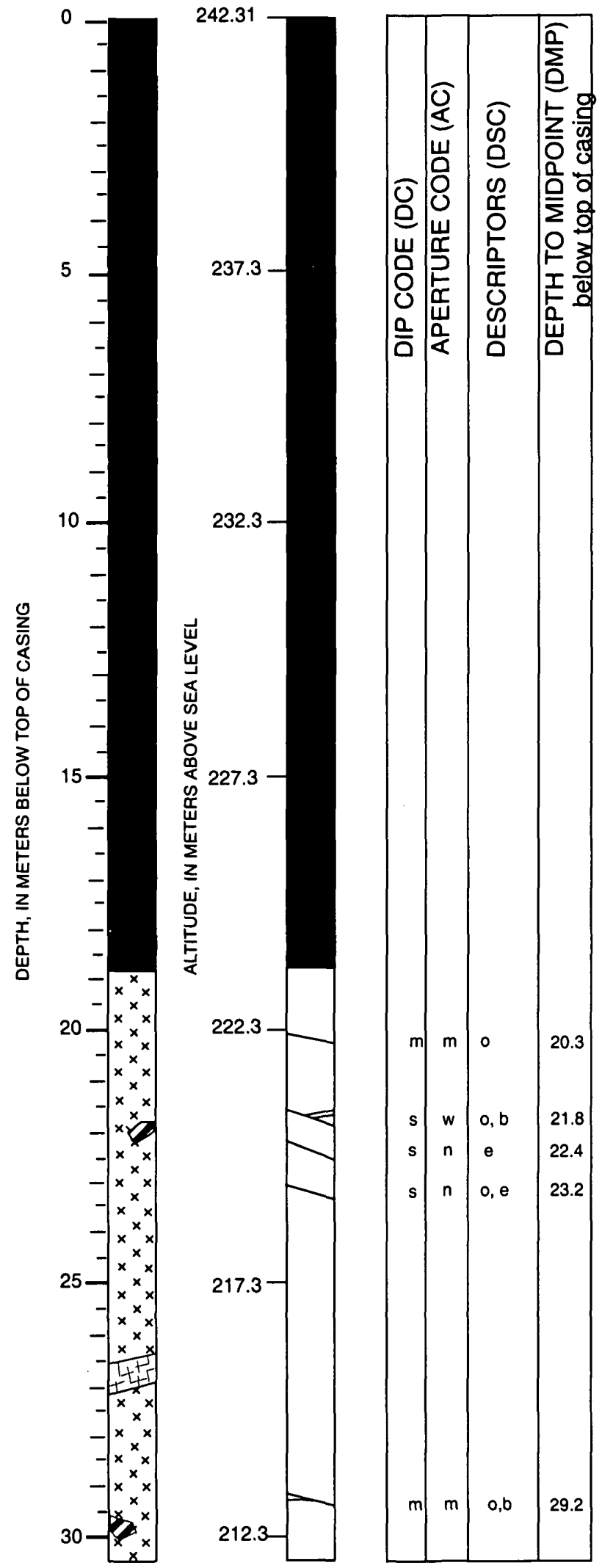

SAND from 0.4 to $3.47 \mathrm{~m}, \sim 3.1 \mathrm{~m}$ wide

TILL from 3.5 to $16.0 \mathrm{~m}, \sim 12.5 \mathrm{~m}$ wide

BEDROCK SURFACE at $16.0 \mathrm{~m}$

BOTTOM OF CASING at $18.90 \mathrm{~m}$

GRANITE from 18.9 to $68.3 \mathrm{~m}$, fine to coarse grained, biotitemuscovite, quartz-rich, $\sim 49.4 \mathrm{~m}$ wide

GRANITE from 18.9 to $19.5 \mathrm{~m}$, coarse grained, $\sim 0.6 \mathrm{~m}$ wide

GRANITE from 19.5 to $21.6 \mathrm{~m}$, fine grained, $\sim 2.1 \mathrm{~m}$ wide

GRANITE from 21.6 to $42.4 \mathrm{~m}$, coarse grained, $\sim 28.0 \mathrm{~m}$ wide

SCHIST XENOLITH at $21.9 \mathrm{~m}$ on one side of the well

PEGMATITE from 26.5 to $27.1 \mathrm{~m}$, coarse grained, gradational contacts above and below, $\sim 0.6 \mathrm{~m}$ wide

BIOTITE SCHLIEREN at $29.9 \mathrm{~m}$ 
FSE7 Continued

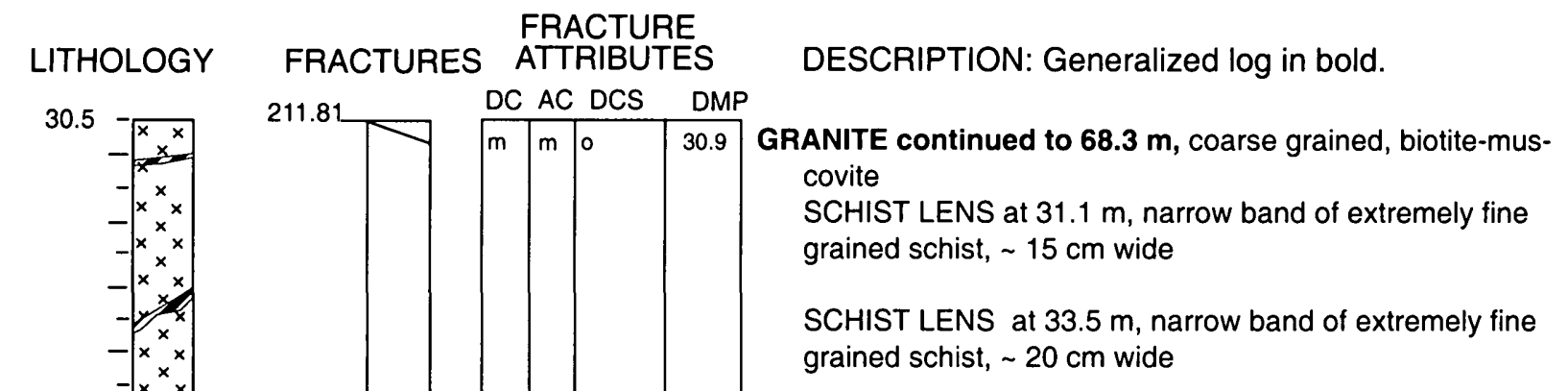

SCHIST LENS at $40.0 \mathrm{~m}$, narrow band of extremely fine grained, biotite-rich, $\sim 10 \mathrm{~cm}$ wide

GRANITE from 42.4 to $47.2 \mathrm{~m}$, fine grained, $\sim 4.8 \mathrm{~m}$ wide

PEGMATITE from 46.3 to $47.2 \mathrm{~m}$, gradual contacts above and below, $\sim 0.9 \mathrm{~m}$ wide

GRANITE from 47.2 to $57.9 \mathrm{~m}$, medium to coarse grained, $\sim 10.7 \mathrm{~m}$ wide

GRANITE from 57.9 to $70.9 \mathrm{~m}$, fine grained, $\sim 13.0 \mathrm{~m}$ wide 


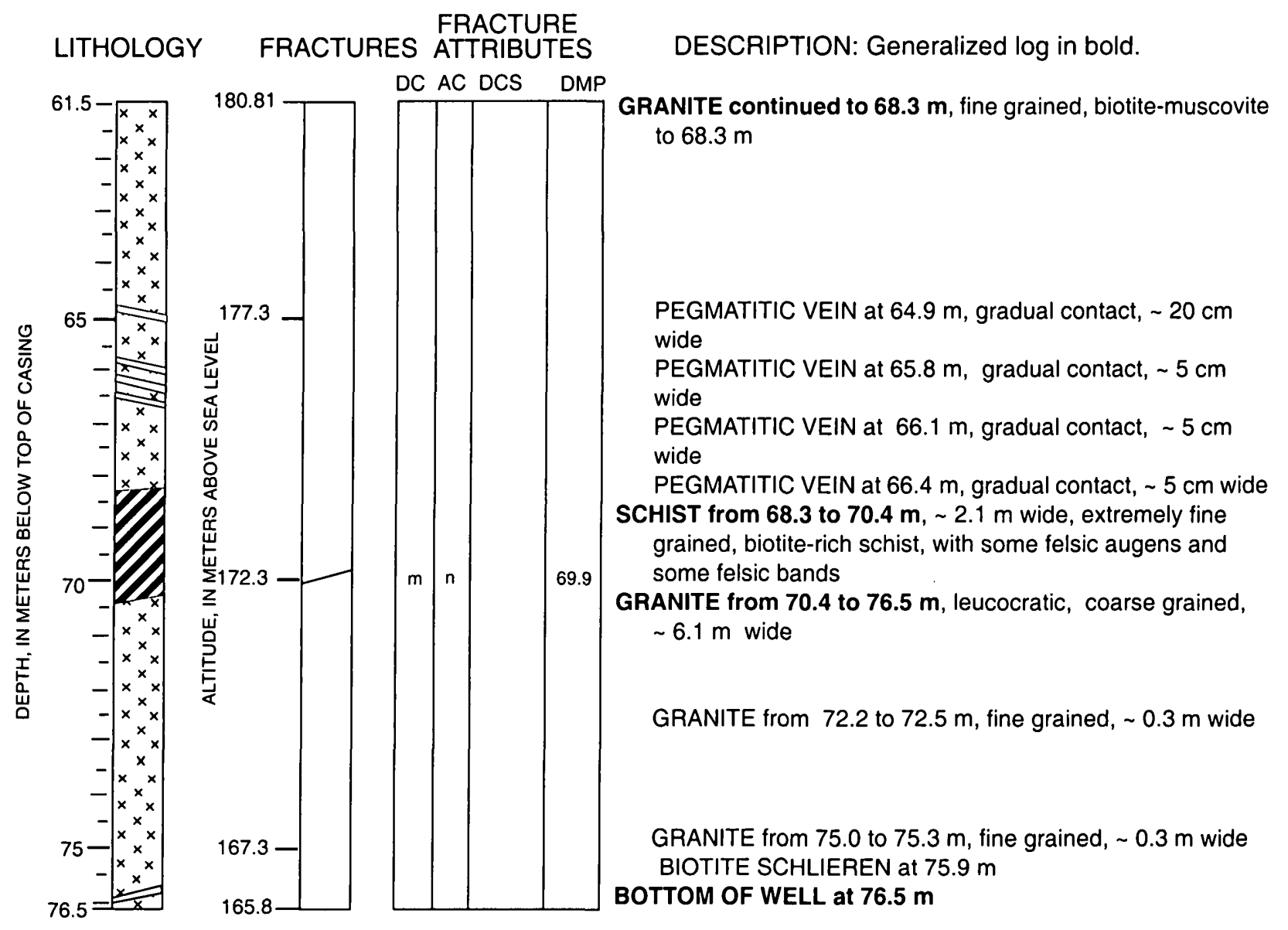




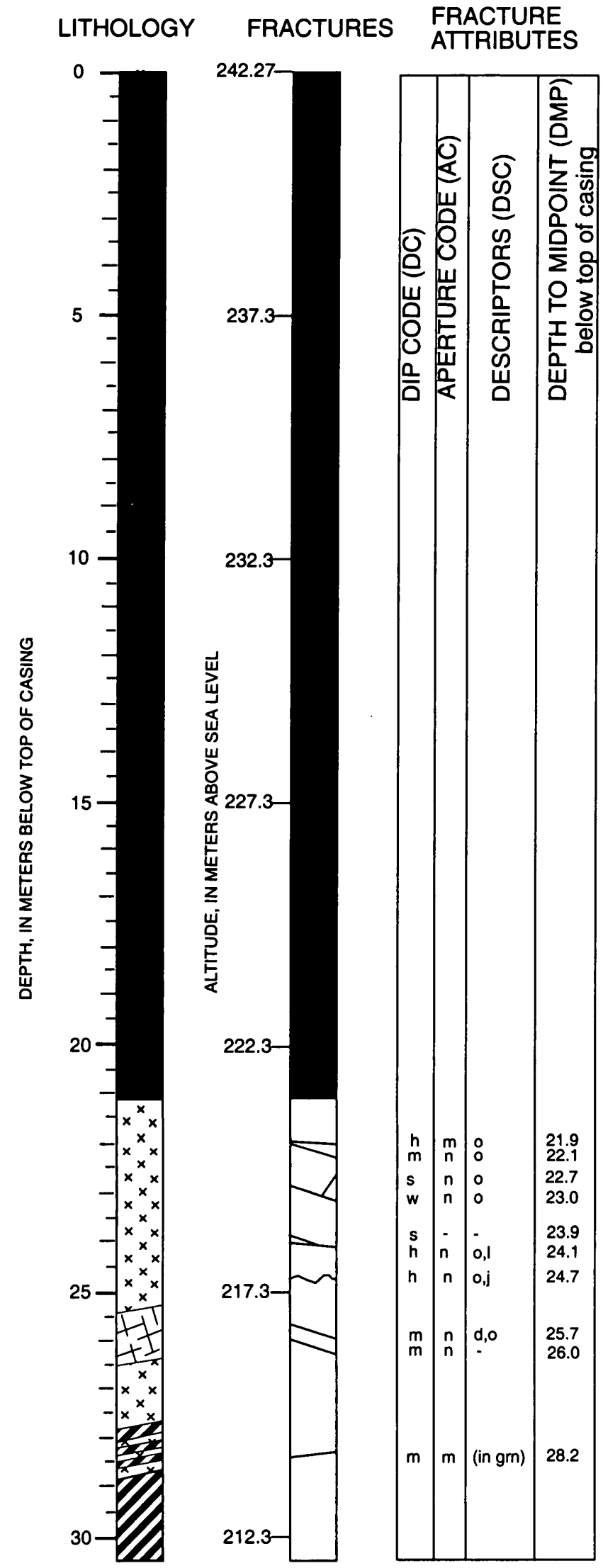

DESCRIPTION: Generalized log in bold.

SAND from 0.5 to $7.1 \mathrm{~m}$, brown, medium to coarse sand, with cobbles, $\sim 6.7 \mathrm{~m}$ wide

TILL from 7.1 to $12.0 \mathrm{~m}, \sim 4.9 \mathrm{~m}$ wide

BEDROCK SURFACE at $12.0 \mathrm{~m}$-- possibly

BEDROCK SURFACE at $14.3 \mathrm{~m}$ - definitely

(very soft drilling from $\sim 15$ to $\sim 18 \mathrm{~m}$ )

BOTTOM OF CASING at $21.03 \mathrm{~m}$

GRANITE from 21.0 to $27.9 \mathrm{~m}$, leucocratic, greater than $95 \%$ felsic minerals, some with iron staining, $\sim 6.9 \mathrm{~m}$ wide

PEGMATITE from 25.3 to $26.2 \mathrm{~m} \sim 0.9 \mathrm{~m}$ wide

SCHIST from 27.9 to $35.2 \mathrm{~m}$, rusty brown, medium to coarse grained, with augens, steeply dipping, $\sim 7.3 \mathrm{~m}$ wide GRANITE DIKE at $28.0 \mathrm{~m}$, fine grained, $\sim 7 \mathrm{~cm}$ wide GRANITE DIKE at $28.4 \mathrm{~m}$, fine grained, $\sim 5 \mathrm{~cm}$ wide APLITE at $28.7 \mathrm{~m}$, extremely fine grained, $\sim 25 \mathrm{~cm}$ wide SCHIST from 28.8 to $31.1 \mathrm{~m}$, biotite-rich, coarse grained to gneissic texture, with augens, $\sim 2.3 \mathrm{~m}$ wide 
FSE8 Continued

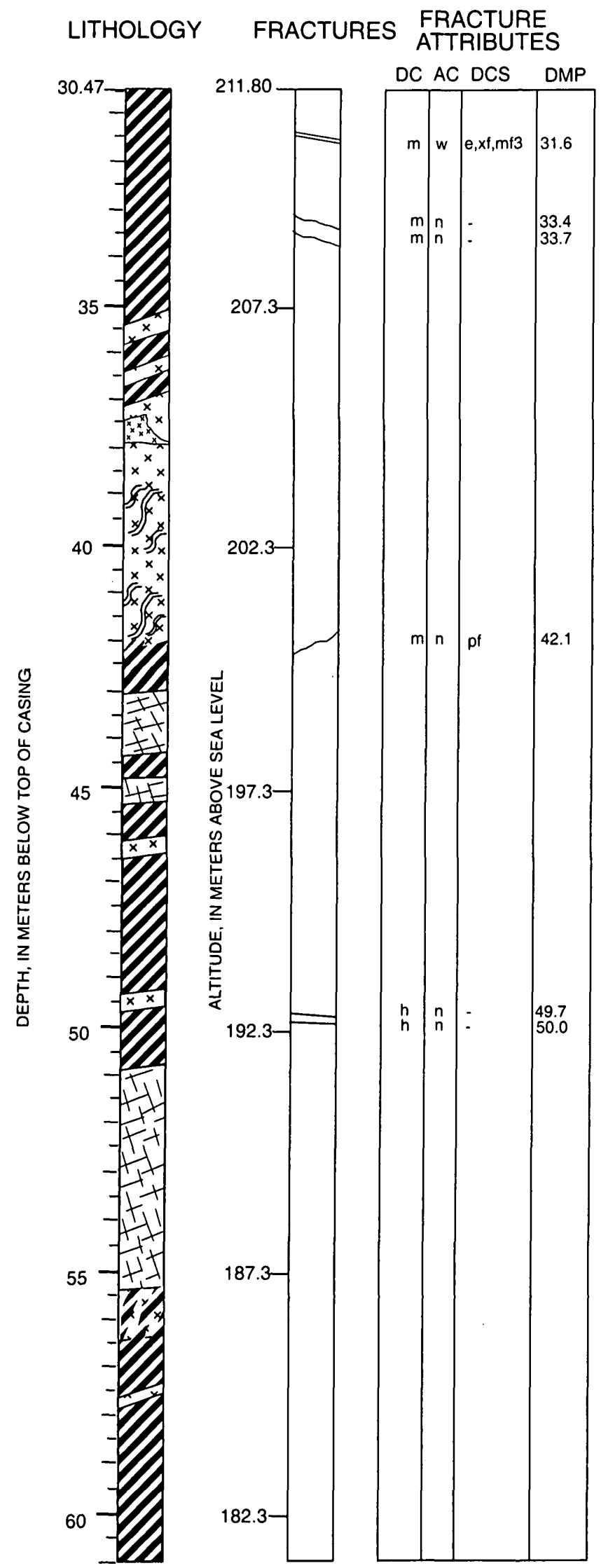

DESCRIPTION: Generalized log in bold.

SCHIST continued to $35.2 \mathrm{~m}$

SCHIST from 31.1 to $35.2 \mathrm{~m}$, coarse grained to gneissic,

felsic rich, banded, $\sim 4.1 \mathrm{~m}$ wide

FELSIC ZONE from 33.2 to $33.5 \mathrm{~m}$, felsic zone with a biotite schlieren in schist, $\sim 0.3 \mathrm{~m}$ wide

MIGMATITE from 35.2 to $42.0 \mathrm{~m}$, zone of mixed rocks, $1.8 \mathrm{~m}$ wide

GRANITE DIKE from 35.2 to $35.7 \mathrm{~m}, \sim 0.5 \mathrm{~m}$ wide

GRANITE DIKE from 36.2 to $36.6 \mathrm{~m}, \sim 0.4 \mathrm{~m}$ wide

GRANITE DIKE from 37.2 to $38.1 \mathrm{~m}$, oxidized, fine grained, aphanitic, equigranular, quartz and biotite, with trace sulfides on one side of well, coarse grained granite on the other side, $\sim 0.9 \mathrm{~m}$ wide

GRANITE from 38.1 to $38.9 \mathrm{~m}$, medium grained, felsic,

$\sim 0.8 \mathrm{~m}$ wide

GNEISS 38.9 to $39.9 \mathrm{~m}$, banded, gradational contact above and below, $\sim 1.0 \mathrm{~m}$ wide

GRANITE from 39.9 to $40.2 \mathrm{~m}$ greenish/grayish brown, aphanitic quartz and biotite, $\sim 0.3 \mathrm{~m}$ wide

GNEISS from 41.2 to $42.0 \mathrm{~m}$, banded, lower contact gradational, $\sim 0.8 \mathrm{~m}$ wide ( 39.3 to $39.9 \mathrm{~m}$ felsic rich, $\sim 0.6 \mathrm{~m}$ wide)

SCHIST from $\mathbf{4 2 . 0}$ to $\mathbf{5 0 . 9} \mathrm{m}$, rusty brown, coarse grained, $\sim 8.9 \mathrm{~m}$ wide

PEGMATITE DIKE from 43.3 to $43.6 \mathrm{~m}, \sim 0.3 \mathrm{~m}$ wide

PEGMATITE DIKE from 44.8 to $45.3 \mathrm{~m}, \sim 0.5 \mathrm{~m}$ wide

GRANITE DIKE from 46.0 to $46.3 \mathrm{~m}, \sim 0.3 \mathrm{~m}$ wide

GRANITE DIKE from 49.4 to $49.7 \mathrm{~m}, \sim 0.3 \mathrm{~m}$ wide

PEGMATITE DIKE from $\mathbf{5 0 . 9}$ to $\mathbf{5 5 . 5} \mathrm{m}$, with prominent biotite flakes, $\sim 4.6 \mathrm{~m}$ wide

SCHIST from 55.5 to $61.2 \mathrm{~m}$, coarse grained to gneissic texture, $\sim 5.7 \mathrm{~m}$ wide

SCHIST from 55.5 to $56.5 \mathrm{~m}$, gneissic

SCHIST from 56.5 to $61.2 \mathrm{~m}$, gradually becomes more felsic with less foliation near the lower contact, APLITE DIKE at $57.9 \mathrm{~m}, \sim 5 \mathrm{~cm}$ wide 
FSE8 Continued

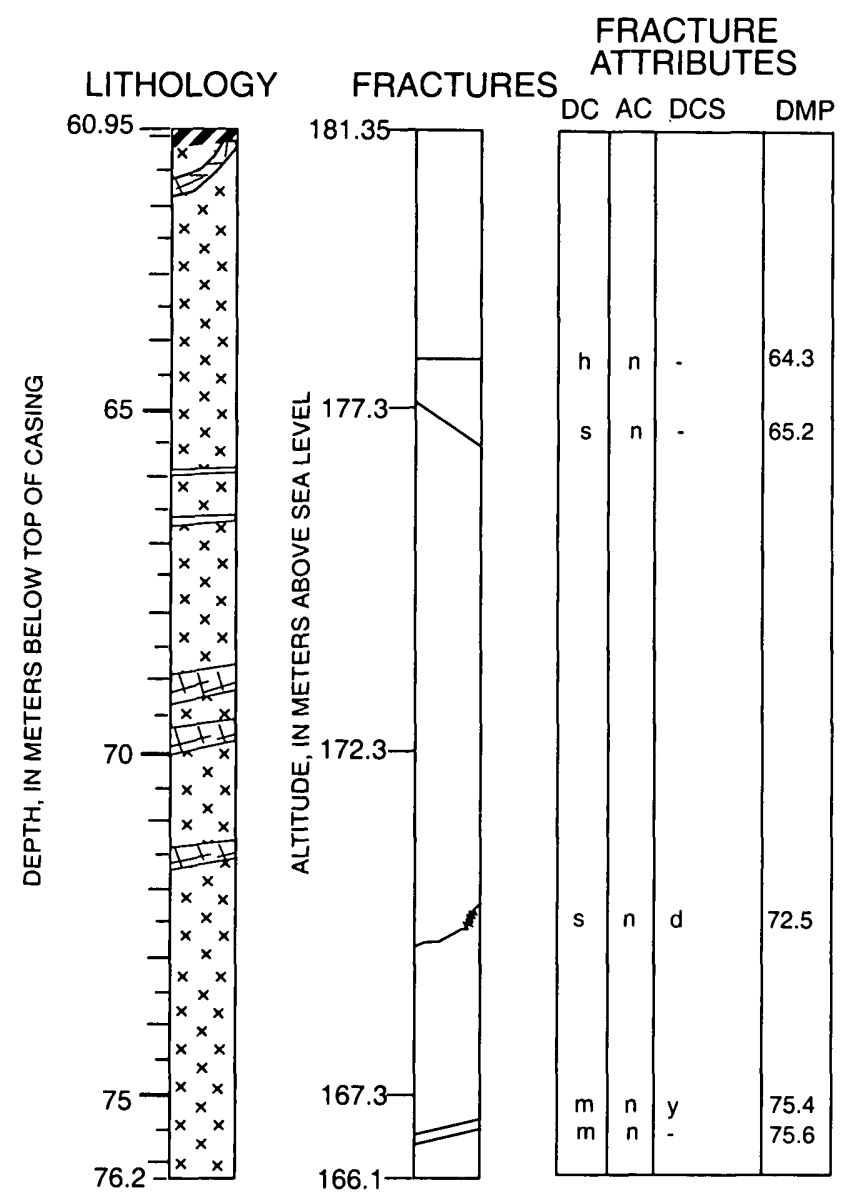

DESCRIPTION: Generalized log in bold.

SCHIST continued to $61.2 \mathrm{~m}$

GRANITE from 61.2 to76.2 $\mathrm{m}$, muscovite-biotite and trace sulfides, $\sim 15.0 \mathrm{~m}$ wide

PEGMATITE DIKE from 61.6 to $61.9 \mathrm{~m}, \sim 0.3 \mathrm{~m}$ wide

PEGMATITE VEIN at $65.8 \mathrm{~m}, \sim 3 \mathrm{~cm}$ wide

PEGMATITE VEIN at $66.6 \mathrm{~m}, \sim 6 \mathrm{~cm}$ wide

PEGMATITE DIKE from 68.9 to $69.2 \mathrm{~m}, \sim 0.3 \mathrm{~m}$ wide

PEGMATITE DIKE from 69.4 to $69.7 \mathrm{~m}, \sim 0.3 \mathrm{~m}$ wide

PEGMATITE VEIN from 71.3 to $71.5 \mathrm{~m}, \sim 0.2 \mathrm{~m}$ wide

(Borehole wells from 75.4 to $75.7 \mathrm{~m}$ looks rubbly and rough) BOTTOM OF WELL at $76.2 \mathrm{~m}$ 
WELL NAME: FSE9

\section{LITHOLOGY}

FRACTURES

$$
0
$$

5$$
=
$$

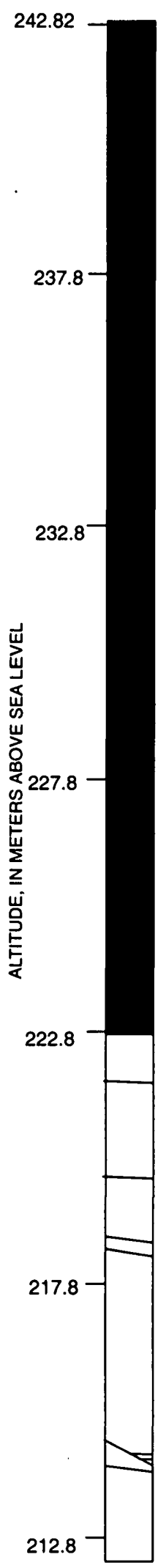

FRACTURE ATTRIBUTES

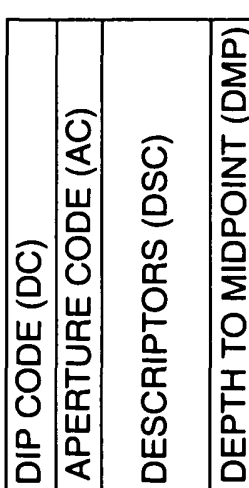

/publications/manuscripts/mirrorlake/WRIR98/pageproofWRIR/Appendix.files/FSE9.app

DESCRIPTION: Generalized log in bold.

SAND and GRAVEL from 1.0 to $6.0 \mathrm{~m}$, brown, fine to coarse, $\sim 5.0 \mathrm{~m}$ wide

Gravel layer at $2.7 \mathrm{~m}, \sim 0.3 \mathrm{~m}$ wide

Gravel and cobble layer at $4.0 \mathrm{~m}, \sim 0.3 \mathrm{~m}$ wide

SAND and GRAVEL from 6.0 to $9.0 \mathrm{~m}$, fine to medium, $\sim 3.0 \mathrm{~m}$ wide

TILL from $~ 9.0$ to $14.4 \mathrm{~m}, \sim 5.4 \mathrm{~m}$ wide

BEDROCK SURFACE at $14.4 \mathrm{~m}$

\section{BOTTOM OF CASING AT $20.1 \mathrm{~m}$}

GRANITE from 20.1 to $28.3 \mathrm{~m}$, white grayish greenish, biotitemuscovite, with weak foliation of biotites and muscovites,

$\sim 8.2 \mathrm{~m}$ wide

GRANITE from 20.1 to $27.7 \mathrm{~m}$, medium to coarse grained, $\sim 7.6 \mathrm{~m}$ wide

22.8

24.1

24.4

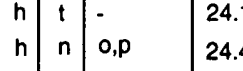

$n$ e,p,b,mf2 27.3

\begin{tabular}{l|l|l}
$n$ & $n$ & $e$
\end{tabular}
GRANITE from 27.7 to $28.3 \mathrm{~m}$, fine grained, $\sim 0.6 \mathrm{~m}$ wide (Steeply dipping fracture at $27.7 \mathrm{~m}$ showing small amounts of borehole enlargement on the upper and lower toes) (Steeply dipping fracture at $28.5 \mathrm{~m}$, with 2 abutting fractures)

SCHIST from 28.3 to $55.5 \mathrm{~m}$, fine grained, steeply dipping foliation with felsic stringers and small augens, biotitemuscovite-sillimanite-quartz-feldspar, $\sim 27.2 \mathrm{~m}$ wide 


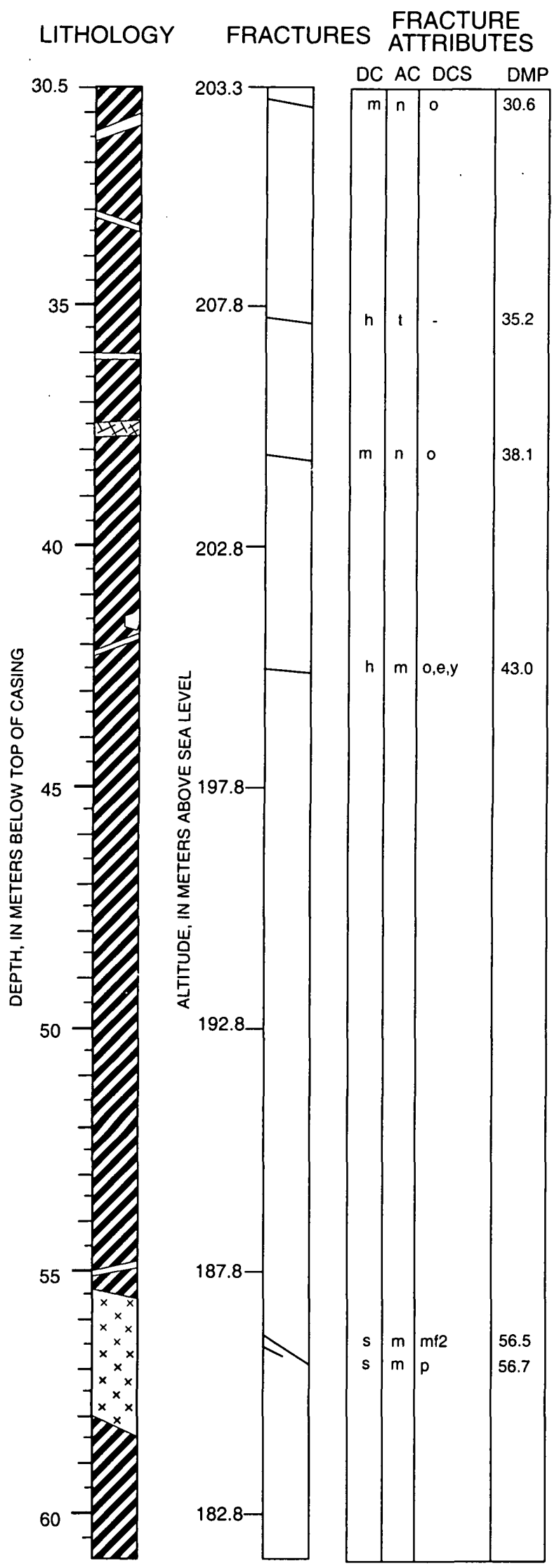

DESCRIPTION: Generalized log in bold.

SCHIST continued to $55.5 \mathrm{~m}$

FELSIC DIKE at $31.2 \mathrm{~m}$, extremely fine grained, $\sim 0.3 \mathrm{~m}$

wide

FELSIC VEIN at $33.2 \mathrm{~m}$, cross-cutting near vertical foliation, $\sim 5 \mathrm{~cm}$ wide

SCHIST, felsic rich from 33.5 to $36.6 \mathrm{~m}, \sim 3.1 \mathrm{~m}$ wide

FELSIC VEIN at $36.0 \mathrm{~m}$, cross-cutting foliation, $2.5 \mathrm{~cm}$ wide

PEGMATITE from 37.7 to $38.0 \mathrm{~m}$, muscovite and felspars, cross-cuts foliation of schist, $\sim 0.3 \mathrm{~m}$ wide

FELSIC ZONE at $41.5 \mathrm{~m}$ in schist, on one side of well, $\sim 0.3 \mathrm{~m}$ wide

FELSIC VEIN at $42.2 \mathrm{~m}$, parallel to foliation, $\sim 5 \mathrm{~cm}$ wide

SCHIST from 46.3 to $48.2 \mathrm{~m}$, with augens, gradual contacts above and below, $\sim 6.0 \mathrm{~m}$ wide

FELSIC DIKE at $55.1 \mathrm{~m}$, cross-cutting foliation of schist,

$\sim 10 \mathrm{~cm}$ wide

GRANITE DIKE from $\mathbf{5 5 . 5}$ to $\mathbf{5 8 . 3} \mathrm{m}$, leucocratic, medium to coarse grained, contact cross-cuts foliation of schist, chill margins (fine-grained) on upper and lower contacts $\sim 2.8 \mathrm{~m}$ wide

SCHIST from $58.3 \mathrm{~m}$ to $61.9 \mathrm{~m}$, coarse grained, biotite-rich, with felsic augens, $\sim 3.6 \mathrm{~m}$ wide 


\section{LITHOLOGY}

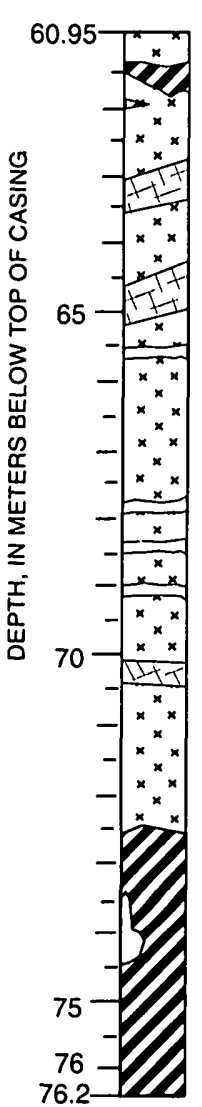

FRACTURES FRACTURE

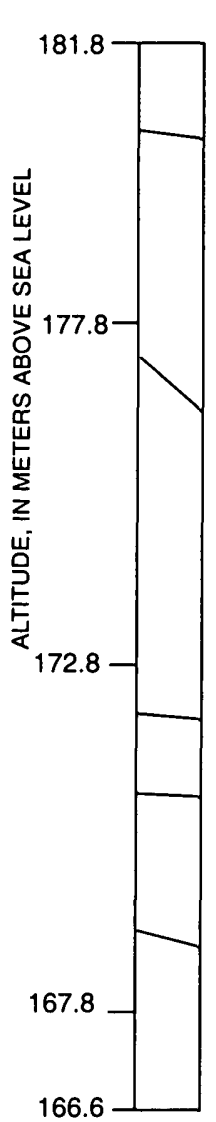

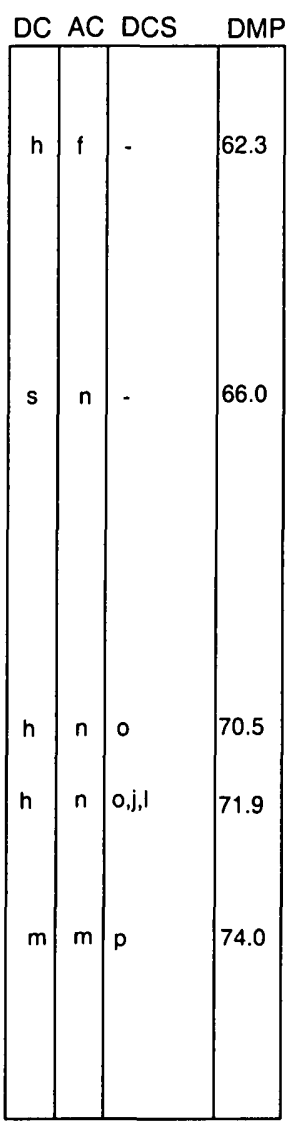

DESCRIPTION: Generalized log in bold.

\section{SCHIST continued to $61.9 \mathrm{~m}$}

GRANITE DIKE at $60.9 \mathrm{~m}$, leucocratic, cross-cuts foliation of banded schist, $\sim 0.3 \mathrm{~m}$ wide SCHIST from 61.3 to $61.9 \mathrm{~m}$, same as above, $\sim 0.6 \mathrm{~m}$ wide

GRANITE from 61.9 to $72.5 \mathrm{~m}, \sim 10.6 \mathrm{~m}$ wide GRANITE from 61.9 to $69.1 \mathrm{~m}$, leucocratic, medium grained, equigranular, muscovite, $\sim 7.2 \mathrm{~m}$ wide PEGMATITE from 63.0 to $63.5 \mathrm{~m}, \sim 0.5 \mathrm{~m}$ wide GRANITE from 63.5 to $67.7 \mathrm{~m}$, leucocratic, muscovite, $\sim 4.2 \mathrm{~m}$ wide PEGMATITE from 64.5 to $65.2 \mathrm{~m}, \sim 0.7 \mathrm{~m}$ wide (Fracture extends from 65.5 to $66.5 \mathrm{~m}$. Aperture is tight along limbs, but shows some borehole enlargement at upper and lower toes)

PEGMATITE at $65.6 \mathrm{~m}, \sim 15 \mathrm{~cm}$ wide

PEGMATITE from 67.7 to $68 \mathrm{~m}, \sim 15 \mathrm{~cm}$ wide PEGMATITE from 68.4 to $68.6 \mathrm{~m}, \sim 0.2 \mathrm{~m}$ wide PEGMATITE from 68.9 to $69.1 \mathrm{~m}, \sim 0.2 \mathrm{~m}$ wide GRANITE from 69.1 to $72.5 \mathrm{~m}$, biotite-muscovite, equigranular, medium to coarse grained texture, $3.4 \mathrm{~m}$ wide PEGMATITE from 70.1 to $70.4 \mathrm{~m}, \sim 0.3 \mathrm{~m}$ wide SCHIST from 72.5 to $76.2 \mathrm{~m}$, fine grained, biotite-rich, $3.7 \mathrm{~m}$ wide FELSIC ZONE from 73.5 to $74.5 \mathrm{~m}$ in schist, on one side of well, $\sim 1.0 \mathrm{~m}$ wide

BOTTOM OF WELL at $76.2 \mathrm{~m}$ 


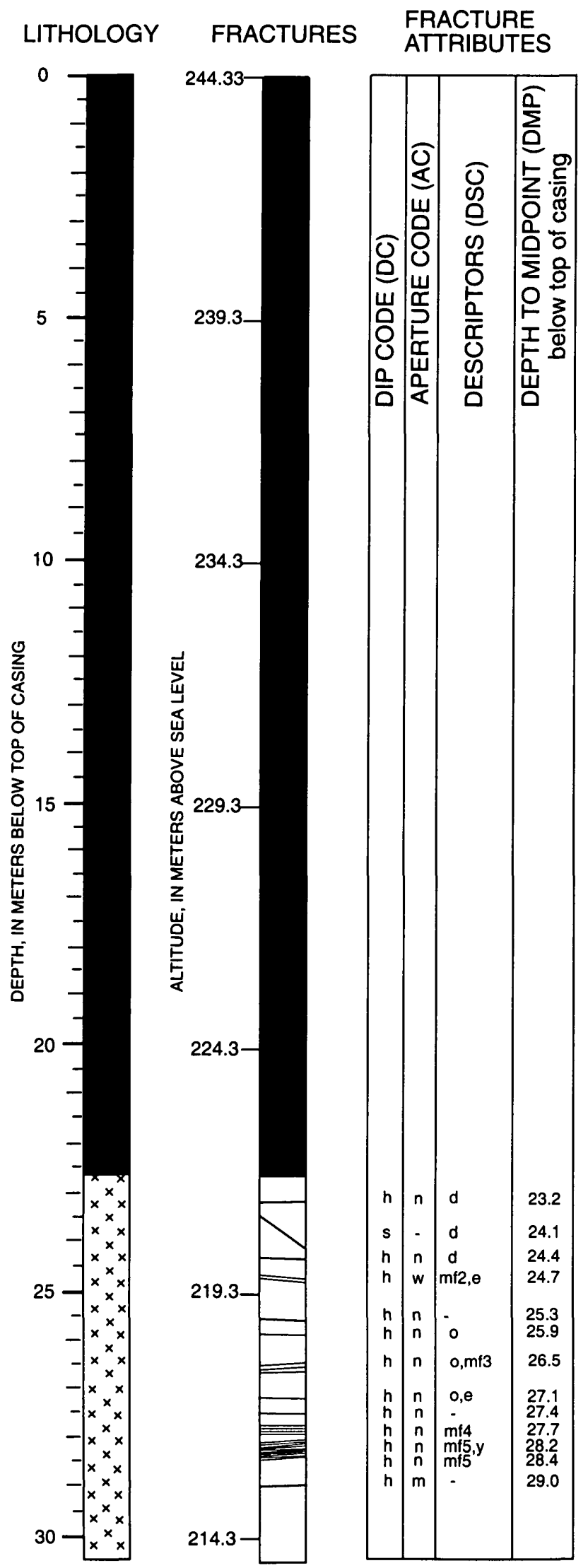

DESCRIPTION: Generalized log in bold.

SAND from 0.61 to $4.0 \mathrm{~m}$, brown, very coarse to medium sand, $\sim 3.4 \mathrm{~m}$ wide

COBBLES WITH GRAVELS from 1.8 to $2.1 \mathrm{~m}, \sim 0.3 \mathrm{~m}$ wide

TILL from 4.0 to18.9 m, gray, very coarse sand to silt and clay, and some oxidized, $\sim 14.9 \mathrm{~m}$ wide

BEDROCK SURFACE at $18.9 \mathrm{~m}$

BOTTOM OF CASING at $22.6 \mathrm{~m}$

GRANITE from 22.6 to $\mathbf{4 2 . 5} \mathrm{m}$, greenish gray, aphanitic to fine grained, biotite-muscovite granite, $\sim 9.4 \mathrm{~m}$ wide (white precipitate, dripping down sides of the well from 22.6 to $24.5 \mathrm{~m}$ )

GRANITE from 22.6 to 28.6 , dark, reddish brown, weakly foliated, $\sim 6.0 \mathrm{~m}$ wide

GRANITE from 28.6 to $32.0 \mathrm{~m}$, yellowish white, felsic rich, $\sim 3.4 \mathrm{~m}$ wide

(several narrow parallel fractures and one fracture that is wide) 


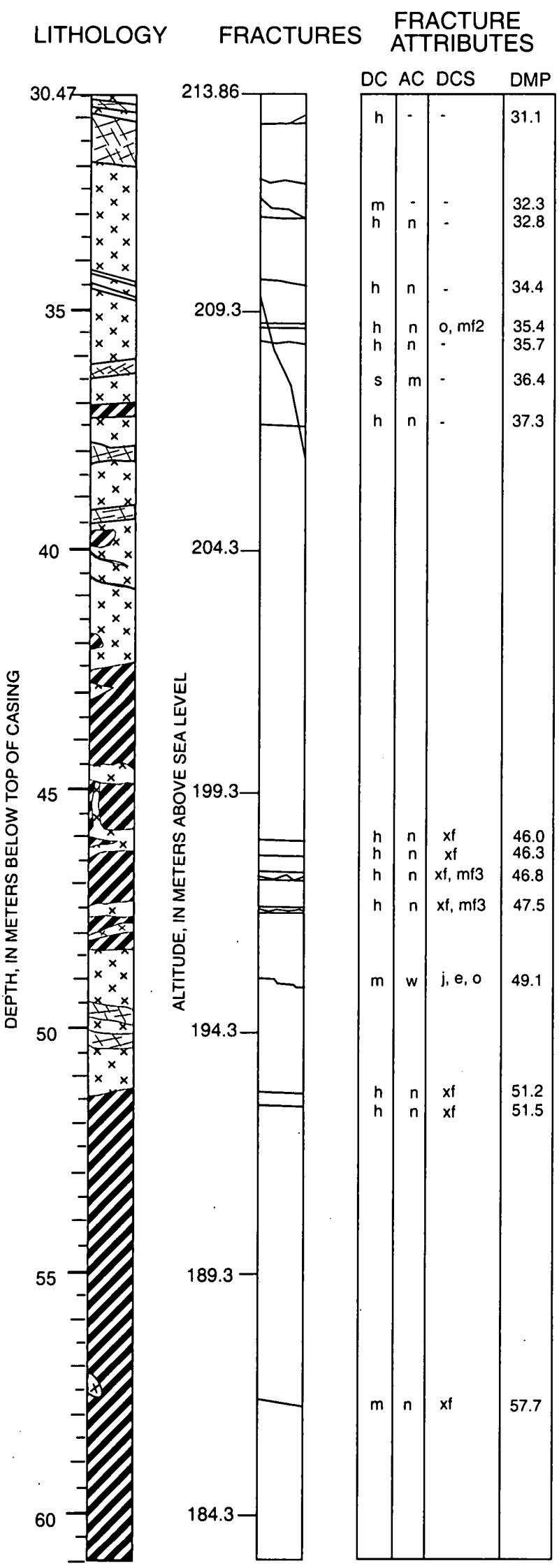

DESCRIPTION: Generalized log in bold.

\section{GRANITE continued to $\mathbf{4 2 . 5} \mathrm{m}$}

PEGMATITE VEIN at $30.7 \mathrm{~m}, \sim 7 \mathrm{~cm}$ wide

PEGMATITE DIKE from 31.0 to $32.0, \sim 1.0 \mathrm{~m}$ wide

GRANITE from 32.0 to $42.5 \mathrm{~m}$, grayish white, fine grained,

$10.5 \mathrm{~m}$ wide

FELSIC VEIN at $34.4 \mathrm{~m}, \sim 5 \mathrm{~cm}$ wide

FELSIC VEIN at $34.6 \mathrm{~m}, \sim 5 \mathrm{~cm}$ wide

PEGMATITE DIKE from $36.1 \mathrm{~m}$ to $36.4 \mathrm{~m}, \sim 0.3 \mathrm{~m}$ wide

SCHIST from 37.0 to $37.3 \mathrm{~m}$, biotite-rich with sulfides, coarse grained $\sim 0.3 \mathrm{~m}$ wide

PEGMATITE DIKE from $37.9 \mathrm{~m}$ to $38.2 \mathrm{~m}, \sim 0.3 \mathrm{~m}$ wide

PEGMATITE DIKE from $39.3 \mathrm{~m}$ to $39.5 \mathrm{~m}, \sim 0.2 \mathrm{~m}$ wide SCHIST XENOLITH at $39.8 \mathrm{~m}$

BIOTITE SCHLIEREN at $40.1 \mathrm{~m}$ and $40.6 \mathrm{~m}$

SCHIST XENOLITH at $42.0 \mathrm{~m}$

SCHIST from $\mathbf{4 2 . 5}$ to $\mathbf{4 8 . 3} \mathrm{m}$, very fine grained biotite-rich, weak to moderate foliation with sulfides, $\sim 5.8 \mathrm{~m}$ wide (very faint horizontal cracks from 43.5 to $43.8 \mathrm{~m}$ )

GRANITE from $44.5 \mathrm{~m}$ to $46.4 \mathrm{~m}$, leucocratic, coarse grained granite, $\sim 1.9 \mathrm{~m}$ wide

GRANITE DIKE from 47.5 to $47.7, \sim 20 \mathrm{~cm}$ wide GRANITE DIKE at $48.0 \mathrm{~m}, \sim 15 \mathrm{~cm}$

GRANITE from $\mathbf{4 8 . 3}$ to $\mathbf{5 1 . 4} \mathrm{m}$, fine grained, altered biotitemuscovite, cross-cut foliation of schist $\sim 3.1 \mathrm{~m}$ wide PEGMATITE DIKE from 49.6 to $49.9 \mathrm{~m}, \sim 0.3 \mathrm{~m}$ wide PEGMATITE DIKE from 50.1 to $50.4 \mathrm{~m}, \sim 0.3 \mathrm{~m}$ wide

SCHIST from $\mathbf{5 1 . 2}$ to $\mathbf{7 6 . 2} \mathrm{m}$, pale yellowish brown, very fine grained, biotite schist, with sulfide minerals, steeply dipping weak foliation, $\sim 25 \mathrm{~m}$ wide

(Several near horizontal linear features from 51.2 to $54.5 \mathrm{~m}$ possibly biotite schlieren spaced approximately 10 to $15 \mathrm{~cm}$ apart)

GRANITE INCLUSION or FELSIC ZONE in SCHIST at $57.2 \mathrm{~m}$ 
FSE10 Continued

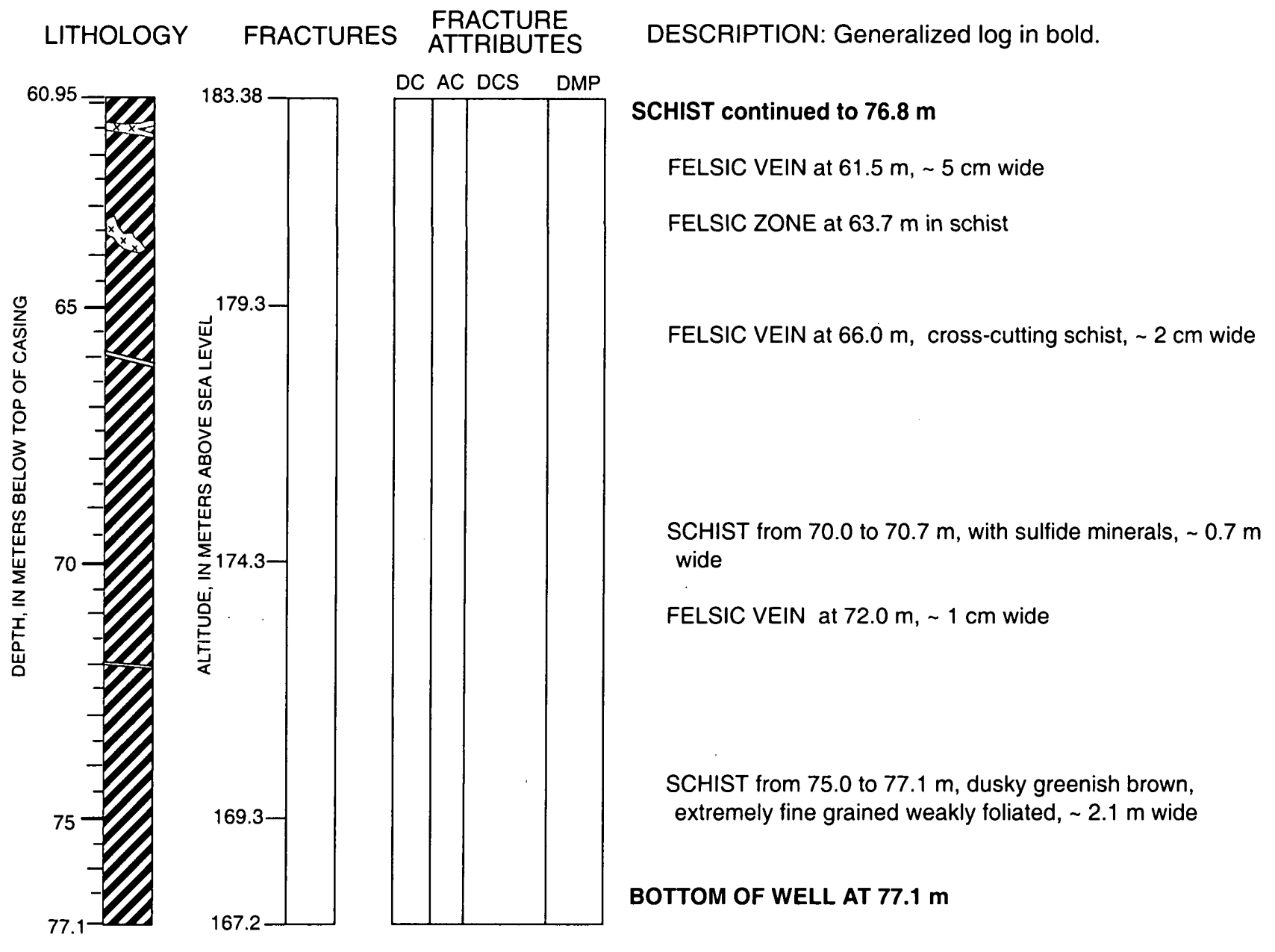




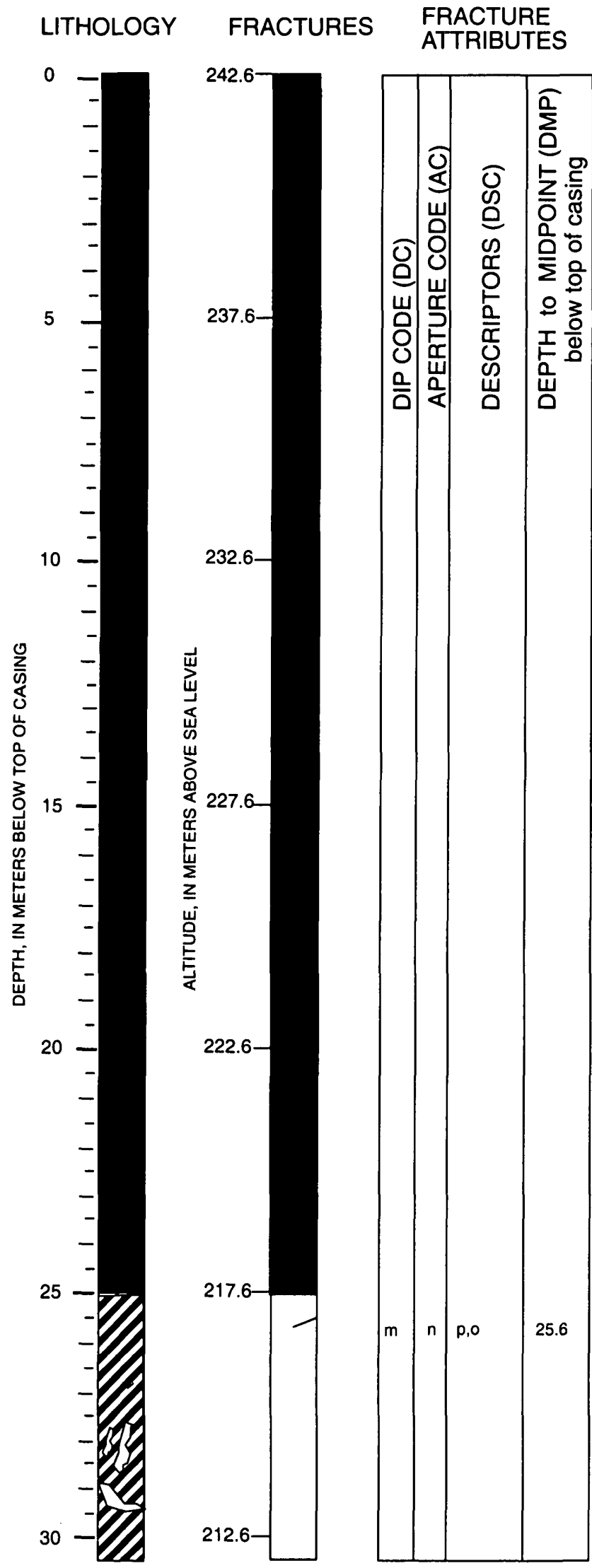

DESCRIPTION: Generalized log in bold.

FILL from $0.5 \mathrm{~m}$ to $\sim 3.0 \mathrm{~m}, \sim 2.5 \mathrm{~m}$ wide

OVERBURDEN, UNDIFFERENTIATED from 3.0 to $20.7 \mathrm{~m}, \sim 17.7 \mathrm{~m}$ wide

BEDROCK SURFACE at $20.7 \mathrm{~m}$

Soft drilling from 20.7 to $21.6 \mathrm{~m}$

BOTTOM OF CASING at $25.0 \mathrm{~m}$

SCHIST from 25.0 to $31.7 \mathrm{~m}$, steeply dipping foliation, with some augens and some banding, biotite-

muscovite-quartz-feldspar and sillimanite, $\sim 6.7 \mathrm{~m}$ wide

FELSIC ZONE from 27.7 to $28.5 \mathrm{~m}$, in schist, on one side of well, $\sim 0.8 \mathrm{~m}$ wide

FELSIC ZONE from 29.0 to $29.3 \mathrm{~m}$, in schist, on one side of well, $\sim 0.3 \mathrm{~m}$ wide 


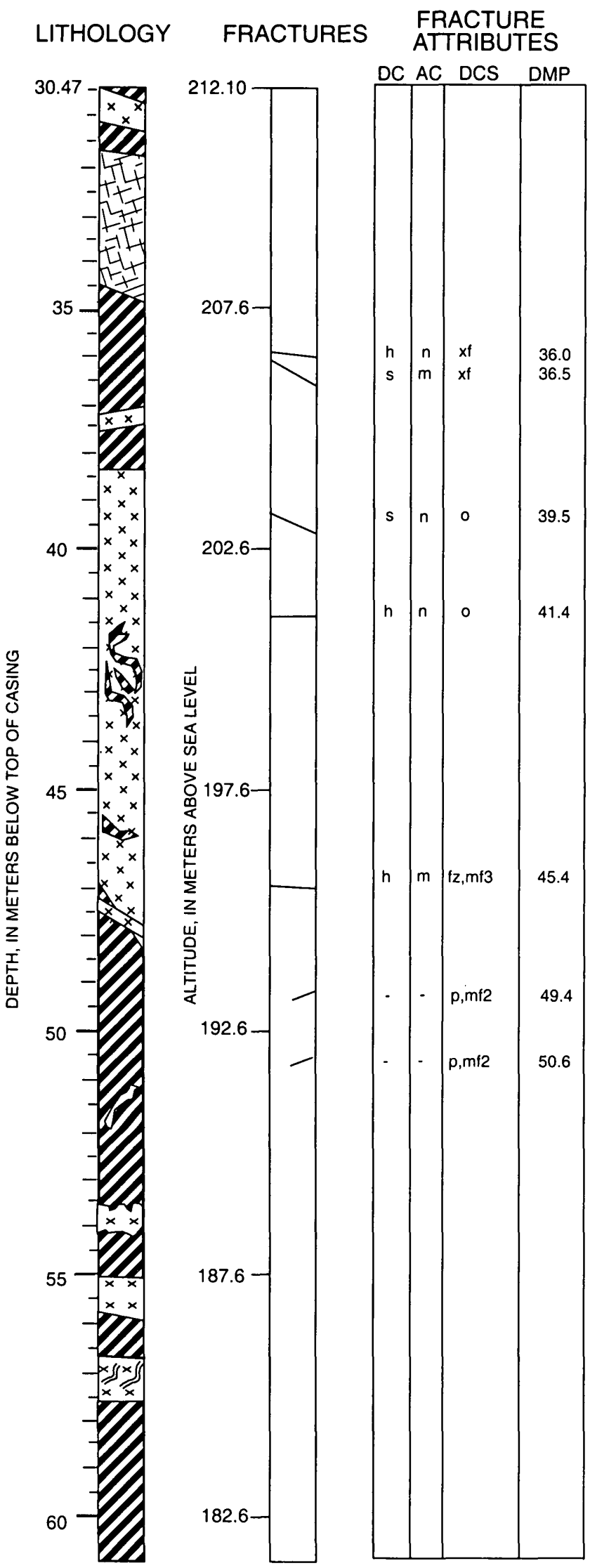

\section{DESCRIPTION: Generalized log in bold.}

\section{SCHIST continued to $31.7 \mathrm{~m}$}

GRANITE DIKE from 30.6 to $31.1 \mathrm{~m}$, leucocratic, fine grained, $\sim 0.5 \mathrm{~m}$ wide

PEGMATITE from 31.7 to $\mathbf{3 4 . 6} \mathrm{m}$, upper contact: near horizontal, lower contact: steeply dipping, both contacts cross-cut foliation of schist, $\sim 2.9 \mathrm{~m}$ wide

SCHIST from 34.6 to $38.4 \mathrm{~m}$, same as above with garnets, $\sim 3.8 \mathrm{~m}$ wide

SCHIST from 34.6 to $36.9 \mathrm{~m}$, banded, coarse grained, $\sim 2.3 \mathrm{~m}$ wide GRANITE DIKE from 36.9 to $37.5 \mathrm{~m}$, leucocratic, coarse grained, parallel to foliation of schist, $\sim 0.6 \mathrm{~m}$ wide SCHIST from 37.5 to $38.4 \mathrm{~m}$, coarse grained, $0.9 \mathrm{~m}$ wide GRANITE from 38.4 to $47.9 \mathrm{~m}$, leucocratic, yellowish white, $\sim 9.5 \mathrm{~m}$ wide

GRANITE from 38.4 to $41.7 \mathrm{~m}$, medium to coarse grained, biotite-muscovite, $\sim 3.3$ m wide

GRANITE from 41.7 to $43.8 \mathrm{~m}$, with swirled lenses of foliated biotites in an equigranular matrix dominated by felsic minerals, $\sim 2.1 \mathrm{~m}$ wide

GRANITE from 43.8 to $46.9 \mathrm{~m}$, coarse grained, biotitemuscovite, $\sim 3.1 \mathrm{~m}$ wide

SCHIST LENS from 45.7 to $46.0 \mathrm{~m}$, folded and swirled into the granite, $\sim 0.3 \mathrm{~m}$ wide

QUARTZ-RICH GRANITE from 46.9 to $47.9 \mathrm{~m}$, dark gray, extremely fine grained, equigranular, possibly altered, $\sim 1.0 \mathrm{~m}$ wide GRANITE DIKE from 47.4 to $47.6 \mathrm{~m}$, steeply dipping, biotite-muscovite, $\sim 22.0 \mathrm{~cm}$ wide

SCHIST from 47.9 to $56.7 \mathrm{~m}$, fine grained, weak and steeply dipping foliation, $\sim 8.8 \mathrm{~m}$ wide

FELSIC ZONE from 51.2 to $51.8 \mathrm{~m}$ in schist, $\sim 0.6 \mathrm{~m}$ wide

GRANITE DIKE from 53.6 to $54.2 \mathrm{~m}$, swirled and embayed upper and lower contacts, $\sim 0.6 \mathrm{~m}$ wide

GRANITE DIKE from 55.1 to $55.8 \mathrm{~m}$, fine grained $\sim 0.7 \mathrm{~m}$ wide

SCHIST from 55.8 to 56.7 , banded, foliation near vertical, $\sim 0.9 \mathrm{~m}$ wide

MIGMATITE from $\mathbf{5 6 . 7}$ to $\mathbf{5 7 . 6} \mathbf{m}$, gneissic texture, few to some foliation in a felsic matrix migmatite, $\sim 0.9 \mathrm{~m}$ wide SCHIST from $\mathbf{5 7 . 6}$ to $67.1 \mathrm{~m}$, coarse grained, gneissic texture, $\sim 9.5 \mathrm{~m}$ wide 
FSE11 Continued

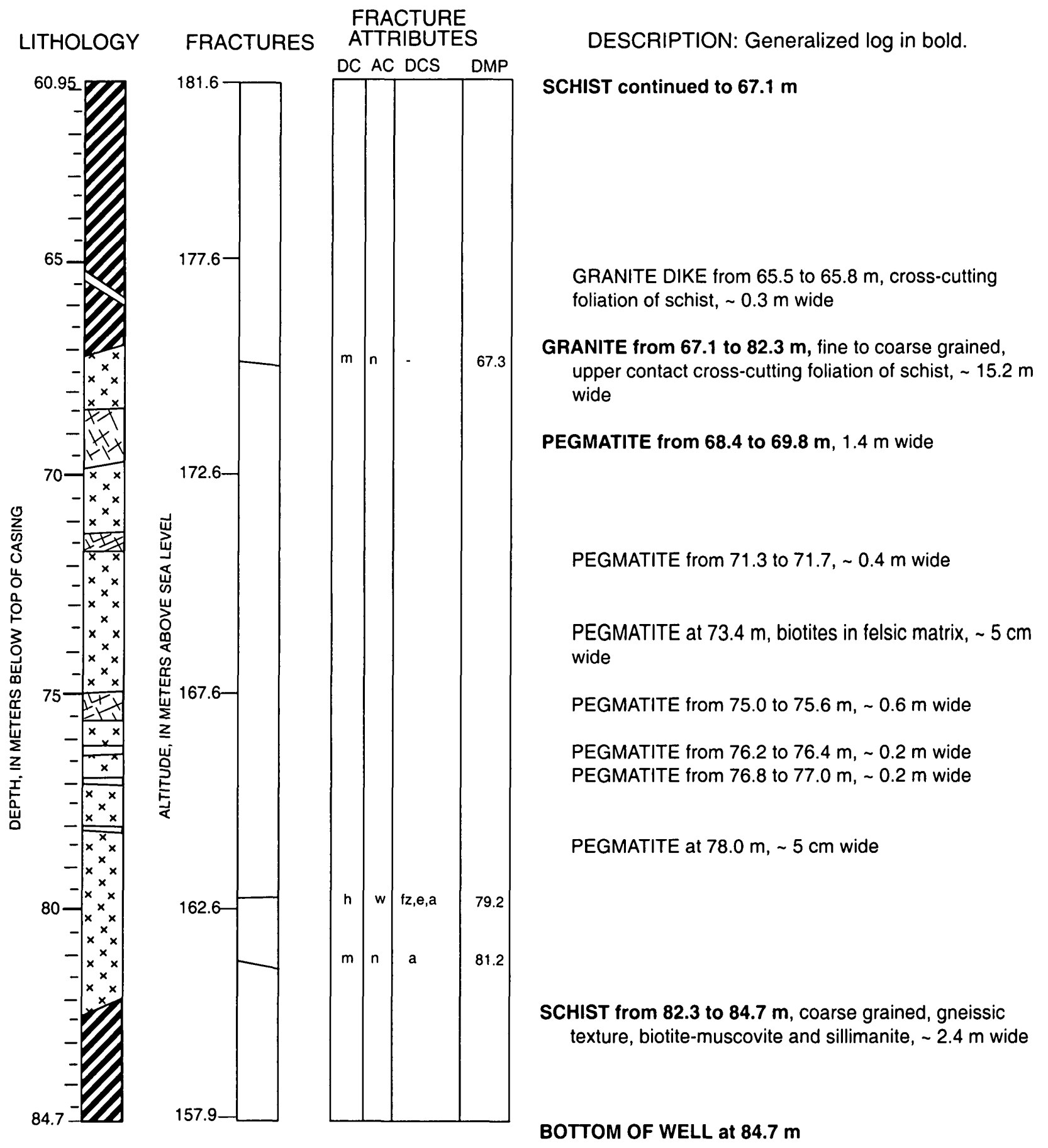


WELL NAME: FSE12

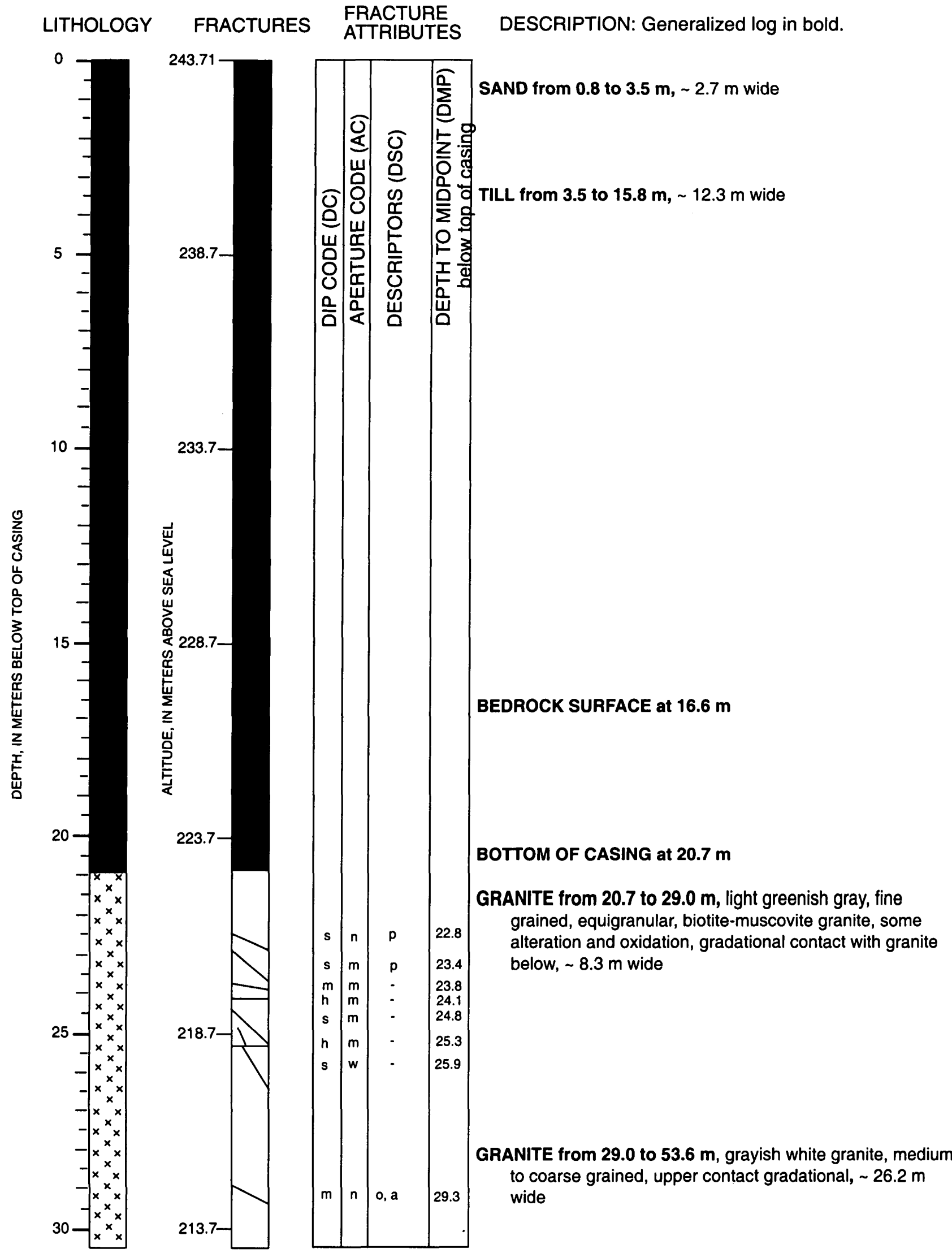


LITHOLOGY
FRACTURE ATTRIBUTES

DC AC DCS DMP

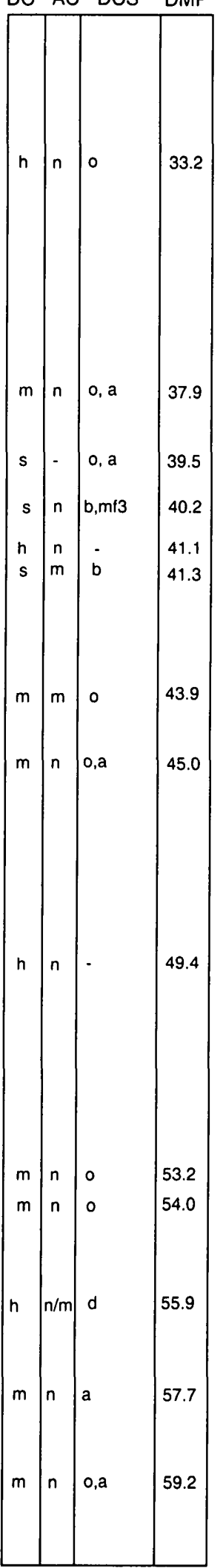

DESCRIPTION: Generalized log in bold.

GRANITE continued to $53.6 \mathrm{~m}$, gray and equigranular, medium to coarse, biotite-muscovite

PEGMATITE from 35.1 to $35.4 \mathrm{~m}$, quartz, muscovite, and feldspar, $\sim 0.3 \mathrm{~m}$ wide

GRANITE from 38.4 to $38.8 \mathrm{~m}$, leucocratic, yellowish white, altered, micaceous, vesicular and porous, gradual contacts above and below, $\sim 0.4 \mathrm{~m}$ wide

PEGMATITE and APLITE from 40.4 to $42.1 \mathrm{~m}$, alternating bands of pegmatite and aplite, leucocratic, yellowish white, pegmatitic muscovite and quartz, $\sim 1.7 \mathrm{~m}$ wide PEGMATITE at $42.1 \mathrm{~m}, \sim 5 \mathrm{~cm}$ wide PEGMATITE at $42.4 \mathrm{~m}, \sim 10 \mathrm{~cm}$ wide PEGMATITE from 43.3 to $43.9 \mathrm{~m}, \sim 0.6 \mathrm{~m}$ wide

PEGMATITE at $44.8 \mathrm{~m}$, muscovite, feldspar and quartz, $\sim 5 \mathrm{~cm}$ wide PEGMATITE at $45.0 \mathrm{~m}, \sim 5 \mathrm{~cm}$ wide PEGMATITE at $46.0 \mathrm{~m}, \sim 10 \mathrm{~cm}$ wide

PEGMATITE at $49.1 \mathrm{~m}, \sim 5 \mathrm{~cm}$ wide PEGMATITE at $49.5 \mathrm{~m}, \sim 5 \mathrm{~cm}$ wide (very low yield in fracture at $49.4 \mathrm{~m}$, noticed during drilling)

PEGMATITE from 51.5 to $51.8 \mathrm{~m}, \sim 0.3 \mathrm{~m}$ wide

\section{PEGMATITE from 53.6 to $55.2 \mathrm{~m}, \sim 1.6 \mathrm{~m}$ wide}

GRANITE from 55.2 to $66.9 \mathrm{~m}$, biotite-muscovite, weakly foliated, $\sim 11.7 \mathrm{~m}$ wide GRANITE from 55.2 to $60.0 \mathrm{~m}$, greenish gray, fine to medium grained texture, biotite-muscovite, $\sim 4.8 \mathrm{~m}$ wide (very low yield in fracture at $55.9 \mathrm{~m}$, noticed during drilling) GRANITE at $56.0 \mathrm{~m}$, porous, vesicular-looking, $\sim 15 \mathrm{~cm}$ wide

GRANITE from 60.0 to $66.9 \mathrm{~m}$, grayish white, medium to coarse grained, gradual textural change from granite above, $\sim 6.9 \mathrm{~m}$ wide 


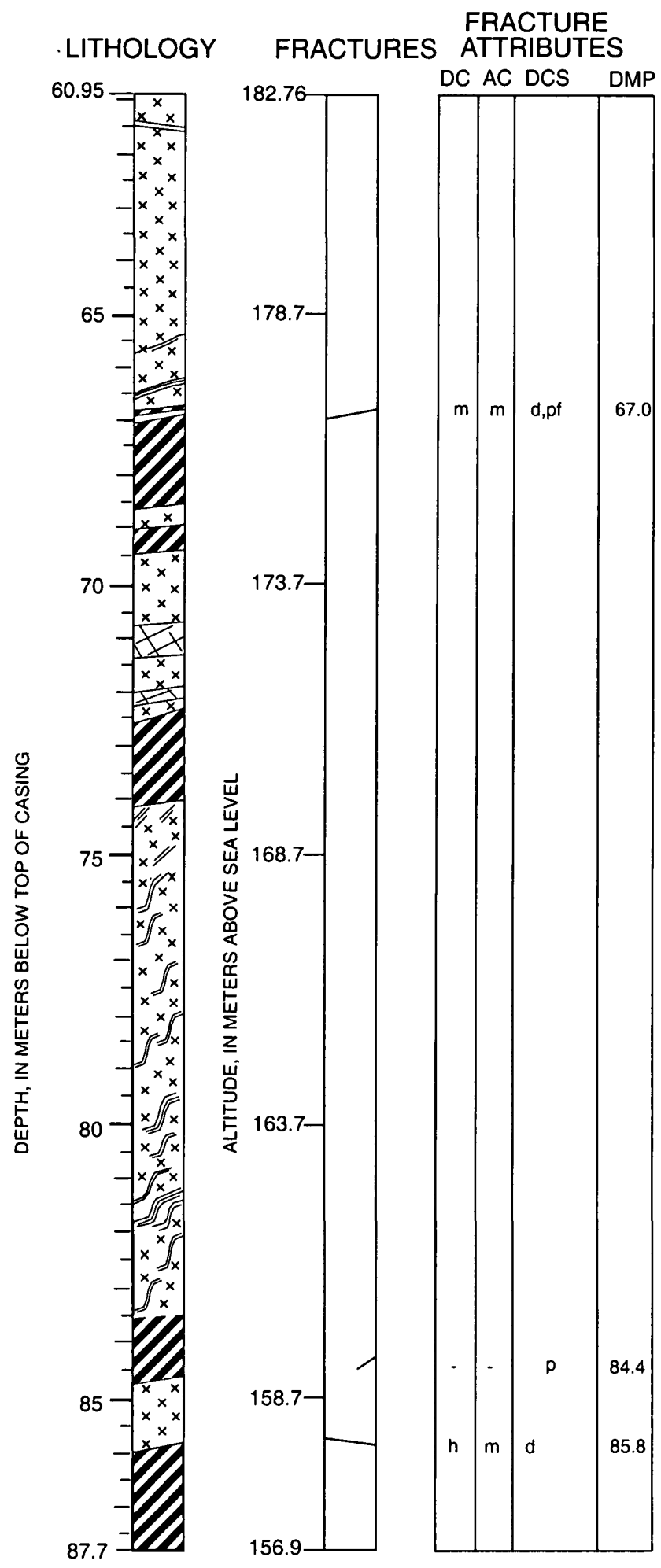

\author{
DESCRIPTION: Generalized log in bold. \\ GRANITE continued to $66.9 \mathrm{~m}$ \\ FELSIC BAND at $61.7 \mathrm{~m}, \sim 10 \mathrm{~cm}$ wide
}

BIOTITE SCHLIEREN at 65.6 and at $66.3 \mathrm{~m}$

SCHIST BAND at $66.9 \mathrm{~m}$, brown with felsic augens,

$\sim 10 \mathrm{~cm}$ wide

SCHIST from 66.9 to $69.4 \mathrm{~m}$, brown to rusty grayish brown and some greenish bands, and some iron staining, biotite and quartz rich schist with iron-sulfide minerals, fine grained, $\sim 2.5 \mathrm{~m}$ wide

GRANITE DIKE from 68.6 to $69.0 \mathrm{~m}, \sim 0.4 \mathrm{~m}$ wide

GRANITE from 69.4 to $72.5 \mathrm{~m}$, brownish light gray, $\sim 3.1 \mathrm{~m}$ wide

PEGMATITE from 70.7 to $71.4 \mathrm{~m}, \sim 0.7 \mathrm{~m}$ wide PEGMATITE from 71.9 to $72.2 \mathrm{~m}, \sim 0.3 \mathrm{~m}$ wide

SCHIST from 72.5 to $74.1 \mathrm{~m}$, dusky brown with white felsic layers, medium to coarse grained texture, sharp contact on top gradual contact with unit below, $\sim 1.6 \mathrm{~m}$ wide

GNEISS or MIGMATITE from $\mathbf{7 4 . 1}$ to $83.5 \mathrm{~m}$, blocky equigranular, coarse grained, with some foliation, gradual contacts above and below, mixed zones of igneous and metamorphic looking units, $\sim 9.4 \mathrm{~m}$ wide

FELSIC ZONE in the gneiss from 78.9 to $79.5 \mathrm{~m}, \sim 0.6 \mathrm{~m}$ wide

SCHISTOSE ZONE from 81.3 to $82.0 \mathrm{~m}$, biotite-rich and highly foliated, $\sim 0.7 \mathrm{~m}$ wide

SCHIST from 83.5 to $84.7 \mathrm{~m}$, dark brown, fine grained, biotite schist, upper contact with gneiss is gradual, $\sim 1.2 \mathrm{~m}$ wide GRANITE DIKE from 84.7 to $85.9 \mathrm{~m}$, yellowish light gray, leucocratic, fine grained, contact is parallel to the foliation of schist, $\sim 1.2 \mathrm{~m}$ wide

SCHIST from 85.9 to $87.7 \mathrm{~m}, \sim 1.8 \mathrm{~m}$ wide

BOTTOM OF WELL at $87.7 \mathrm{~m}$ 
WELL NAME: FSE13

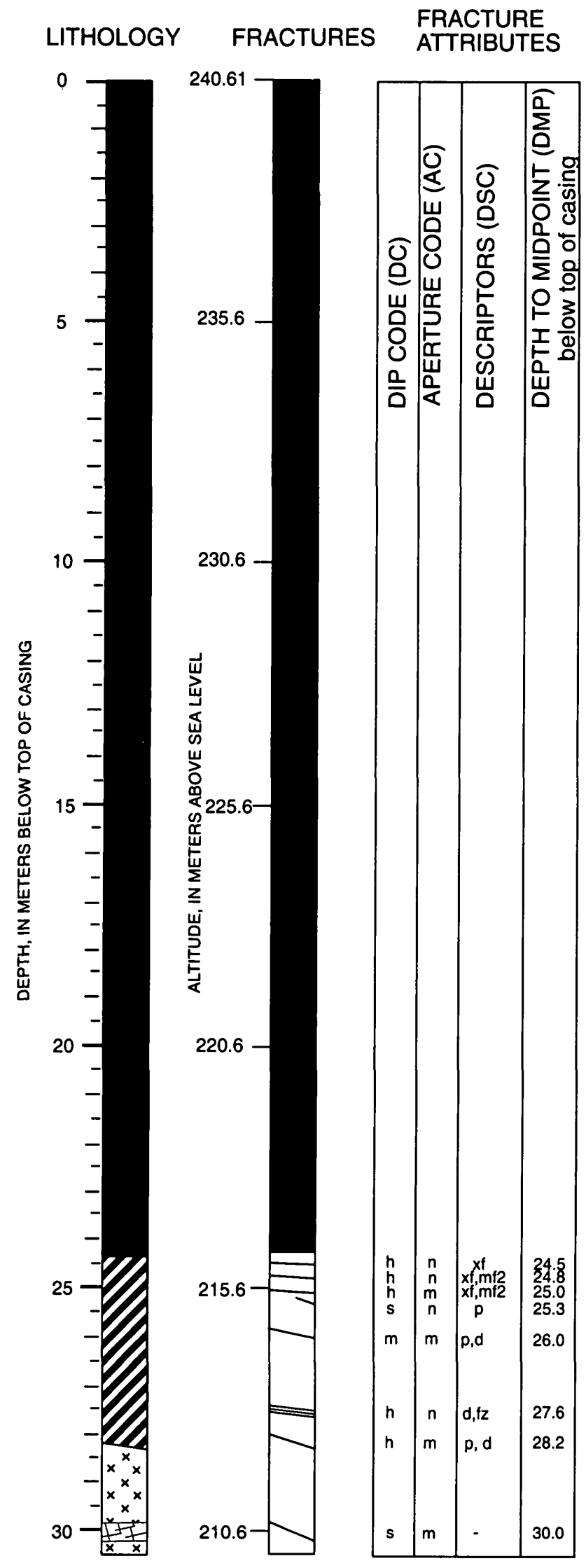

DESCRIPTION: Generalized log in bold.

FILL from 0.8 to $3.2 \mathrm{~m}, \sim 2.4 \mathrm{~m}$ wide

Fine to coarse SAND and GRAVEL from 3.2 to $5.4 \mathrm{~m}$,

$\sim 2.4 \mathrm{~m}$ wide

TILL from 5.4 to $21.6 \mathrm{~m}, \sim 16.2 \mathrm{~m}$ wide

Difficult driling from 15.6 to $15.8 \mathrm{~m}$, possible cobble layer, $\sim 0.2 \mathrm{~m}$ wide

TILL from 19.1 ro $21.6 \mathrm{~m}$, clay rich, gray, $\sim 2.5 \mathrm{~m}$ wide

\section{BEDROCK SURFACE at $22.5 \mathrm{~m}$}

\section{BOTTOM of CASING at $24.4 \mathrm{~m}$}

SCHIST from 24.4 to $28.2 \mathrm{~m}$, very fine grained, biotitemuscovite-quartz-feldspar and sillimanite, weathered, steeply dipping, $\sim 3.8 \mathrm{~m}$ wide

GRANITE from 28.2 to $35.1 \mathrm{~m}, \sim 6.9 \mathrm{~m}$ wide GRANITE from 28.2 to $31.2 \mathrm{~m}$, leucocratic with some pegmatite veins, upper contact cross-cuts foliation of schist Biotite schlieren from 28.3 to $28.6 \mathrm{~m}, \sim 0.3 \mathrm{~m}$ wide Pegmatite from 29.9 to $30.2 \mathrm{~m}, \sim 0.3 \mathrm{~m}$ wide 


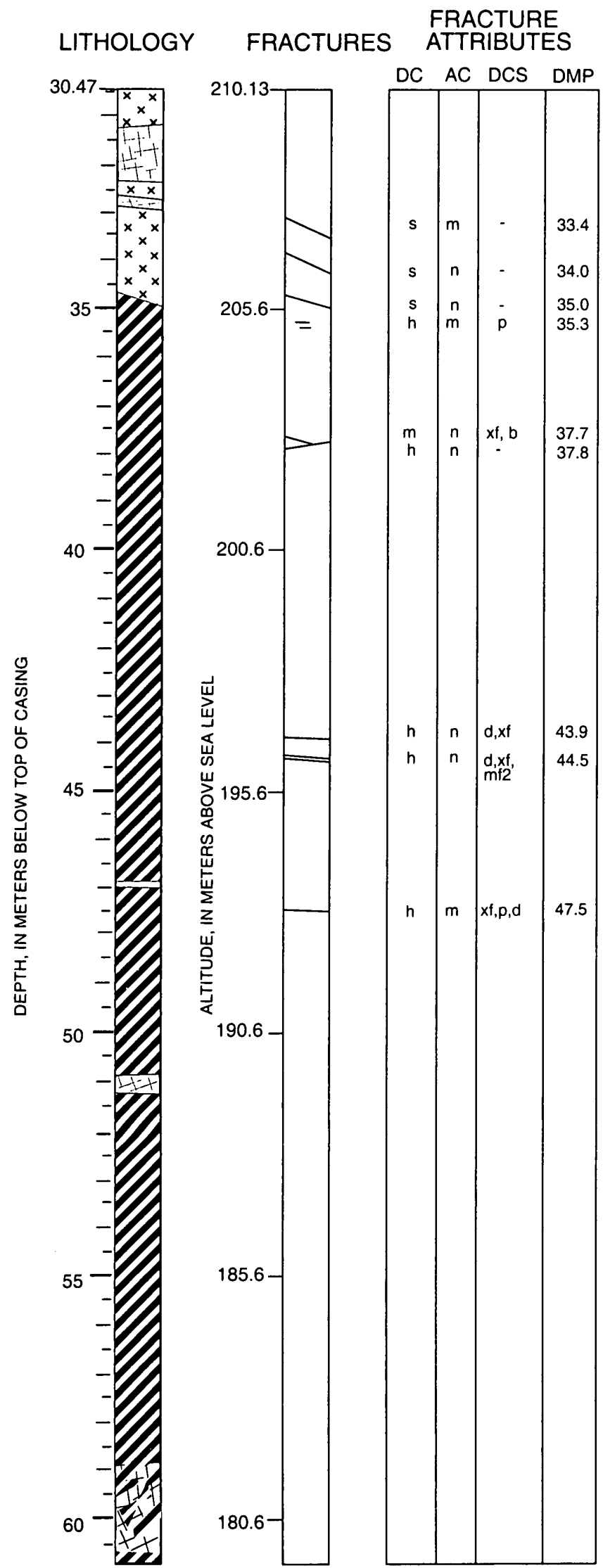

\section{DESCRIPTION: Generalized log in bold.}

\section{Granite continued to $35.1 \mathrm{~m}$}

PEGMATITE 31.2 to $32.3 \mathrm{~m}$, massive, rich in muscovite, gradual contacts with granite above and below, $\sim 1.1 \mathrm{~m}$ wide

PEGMATITE 32.6 to $32.8 \mathrm{~m}, \sim 15 \mathrm{~cm}$ wide

SCHIST from 35.1 to $48.8 \mathrm{~m}$, biotite-rich, with steeply dipping foliation, $\sim 13.7 \mathrm{~m}$ wide

SCHIST from 35.1 to $36.3 \mathrm{~m}$, fine grained, $\sim 1.2 \mathrm{~m}$ wide

SCHIST from 36.3 to $48.8 \mathrm{~m}$, coarse grained biotite-rich, augen to banded schist, steeply dipping foliation,

$\sim 12.5 \mathrm{~m}$ wide

(Rusty-brown precipitation (iron oxidation) occurring between fractures at 43.9 and $44.5 \mathrm{~m}$ )

PEGMATITE DIKE at $46.9 \mathrm{~m}$, cross-cutting near vertical foliation, $\sim 7 \mathrm{~cm}$ wide

MIGMATITE from $\mathbf{4 8 . 8}$ to $\mathbf{5 4 . 9} \mathrm{m}$, coarse gneissic texture, dominated by foliated biotite-rich zones mixed with coarse grained, equigranular felsic zones (leucosome), gradational contacts with schist above and pegmatite below, $\sim 6.1 \mathrm{~m}$ wide

PEGMATITIC from 50.8 to $51.2 \mathrm{~m}$, possibly felsic portion of migmatite, $\sim 0.4 \mathrm{~m}$ wide

SCHIST from 54.9 to $61.6 \mathrm{~m}$, coarse grained with felsic augens and felsic-rich zones,steeply dipping foliation, $\sim 6.7 \mathrm{~m}$ wide

PEGMATITE and SCHIST from 58.8 to $60.3 \mathrm{~m}$, interfingered, schistose portions have coarse texture, possibly migmatite interfingered with schist, $\sim 1.5 \mathrm{~m}$ wide

PEGMATITE at $60.3 \mathrm{~m}, \sim 0.4 \mathrm{~m}$ wide 
FSE13 Continued

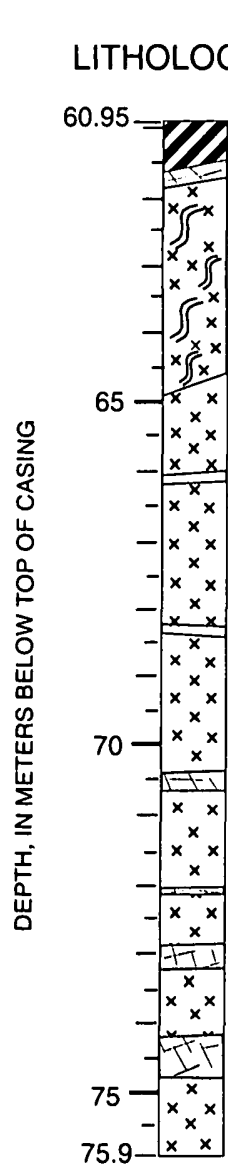

\section{FRACTURES}

179

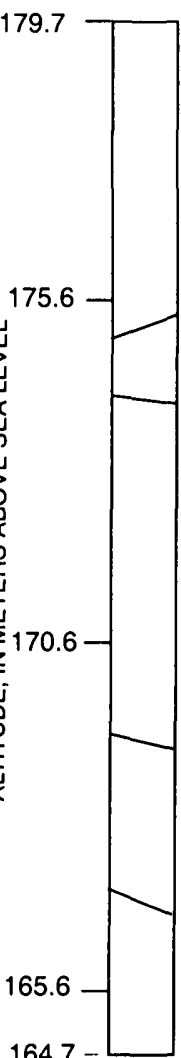

FRACTURE

ATTRIBUTES

DC AC DCS DMP

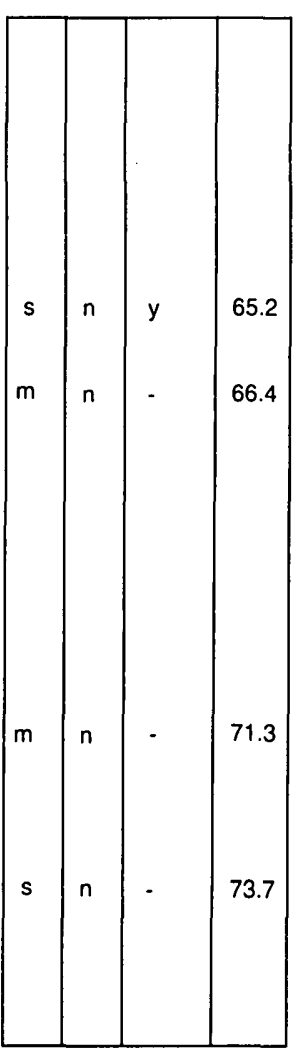

DESCRIPTION: Generalized log in bold.

\section{SCHIST continued to $61.6 \mathrm{~m}$}

PEGMATITE DIKE at $61.5 \mathrm{~m}, \sim 15 \mathrm{~cm}$ wide

MIGMATITE from 61.6 to $65.1 \mathrm{~m}$, coarse grained texture, predominanitly equigranular felsic minerals with some biotite-rich foliated zones (leucosome), $3.5 \mathrm{~m}$ wide

GRANITE from 65.1 to $75.6 \mathrm{~m}$, leucocratic, medium to coarse texture, biotite-muscovite, top contact cross-cuts foliation of migmatite, $\sim 10.5 \mathrm{~m}$ wide

(very low yielding fracture at $65.2 \mathrm{~m}$, noted during drilling) PEGMATITE VEIN at $66.1 \mathrm{~m}, \sim 5 \mathrm{~cm}$ wide

PEGMATITE VEIN at $68.3 \mathrm{~m}, \sim 5 \mathrm{~cm}$ wide

PEGMATITE DIKE from 70.4 to $70.7 \mathrm{~m}, \sim 0.3 \mathrm{~m}$ wide

PEGMATITE VEIN at $72.2, \sim 15 \mathrm{~cm}$ wide

PEGMATITE DIKE from 72.8 to $73.2 \mathrm{~m}, \sim 0.4 \mathrm{~m}$ wide

PEGMATITE DIKE from 74.2 to $74.8 \mathrm{~m}, \sim 0.6 \mathrm{~m}$ wide

BOTTOM OF WELL at $75.9 \mathrm{~m}$ 
LITHOLOGY

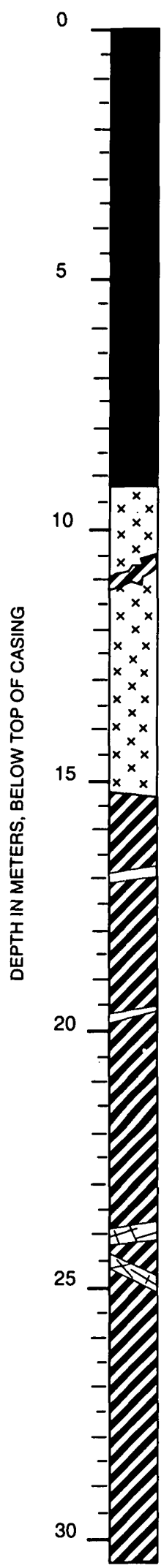

\section{FRACTURE}

232.15

227.2
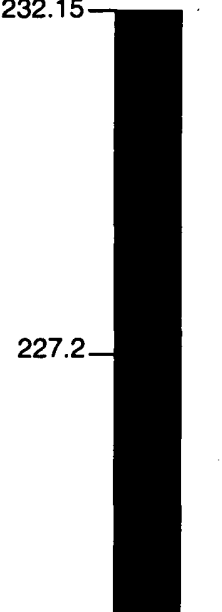

222.2

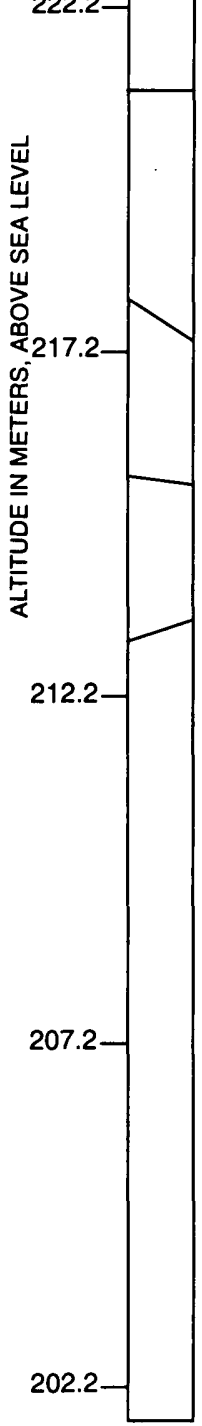

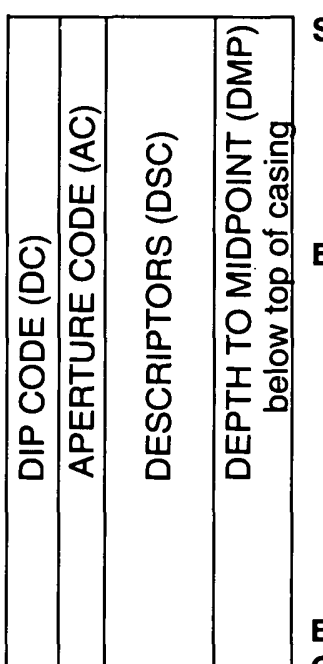

BOTTOM OF CASING at $9.14 \mathrm{~m}$

GRANITE from 9.1 to $15.2 \mathrm{~m}$, leucocratic with some oxidized feldspars and quartz, biotite-muscovite granite, with some biotite schlieren, $\sim 6.1 \mathrm{~m}$ wide

GRANITE or GNEISS from 10.7 to $11.3 \mathrm{~m}$, biotite-rich, coarse grained, foliated, $\sim 0.6 \mathrm{~m}$ wide

SCHIST from 15.2 to $\mathbf{3 4 . 4} \mathrm{m}$, grayish black, coarse grained, biotite-muscovite-quartz-feldspar-sillimanite and garnet, with some augens, $\sim 19.2 \mathrm{~m}$ wide

FELSIC DIKE from 16.8 to $17.1 \mathrm{~m}, \sim 0.3 \mathrm{~m}$ wide

FELSIC VEIN at $19.6 \mathrm{~m}$, coarse grained, irregular edges, parallel to foliation of the schist, $\sim 20 \mathrm{~cm}$ wide

PEGMATITE DIKE from 23.8 to $24.1 \mathrm{~m}$, parallel to the foliation of schist, $\sim 20 \mathrm{~cm}$ wide

PEGMATITE DIKE from 24.3 to $24.6 \mathrm{~m}, \sim 0.3 \mathrm{~m}$ wide

SCHIST from $\sim 27.0$ to $\sim 31.0 \mathrm{~m}$, biotite-rich, weakly foliated with augens, $\sim 4.0 \mathrm{~m}$ wide 
LITHOLOGY

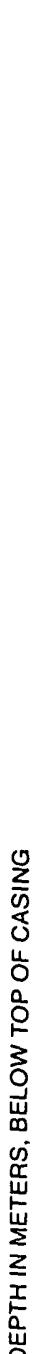

FRACTURE

FRACTURES ATTRIBUTES

DC AC DCS

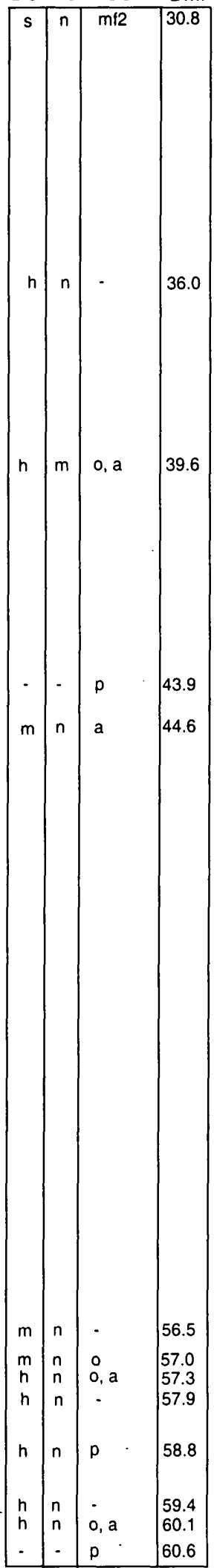

DESCRIPTION: Generalized log in bold.

\section{SCHIST continued to $34.4 \mathrm{~m}$}

PEGMATITE from 30.8 to $31.1 \mathrm{~m}$, steeply dipping and

parallel to the foliation of schist, $\sim 0.3 \mathrm{~m}$ wide

SCHIST from 31.1 to $34.4 \mathrm{~m}$, felsic rich, biotite schist, some weak banding, $\sim 3.3 \mathrm{~m}$ wide

PEGMATITE from 34.4 to $36.0 \mathrm{~m}$, muscovite-rich, some biotites parallel to foliation of schist, $\sim 1.6 \mathrm{~m}$ wide SCHIST from 36.0 to $54.5 \mathrm{~m}, \sim 18.5 \mathrm{~m}$ wide

SCHIST from 36.0 to $44.0 \mathrm{~m}$, biotite schist, fine to coarse grained, some laminated zones, some weak banding, $\sim 8.0 \mathrm{~m}$ wide

SCHIST from 44.0 to $54.4 \mathrm{~m}$, coppery brown, with coticule layers, moderately dipping foliation, $\sim 10.4 \mathrm{~m}$ wide GRANITE DIKE from 44.8 to $45.4 \mathrm{~m}$, grayish white, gradational contacts above and below, $\sim 0.6 \mathrm{~m}$ wide

GRANITE DIKE from 46.3 to $46.5 \mathrm{~m}$, greenish white, parallel to the foliation of schist, $\sim 0.2 \mathrm{~m}$ wide

GRANITE DIKE at $48.2 \mathrm{~m}$, parallel to the foliation of schist, $\sim 15 \mathrm{~cm}$ wide

GRANITE from 54.5 to $68.9 \mathrm{~m}, \sim 14.4 \mathrm{~m}$ wide

GRANITE from $~-59.5$ to $62.5 \mathrm{~m}$, muscovite-biotite, with greenish microcline, with some sulfide minerals, $\sim 3.0 \mathrm{~m}$ wide 
H1 Continued

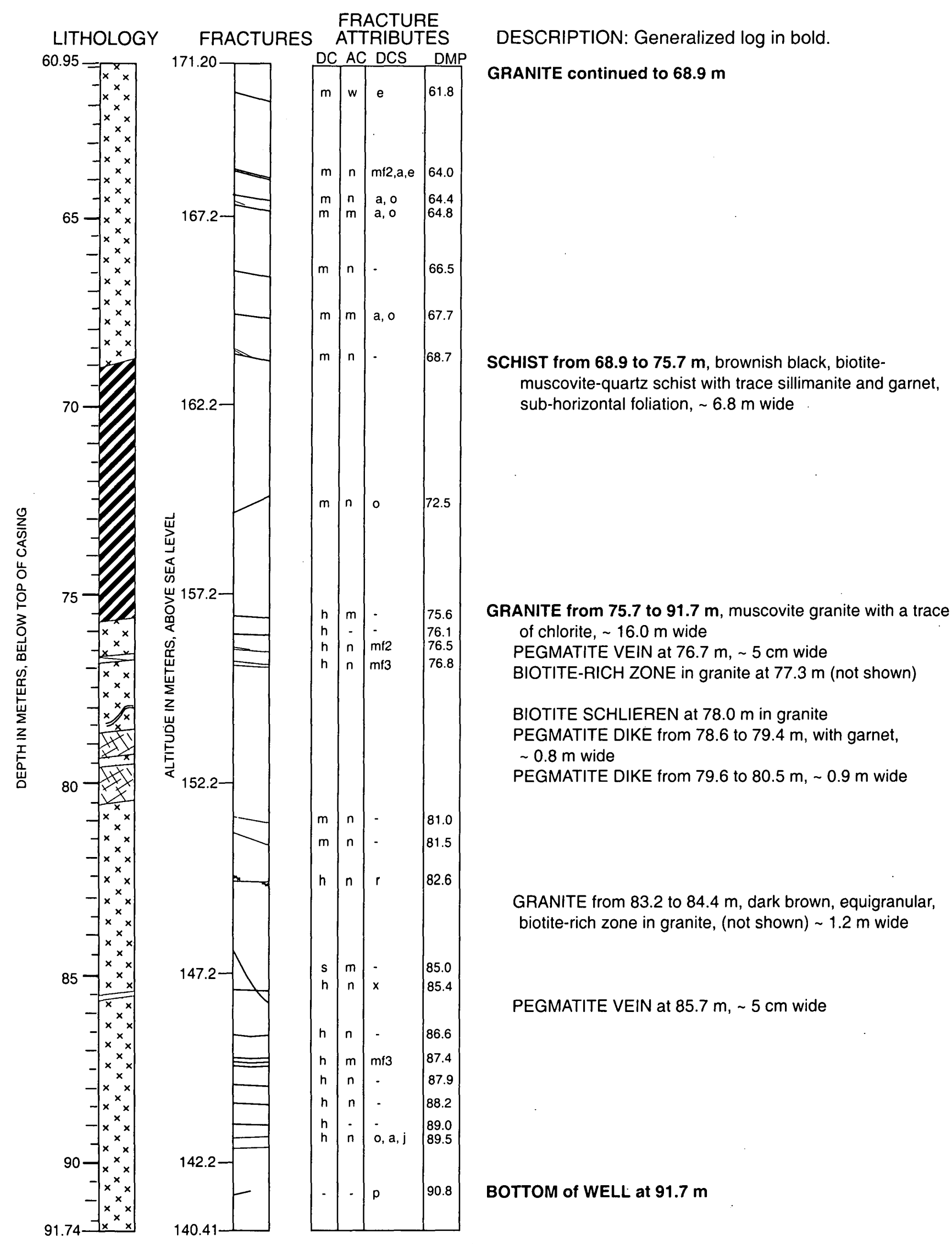

168 Lithology and Fracture Characterization From Drilling Investigations in the Mirror Lake Area, Grafton County, New Hampshire 


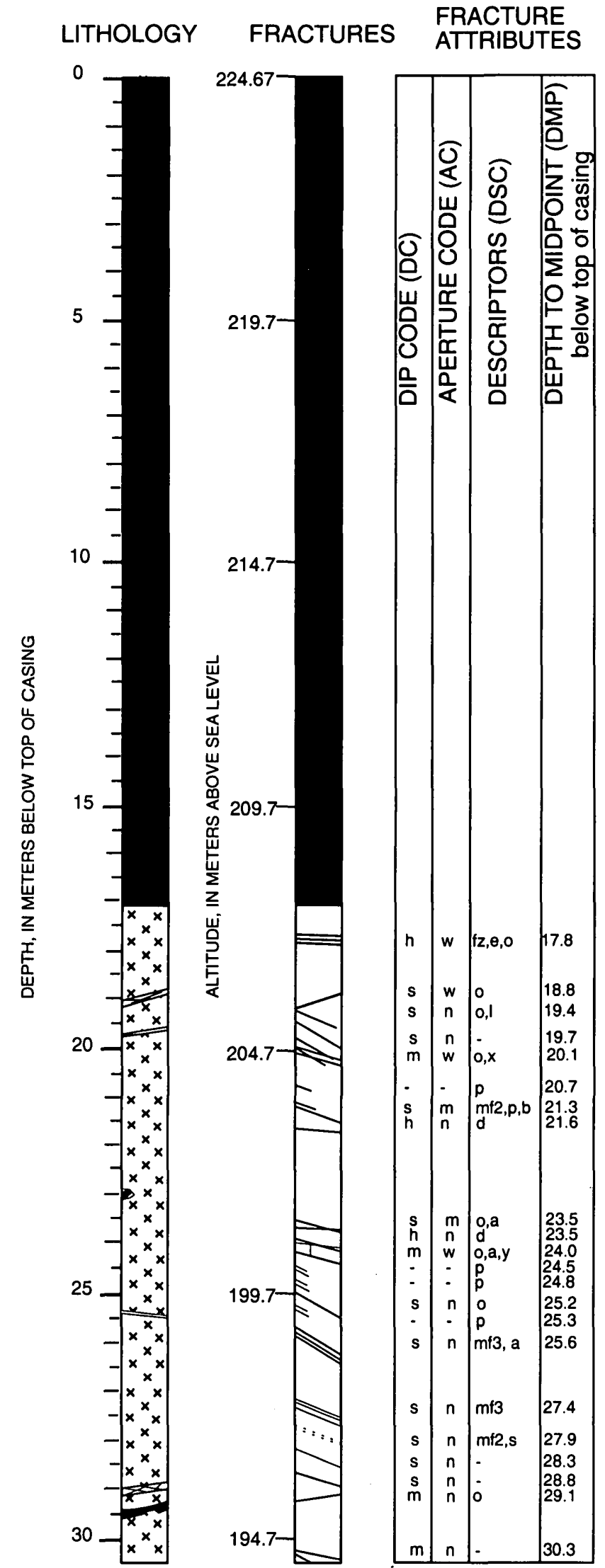

DESCRIPTION: Generalized log in bold.

SAND, GRAVEL and FILL from 0.5 to $9.4 \mathrm{~m}$, brown, fine to coarse sand, fine to coarse gravel, and boulder-sized fill, $8.9 \mathrm{~m}$ wide

TILL from 9.4 to $13.0 \mathrm{~m}$, gray, $\sim 3.6 \mathrm{~m}$ wide

BEDROCK SURFACE at $12.7 \mathrm{~m}$

Cuttings: GRANITE, biotite-muscovite, oxidized, $\sim 4.0 \mathrm{~m}$ wide

\section{BOTTOM OF CASING at $17.07 \mathrm{~m}$}

GRANITE from 17.1 to $46.5 \mathrm{~m}$, biotite-muscovite, greenish gray with some oxidized zones, $\sim 29.4 \mathrm{~m}$ wide PEGMATITE VEIN at $18.9 \mathrm{~m}, \sim 7.0$ to $10 \mathrm{~cm}$ wide (the fracture is along the lower contact between the pegmatite and granite)

PEGMATITE VEIN at $19.7 \mathrm{~m}, \sim 2.0 \mathrm{~cm}$ wide

SCHIST XENOLITH in granite at $23.0 \mathrm{~m}, \sim 15 \mathrm{~cm}$ long GRANITE from 23.7 to $24.1 \mathrm{~m}$, highly oxidized zone, $\sim 0.4 \mathrm{~m}$ wide

GRANITE from 24.4 to $27.5 \mathrm{~m}$, light greenish gray to greenish gray, $\sim 3.1 \mathrm{~m}$ wide

PEGMATITE at $28.9 \mathrm{~m}$, oxidized along upper and lower contacts, $\sim 9 \mathrm{~cm}$ wide. (fracture at $29.1 \mathrm{~m}$ along bottom contact between pegmatite and granite)

BASALT DIKE at $29.6 \mathrm{~m}$, irregularly shaped, grayish black, welded to host, $\sim 10 \mathrm{~cm}$ wide 


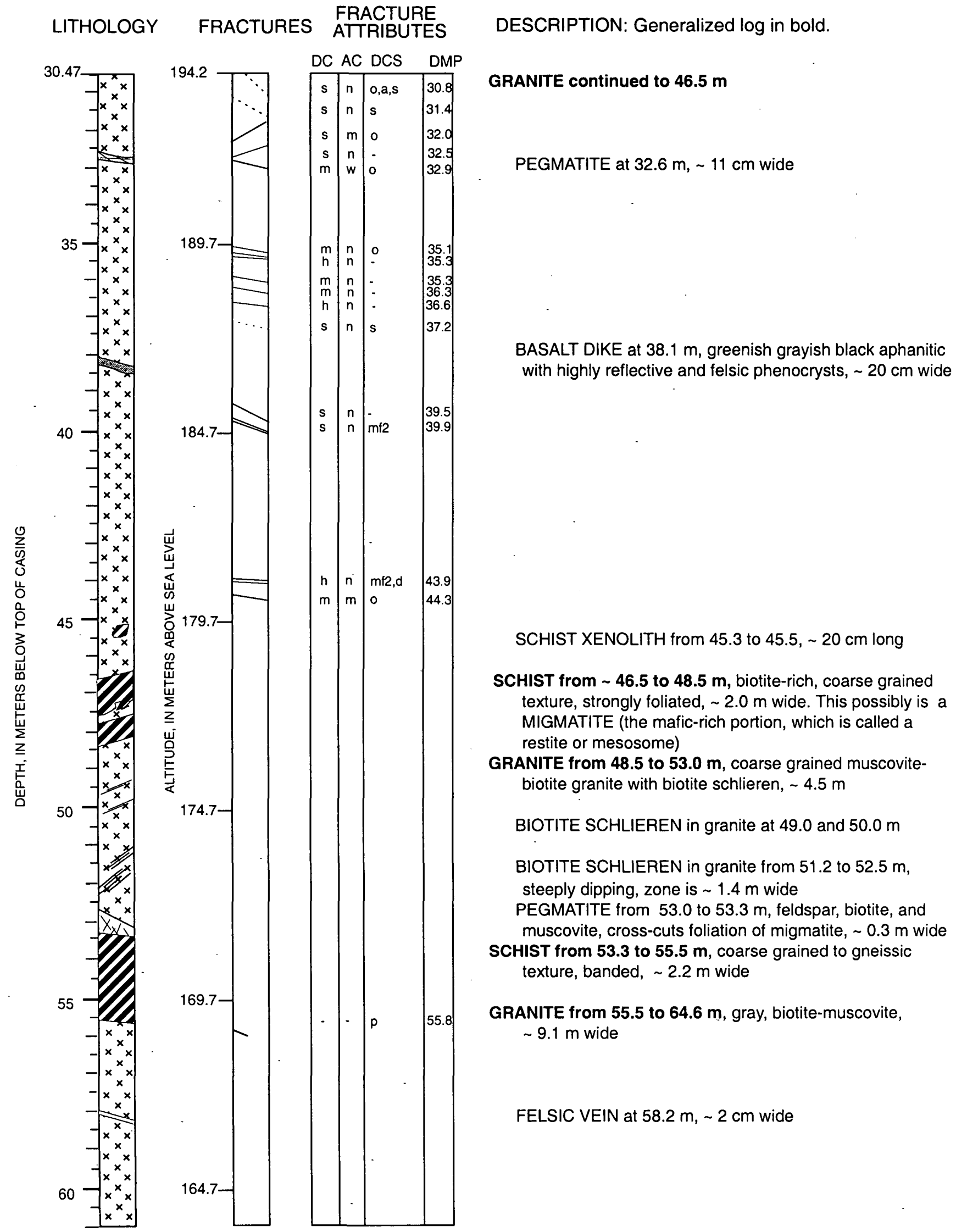




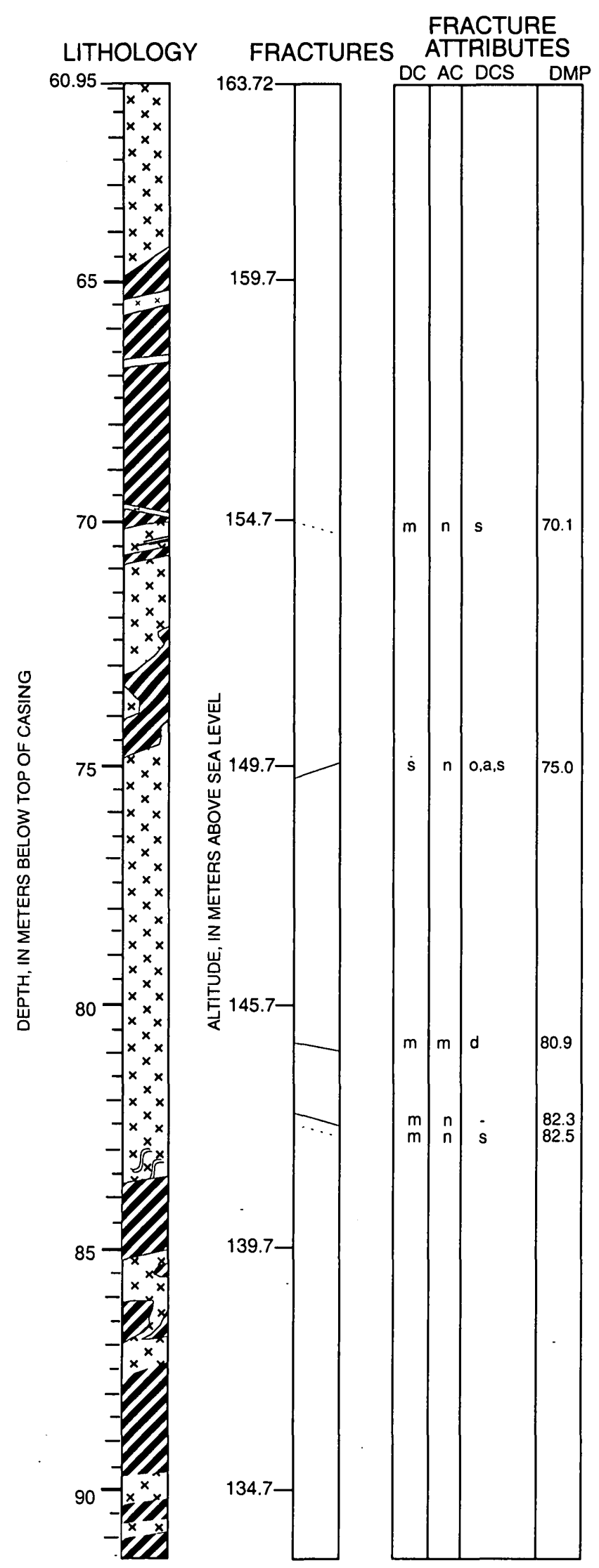

DESCRIPTION: Generalized log in bold.

\section{GRANITE continued to $64.6 \mathrm{~m}$}

GRANITE from 61.6 to $64.6 \mathrm{~m}$, biotite-muscovite, coarse grained, $\sim 3.0 \mathrm{~m}$ wide

SCHIST from 64.6 to $69.8 \mathrm{~m}$, coarse grained to gneissic texture, steeply dipping foliation, with some augens, - $5.2 \mathrm{~m}$ wide

GRANITE from 65.3 to $65.6 \mathrm{~m}$, parallel to foliation, $\sim 0.3 \mathrm{~m}$ wide

FELSIC VEIN at 69.8 , cross-cuts foliation of schist, $1-2 \mathrm{~cm}$ wide

GRANITE from 69.8 to $73.0 \mathrm{~m}$, biotite-muscovite, $3.2 \mathrm{~m}$ wide

SCHIST or MIGMATITE from 73.0 to $75.3 \mathrm{~m}$, coarse grained to gneissic texture, weakly foliated, looks like a mixture of igneous and metamorphic zones, $\sim 1.7 \mathrm{~m}$ wide

GRANITE from 75.3 to $83.6 \mathrm{~m}, \sim 8.3 \mathrm{~m}$ wide GRANITE from 75.3 to $77.5 \mathrm{~m}$, biotite-rich granite, weakly foliated, $\sim 2.2 \mathrm{~m}$ wide

GRANITE from 77.5 to $83.0 \mathrm{~m}$, biotite-muscovite granite, more felsic than the granite above, $\sim 5.5 \mathrm{~m}$ wide

GRANITE from 83.0 to $83.6 \mathrm{~m}$, gneissic texture, near vertical foliations, coarse grained gradual contacts, $\sim 0.6 \mathrm{~m}$ wide

SCHIST from 83.6 to $85.1 \mathrm{~m}$, gneissic texture, $\sim 1.5 \mathrm{~m}$ wide

GRANITE from 85.1 to $87.5 \mathrm{~m}$, with schist xenoliths, $\sim 2.4 \mathrm{~m}$ wide

SCHIST from 87.5 to $94.7 \mathrm{~m}$, coarse grained to gneissic, felsic-rich, swirled foliation, $\sim 9.2 \mathrm{~m}$ wide

GRANITE DIKE from 89.7 to $90.3 \mathrm{~m}$, biotite-muscovite, crosscuts foliation, near horizontal, $\sim 0.6 \mathrm{~m}$ wide GRANITE DIKE from 90.7 to $91.0, \sim 0.3 \mathrm{~m}$ wide 


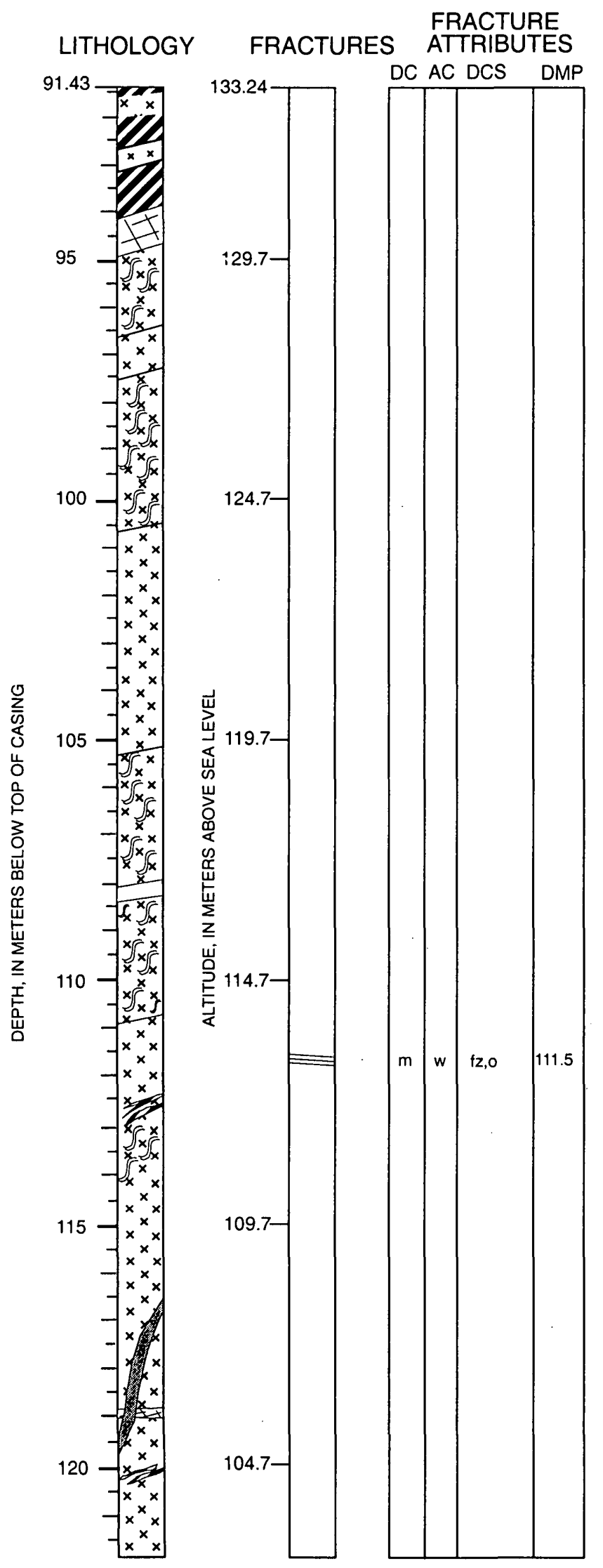

DESCRIPTION: Generalized log in bold.

SCHIST continued to $94.7 \mathrm{~m}$

GRANITE DIKE with schlieren from 91.5 to $92.0 \mathrm{~m}, \sim 0.5 \mathrm{~m}$

wide

GRANITE DIKE from 92.7 to $93.0 \mathrm{~m}, \sim 0.3 \mathrm{~m}$ wide

PEGMATITE from 94.0 to $94.7 \mathrm{~m}, \sim 0.7 \mathrm{~m}$ wide

GNEISS from 94.7 to $96.7 \mathrm{~m}$, gneissic texture, steeply dipping foliation, $\sim 2.0 \mathrm{~m}$ wide

GRANITE from 96.7 to $97.6 \mathrm{~m}$ with some foliated biotites and muscovite, gradual contacts, $\sim 0.9 \mathrm{~m}$ wide

GNEISS from $\sim 97.6$ to $\mathbf{1 0 0 . 6} \mathrm{m}$, gneissic texture moderately dipping foliation, $\sim 3.0 \mathrm{~m}$ wide

GRANITE from 100.6 to $105.3 \mathrm{~m}, \sim 4.7 \mathrm{~m}$ wide

GRANITE from 100.6 to $101.4 \mathrm{~m}$, moderate orange pink to light brown, and green mottled, partial fracture-gradual lower contact, $\sim 0.9 \mathrm{~m}$ wide

GRANITE from 101.4 to $105.3 \mathrm{~m}$, cross-cuts foliation of gneiss subparallel to near horizontal contact and dipping foliation, biotite-muscovite, fine grained granite, $\sim 3.9 \mathrm{~m}$ wide

GNEISS from 105.3 to $110.8 \mathrm{~m}$, coarse grained, $\sim 5.5 \mathrm{~m}$ wide

APLIITE DIKE from 108.0 to $108.4 \mathrm{~m}, \sim 0.4 \mathrm{~m}$ wide

GRANITE from $\mathbf{1 1 0 . 8}$ to $134.4 \mathrm{~m}$, biotite-muscovite, sugar texture, $\sim 23.6 \mathrm{~m}$ wide

GRANITE from 111.5 to $114.0 \mathrm{~m}$, some parts weakly foliated with gneissic texture, gradual contacts, altered, $\sim 2.5 \mathrm{~m}$ wide

GRANITE from 114.0 to $121.0 \mathrm{~m}$, biotite granite, coarse grained, salt and pepper, $\sim 7.0 \mathrm{~m}$ wide

BASALT DIKE at $118.1 \mathrm{~m}$, near vertical, basalt exposed vertically over $3.0 \mathrm{~m}$ of the borehole, $\sim 20 \mathrm{~cm}$ wide

PEGMATITE DIKE at $119.0 \mathrm{~m}$, cross-cut by basalt, near horizontal, $\sim 20 \mathrm{~cm}$ wide

BIOTITE SCHLIEREN in granite at $120.2 \mathrm{~m}$

GRANITE from 120.4 to $121.9 \mathrm{~m}$, coarse grained, less biotite, some schlieren migmatitic/gneissic, $\sim 1.5 \mathrm{~m}$ wide 
IS1 Continued

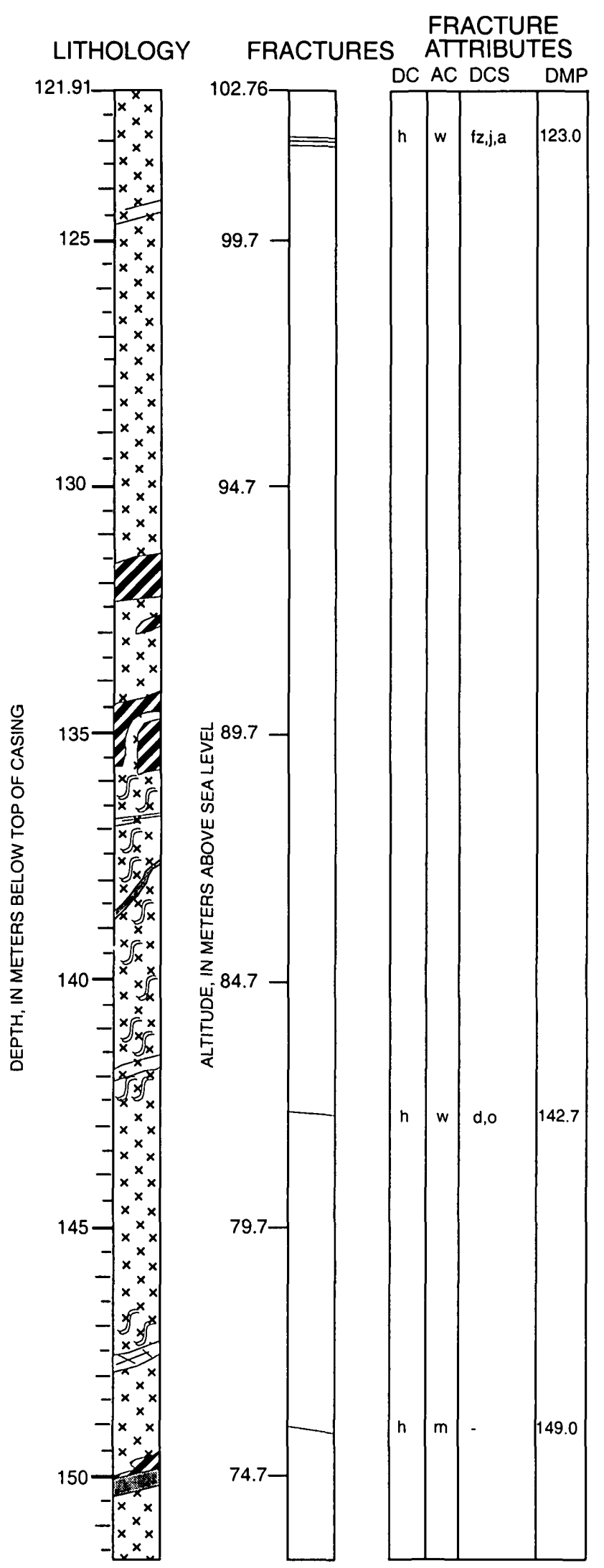

DESCRIPTION: Generalized log in bold.

GRANITE continued to $134.4 \mathrm{~m}$

GRANITE from $122.0 \mathrm{~m}$ to $124.8 \mathrm{~m}$, coarse grained to gneissic texture, moderately dipping foliation, altered, felsic-rich, coarse grained, $\sim 2.8 \mathrm{~m}$ wide

GRANITE from 124.8 to $128.2 \mathrm{~m}$, biotite-rich, equigranular texture, $\sim 3.4 \mathrm{~m}$ wide

GRANITE from 126.9 to $127.0 \mathrm{~m}$, black, very reflective, biotite-rich zone, $\sim 20 \mathrm{~cm}$ wide (not shown)

GRANITE 128.2 to $131.7 \mathrm{~m}$, biotite-muscovite granite, more felsic than the granite above, with some schist xenoliths, equigranular, weakly foliated, $\sim 3.5 \mathrm{~m}$ wide

SCHIST from 131.6 to $132.4 \mathrm{~m}$, coarse grained to gneissic texture, $\sim 0.8 \mathrm{~m}$ wide

GRANITE 132.4 to $134.4 \mathrm{~m}$, biotite-muscovite granite, $3.5 \mathrm{~m}$ wide

SCHIST from 134.4 to $135.9 \mathrm{~m}$, coarse grained, gneissic texture, with swirled foliations, $\sim 1.5 \mathrm{~m}$ wide GNEISS from 135.9 to $142.7 \mathrm{~m}$, or granite with gneissic texture, with some biotite schlieren, $\sim 8.8 \mathrm{~m}$ wide BIOTITE SCHLIEREN in GNEISS at $136.6 \mathrm{~m}, \sim 0.3 \mathrm{~m}$ wide

BASALT VEIN in GRANITE at $138.1 \mathrm{~m}, 5$ to $10 \mathrm{~cm}$ wide

GRANITE from 142.7 to $151.5 \mathrm{~m}, \sim 8.8 \mathrm{~m}$ wide GRANITE DIKE from 142.7 to $146.5 \mathrm{~m}$, biotite rich, $\sim 3.8 \mathrm{~m}$ wide

GRANITE from 146.5 to $151.5 \mathrm{~m}$, grayish white, fine grain, less biotite rich than the granite immediately above, $\sim 5.0 \mathrm{~m}$ wide PEGMATITE DIKE from 147.5 to $147.8 \mathrm{~m}$, muscovitequartz, $\sim 0.3 \mathrm{~m}$ wide

BASALT DIKE from 149.7 to $150.1 \mathrm{~m}$, dark greenish gray, altered, $\sim 0.4 \mathrm{~m}$ wide BOTTOM OF WELL AT $151.5 \mathrm{~m}$ 
WELL NAME: K1

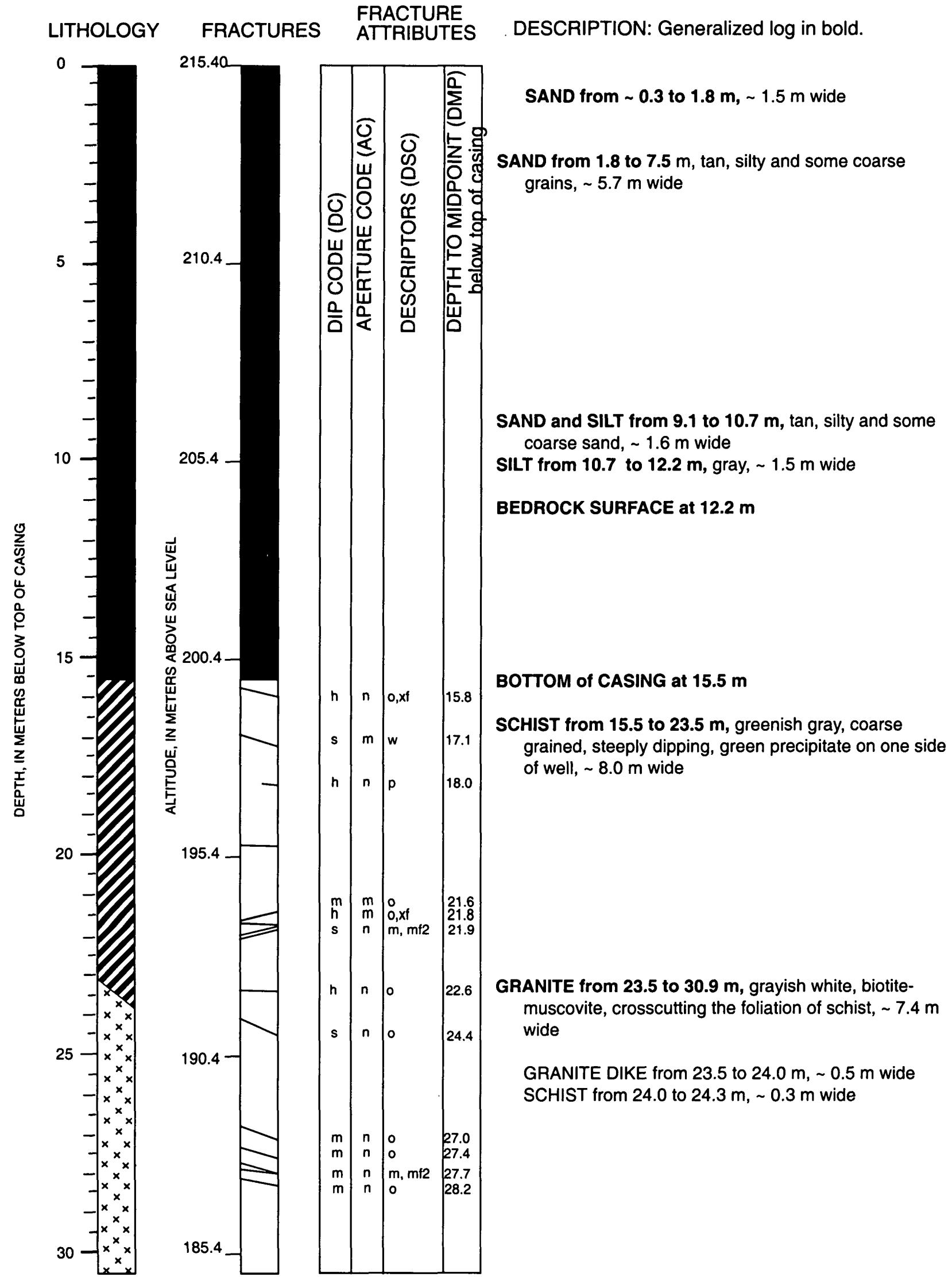

174 Lithology and Fracture Characterization From Drilling Investigations in the Mirror Lake Area, Grafton County, New Hampshire 


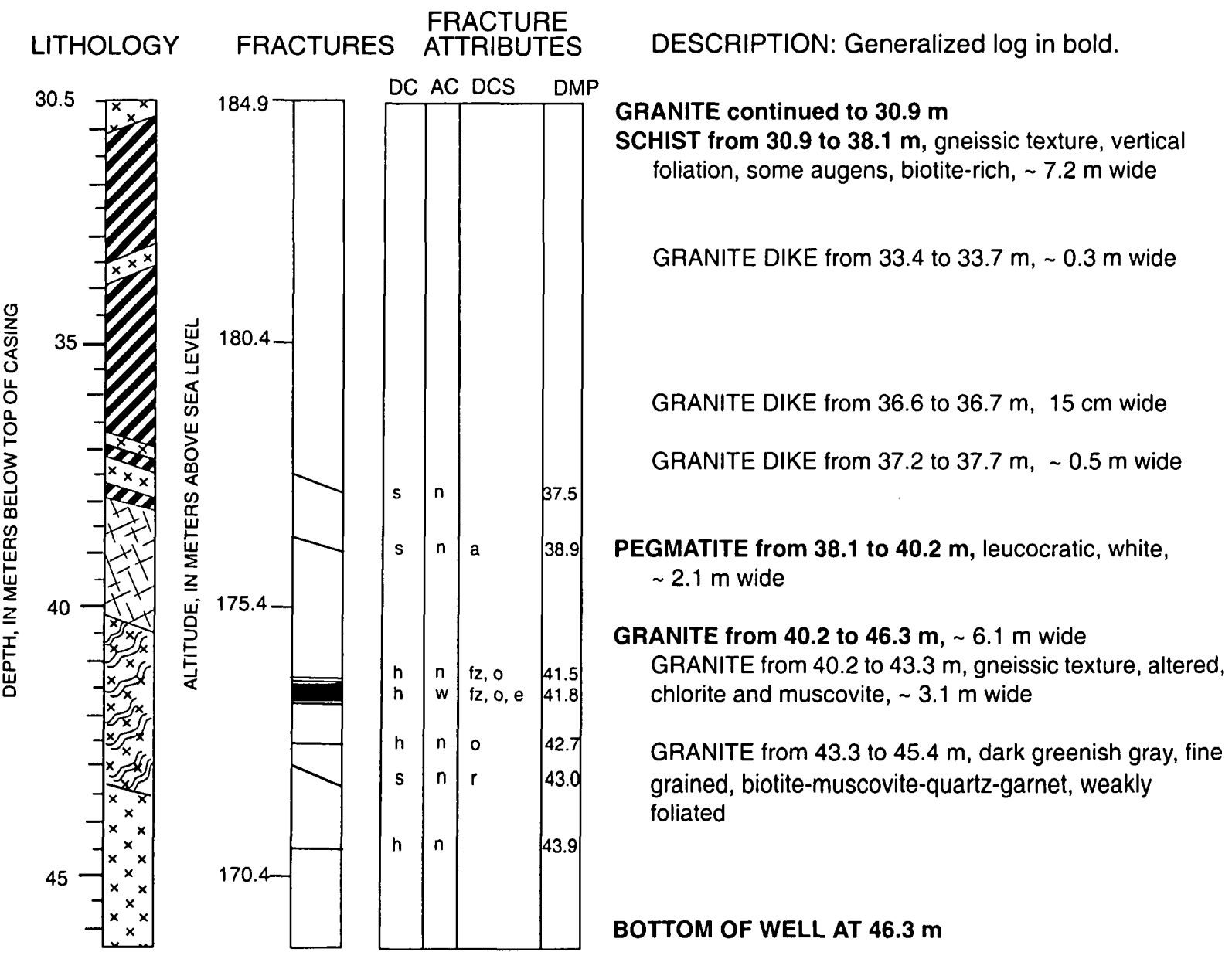


WELL NAME: K2

LITHOLOGY

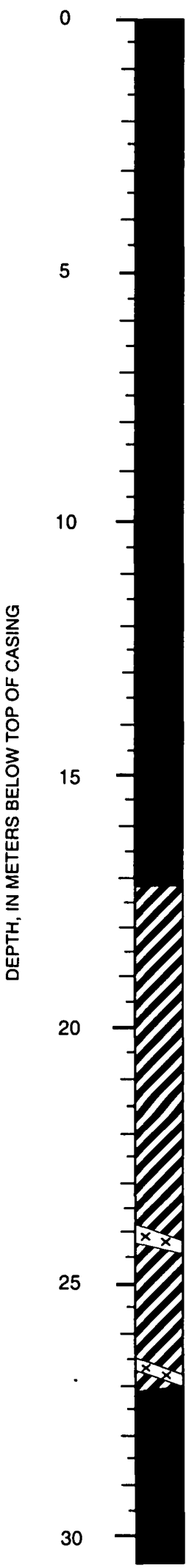

FRACTURE

FRACTURES ATTRIBUTES

215.18

210.2

205.2

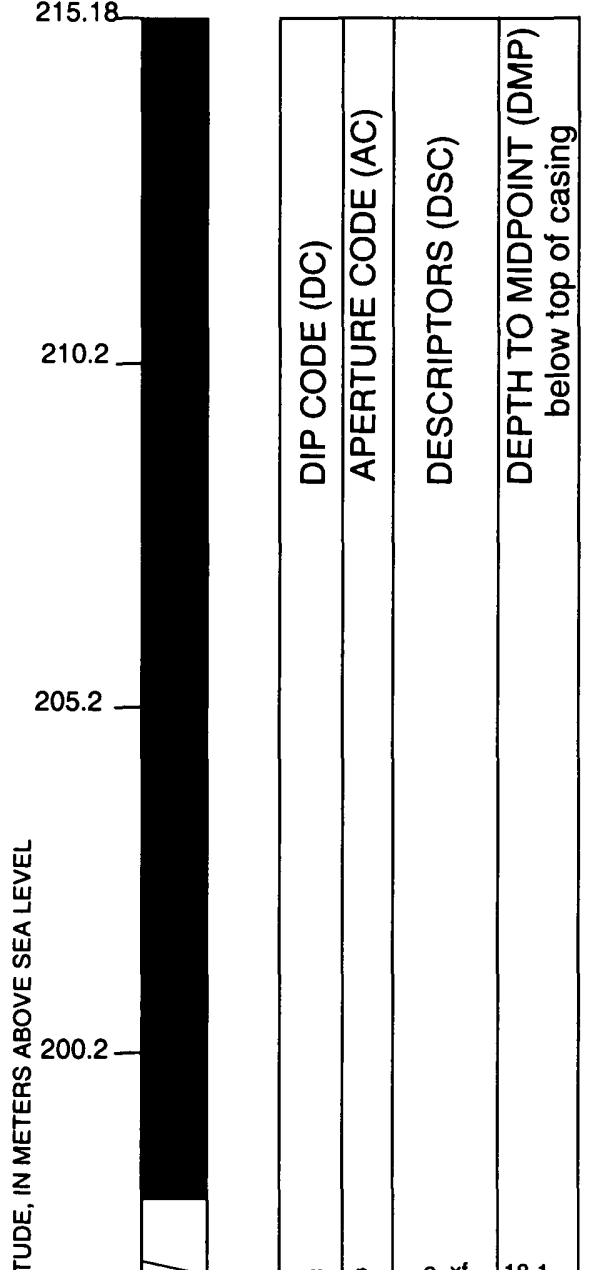

$0, \times f$

点

195.2

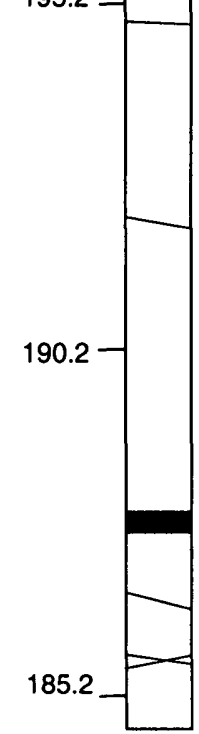

DESCRIPTION: Generalized log in bold

SAND \& GRAVEL from $\sim 0.37$ to $1.8 \mathrm{~m}$, red, fine sand to medium gravel with mostly silt and fine sand, probably till, $\sim 1.43 \mathrm{~m}$ wide

TILL from $\sim 1.8$ to $8.0 \mathrm{~m}$, gray, fine sand to medium gravel with mostly silt and fine sand, $\sim 6.2 \mathrm{~m}$ wide

Till from 8.0 to $9.5 \mathrm{~m}$, gray, small balls of silty till in addition to sand and gravel, $\sim 1.5 \mathrm{~m}$ wide

Till from 9.5 to $14.1 \mathrm{~m}$, gray, very silty till, $\sim 4.6 \mathrm{~m}$ wide

BEDROCK SURFACE at $14.1 \mathrm{~m}$

\section{BOTTOM of CASING at $17.37 \mathrm{~m}$}

SCHIST from 17.4 to $26.8 \mathrm{~m}$, banded, moderate dip, coarse grained, biotite-muscovite, $\sim 9.4 \mathrm{~m}$ wide

GRANITE DIKE from 23.8 to 24.1 , greenish white, biotite-muscovite, coarse grained, cross-cuts foliation of schist, $\sim 0.3 \mathrm{~m}$ wide

PEGMATITE DIKE from 26.4 to $26.7 \mathrm{~m}, \sim 0.3 \mathrm{~m}$ wide

BASALT from 26.8 to $\mathbf{3 0 . 9} \mathrm{m}$, dark greenish gray to black, with felsic phenochrysts and extremely narrow veins, $4.1 \mathrm{~m}$ wide 


\section{LITHOLOGY}

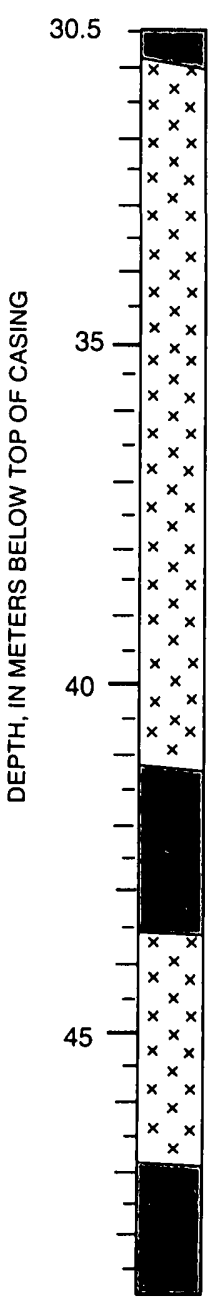

FRACTURE FRACTURES ATTRIBUTES

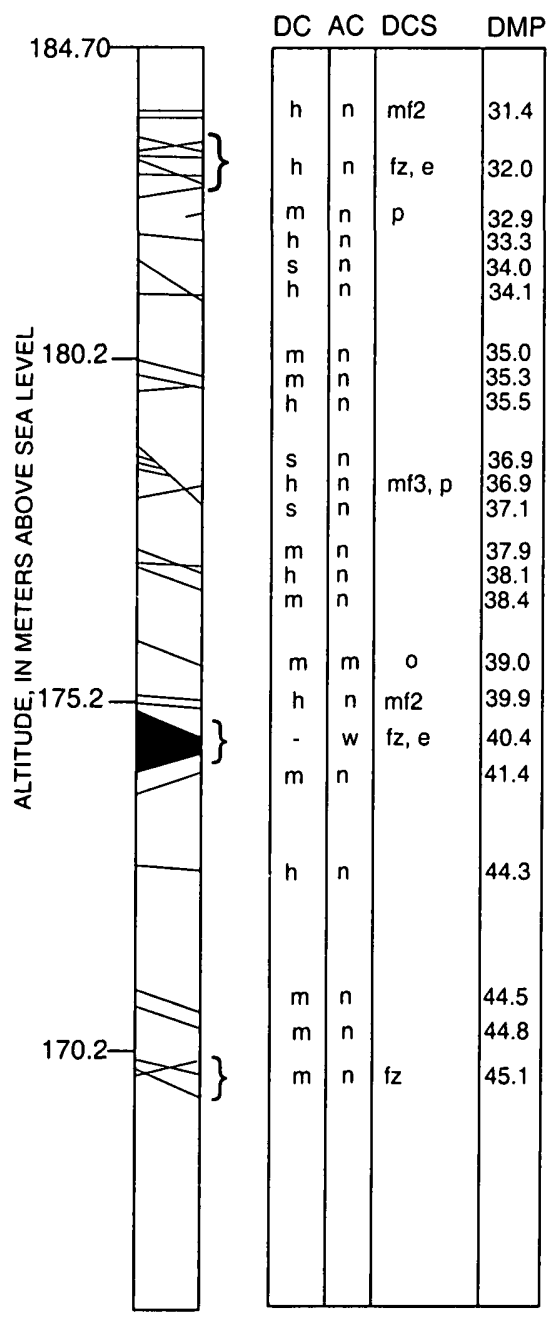

DESCRIPTION: Generalized log in bold

\section{BASALT continued to $30.9 \mathrm{~m}$}

GRANITE from 30.9 to $41.1 \mathrm{~m}$, grayish white, coarse grained, biotite-muscovite, $\sim 10.2 \mathrm{~m}$ wide

BASALT from 41.1 to $43.6 \mathrm{~m}, 2.5 \mathrm{~m}$ wide

(Fracture zone, fractures too numerous to count, well bore angular and jagged)

GRANITE from 43.6 to $46.9 \mathrm{~m}$, coarse grained, biotitemuscovite, $3.3 \mathrm{~m}$ wide

BASALT from $\mathbf{4 6 . 9}$ to $\mathbf{4 8 . 8} \mathrm{m}, 1.9 \mathrm{~m}$ wide

BOTTOM OF WELL AT $48.8 \mathrm{~m}$ 


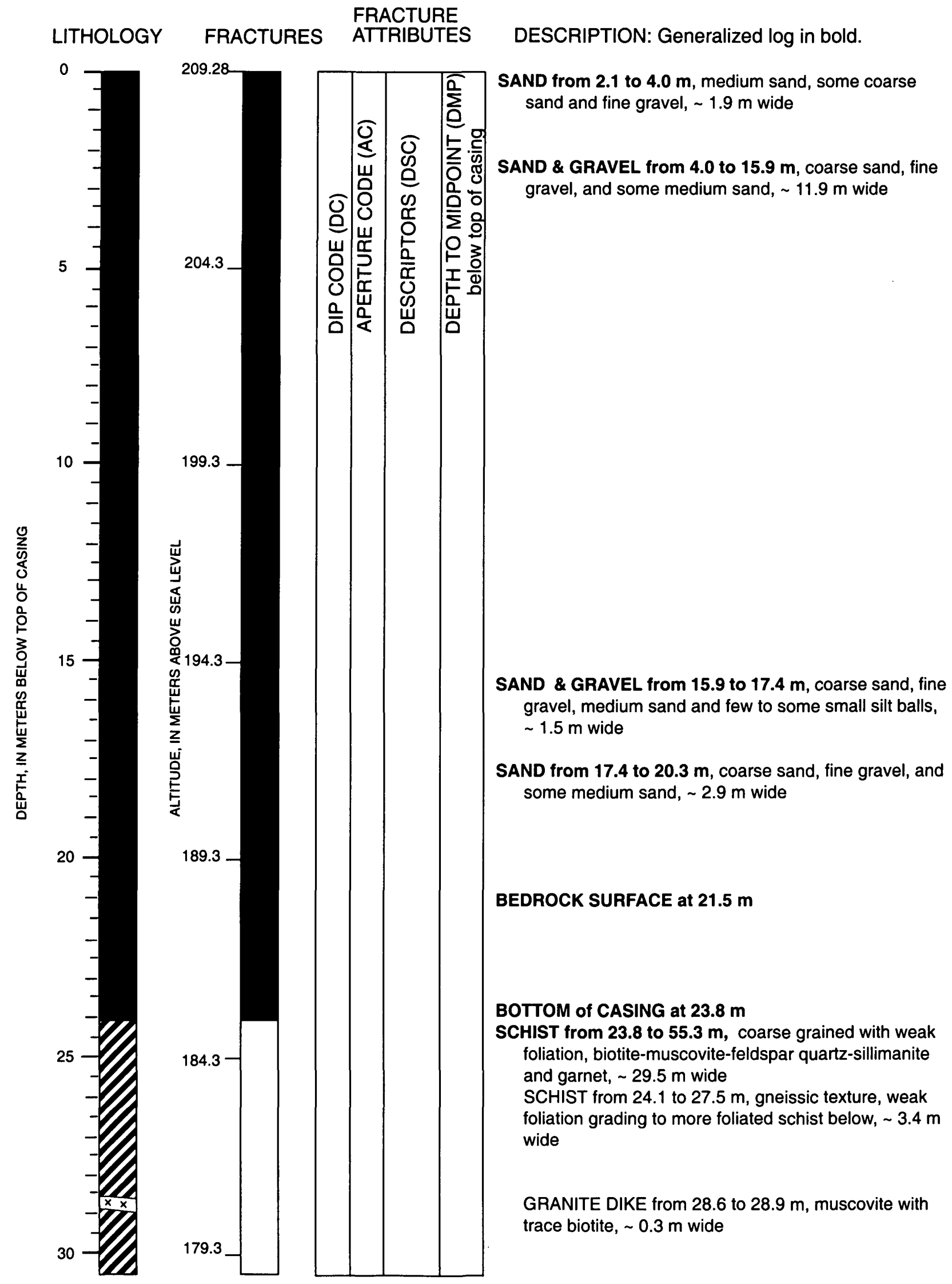




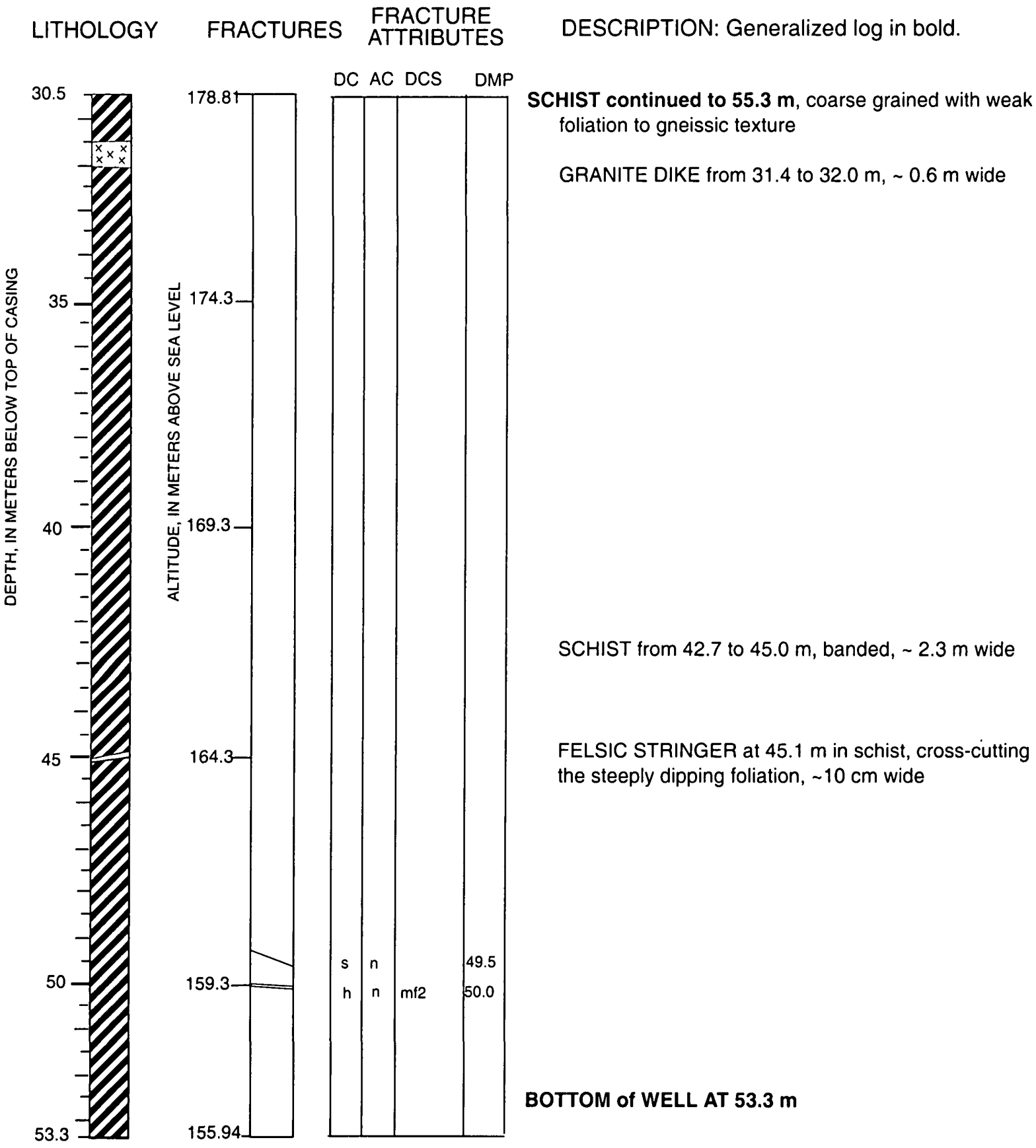


LITHOLOGY

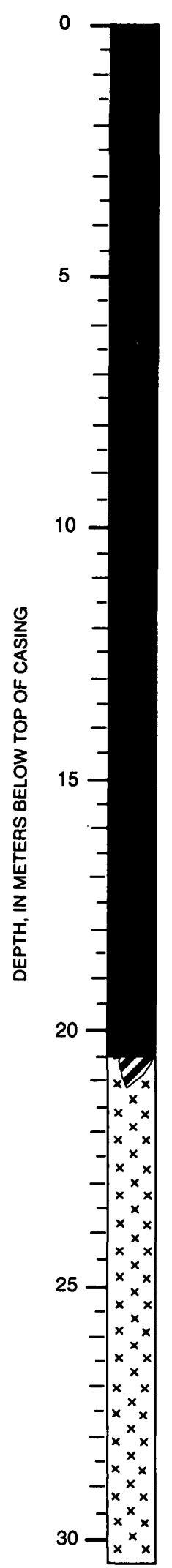

FRACTURE

ATTRIBUTES

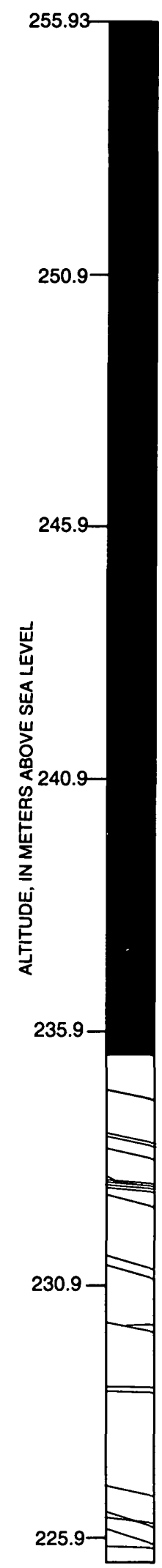

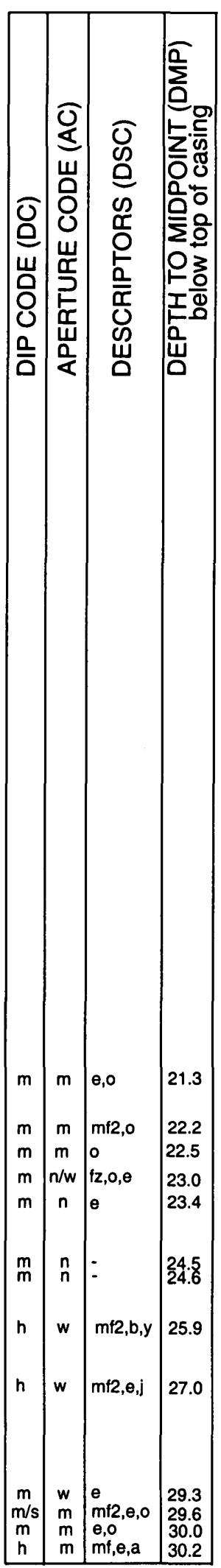

DESCRIPTION: Generalized log in bold.

GRAVEL and SAND from 0.76 to $\sim 2.3 \mathrm{~m}, \sim 1.5 \mathrm{~m}$ wide

TILL from 2.3 to $16.9 \mathrm{~m}, \sim 14.6 \mathrm{~m}$ wide

TILL from 2.3 to $4.5 \mathrm{~m}$, sandy till with gravels, $\sim 2.2 \mathrm{~m}$ wide

TILL from 4.5 to $16.9 \mathrm{~m}$, gray, silty till, $\sim 12.4 \mathrm{~m}$ wide

BEDROCK SURFACE at $16.9 \mathrm{~m}$

BOTTOM OF CASING at $20.42 \mathrm{~m}$

GRANITE from 20.4 to $35.1 \mathrm{~m}$, gray, biotite-muscovite, foliated, altered, $\sim 14.7 \mathrm{~m}$ wide SCHIST from 20.4 to $21.0 \mathrm{~m}$, schist xenolith or lower contact of schist intersecting one side of well, biotitemuscovite-quartz-schist, with some garnets and pyrite minerals, $\sim 0.6 \mathrm{~m}$ wide
GRANITE from $\sim 29.0$ to $30.5 \mathrm{~m}$, light olive gray to greenish gray, with some chlorite, $\sim 1.5 \mathrm{~m}$ wide 
R1 Continued

LITHOLOGY

FRACTURE

FRACTURES ATTRIBUTES

焉

44.3

45

(1)

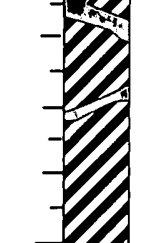

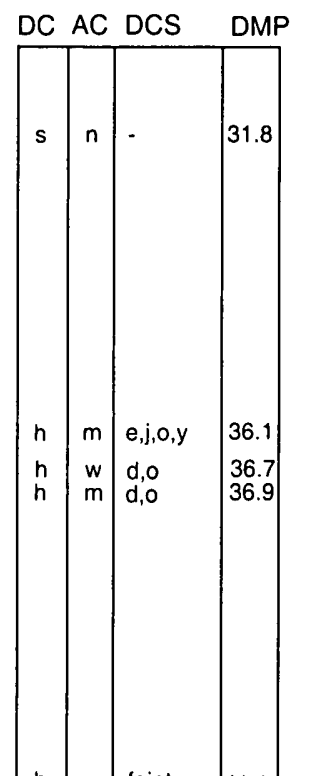

42.5

43.5

44.3

50

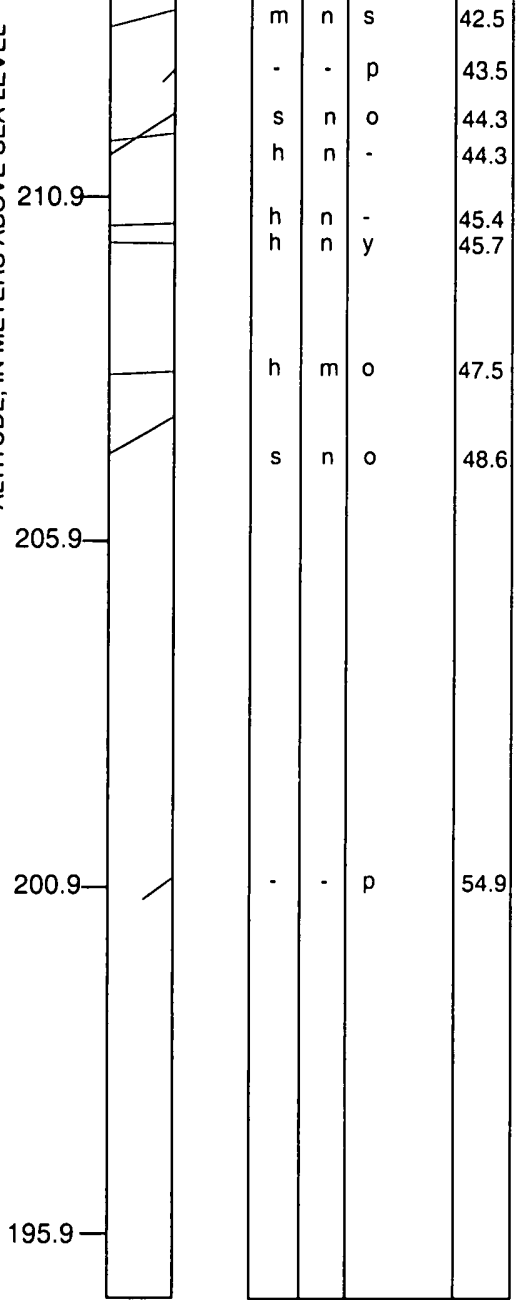

DESCRIPTION: Generalized log in bold.

GRANITE continued to $35.1 \mathrm{~m}$

PEGMATITE VEIN at $33.2 \mathrm{~m}, \sim 4 \mathrm{~cm}$ wide

BASALT VEIN at $33.9 \mathrm{~m}, \sim 2 \mathrm{~cm}$ wide

BASALT DIKE from 35.1 to $37.7 \mathrm{~m}$, dark gray, with some oxidized zones and some felsic phenocrysts, some thermal cracks in basalt- not counted as fractures $\sim 2.6 \mathrm{~m}$ wide GRANITE from 37.7 to $38.5 \mathrm{~m}$, same as above, $\sim 0.8 \mathrm{~m}$ wide

BASALT VEIN from 38.5 to $39.5 \mathrm{~m}$, on one side of well

BASALT VEIN at $39.9 \mathrm{~m}, 20 \mathrm{~cm}$ wide GNEISS from 38.4 to $41.0 \mathrm{~m}, \sim 1.6 \mathrm{~m}$ wide

SCHIST from 41.0 to $56.3 \mathrm{~m}, \sim 15.3 \mathrm{~m}$ wide

SCHIST or GNEISS from 41.0 to $45.0 \mathrm{~m}$, biotite-garnet and some pyrite minerals, coarse grained to gneissic texture, banded, $\sim 4.0 \mathrm{~m}$ wide

QUARTZITE layer in schist from 45.0 to $45.6 \mathrm{~m}, \sim 0.6 \mathrm{~m}$ wide, (not shown)

SCHIST from 45.6 to $56.3 \mathrm{~m}$, medium to fine grained, quartz-phlogopite-muscovite-biotite-with some garnets, $10.7 \mathrm{~m}$ wide

BASALT DIKE from $\sim 46.0$ to $\sim 46.8 \mathrm{~m}$, irregularly shaped, $\sim 0.4 \mathrm{~m}$ wide

BASALT VEIN at $47.9 \mathrm{~m},<10 \mathrm{~cm}$ wide SCHIST from 48.0 to $56.2 \mathrm{~m}$, coarse grained, steeply dipping, with augens, $\sim 8.2 \mathrm{~m}$ wide

BASALT from 50.6 to $50.9 \mathrm{~m}$, parallel to foliation, $\sim 0.3 \mathrm{~m}$ wide

FELSIC VEIN at $54.0 \mathrm{~m}, \sim 2 \mathrm{~cm}$ wide

APLITE or FELSIC ZONE in schist from 54.2 to $54.7 \mathrm{~m}$, $\sim 0.5 \mathrm{~m}$ wide

GRANITE from 56.2 to $69.0 \mathrm{~m}, \sim 12.7 \mathrm{~m}$ wide GRANITE from $56.3 \mathrm{~m}$ to $68.9 \mathrm{~m}$, gray, $\sim 12.7 \mathrm{~m}$ wide

ALPLITE VEIN at $57.3 \mathrm{~m}$, some borehole enlargement along lower contact, possibly a fracture, $\sim 5 \mathrm{~cm}$ wide 
R1 Continued

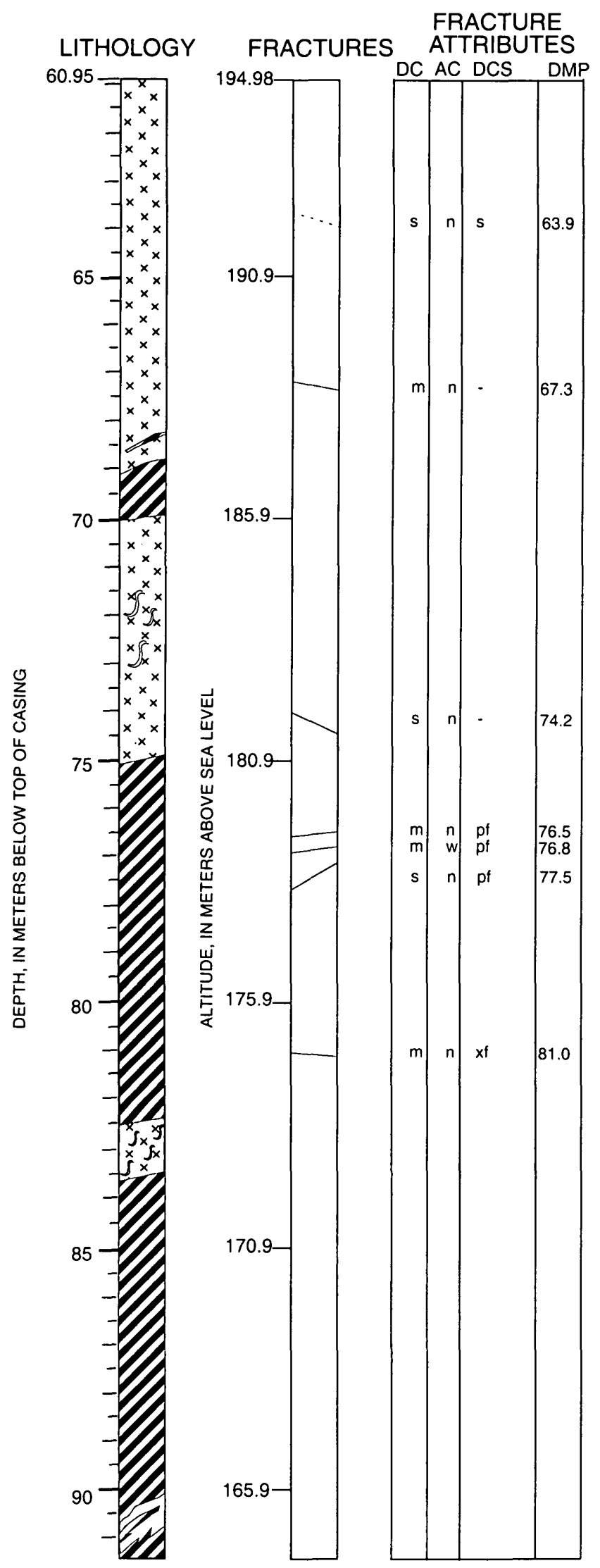

DESCRIPTION: Generalized log in bold.

GRANITE continued to $69.0 \mathrm{~m}$

BIOTITE SCHLEIREN at $68.3 \mathrm{~m}$

SCHIST from $69.0 \mathrm{~m}$ to $70.0 \mathrm{~m}$, gneissic texture with migmatite from 70.7 to $73.0 \mathrm{~m}$, foliated biotite, steeply dipping, $\sim 1.0 \mathrm{~m}$ wide

GRANITE from 73.0 to $75.0 \mathrm{~m}$, biotite-muscovite-chlorite, $\sim 2.0 \mathrm{~m}$ wide

SCHIST from 75.0 to $82.5 \mathrm{~m}$, biotite-muscovite-garnet-quartzfeldspar, banded, $\sim 7.5 \mathrm{~m}$ wide

GNEISS at $79.8 \mathrm{~m}$-- banded gneiss from 81.1 to $83.2 \mathrm{~m}$

GRANITE or GNEISS from 82.5 to $83.5 \mathrm{~m}$, coarse grained, $\sim 1.0 \mathrm{~m}$ wide

SCHIST from 83.5 to $94.2 \mathrm{~m}$, augened schist, steep foliation, altered? $~ 10.7 \mathrm{~m}$ wide

FELSIC ZONE in schist from $\sim 90.0$ to $91.5 \mathrm{~m}, \sim 1.5 \mathrm{~m}$ wide 
R1 Continued

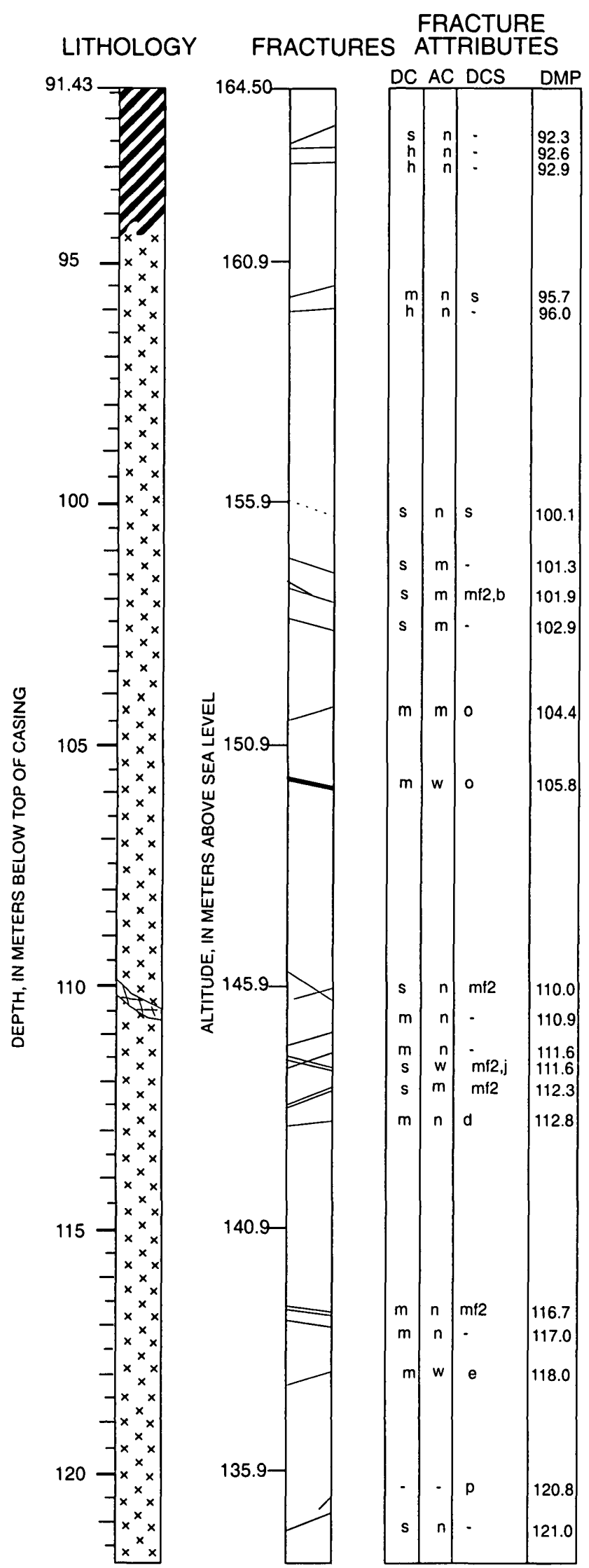

DESCRIPTION: Generalized log in bold.

SCHIST continued to $94.2 \mathrm{~m}$, near vertical foliation

GRANITE from 94.2 to $134.7 \mathrm{~m}, \sim 40.5 \mathrm{~m}$ wide

GRANITE from 107.6 to $120.4 \mathrm{~m}$, greenish yellow, muscovite-chlorite granite, fine grained with some aphanitic zones, $\sim 12.8 \mathrm{~m}$ wide

(110.0 to $112.8 \mathrm{~m}$ several fractures)

GRANITE from 120.4 to $123.4 \mathrm{~m}$, grayish white, biotite, $\sim 3.0 \mathrm{~m}$ wide 
R1 Continued

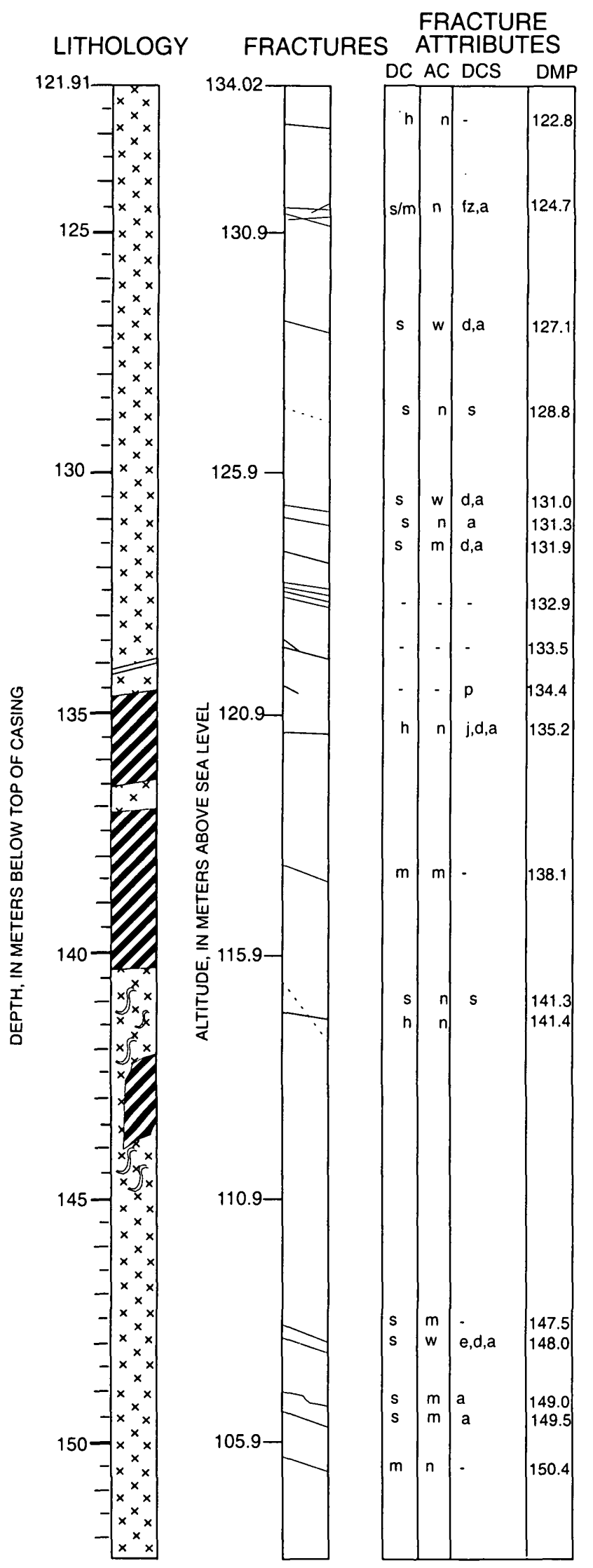

DESCRIPTION: Generalized log in bold.

GRANITE continued to $134.7 \mathrm{~m}$

GRANITE from 123.4 to $125.6 \mathrm{~m}$, greenish gray, chlorite granite

(fracture zone: many fractures in different orientations. All of them appear to have narrow to moderate apertures) GRANITE from 125.6 to $129.5 \mathrm{~m}$, biotite granite, $\sim 3.9 \mathrm{~m}$ wide

GRANITE from 129.5 to $131.0 \mathrm{~m}$, chlorite-biotite, very soft, $\sim 1.5 \mathrm{~m}$ wide

(131.2 $\mathrm{m}$ fracture zone, intensely fractured)

PEGMATITE VEIN at $134.2 \mathrm{~m}, \sim 1-2 \mathrm{~cm}$ wide

SCHIST from $134.7 \mathrm{~m}$ to $136.4 \mathrm{~m}$, decomposed and altered looking, felsic schist $\sim 1.7 \mathrm{~m}$ wide

(Rough borehole wall 135.0 to 135.6 )

GRANITE from 136.4 to $137.1 \mathrm{~m}, \sim 0.7 \mathrm{~m}$ wide

SCHIST from 137.1 to $140.2 \mathrm{~m}$, biotite-chlorite schist, banded, near vertical foliation, $\sim 3.1 \mathrm{~m}$ wide

GRANITE from 140.2 to $163.0 \mathrm{~m}$, biotite with some to few chlorite, gneissic texture, $\sim 22.8 \mathrm{~m}$ wide

SCHIST from 142.0 to $\sim 144.0 \mathrm{~m}$ on one side of the well, coarse grained, gradual lower contact, $\sim 2.0 \mathrm{~m}$ wide

GRANITE from 143.5 to $\sim 163.0 \mathrm{~m}$, chlorite with some biotite granite, weakly foliated, $\sim 19.5 \mathrm{~m}$ wide 
R1 Continued

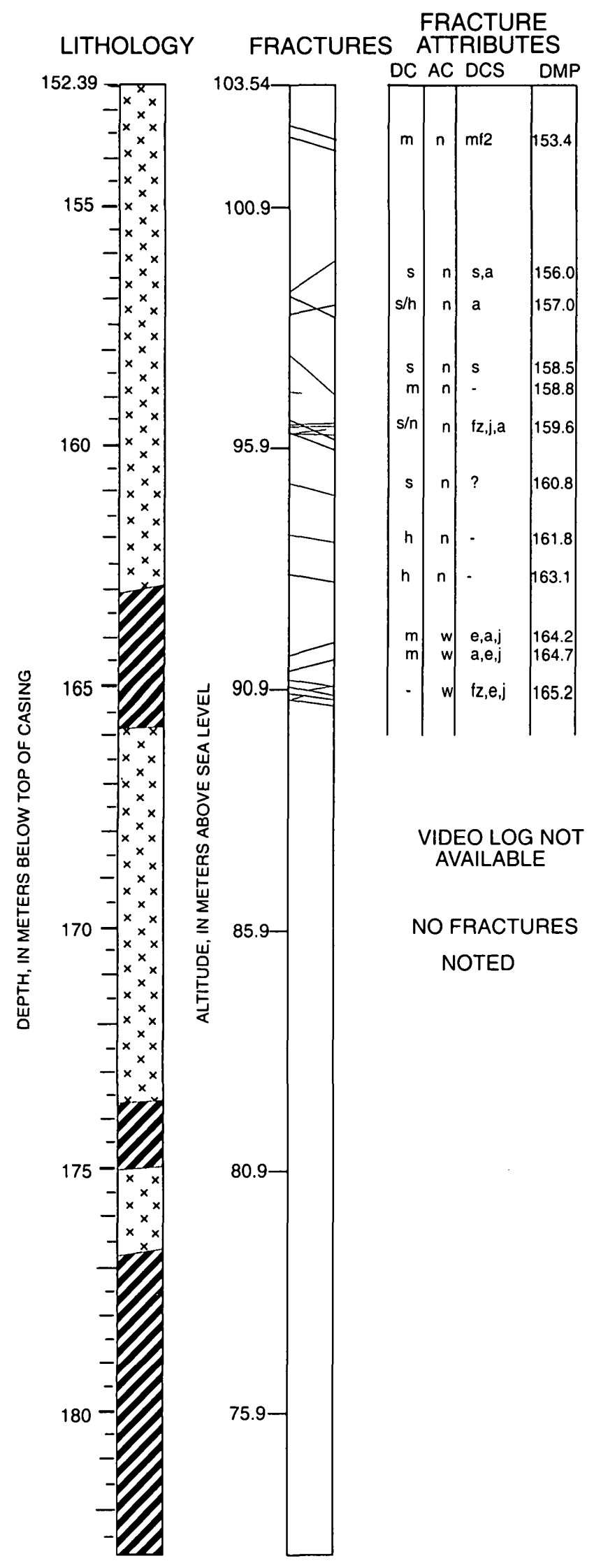

DESCRIPTION: Generalized log in bold.

\section{GRANITE continued to $163.0 \mathrm{~m}$}

(Several steeply dipping fractures intersect the borehole at 159.5 to $161.0 \mathrm{~m}$. Borehole is very angular.)

SCHIST from 163.0 to $165.9 \mathrm{~m}$, greenish quartz rich (quartzite?), near vertical foliation, $\sim 2.9 \mathrm{~m}$ wide

(Fracture zone from 164.5 to $167.5 \mathrm{~m}$ )

BOTTOM OF HOLE AT $165.5 \mathrm{~m}$. The well has an enlarged and angular diameter at $165.5 \mathrm{~m}$. The hole was originally drilled to $193.5 \mathrm{~m}$ but caved in at this fracture or fault zone.

All descriptions of the well are based only on descriptions of rock cuttings and drilling conditions. Hence there are no fractures noted below this point. Contacts are approximate.

GRANITE from 165.9 to $173.7 \mathrm{~m}, \sim 6.2 \mathrm{~m}$ wide

SCHIST from 173.7 to $175.0 \mathrm{~m}, \sim 1.3 \mathrm{~m}$ wide

GRANITE from 175.0 to $176.8 \mathrm{~m}, \sim 1.8 \mathrm{~m}$ wide

SCHIST and QUARTZITE from $176.8180 .0 \mathrm{~m}$, very hard drilling -Quartz-biotite aggregates with trace of sulfide minerals, lacks foliation, possibly quartzite with sulfide minerals, $\sim 3.2 \mathrm{~m}$ wide

SCHIST from 180.0 to $193.5 \mathrm{~m}$, quartz-biotite aggregates, some sulfide minerals in the schist, $\sim 13.5 \mathrm{~m}$ wide 
R1 Continued

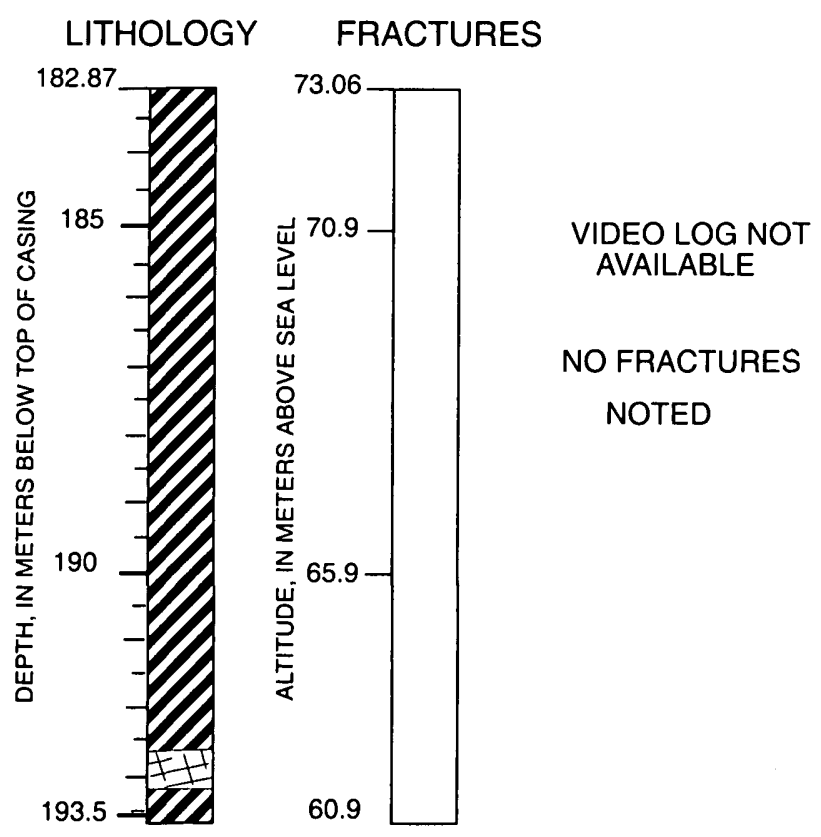

DESCRIPTION: Generalized log in bold.

SCHIST continued to $193.5 \mathrm{~m}$

SCHIST from 186 to $189 \mathrm{~m}$, biotite schist with lesser amounts of quartz and feldspar than above, $\sim 3 \mathrm{~m}$

PEGMATITE from 192 to $193.5 \mathrm{~m}$, soft rock, $\sim 1.5 \mathrm{~m}$ wide, (very fast drilling, which indicates the likely location of the pegmatitic muscovite or the possibility of fractures)

BOTTOM of DRILLED HOLE at $193.5 \mathrm{~m}$ 


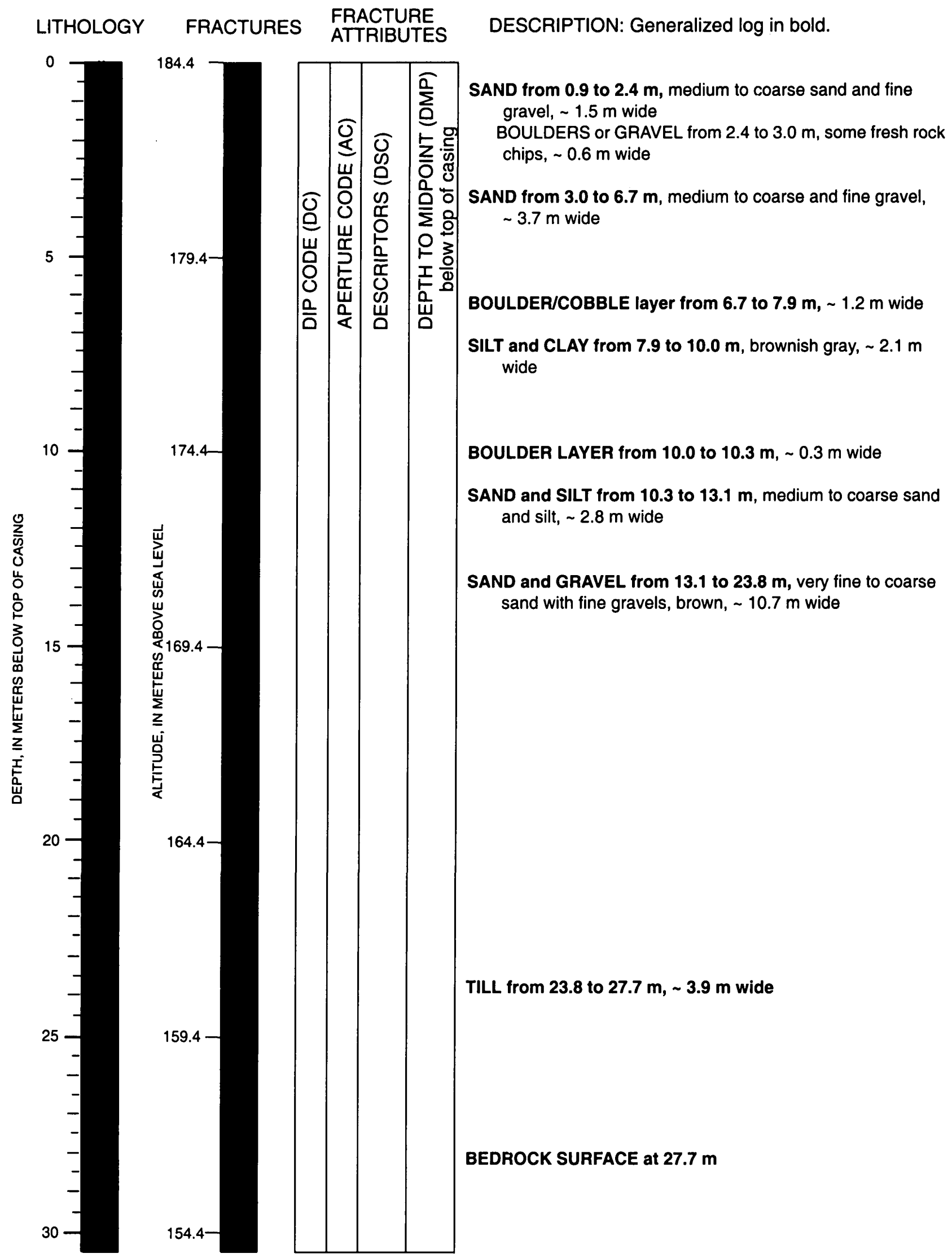




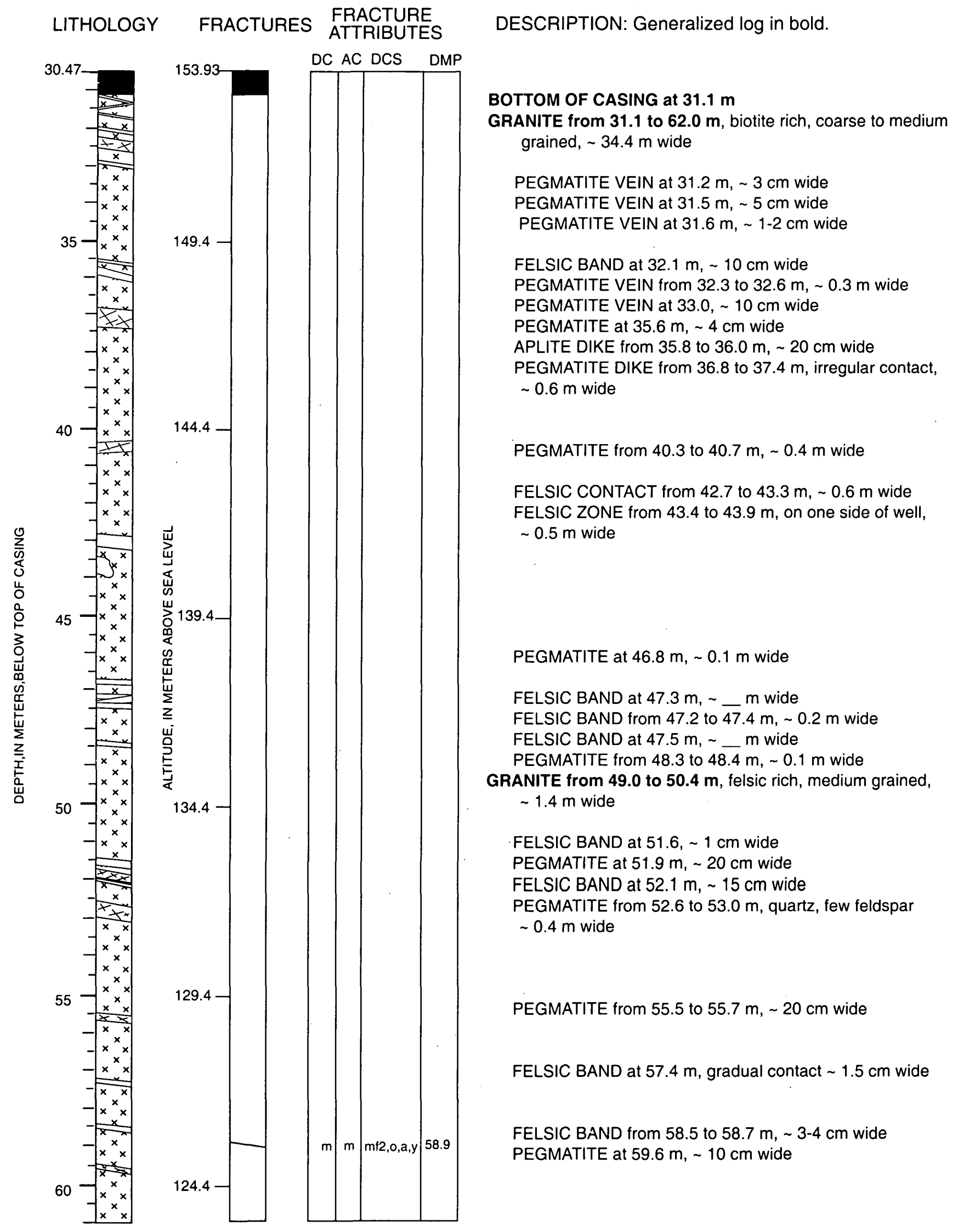


RR1 Continued

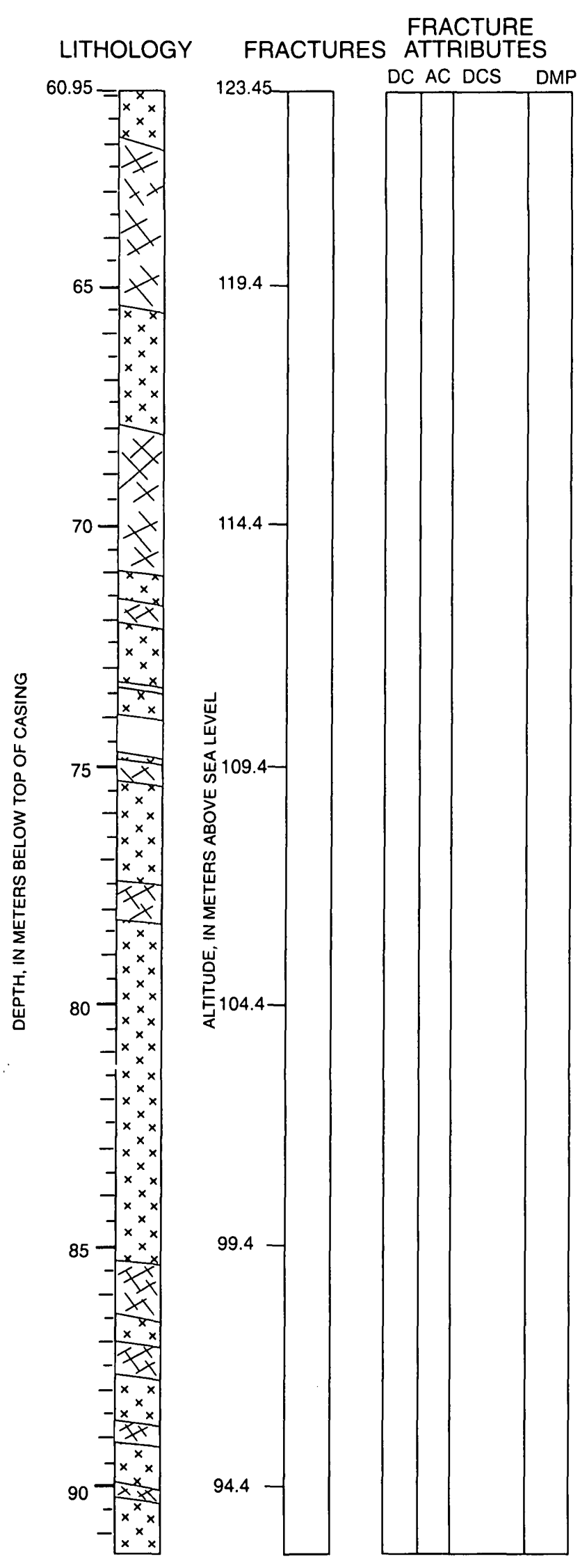

DESCRIPTION: Generalized log in bold.

GRANITE continued to $62.0 \mathrm{~m}$

PEGMATITE VEIN from 61.2 to $61.6 \mathrm{~m}, \sim 0.4 \mathrm{~m}$ wide

PEGMATITE from 62.0 to $65.5 \mathrm{~m}$, felsic-biotites, $\sim 3.5 \mathrm{~m}$ wide

GRANITE from 65.5 to $68.0 \mathrm{~m}$, biotite (-muscovite?) $2.5 \mathrm{~m}$ wide

top of APLITE/PEGMATITE at $67.0 \mathrm{~m}$

PEGMATITE from 68.0 to $71.1 \mathrm{~m}$, schlieren - steep, $\sim 3.1 \mathrm{~m}$ wide

GRANITE from 71.1 to $85.3 \mathrm{~m}$, medium to coarse grained, biotite-muscovite granite, $\sim 14.2 \mathrm{~m}$ wide

PEGMATITE from 71.7 to $72.2 \mathrm{~m}$, biotites along bottom edge, $\sim 0.5 \mathrm{~m}$ wide

FELSIC BAND at $73.4 \mathrm{~m}, \sim 10$ to $15 \mathrm{~cm}$ wide

FELSIC BAND at $74.0 \mathrm{~m}, \sim 10 \mathrm{~cm}$ wide

FELSIC BAND at $74.6 \mathrm{~m}, \sim 10 \mathrm{~cm}$ wide

PEGMATITE from 74.9 to $75.3 \mathrm{~m}, \sim 0.4 \mathrm{~m}$

PEGMATITE from 77.5 to $78.3 \mathrm{~m}, \sim 0.8 \mathrm{~m}$

GRANITE from 78.3 to $85.3 \mathrm{~m}$, same as above, $\sim 7.0 \mathrm{~m}$ wide

GRANITE with biotite schlieren from 80.9 to $81.0, \sim 0.1 \mathrm{~m}$ wide

FELSIC BAND from 83.2 to $83.4 \mathrm{~m}, \sim 2 \mathrm{~cm}$ wide

PEGMATITE from 85.3 to $86.5 \mathrm{~m}, \sim 1.2 \mathrm{~m}$ wide

GRANITE from 86.5 to $140.6 \mathrm{~m} \sim 54.1 \mathrm{~m}$ wide

PEGMATITE from 87.1 to $87.8 \mathrm{~m}, \sim 0.7 \mathrm{~m}$ wide

PEGMATITE from 88.7 to $89.1 \mathrm{~m}, \sim 0.4 \mathrm{~m}$ wide

PEGMATITE from 90.0 to $90.3 \mathrm{~m}, 0.3 \mathrm{~m}$ wide 
RR1 Continued

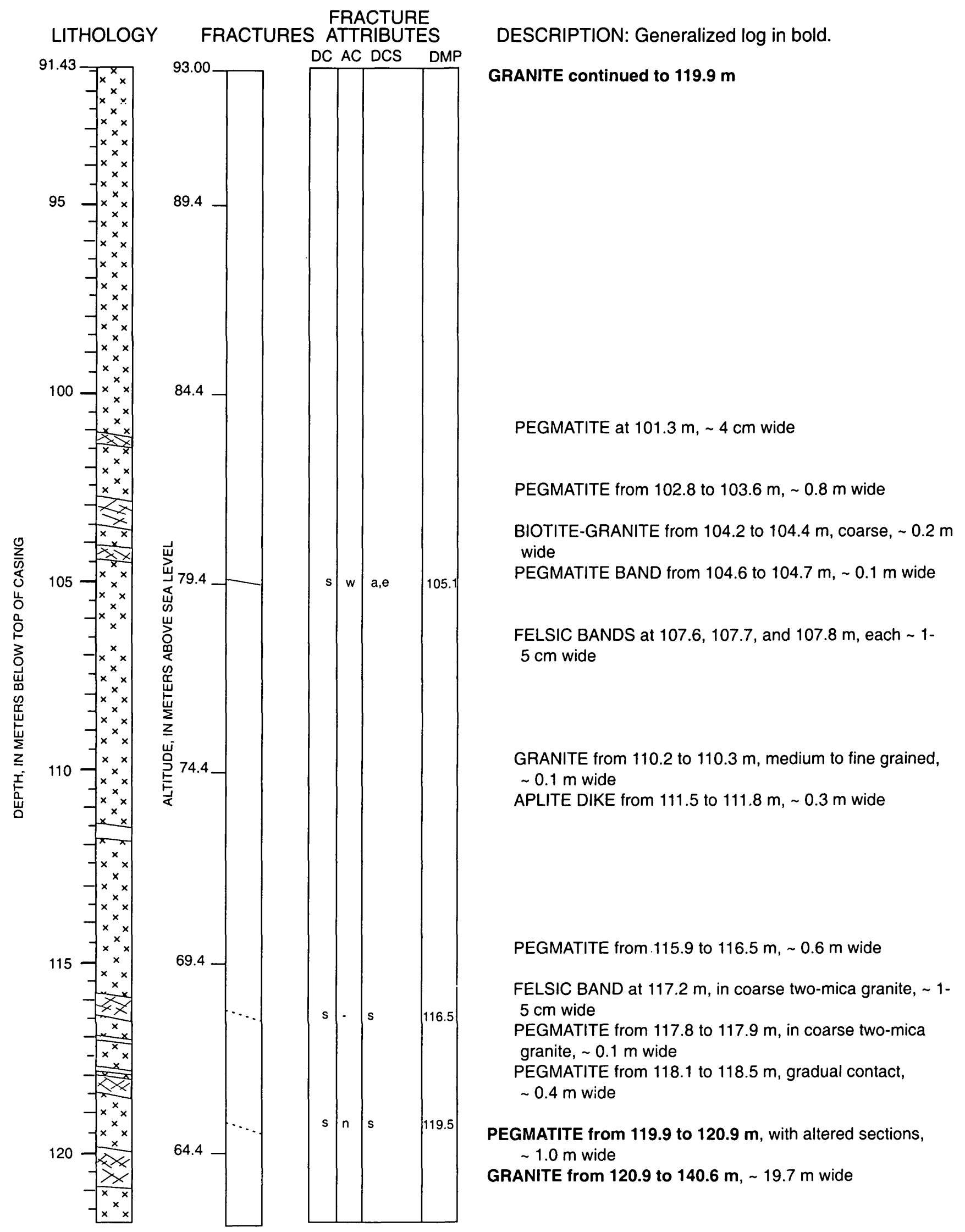


RR1 Continued

FRACTURE

LITHOLOGY FRACTURES ATTRIBUTES

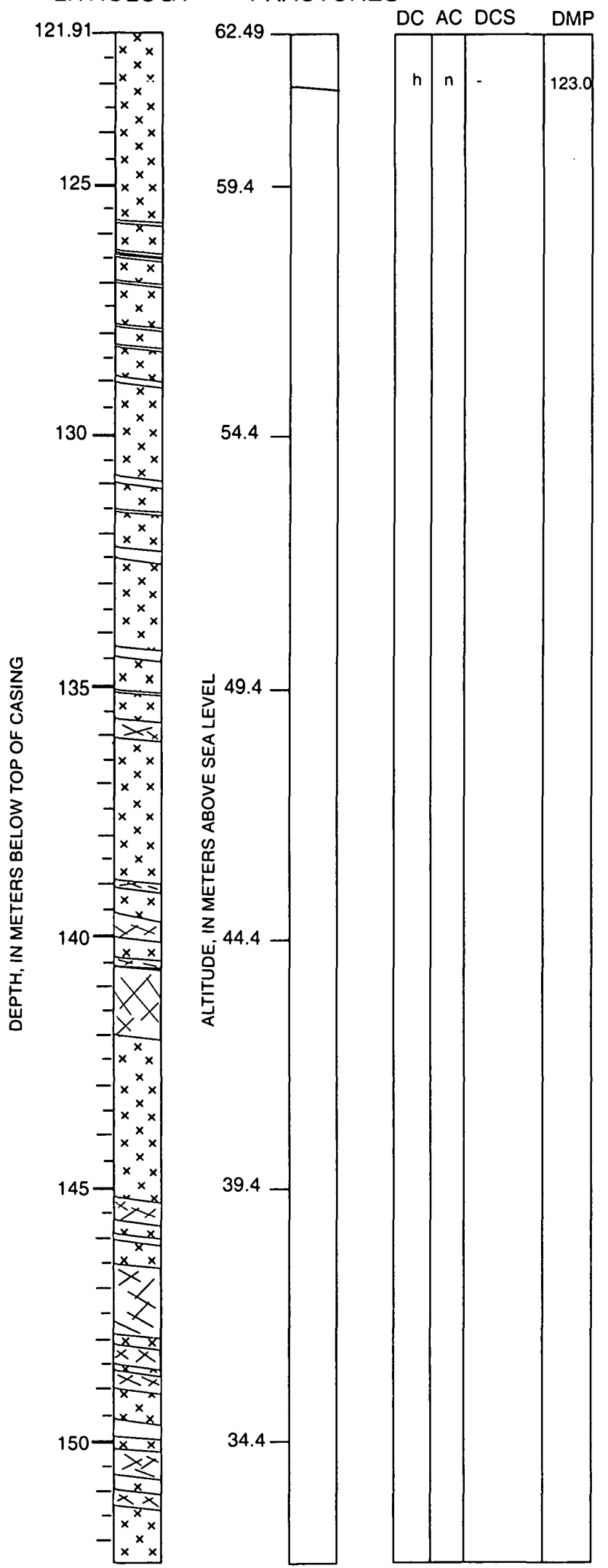

DESCRIPTION: Generalized log in bold.

GRANITE continued to $140.6 \mathrm{~m}$

FELSIC BAND at $125.8 \mathrm{~m}, \sim 4 \mathrm{~cm}$ wide FELSIC BAND at $126.4 \mathrm{~m}, \sim 3 \mathrm{~cm}$ wide FELSIC BAND at $126.5 \mathrm{~m}, \sim 10 \mathrm{~cm}$ wide PEGMATITE VEIN at $127.0 \mathrm{~m}, \sim 10 \mathrm{~cm}$ wide FELSIC BAND at $127.8 \mathrm{~m}, \sim 3 \mathrm{~cm}$ wide FELSIC BAND at $128.3 \mathrm{~m}, \sim 3 \mathrm{~cm}$ wide APLITE at $129.9 \mathrm{~m},<10 \mathrm{~cm}$ wide

FELSIC BAND/PEGMATITE at 131.0, $\sim \mathrm{cm}$ wide PEGMATITE in biotite granite at $131.6 \mathrm{~m}, ~-5 \mathrm{~cm}$ wide PEGMATITE $132.4 \mathrm{~m}, \sim 20.0 \mathrm{~cm}$ wide

APLITE DIKE at $134.4 \mathrm{~m}, \sim 0.1 \mathrm{~m}$ wide

APLITE/PEGMATITE at $135.1 \mathrm{~m}$

PEGMATITE from 135.7 to $136.1 \mathrm{~m}, \sim 0.4 \mathrm{~m}$ wide

PEGMATITE from 138.9 to $139.2 \mathrm{~m}, \sim 0.3 \mathrm{~m}$ wide

PEGMATITE from 139.6 to $140.0, \sim 0.4 \mathrm{~m}$ wide PEGMATITE at $140.6 \mathrm{~m}, \sim 0.1 \mathrm{~m}$ wide

PEGMATITE from 140.6 to $141.9 \mathrm{~m}, \sim 1.3 \mathrm{~m}$ wide GRANITE from 141.9 to $146.7 \mathrm{~m}$, fine to medium grained, $\sim 4.8 \mathrm{~m}$ wide

PEGMATITE from 145.3 to $145.7 \mathrm{~m}, \sim 0.4 \mathrm{~m}$ wide

FELSIC BAND at $146.6 \mathrm{~m}$ PEGMATITE from 146.7 to $147.9 \mathrm{~m}, \sim 1.2 \mathrm{~m}$ wide GRANITE from 147.9 to $165.2 \mathrm{~m}, \sim 17.3 \mathrm{~m}$ wide PEGMATITE from 148.1 to $148.4 \mathrm{~m}, \sim 0.3 \mathrm{~m}$ wide PEGMATITE from 148.6 to $148.9 \mathrm{~m}, \sim 0.3 \mathrm{~m}$ wide

FELSIC BAND from 149.6 to $149.8 \mathrm{~m}, \sim 1.0 \mathrm{~cm}$ wide PEGMATITE from 150.2 to $150.7 \mathrm{~m}, \sim 0.5 \mathrm{~m}$ wide PEGMATITE from 151.0 to $151.3 \mathrm{~m}, \sim 0.3 \mathrm{~m}$ wide 
RR1 Continued

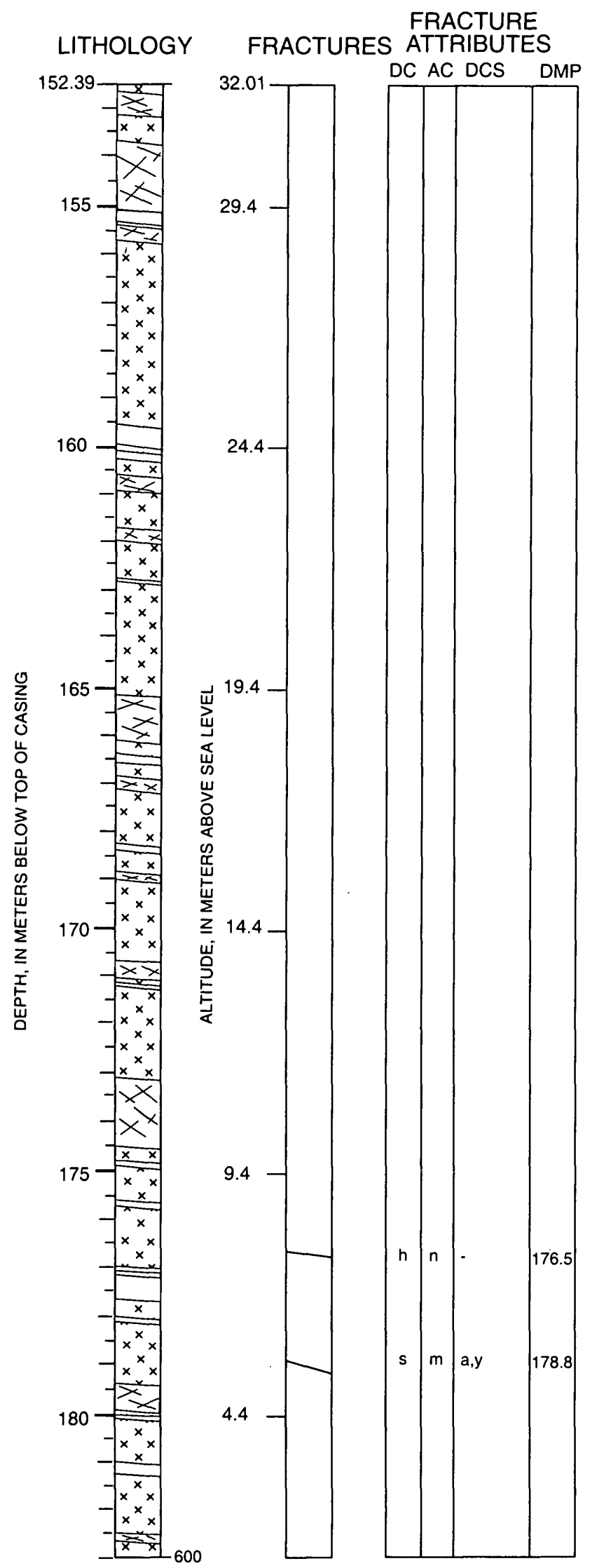

DESCRIPTION: Generalized log in bold.

GRANITE continued to $165.2 \mathrm{~m}$

PEGMATITE from 152.7 to $153.2 \mathrm{~m}, \sim 0.5 \mathrm{~m}$ wide

PEGMATITE from 153.3 to $155.0, \sim 1.7 \mathrm{~m}$ wide

APLITE BAND from 155.0 to $155.2 \mathrm{~m}, \sim 0.2 \mathrm{~m}$ wide

GRANITE from 155.7 to $155.9 \mathrm{~m}$, fine grained, $\sim 20 \mathrm{~cm}$

wide

PEGMATITE from 155.4 to $156.2 \mathrm{~m}, \sim 0.8 \mathrm{~m}$ wide

APLITE from 159.6 to $160.0 \mathrm{~m}, \sim 0.4 \mathrm{~m}$ wide

FELSIC BAND at $160.2 \mathrm{~m}$

PEGMATITE from 160.6 to $160.9 \mathrm{~m}, \sim 0.3 \mathrm{~m}$ wide

APLITE/PEGMATITE from 161.7 to $162.0 \mathrm{~m}, \sim 0.3 \mathrm{~m}$ wide

FELSIC BAND at $162.8 \mathrm{~m}, \sim 3 \mathrm{~cm}$ wide

PEGMATITE from 165.2 to $166.2 \mathrm{~m}, \sim 1.0 \mathrm{~m}$ wide GRANITE from 166.2 to $173.2 \mathrm{~m}$, biotite-muscovite, medium to coarse grained, not foliated, $\sim 7.0 \mathrm{~m}$ wide

FELSIC BAND from 166.4 to $166.6 \mathrm{~m}, \sim 3 \mathrm{~cm}$ wide PEGMATITE from 166.9 to $167.1 \mathrm{~m}, \sim 10 \mathrm{~cm}$ wide FELSIC BAND/PEGMATITE, at $168.4 \mathrm{~m}, \sim 10 \mathrm{~cm}$ wide PEGMATITE at $168.9 \mathrm{~m}, \sim 10 \mathrm{~cm}$ wide

PEGMATITE from 170.7 to $171.1 \mathrm{~m}, \sim 0.4 \mathrm{~m}$ wide PEGMATITE at $171.3 \mathrm{~m},<10 \mathrm{~cm}$ wide

PEGMATITE from 173.2 to $174.5 \mathrm{~m}, \sim 1.3 \mathrm{~m}$ wide

APLITE at $174.8 \mathrm{~m}, \sim 1-5 \mathrm{~cm}$ wide

APLITE at $175.6 \mathrm{~m}, \sim 3 \mathrm{~cm}$ wide

FELSIC BAND at $177.1 \mathrm{~m}, \sim 2 \mathrm{~cm}$ wide

FELSIC BAND from 177.2 to $177.7 \mathrm{~m}$, gradual contacts

FELSIC BAND at $178.2 \mathrm{~m}, \sim 2 \mathrm{~cm}$ wide

PEGMATITE from 179.4 to $179.9 \mathrm{~m}$

APLITE at $180.1 \mathrm{~m}, \sim 1-5 \mathrm{~cm}$ wide

APLITE from 181.0 to $181.3 \mathrm{~m}$, biotites on edge of aplite/ schlieren, $\sim 0.3 \mathrm{~m}$ wide

PEGMATITE from 182.5 to $182.7 \mathrm{~m}, \sim 20 \mathrm{~cm}$ wide

BOTTOM OF WELL AT $184.1 \mathrm{~m}$ 
WELL NAME: T1

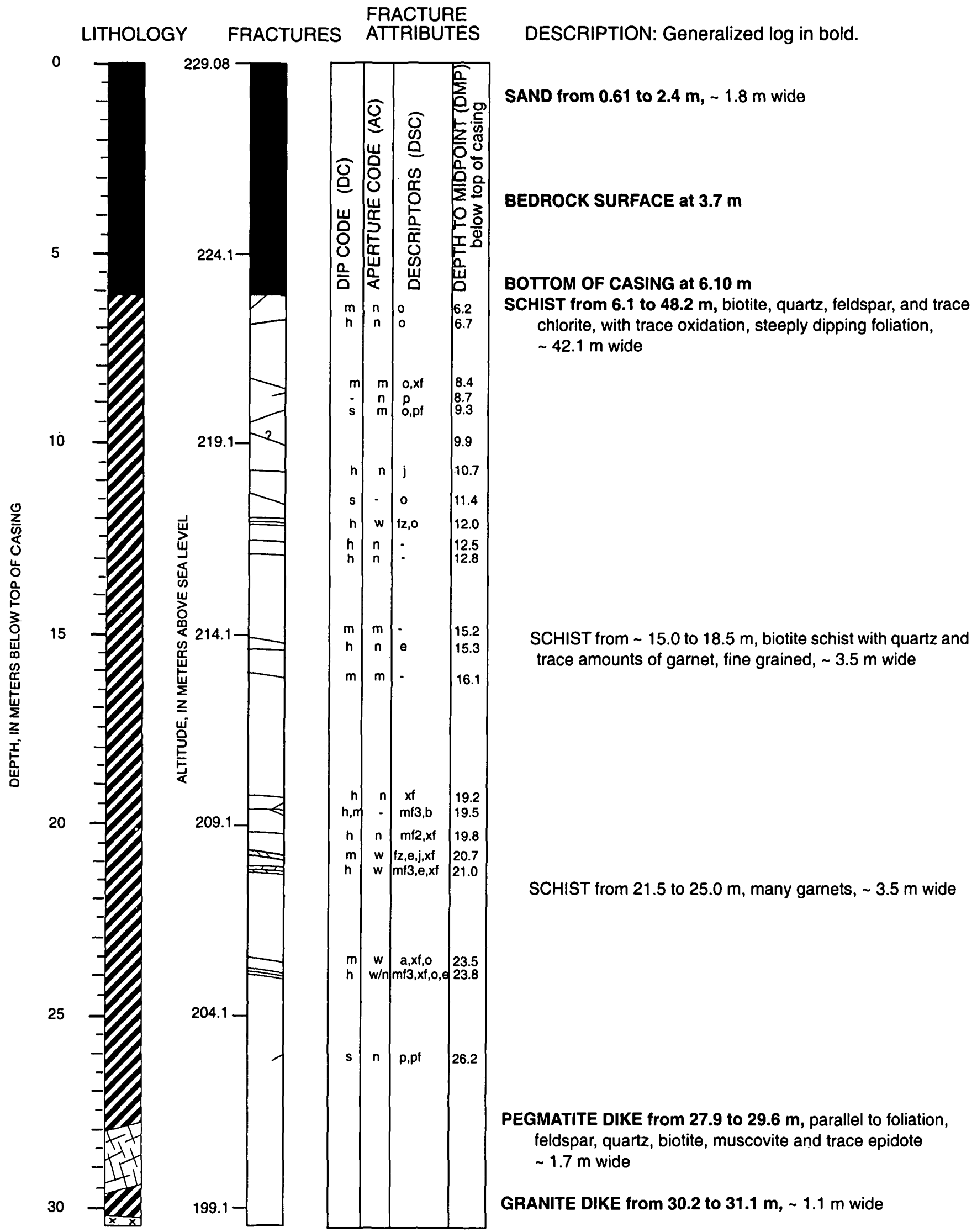




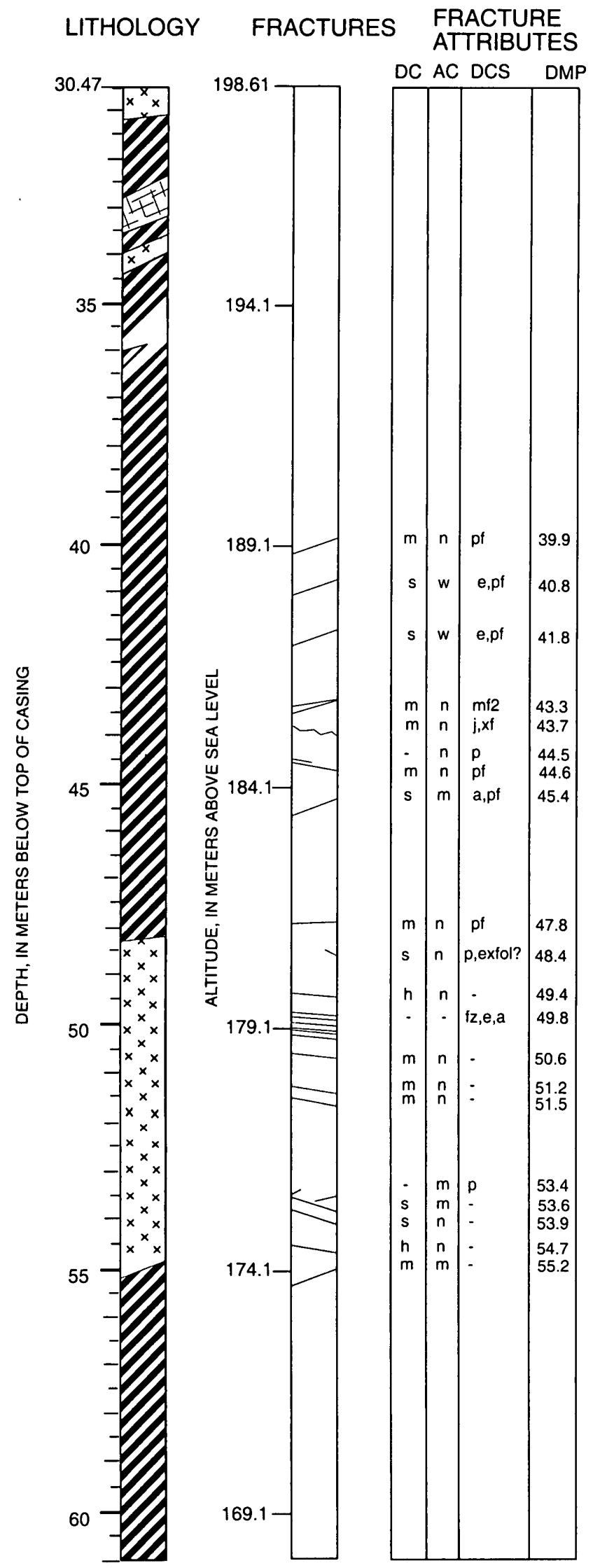

DESCRIPTION: Generalized log in bold.

\section{GRANITE continued to $31.1 \mathrm{~m}$}

SCHIST from 31.1 to $\mathbf{4 8 . 2} \mathrm{m}$, quartz, feldspar muscovite, biotite with garnet, steeply dipping foliation, fine grained with some felsic augens and some banding, $\sim 17.1 \mathrm{~m}$ wide PEGMATITE DIKE from 32.6 to $33.2 \mathrm{~m}, \sim 0.6 \mathrm{~m}$ wide

GRANITE DIKE from 33.8 to $34.2 \mathrm{~m}, \sim 0.4 \mathrm{~m}$ wide

FELSIC ZONE in schist from $\sim 35.0$ to $\sim 36.5 \mathrm{~m}, \sim 1.0 \mathrm{~m}$ wide

GRANITE from $\mathbf{4 8 . 2}$ to $\mathbf{5 4 . 9} \mathrm{m}$, biotite granite, weakly foliated $\sim 6.7 \mathrm{~m}$ wide

(Fracture zone extends from 49.7 to $50.6 \mathrm{~m}$. Fractures are oriented in multiple directions. Fractures are too numerous to count.)

SCHIST from 54.9 to $85.3 \mathrm{~m}$, coarse grained, gneissic texture, steeply dipping foliation, $\sim 30.4 \mathrm{~m}$ wide 


\section{T1 Continued}

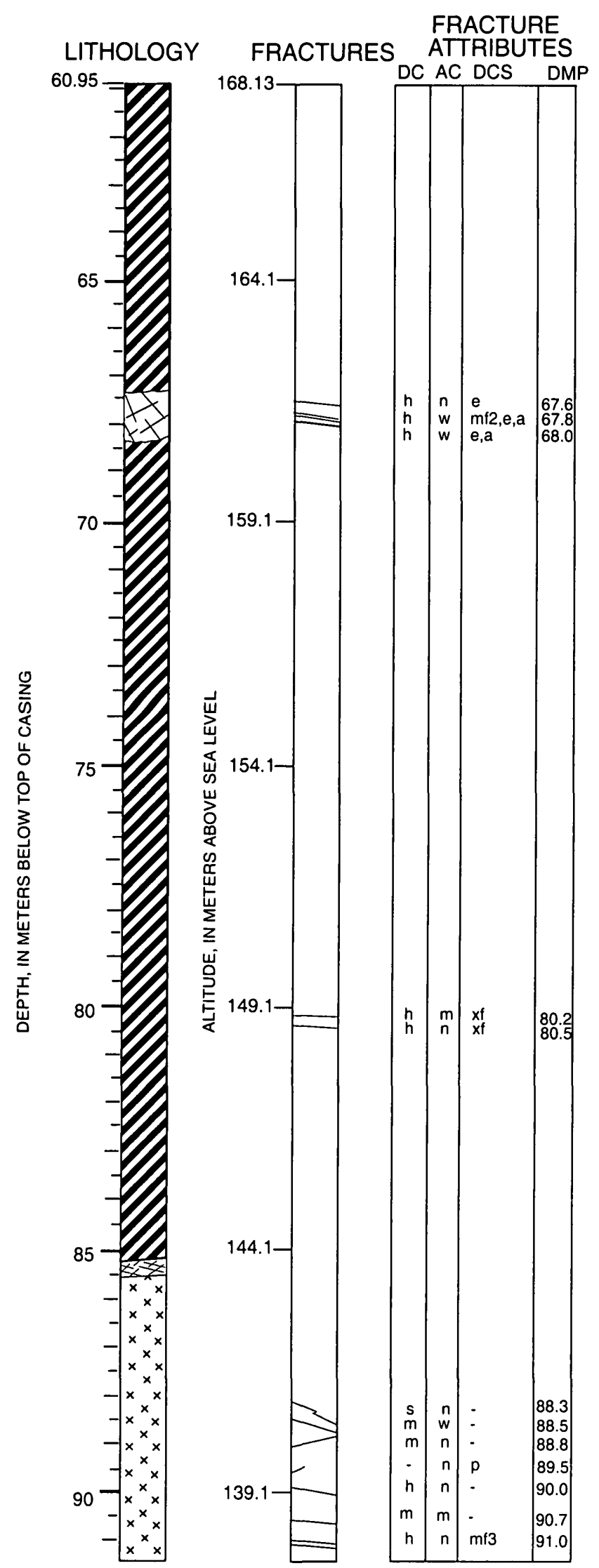

DESCRIPTION: Generalized log in bold.

\section{SCHIST continued to $85.3 \mathrm{~m}$}

PEGMATITE DIKE from 67.4 to $68.3 \mathrm{~m}$, cross-cuts the foliation of the schist, $\sim 0.9 \mathrm{~m}$ wide

(Fractures are completely within the pegmatite)

PEGMATITE or felsic zone in schist from 77.0 to $77.6 \mathrm{~m}$, coarse grained, gradational contacts with schist above and below, $\sim 0.6 \mathrm{~m}$ wide

SCHIST at $76.8 \mathrm{~m}$, extremely fine grained coticule (quartz and garnet layer), parallel to the foliation of the schist, $\sim 5 \mathrm{~cm}$ wide - (not shown)

PEGMATITE from 85.3 to $85.6 \mathrm{~m}$, gradational contact with granite below, $\sim 0.3 \mathrm{~m}$ wide

GRANITE from 85.6 to $121.9 \mathrm{~m}$, fine to coarse grained, weakly foliated, $\sim 36.3 \mathrm{~m}$ wide 
T1 Continued

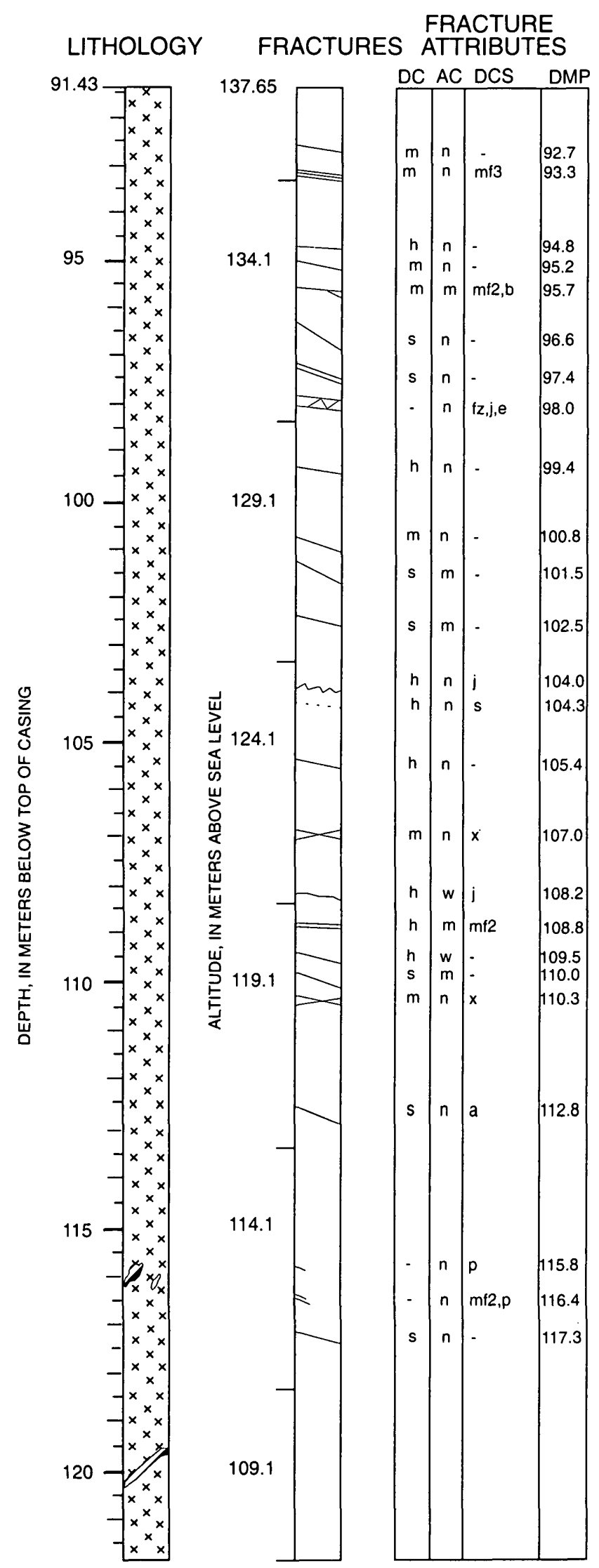

DESCRIPTION: Generalized log in bold.

\section{GRANITE continued to $121.9 \mathrm{~m}$}

GRANITE from 91.5 to $93.0 \mathrm{~m}$, medium to coarse grained with sulfide minerals, $\sim 1.5 \mathrm{~m}$ wide

(Borehole wall is rough from 97.8 to $98.1 \mathrm{~m}$ )

(Borehole wall is rough from 107.9 to $108.3 \mathrm{~m}$ )

(Borehole wall is rough from 109.1 to $109.4 \mathrm{~m}$ )

SCHIST XENOLITH at $115.8 \mathrm{~m}$, dusky brown, fine grained, biotite-rich schist, $\sim 20 \mathrm{~cm}$ long

SCHIST (?) LAYER at $119.6 \mathrm{~m}$, extremely fine grained, greenish brown layer, $\sim 10 \mathrm{~cm}$ wide 
T1 Continued

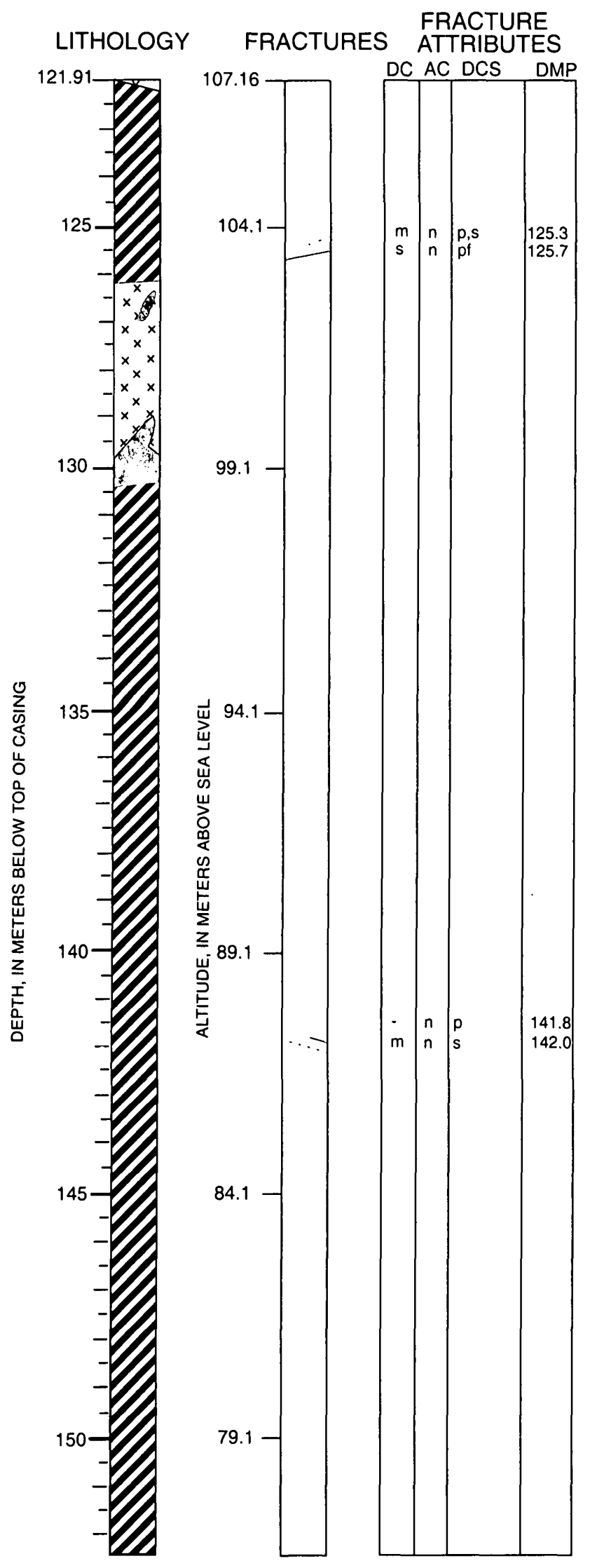

DESCRIPTION: Generalized log in bold.

SCHIST from 121.9 to $126.2 \mathrm{~m}$, dark greenish gray, coarse grained with some weak banding, with some garnets, $\sim 4.3 \mathrm{~m}$ wide

GRANITE from 126.2 to $129.2 \mathrm{~m}$, greenish white, with microcline, fine to medium grained, $\sim 3.0 \mathrm{~m}$ wide BASALT INCLUSION at $126.3 \mathrm{~m}$, extremely fine grained, $\sim 15 \mathrm{~cm}$ long

BASALT from 129.2 to $130.4 \mathrm{~m}$, olive gray, extremely fine grained, equigranular, $\sim 1.2 \mathrm{~m}$ wide

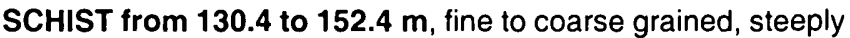
dipping foliation, with some quartz layers, $\sim 22.0 \mathrm{~m}$ wide 


\section{LITHOLOGY FRACTURES ATTRIBUTES DESCRIPTION: Generalized log in bold.}

0

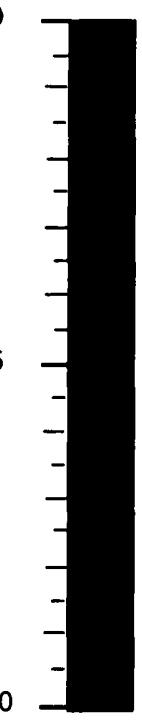

$$
\begin{array}{ccc}
10 & 1 & \\
& 1 & 1 \\
& 1 & 1 \\
& 1 & 1 \\
& 1 & 1
\end{array}
$$

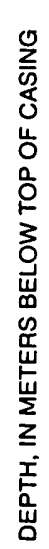

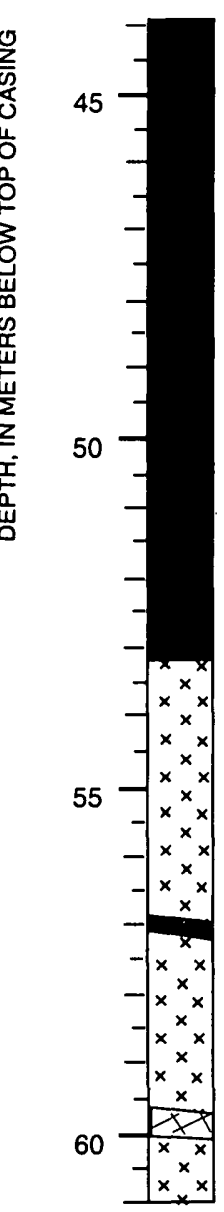

249.29

239.3

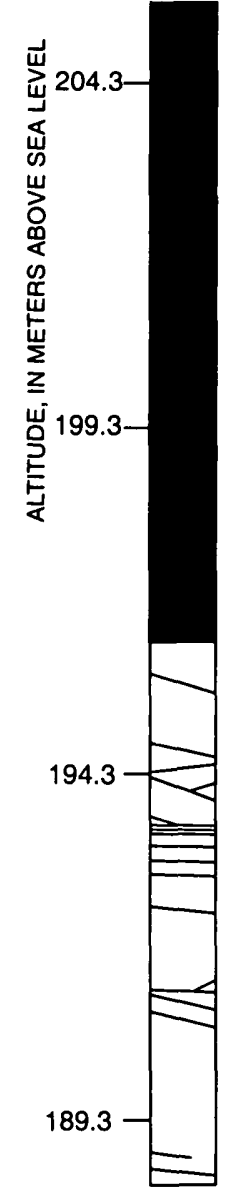

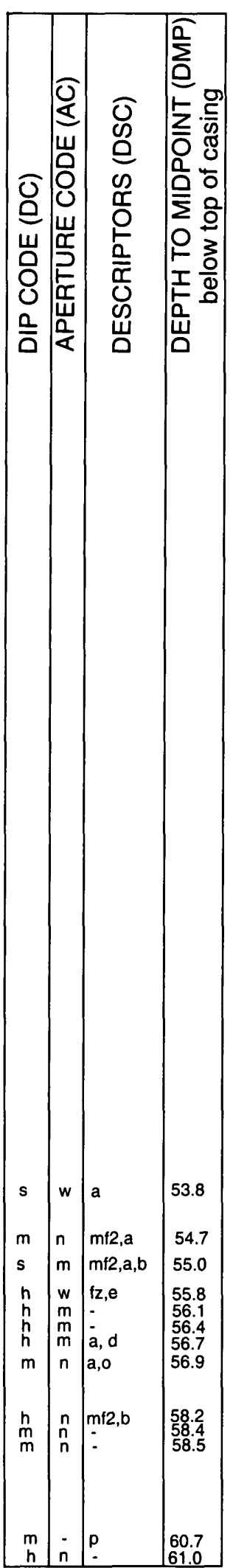

UNCONSOLIDATED SEDIMENTS from 0.73 to $49.5 \mathrm{~m}$,

$\sim 48.8 \mathrm{~m}$ wide

NOTE: Casing from 10 to $44 \mathrm{~m}$ not shown

\section{BEDROCK SURFACE at $51.6 \mathrm{~m}$}

BOTTOM OF CASING at $53.2 \mathrm{~m}$

GRANITE from $\mathbf{5 3 . 2}$ to $\mathbf{1 0 4 . 6} \mathrm{m}$, biotite-muscovite, with trace chlorite, fine-grained equigranular texture, highly altered, $\sim 51.4 \mathrm{~m}$ wide

BASALT from 56.9 to $57.2 \mathrm{~m}, \sim 0.3 \mathrm{~m}$ wide

PEGMATITE at 59.7 to $60.1 \mathrm{~m}, \sim 0.4 \mathrm{~m}$ wide 
TR1 Continued

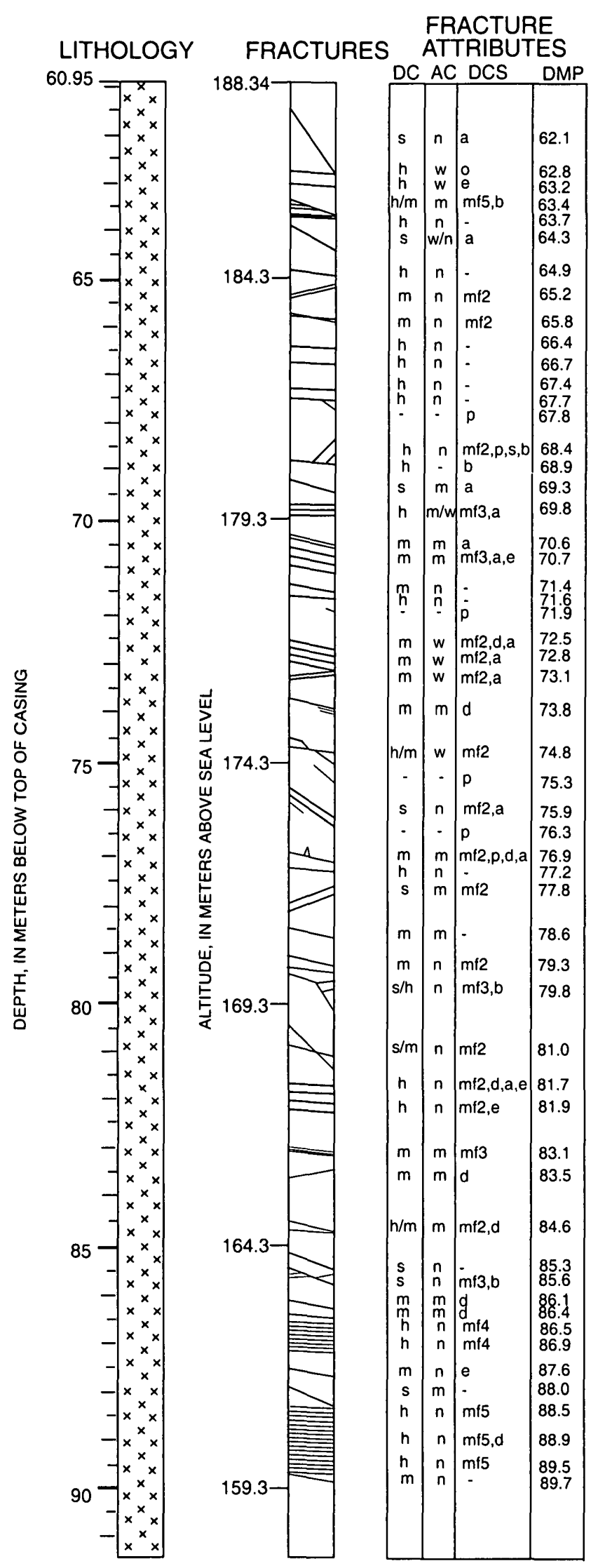

DESCRIPTION: Generalized log in bold.

\section{GRANITE continued to $104.6 \mathrm{~m}$}

GRANITE from 70.5 to $89.8 \mathrm{~m}$, chlorite-muscovite granite with trace biotite, rock matrix looks altered, $\sim 19.4 \mathrm{~m}$ wide

(intense fracturing from 88.4 to $89.7 \mathrm{~m}$, then solid, unfractured rock at $89.9 \mathrm{~m}$ )

GRANITE from 89.7 to $104.6 \mathrm{~m}$, biotite-muscovite granite, $\sim 14.9 \mathrm{~m}$ wide 


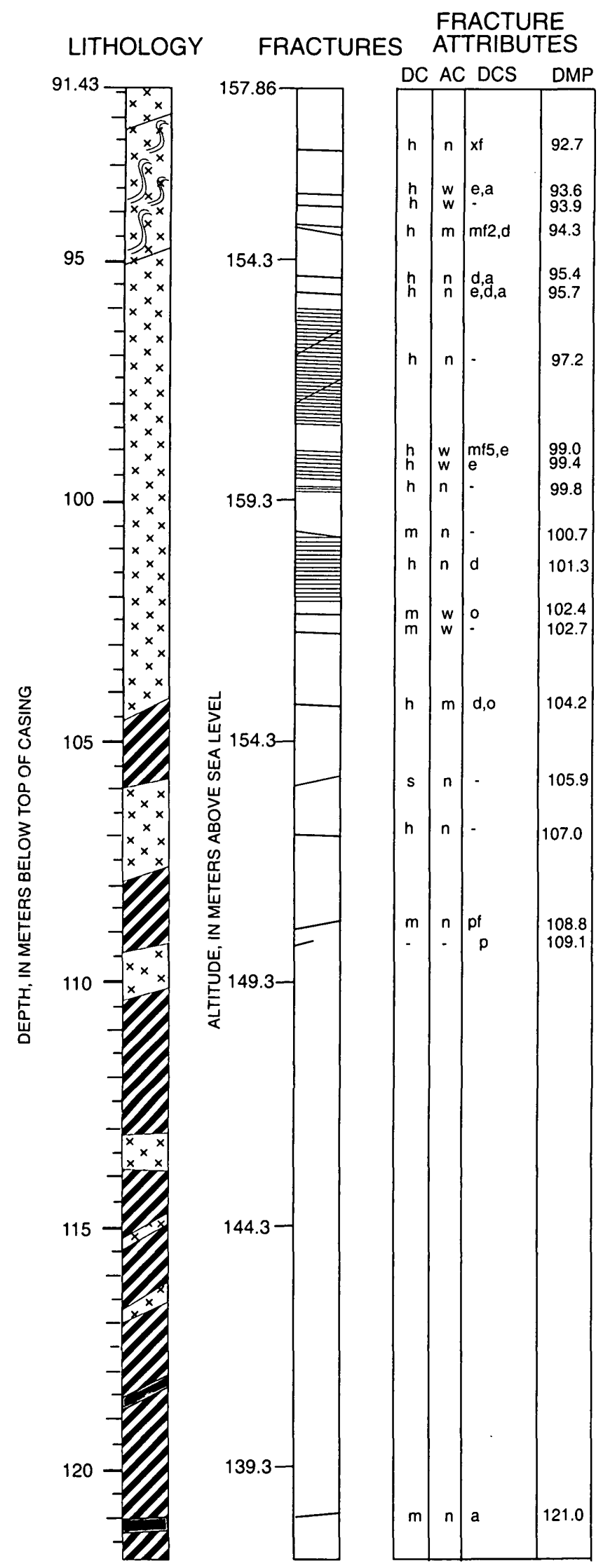

DESCRIPTION: Generalized log in bold.

\section{GRANITE continued to $104.6 \mathrm{~m}$}

GRANITE from 91.8 to $95.0 \mathrm{~m}$, some fine-grained biotite and pegmatitic feldspar and quartz, gneissic texture, steeply dipping foliation, $\sim 3.2 \mathrm{~m}$

GRANITE from 95.0 to $104.5 \mathrm{~m}$, chlorite-muscovite granite, appears to be decomposed and altered, $\sim 9.5 \mathrm{~m}$ wide (Intensely fractured zone from 96.0 to $98.5 \mathrm{~m}$. Fractures are too numerous to count)

(Intensely fractured zone from 99.0 to $99.7 \mathrm{~m}$. Fractures are too numerous to count)

(Intensely fractured zone from 100.5 to $102.5 \mathrm{~m}$. Fractures are too numerous to count)

SCHIST from 104.6 to $105.9 \mathrm{~m}$, coarse-grained texture, with some augens, $\sim 1.3 \mathrm{~m}$ wide

GRANITE 105.9 to $107.9 \mathrm{~m}, \sim 2.0 \mathrm{~m}$ wide

Rock matrix appears to be rotten and decomposed from 108.8 to $110.3 \mathrm{~m}$

SCHIST from 107.9 to $122.7 \mathrm{~m}$, same as above, $\sim 14.8 \mathrm{~m}$ wide

GRANITE 109.4 to $110.3 \mathrm{~m}, \sim 0.9 \mathrm{~m}$ wide

SCHIST from 110.3 to $113.1 \mathrm{~m}$, felsic rich schist, with some augens, near horizontal to moderately dipping foliation, $\sim 2.8 \mathrm{~m}$ wide

GRANITE DIKE from 113.1 to $113.8 \mathrm{~m}$, leucocratic, altered and decomposed looking, $\sim 0.5 \mathrm{~m}$ wide

GRANITE VEIN at $115.2 \mathrm{~m}, \sim 10 \mathrm{~cm}$ wide

GRANITE VEIN at $116.7 \mathrm{~m}, \sim 15 \mathrm{~cm}$ wide

BASALT DIKE at $118.4 \mathrm{~m}, \sim 0.2 \mathrm{~m}$ wide

BASALT DIKE from 121.0 to $121.3 \mathrm{~m}$, basalt and schist appear to be altered, $\sim 0.3 \mathrm{~m}$ wide 
TR1 Continued

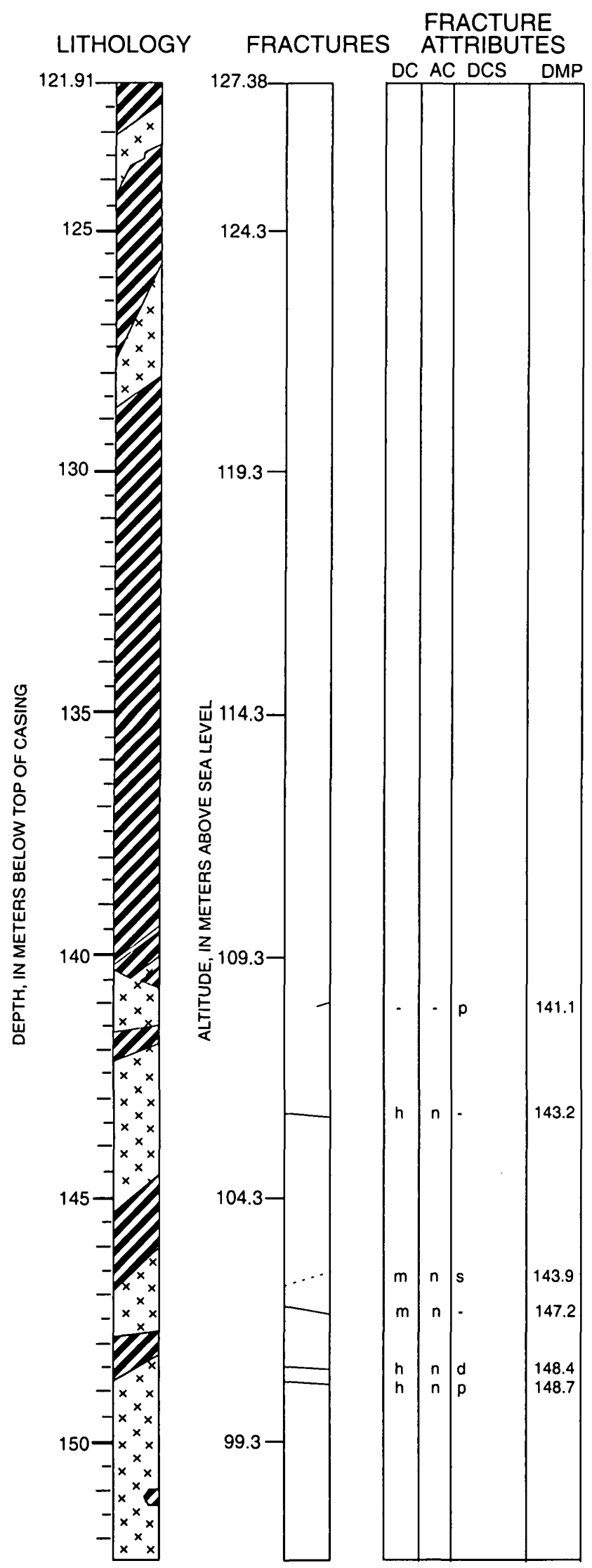

DESCRIPTION: Generalized log in bold.

SCHIST continued to $122.7 \mathrm{~m}$
GRANITE DIKE from 122.7 to $123.7 \mathrm{~m}, \sim 1.0 \mathrm{~m}$ wide

SCHIST from 123.7 to $126.5 \mathrm{~m}, \sim 2.8 \mathrm{~m}$ wide

GRANITE DIKE from 126.5 to $128.3 \mathrm{~m}, \sim 1.8 \mathrm{~m}$ wide

SCHIST from 128.3 to $140.5 \mathrm{~m}$, fine grained, biotite-rich with trace garnet, $\sim 12.2 \mathrm{~m}$ wide

FELSIC VEIN at $134.0 \mathrm{~m}$, sub-parallel to foliation, $\sim 2$ to $3 \mathrm{~cm}$ wide

GRANITE DIKE from 140.5 to $142.0 \mathrm{~m}$, coarse-grained texture, $\sim 1.5 \mathrm{~m}$ wide

SCHIST from 141.7 to $142.0 \mathrm{~m}$, schist same as above, $\sim 0.3 \mathrm{~m}$ wide

GRANITE DIKE from 142.0 to $145.0 \mathrm{~m}, \sim 1.5 \mathrm{~m}$ wide

SCHIST from 145.0 to $146.5 \mathrm{~m}$, biotite schist with trace garnet, $\sim 1.5 \mathrm{~m}$ wide

GRANITE from 146.5 to $159.7 \mathrm{~m}$, biotite-muscovite granite,

$13.2 \mathrm{~m}$ wide

SCHIST from 147.8 to $148.5 \mathrm{~m}$, same as above, $\sim 0.7 \mathrm{~m}$ wide

SCHIST XENOLITH at $151.18 \mathrm{~m}, \sim 0.3 \mathrm{~m}$ wide 
TR1 Continued

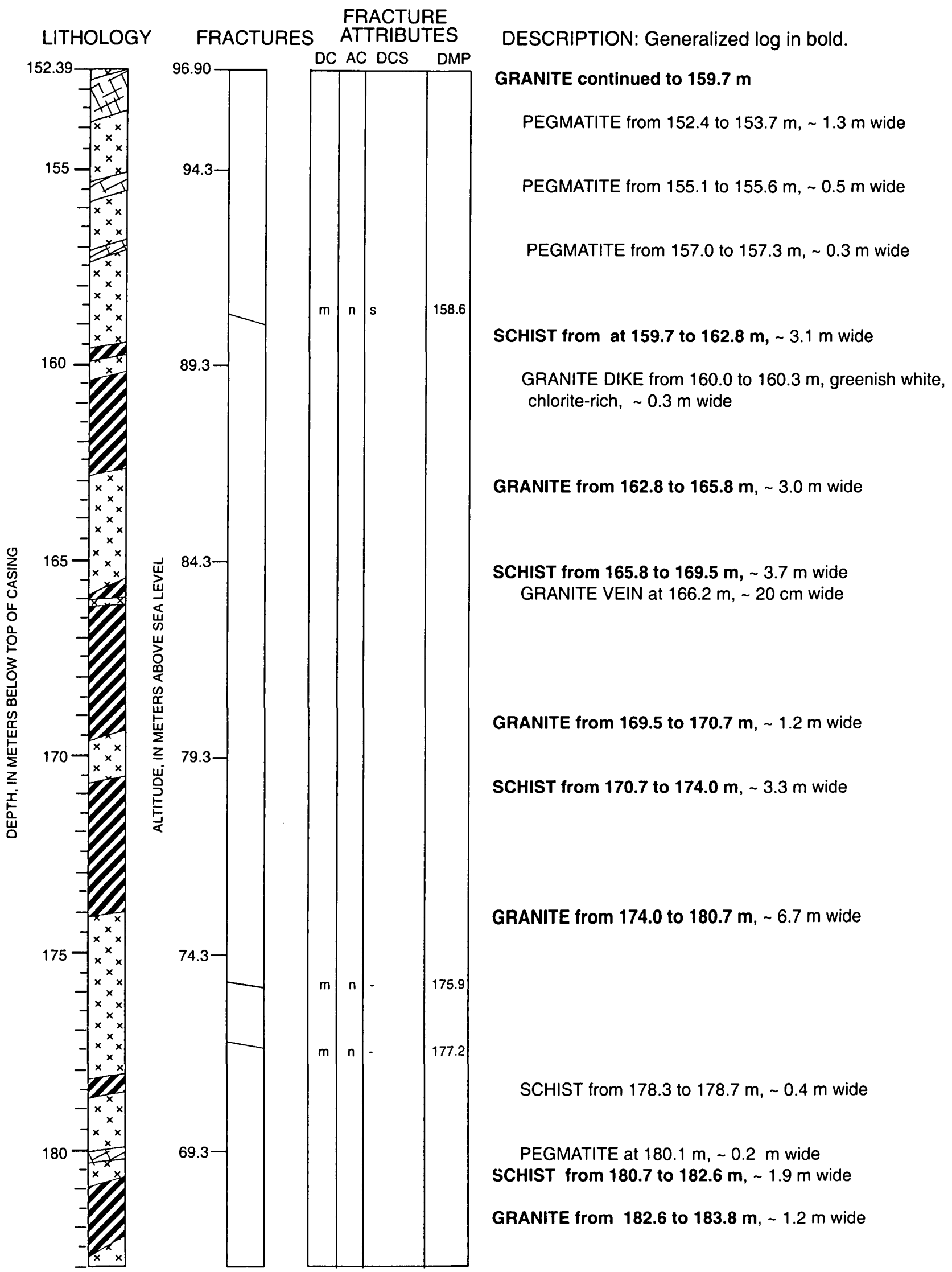


TR1 Continued

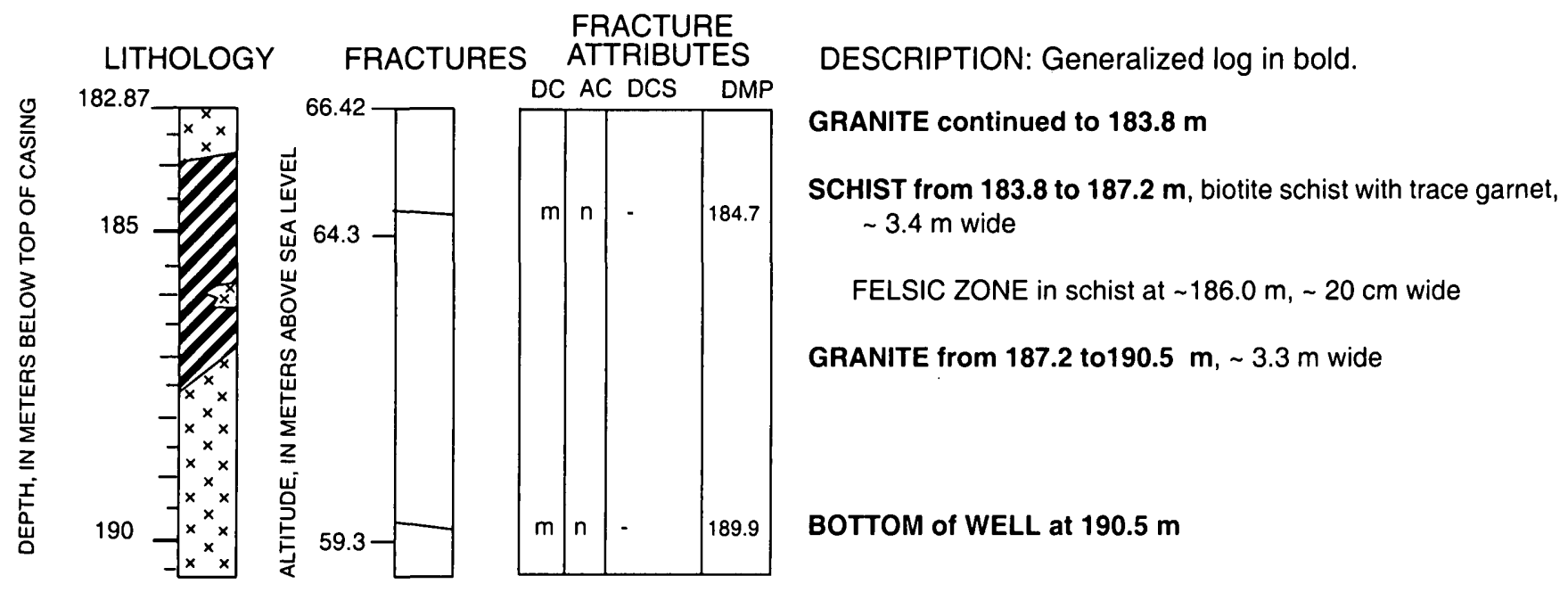




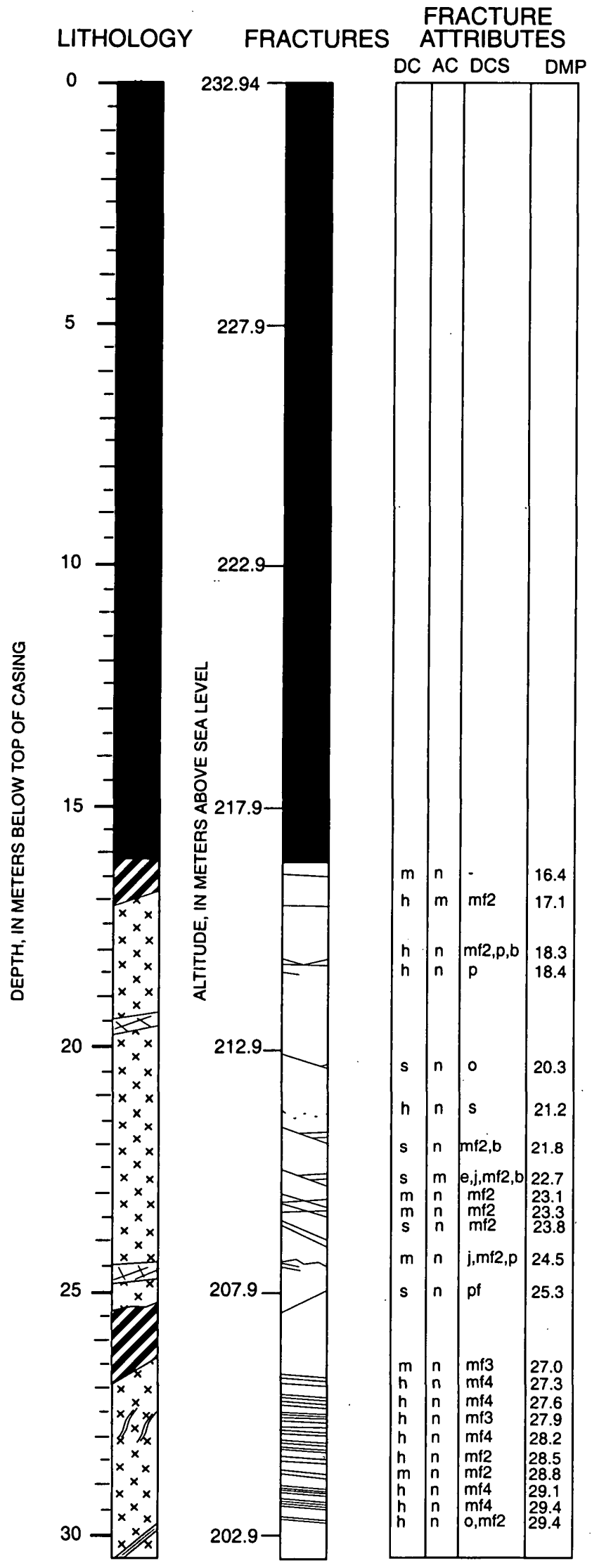

DESCRIPTION: Generalized log in bold.

SAND and GRAVEL from 0.70 to $2.0 \mathrm{~m}, \sim 1.3 \mathrm{~m}$ wide

TILL from $\sim 2.0$ to $13.2 \mathrm{~m}, \sim 11.2 \mathrm{~m}$ wide

BEDROCK SURFACE at $13.2 \mathrm{~m}$

BOTTOM OF CASING at $16.2 \mathrm{~m}$

SCHIST from 16.2 to $17.2 \mathrm{~m}$, greenish gray / black, banded, $\sim 1.0 \mathrm{~m}$ wide

GRANITE from $\mathbf{1 7 . 2}$ to $\mathbf{2 5 . 3} \mathrm{m}$, greenish white, coarse grained with some fine grained zones, some trace oxidation, with biotite schlieren, $\sim 8.1 \mathrm{~m}$ wide

PEGMATITE from 19.4 to $19.7 \mathrm{~m}$, muscovite, gradual lower contact, $\sim 0.3 \mathrm{~m}$ wide (microcracks oserved at 20.7 and $21.5 \mathrm{~m}$, as comparison to core)

(Fracture zone from 70 to 81 feet, Fault zone?? altered, rock wall looks very porous and rough)

PEGMATITE from 24.4 to $24.8 \mathrm{~m}, \sim 0.4 \mathrm{~m}$ wide

SCHIST from 25.3 to $26.5 \mathrm{~m}$, greenish brown, biotite-chlorite schist, near vertical foliation, extremely fine grained, $\sim 1.2 \mathrm{~m}$

GRANITE from $\mathbf{2 6 . 5}$ to $\mathbf{3 0 . 6} \mathrm{m}$, greenish white, predominantly quartz $(90 \%)$ and some biotite, $\sim 4.1 \mathrm{~m}$ wide

PEGMATITE VEIN at $30.1 \mathrm{~m}$, vein quartz, $\sim 10 \mathrm{~cm}$ wide (Some of the narrow fractures from 27 to $30 \mathrm{~m}$ may be "microcracks" rather than narrow fractures. There were more cracks in this zone in addition to the ones noted that 


\section{LITHOLOGY}

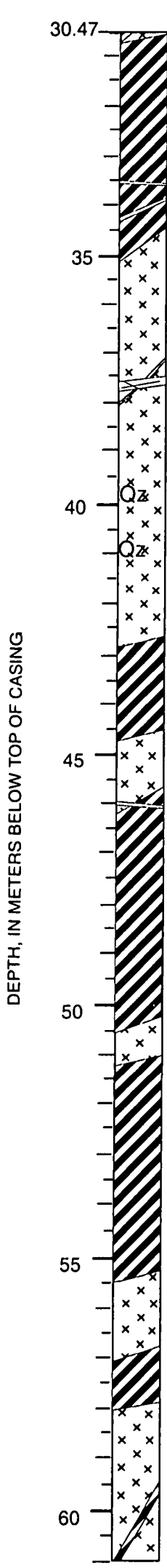

FRACTURE FRACTURES ATTRIBUTES

DC AC DCS DMP

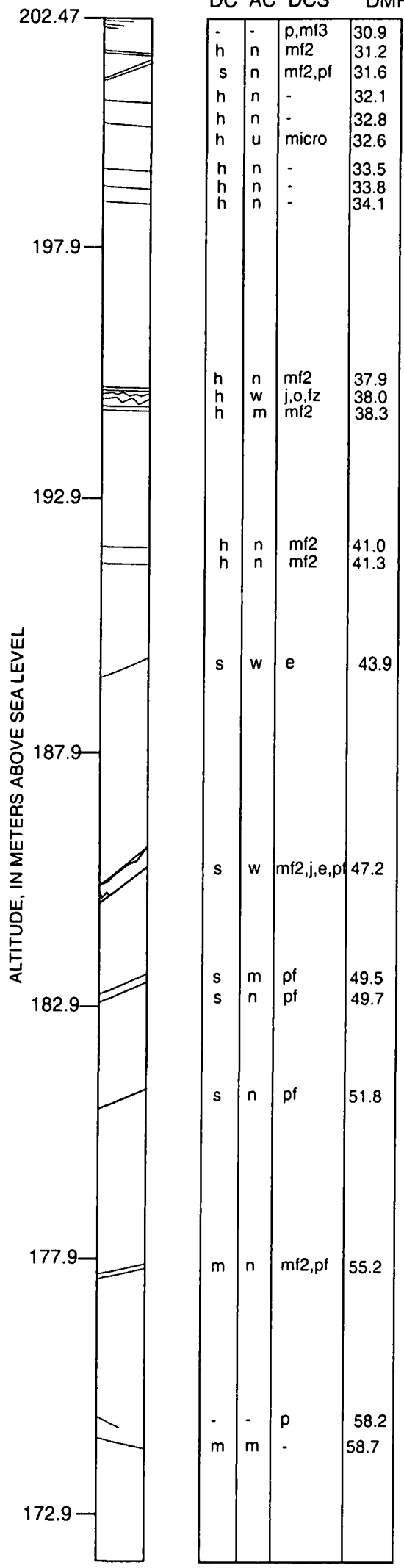

DESCRIPTION: Generalized log in bold.

GRANITE continued to $30.6 \mathrm{~m}$

SCHIST from 30.6 to $34.5 \mathrm{~m}$, altered, highly fractured, banded, steeply dipping foliation, $\sim 3.9 \mathrm{~m}$ wide

FELSIC VEIN at $33.5 \mathrm{~m}, \sim 2 \mathrm{~cm}$ wide

FELSIC VEIN at $34.2 \mathrm{~m}, \sim 2 \mathrm{~cm}$ wide

(multiple microcracks from 106 to 108 feet)

QUARTZ from 34.5 to $\sim \mathbf{4 0 . 0} \mathrm{m}$, smoky gray and greenish gray vein quartz, $\sim 5.5 \mathrm{~m}$ wide

QUARTZ and GRANITE from $\sim \mathbf{4 0 . 0}$ to $\mathbf{4 3 . 0} \mathrm{m}$, green and reddish fine grained quartz layers, alternating bands of quartz and medium to coarse grained granite, $\sim 3.0 \mathrm{~m}$ wide (near horizontal microcracks at $39.3,42.4$ and $42.7 \mathrm{~m}$ )

SCHIST from 43.0 to $44.7 \mathrm{~m}$, biotite schist, fine grained, banded $\sim 1.7 \mathrm{~m}$ wide

GRANITE from 44.7 to $46.2 \mathrm{~m}, \sim 1.5 \mathrm{~m}$ wide

SCHIST from 46.2 to $50.3 \mathrm{~m}$, same as schist above, $\sim 4.1 \mathrm{~m}$ wide

FELSIC VEIN at $46.0 \mathrm{~m}, \sim 1 \mathrm{~cm}$ wide

(near horizontal microcracks at 47.4 and $48.1 \mathrm{~m}$ )

GRANITE DIKE from 50.3 to $51.2 \mathrm{~m}$, coarse grained, $\sim 0.9 \mathrm{~m}$ wide

(near horizontal microcrack at $50.1 \mathrm{~m}$ )

SCHIST from 51.2 to $51.8 \mathrm{~m}$, trace muscovite, biotite, gneissic texture, coarse grained, equigranular, weak foliation, gradual lower contact, $\sim 0.6 \mathrm{~m}$ wide

SCHIST from $\mathbf{5 1 . 8}$ to $\mathbf{5 5 . 4} \mathrm{m}$, dusky brown, with small felsic augens, equigranular, coarse grained, $\sim 6.1 \mathrm{~m}$ wide

GRANITE from 55.4 to $56.9 \mathrm{~m}, \sim 1.5 \mathrm{~m}$ wide

SCHIST from 56.9 to $57.9 \mathrm{~m}$, biotite schist, coarse grained, $1.0 \mathrm{~m}$ wide

GRANITE from $\mathbf{5 7 . 9}$ to $\mathbf{6 2 . 8} \mathrm{m}$, brownish gray, biotite granite with some biotite schlieren at $59.5 \mathrm{~m}, \sim 2.9 \mathrm{~m}$ wide 
TR2 Continued

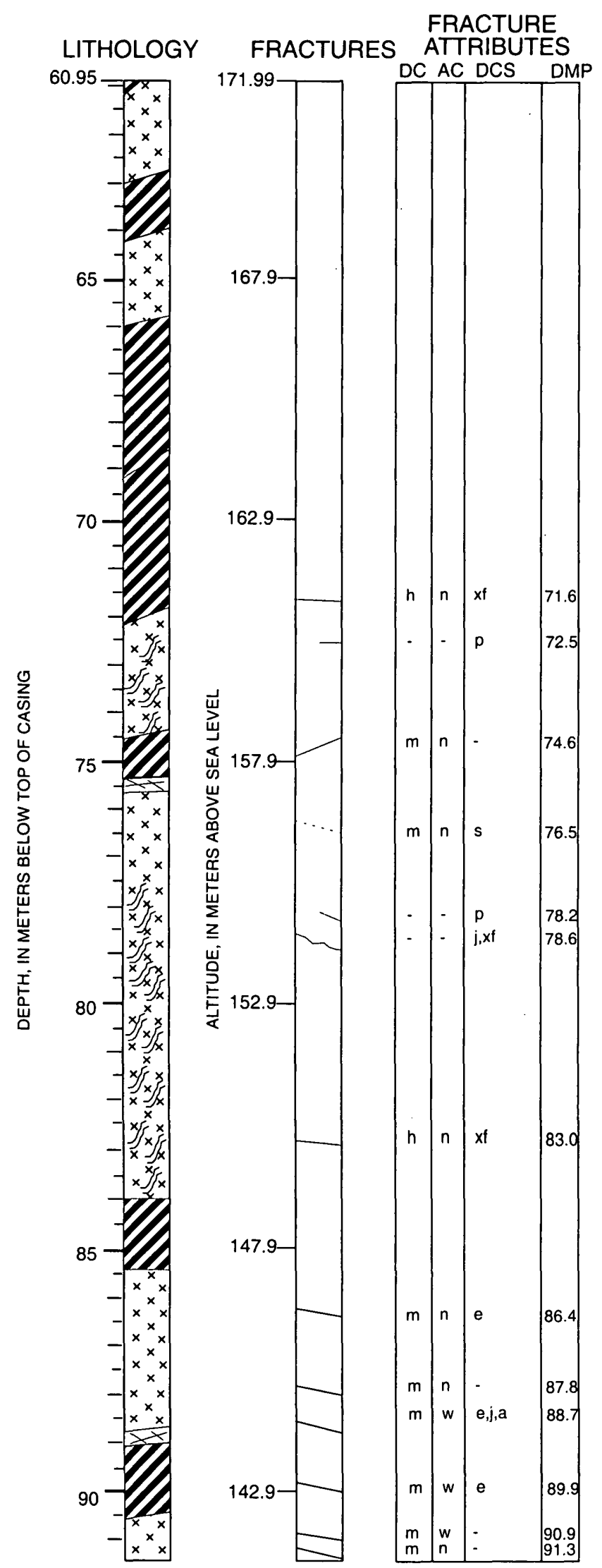

DESCRIPTION: Generalized log in bold.

GRANITE continued to $62.8 \mathrm{~m}$

SCHIST from $62.8 \mathrm{~m}$ to $76.4 \mathrm{~m}$,

SCHIST from 62.8 to $69.0 \mathrm{~m}$, greenish gray biotite schist, equigranular, coarse grained to gneissic texture, $\sim 6.2 \mathrm{~m}$ wide

BIOTITE SCHLIEREN at $63.1 \mathrm{~m}$, (not shown)

GRANITE from 64.1 to $65.9 \mathrm{~m}, \sim 1.8 \mathrm{~m}$ wide

SCHIST 69.0 to $75.3 \mathrm{~m}$, biotite and quartz-rich with augens and weakly foliated, gneissic texture, some banding,

$\sim 6.3 \mathrm{~m}$ wide

FELSIC ZONE from 72.0 to $74.5 \mathrm{~m}$, grading to less foliated and more felsic-rich, $\sim 2.5 \mathrm{~m}$ wide

SCHIST from 74.5 to $75.4 \mathrm{~m}$, biotite-schist with trace sillimanite and sulfide minerals, $\sim 0.9 \mathrm{~m}$ wide PEGMATITE DIKE at $75.5 \mathrm{~m}, \sim 20 \mathrm{~cm}$ wide

GRANITE from 75.6 to $77.7 \mathrm{~m}$, biotite-muscovite granite, $2.1 \mathrm{~m}$ wide MIGMATITE from 77.7 to $84.0 \mathrm{~m}$, coarse grained, alternating zones of felsic minerals (leucosome) and mafic foliated minerals (mesosome), $\sim 6.0 \mathrm{~m}$ wide

SCHIST from $\mathbf{8 4 . 0}$ to $\mathbf{8 5 . 3} \mathrm{m}$, coarse-grained to gneissic, biotite-quartz with trace sulfide minerals and garnet, $\sim 1.3 \mathrm{~m}$ wide

GRANITE from 85.3 to $89.1 \mathrm{~m}$ wide, biotite-muscovite $\sim 3.8 \mathrm{~m}$ wide

PEGMATITE from 88.8 to $89.1 \mathrm{~m}, \sim 0.3 \mathrm{~m}$ wide SCHIST from $89.1 \mathrm{~m}$ to $90.5 \mathrm{~m}$, coarse-grained, biotite-quartz with trace sulfide minerals and garnet, $\sim 1.4 \mathrm{~m}$ wide

GRANITE from 90.5 to $103.0 \mathrm{~m}, \sim 102.5 \mathrm{~m}$ wide 
TR2 Continued

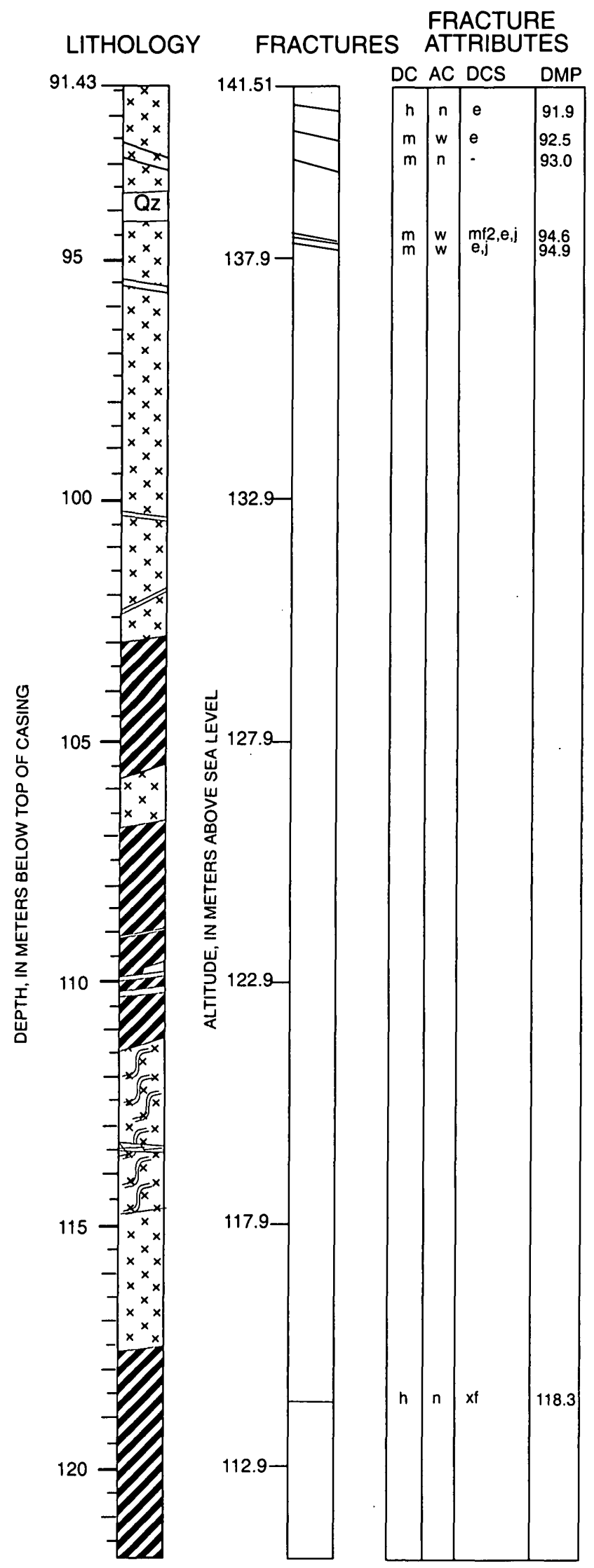

DESCRIPTION: Generalized log in bold.

GRANITE continued to $103.0 \mathrm{~m}$

SCHIST XENOLITH at $93.0 \mathrm{~m}$

QUARTZ in granite from 93.6 to $94.2 \mathrm{~m}, \sim 0.6 \mathrm{~m}$ wide

APLITE VEIN at $95.7 \mathrm{~m}, \sim 1.5 \mathrm{~m}$ wide

FELSIC VEIN at $100.3 \mathrm{~m}, \sim 10$ to $15 \mathrm{~cm}$ wide

PEGMATITE VEIN at $102.1 \mathrm{~m}$, steeply dipping, $-2-3 \mathrm{~cm}$ wide

SCHIST from 103.0 to $105.7 \mathrm{~m}$, gneissic texture, biotite with quartz, garnet and trace sulfide minerals, weakly foliated, near vertical foliation, $\sim 2.7 \mathrm{~m}$ wide

FELSIC ZONE in schist from 105.7 to $106.8 \mathrm{~m}, \sim 1.1 \mathrm{~m}$ wide SCHIST from 106.8 to $111.4 \mathrm{~m}$, gneissic texture $\sim 4.6 \mathrm{~m}$ wide

FELSIC VEIN at $108.8 \mathrm{~m}, \sim 2 \mathrm{~cm}$ wide

QUARTZ on one side of well at $109.8 \mathrm{~m}, \sim 10 \mathrm{~cm}$ wide FELSIC VEIN at $109.9 \mathrm{~m}, \sim 3 \mathrm{~cm}$ wide FELSIC VEIN at $110.3 \mathrm{~m}, \sim 10 \mathrm{~cm}$ wide

GNEISS from 111.4 to $114.7 \mathrm{~m}$, muscovite-biotite gneiss with garnet, $\sim 3.3 \mathrm{~m}$ wide

PEGMATITE VEIN at $113.4 \mathrm{~m}, \sim 5 \mathrm{~cm}$ wide

GRANITE from 114.7 to $117.6 \mathrm{~m}$, felsic-rich, muscovite-biotite granite, sugar texture, with some biotite schlieren, $\sim 2.9 \mathrm{~m}$ wide

SCHIST from 117.6 to $125.6 \mathrm{~m}$, gray, fine grained, near vertical foliation, with some quartz layers, $\sim 8.0 \mathrm{~m}$ wide 
TR2 Continued

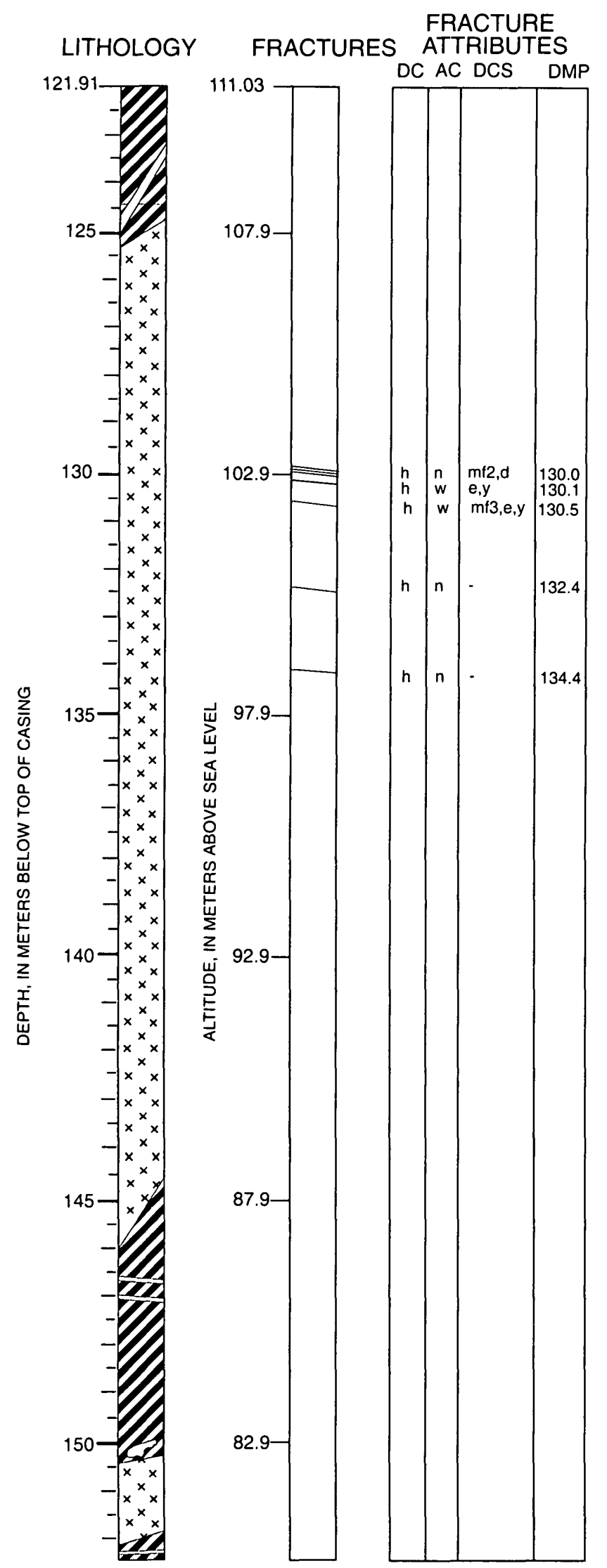

DESCRIPTION: Generalized log in bold.

SCHIST continued to $125.6 \mathrm{~m}$

GRANITE DIKE at

GRANITE from 125.6 to $145.2 \mathrm{~m}$, biotite-muscovite, with some altered zones and some zones that exhibit greenish muscovite granite, some biotite, with trace garnet,

$19.6 \mathrm{~m}$ wide

SCHIST from 145.2 to $150.4 \mathrm{~m}$, quartz-rich biotite-schist, fine grained, near vertical foliation, with some banding, $\sim 5.2 \mathrm{~m}$ wide

FELSIC VEIN at $146.6 \mathrm{~m}$, cross-cuts foliation of schist, $\sim 2 \mathrm{~cm}$ wide

FELSIC VEIN at $147.0 \mathrm{~m}, \sim 2 \mathrm{~cm}$ wide

FELSIC ZONE in schist from 150.0 to $150.3 \mathrm{~m}, \sim 0.3 \mathrm{~m}$ wide

GRANITE from 150.3 to $151.9 \mathrm{~m}, \sim 0.6 \mathrm{~m}$ wide

SCHIST from 151.9 to $155.0 \mathrm{~m}$, biotite schist with trace sulfide minerals, $\sim 3.1 \mathrm{~m}$ wide

FELSIC VEIN at $152.1 \mathrm{~m}, \sim 2 \mathrm{~cm}$ wide 
TR2 Continued

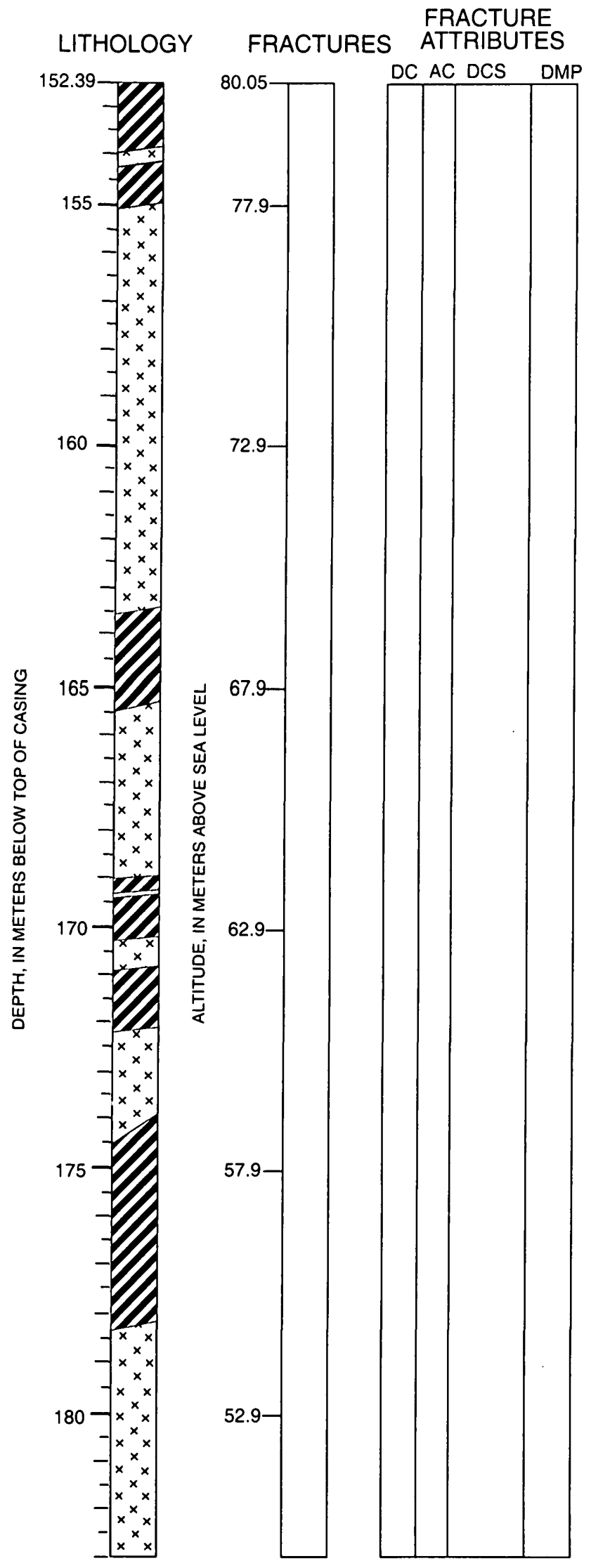

DESCRIPTION: Generalized log in bold.

SCHIST continued to $155.0 \mathrm{~m}$

GRANITE from 153.9 to $154.2 \mathrm{~m}, \sim 0.3 \mathrm{~m}$ wide

GRANITE from 155.0 to $163.5 \mathrm{~m}$, fine grained granite, biotitemuscovite-quartz rich granite $\sim 8.5 \mathrm{~m}$ wide

SCHIST from 163.5 to $165.4 \mathrm{~m}$, biotite-garnet-quartz and feldspar schist, $\sim 1.9 \mathrm{~m}$ wide

GRANITE from 165.4 to $169.0 \mathrm{~m}$, biotite-muscovite, $\sim 3.6 \mathrm{~m}$ wide

SCHIST from 169.0 to $172.2 \mathrm{~m}$, biotite-garnet-quartz and feldspar schist, $\sim 3.2 \mathrm{~m}$ wide

FELSIC VEIN at $169.4 \mathrm{~m}, \sim 2-3 \mathrm{~cm}$ wide

GRANITE DIKE from 170.3 to $170.9 \mathrm{~m}, \sim 0.6 \mathrm{~m}$ wide

GRANITE from 172.2 to $174.1 \mathrm{~m}, \sim 1.9 \mathrm{~m}$ wide

SCHIST from 174.1 to $\mathbf{1 7 8 . 2} \mathrm{m}$, biotite-rich schist with traces of garnet, $\sim 4.1 \mathrm{~m}$ wide

GRANITE from 178.2 to $190.0 \mathrm{~m}$, quartz-biotite-muscovite granite with trace garnet, $\sim 11.2 \mathrm{~m}$ wide 
TR2 Continued

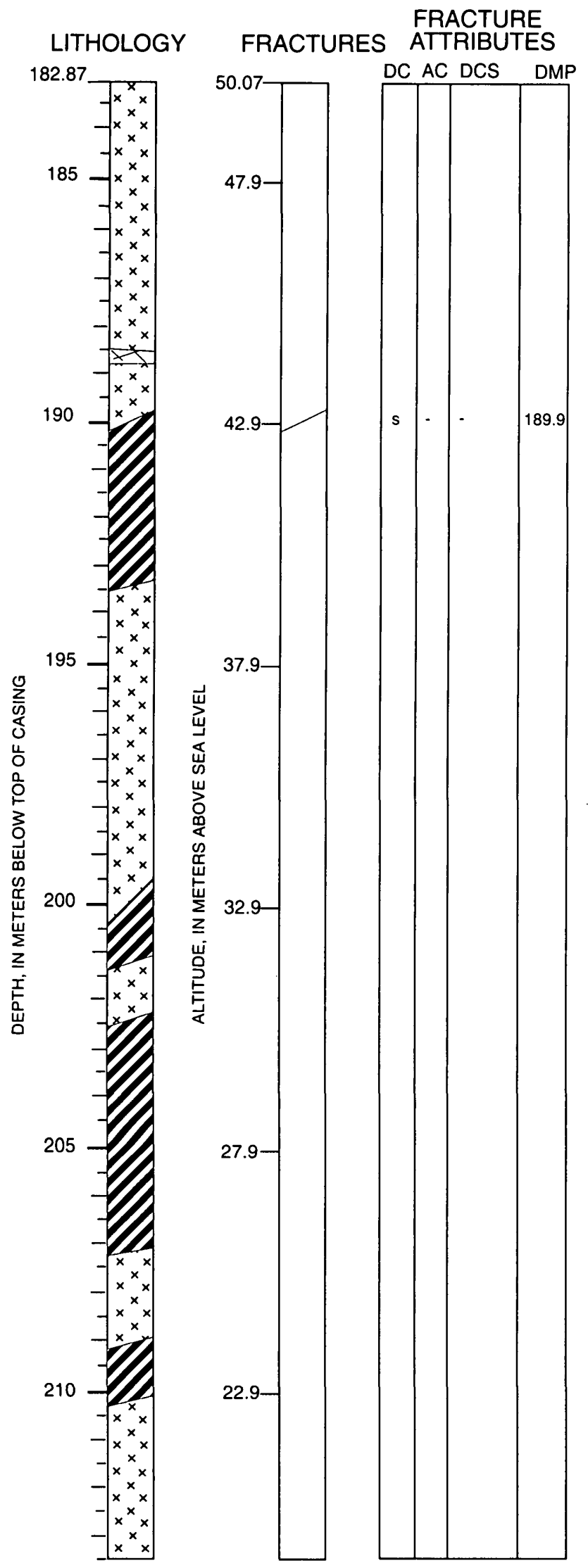

DESCRIPTION: Generalized log in bold.

GRANITE continued to $190.0 \mathrm{~m}$

PEGMATITE from 178.5 to $178.8 \mathrm{~m}$, muscovite, $\sim 0.3 \mathrm{~m}$ wide

SCHIST from 190.0 to $193.3 \mathrm{~m}$, green, chlorite schist, $\sim 3.3 \mathrm{~m}$ wide

GRANITE from 193.3 to $200 \mathrm{~m}$, biotite-muscovite granite, with biotite schlieren at $197.5 \mathrm{~m}, \sim 6.7 \mathrm{~m}$ wide

SCHIST from 200.0 to $201.3 \mathrm{~m}$, fine grained, $\sim 1.3 \mathrm{~m}$ wide

GRANITE from 201.3 to $202.4 \mathrm{~m}$, biotite-granite, $\sim 1.4 \mathrm{~m}$ wide

SCHIST from 202.4 to 207.2 m, biotite-schist with non-

magnetic metallic minerals and trace chlorite, $\sim 4.8 \mathrm{~m}$ wide

GRANITE from 207.2 to $209.1 \mathrm{~m}, \sim 1.9 \mathrm{~m}$ wide

SCHIST from 209.1 to $210.2 \mathrm{~m}$, biotite-schist with nonmagnetic metallic minerals, $\sim 1.1 \mathrm{~m}$ wide

GRANITE from 210.2 to $231.6 \mathrm{~m}$, biotite-muscovite and trace garnet, $\sim 21.4 \mathrm{~m}$ wide 
TR2 Continued

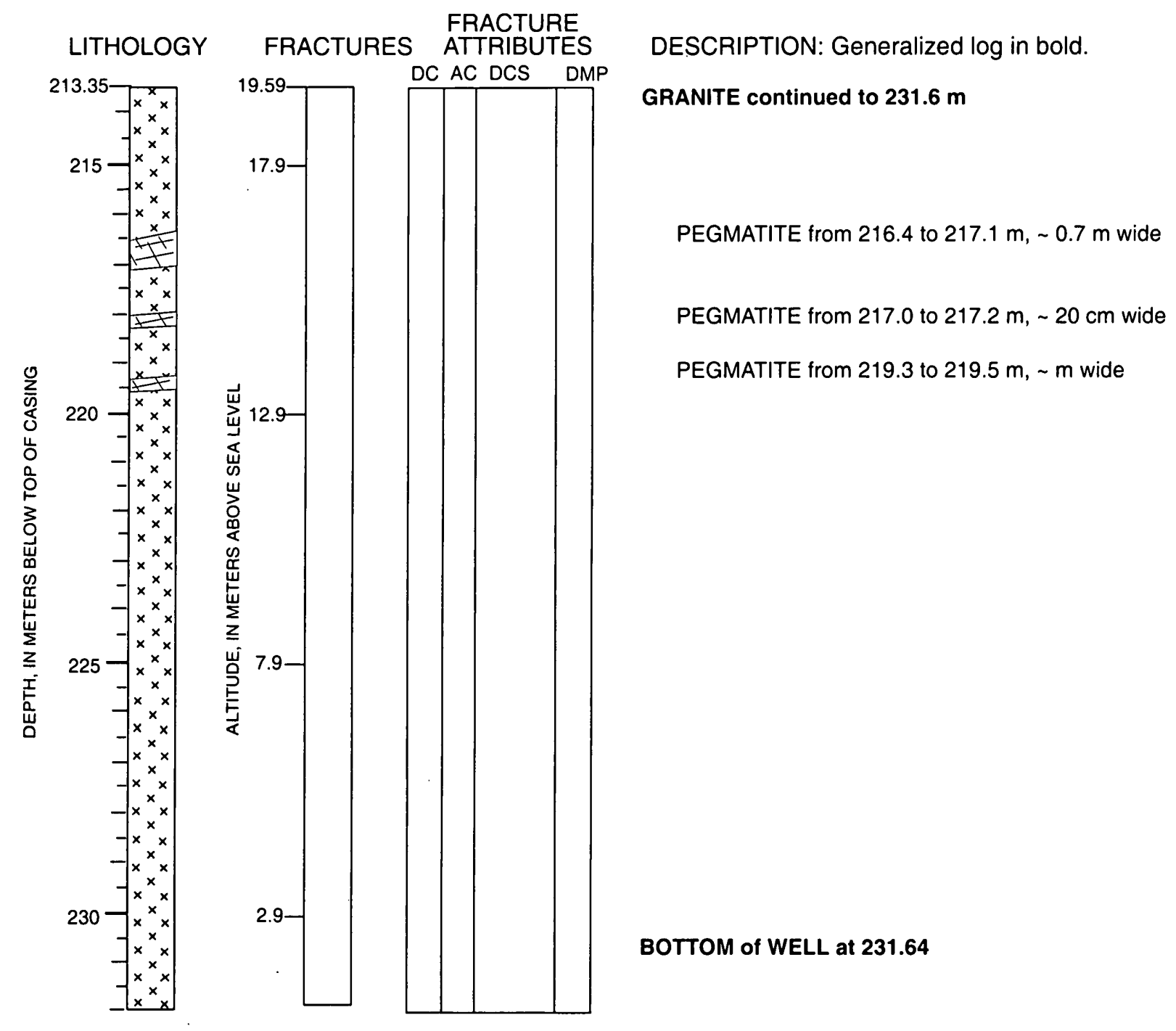


A. Printed on recyled paper 